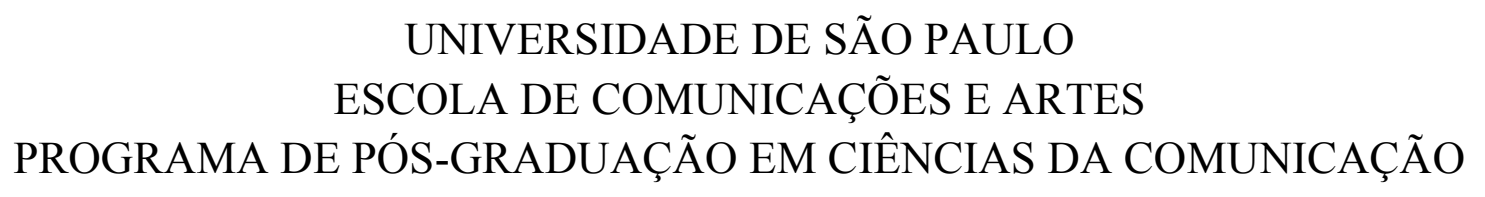

CRISTIANE OLIVEIRA REIMBERG

\title{
O exercício da atividade jornalística na visão dos profissionais: sofrimento e prazer na perspectiva teórica da psicodinâmica do trabalho
}

São Paulo 


\title{
O exercício da atividade jornalística na visão dos profissionais: sofrimento e prazer na perspectiva teórica da psicodinâmica do trabalho
}

\author{
Tese apresentada à Escola de \\ Comunicações e Artes da \\ Universidade de São Paulo como \\ exigência parcial para a obtenção do \\ título de Doutor em Ciências no \\ Programa de Ciências da \\ Comunicação \\ Área de Concentração: Estudo dos \\ Meios e da Produção Mediática \\ Orientadora: Profa. Dra. Alice Mitika \\ Koshiyama
}

São Paulo 
Autorizo a reprodução e divulgação total ou parcial deste trabalho, por qualquer meio convencional ou eletrônico, para fins de estudo e pesquisa, desde que citada a fonte.

Catalogação na Publicação Serviço de Biblioteca e Documentação

Escola de Comunicações e Artes da Universidade de São Paulo Dados fornecidos pelo(a) autor(a)

Reimberg, Cristiane Oliveira

O exercício da atividade jornalística na visão dos

profissionais: sofrimento e prazer na perspectiva teórica da psicodinâmica do trabalho / Cristiane Oliveira Reimberg. --

São Paulo: C. O. Reimberg, 2015.

$376 \mathrm{p}$.

Tese (Doutorado) - Programa de Pós-Graduação em Ciências da Comunicação - Escola de Comunicações e Artes /

Universidade de São Paulo.

Orientadora: Alice Mitika Koshiyama

Bibliografia

1. Jornalismo e Cidadania 2. História dos Jornalistas no Brasil 3. Organização do Trabalho 4. Direitos Trabalhistas 5. Psicodinâmica do Trabalho I. Koshiyama, Alice Mitika II. Título. 
REIMBERG, C. O. O exercício da atividade jornalística na visão dos profissionais: sofrimento e prazer na perspectiva teórica da psicodinâmica do trabalho. Tese apresentada à Escola de Comunicações e Artes da Universidade de São Paulo para obtenção do título de Doutor em Ciências da Comunicação.

Aprovada em:

Banca examinadora:

Prof. Dr.:

Instituição:

Julgamento:

Assinatura:

Prof. Dr.:

Instituição:

Julgamento:

Assinatura:

Prof. Dr.:

Instituição:

Julgamento:

Assinatura:

Prof. Dr.:

Instituição:

Julgamento:

Assinatura:

Prof. Dr.:

Instituição:

Julgamento:

Assinatura: 
Aos meus pais, José e Lourdes, a quem devo o que sou. À querida irmã, Leiliane. À grande mestre, Alice. 


\section{Agradecimentos}

Longe de ser um trabalho solitário, a elaboração de uma tese depende da colaboração de várias pessoas. A principal delas é minha orientadora, a Profa. Dra. Alice Mitika Koshiyama, que compartilhou seus conhecimentos comigo não só nesses quatro anos de doutorado, mas também na elaboração de minha dissertação de mestrado. Só tenho a agradecer por sua generosidade, sabedoria e capacidade de instruir.

Esse trabalho não teria sido concluído sem o apoio de meus pais, José Bueno Reimberg e Aparecida de Lourdes Oliveira Reimberg, e minha irmã, Leiliane Oliveira Reimberg. Com eles partilhei minhas angústias e dúvidas, recebendo carinho, sugestões e equilíbrio para continuar por maiores que fossem as dificuldades. Encontrei essa mesma disponibilidade na amiga Margarida Adamatti, desde a época da faculdade de jornalismo, temos dividido nossas aventuras na profissão, na pesquisa e na vida.

Também foram fundamentais as sugestões dadas pela banca de qualificação, composta pelos professores Laerte Sznelwar e Roberto Heloani, que me ajudaram a construir o fio condutor da pesquisa. Assim como foram importantes as disciplinas cursadas, ministradas pelos professores: Eugênio Bucci, estimulando reflexões filosóficas; Leny Sato, contribuindo com conceitos da psicologia social; Luciano Maluly, pensando o exercício do jornalismo e a falta que a rua faz às reportagens; Roseli Figaro, refletindo sobre a comunicação e o trabalho; e mais uma vez Alice, mostrando o processo conflituoso de construção da cidadania, e Laerte, discutindo a psicodinâmica do trabalho e a ergonomia.

Outro apoio essencial foi dado pelos colegas da Fundacentro. Agradeço especialmente as amigas e jornalistas da Assessoria de Comunicação Social - ACS, Alexandra Rinaldi, Aline Souza e Débora Santos, e a nossa estagiária Rebeca Melo, pela ajuda, principalmente, na reta final da pesquisa. Agradeço ainda as companheiras do Programa Organização do Trabalho e Adoecimento da Fundacentro - Proort, sobretudo, a Maria Maeno, que aceitou a inclusão de meu projeto no programa, e a Myrian Matsuo, pelas ideias que foram incorporadas à tese.

Também agradeço aos colegas do Grupo de Pesquisa "Jornalismo e a Construção da Cidadania", da ECA/USP, pelos ricos debates e trocas de conhecimentos nesses quatro anos. Por fim, agradeço aos jornalistas que concederam entrevistas para esta pesquisa. Sem a generosidade deles em compartilharem seus trabalhos e suas vidas, este estudo não seria possível. 
Sozinhos, ficamos livres, mas não podemos exercitar a nossa liberdade. Com o grupo, encontramos os meios de multiplicar as forças individuais, mediante a organização. É assim que nosso campo de luta se alarga e que um maior número de pessoas se avizinha da consciência possivel, rompendo as amarras da alienação. É também pela organização que pessoas inconformadas se reúnem, ampliando, destarte, sua força e arrastando, pela convicção e o exemplo, gente já predisposta mas ainda não solidamente instalada nesses princípios redentores.

Milton Santos 


\section{Resumo}

REIMBERG, C. O. O exercício da atividade jornalística na visão dos profissionais: sofrimento e prazer na perspectiva teórica da psicodinâmica do trabalho. 2015. $376 \mathrm{f}$. Tese (Doutorado) - Escola de Comunicações e Artes, Universidade de São Paulo, São Paulo, 2015.

O objetivo desta pesquisa é refletir sobre a organização do trabalho no jornalismo, analisando quando o trabalho é fonte de sofrimento e quando ele é fonte de prazer, a partir da subjetividade dos jornalistas entrevistados. Para tanto, utilizamos a psicodinâmica do trabalho, delineada por Christophe Dejours, como referencial teórico, e entendemos a segurança e a saúde no trabalho como direitos sociais que compõem a cidadania. No estudo do contexto histórico, relacionamos a organização do trabalho e a saúde do trabalhador com a história do jornalismo e suas práticas organizacionais. Fazemos uma pesquisa qualitativa que usa a análise de conteúdo, conforme Bardin. Realizamos 21 entrevistas semiabertas com jornalistas de diferentes gerações, entre 25 e 82 anos de idade, a partir de um roteiro base de 25 perguntas. Os entrevistados dividiram conosco suas memórias e vivências para que analisássemos como se dá a organização do trabalho jornalístico na prática e como são as relações de prazer e sofrimento no trabalho. A escolha dessas pessoas se baseou em uma pesquisa, que considerou o envolvimento profissional, o trabalho por elas realizado, a pluralidade de idades e a experiência em diferentes meios de comunicação jornalísticos. Analisamos o conteúdo do material transcrito a partir de seis categorias temáticas: 1) Direitos trabalhistas, em que analisamos jornada de trabalho, formas de contratação, compensação ou pagamento de horas extras e plantões; 2) Organização do trabalho, em que discutimos a pressão, o ritmo, as relações, as limitações e as rotinas de trabalho; 3) Sofrimento, em que refletimos sobre os sofrimentos, dores e adoecimentos, estresse, assédio moral, álcool e drogas, riscos e violências relacionados ao trabalho; 4) Sentido do trabalho, em que pensamos sobre os sentidos de ser jornalista, a relação trabalho e vida pessoal e o envolvimento com o trabalho; 5) Prazer no trabalho, em que avaliamos o prazer, a satisfação, a criatividade e a autonomia presentes no trabalho do jornalista; 6) Futuro do jornalista, que nos dá pistas para a conclusão deste estudo. Os depoimentos mostram que as pessoas reconhecem situações negativas com a precarização do trabalho, mas ao mesmo tempo declaram o grande envolvimento que têm com a profissão, pois o trabalho dá sentido à vida, e o reconhecimento e o sentido do trabalho podem transformar o sofrimento em prazer.

Palavras-chave: Jornalismo e Cidadania; História dos Jornalistas no Brasil; Organização do Trabalho; Direitos Trabalhistas; Psicodinâmica do Trabalho; Sofrimento; Prazer. 


\begin{abstract}
REIMBERG, C. O. The exercise of the journalistic activity from the professionals point of view: suffering and pleasure in the theorical perspective of work psychodynamic. 2015. 376 f. Tese (Doutorado) - Escola de Comunicações e Artes, Universidade de São Paulo, São Paulo, 2015.

The aim of this research is to reflect on work organization in the journalistic field, analising how work can be the source of suffering and how it can be the source of pleasure, beginning from the subjectivity of interviewed journalists. As for that, we used psychodynamic at work, going through Christophe Dejours studies as theoritical reference, as we understand the occupational safety and health as social right that surrounds citizenship. In the study of the historical context, we related work organization and worker's health with the story of journalism and it's organizational practices. We did a qualitative research which uses the contents analysis, according to Bardin. 21 semi-opened interviews were conductected with journalists from different generations, between 25 and 82 years old, beginning from a script with 25 questions. Interviewers divided with us their memories and experiences in order to analyse how work organization works in practice and how are the relations between pleasure and suffering at work. The choice for picking these professionals was based on a research that considered the professional engagement, the work done by them, the plurality of ages and the experience in different press communication vehicles. We also analysed the contents of the transcription, beginning from six temathical categories: 1) Work Rights, where we analysed work shifts, ways of hiring, overtime, extra payment, on and off duty; 2) Work organization, where we discussed pressure, rhythm, relations, limitations and work routine; 3) Suffering, where we reflected about sufferings, pains, illnesses, stress, moral harassment, alcohol, drugs, risks and violences related to work; 4) Meanings of work, where we considered the meaning of being a journalist, the relation between personal life and involvement with work; 5) Pleasure at work, where we evaluated pleasure, satisfaction, criativity, autonomy, all of them present at journalists job; 6) The future of journalists, which gives us the clue for the conclusion for this study. Testimonials showed that people can recognise negative situations when it comes to a term of undermining work, but at the same time declared a great involvement they have with their profession, as work gives sense to life, and the recognition and meaning of work can change suffering into pleasure.
\end{abstract}

Keywords: Journalism and Citizenship; History of Journalists in Brazil; Work Organization; Work Rights; Work Psychodynamic; Suffering; Pleasure. 


\section{LISTA DE QUADROS}

Quadro 1 - Categorias e Subtemas

Quadro 2 - Jornalistas entrevistados de 20 a 29 anos

Quadro 3 - Jornalistas entrevistados de 30 a 39 anos

Quadro 4 - Jornalistas entrevistados de 40 a 49 anos

Quadro 5 - Jornalistas entrevistados de 50 a 59 anos 46

Quadro 6 - Jornalistas entrevistados de 60 a 69 anos 46

Quadro 7 - Jornalistas entrevistados com mais de 70 anos 47 


\section{LISTA DE SIGLAS}

ABI - Associação Brasileira de Imprensa

AIDS - Síndrome da Imunodeficiência Adquirida

ALESP - Assembleia Legislativa do Estado de São Paulo

AVC - Acidente Vascular Cerebral

AZT - Azidotimidina

CBN - Central Brasileira de Notícias

CEBES - Centro Brasileiro de Estudos de Saúde

CAT - Comunicado de Acidente de Trabalho

CCQ - Círculos de Controle de Qualidade

CIPA - Comissão Interna de Prevenção de Acidentes

CMI - Centro de Mídia Independente

CNT - Central Nacional de Televisão

CORFEP - Comissão de Registro e Fiscalização do Exercício Profissional

CPJ - Comitê para a Proteção dos Jornalistas

CPU - Unidade Central de Processamento

CREMESP - Conselho Regional de Medicina do Estado de São Paulo

CT-SST - Comissão Tripartite de Segurança e Saúde no Trabalho

DIESAT - Departamento Intersindical de Estudos e Pesquisas de Saúde e dos

Ambientes de Trabalho

DN - Diário da Noite

DORT - Distúrbios Osteomusculares Relacionados ao Trabalho

EBC - Empresa Brasil de Comunicação

ECA - Escola de Comunicações e Artes

FAB - Força Aérea Brasileira

FFLCH - Faculdade de Filosofia, Letras e Ciências Humanas

FGTS - Fundo de Garantia do Tempo de Serviço

FIA - Fundação Instituto de Administração

FIPE - Fundação Estudo de Pesquisas Econômicas

FOMERCO - Fórum Universitário do Mercosul

FUNDACENTRO - Fundação Jorge Duprat Figueiredo de Segurança e Medicina do Trabalho

GEISAT - Grupo Executivo Interministerial de Saúde do Trabalhador 
IP - Internet Protocol

JB - Jornal do Brasil

LER - Lesões por Esforços Repetitivos

MPB - Música Popular Brasileira

MPL - Movimento Passe Livre

MPT - Ministério Público do Trabalho

MTE - Ministério do Trabalho e Emprego

MST - Movimento dos Sem Terra

MTST - Movimento dos Trabalhadores Sem Teto

NP - Notícias do Planalto

NR - Norma Regulamentadora

OIT - Organização Internacional do Trabalho

OMS - Organização Mundial da Saúde

ONG - Organização Não Governanmental

ONU - Organização das Nações Unidas

PDT - Psicodinâmica do Trabalho

PEC - Press Emblem Campaign

PJ - Pessoa Jurídica

PLANSAT - Plano Nacional de Segurança e Saúde no Trabalho

PNSST - Política Nacional de Segurança e Saúde no Trabalho

PROOT - Programa Organização do Trabalho e Adoecimento

PUC - Pontifícia Universidade Católica

QVT - Qualidade de Vida do Trabalho

RGPS - Regime Geral da Previdência Social

RSF - Repórteres sem Fronteiras

SBT - Sistema Brasileiro de Televisão

SEINESP - Sindicato de Empresas de Internet do Estado de São Paulo

SEMSAT - Semana de Saúde do Trabalhador

SIPAT - Semana Interna de Prevenção de Acidentes do Trabalho

SJSP - Sindicato dos Jornalistas Profissionais no Estado de São Paulo

SUS - Sistema Único de Saúde

TAC - Termo de Ajustamento de Conduta

UFBA - Universidade Federal da Bahia

UFSC - Universidade Federal de Santa Catarina 
UNESP - Universidade Estadual Paulista

URSS - União das Repúblicas Socialistas Soviéticas

USP - Universidade de São Paulo 


\section{Sumário}

Introdução 17

Capítulo 1 - A construção da pesquisa 25

1.1 - Em busca das narrativas dos sujeitos 25

1.2 - O referencial teórico e o lugar de onde se fala 27

1.3 - Procedimentos metodológicos 31

1.4 - Os sujeitos da pesquisa 43

1.5 - As testemunhas da história 48

1.6 - Eles sujaram os sapatos 53

1.7 - Trabalho que dá prazer 60

1.8 - Trabalho que faz sofrer 65

1.9 - O jornalismo em questão 69

1.10 - Jornalismo que transforma 73

Capítulo 2 - Cidadania, jornalismo e direitos 77

trabalhistas dos jornalistas

2.1 - A relação entre jornalismo e cidadania 77

2.2 - O significado da cidadania 78

2.3 - A construção da cidadania como processo conflituoso 82

2.4 - Jornalismo e cidadania 99 
4.4 - Quando o trabalho é cenário para o assédio moral 284

$$
\begin{aligned}
& \text { 4.5 - O estresse no trabalho do jornalista } 292 \\
& 4.6 \text { - Os riscos do trabalho jornalístico } 300 \\
& 4.7 \text { - Álcool e drogas } 313 \\
& 4.8 \text { - O sentido do trabalho } 316 \\
& 4.9 \text { - O trabalho como fonte de prazer } 331 \\
& 4.10 \text { - Espaço de criatividade e autonomia } 339
\end{aligned}
$$

Conclusão 351

Referências Bibliográficas 359

Anexos 375

I. Jornalistas entrevistados por ordem cronológica 375

II.Termo de Consentimento Livre e Esclarecido 376 


\section{Introdução}

Iniciada em 2011, no Programa de Pós-Graduação em Ciências da Comunicação, da Escola de Comunicações e Artes da Universidade de São Paulo ECA/USP, sob a orientação da Profa. Dra. Alice Mitika Koshiyama, esta pesquisa de doutorado estuda como se dá a organização do trabalho no jornalismo, refletindo sobre a relação de sofrimento e prazer no trabalho do jornalista. Para realizá-la, partimos da perspectiva de que a saúde no trabalho é um direito de cidadania. Assim relacionamos estudos sobre a organização do trabalho e saúde do trabalhador com a história do jornalismo e suas práticas organizacionais.

Trilhamos um caminho de reconstrução das palavras e recuperação das vivências dos jornalistas para perceber os impactos dessa organização à saúde e como são as relações de prazer e sofrimento no trabalho por meio de 21 entrevistas semiabertas com trabalhadores de diferentes gerações. Essas pessoas foram consideradas, levando-se em conta a carreira por elas desenvolvida, a pluralidade de veículos e as idades necessárias à pesquisa, além do envolvimento profissional. Todo o material foi transcrito e analisado, segundo critérios da pesquisa qualitativa e da análise de conteúdo. Utilizamos ainda a psicodinâmica do trabalho como referencial teórico, não fazendo uso de sua metodologia.

A escolha desse tema remete a nossa própria história e vivência profissional. Jornalista formada pela Faculdade de Comunicação Social Cásper Líbero em 2002, tive como primeiro trabalho na área um estágio no ano de 2000 em uma pequena editora especializada em Segurança e Saúde no Trabalho, cujo proprietário era o médico do trabalho e auditor fiscal do Ministério do Trabalho e Emprego, Mário Bonciani.

Nos anos seguintes, 2001 e 2002, optei por me dedicar ao projeto experimental da faculdade, exigência como trabalho de conclusão de curso. No meu caso, o livro reportagem "Nômades Urbanos", que retratava como viviam as pessoas em situação de rua na cidade de São Paulo, feito com as amigas e jornalistas Margarida Adamatti e Paula Bosi. A dedicação a esse trabalho com a realização de 161 entrevistas, das quais 131 foram com pessoas em situação de rua, ilustra o meu envolvimento com a profissão.

Quando ouço algum colega dizer que a faculdade de jornalismo não forma o jornalista, que a pessoa só aprende a ser jornalista no mercado, costumo falar que 
aprendi a ser jornalista na faculdade, não só pelas aulas e professores que me inspiraram, mas também por ter feito esse livro reportagem. Ele diz muito sobre mim, sobre a profissional que sou e o jornalismo que acredito.

Para entrevistar as pessoas que viviam nas ruas da cidade, tivemos que nos despir de nossos medos e preconceitos. Lidamos ainda estudantes com os sofrimentos da profissão, que naquela época nem sabíamos que eram sofrimentos. Ouvimos histórias sobre as quais nos faltavam estrutura psicológica, relatos de abandonos, drogas, estupros e tantas dores que poderiam ter alguma visibilidade ao se tornarem palavras. Horas, dias, meses de dedicação. Madrugadas a fio escrevendo. Um envolvimento tremendo que só era possível porque o trabalho de jornalista tinha sentido para mim, e esse livro concretizava o papel social do jornalismo em que eu acreditava mesmo antes de entrar na faculdade.

Se escrever Nômades Urbanos contou com os ingredientes de sofrimento do jornalismo, ele também proporcionou momentos de prazer. O prazer do resultado do trabalho, da identificação com o texto escrito, da publicação de nosso nome na capa e o reconhecimento, pois o nosso trabalho foi o vencedor do Prêmio Cásper Líbero de Jornalismo, da própria faculdade, na categoria livro-reportagem, escolhido por um júri formado pelos jornalistas César Tralli, Luiz Maklouf Carvalho e Mino Carta.

A relação entre sofrimento e prazer marca a atividade jornalística e hoje olhando para o passado vejo que foi assim desde o início na faculdade. $\mathrm{O}$ envolvimento com a profissão é alimentado pelas histórias contadas pelos professores, pelas reportagens realizadas durante o curso e pelos estágios estimulados. Desde cedo, você aprende que para ser jornalista precisa trabalhar muito, se destacar, ser jornalista 24 horas, que é natural não ter horário e que a saída é individual. Se você for bom, você consegue. Por outro lado, você discute o papel do jornalismo para a consolidação da democracia e aprende a acreditar nisso.

Uma mistura de mito heróico com certo ceticismo, que faz de o jornalista um pessimista, crítico de tudo. Ele denúncia, mas pode ser massa de manobra. Pode manipular, mas também ser manipulado. Vê os defeitos do trabalho dos outros, porém nem sempre vê suas limitações. Até percebe que a saída é coletiva, no entanto, é tomado pelo individualismo.

Claro que acredito que o jornalismo é importante para a consolidação dos direitos já que por meio do direito à informação as pessoas podem conhecer seus direitos, problemas e realidades podem ser revelados. Se não acreditasse, o trabalho não 
teria sentido pra mim e eu não teria a dedicação que sempre tive ao trabalho. Mas também vejo a forma que isso é utilizada para gerar produtividade e ocultar a exploração do trabalhador jornalista, que muitas vezes não se vê como sujeito do trabalho. O medo do fracasso completa esse cenário. É preciso ser o melhor para vencer. Se você não venceu é porque não serve para o jornalismo.

Naquela época eu ainda não pensava nisso ou pelo menos em todos os paradoxos do jornalismo. Eu só queria ser jornalista, com toda a paixão que essa profissão envolve, já demonstrada em outros estudos como de Heloani (2003b), Ribeiro (2001) e Travancas (1993). Queria trabalhar com jornalismo impresso e continuar escrevendo sobre temas sociais, especialmente sobre saúde, infância e educação, os quais mais me fascinavam.

Foi assim que em 2003, já formada, outra amiga, a jornalista Mônica Calmon, me indicou para substituí-la na revista Proteção. Ela achou que escrever sobre Segurança e Saúde no Trabalho era minha cara. Se não era, virou, pois passei oito anos e meio trabalhando nessa publicação especializada em falar sobre a saúde e segurança do trabalhador. Foram momentos de sofrimento pela demanda de trabalho e pressão do tempo, mas de muito prazer pelo reconhecimento do trabalho e a identificação que eu tinha com o material produzido.

Busquei aliar o meu trabalho jornalístico com o estudo. Assim fui fazendo especialização, mestrado, até chegar ao doutorado. A pesquisadora é muito movida pela jornalista até nas escolhas do tema. Quando entrei na especialização em jornalismo social na Pontifícia Universidade Católica de São Paulo - PUC/SP, talvez o mais natural fosse buscar um tema que tivesse a ver com a área que eu já trabalhava, pelo menos foi o que me disseram. Mas eu não queria. A pesquisa para mim era uma oportunidade de explorar temas sobre os quais eu não podia escrever na revista. Dessa forma, cheguei à Pastoral da Criança e estudei temas como saúde, educação, infância, comunicação popular e cidadania.

No mestrado na ECA/USP, fui fazer trabalho de campo, explorando o mesmo universo e aprofundando o que começou como análise de conteúdo do Jornal Pastoral da Criança. Entrevistamos 61 voluntárias da Pastoral da Criança da Arquidiocese de São Paulo, além de outras dez pessoas da equipe estadual e nacional, entre elas, a fundadora Zilda Arns. Uma vontade de fazer pesquisa de campo e entrevistas que tem muito a ver com a motivação jornalística. 
Ainda quando estava no mestrado, comecei a pensar o meu tema de doutorado. Mais uma vez ouvia dizer que o ideal seria continuar com o mesmo assunto no doutorado, aprofundar outra vertente, como o trabalho de rádio da instituição, por exemplo. Mas depois de estudar o tema por uma especialização e um mestrado, eu precisava explorar outro universo.

Para tanto, a minha resistência em estudar algo relacionado à saúde e ao trabalho precisou ser vencida. Não que eu não gostasse do tema. Pelo contrário, gostava tanto, e o trabalho da revista Proteção exigia tanto de mim, que não me via motivada a fazer um doutorado que envolvesse mais Segurança e Saúde no Trabalho na minha vida.

Foi o livro "A condição operária e outros estudos sobre a opressão", de Simone Weil, que me fez mudar de ideia. Li o livro para a disciplina A Memória das Testemunhas, da Prof ${ }^{a}$. Dra. Ecléa Bosi, no ano de 2008 e fiz um seminário sobre a questão do trabalho. As palavras de Simone Weil me fizeram ver que havia um universo a ser explorado, para o qual a jornalista não era suficiente, era necessária a dedicação da pesquisadora.

Weil se fez trabalhadora para entender o que se passava com os operários. Entendia que só a partir da vivência da vida na fábrica conseguiria refletir plenamente sobre a condição de trabalho e assim foi sentir as dores dos trabalhadores que a impossibilitaram de pensar. Esgotamento, ritmo intenso, cansaço, dores, demissão de adoecidos, pressão por produção foram relatados no texto "Diário da Fábrica", de 1934 a 1935.

Em diversos textos da coletânea, podemos ver os sofrimentos vividos pelos trabalhadores e que a separação entre corpo e mente não ocorria como apregoavam taylorismo e fordismo. As humilhações e o ritmo tão intenso resultavam em uma sensação de bloqueio do pensamento. A angústia e a impotência também foram relatadas. $\mathrm{O}$ trabalhador se sentia um nada, com corpo e pensamento esgotados:

$\mathrm{O}$ corpo está às vezes esgotado, de noite à saída da fábrica, mas o pensamento está sempre esgotado, mais ainda do que o corpo. Quem passou por este esgotamento e não o esqueceu, pode reconhecê-lo nos olhos de quase todos os operários que desfilam à saída da fábrica. (WEIL, 1979, p. 134)

A forma como Simone Weil exprimiu o que se sentia frente a uma organização do trabalho opressora despertou em mim o desejo de estudar o trabalho como pesquisadora. Havia muito a ser dito, muito a ser explorado, como mostra a fala da autora: 
Sinto-me desfalecer de cansaço e de desânimo. Que horas são? Ainda duas horas antes da saída Como vou poder agüentar. Chega o contramestre. Quantas você faz? 400 por hora? É preciso 800. Se não, você não fica. Se, a partir de agora, você fizer 800 talvez eu concorde que você fica. Fala sem levantar a voz. Para que levantar a voz, se com uma palavra pode provocar tanta angústia. Que responder? Vou tentar. Forçar. Forçar ainda. Vencer, em cada segundo, este desgosto, este desânimo que paralisa. Mais depressa. Trata-se de dobrar a cadência. Quantas fiz ao fim de uma hora? 600. O sinal. Bater ponto, vestir-se, sair da fábrica com o corpo todo esvaziado da energia vital, a alma oca de pensamentos, o coração mergulhado no desgosto, raiva muda, e acima de tudo isso, um sentimento de impotência e de submissão. Por que a última esperança para o dia seguinte é que se dignem deixar-me passar ainda um dia como este. Quanto aos dias que virão depois, estão muito longe. A imaginação se recusa a percorrer um número tão grande de minutos tristes. (WEIL, 1979, p.100)

Com toyotismo e pós-fordismo, as técnicas de opressão se sofisticaram. O controle é maior mesmo sem um supervisor, porque ele é onipresente. A subjetividade do trabalhador é capturada. A sua vida continua a se resumir ao trabalho, e os minutos tristes se transfiguram de momentos alegres, mas no fundo é o mesmo tempo que marca a cadência da produção e da opressão.

O trabalhador não é sujeito da fabricação e não domina o destino nem o sentido do seu trabalho. Buscamos pensar essas questões a partir do trabalho do jornalista. $\mathrm{O}$ fato de fazer um trabalho intelectual o tira dessas condições? Algumas das respostas encontradas por Heloani (2003b) mostram que não, como quando um jornalista afirma se sentir em uma linha de montagem. Por outro lado, apesar dessa crítica aparecer nas falas dos nossos entrevistados em relação ao jornalismo de forma geral, eles acreditam encontrar possibilidades de fazer diferente.

Pensar a autonomia dos jornalistas frente à organização do trabalho é um ponto interessante, pois Weil (1979, p.96-97) já na década de 30 defendia a autonomia dos trabalhadores. Para a autora, "não podemos admitir que a vida dos homens seja sacrificada em nome da fabricação dos produtos" (Ibid., p.114). É preciso conciliar as exigências da fabricação com as aspirações das pessoas. A organização ideal seria aquela que proporcionasse o maior número de produtos possíveis e bem feitos com trabalhadores felizes.

O contato com Simone Weil ocorreu quando eu ainda estava no meio do meu mestrado e deixei essa vontade de pesquisar o mundo do trabalho guardada para quando fosse pensar o doutorado, o que ocorreu em 2010. Já havia comentado com a professora Alice, que me orientou no mestrado, sobre a minha vontade de estudar algo relacionado 
à saúde e segurança do trabalhador. Meu desafio era encontrar um tema em que eu pudesse aliar as questões do trabalho à comunicação.

Meu primeiro pensamento foi desenvolver um estudo sobre a comunicação em saúde do trabalhador nos jornais sindicais, escolhendo algumas categorias de trabalhadores. Mas faltava alguma coisa. O trabalho da jornalista, no entanto, acabou dando as pistas para resolver o dilema da pesquisadora.

A ideia desse doutorado nasceu a partir de uma entrevista com o psiquiatra francês Christophe Dejours, realizada por mim e intermediada pelo professor doutor Laerte Sznelwar, do Departamento de Engenharia de Produção da Escola Politécnica da Universidade de São Paulo, durante o VI Colóquio Internacional de Psicodinâmica e Psicopatologia do Trabalho e o I Congresso da Associação Internacional de Psicodinâmica e Psicopatologia do Trabalho, ocorridos no final de abril de 2010, em São Paulo/SP.

A entrevista foi publicada na revista Proteção, n 122 , edição de junho de 2010. Gostei tanto do resultado do trabalho, que levei um exemplar para a Alice na ECA. Nesse momento eu estava me preparando para prestar o doutorado. Ao ler o texto, Alice sugeriu que eu pensasse um tema que aliasse o que foi dito por Dejours com o trabalho do jornalista. Para me inspirar, indicou o trabalho de pós-doutorado em comunicação do professor da Universidade Estadual de Campinas, realizado na ECA/USP, Roberto Heloani: "Mudanças no mundo do trabalho e impactos na qualidade de vida do jornalista".

O estudo de Heloani, que também era minha fonte na revista Proteção, foi fundamental para a construção da pesquisa. Outra referência importante foi o livro de Jorge Cláudio Ribeiro, "Sempre Alerta, condições e contradições do trabalho jornalístico", feito a partir de seu doutorado em ciências sociais na PUC/SP. Completa essa tríade a própria fala de Dejours durante a entrevista:

$\mathrm{O}$ grande meio de transformar o sofrimento em prazer é o reconhecimento. Esse reconhecimento acontece a partir da gratidão em relação ao trabalho que foi feito. É o reconhecimento na forma de julgamento da qualidade do trabalho. Essa qualidade está sempre relacionada a certo modo de sofrimento no trabalho. Por exemplo, você não pode ser uma boa jornalista se você não sofrer com o que você faz, com relação aos prazos, à escrita, à autocensura, tudo isso faz parte. O prazer só pode vir no segundo momento, quando, por exemplo, há o reconhecimento sobre a qualidade do artigo publicado. (DEJOURS, 2010) 
Com essas três referências, ganhei não só um tema para desenvolver o projeto do doutorado como o alicerce para realizá-lo. Assim em 2011, após passar pelas provas, avaliação de projeto e entrevista, iniciei esta pesquisa em que jornalista e pesquisadora se encontraram para falar do cotidiano de trabalho jornalístico.

Não foi uma tarefa fácil realizá-la. O tema, ao mesmo tempo em que me fascinava, gerava muita insegurança. Afinal eu era uma jornalista totalmente envolvida com a profissão e questioná-la significava questionar o próprio sentido que eu dava ao meu trabalho. Por outro lado, não queria procurar nos entrevistados somente aquilo que eu acreditava. Isso fez com que no começo eu assumisse uma postura muito mais crítica em relação à profissão, o que de certa forma poderia me fazer perder a dimensão do sentido do trabalho e do prazer, frisando mais os sofrimentos. Mas não era isso que eu devia fazer. Essa atitude inicial buscava dar uma pretensa objetividade e neutralidade que não existem de fato nos estudos científicos. Eu não podia me negar como sujeito.

Sofrimento e prazer são indissociáveis no trabalho do jornalista. Eu vivenciava isso no meu trabalho e estudar o que você vivencia é bem mais difícil do que olhar para o que diz respeito ao outro. Olhar para os problemas de sua profissão é olhar para os seus problemas. Pensar sobre os sofrimentos de sua profissão é pensar sobre os seus sofrimentos.

Na qualificação, ficou claro para mim que me colocar como sujeito seria uma forma de expor minhas limitações na pesquisa e o meu envolvimento com a profissão. Isso não significa que busquei me projetar nos meus entrevistados. Mas não posso negar a minha subjetividade implícita na pesquisa, seja como pesquisadora, seja como jornalista.

Falo de dentro do trabalho, mas essa fala vem também de outros sujeitos. Os 21 jornalistas que me concederam entrevistas. Um grupo heterogêneo de entrevistados, que buscou reunir pessoas com diferentes experiências profissionais e de diversas faixas etárias. Os entrevistados tinham entre 25 e 82 anos. São eles e suas histórias que dão vida a pesquisa.

Como se dão as relações de sofrimento e prazer no trabalho do jornalista? Essa é a grande questão que move esta pesquisa e que está latente em todos os capítulos da tese. Começamos apresentando os objetivos e a metodologia do estudo, para logo depois apresentar os sujeitos da pesquisa. Assim damos as primeiras pistas do envolvimento que os move no trabalho do jornalista. Eis o primeiro capítulo. 
No segundo capítulo, abordamos o direito à saúde no trabalho. Além de pontuar a questão da cidadania, ele nos permite apresentar os direitos trabalhistas dos jornalistas e a sua desobediência na prática. Os entrevistados relatam a precarização das relações de trabalho, as longas jornadas, o não pagamento de horas extras, o lado obscuro dos bancos de horas, a falta de direitos básicos como o registro em carteira e o direito à aposentadoria.

Sofrimentos que fazem parte do trabalho do jornalista. Essa discussão sobre a falta de direitos encerra esse capítulo e alimenta a discussão a ser iniciada no terceiro sobre a organização no trabalho. Os relatos sobre pressão, ritmo acelerado e relações de trabalho são contextualizados a partir da história do jornalismo e da organização do trabalho, que estão em livros e artigos, frutos de pesquisas ou notícias, e a história que emerge das memórias dos sujeitos entrevistados.

No último capítulo, depois de falar sobre os sofrimentos da falta de direitos e da organização precarizada do trabalho, refletimos sobre a psicodinâmica do trabalho. Recuperamos o sentido do trabalho para os jornalistas e suas falas sobre o que consideram sofrimento e prazer. O mesmo trabalho que faz sofrer é aquele que dá prazer. Ele dá sentido à vida dos jornalistas.

Esse trabalho não termina com a defesa da pesquisa. Pretendemos dar continuidade ao tema não só produzindo artigos e apresentando o trabalho em congressos, mas também organizando debates em parceria com nossa orientadora. Pretendemos continuar estudando o trabalho do jornalista a partir de outros enfoques, como a questão de gênero.

Para tanto, criamos em 2014 um projeto baseado nesta pesquisa de doutorado no Programa Organização do Trabalho e Adoecimento - Proort, da Fundacentro, instituição de pesquisa federal sobre segurança e saúde do trabalhador, pertencente ao Ministério do Trabalho e Emprego. Já lançamos novamente o projeto para o ano de 2015. Trabalhamos na instituição desde 2012, após termos sido aprovada em concurso público no ano de 2010, para o cargo de analista em ciência e tecnologia, campo do conhecimento de comunicação social. Acreditamos que a atuação na entidade permite que aliemos o nosso lado jornalista, com a publicação de conteúdos informativos sobre segurança e saúde do trabalhador, tendo como parâmetro a comunicação pública e como base o trabalho realizado pelos pesquisadores, no site da instituição, e o nosso lado pesquisadora dentro do Proort. Mais uma vez jornalista e pesquisadora se encontraram. 


\title{
Capítulo 1
}

\section{A construção da pesquisa}

\section{1 - Em busca das narrativas dos sujeitos}

Como Christophe Dejours nos falou durante a entrevista realizada em 2010, não é possível ser jornalista sem sofrer. O sofrimento faz parte do trabalho, e o prazer vem em um segundo momento, seja pelo reconhecimento dado ao produto do trabalho, seja pelo próprio sentido que atribuímos ao trabalho realizado.

Ao conversar com os jornalistas, tentamos esboçar como se dão as relações de sofrimento e prazer no trabalho desses profissionais. São esses sujeitos que delineiam o nosso objeto de pesquisa, a organização do trabalho jornalístico - que abrange novas tecnologias, a flexibilidade do capital e das relações de trabalho - e seu impacto sobre a saúde e vida desses trabalhadores. Em todo momento sofrimento e prazer estão presentes nessa organização, que só é suportada pelo sentido que os jornalistas atribuem ao seu trabalho.

Esse cenário emerge da memória desses sujeitos. Trabalhamos com as narrativas das memórias dos jornalistas em relação ao trabalho. Segundo Pollak (1989), na tradição metodológica durkheimiana, a memória coletiva de determinado grupo define o que é comum e o que diferencia dos outros, fundamentando e reforçando os sentimentos de pertencimento; já Halbwachs reforça a coesão social e o processo de negociação entre a memória coletiva e memórias individuais. Ainda há as zonas de silêncios e "nãoditos", entre o esquecimento e o reprimido inconsciente.

\begin{abstract}
A memória, essa operação coletiva dos acontecimentos e das interpretações do passado que se quer salvaguardar, se integra, como vimos, em tentativas mais ou menos conscientes de definir e de reforçar sentimentos de pertencimento e fronteiras sociais entre coletividades de tamanhos diferentes. (POLLAK, 1989, p.9)
\end{abstract}

Essas considerações são importantes para situar nosso objeto de pesquisa, pois a organização do trabalho jornalístico de que falamos emerge das memórias individuais dos sujeitos da pesquisa, os jornalistas entrevistados. Segundo o autor, "a memória individual resulta da gestão de um equilíbrio precário, de um sem número de contradições e de tensões". Por outro lado,

(...) a história de vida ordena acontecimentos que balizaram uma existência. Além disso, ao contarmos nossa vida, em geral tentamos estabelecer uma certa coerência por meio de laços lógicos entre 
acontecimentos chaves (que aparecem então de uma forma cada vez mais solidificada e estereotipada), e de uma continuidade, resultante da ordenação cronológica. Através desse trabalho de reconstrução de si mesmo o indivíduo tende a definir seu lugar social e suas relações com os outros. (POLLAK, 1989,p.13)

Fazemos, assim, um trabalho de enquadramento de uma memória de um grupo, como diz Pollak, que tem limites e deve se alimentar de materiais fornecidos pela história, o que procuramos fazer por meio da pesquisa bibliográfica, acompanhamento de notícias sobre o trabalho dos jornalistas, consultas a documentos e legislação.

Feita essa contextualização, apontamos que o objetivo geral desse trabalho é estudar como se dá a organização do trabalho no jornalismo enquanto que o específico é ver quando o trabalho é fonte de sofrimento e quando ele é fonte de prazer.

O objetivo teórico consiste em relacionar estudos sobre a organização do trabalho e saúde do trabalhador com a história do jornalismo e suas práticas organizacionais. Já o objetivo prático é ouvir as narrativas dos jornalistas sobre essa organização, o prazer e o sofrimento.

Partimos da hipótese de que a organização do trabalho no jornalismo com ritmo acelerado, sobrecarga e jornada excessiva possibilita um cenário propício ao adoecimento, especialmente, sintomas físicos ligados ao estresse e à postura corporal adotada durante o trabalho, LER/DORT (Lesões por Esforços Repetitivos /Distúrbios Osteomusculares Relacionados ao Trabalho) e transtornos mentais e de comportamento. Ao mesmo tempo, a qualidade do texto piora por não se ter tempo para fazer uma apuração adequada.

O sofrimento gerado pelo trabalho, no entanto, é amenizado quando o jornalista tem seu trabalho reconhecido ou quando consegue atribuir um valor positivo para a atividade que realiza. Passa-se, então, do sofrimento ao prazer. Mais do que isso, percebemos, ao longo das entrevistas, que é o sentido do trabalho que faz com que os jornalistas suportem as condições adversas e as superem na tentativa de produzir aquilo que eles acreditam ser um bom trabalho.

Esse reconhecimento do trabalho, que inclui o sujeito se identificar com o material produzido, um trabalho não alienado, traz implicações não só na transformação do sofrimento em prazer, como diz Dejours, mas também pode contribuir para uma prática jornalística voltada para princípios éticos e para o interesse do cidadão. 
A esses aspectos, outro fator é preponderante: certa "vocação" ao jornalismo, um “amor" à profissão ou até mesmo um imaginário criado em torno da mesma, como já foi constatado por alguns estudos como os de Heloani (2003b) e Travancas (1993).

A pesquisa de Heloani (2003b) dá alguns subsídios para o estudo que pretendemos desenvolver. Ao centrar na questão do estresse, deixa vários espaços a ser explorados e aprofundados.

Verificamos que faltam estudos sistemáticos acerca da atividade do jornalista como sendo propiciadora de stress e outras doenças ocupacionais. A experiência clínica nos leva a supor que o stress nesta área advém sobretudo do trabalho que faz do jornalismo uma profissão de risco e também de morte precoce. (HELOANI, 2003b, p.20)

Por outro lado, a pesquisa de Heloani (2003b, p.54), aponta que de 22 entrevistados em profundidade, 18 afirmaram ter satisfação no trabalho. "Chama a atenção o fato que a maioria dos depoentes, apesar da falta de infraestrutura e de outras demandas, fazem da profissão um verdadeiro fetiche. Gostam e muito, alguns nutrindo por ela verdadeira paixão". É esse universo de sofrimento e prazer que quisemos explorar com esta pesquisa de doutorado.

\section{2 - O referencial teórico e o lugar de onde se fala}

Esta pesquisa se insere nos estudos de Informação e Mediações nas Práticas Sociais, nossa linha de pesquisa dentro da área de concentração Estudo dos Meios e da Produção Mediática, porque pretende estudar o processo de produção jornalística a partir da organização do trabalho, das relações profissionais e do direito à saúde, para assim mapear as relações de prazer e sofrimento no trabalho do jornalista, a partir das narrativas dos próprios trabalhadores da notícia.

Nesse cenário, muitas vezes há um ambiente propício ao adoecimento e são criadas estratégias defensivas para que o trabalho seja realizado. Buscaremos também observar como se constrói ou não a cidadania entre os jornalistas no ambiente de trabalho, a partir do direito à saúde no trabalho e a falta de consolidação dos direitos trabalhistas entre esses profissionais. 
Para tanto, analisamos como essas relações foram construídas ao longo da história do jornalismo, observando a organização do trabalho e a saúde do trabalhador, as relações profissionais e a contribuição ou não do movimento sindical para a saúde do jornalista, além do impacto das novas tecnologias nesse contexto.

A relação de prazer e sofrimento no trabalho do jornalista terá a psicodinâmica do trabalho como referencial teórico. No entanto, trata-se de um estudo do campo da comunicação, dentro da área do conhecimento de ciências sociais aplicadas, que tem como referência metodológica a pesquisa qualitativa e a análise de conteúdo. Não utilizamos o procedimento metodológico da psicodinâmica do trabalho ${ }^{1}$ e sim a teoria construída por Dejours sobre prazer e sofrimento para pensar o trabalho do jornalista. A mediação dessa teoria foi fundamental para analisar o conteúdo das entrevistas. Sem ela, esse trabalho não seria o mesmo.

Segundo Minayo (2010, p.57), o método qualitativo "se aplica ao estudo da história, das relações, das representações, das crenças, das percepções e das opiniões, produtos das interpretações que os humanos fazem a respeito de como vivem, constroem seus artefatos e a si mesmos, sentem e pensam". Esse tipo de abordagem se conforma "melhor a investigações de grupos e segmentos delimitados e focalizados, de história social sob ótica dos atores, de relações e para análises de discursos e de documentos", o que vai ao encontro dos objetivos desta pesquisa, que estuda jornalistas e a forma como eles veem a organização do trabalho, o prazer e o sofrimento.

Para isso, buscamos fazer uma contextualização histórica, alicerçada em uma pesquisa bibliográfica que se baseou em quatro vertentes: Cidadania; Organização do

\footnotetext{
${ }^{1}$ Dejours (1992, p.141-158) descreve o procedimento metodológico que utiliza. A pesquisa se inicia a partir da demanda dos trabalhadores. Primeiramente é realizada uma fase documental sobre o processo de trabalho e de visita ao local de trabalho. A pesquisa em si se realiza com um grupo de trabalhadores, e os pesquisadores se apresentam e mostram claramente o enunciado do estudo. Depois os trabalhadores expressam suas opiniões. Há uma elaboração coletiva dos temas discutidos nessas reuniões. "O alvo da pesquisa é a relação do coletivo com o trabalho e os efeitos mascarados dos sistemas coletivos de defesa em relação ao sofrimento" (Ibid., p. 145). O material de análise da pesquisa é resultado da discussão coletiva, os comentários são analisados, inclusive as posições contraditórias no grupo. Não se trata apenas da descrição dos fatos apresentados, é feita uma observação clínica pela equipe de pesquisadores e a interpretação das defesas coletivas. O método de investigação consiste na análise do trabalho psíquico imposto ao sujeito. Todo esse material é validado, durante a própria pesquisa, no desenvolvimento da investigação, e em um segundo momento, quando se reúnem os trabalhadores que participaram da pesquisa para lhes devolver uma síntese dos resultados, podendo-se modificar o relatório final a partir das novas contribuições dessa discussão. Essa é a base do procedimento metodológico da psicodinâmica do trabalho, o qual não é utilizado nesta pesquisa. Nós nos baseamos na teoria desenvolvida pelo autor para pensar o sofrimento e o prazer no trabalho dos jornalistas a partir da análise de conteúdo das entrevistas realizadas.
} 
Trabalho; História do Jornalismo; e Saúde do Trabalhador. Os autores dessas áreas subsidiaram a construção dos três capítulos seguintes da tese e contextualizaram a narrativa e a análise das entrevistas.

A questão da cidadania foi analisada a partir de autores como Marshall (1967), Manzini-Covre (1993), Santos (2007), Heller (1989), Saes (2000), Dagnino (2004), Gentilli (2005) e Bobbio (1992), além de documentos como a Declaração Universal dos Direitos Humanos, o Pacto Internacional dos Direitos Econômicos, Sociais e Culturais, a Constituição Brasileira e a CLT (Consolidação das Leis do Trabalho). Essa reflexão subsidia a análise sobre os direitos do trabalhador jornalista, que aparece no segundo capítulo, a partir dos relatos apresentados pelos entrevistados.

A organização do trabalho, que teve subsídios de autores como Heloani (2003a), Antunes (2007, 2009), Alves (2011) e Harvey (1992), juntamente com os textos de história do jornalismo nos ajudaram a contextualizar o terceiro capítulo da tese. $\mathrm{O}$ intuito foi construir uma história da organização do trabalho no jornalismo. Contribuíram para isso Abramo (2007), Hime (1997), Silva (1988), Traquina (2005, 2008), Marcondes Filho (2009), Sodré (2011), Kotscho (2006), Kucinski (1998, 2005), Dines (1986), Koshiyama (2005), Ribeiro (1998), entre outros.

Especificamente sobre o trabalho do jornalista, três publicações foram centrais para essa pesquisa. Heloani (2003b) estudou a qualidade de vida do "trabalhadorjornalista" no mundo contemporâneo, considerando a relação com o trabalho e sintomas psicológicos. Entre as suas conclusões, aponta: a obrigação dos jornalistas se adaptarem às novas tecnologias "freneticamente"; o efeito colateral danoso das práticas organizacionais; a falta de identificação coletiva; o enxugamento das redações (p.78$80)$.

Outra pesquisadora a entrevistar jornalistas foi Travancas (1993), que refletiu sobre a constituição da identidade do jornalista. O ambiente jornalístico é descrito como "um espaço com divisões hierárquicas e regras fixas" (Ibid., p.29). Um dos aspectos levantados pela autora é que os jornalistas não são donos do seu tempo, sendo comum ser chamado quando está de folga para uma urgência ou levar matérias para casa.

Já Ribeiro (2001) apresenta o funcionamento da empresa jornalística, a redação e suas contradições, fazendo inclusive uma comparação da redação com a linha de montagem. Ele mostra como a tensão é usada para gerar mais produção e como ocorre o estabelecimento das avaliações individuais. 
Esses três estudos citados olharam para as condições de trabalho dos jornalistas nos anos 80, 90 e início de 2000. Tentamos aprofundar esse percurso histórico e observar como estão essas relações na atualidade, a partir dos depoimentos de nossos entrevistados, com o aprofundamento do advento da internet e as mudanças na organização do trabalho, que atingem grande complexidade com um discurso que nem sempre corresponde às práticas e exigem um envolvimento total dos trabalhadores.

Outros trabalhos acabaram se destacando na reta final: a dissertação de mestrado de Ferraciolli (2000) e os artigos de Kilesse e Machado (2009a, 2009b) e o de Grisci e Rodrigues (2007). O primeiro apresenta pesquisa realizada a partir de 19 entrevistas semiestruturadas com jornalistas do Paraná entre 25 e 50 anos em que avalia o sofrimento presente nas condições de trabalho, tendo a psicodinâmica do trabalho e outros estudos da área de psicologia como referência. Essa dissertação não chega a trabalhar a relação entre prazer e sofrimento. Os segundos abordam a questão do estresse e a saúde dos jornalistas, baseado em pesquisa realizada com 44 jornalistas de uma empresa jornalística de Minas Gerais. Já os terceiros refletem sobre a passagem do fordismo para o pós-fordismo a partir de um estudo de caso das rotinas produtivas de um jornal do Rio Grande do Sul, que contou com seis entrevistas semiestruturadas com jornalistas e observação não-participante.

Também procuramos agregar estudos mais recentes sobre o trabalho do jornalista. Dois livros congregam pesquisas realizadas no âmbito da Universidade de São Paulo e da Universidade Federal de Santa Catarina. Figaro, Nonato e Grohmann (2013), da USP, refletem sobre as mudanças no mundo do trabalho do jornalista. Cada um é responsável por um artigo, respectivamente, "Perfis e Discursos de Jornalistas no Mundo do Trabalho"; "O Perfil Diferenciado dos Jornalistas Associados ao Sindicato de São Paulo"; e “O jornalista profissional no Estado de São Paulo”. Já Mick e Lima (2013), da UFSC, realizaram um perfil do jornalista brasileiro, detalhando características demográficas, políticas e do trabalho jornalístico em 2012.

Da vertente da saúde do trabalho, destacamos os textos de Dejours (1992, 2012a,b), pois é a ação psicodinâmica entre prazer e sofrimento no trabalho que guia essa pesquisa.

O sofrimento começa quando a relação homem-organização do trabalho está bloqueada; quando o trabalhador usou o máximo de suas faculdades intelectuais, psicoafetivas, de aprendizagem e de adaptação. Quando um trabalhador usou de tudo de que dispunha de saber e de poder na organização do trabalho e quando ele não pode mais mudar de tarefa: isto é, quando foram esgotados os meios de 
defesa contra a exigência física. Não são tanto as exigências mentais ou psíquicas de trabalho que fazem emergir o sofrimento (se bem que este fator seja evidentemente importante quanto à impossibilidade de toda a evolução em direção ao seu alívio). A certeza de que o nível de insatisfação não pode mais diminuir marca o começo do sofrimento. (DEJOURS, 1992, p.52)

Dejours (1992) mostra que o sofrimento auxilia a produtividade através do uso que se faz dos mecanismos de defesa usados contra ele. No jornalismo, percebemos que há tanto a exploração da tensão e do medo, quanto à neutralização do medo para enfrentar os riscos da profissão em coberturas perigosas. Por outro lado, percebe-se a existência de um prazer proveniente do conteúdo significativo e simbólico do trabalho, o que pode ser indício de uma ideologia defensiva para enfrentar as precariedades do dia a dia.

Como afirma Dejours (2012b, p.14), o trabalho pode também abrir "as portas ao prazer" e desempenhar "um papel de mediador na construção da saúde". Além isso, "o trabalho vivo não consiste apenas em produzir, mas implica ainda transformar-se a si próprio" (p.20). Essa dimensão transformadora do trabalho também é latente no trabalho do jornalista.

A psicodinâmica do trabalho pleiteia em favor da hipótese segundo a qual o trabalho não é redutível a uma atividade de produção no mundo objetivo. O trabalho é sempre uma provação para a subjetividade, da qual esta sai sempre ampliada, engrandecida ou, ao contrário, reduzida, mortificada. Trabalhar constitui, para a subjetividade, uma provação que a transforma. Trabalhar não é apenas produzir, mas ainda transformar-se a si próprio e, no melhor dos casos, é uma ocasião oferecida à subjetividade de provar-se a si mesma, de realizar-se. (DEJOURS, 2012b, p. 33-34)

\section{3 - Procedimentos metodológicos}

Buscamos reconstituir a história da organização do trabalho no jornalismo a partir de estudos na área de comunicação e das entrevistas realizadas com jornalistas de diferentes gerações. Também consultamos a legislação, documentos e acompanhamos notícias sobre o trabalho dos jornalistas em sites especializados em cobertura ou crítica de mídia, como o Comunique-se e o Observatório da Imprensa, além da revista 
Imprensa e o próprio jornal Unidade do Sindicato dos Jornalistas Profissionais no Estado de São Paulo.

Realizamos buscas de artigos, livros e estudos sobre o trabalho e a saúde do jornalista, em bases de dados como a Scientific Electronic Library Online - SciELO, biblioteca eletrônica que abrange uma coleção selecionada de periódicos científícos brasileiros; a Biblioteca Virtual em Saúde - BVS, que trabalha em rede e possibilita a consulta a artigos a partir de busca integrada em cerca de 70 bases de dados de diversos países; e o Portal de Periódicos da Capes (Coordenação de Aperfeiçoamento de Pessoal de Nível Superior). Também contamos com o sistema Dedalus da USP e suas bibliotecas.

Assim contextualizamos questões relacionadas à cidadania, ao jornalismo, à organização do trabalho e à saúde do trabalhador para depois realizar as entrevistas semiabertas com os jornalistas. Ouvimos os relatos desses profissionais sobre a organização do trabalho, a percepção deles sobre a própria saúde, relações entre vida pessoal e trabalho, práticas profissionais, prazer e sofrimento no trabalho. Também fizemos perguntas sobre o uso das novas tecnologias, buscando delinear os impactos que elas tiveram sobre as práticas jornalísticas e sobre o trabalho.

Formamos um grupo heterogêneo com profissionais de diferentes faixas etárias e com experiência em diferentes veículos de comunicação (jornais, revistas, internet, TV e rádio), mesmo freelancers, pois eles também estão submetidos à forma como o jornalismo está organizado e fazem parte dessa organização, em um ambiente permeado de terceirizações, quarteirizações e casos de profissionais que são contratados como pessoa jurídica.

Optamos por fazer uma seleção intencional, aquela em que "o pesquisador faz a seleção por juízo particular, como conhecimento do tema ou representação subjetiva" (DUARTE, 2005, p-69). Dessa forma, criamos seis grupos divididos por faixa etária: 20 a 29 anos, 30 a 39 anos, 40 a 49 anos, 50 a 59 anos, 60 a 69 anos e mais de 70 anos. Para termos a visão de diferentes gerações, estipulamos que cada grupo teria pelo menos dois entrevistados.

Para selecionar os entrevistados, criamos em conjunto com nossa orientadora uma lista com diversas possibilidades, chegando a 70 nomes de jornalistas. Essas pessoas eram consideradas, levando-se em conta o trabalho que realizavam, a pluralidade de veículos e meios de comunicação, as idades dos jornalistas em relação aos grupos criados para a pesquisa, e o grande envolvimento com a profissão. Os 
próprios jornalistas chegaram a indicar outros profissionais. Eventos e livros relacionados ao jornalismo também nos auxiliaram a compor essa lista.

Levantados os nomes, pesquisávamos a vida profissional da pessoa utilizando redes sociais, como Linkedin e Facebook, e sites, como Portal dos Jornalistas e a Plataforma Lattes. Além disso, fizemos uma pesquisa sobre a produção jornalística dos entrevistados, lendo, ouvindo ou assistindo as suas obras. A consulta aos livros também foi fundamental para a seleção de entrevistados, tanto aqueles escritos por eles mesmos como os que citavam seus nomes ou traziam seus trabalhos.

Com essas informações, fechamos a lista buscando formar um grupo com experiências heterogêneas. Entramos em contato com 41 jornalistas, dos 70 nomes levantados inicialmente. De alguns conseguimos retorno, outros não manifestaram interesse. Por fim, realizamos 21 entrevistas semiabertas, um dos tipos possíveis de entrevista individual em profundidade, buscando um material qualitativo.

Esse tipo de entrevista traz uma "técnica qualitativa que explora um assunto a partir da busca de informações, percepções e experiências de informantes para analisálas e apresentá-las de forma estruturada". Procuram-se respostas intensas e "elementos para a compreensão de uma situação ou estrutura de um problema”. (DUARTE, 2005, p.62-63)

Nesta pesquisa, procuramos subsídios para construir um panorama da organização do trabalho no jornalismo e de como se dá a relação de prazer e sofrimento no trabalho do jornalista. Para tanto, os jornalistas falaram de sua história e experiências, dando vazão a sua subjetividade, mas também aos fatos concretos que vivenciaram.

Os jornalistas entrevistados receberam um Termo de Consentimento Livre e Esclarecido $^{2}$, no qual conheceram detalhes da pesquisa e puderam optar pela identificação ou não de seu nome. Para criar o termo, nos inspiramos em um modelo fornecido por Roberto Heloani. Geralmente os trabalhos realizados no âmbito da psicologia e das ciências sociais optam pelo sigilo do nome do entrevistado. Resolvemos dar ao entrevistado a opção de identificação do nome porque acreditamos que seria relevante para a pesquisa saber quem eram os jornalistas ou onde trabalharam.

\footnotetext{
${ }^{2}$ Não chegamos a submeter o termo a comitê de ética, pois essa não é uma exigência do campo da comunicação.
} 
Saber quem fala e de onde fala foi importante para a construção da narrativa sobre o trabalho do jornalista.

Ao mesmo tempo, não queríamos que as falas dos jornalistas pudessem de alguma forma prejudicá-los em suas carreiras. Para profissionais mais jovens ou que atuavam em determinados meios poderia não ser bom ter seu nome relacionado a uma pesquisa ligada à organização do trabalho. Todos esses aspectos foram conversados com os entrevistados, que ficaram livres para escolher se queriam o sigilo. Três jornalistas pediram para ver o que seria publicado do que falaram antes da finalização da tese: Aline Scarso, Bob Fernandes e um dos jornalistas que não quis se identificar, o qual chamamos de João, de 27 anos, que também solicitou que não se falasse o nome dos locais que ele trabalhou.

Realizamos entrevistas semiabertas, que segundo Duarte (2005, p.66), contam com um roteiro de questões voltadas para o interesse da pesquisa e buscam tratar da amplitude do tema, explorando ao máximo cada resposta. É conduzida em parte pelo entrevistado, valorizando seu conhecimento, mas ajustada ao roteiro do pesquisador.

Optamos por elaborar um roteiro maior pensando na possibilidade de esgotar ao máximo os temas abordados. As questões foram elaboradas a partir de duas entrevistas testes realizadas em 2011. Assim foi possível refletir sobre o que foi perguntado e agregar novos questionamentos. À medida que a pesquisa avançava, com a leitura da bibliografia, a participação em eventos e a qualificação, o roteiro foi aperfeiçoado até chegar à versão final usada para as 21 entrevistas:

1. Dados Gerais: nome, idade, tempo de atuação no jornalismo; Formado em quê? Quando?; Onde já trabalhou e quais atividades na área já realizou?; Onde trabalha atualmente e que atividade realiza?; Qual o seu tipo de contrato de trabalho?

2. Fale sobre o seu trabalho.

3. Como é a sua rotina de trabalho?

4. Como você avalia o seu ritmo de trabalho (horas por dia, fim de semana, matérias produzidas)?

5. Existe muita pressão no seu trabalho? De que forma? (avaliação individual?)

6. Como você avalia a condição de trabalho do jornalista atualmente?

7. Você considera a sua profissão estressante? Pode dar algum exemplo de situações desse tipo? 
8. Já houve alguma situação de trabalho que o levou a ter algum tipo de dor, por exemplo, dor de cabeça, dor nos pulsos, lombar. Se sim, é comum isso acontecer? Com que frequência? Em que situações?

9. Existe alguma limitação no seu trabalho que o incomode?

10. Você acredita que tem autonomia para realizar o seu trabalho? Se sim, de que forma? Se não, por quê?

11. Há liberdade para a sugestão de pautas?

12. As matérias costumam ser feitas mais na redação ou é comum sair à rua?

13. O trabalho permite que você exerça toda a sua criatividade? Ou há espaço para exercê-la?

14. O que você acha necessário para melhorar o seu trabalho como jornalista tanto nas práticas profissionais quanto nas condições de trabalho e saúde?

15. Você acha que o seu trabalho afeta a sua vida pessoal de alguma forma?

16. Você acredita que existe muita competitividade entre os colegas do seu meio de trabalho? E em outros lugares que você trabalhou?

17 - Como é o seu relacionamento com a chefia? E em outros locais que trabalhou?

18 - Qual o impacto das novas tecnologistas no jornalismo?

19 - Você já vivenciou ou presenciou alguma situação de assédio moral?

20 - Há relatos de uso excessivo de álcool ou drogas por jornalistas. Você já teve conhecimento de alguma situação desse tipo?

21 - Você já vivenciou algum tipo de violência por ser jornalista?

22 - O que vê como sofrimento no [seu] trabalho de jornalista?

23 - O que é prazer para você no trabalho de jornalista?

24 - O que é ser jornalista para você?

25 - Tem algo mais que você gostaria de falar sobre o trabalho do jornalista e não foi contemplado nas questões?

Não se trata de um roteiro fechado. A ordem das questões mudava de acordo com a entrevista, assim como surgiam outras perguntas conforme as colocações e experiências dos entrevistados. Da mesma forma, alguns temas foram tratados antes de serem perguntados. Isso deu dinamicidade às entrevistas. Além disso, as questões 2 e 25 são abertas para que o entrevistado possa acrescentar reflexões não direcionadas pela pesquisadora.

Da forma que as entrevistas aconteceram, a maioria dos temas do roteiro foi abordada nas falas dos jornalistas. As entrevistas foram gravadas para a transcrição na 
íntegra. Também temos um caderno de campo em que anotamos nossas impressões durante a entrevista, os gestos dos entrevistados e os principais pontos abordados.

Buscamos "visões e relatos diversificados" (DUARTE, 2005, p.69). A partir da fala dos jornalistas, refletimos sobre o cotidiano de trabalho, as condições organizacionais vivenciadas pelos profissionais e o sentido que os mesmos dão ao trabalho que realizam. Quando observamos se o trabalho é fonte de prazer ou sofrimento, partimos das perspectivas da psicodinâmica do trabalho, desenvolvida por Christophe Dejours. Para tanto, fizemos a análise dos conteúdos das falas, tendo os conceitos de psicodinâmica como referência teórica.

Como se trata de uma pesquisa qualitativa e se utiliza a análise de conteúdo, também tivemos Minayo (2010) e Bardin (2009) como referências para definir os procedimentos metodológicos. O foco das abordagens qualitativas, segundo Minayo (2010, p.268), é a “compreensão da intensidade vivencial dos fatos e das relações humanas". Destacamos ainda a relação com a dinâmica da história.

as modalidades qualitativas aqui propostas, na sua aplicação $(a)$ devem ser contextualizadas, permitindo distinguir as visões dominantes de outras formas de pensar a realidade (pois as classes e segmentos se encontram entre si, no seio de uma sociedade em relação e aculturação recíproca); (b) devem levar em conta a origem e a historicidade dos fatos sociais e dos grupos que estão sendo estudados; (c) devem incluir os espaços formais da economia e da política como matrizes essenciais da cultura da família, da vizinhança, dos grupos etários, dos grupos de lazer, dos grupos religiosos, mas também percebê-los como sendo permeados por esse mundo da vida; $(d)$ devem considerar espaços ao mesmo tempo de consensos e de conflitos, contradições, subordinação e resistência, tanto as unidades de trabalho como o bairro, o sindicato como a casa, a consciência como o sexo, a política como a religião. (MINAYO, 2010, p.30)

Uma questão importante a ser considerada é que as entrevistas trazem as reflexões do sujeito sobre a realidade que vivenciam, com todas suas crenças, maneiras de sentir e atuar, mas também "como forma privilegiada de interação social", estão sujeitas "à mesma dinâmica das relações existentes na própria sociedade". No caso de grupos marcados por conflitos, "cada entrevista expressa de forma diferenciada a luz e a sombra da realidade, tanto no ato de realizá-la como nos dados que aí são produzidos". (Ibid., p. 262-263)

A autora recomenda que ao se utilizar entrevistas semiestruturadas, é preciso estar atento para não analisar apenas os temas previamente estabelecidos e estar aberto para "explorar as estruturas de relevâncias dos entrevistados, trazidas do campo" (Ibid., 
p.267). Outra ressalva é de que "os pesquisadores são, dialeticamente, autores e frutos de seu tempo histórico" (Ibid.,p.41).

Outro aspecto distintivo das Ciências Sociais é o fato de que ela é intrínseca e extrinsecamente ideológica. Ninguém hoje ousaria negar a evidência de que toda ciência, em sua construção e desenvolvimento, passa pela subjetividade e por interesses diversos. Nos processos de produção do conhecimento se veiculam interesses e visões de mundo historicamente construídos. (MINAYO, 2010, p.4142)

Compartilhamos da visão de Minayo (2010, p.46) que afirma não ser possível acreditar em ciência neutra, "pois todo o processo de construção teórica é, ao mesmo tempo, uma dialética de subjetivação e objetivação", havendo espaço para a criatividade do pesquisador. Além disso, ela fala sobre a articulação entre hermenêutica e dialética, trazendo aspectos importantes a serem considerados pela pesquisa qualitativa:

- O investigador deve buscar, ao máximo, com dados históricos e também pela "empatia" o contexto de seu texto, dos entrevistados e dos documentos que analisa. $\mathrm{O}$ "discurso" sempre expressa um saber partilhado com outros e marcado pela tradição, pela cultura e pela conjuntura.

(...)

- O investigador não deve buscar nos textos uma verdade essencialista, mas o sentido que o entrevistado (autor, biografado) quis expressar...

(...)

Como práxis interpretativa são os seguintes o caminho da hermenêutica:

- buscar as diferenças e as semelhanças entre o contexto do autor e o contexto do investigador;

- explorar as definições de situação do autor, que o texto ou a linguagem em análise permite...;

- supor o compartilhamento entre o mundo observado e os sujeitos da pesquisa com o mundo da vida do investigador (porque compreender é sempre compreender-se). E a partir de tal postura, perguntar "por que" e "sob que condições" o sujeito da linguagem que busca entender cria determinadas situações, valoriza determinadas coisas, atribui determinadas responsabilidades a certos atores sociais e, em síntese, expressa-se e posiciona-se de tal maneira e não de outra;

- buscar entender as coisas e os textos "neles mesmos"...;

- apoiar toda a reflexão sobre determinada realidade sobre o contexto histórico, partindo do pressuposto que o investigador-intérprete e seu "sujeito" de observação e pesquisa são expressões de seu tempo e se seu espaço cultural. (MINAYO, 2010, p. 344-345)

Como se pode ver a autora valoriza a questão do materialismo histórico para se pensar a pesquisa qualitativa, o que também é considerado neste estudo. Segundo Marx (2010a, p. 97), “o modo da vida material condiciona o processo da vida social, política e espiritual em geral. Não é a consciência do homem que determina o seu ser, mas, ao 
contrário, é o seu ser social que determina a sua consciência”. Hegel contribuiu para a dialética ao mostrar que não há dicotomia entre sujeito e objeto. Marx rearticula sujeito e objeto em termos históricos e materiais.

Meu método dialético, por seu fundamento, difere do método hegeliano, sendo a ele inteiramente oposto. Para Hegel, o processo do pensamento - que ele transforma em sujeito autônomo sob o nome de ideia - é o criador do real, e o real é apenas uma manifestação externa. Para mim, ao contrário, o ideal não é mais do que o material transposto para a cabeça do ser humano e por ela interpretado.

Critiquei a dialética hegeliana, no que ela tem de mistificação... A mistificação por que passa a dialética nas mãos de Hegel não o impediu de ser o primeiro a apresentar suas formas gerais de movimento, de maneira ampla e consciente. (MARX, 2012, p.28-29)

Para Minayo (2010, p.340), a grande contribuição marxista para a dialética é “inverter, teoricamente e na sua aplicação prática, a visão hegeliana de primazia do pensamento sobre a ação na construção da realidade, valorizando a historicidade, e a relação entre a base material e as representações da realidade". Trazendo isso para a pesquisa qualitativa, percebe que "não existe ponto de vista fora da história, nada é eterno, fixo e absoluto, portanto, não há nem ideias, nem instituições nem categorias estáticas".

Essas considerações são importantes para pontuar com que perspectivas foi realizada a análise de conteúdo das entrevistas. Segundo Bardin (2009, p.23), a análise de conteúdo foi além da descrição, possibilitando a construção de inferências a partir do material analisado. O autor também aponta que "a técnica de análise de conteúdo adequada ao domínio e ao objetivo pretendidos tem de ser reinventada a cada momento" (Ibid., p.32).

Neste estudo, optamos por uma análise temática das entrevistas, que, segundo Bardin (2009, p.37) trata-se de uma análise dos significados. A análise temática "é transversal, isto é, recorta o conjunto das entrevistas através de uma grelha de categorias projetada sobre os conteúdos. Não se têm em conta a dinâmica e a organização, mas a frequência dos temas extraídos do conjunto dos discursos" (Ibid., p.220).

O tratamento descritivo seria a primeira fase da análise de conteúdo. A criação de categorias permite "a classificação dos elementos de significação constitutivos da mensagem" em espécie de "gavetas ou rubricas significativas" (p.39). Essa classificação tenta fazer emergir um sentido para a análise.

A intenção da análise de conteúdo é a inferência de conhecimentos relativos às condições de produção (ou, eventualmente, de recepção), inferência esta que recorre a indicadores (quantitativos ou não). 
O analista é como um arqueólogo. Trabalha com vestígios: "os documentos" que pode descobrir ou suscitar. Mas os vestígios são as manifestações de estados, de dados e de fenômenos. Há qualquer coisa para descobrir por e graças a eles. Tal como a etnografia necessita da etnologia para interpretar as suas descrições minuciosas, o analista tira partido do tratamento das mensagens que manipula para inferir (deduzir de maneira lógica) conhecimentos sobre o emissor da mensagem ou sobre o seu meio, por exemplo. Tal como um detective, o analista trabalha com índices cuidadosamente postos em evidência por procedimentos mais ou menos complexos. Se a descrição (a enumeração das características do texto, resumida após tratamento) é a primeira etapa necessária e se a interpretação (a significação concedida a essas características) é a última fase, a inferência é o procedimento intermédio, que vem permitir a passagem, explícita e controlada, de uma à outra. (BARDIN, 2009, p.40-41)

Especificamente sobre o uso da análise de conteúdo em entrevistas, Bardin (2009, p.89) coloca que é um recurso indispensável. As entrevistas devem ser registradas e integralmente transcritas, inclusive hesitações, risos, silêncios e estímulos do entrevistador. No caso desta pesquisa, as 21 entrevistas foram realizadas pessoalmente e gravadas. Todas foram $\operatorname{transcritas}^{3}$ da forma recomendada, totalizando 406 páginas de transcrições ${ }^{4}$ e um total de 1.140.274 caracteres com espaço. Uma média de 19,5 páginas e 54.298 caracteres por entrevista. As entrevistas somaram 27 horas, 57 minutos e 30 segundos de gravação. A gravação mais curta teve 40 minutos e 28 segundos, já a mais longa, 2 horas, 8 minutos e 52 segundos. A média de duração de entrevista gravada foi de 1 hora e 20 minutos.

$\mathrm{O}$ analista que lida com este tipo de material verbal fica rápida e concretamente sujeito a um dilema. Pode, certamente, proceder a uma análise de conteúdo clássica, com grelha de análise categorial, privilegiando a repetição de frequência dos temas, com todas as entrevistas juntas. A técnica já deu provas e permite percorrer ao nível manifesto todas as entrevistas. Mas, no fim, esta redução deixará na sombra parte da riqueza de informação específica deste tipo de investigação. $O$ resultado final será uma abstracção incapaz de transmitir o essencial das significações produzidas pelas pessoas, deixando escapar o latente, o original, o estrutural, o contextual. É possível resolver uma dessas insuficiências referenciando temas numa base latente... No entanto, a técnica temática de frequência tipo Berelson, ainda que indispensável, mostra-se, quando utilizada apenas sobre esse tipo de material, demasiado limitada. A manipulação temática acaba então por colocar todos os elementos significativos

\footnotetext{
${ }^{3}$ Das 21 entrevistas, 19 foram transcritas pela própria pesquisadora. As duas faltantes foram transcritas pela sua irmã Leiliane Oliveira Reimberg e depois ouvidas na íntegra pela pesquisadora para fazer as marcas da pré-análise.

${ }^{4}$ Para fazer a contagem do número de páginas das entrevistas, colocamos todas em um mesmo documento, utilizando a mesma configuração da tese: times new roman 12, espaçamento entre linhas de 1,5 e não utilizamos espaçamento entre parágrafos.
} 
numa espécie de "saco de temas", destruindo definitivamente a arquitectura cognitiva e afectiva das pessoas singulares.

Teremos então de rejeitar a análise horizontal em matérias de entrevistas? Não, porque esse tipo de análise é insubstituível no plano da síntese, da fidelidade entre analistas; permite a relativização, o distanciamento; mostra as constâncias, as semelhanças, as regularidades. Só que é preciso completá-la, e de preferência previamente, por outra técnica de decifração - e de arroteamento entrevista por entrevista. (BARDIN, 2009, p.91)

$\mathrm{Na}$ análise que fizemos, tentamos aliar a busca de um ponto de vista geral, que emerge do todo das entrevistas, com as singularidades específicas de cada entrevistado. Dessa forma, mostramos semelhanças e diferenças, dando espaço também para a história pessoal de cada sujeito.

Seguimos alguns procedimentos para colocar isso em prática. Conforme ouvíamos e fazíamos a transcrição, costumávamos já indicar os trechos que consideramos mais importantes na cor vermelho escuro e fazer comentários em laranja de nossas primeiras impressões. Em alguns casos, já fizemos as primeiras relações entre as entrevistas. Como fomos transcrevendo todas de forma seguida, estavam vivas em nossa memória as falas dos entrevistados transcritas anteriormente. Além disso, havia o caderno de anotações de campo usado durante as entrevistas, que permitia de forma rápida comparar as impressões tidas durante a entrevista com as impressões ao realizar as transcrições. Chamamos essa fase de pré-análise.

Para analisar o conteúdo e aprofundar essas relações, classificamos as informações de forma criteriosa, organizando grupos de temas comuns, gerando categorias. Essas "são estruturas analíticas construídas pelo pesquisador que reúnem e organizam o conjunto de informações obtidas a partir do fracionamento e da classificação em temas autônomos, mas inter-relacionados". No caso de entrevistas semiabertas, "as categorias têm origem no marco teórico e são consolidadas no roteiro de perguntas" semiestruturadas. (DUARTE, 2005, p.79)

Inicialmente estabelecemos cinco categorias temáticas centrais para a análise: direitos trabalhistas, organização do trabalho, sentido do trabalho, sofrimento no trabalho e prazer no trabalho. Outra categoria complementar surgiu conforme relíamos as entrevistas e separávamos os temas: futuro do jornalista. Dessas categorias, das questões e das releituras das entrevistas, emergiram outros subtemas que foram trabalhados nas questões feitas aos jornalistas. Em relação aos direitos trabalhistas, os principais subtemas foram jornada de trabalho, bancos de horas e formas de contratação. Para organização do trabalho, emergiram rotinas de trabalho, características dos locais 
de trabalho, impactos das novas tecnologias, relações de trabalho, pressão e ritmo de trabalho, limitações. Em sentido de trabalho, além de olharmos para o significado de ser jornalista, observamos a relação entre trabalho e vida pessoal e o envolvimento com a profissão. Já a parte de prazer, abrangeu tanto o que os jornalistas apontaram como prazer na questão específica sobre isso quanto o que emergia durante suas falas em toda a entrevista, os discursos sobre autonomia e criatividade. O mesmo ocorreu com sofrimento, que ainda trouxe como subtemas o adoecimento, o estresse, o assédio moral, a discussão sobre riscos e violência no trabalho do jornalista, além das impressões sobre o uso de álcool e drogas. Em relação ao futuro dos jornalistas, os subtemas foram as reflexões sobre o que é necessário mudar para melhorar as condições de trabalho e de saúde do jornalista e outras pontuações feitas pelos entrevistados sobre o futuro da profissão, questões essas que foram tratadas na conclusão da tese.

A categorização é uma operação de classificação de elementos constitutivos de um conjunto por diferenciação e seguidamente, por reagrupamento segundo o gênero (analogia), com os critérios previamente definidos. As categorias são rubricas ou classes, as quais reúnem um grupo de elementos (unidades de registro, no caso da análise de conteúdo) sob um título genérico, agrupamento esse efectuado em razão das características comuns destes elementos.

(...)

Classificar elementos em categoria impõe a investigação do que cada um deles tem em comum com outros. $O$ que vai permitir o seu agrupamento é a parte comum existente entre eles. (BARDIN, 2009, p. 145-146)

Estabelecidas as categorias, relemos cada entrevista e fomos separando seus conteúdos em documentos diferentes conforme o tema em questão. Assim fomos criando diferentes documentos baseados primeiro no que chamamos de categorias temáticas centrais e outros baseados em alguns do subtemas. Dessa forma, pudemos olhar para o todo a partir de vários lugares e fazer as inferências que levaram às interpretações, vendo o que se repetia nas falas e o que as diferenciava. Tentamos ressaltar não só o que havia de comum como deixar espaço para as singularidades individuais dos sujeitos.

Cada trecho retirado para as categorias centrais e alguns subtemas ganhou cores de realce no texto diferentes e padronizadas. Assim, ao olhar para cada entrevista, sabíamos o que tinha sido usado para cada categoria temática e subtemas, e o que ficou de fora, permitindo que assim percebêssemos informações interessantes que não se enquadravam dentro das categorias estabelecidas e refletir sobre como aproveitá-las. Isso fez com que novos subtemas surgissem. Procuramos também dar espaço para as 
narrativas dos jornalistas e contar histórias individuais, que pudessem ilustrar o todo a partir das escolhas temáticas, ao mesmo tempo em que se valorizava a subjetividade de cada entrevistado.

Montamos o seguinte quadro, que foi impresso, para guiar nossas escolhas e permitir a divisão do conteúdo nos documentos, para a posterior análise:

\section{Quadro 1 - Categorias e Subtemas}

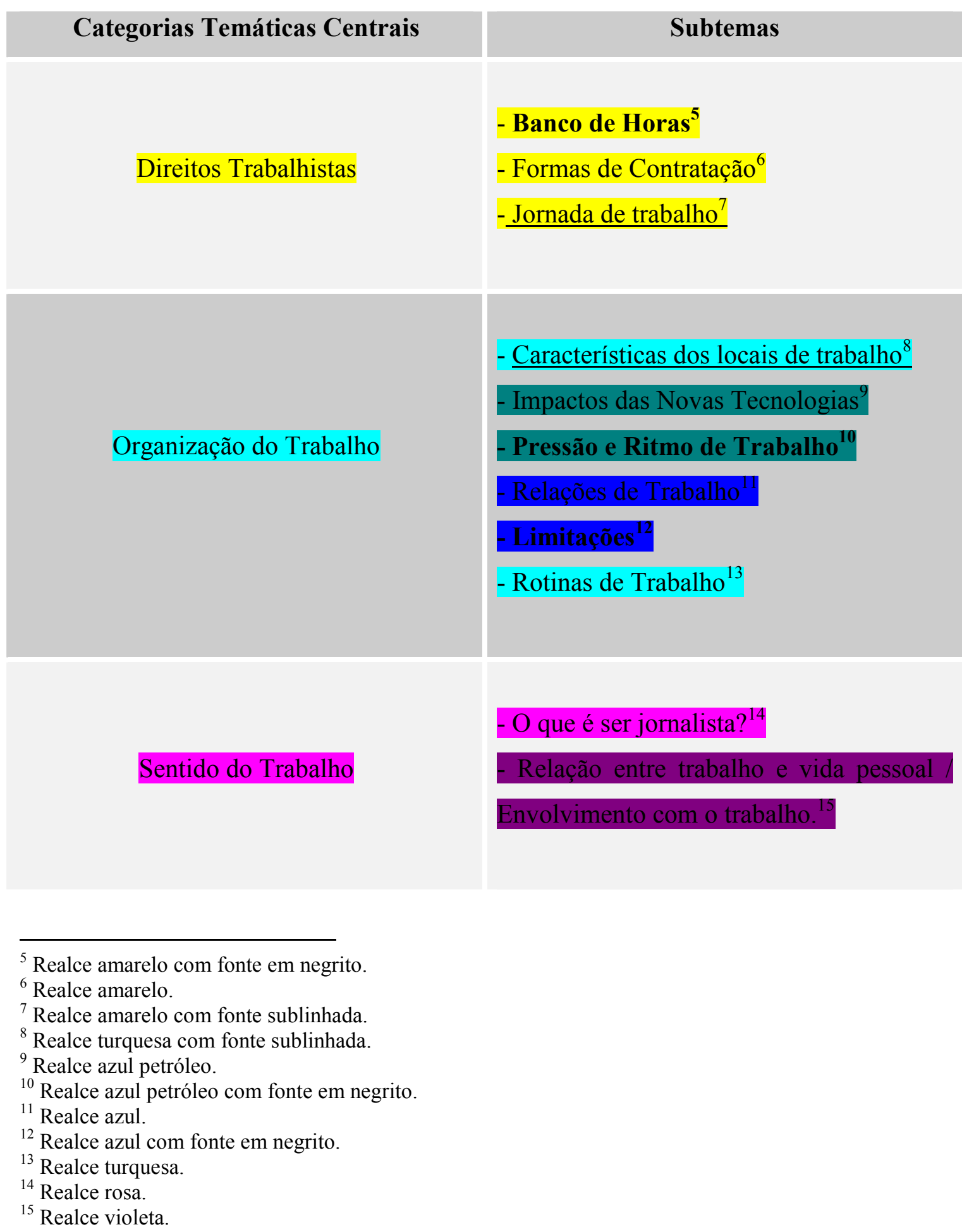




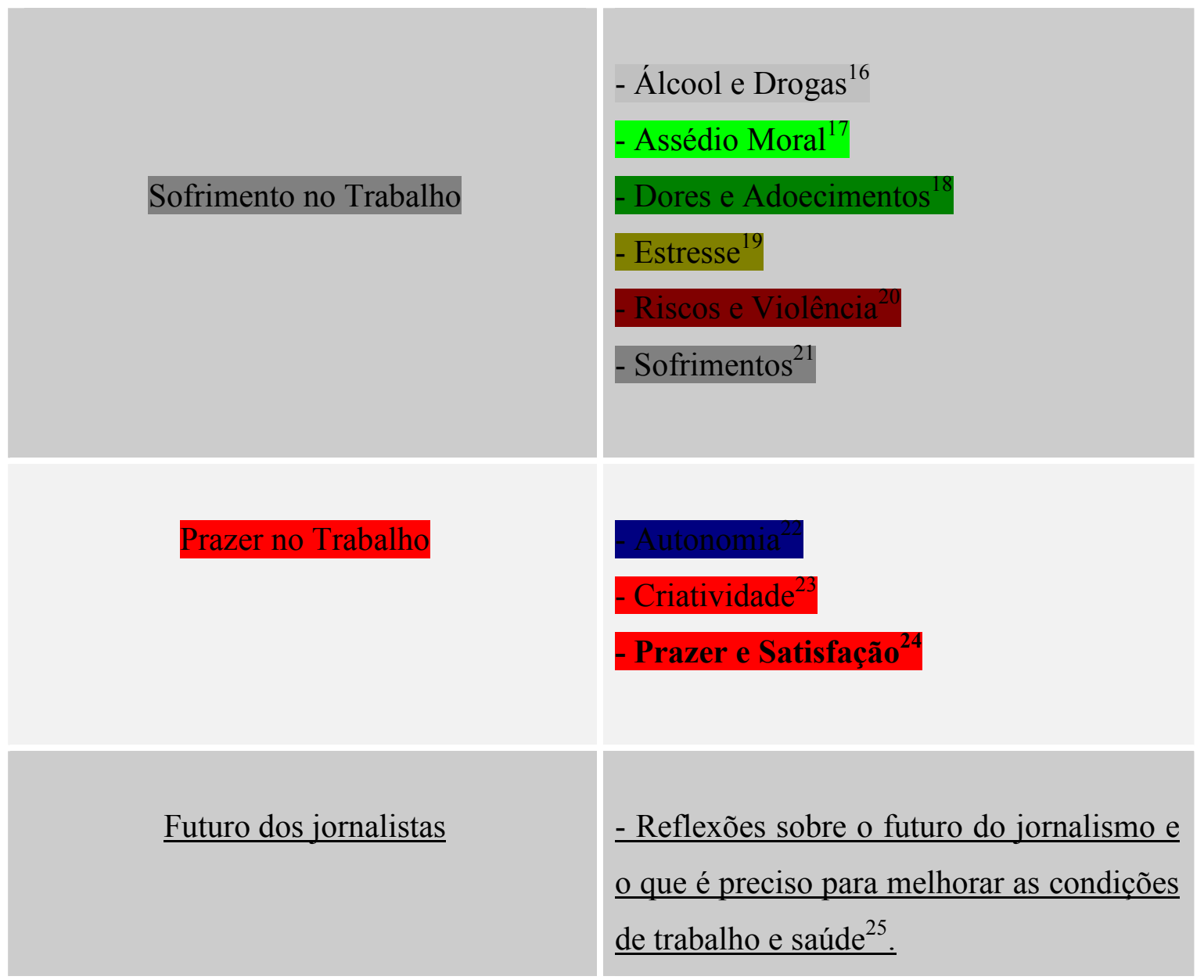

\section{4 - Os sujeitos da pesquisa}

Entre 10 de dezembro de 2013 e $1^{\circ}$ de julho de 2014, realizamos 20 entrevistas. Considerávamos que já havíamos fechado o quadro dos entrevistados, mas acabamos realizando mais uma entrevista no dia 21 de agosto, porque um dos jornalistas que gostaríamos de entrevistar e não tínhamos conseguido até então estaria em um evento

\footnotetext{
${ }^{16}$ Realce cinza $25 \%$.

${ }^{17}$ Realce verde brilhante.

${ }^{18}$ Realce verde.

${ }^{19}$ Realce amarelo escuro.

${ }^{20}$ Realce vermelho escuro.

${ }^{21}$ Realce cinza $50 \%$.

${ }^{22}$ Realce azul escuro.

${ }^{23}$ Realce vermelho.

${ }^{24}$ Realce vermelho com fonte em negrito.

${ }^{25}$ Sublinhado sem realce.
} 
em São Paulo. Assim fizemos a entrevista com Lúcio Flávio Pinto nessa data e fechamos um grupo de 21 entrevistados, formado por sete mulheres e 14 homens.

Foram entrevistados quatro jornalistas do grupo de 20 a 29 anos, cinco jornalistas do grupo de 30 a 39 anos, três jornalistas do grupo de 40 a 49 anos, três jornalistas do grupo de 50 a 59 anos, três jornalistas do grupo de 60 a 69 anos e três jornalistas do grupo com mais de 70 anos. A mais jovem entrevistada foi a jornalista Priscilla Nery Rocha, de 25 anos, e o mais velho, Alberto Dines, de 82 anos.

Montamos abaixo quadros resumos, divididos por faixa etária, com as informações de todos entrevistados, para possibilitar a visualização rápida de quem são os sujeitos desta pesquisa. Para aqueles que optaram pela não identificação, criamos um nome fictício sem sobrenome.

\section{Quadro 2 - Jornalistas entrevistados de 20 a 29 anos}

\begin{tabular}{|c|c|c|}
\hline Sujeito & Idade & Experiência Profissional \\
\hline Priscilla Nery Rocha & 25 anos & $\begin{array}{l}\text { Portais de internet e revistas } \\
\text { especializadas Emergência } \\
\text { e Proteção (sobre saúde e } \\
\text { trabalho). }\end{array}$ \\
\hline $\begin{array}{c}\text { Vivian de Oliveira Neves } \\
\text { Fernandes }\end{array}$ & 27 anos & $\begin{array}{c}\text { Radioagência NP e tablóide } \\
\text { Brasil de Fato (SP). }\end{array}$ \\
\hline João & 27 anos & $\begin{array}{l}\text { Revista de informação e } \\
\text { produção de conteúdo para } \\
\text { empresa não pertencente à } \\
\text { mídia. }\end{array}$ \\
\hline Aline Scarso & 27 anos & $\begin{array}{l}\text { Radioagência NP, portal } \\
\text { sobre direitos das crianças, } \\
\text { jornal Brasil de Fato e TV } \\
\text { Brasil. }\end{array}$ \\
\hline
\end{tabular}


Quadro 3 - Jornalistas entrevistados de 30 a 39 anos

\begin{tabular}{|c|c|c|}
\hline Sujeito & Idade & Experiência Profissional \\
\hline Pedro & 32 anos & $\begin{array}{c}\text { Revistas e editora } \\
\text { especializadas, Folha de } \\
\text { S.Paulo. }\end{array}$ \\
\hline Maria & 33 anos & $\begin{array}{c}\text { Mídia alternativa, } \\
\text { movimentos sociais e EBC } \\
\text { (Empresa Brasil de } \\
\text { Comunicação). }\end{array}$ \\
\hline Bruno Torturra & 35 anos & Revista Trip e Mídia Ninja. \\
\hline $\begin{array}{c}\text { ] } \\
\text { Leonardo Sakamoto }\end{array}$ & 36 anos & $\begin{array}{l}\text { Editora Abril, blog no IG e } \\
\text { UOL, ONG Repórter Brasil. }\end{array}$ \\
\hline Miguel & 39 anos & $\begin{array}{l}\text { Sites e agência de notícias, } \\
\text { TV e, principalmente, em } \\
\text { rádio, na } \mathrm{CBN} .\end{array}$ \\
\hline
\end{tabular}

Quadro 4 - Jornalistas entrevistados de 40 a 49 anos

\begin{tabular}{|c|c|c|}
\hline Sujeito & Idade & Experiência Profissional \\
\hline Antonio & 40 anos & $\begin{array}{l}\text { Jornal no nordeste, revista } \\
\text { especializada e agência de } \\
\text { notícias científica em São } \\
\text { Paulo, freelancer. }\end{array}$ \\
\hline Ivan Marsiglia & 43 anos & $\begin{array}{c}\text { Revistas Playboy e Trip, O } \\
\text { Estado de S. Paulo. }\end{array}$ \\
\hline Fernanda Cirenza & 49 anos & $\begin{array}{c}\text { Folha de S.Paulo, revista } \\
\text { Marie Claire, freelancer, } \\
\text { Diário de São Paulo, revista } \\
\text { Brasileiros. }\end{array}$ \\
\hline
\end{tabular}


Quadro 5 - Jornalistas entrevistados de 50 a 59 anos

\begin{tabular}{|c|c|c|}
\hline Sujeito & Idade & Experiência Profissional \\
\hline Paula Puliti & 50 anos & $\begin{array}{c}\text { Gazeta de Pinheiros, revista } \\
\text { Saúde, O Estado de S. } \\
\text { Paulo, Folha de S. Paulo, } \\
\text { Diário do Grande ABC, } \\
\text { Agência Estado. }\end{array}$ \\
\hline Marilu Calo Cabañas & 51 anos & $\begin{array}{c}\text { Rádios Guarujá, } \\
\text { Bandeirantes, Cultura e } \\
\text { Brasil Atual, além de } \\
\text { passagem pela TV, no SBT. }\end{array}$ \\
\hline Bob Fernandes & 58 anos & $\begin{array}{c}\text { Rádio Jornal do Brasil, } \\
\text { Veja, Jornal do Brasil, } \\
\text { Folha de S.Paulo, Isto é, } \\
\text { Carta Capital, Terra } \\
\text { Magazine, Rádio } \\
\text { Metrópole, TV Gazeta. }\end{array}$ \\
\hline
\end{tabular}

Quadro 6 - Jornalistas entrevistados de 60 a 69 anos

\begin{tabular}{|c|c|}
\hline Sujeito & Idade \\
\hline Aureliano Biancarelli & 63 anos \\
\hline Lúcio Flávio Pinto & \\
\hline & \\
\hline
\end{tabular}

Experiência Profissional

Veja, Jornal da Tarde, Folha de S.Paulo, freelancer.

Província do Pará, Veja, Isto é, O Liberal, TV

Liberal, O Estado de S.

Paulo, Jornal Pessoal.

O Estado de S. Paulo, Folha

Ricardo Kotscho

66 anos

de S.Paulo, Jornal do

Brasil, Isto é, Época, Globo, SBT, CNT, Bandeirantes, 
Record, blog Balaio do

Kotscho, e revista

Brasileiros.

\section{Quadro 7 - Jornalistas entrevistados com mais de 70 anos}

\begin{tabular}{|c|c|c|}
\hline Sujeito & Idade & Experiência Profissional \\
\hline Clóvis Rossi & 71 anos & $\begin{array}{c}\text { Correio da Manhã, } \\
\text { O Estado de S. Paulo, Isto } \\
\text { é, Folha de S.Paulo. }\end{array}$ \\
\hline Audálio Dantas & 81 anos & $\begin{array}{c}\text { Folha da Manhã, revistas O } \\
\text { Cruzeiro, Quatro Rodas, } \\
\text { Realidade e Negócios da } \\
\text { Comunicação. }\end{array}$ \\
\hline Alberto Dines & 82 anos & $\begin{array}{l}\text { Revistas Visão e Manchete, } \\
\text { jornais Última Hora, Diário } \\
\text { da Noite, Jornal do Brasil, } \\
\text { Folha de S.Paulo, Editora } \\
\text { Abril, El País e } \\
\text { Observatório da Imprensa. }\end{array}$ \\
\hline
\end{tabular}

A seguir, vamos apresentar cada entrevistado. Para tanto, fizemos um texto para cada grupo de faixa etária, assim pudemos contar as experiências dos jornalistas daquele grupo. Essa divisão não significa que um tema trabalhado em um grupo não tenha aparecido em outro e sim que para fazer o texto buscamos um tema que foi comum aos entrevistados daquele grupo, para depois apresentá-los. De certa forma, cada temática que serve de mote para os textos se complementa. Juntos eles trazem visões do jornalismo e do trabalho do jornalista que se completam e serão aprofundadas ao longo da tese. 


\section{5 - As testemunhas da história}

Para Clóvis Rossi, o jornalista é testemunha da história. Essa é uma definição que se encaixa bem aos três entrevistados com mais de 70 anos desta pesquisa. Juntos eles somam 234 anos de vida e 173 de profissão. Rossi, o caçula do grupo, tinha 71 anos de idade e 51 de carreira ${ }^{26}$ quando nos concedeu entrevista. Audálio Dantas, 81 anos e quase 60 de jornalismo ${ }^{27}$. Já Alberto Dines contava com 82 anos de idade e 62 como jornalista $^{28}$.

Nos anos 50, Audálio já trabalhava na Folha da Manhã, indo em 1959 para a revista O Cruzeiro. Nessa mesma década, Alberto Dines também começava no jornalismo, apesar de desejar trabalhar com cinema. Como já escrevia para a revista Cena Muda, acabou indo trabalhar na revista Visão, que considera seu primeiro trabalho como jornalista.

Embora eu não pretendesse ser jornalista, eu comecei na Visão, porque era um emprego. Eu estava escrevendo na Cena Muda e queria escrever sobre cinema e cultura, mas, sobretudo, sobre cinema, porque eu estava envolvido com a nascente indústria cinematográfica, tinha feito documentários, tinha feito umas bobagens lá, estudava cinema que nem um louco. Então achava que o jornalismo não seria a minha, mas à medida que eu fui me desenvolvendo como jornalista, me envolvendo com o jornalismo, eu comecei a perceber que não eram incompatíveis, ao contrário, eram convergentes, e não me incomodei que o jornalismo se sobrepusesse ao cinema - Alberto Dines.

$\mathrm{Na}$ década seguinte, os três profissionais já estão em cena. Clóvis Rossi se formou em jornalismo em 1965 na Faculdade Cásper Líbero. Iniciou sua carreira na sucursal de São Paulo do Correio da Manhã e depois teve rápidas passagens pela TV Excelsior e pela revista Auto Esporte até ir para O Estado de S. Paulo. "No Estadão, eu fiz a carreira ao contrário. Comecei como chefe e terminei como repórter", contou o jornalista que assumiu seu primeiro cargo de chefia dos 22 para os 23 anos.

Enquanto isso, também nos anos 60, Alberto Dines comandava a reforma do Jornal do Brasil: “Tentei fazer algumas inovações muito tempo atrás, para tornar mais

\footnotetext{
${ }^{26}$ Informação dada pelo jornalista na entrevista realizada em 9 de abril de 2014, em sala de reunião na Folha de S.Paulo.

${ }^{27}$ Informação dada pelo jornalista na entrevista realizada em 8 de maio de 2014, na Livraria Cortez, em Perdizes, São Paulo.

${ }^{28}$ A entrevista com Alberto Dines ocorreu em 29 de abril de 2014, em seu escritório, na Vila Madalena, em São Paulo. Na ocasião ele falou sobre todas suas experiências profissionais sem precisar ano. No Portal dos Jornalistas, informa-se que a carreira dele se iniciou em 1952.
} 
organizado o trabalho na redação". Antes de chegar lá passou, entre outros locais, pelos jornais Última Hora e Diário da Noite. Teve como chefes Samuel Wainer, com quem tinha contato direto, e Assis Chateaubriand, que apesar de já estar tetraplégico, ordenou sua demissão. Isso porque ele não cumpriu uma determinação do dono dos Diários Associados.

\begin{abstract}
Estávamos em 60. Naquele tempo, Portugal era dominado por uma ditadura de Salazar, e Chateaubriand era muito amigo de Salazar. Um grupo de rebeldes, antisalazaristas, sequestrou o navio de passageiros no meio do mar. Foi a primeira vez que teve um sequestro, mas sem violência, só pra chamar atenção de que Portugal era uma ditadura. Só que o navio foi sequestrado no mar perto de Recife. Aí veio uma ordem, nenhuma linha sobre o sequestro do Santa Maria. Santa Maria era o nome do navio. Por acaso, nós estávamos com um fotógrafo dentro do Santa Maria, fazendo as fotografias que iam ser mandadas de barco, depois de avião, pra gente publicar. Quando chegaram (risos) as fotos, não tive dúvida, dei na capa, na página central Alberto Dines.
\end{abstract}

O mesmo Chateaubriand, antes, havia elogiado seu trabalho por causa das mudanças que fez no Diário da Noite:

Chateaubriand já estava tetraplégico naquela altura, tinha tido um derrame, então ele ficava deitado e tal, mas ele mandava no jornal e tudo. Quando ele viu o Diário da Noite que eu tinha feito, ele gostou muito, adorou. Aí mandou me chamar pra me dar parabéns - Pô, está ótimo e tal, está igual aos tablóides ingleses. Claro, eu (risos) estava copiando os tablóides ingleses. Ele até me mandou passar dez dias em Londres pra acompanhar um dos tablóides... - Alberto Dines.

Antes do Diário da Noite, por volta de 1959, Alberto Dines trabalhou na Última Hora. O jornalista contou que foi escolhido por Samuel Wainer, que era naturalmente sedutor. "Não fui pedir emprego, ele me escolheu. (...) Era um sujeito com charme enorme, também com uma vibração pessoal muito grande e foi por isso que ele encantou o Getúlio Vargas, encantou tanta gente assim". Já como chefe "era um louco, um desvairado (risos)". Uma loucura movida pelo trabalho. Alberto Dines começou fazendo o segundo caderno da edição matutina da Última Hora, numa época em que o jornal tinha duas edições. O trabalho teve um bom retorno, e ele recebeu uma nova proposta de Wainer.

Eu vou fazer o seguinte, você vai assumir a edição matutina inteira. Eu nunca tinha dirigido um jornal, tinha também uns 27 anos. Eu aceitei. A primeira edição foi um desastre, porque eu não tinha experiência de jornal, tinha de revista. A primeira edição foi horrível, eu fiz uma revista. No dia seguinte peguei o jeito da coisa, e fui indo. Ele gostou (risos), e falou assim: Quer saber de uma coisa, você vai ser o editor das duas edições. Aí foi uma loucura. (...) O Samuel era [assim]. Ele fazia isso com todo mundo, ele usava as pessoas. Usava 
pelo bem, usava quem ele gostava. Não fazia com quem não gostava. Então ele tirava o couro das pessoas, mas eu não saí de lá por causa disso não, quer dizer, eu estava cansado, mas é porque o jornal estava dividido com o pessoal da fase antiga... - Alberto Dines.

Assim foram testemunhando a história. Se Audálio Dantas cobriu a eleição de Salvador Allende em 1970 para a revista Realidade ${ }^{29}$, Clóvis Rossi em 1973 foi fazer sua primeira cobertura internacional, ainda em O Estado de S. Paulo, do golpe de Estado no mesmo país ${ }^{30}$. Da cobertura, o primeiro jornalista relatou:

Eu tive casos em que eu já cheguei em cima, por exemplo, fui ao Chile cobrir a eleição do Salvador Allende, as consequências posteriores e, por circunstâncias, eu cheguei muito próximo do fechamento da revista, que era o assunto para aquela edição. Não tinha conversa. (...) Tive dois ou três dias de elaboração, de trabalho até altas horas, e a não conclusão por insatisfação com o texto e assim por diante. Às vezes também tem assuntos que não exigiam uma pressa muito grande, mas o texto te exigia um trabalho mais apurado e te dava mais angústia - Audálio Dantas.

As duas coberturas são apenas exemplos entre tantas outras. Clóvis Rossi contou que após essa cobertura passou a acumular a função de cobrir assuntos internacionais, como a Revolução dos Cravos em Portugal e a situação e o golpe na Argentina, no Estadão, onde ficou até 1977. Trabalhou no Jornal do Brasil, na Isto é, no Jornal da República, e depois na Folha de S.Paulo, jornal em que trabalha até hoje como colunista e onde nos recebeu no dia da entrevista.

Audálio Dantas, que começou na Folha da Manhã, saiu do jornal para trabalhar na revista O Cruzeiro, no final de 1959. De lá foi pra revista Quatro Rodas, na qual trabalhou como redator chefe. Depois foi um dos editores da revista Realidade. "Aí nesta revista eu praticamente encerrei a minha carreira do dia a dia. Continuei fazendo jornalismo eventualmente".

Ele saiu da Realidade para se tornar presidente do Sindicato dos Jornalistas Profissionais do Estado de São Paulo, no qual teve papel fundamental para o jornalismo como sujeito da história ao denunciar perseguições a jornalistas durante a ditadura militar e a morte de Vladimir Herzog ${ }^{31}$. Depois foi deputado federal. "Eu fiquei quatro anos numa luta política muito forte porque era ainda tempo da ditadura. De certa forma,

\footnotetext{
${ }^{29}$ É possível saber mais sobre os bastidores da reportagem citada na entrevista e ler a matéria na íntegra no livro Tempo de Reportagem, de Dantas (2012b). Ele chegou a Santiago em 17 de setembro de 1970, e a reportagem foi publicada na edição de novembro de 1970 da revista Realidade.

${ }^{30}$ Rossi (1999) também fala dessa e de outras matérias em seu livro "Enviado especial: 25 anos ao redor do mundo".

${ }^{31}$ Essa história foi contada por Dantas (2012a)
} 
eu continuei fazendo jornalismo nessas funções. Como deputado eu fiz porque a minha principal briga era contra a censura, contra a ditadura militar, aquela coisa toda".

Dantas foi presidente da Imprensa Oficial do Estado de São Paulo nos anos 80. Atuou na Superintendência de Comunicação da Eletropaulo nos anos 90. Trabalhou ainda em uma empresa própria de comunicação. Na época em que foi realizada a entrevista, ele atuava como diretor executivo da revista Negócios da Comunicação ${ }^{32}$.

\begin{abstract}
A revista é mensal, mas eu participo do dia a dia da revista, porque acompanho o desenvolvimento dos assuntos, participo da reunião de pauta... Eu não me preocupo muito com a edição porque geralmente ela está nas mãos de profissionais competentes, mas me preocupo com o todo da revista, a abordagem, os assuntos do mês. E depois faço o editorial. Quer dizer, é um trabalho leve, vai. Mas eu estou lá praticamente todo dia, na parte da tarde - Audálio Dantas.
\end{abstract}

O jornalista de 81 anos tem 12 livros publicados, incluindo quatro infantojuvenis. "As duas guerras de Vlado Herzog”, publicado em 2012, recebeu o prêmio Jabuti 2013 na categoria reportagem. "Eu fiquei feliz (risos), porque na verdade ele é biografia, ele é história, ele é denúncia, uma série de coisas, mas ele foi como reportagem. É a minha maneira de contar a história. Eu acho que é aquela que eu fiz a vida inteira". E continua a fazer como mostra o seu novo livro lançado em 2014.

Agora mesmo eu publiquei um livro, chama $\mathrm{O}$ céu de Luiz, sobre Luiz Gonzaga, e fui lá à região que ele nasceu, viveu um bom tempo, morreu até, lá próximo pelo menos. Eu poderia ter escrito daqui, há uma vastíssima bibliografia sobre Luiz Gonzaga, mas eu fiz questão de ir. Acho que o jornalista tem que ir sempre, ele deve ser testemunha do fato - Audálio Dantas.

Entre os livros que Alberto Dines escreveu, um marcou a vida dele até hoje: “Morte no Paraíso - a tragédia de Stefan Zweig”. Escrito em 1981, teve quatro edições, sendo uma em alemão, terá uma nova edição em português e pode ter uma tradução em espanhol. "Pensei que ia ser uma biografia, publicar e pronto, e eu acabei me envolvendo com o personagem... Depois eu criei uma entidade em Petrópolis onde esse escritor viveu". O local é a própria casa onde Zweig morou e se matou, que virou um museu. "O negócio em Petrópolis dá um trabalho danado, mas isso é amor à arte, isso não é profissional, eu só ganho, digamos, míseros direitos autorais da obra”.

Dines trabalhou no Jornal do Brasil de 1962 a 1973, quando foi demitido. "A minha saída foi uma das coisas mais sórdidas que eu já assisti alguém fazer, por sorte eu

\footnotetext{
${ }^{32}$ No mês de dezembro de 2014, noticiou-se na mídia especializada em comunicação que Audálio Dantas deixou a revista para se dedicar a projetos pessoais e culturais como palestras sobre jornalismo e organização de eventos.
} 
estava muito bem amparado, já fazia análise naquela época, mesmo assim eu tive o baque". Depois foi para os Estados Unidos, porque "as portas se fecharam" para ele.

O jornalista já havia estado no país em 1964 para fazer um curso pelo Jornal do Brasil no World Press Institute, que ficava na Universidade de Columbia. Até hoje tem as anotações das aulas guardadas, em que aliava o que os professores falavam com suas ideias. Nessa segunda visita, em 1974 e 1975, foi professor visitante da mesma universidade na Escola de Pós-Graduação em Jornalismo (DINES, 1986, p.14). Antes disso, já havia dado aulas na PUC/RJ: "Embora seja formado em coisa alguma, muito menos em jornalismo, desde 1963 - com apenas 11 anos de experiência profissional senti necessidade de associar-me a uma escola (no caso a PUC, Rio) para sistematizar e organizar minha experiência” (Ibid., p.22).

Voltou ao Brasil em 1975 a convite da Folha de S.Paulo, onde criou a coluna Jornal dos Jornais, pioneira em crítica de mídia, e ficou até 1980. Nos anos 1980, mudou-se para Portugal e lá trabalhou para a Editora Abril. Nos anos 1990, nasceu o Observatório da Imprensa, especializado na crítica de mídia, está presente na internet desde abril de 1996 e na TV desde maio de 1998.

Atualmente Dines trabalha pelo menos 10 horas por dia em atividades jornalísticas. Escreve um artigo por semana, que é comprado por um grupo de jornais e publicado aos sábados. Ele costuma escrever esse texto às sextas. "Essa coluna já teve mais clientes, mas à medida que eu expunha meus pontos de vistas com firmeza, os clientes passaram a não continuar". Esse artigo sai, por exemplo, na edição on-line brasileira do jornal El País. Também escreve pelo menos um artigo para a página do Observatório da Imprensa nas segundas, que é publicado na terça. Atualmente ele trabalha como consultor da edição on-line. "Mas eu estou muito atento, falando quase todos os dias com o Luiz Egypto [o editor], e trocando muitos e-mails, passando dicas, ideias, a gente está tentando reconstituir o clima de redação".

Já o programa de TV, é produzido pela equipe do Observatório no estúdio da TV Brasil, no Rio de Janeiro. Dines mora em São Paulo e apresenta o programa no Rio, viajando constantemente. "Isso é mortal pra mim, eu vou há 16 anos, praticamente toda semana, terça de manhã, o programa é terça de noite, e volto na quarta-feira no fim da tarde, porque no dia seguinte eu tenho que começar a discutir o próximo programa." De volta à capital paulista, os contatos são por e-mail e telefone várias vezes ao dia. Dines também escreve os textos para a versão televisiva e no caso dos programas especiais as 
exigências são ainda maiores. "Então a dedicação é muito intensa, embora seja um programa de 1 hora uma vez por semana."

Nessa conta de trabalho, ainda entram as leituras diárias que faz de quatro jornais, revistas brasileiras e internacionais, como The Economist. Em seu escritório, na Vila Madalena, em São Paulo, é possível ver Folha de S.Paulo, O Estado de S.Paulo e O Globo empilhados em sua mesa. Os jornais dividem espaço com outras pilhas de papéis e revistas, cercados de livros em todas as paredes e caricaturas. O corredor que leva ao escritório tem mais livros. No caminho é possível avistar outro cômodo como mais obras. Um templo do jornalismo, onde os papéis de paredes são feitos de livros. "Tem muita leitura que você tem que computar, agora por outro lado, não é uma leitura que eu descarto, ao contrário, é uma leitura que só me enriquece, porque eu acho que nós somos homens e mulheres do mundo, não podemos viver a parte". E finaliza: "Isso é uma devoção absoluta".

\section{6 - Eles sujaram os sapatos}

"Repórter tem que sujar os sapatos. Tomar sol, tomar chuva, tem que ir aos lugares, ir atrás das histórias, e não ter informações de segunda mão, de terceira mão, quarta mão, como é hoje". A afirmação de Ricardo Kotscho ${ }^{33}, 66$ anos, completados em março de 2014, resume um pouco da história dele e dos outros entrevistados na faixa etária de 60 a 69 anos. Eles sujaram os sapatos. Ao que Lúcio Flávio Pinto ${ }^{34}, 65$ anos, completa: “O jornalismo verdadeiro, que continua sendo necessário e vital, é aquele jornalismo do jornalista que diz - meninos, eu vi”. E Aureliano Biancarelli ${ }^{35}, 63$ anos, confirma "Os velhos repórteres costumam dizer que repórter tem que colocar o pé no chão, fazer reportagem é sair pelos caminhos, sair pelas ruas, sair e ouvir as pessoas".

\footnotetext{
33 A entrevista foi realizada no apartamento do entrevistado em 26 e 27 de fevereiro de 2014, pois no primeiro dia não foi possível realizar todas as perguntas.

${ }^{34}$ Essa foi a última entrevista realizada, em 21 de agosto de 2014, aproveitando a vinda de Lúcio Flávio Pinto para o II Congresso Internacional de Ciências do Trabalho, Meio-Ambiente, Direito e Saúde, como palestrante. Na ocasião ele ainda tinha 64 anos, mas completaria 65 no próximo mês, em setembro. Assim como Ricardo Kotscho, ele deu a nova idade que logo completaria para ser colocada na tese. Iniciamos a entrevista no auditório do evento e encerramos em um restaurante após o almoço.

${ }^{35}$ Entrevista realizada em sala de reunião do Cremesp (Conselho Regional de Medicina do Estado de São Paulo) em 08 de janeiro de 2014.
} 
E como eles desbravaram caminhos. Contam suas histórias de repórteres com brilho nos olhos e a animação de meninos. Causos não faltaram nessas entrevistas como a cobertura realizada por Ricardo Kotscho da tragédia de Caraguatatuba/SP, em 1967, onde fortes chuvas causaram o deslizamento de terras. Segundo história relatada no site da prefeitura $^{36}$ local, 3000 pessoas, de um total de 15 mil habitantes, ficaram desabrigadas.

A história também foi contada por Kotscho (2006, p.37-38): “ 'Ricardinho, te prepara. Maior tragédia em Caraguatatuba, centenas de mortos, vou te mandar pra lá. Pega um fotógrafo'. O sempre calmo Clóvis Rossi parecia meio nervoso". Ricardo Kotscho estava no início de sua carreira no jornal O Estado de S. Paulo. Ele foi cobrir a tragédia com outro jornalista, como relatou na entrevista:

Cada dia um de nós dois ia de Caraguatatuba para Ubatuba de carro, estrada péssima, tinha acabado com a chuva, e entregava um envelope num avião da FAB, que ia pra Santos, e em Santos tinha alguém do jornal que ia lá pegar o envelope com as matérias. Era assim que a gente mandava - Ricardo Kotscho.

Naquela época Kotscho, ainda conhecido como Ricardinho, era o mais novo repórter do Estadão e entrou para o jornal na mesma época em que ingressou no curso de jornalismo, na Escola de Comunicações e Artes - ECA/USP, que não conseguiu concluir por causa do trabalho. Faltava muito devido às viagens que fazia para realizar matérias. Muitos jornalistas tinham dois empregos e preferiam não viajar.

Eu pegava muita viagem, adorava isso, sugeria reportagens de viagem, eu não parava em São Paulo. Isso é uma das mudanças que eu sinto. A gente tinha muita iniciativa de propor pauta, de pedir pra trabalhar. É a única profissão do mundo (risos), que a gente briga pra trabalhar. Você briga pela pauta, para ir ao lugar fazer a matéria, você briga por espaço - Ricardo Kotscho.

Em uma dessas brigas por espaço, ele chegou a sair do Estadão. Tudo por causa de uma reportagem "muito difícil" no Espírito Santo sobre um naufrágio. Ele e um repórter do Jornal da Tarde conseguiram falar com os sobreviventes, "que tinham histórias fantásticas". Quando chegou, às 10 horas da noite, o jornal estava quase fechando e tinham reservado 30 linhas para ele, que em princípio se recusou a escrever. "Eu sempre escrevi muito, 30 linhas eu não faço. (...) Tanto me encheram o saco que eu acabei fazendo... No dia seguinte, eu tinha um convite pra trabalhar no JB, de um amigo, eu fui embora sem falar com ninguém e não voltei mais pro Estadão”. Quando

\footnotetext{
${ }^{36} \mathrm{http}: / /$ www.portal.caraguatatuba.sp.gov.br/caragua_conteudo.php?id=89
} 
uma matéria assinada foi publicada no Jornal do Brasil, Clóvis Rossi, então chefe de reportagem de O Estado de S. Paulo, foi buscá-lo - "larga mão de ser moleque" - e o trouxe de volta.

Foi por também querer fazer tanto uma matéria que Aureliano Biancarelli usou suas férias e recursos próprios para ir à Serra Pelada ${ }^{37}$, numa época que o garimpo tinha cerca de 100 mil pessoas. Ele trabalhava no Jornal da Tarde, que permitia, segundo ele, o uso da criatividade como nenhum outro.

Eu queria muito fazer uma matéria sobre Serra Pelada, e o jornal não se interessava, não me mandava pra lá, nessa época tinham 100 mil pessoas em Serra Pelada. Então eu peguei minhas férias, paguei uma passagem de ônibus e me inscrevi como garimpeiro e fiquei 15 dias como garimpeiro lá dentro. Depois o jornal deu uma semana, todas as contracapas com essa história. Quer dizer, eu pude fazer a minha história, contar a minha história, coisa que outros jornais muito rigorosos em seu espaço, nos seus objetivos, nos seus propósitos, não me dariam essa oportunidade - Aureliano Biancarelli.

Já Lúcio Flávio Pinto tem uma relação direta com a Amazônia, não só pelo fato de ser de Belém, mas pelas matérias que fez na região. Em 1971, fez parte da equipe que produziu uma edição especial da revista Realidade sobre a Amazônia, publicação que ganhou o Prêmio Esso de Jornalismo. A região continuou a ser sua pauta no período em que trabalhou em $\mathrm{O}$ Estado de S. Paulo e continua a escrever sobre os conflitos locais em seu Jornal Pessoal, apesar de atualmente sofrer com a falta de recursos para desenvolver suas matérias, o que não o impede de criar formas para fazê-las, como pesquisa e uso de fontes privilegiadas que conquistou ao longo da carreira.

Tive a possibilidade, quando eu passei a trabalhar no Estadão, de estar em todos os fatos da Amazônia inteira. Nenhuma proposta minha de viagem foi recusada. Eu sempre tive os recursos, inclusive às vezes pra algumas viagens caras, que o jornal me dava. Então isso, de 1966 a 1989, foi o grande capital que eu tive de poder circular na sociedade, estar em todos os locais importantes da história da Amazônia nesse período, coisa que hoje eu não tenho. Minha rotina hoje é uma rotina solitária porque não tem outra pessoa no jornal. Eu sou sozinho no jornal e com recursos limitados. Se sempre eu podia ir a Roraima, Rondônia, Acre, sem problema, eu hoje malmente vou a Ver-o-peso, a feira de Belém - Lúcio Flávio Pinto.

\footnotetext{
${ }^{37}$ Ricardo Kotscho também chegou a fazer uma matéria sobre Serra Pelada com o repórter fotográfico Jorge Araújo, na época em que trabalhavam na Folha de S. Paulo. Kotscho não falou sobre o caso na entrevista, mas Araújo relatou no evento de comemoração de 50 anos de profissão do jornalista que eles moraram em Serra Pelada como garimpeiros por 15 dias. Em 1984, Ricardo Kotscho lançou o livro "Serra Pelada: uma ferida aberta na selva". Kotscho (2006, p. 130-131) também fala sobre as matérias feitas na região.
} 
Mesmo assim, o trabalho realizado por ele no jornal criado em 1987, desenvolvido e tocado por ele mesmo, rendeu-lhe a inclusão na lista dos 100 heróis da informação da organização Repórteres Sem Fronteiras - RSF. Ele é o único brasileiro citado.

Com a minha pequena capacidade de deslocamento, de apuração até, a pauta surgia de uma leitura atenta de todas as formas de informação direta, os jornais, as publicações oficiais, sobretudo, o Diário Oficial do Estado, o Diário Oficial do Município, da União, os balanços das empresas, os editais, tudo, e aí é acompanhar o que a imprensa deixa de publicar. (...) Então o que acontece é que como eu estou limitado fisicamente pra poder financiar passagem, deslocamento, e como estou atado aos processos judiciais, eu tenho que usar uma capacidade de análise, de tirocínio, que é meu grande patrimônio, que estava falando do período em que eu fui explorado pela empresa. E como eu não tinha capital pra me financiar, eu usei o meu trabalho, que são as minhas fontes, eu ligo pra lugares distantes, exterior, que eu tenho fontes confiáveis, seguras, com as quais eu tenho relacionamento de décadas, então, o Jornal Pessoal só existe porque quando eu comecei o Jornal Pessoal eu tinha 21 anos de profissão em algumas das principais empresas do país, trabalhando como enviado especial, que eu acho que é o trabalho principal do repórter, formando essa rede de fontes ligadas por uma confiança mútua e respeito - Lúcio Flávio Pinto.

Lúcio Flávio Pinto trabalha com jornalismo desde 1966, quando iniciou a carreira no jornal A Província do Pará. "Entrei muito cedo no jornal, ainda era estudante secundarista, na época, com 16 anos”. Trabalhou no Correio da Manhã, Veja, Isto é, O Estado de São Paulo, no qual ficou de 1971 a 1989, e em publicações alternativas como Opinião, e o Jornal Pessoal, em que atua até hoje. Também passou pelo jornal O Liberal e pela TV Liberal, afiliada da Rede Globo, onde apresentou o Bom dia Pará.

Formado em sociologia pela Escola de Sociologia e Política de São Paulo, Lúcio Flávio é filho de jornalista. Ele e três irmãos seguiram a carreira do pai. "Então o jornalismo parece que estava no meu sangue", conclui.

Não tive alternativa até hoje, 50 anos de jornal, faço aquilo que parece que a natureza me impôs e, na medida em que eu fui avançando nessa profissão, eu fui tomando cada vez mais consciência de que essa é minha função na sociedade, fazer jornalismo como eu faço até hoje Lúcio Flávio Pinto.

Desde o começo, diferentemente de seus colegas de profissão em Belém, no Rio de Janeiro e em São Paulo, que utilizavam laudas soltas, Lúcio usava um caderno de anotações. "Uma vez utilizadas as anotações pra matéria daquele dia, eles jogavam fora”. Ele não. Tem centenas de cadernos guardados até hoje. O costume vem de uma preocupação em preservar a história contemporânea. 
Chegou a ser professor da Faculdade de Comunicação da Universidade Federal do Pará, onde passou sete anos com o propósito de "descobrir repórteres de linha de frente". "Sete anos depois, eu não consegui descobrir nenhum, embora passassem por mim pessoas inteligentes, que sabiam escrever, mas nenhum disposto a ir ver a realidade na rua, com as pessoas. Aí eu saí". Também tentou voltar para a grande imprensa, assumindo como diretor de uma sucursal que seria instalada em Belém, e não conseguiu:

Dois dias depois pedi demissão. Não consegui voltar porque eu vi quais são os interesses da empresa. E no Jornal Pessoal não tem nenhum. Já perdi muitos amigos porque eu não considero debatendo lá que o cara é meu amigo, ou que é meu parente. A única limitação que eu tenho são minhas próprias limitações - Lúcio Flávio Pinto.

Desde quando saiu da Folha de S.Paulo, onde trabalhou de 1989 a 2004, Aureliano Biancarelli continua buscando alternativas para fazer jornalismo. Chegou a passar seis meses no Caderno Aliás do Estadão, em 2007, de onde saiu após mudanças internas, mas o que mais fez foi trabalhar como freelancer. Escreveu matérias para as revistas Piauí, Fórum e Brasileiros. Faz trabalhos para as publicações do Conselho Regional de Medicina do Estado de São Paulo - Cremesp. Já fez textos para o Centro Brasileiro de Estudos de Saúde - Cebes e para o Ministério da Saúde. Para esse último, ficou dois meses em Moçambique, fazendo uma série de reportagens sobre como estava a cooperação do Brasil com relação à Aids no país africano.

Mesmo todas essas matérias não conseguem preencher o lado repórter de Biancarelli. "Não, não. Elas reduzem um pouco esse vazio, mas não resolvem, não resolvem não". Talvez os frilas não preencham totalmente o vazio pela vasta carreira e o grande envolvimento com o jornalismo.

Aureliano Biancarelli se formou em jornalismo em 1973 na ECA/USP. Até 2004 suas experiências profissionais foram dentro de redações, exceto de 1976 a 1981, quando viveu na França. Começou na Veja, na época de Mino Carta. "A Veja daquela época não é a mesma de hoje". Nessa revista, teve um "um grande aprendizado". "Lá eu aprendi a ser repórter". Também fez frilas para outras publicações da Editora Abril. Em 1976, ganhou uma bolsa de estudos de um ano, oferecida pelo governo francês para especialização de jornalistas. Acabou ficando lá até 1981, fazia reportagens como freelancer para o Brasil e trabalhava em outros serviços, como em hotel, para poder se manter. 
Ao voltar para o Brasil, foi trabalhar no Jornal da Tarde, onde ficou por nove anos, e depois foi para a Folha de S.Paulo. No JT, teve experiências de reportagens mais amplas, com mais tempo e mais espaço para a criatividade. Na Folha, foi contratado para fazer a matéria do dia que tivesse algum apelo na área do cotidiano, da cidade:

Então isso me deu um privilégio de estar sempre com a matéria que era a chamada do dia. Muitos desses fatos estavam ligados a comportamentos das pessoas, que envolvia polícia, educação, saúde, direitos humanos, violência, direitos da mulher, gênero, diversidade. $\mathrm{Eu}$ comecei em 1989, época em que a Aids estava ganhando importância na mídia e ao mesmo tempo você não tinha nenhuma perspectiva de remédio, o coquetel só viria em 1996. Você só tinha o AZT nessa época, então, diagnóstico de Aids era o diagnóstico da morte, era um tema muito envolvente, você trabalhar com a morte. Era muita matéria sobre luto também. Temas que iam se cruzando. Você tinha a questão da sexualidade, do sexo, do prazer. Tinha um conjunto de elementos, que faziam tudo para você ter boas matérias sempre e com boas leituras. Eu fiquei muito tempo trabalhando nessa área, tanto que acabei sendo identificado como repórter de saúde. O que eu não me sinto, não me vejo, porque eu não fiquei falando de saúde, remédio e doença, eu fiquei falando das pessoas que eram portadoras de uma doença. Tanto que depois, sempre quando eu ia trabalhar com mal de alzheimer ou com tuberculose ou com hepatite, eu via sempre o trabalho que estava sendo feito pelas pessoas que eram portadoras e pelos grupos militantes. Era muito mais uma militância, uma saúde pública e política, do que provavelmente uma saúde de consultório. Mas acabou ficando essa coisa. Eu trabalhei 14 anos na Folha e acabei numa das rodas de demissões sendo demitido - Aureliano Biancarelli.

Assim como Aureliano Biancarelli, Ricardo Kotscho faz um jornalismo muito ligado à vida e à história de pessoas. Ele contou que já foi criticado por isso quando escreveu o livro "A aventura da reportagem" com o Gilberto Dimenstein. "Fui criticado por um colega, Carlos Eduardo Lins da Silva..., ele falou que eu era jornalista de matérias humanas." Isso teria sido dito de forma pejorativa na avaliação do entrevistado, que respondeu: "é claro, eu sou um ser humano escrevendo para humanos, então, as matérias são humanas. Queria o quê? Que eu fizesse matérias minerais, animais" (risos). Ele ainda se recorda que o texto de Silva dizia que Dimenstein tratou mais da parte oficial, da cobertura do governo e dos gabinetes em Brasília, enquanto ele mais da cobertura de rua, dos fundões do Brasil, dos garimpos. Afirmação essa que vai ao encontro do jornalismo centrado nas pessoas que Kotscho defende:

Eu acho muito ruim você fazer uma reportagem sem olhar pra cara da pessoa, como nós estamos conversando aqui. Eu detesto fazer matéria por telefone e dar entrevista por telefone. Primeiro que eu sou meio surdo, então, posso entender errado (risos). E eu não gosto. Eu gosto de ir ao lugar, ver a casa da pessoa, o entorno, a família, sempre. Pra 
mim, o centro do jornalismo é o personagem, pessoas escrevendo para pessoas - Ricardo Kotscho.

Para Kotscho, sujar os sapatos, falar com as pessoas, conhecer os lugares dos sujeitos, a vida como ela é, continua sendo o desafio pelo qual se deve brigar e que não mudou "apesar de toda tecnologia, toda internet, toda revolução que aconteceu nas comunicações humanas", que ele considera a maior revolução desde Gutemberg. "Essa natureza, esse sentido não mudou e pena que cada vez menos gente pense assim, mas ainda tem em todos os lugares um ou outro que aceita esse desafio de ir atrás, de brigar para trabalhar e de não ficar pendurado no telefone ou na internet".

É isso que Kotscho tem feito nesses 50 anos de jornalismo ${ }^{38}$, nos quais passou por vários lugares. Quando questionado por onde passou, afirmou: "Eu trabalhei nos principais veículos do país, em televisão, jornal e revista, com exceção da revista Veja. Eu só não trabalhei na Veja. Nas outras grandes empresas, todas, eu trabalhei”. Grande parte dessa trajetória está relatada em "Do golpe ao Planalto: uma vida de repórter" (KOTSCHO, 2006).

Ricardo Kotscho iniciou sua carreira no jornalismo também aos 16 anos, passando por dois jornais de bairro - Folha Santamarense e Gazeta de Santo Amaro. Na grande imprensa, começou no jornal O Estado de S. Paulo, onde ficou por 11 anos. De lá foi para o Jornal do Brasil, ser correspondente na Alemanha em 1977 e 1978. Ao voltar ao Brasil, foi para a Isto é, e depois: Jornal da República, Folha de S.Paulo, Globo Rural, Folha de S.Paulo novamente, mais uma vez JB, assessor do Lula na candidatura à presidência em 1989, Jornal do Brasil de novo, trabalhou nas Caravanas da Cidadania mais uma vez no PT e na candidatura de Lula, fez frilas para várias publicações e prestou consultoria ao Sindicato dos Bancários, depois passou por SBT Repórter, CNT, Canal 21/Bandeirantes, Época, Folha de S.Paulo, campanha do Lula em 2002, secretário de imprensa e divulgação da Presidência da República até o fim de 2004. Escreve para seu blog, Balaio do Kotscho, primeiro hospedado no IG e atualmente no R7, é comentarista do Jornal da Record News e repórter especial da revista Brasileiros.

\footnotetext{
${ }^{38}$ No dia 30 de maio de 2014, no auditório da Faculdade Cásper Líbero e com organização da ECA/USP, foi realizado um evento em comemoração aos 50 anos de reportagem de Ricardo Kotscho. Além da presença da filha, a jornalista Mariana Kotscho, como mediadora, o debate contou com os jornalistas: Eliane Brum, que trabalhou com Kotscho na Época; Audálio Dantas, com quem Ricardo Kotscho teve muito contato ao cobrir o assassinato de Vladimir Herzog na ditadura militar; o repórter fotográfico Jorge Araújo, com quem teve várias parcerias chamadas por eles de um "casamento perfeito"; Clóvis Rossi, que foi seu chefe no Estadão; Hélio Campos Mello, que conheceu na Isto é e é proprietário da Brasileiros.
} 
Desses 50 anos de história, Kotscho avalia que quando começou a rotina, as circunstâncias e até mesmo a profissão eram outras. O país vivia uma ditadura militar, que era um inimigo comum. "Os jornalistas, a grande maioria, não todos, tinha os dedos-duros também, além de jornalistas, eram cidadãos, denunciavam a tortura, o arbítrio, que havia naquela época". Em sua avaliação, "era uma profissão mais coletiva, um trabalho mais coletivo; e hoje mais individual, cada um cuidando da sua carreira. E eu não faço um julgamento de mérito, do que é melhor, do que é pior, eu acho que é diferente". E essas diferenças não o fazem gostar menos de ser jornalista, 50 anos depois.

Quando você conversa com jornalistas moços ou velhos, a tendência nossa é sempre de muitas queixas, de muitas críticas, é uma característica dos jornalistas, como se fosse a pior profissão do mundo. E quando se fala do país, a mesma coisa, como se o Brasil tivesse pra acabar, a beira do abismo. E eu penso exatamente o contrário. Eu continuo achando que o jornalismo é a melhor profissão do mundo, que te permite conhecer pessoas e lugares que de outra maneira você não conheceria, e o Brasil ainda é pra um jornalista o melhor país do mundo, porque tem muita história pra contar, que não foi contada ainda. (...) Eu não gostaria de viver em outro lugar não. Nem de ter outra profissão. Aliás, eu não saberia fazer outra coisa Ricardo Kotscho.

\section{7 - Trabalho que dá prazer}

Os entrevistados do grupo de 50 a 59 anos atrelam em suas falas o prazer ao conteúdo do trabalho. Para Bob Fernandes ${ }^{39}$, 58 anos, que já cobriu cinco copas do mundo e momentos como a Guerra da Somália em 1992, é muito prazeroso contar uma história de dentro dela. Já para Marilu Calo Cabañas ${ }^{40}$, 51 anos, conhecida pela cobertura social que desenvolve, aprender com os entrevistados é uma fonte de prazer. Paula Puliti ${ }^{41}, 50$ anos, referência no jornalismo econômico, tem prazer quando realiza uma matéria que gostou.

O trabalho em si é sempre muito prazeroso. As relações humanas no trabalho é que são muito complicadas. Eu tive sorte por um bom tempo e tive um azar por um pequeno tempo. Graças a Deus por pouco tempo. A maior parte da minha trajetória foi de muita alegria. Sempre muito intenso, são muito fortes as emoções que você passa

\footnotetext{
${ }^{39}$ Entrevista realizada no apartamento do entrevistado em 09 de maio de 2014.

${ }^{40}$ Entrevista realizada no apartamento da entrevistada em 06 de maio de 2014.

${ }^{41}$ Entrevista realizada no apartamento da entrevistada em 16 de abril de 2014.
} 
com os entrevistados, mas muito prazeroso, porque você aprende muito com o jornalismo - Marilu Cabañas.

Quando falam dos trabalhos que realizaram, é possível perceber o envolvimento de cada um. A animação de Marilu Cabañas do princípio ao fim da entrevista, demonstrando suas alegrias e tristezas em cada história que conta. A disponibilidade de Paula Puliti, que mesmo afastada do trabalho ${ }^{42}$ na Agência Estado, onde trabalhou até julho de 2012, nos recebeu e compartilhou sua trajetória. E Bob Fernandes, que passa dos questionamentos iniciais sobre o intuito da pesquisa, para uma relação de confiança, compartilhando, de forma animada, as histórias de suas matérias e de seu trabalho.

Na avaliação de Paula Puliti, o trabalho do jornalista tem o papel de traduzir um fato. O jornalista é um intermediário entre fonte e público. As definições por ela apresentadas têm muito a ver com o trabalho que realiza como jornalista na área econômica. O livro "O Juro da Notícia - Jornalismo econômico pautado pelo capital financeiro", publicado em 2013 e lançado em 13 de janeiro de 2014, na Livraria Cultura, é uma mostra disso. Fruto de tese de doutorado da jornalista na ECA/USP, ela analisou o conteúdo econômico de 1989 a 2002 da Folha de S.Paulo e O Estado de S. Paulo e entrevistou mais de 40 pessoas, por telefone ou pessoalmente, entre economistas do mercado financeiro, jornalistas de redação e de assessorias de imprensa, acadêmicos e banqueiros.

Paula Puliti se formou em jornalismo em 1987 pela ECA/USP e iniciou sua carreira na Gazeta de Pinheiros, depois passou por: revista Saúde, O Estado de S. Paulo e Folha de S.Paulo. Quando saiu do jornal, foi estudar e morar em Londres por um ano e meio. De volta ao Brasil, tornou-se editora de internacional do Diário do Grande ABC. Em 1995 foi trabalhar na Agência Estado, empresa a que está ligada até hoje e onde também exerceu a função de editora.

A jornalista trabalhou como repórter no início da carreira, depois atuou mais como editora, pois afirma ter facilidade em mexer no texto dos outros. Seu trabalho também foi marcado pelo contato com especialistas. "Meus amigos me chamavam de repórter de gabinete." No jornalismo econômico, o contato com as secretárias e mais recentemente com as assessorias é importante para obter as entrevistas, mas cria uma dependência.

É muito telefone, muito telefone, e eventualmente é uma coletiva. Isso me incomodou muito no jornalismo econômico. (...) Você depende da

\footnotetext{
${ }^{42}$ Paula Puliti teve que fazer uma cirurgia na cabeça devido a uma doença genética.
} 
assessoria, depende da secretária, você depende. Eu sou muito crítica do jornalismo feito pelo telefone, mas cada vez mais comum. Cada vez mais é telefone, é release, essas coisas - Paula Puliti.

Já Marilu Calo Cabañas atua no jornalismo desde os 17 anos, quando iniciou a carreira na rádio Guarujá Paulista AM, onde trabalhou por cinco anos. Apresentava, das $7 \mathrm{~h}$ às 9h, o programa Alô Marilu. Mais voltado para música, ganhou um espaço de meia hora para debate popular quando Marilu Cabañas entrou para o curso de jornalismo. "Então na última meia hora eu ouvia uns 10 ouvintes sobre um determinado tema". Nos sábados, ela criou um programa infantil com uma gincana, para ajudar creches ou asilos. "Era super divertido, envolvia as escolas". Também participava no Jornal do Meio Dia, fazendo redação e reportagem.

Em 1983, ao se formar em jornalismo pela Faculdade Católica de Santos, hoje Unisantos, decidiu pedir demissão e procurar uma oportunidade em São Paulo. "Já tinha percorrido quase todas as emissoras, jornais, entregando currículo, que ingenuidade, e não conseguia nada". Até que o seu instrutor de autoescola falou que tinha um amigo que conhecia o pessoal da Bandeirantes. $\mathrm{O}$ amigo era um jardineiro que era ouvinte dos programas de Marilu. Eles combinaram e foram de ônibus para São Paulo. Lá o jardineiro procurou por Ricardo Saad, um dos donos da emissora, e foi muito bem recebido. Ela foi encaminhada para falar com o superintendente na época, Salomão Ésper. Marilu contou que fazia programa popularesco, e Salomão a corrigiu, o correto era programa popular. "Comecei a discutir com ele, que me disse, se você está discutindo comigo, dará uma bela repórter. Depois que me dei conta, quem que sou eu para ficar discutindo com o superintendente (risos). Mas ele tinha dado abertura".

Ésper disse que ela falaria com o diretor de jornalismo, José Paulo de Andrade, mas outro dia, porque ele estava de mau humor. Marilu Cabañas foi outras vezes à Bandeirantes, mas não conseguia falar com o diretor. "Até que um dia ele me recebeu, tudo bem, deixa o seu currículo aí e nada. Não ligou, e eu grudada no telefone para ver se ele ligava. Quando deu nove meses, a secretária ligou falando para eu subir que o José Paulo queria falar comigo, tinha uma oportunidade...” E com essa oportunidade passou cinco anos na Bandeirantes.

Eu já tinha uma linha humanística da rádio Guarujá, já me sensibilizava demais com as pessoas que moravam nos morros, nas favelas do Guarujá, e os turistas vinham de São Paulo, vinha aquele luxo invadir a cidade... Eu já fazia matérias ali no morro, na Vila Zilda, por exemplo. Me chocava... Era sempre muito legal, eu me identificava com essas pessoas, porque eu também sou de origem pobre. Era como se eu estivesse ajudando minha própria família, então 
eu via uma senhora, eu via minha mãe. Eu via uma menina pequena tentando estudar, eu me via, sabe. Pedreiro eu via meu pai que era carpinteiro, falecido quando eu tinha oito anos. A história de vida dessas pessoas sempre me comovia porque eu acho que eu me comovia com minha história também e queria fazer alguma coisa. $\mathrm{Na}$ Bandeirantes, era incrível, a gente ia direto para a Zona Leste. Aprendi muito com as mulheres do movimento de saúde... Eu falava mesmo com as pessoas que estavam sofrendo na pele. Essa foi a escola da Bandeirantes - Marilu Cabañas.

Foi na Bandeirantes que ela recebeu o seu primeiro prêmio jornalístico Vladimir Herzog, voltado para a questão dos direitos humanos, devido a uma série de reportagens sobre saúde em que percorreu hospitais e pôde mostrar os problemas de saúde pública enfrentados pela população. Quando foi chamada para fazer as reportagens, respondeu: "é tudo o que eu quero na vida". Além da audiência do público, Marilu recebia telefonemas de outros colegas de jornais e TV pedindo informações.

Depois ela trabalhou dois anos e meio no SBT e 16 anos na Rádio Cultura. Na $\mathrm{TV}$, foi ganhar um salário quatro vezes maior. O convite: participar de um programa jornalístico novo que misturava Fantástico e Globo Repórter. A surpresa: “Como o programa ainda não tinha data de estreia, fui fazendo reportagens para o jornal das $7 \mathrm{~h} e$ depois faria para o que vai estrear... E teve a estreia... Meu Deus, o que é isso? Adivinha o programa? Aqui e Agora". Ficou seis meses no programa, na esperança de que mudaria, depois trabalhou em outro jornalístico da emissora, até ser demitida.

Aí surgiu a proposta para a Rádio Cultura. Outro mundo. Foi uma escola na área cultural, na área musical, eu podia aprimorar a minha audição em matéria de rádio. No SBT, aprimorei o texto enxuto e teve algumas matérias legais. É que estou contando o que mais me marcou. No SBT também a superficialidade, eu tive que fazer matéria sobre jaqueta de couro no Itaim Bibi. Como assim? Por que vou fazer essa matéria? - Marilu Cabañas.

Na Rádio Cultura, pôde aprofundar seus conhecimentos na área cultural. "Entrei em contato com cinema, teatro, literatura, música. Foi uma faculdade, por causa dos colegas, eles eram tão de ponta nessa área, tanto MPB quanto música erudita. E na área cultural eles tinham um histórico". Aos poucos a jornalista colocou pautas sociais na emissora. "Meu chefe foi topando, eu fazia séries, e consegui conciliar as questões sociais com uma plástica melhor. (...) Foi muito legal unir essas duas frentes. Foi muito prazeroso por muito tempo".

Marilu Cabañas já soma 34 anos de profissão. Na época da entrevista, estava havia quase três anos na Rádio Brasil Atual. Foi lá que recebeu seu último prêmio, mais 
um Herzog, que teve um significado especial pelo fato da série de reportagens "Voz Guarani-Kaiowá" tratar da questão indígena. O trabalho retratou a luta dos índios por suas terras, em municípios de Mato Grosso do Sul. A mãe de Marilu era de origem guarani e estava muito doente na época da premiação, vindo a falecer depois. O que faz a jornalista afirmar sobre todos os prêmios que ganhou na carreira:

Foram muito importantes, principalmente pra minha mãe, ela se sentia
muito orgulhosa da filha. Eu, filha de carpinteiro e empregada
doméstica. Ela pobre, vindo do interior do Paraguai, com um
chinelinho e um vestidinho, com 18 anos para o Brasil, foi para
Santos, trabalhou. Ela não sabia o que era sábado, domingo, feriado.
Não tinha folga de nada. [até aí fala sorrindo, pára, respira forte, meio
engolindo a emoção, a voz embarga com o choro] Foram pela minha
mãe, Cristiane, todos os prêmios. Ainda mais o último agora sobre os
guaranis... Era pra ela tudo - Marilu Cabañas. [Chora, muito
emocionada]

Com uma carreira um pouco mais longa, o jornalista Bob Fernandes tem 36 anos de jornalismo. Atua na área desde 1978 e se formou em jornalismo em 1981 na Faculdade de Comunicação da Universidade Federal da Bahia. Seu primeiro emprego foi um estágio na assessoria de comunicação da reitoria da UFBA. "Eu cobria artes e espetáculos, quer dizer, Museu de Arte Sacra, peças de teatro, o Teatro Castro Alves”. Praticamente ao mesmo tempo começou a estagiar na rádio Jornal do Brasil que estreava sua sucursal na Bahia. "Eu trabalhei no primeiro dia que ela foi inaugurada".

Em 1979, trancou a faculdade para morar no Rio de Janeiro. Ao voltar para o Nordeste, foi trabalhar na sucursal da revista Veja para os estados da Bahia e Sergipe. Em princípio como estagiário, mas recebendo e trabalhando como profissional. Depois de formado, foi regularizado como profissional. Foram dois anos e meio na Veja. Até que em maio de 1983 se mudou para Brasília com o intuito de trabalhar no Jornal do Brasil, no qual ficou até fevereiro de 1986. Saiu para trabalhar na revista Status, que tinha deixado de ser uma publicação de nu feminino para se tornar uma revista de reportagem da Editora Três, que editava a Isto é. "Eu tinha convite, para ganhar mais, e estava meio cansado de política e Brasília”. Após sete meses, acabou voltando para o Jornal do Brasil. Depois trabalhou como repórter na sucursal de Brasília da Folha de S.Paulo. Nesses dois períodos, cobria a Constituinte.

Em 1989, foi convidado para dirigir a revista Isto é em Brasília. "Fiquei três anos e no fim de 91 eu saí para ser correspondente nos Estados Unidos, onde fiquei dois anos". De volta ao Brasil, participou do projeto de criação da revista Carta Capital, dirigido por Mino Carta. Enquanto a revista não saía, trabalhou seis meses como 
repórter especial da Folha. Na Carta Capital, ficou 10 anos, sendo cerca de nove como editor chefe. "Eu fiz aproximadamente 150 capas de revistas, longas reportagens, entre a Isto é e Carta Capital, todas sem exceção foram escritas à noite e de madrugada porque é a hora que não tem interrupções, não tem incômodos, coisas distraindo".

Ao sair da Carta Capital, criou a revista eletrônica Terra Magazine, onde trabalhava havia oito anos e meio até a data da entrevista, no Portal Terra. Após as eleições presidenciais de 2014, o espaço deixou de existir. Também fez comentários para a Rádio Metrópole da Bahia por quatro anos e é comentarista da TV Gazeta há mais de três. "Eu sempre tive mais prazer, o desgaste existe quando há o que eu chamo de power games - você perder tempo com disputas inúteis". Pode-se dizer que os entrevistados desse grupo procuraram não perder tempo.

\section{8 - Trabalho que faz sofrer}

Se o trabalho causa prazer, ele também faz sofrer. Sofrimento e prazer estão sempre presentes no trabalho do jornalista. Entre os entrevistados de 40 a 49 anos, o sofrimento está na própria produção do texto jornalístico. Escrever causa desgaste e sofrimento. É o que aparece na fala de Ivan Marsiglia ${ }^{43}, 43$ anos: "O mais pesado pra mim realmente e desgastante é a hora de escrever, que equiparado, é o que eu mais gosto. A hora de escrever, quando eu saio pra apurar, volto com o material, ainda não estou no fechamento, mas eu preciso escrever o texto, é o mais difícil”.

Além de mostrar o sofrimento da escrita, a afirmação deixa claro que prazer e sofrimento estão lado a lado. A questão também aparece nas falas de Fernanda Cirenza $^{44}, 49$ anos, que considera sofrimento o processo de construção de um bom texto, e de Antonio ${ }^{45}, 40$ anos, que acredita que o jornalista sofre para produzir a matéria. Os entrevistados também demonstraram muito envolvimento com a profissão durante as entrevistas.

\footnotetext{
${ }^{43}$ Entrevista realizada no local de trabalho, numa espécie de praça em que não havia circulação de pessoas, em 08 de abril de 2014.

${ }_{44}^{44}$ Entrevista realizada no local de trabalho, em sala de reunião, em $1^{\circ}$ de abril de 2014.

${ }^{45}$ Nome fictício, pois o entrevistado optou por não se identificar. Entrevista realizada em 10 de dezembro de 2013, em sala do departamento de Jornalismo, da ECA/USP, onde a pesquisadora faz doutorado. Essa foi a primeira entrevista da pesquisa, desconsiderando as entrevistas da fase de teste de 2011, que não entraram para a análise final, mas serviram para aperfeiçoar o questionário e produzir um artigo que foi publicado na revista Alterjor (REIMBERG, 2012a).
} 
Nas falas de Antonio, por exemplo, a crítica ao jornalismo e certa desilusão em alguns momentos não excluem o envolvimento com o trabalho. Ele se formou em uma universidade pública do nordeste. Enquanto estudava, também trabalhava como professor:

É uma profissão que requer sim, são raras as exceções, um suporte minimamente financeiro. Eu fui um trabalhador estudante de jornalismo. Eu dava aula, eu cheguei a cursar algumas disciplinas de letras, dei aulas de português durante oito anos, redação e literatura pra sobreviver. Mas eu deveria na verdade estar na graduação fomentando o meu curso, minha graduação. Estágio não havia. A única possibilidade de conciliar, no meu caso, era dando aula Antonio.

Para ele, as exigências de investimentos continuam no desenvolvimento da carreira. "Então é uma profissão cara, é uma profissão que requer cursos de atualização, familiaridade com as novas tecnologias". Depois de formado, Antonio chegou a atuar em jornais locais e se tornou professor do curso de comunicação da universidade pública em que estudou, após passar por concurso, até decidir vir para São Paulo, onde fez mestrado e teve algumas experiências profissionais. Trabalhou de forma efetiva como repórter de uma publicação de crítica de mídia e em uma agência de notícias de divulgação científica. Também fez frilas para diferentes veículos como as revistas Saúde, da Editora Abril, e Língua Portuguesa, da Editora Segmento. Na época da entrevista, continuava atuando como jornalista freelancer e como analista ${ }^{46} \mathrm{em}$ uma agência de comunicação corporativa.

Quando eu vim pra São Paulo, eu vim buscar o mercado de São Paulo... São Paulo é o maior mercado, então vamos ver. Eu preciso saber como funciona o mercado pra não ficar essa coisa da teoria... Então em São Paulo eu priorizei isso, mas no próximo ano eu vou encontrar uma forma de conciliar, pelo menos dar aulas pra algumas turmas e conciliar com outras atividades de freelancer, porque não dá de fato pra confiar nisso, se sustentar - Antonio.

\footnotetext{
${ }^{46}$ Esse trabalho é voltado para a assessoria de comunicação, por isso não trabalharemos as informações sobre isso na pesquisa. Como Antonio continua fazendo reportagens como freelancer, foi entrevistado. Para a agência, ele trabalha alguns dias em casa, outros na agência, pela manhã, analisando as notícias que saem na mídia sobre determinada empresa, que contratou os serviços da agência, que por sua vez terceirizou o serviço para Antonio, que precisa se dedicar diariamente a esse trabalho e emitir nota fiscal como pessoa jurídica. No segundo capítulo, discutiremos as formas de contratação, mas centrando nos trabalhos jornalísticos, que também apareceram ao longo das entrevistas, e não de assessoria, que não é o tema dessa pesquisa de doutorado. Mas achamos importante pontuar que também existem problemas em relação aos direitos trabalhistas na área de assessoria. Por outro lado, acreditamos que a relação de prazer e sofrimento é completamente diferente, pois o sentido do trabalho é outro, por isso, não cabe a essa pesquisa misturar as duas áreas.
} 
Mais para frente, Antonio se questiona, mostrando as marcas de sofrimento que o jornalismo lhe deixou: "O que eu fiz pra minha profissão? E no jornalismo, eu só sobrevivi. Então está complicado, equacionar isso está complicado".

Já Ivan Marsiglia se formou em jornalismo pela Universidade Metodista em 1992. Também tem graduação em ciências sociais pela USP. Em 1993, fez o curso de trainee da Editora Abril, onde passou a trabalhar. Atuou como repórter e editor da revista Playboy por cinco anos. Em 1998 foi para Paris por um ano estudar na Fondation Journalistes en Europe. Na época que estava no exterior, chegou a fazer duas matérias para a Veja. De volta ao Brasil, voltou a trabalhar na Playboy, de onde saiu após um ano, para trabalhar na revista Trip, como redator chefe. "Era uma revista de reportagens interessantes e resolvi trocar o mainstream por uma coisa mais alternativa".

Depois de três anos, saiu da Trip para trabalhar na Secretaria de Imprensa da Presidência da República ${ }^{47}$. "Era o primeiro governo Lula, fui trabalhar com Ricardo Kotscho, que era um jornalista que eu admirava”. Foram quatro anos em Brasília, sendo que no último trabalhou na Secretaria de Direitos Humanos, na época em que o ministro era Paulo Vannuchi. No final de 2007, recebeu um convite para trabalhar no caderno Aliás, do jornal O Estado de S. Paulo e aceitou pela possibilidade de escrever de maneira mais autoral.

Segundo Marsiglia, o Aliás tem tanto um lado intelectual, de artigos acadêmicos, quanto outro de reportagem com liberdade de texto, na contracapa do caderno, que "é um espaço dedicado ao que se chama de jornalismo literário ou jornalismo narrativo". Ao longo da carreira chegou a fazer eventualmente trabalhos como frila, como textos para a revista Caros Amigos.

O que eu gosto no jornalismo é essa possibilidade de você ter uma atividade que ela tanto é de reflexão, tem alguma reflexão, um conteúdo intelectual, exige um pensamento, mas também ela tem ação, te põe no centro do debate público, te faz conviver com pessoas mais imediatamente, cotidianamente. $\mathrm{O}$ pesquisador acadêmico também tem contato com pessoas, mas no jornalismo esse contato é diário, é a rua, é uma temperatura política urbana grande. E isso é o que sempre me fascinou no jornalismo e, ao mesmo tempo, com o mesmo nível de interesse, a possibilidade de escrever, foi o que eu

\footnotetext{
${ }^{47}$ Também neste caso trata-se de um trabalho de assessoria de comunicação, apesar de a área não ser abrangida pela pesquisa, vale ressaltar que a pessoa contratada em cargo comissionado é um servidor público durante o período, mas não de forma efetiva. Há recolhimento de INSS conforme o Regime Geral da Previdência Social - RGPS, mas como não é CLT, a pessoa não tem direito a Fundo de Garantia nem Seguro Desemprego. O servidor público comissionado tem direito às férias, ao décimo terceiro, ao auxílio alimentação e ao plano de saúde do órgão em que está lotado.
} 
gostei de fazer. Então, eu ao longo dessa minha carreira procurei me manter próximo da reportagem, do texto, embora tenha trabalhado em funções que não tenham a ver com isso. Quando eu era redator chefe na Trip, eu era mais um editor de texto, fazia matérias eventualmente, ou quando fui assessor de imprensa, em que produzia alguns textos internamente de governo, de divulgação, mas não era uma coisa de poder escrever de maneira mais autoral... - Ivan Marsiglia.

Nesse grupo, a jornalista Fernanda Cirenza é a que tem mais tempo de experiência na profissão. Nos anos 1980, formou-se em jornalismo na Faculdade Cásper Líbero. Antes mesmo de se formar começou a trabalhar na área como produtora de um programa feito pela Secretaria do Interior, na época do governador Franco Montoro ${ }^{48}$, que era transmitido pela TV Cultura. "Eu promovia as viagens das equipes, ligava pras prefeituras, avisava que a TV Cultura estava indo pra fazer uma matéria..." Assim era possível contar com o apoio dos governos locais e saber por onde começar o trabalho na cidade. Saiu após um ano para fazer um frila para a Globotec, um braço das Organizações Globo, que produzia vídeos institucionais. Lá trabalhou com produção e pesquisa em um documentário sobre a história da imprensa no Brasil, coordenado por Otto Lara Resende. Em seguida trabalhou com assessoria de imprensa no Sesc Pompeia. Começou a trabalhar com jornalismo impresso na revista Casa Vogue, que na época pertencia à Editora Carta, e na revista $\mathrm{HV}$, uma publicação destinada ao público jovem, que não existe mais. Em 1988, foi para a Folha de S. Paulo após enviar o currículo, passar por prova e várias etapas de seleção. "Fiquei 12 longos e adoráveis anos na Folha de S. Paulo. Lá eu fiz um monte de trabalho, fui redatora, repórter, editora, circulei bem no jornal nesses 12 anos". Saiu do jornal em 2000 para trabalhar como editora na revista Marie Claire, da Editora Globo, onde ficou nove anos. Ao sair de lá, fez frilas por um ano, o que considerou "uma experiência muito interessante". Foi trabalhar para um dos locais em que fazia frila, o jornal Diário de São Paulo, a convite do então diretor Leão Serva. "Fui trabalhar na redação todos os dias. Fiquei lá quase um ano até o Leão sair. Aí eu vim pra Brasileiros."

No trabalho de jornalista, nesses 30 anos ou mais de atuação, o que eu mais gosto é desse momento da conversa, conhecer uma pessoa, conhecer o trabalho de uma pessoa, eu adoro essa coisa da reportagem. Eu escrevo bastante, eu faço bastante reportagem, mas a minha trajetória é bastante voltada pra edição... Em geral, eu sempre sou mais solicitada pra fechar coisas. Embora aqui na editora, por exemplo, eu assumo um cargo de redatora chefe, então, (...) todas as informações estão centralizadas em mim, das publicações impressas, hoje só a Brasileiros, mas eu toquei por um tempo uma revista

\footnotetext{
${ }^{48}$ Franco Montoro foi empossado governador do estado de São Paulo em março de 1983.
} 
chamada Inovação Brasileiros, o site e as plataformas digitais. Quer dizer, tudo isso circula no que a gente chama de um grande mesão porque os repórteres, os agentes promotores de informação, que somos nós, trabalham pra todos os suportes. O cara que tem que fazer uma matéria pra revista, também está publicando no site, no Inova BR, que é uma plataforma sobre inovação, então a gente é meio multitarefado. Essa é um pouco a dinâmica aqui, mas a minha linha de frente é fechar a revista, eu preciso botar a revista no forno - Fernanda Cirenza.

\section{9 - O jornalismo em questão}

As falas dos jornalistas da faixa etária de 30 a 39 anos foram marcadas por questionamentos. Eles criticam as condições de trabalho, como mostra a afirmação de Pedro ${ }^{49}, 32$ anos: "O ritmo de trabalho, aí eu falo principalmente da Folha, é uma coisa que me incomodava muito no período todo que eu fiquei, porque eu achava que ele extrapolava o bom senso". E também às práticas jornalísticas, como afirma Miguel $^{50}, 39$ anos: "Dentro de cada experiência, eu sempre questionei muito se é assim que tem que ser feita a atribuição do trabalho. Na realidade, vivi várias situações absurdas, bem questionáveis, por que é dessa maneira e não de outra?"

Situação absurda foi relatada por Leonardo Sakamoto ${ }^{51}, 36$ anos, que já acompanhou libertação de trabalhadores em condições análogas à escravidão. Em uma cobertura feita por um colega da Repórter Brasil, de um desses casos, a físcalização não encontrava nenhum trabalhador na fazenda. Depois de muito tempo, eles começaram a aparecer.

Os trabalhadores começaram a sair de uma grota e falaram que tinham sido colocados lá por gatos, pelos contratadores de mãos de obra dos fazendeiros, por quê? Porque os fazendeiros queriam que eles se escondessem para não serem pegos pela fiscalização, mas não somos bichos, acabou. Mas se você pegar as grandes redações de jornais, revistas daqui do Brasil, já tivemos casos e mais casos de jornalistas que eram frilas fixos e trabalhavam na redação. Quando chegou a fiscalização da Superintendência, eles foram levados ao banheiro - se esconde, se esconde pra não ser pego. Qual que é a diferença conceitual entre as duas situações? Nenhuma, absolutamente nenhuma. Então, os trabalhadores se negaram, teve uma hora que eles

\footnotetext{
${ }^{49}$ Nome fictício, pois o jornalista optou pela preservação de sua identidade. A entrevista foi concedida em 13 de fevereiro de 2014 no apartamento do entrevistado.

${ }^{50}$ Nome fictício, pois o jornalista optou pela preservação de sua identidade. A entrevista foi concedida em 15 de dezembro de 2013 no apartamento do entrevistado.

${ }^{51}$ Entrevista concedida na ONG Repórter Brasil em 10 de janeiro de 2014.
} 
foram embora, os jornalistas não, ficaram! Então o que acontece, você tem uma situação que é muito semelhante às piores formas de exploração que se encontram por aí, não estou falando sempre, mas muitas redações são semelhantes a essa forma de exploração. A única diferença é que a gente se vê acima de tudo isso, como uma áurea intocável, a gente não se vê como trabalhador. Se a gente se visse, não aceitava isso - Leonardo Sakamoto.

Os entrevistados consideram que o jornalismo está em transformação e colocam o jornalismo em questão, mas não acreditam que seja o fim. Pelo contrário, muitas de suas afirmações sobre prazer, sentido do trabalho e envolvimento vão ao encontro dos outros jornalistas ouvidos pela pesquisa, mas as críticas tiveram destaque em suas falas. "A gente vive um momento de repensar o modelo de negócio tradicional jornalístico que está morrendo, esse modelo de negócio de grandes empresas, e não que as grandes empresas vão morrer, mas o modelo que concentra o jornalismo nesse processo está deixando de existir", acredita Leonardo Sakamoto, que ao mesmo tempo classifica o período como um "tempo doloroso".

Acho que a gente vive uma época muito interessante, muito rica pra nossa profissão justamente porque ela não é mais exclusividade nossa. Porque o jornalista saiu do jornal, e a comunicação social deixa de ser um monopólio dos profissionais de comunicação social e passa a ser uma atividade difundida na sociedade toda. E isso pra muita gente torna a nossa profissão obsoleta, pra mim torna a nossa profissão muito mais instigante, muito mais interessante, porque a gente consegue agora permear a sociedade toda - Bruno Torturra ${ }^{52}, 35$ anos.

O modelo de jornalismo mais uma vez é questionado por Maria ${ }^{53}, 33$ anos, que trabalha na Empresa Brasileira de Comunicação - EBC e teve atuação em mídia alternativa e movimentos sociais:

Jornalismo pra mim é o jornalismo público, eu não acredito que o jornalismo que a Folha faz é. Se o foco não é o cidadão, então pra mim não é jornalismo. Se o foco é ter que queimar a Dilma, não é jornalismo. Por mais que a matéria tenha os dados reais, ela foi trabalhada pra ser manipulada - Maria.

A organização do trabalho no jornalismo novamente está na berlinda. "Sempre tem aquela coisa de que é muito trabalho pra o tanto de gente, que não é suficiente. Então, todo mundo tem que trabalhar muito", destaca Miguel. Os métodos de avaliação individual de jornalistas também foram criticados por Pedro.

\footnotetext{
${ }^{52}$ Entrevista concedida em seu apartamento/escritório em $1^{\circ}$ de maio de 2014.

${ }^{53}$ Nome fictício, pois a jornalista optou pela preservação de sua identidade. A entrevista foi concedida em $1^{\circ}$ de julho de 2014 em um café.
} 
Pedro e Miguel são os jornalistas com mais experiência na grande mídia. O primeiro se formou em 2002 em jornalismo em uma faculdade particular de São Paulo e trabalhou na Folha de S.Paulo por cinco anos. "Decidi sair do jornal porque eu não aguentava mais. Ritmo muito intenso.” Já Miguel, formado em jornalismo por uma universidade particular de São Paulo em 1997, trabalhou por mais de quatro anos na CBN e saiu da rádio para estudar. Fez mestrado em uma universidade pública.

No caso de Pedro, antes da Folha trabalhou em revistas impressas especializadas e foi colaborador de uma revista digital, além de trabalhar em editora de livros. $\mathrm{Na}$ Folha, começou fazendo frilas de casa, depois se tornou repórter trabalhando por seis meses na empresa sem ser registrado até ser contratado. Também foi editor.

Já Miguel iniciou a carreira em uma agência de notícias de um grande jornal, onde foi redator e repórter, durante quatro anos. Depois passou a trabalhar na TV de um portal de internet, no qual desenvolveu as funções de produtor, redator e pauteiro. "Naquele momento nem tinha YouTube ainda, então era outro momento que a gente vivia na internet, fiquei dois anos lá”. Já na CBN teve várias funções: redator, repórter, coordenador de equipe de plantão, chefe interino de reportagem e editor.

Também viveu no interior de São Paulo, onde chegou a trabalhar por três meses em uma emissora de TV como produtor e em um portal de notícias local como editor. De volta a São Paulo, passou a trabalhar como repórter em um grande portal. Nessa trajetória, algumas experiências não foram como imaginava:

Não foram experiências tão saborosas, mas algo dentro delas também era positivo e fez com que eu achasse que era aquilo mesmo, que eu tinha feito a escolha certa e que era o caminho a seguir... Com o passar do tempo, tanto na faculdade como no exercício da profissão, foi aumentando uma consciência também em relação ao que é jornalismo, o que é a profissão, qual é a função social. Isso foi aguçando também um espírito crítico, que de certa forma eu procurei colocar na prática, no dia a dia do que eu faço, do que eu fiz nesses anos do jornalismo - Miguel.

Já Maria, Bruno Torturra e Leonardo Sakamoto têm uma trajetória mais ligada aos movimentos sociais ou mídias alternativas. Maria atualmente trabalha na EBC, mas iniciou a carreira ainda estagiária no Correio da Cidadania. Formada em jornalismo, também trabalhou no Movimento dos Sem Terra e com assessoria de imprensa em uma empresa do governo do estado. $\mathrm{Na} \mathrm{EBC}$, é editora e faz parte da Comissão de Empregados:

Para mim trabalho não é só o trabalho, é uma militância que tem uns desgastes que nem todo mundo tem. Então hoje em dia o que me 
cansa não é o trabalho exatamente, são essas atividades políticas dentro da empresa que são realmente muito desgastantes emocionalmente e às vezes afetam até coisas de trabalho. Mas não pretendo sair do meu trabalho antes de me aposentar - Maria.

Bruno Torturra, por sua vez, iniciou a carreira na revista Trip, em 2002. "Mandei uma carta pra revista Trip, querendo trabalhar lá, entrei pra escrever sobre música, era algo que eu me interessava muito na época e depois de alguns meses comecei a dar sugestão de pauta e virei repórter". Ele chegou a cursar três anos de publicidade na Escola Superior de Propaganda e Marketing e um ano na ECA/USP, mas não concluiu a graduação. Na publicação, foram 11 anos de trabalho, exercendo diferentes funções: repórter, correspondente internacional, repórter especial e diretor de redação. "Saí pra ser independente". Passou a produzir streaming ${ }^{54}$, transmissões ao vivo da rua e depois de casa. "Idealizei, montei a Pós-TV. Depois de algum tempo, a Mídia Ninja, com a proposta de criar uma narrativa independente. E hoje eu estou começando esse projeto chamado Fluxo, que é meu primeiro espaço físico para montar uma redação, um veículo propriamente dito". Ele pretende explorar as possibilidades do jornalismo em rede, ter um estúdio para produzir e "um espaço físico onde os jornalistas podem conviver e criar coletivamente".

Com o tempo também eu comecei a parar de me sentir jornalista, porque eu comecei a misturar muito a minha profissão com o meu ativismo político. E aí se fundiu realmente a minha ação política no mundo com o que eu faço profissionalmente. E de uns tempos pra cá eu parei de ser um jornalista clássico, no sentido de: - Ah, o que você faz? - Eu faço entrevista, reportagens, artigos. Eu comecei a me tornar mais um articulador, um ativista e um empreendedor ao mesmo tempo, muito mais do que um repórter, do que um editor, um publisher, mas espero daqui há muito pouco tempo voltar a ser repórter, que é o que eu mais gosto de fazer - Bruno Torturra.

Por fim, Leonardo Sakamoto, que atua na área desde 1995, quando tinha 18 anos. É formado em jornalismo pela ECA/USP em 1998 e tem mestrado e doutorado em ciências políticas pela FFLCH/USP (Faculdade de Filosofia, Letras e Ciências Humanas). Trabalhou nas revistas OffShore e Scuba, nos jornais Gazeta Mercantil, por três meses, e DCI, como freelancer. Na Editora Abril, atuou como repórter no Guia

\footnotetext{
${ }^{54}$ Segundo Lorenzotti (2014, p. 123), streaming significa "fluxo de mídia, é a tecnologia que permite o envio de informações multimídia através de pacotes, utilizando rede de computadores, sobretudo a Internet. Quando a ligação de rede é banda larga, a velocidade de transmissão da informação é elevada, dando a sensação de que o áudio e o vídeo são transmitidos em tempo real. Atualmente, rádios AM e FM e TV's, bem como várias empresas que realizam eventos, utilizam esta tecnologia para interação digital com seus ouvintes e clientes. A informação pode ser transmitida em diversas arquiteturas, como na forma Multicast IP ou Broadcast".
} 
Quatro Rodas e na Caminhos da Terra. "Sempre quis me especializar nessa área de direitos humanos, e a Terra acabou sendo um momento pra fazer essa passagem, porque é uma revista que misturava antropologia, cultura, a questão social e turismo". Também foi apresentador da TV USP e repórter especial do portal IG.

Entre 2000 e 2002, foi professor convidado do curso de jornalismo da ECA/USP. Já a ONG Repórter Brasil foi fundada em 2001 por Sakamoto e outros profissionais, onde é coordenador. "A Repórter tem uma série de atividades ligadas ao jornalismo, ligadas à educação, produção de documentário, de site, tem vários longas metragens, várias grandes reportagens". Esse trabalho foi conciliado com frilas e com o Blog do Sakamoto, criado em 2006, primeiro no site da ONG, depois por três anos no IG e em seguida no UOL. Desde 2009, é professor da pós-graduação da PUC/SP (Pontifícia Universidade Católica). Em 2011, também passou a dar aulas na graduação da mesma universidade.

\subsection{0 - Jornalismo que transforma}

O potencial do jornalismo em contribuir para a transformação da realidade foi uma constante nas falas dos entrevistados entre 20 e 29 anos. Para João ${ }^{55}, 27$ anos, quando o jornalista faz uma reportagem, ele influencia a sociedade. “O jornalista é uma pessoa na sociedade no meio de várias outras que tem a capacidade ou a possibilidade de ajudar a promover transformações sociais, mas ele é um agente que faz isso, não acho que ele é o agente, não é quarto poder, não é o agente mais importante".

Transformar é a força propulsora do jornalismo, o que dá sentido ao trabalho e à ação do jornalista como sujeito no mundo. Ser jornalista, para Priscilla Nery ${ }^{56}, 25$ anos, é atuar para transformar o seu meio. Já Vivian Fernandes, 27 anos, reforça a persistência do jornalista em querer mudar as injustiças, apesar das dificuldades e de nem sempre ser possível fazer isso, e a importância do jornalismo para a democracia.

O papel democrático também está presente na visão de Aline Scarso ${ }^{57}, 27$ anos. Em sua avaliação, a função do jornalista é ser um defensor da democracia e não deve se

\footnotetext{
${ }^{55}$ Nome fictício, pois o entrevistado optou por não se identificar. Entrevista realizada em 03 de junho de 2014, em sala de reunião do seu local de trabalho.

${ }^{56}$ Entrevista realizada em 19 de dezembro de 2013 em um shopping em São Paulo.

${ }^{57}$ Entrevista realizada em 20 de junho de 2014 em um café em São Paulo.
} 
limitar a ser uma pessoa que vê e reporta, como tem acontecido atualmente. "Eu acho que a função dele é muito maior do que isso". Uma dessas ações é ser contra qualquer violação dos direitos humanos. "Tudo que fosse violação dos direitos deveria ser motivo de indignação pros jornalistas, porque isso é você garantir, você realmente estar prestando um serviço pra sociedade, você está defendendo a sociedade do autoritarismo". No entanto, isso nem sempre ocorre: "Eu não vejo o jornalista fazendo isso hoje".

Em relação à experiência profissional, entre os mais jovens, há atuação em grande imprensa, mídia especializada, imprensa alternativa, comunicação pública e internet. Aline Scarso, por exemplo, formada em jornalismo pela Universidade Estadual Paulista - Unesp em 2008, iniciou a carreira na radioagência $\mathrm{NP}^{58}$, ligada aos movimentos sociais, do grupo Brasil de Fato. Depois, acabou indo trabalhar em uma instituição público-privada, a Fundação Instituto de Administração - FIA. Lá, por seis meses trabalhou num projeto da Fundação Telefônica, produzindo conteúdo sobre direitos das crianças e adolescentes na internet. Não se identificou com o ambiente de trabalho e voltou ao Brasil de Fato, para trabalhar na agência de notícias e no jornal impresso. Trabalhou ainda um mês em uma ONG até ser chamada no concurso da Empresa Brasil de Comunicação - EBC, onde estava havia um ano e dois meses na época da entrevista. "Hoje eu trabalho na televisão, trabalho na TV Brasil. Eu acho que eu já fiz tudo, já fiz rádio, já fiz internet, já fiz impresso, e caí na televisão que era o que eu não esperava".

Outro entrevistado do grupo foi João, formado em jornalismo por uma universidade pública e com especialização em outra área. Ele trabalhou em uma revista de informação por quase dois anos e atualmente trabalha com produção de conteúdo em uma empresa que não é de mídia ${ }^{59}$. Na publicação, passou por várias editorias.

Já Priscilla Nery se formou em jornalismo em 2011 pela Universidade Metodista e atua na área desde novembro de 2009. Começou como estagiária em uma produtora de conteúdo, que produzia matérias para alguns sites como Terra, MSN e IG. Ela escrevia para o site Vila Mulher, que é uma comunidade com interação com o público feminino, sobre temas como saúde, finanças e família. Depois se tornou estagiária de uma revista especializada chamada Emergência, que cobre a área de atendimento médico préhospitalar e resgate, da Proteção Publicações e Eventos. Em 2012, passou a também ser

\footnotetext{
${ }^{58}$ A radioagência Notícias do Planalto atualmente se chama radioagência Brasil de Fato.

${ }^{59}$ Para a análise da tese, focaremos na experiência da revista de informação.
} 
repórter da revista Proteção, da mesma editora, que cobre a área de Segurança e Saúde no Trabalho.

Vivian Fernandes, por sua vez, se formou em jornalismo na Universidade Federal de Viçosa, em Minas Gerais, no ano de 2008. Logo depois fez um curso na escola do MST (Movimento dos Sem Terra). Em seguida, chegou a fazer dois frilas em Belo Horizonte. Ela participava do Comitê do Brasil de Fato, de Minas Gerais, onde escrevia algumas matérias e acompanhava as agendas de movimentos sociais e sindicatos para elencar pautas. No outro trabalho, fez a produção e edição de um vídeo para uma ONG. Já em São Paulo, em 2010, começou a trabalhar na radioagência NP como repórter. Desde agosto de 2013, é editora do tablóide Brasil de Fato, edição regional de São Paulo, que é distribuído gratuitamente e tem pautas sociais. Em 2014, concluiu o mestrado em ciências da comunicação na ECA/USP, onde defendeu a dissertação "A América Latina na Mídia Alternativa - A produção de notícias na Radioagência NP e na Agência Pulsar". 



\section{Capítulo 2}

\section{Cidadania, jornalismo e direitos trabalhistas dos jornalistas}

\section{1 - A relação entre jornalismo e cidadania}

A relação entre jornalismo e cidadania pode ser observada a partir de dois patamares diferentes. O primeiro é a contribuição do jornalismo para a cidadania quando possibilita o acesso à informação, o que é um direito do cidadão. O segundo é olhar para o jornalista como portador de direitos e levantar questões trabalhistas, as quais muitas vezes não são respeitadas na área da comunicação.

Em um cenário verdadeiramente democrático, o jornalismo pode ter um papel importante, cumprindo o dever de informar e respeitando o direito à informação do cidadão. Ter acesso à informação, dessa forma, é uma condição necessária à ampliação dos direitos. Para Gentilli (2005, p.22-23), a informação pública realizada pelo jornalismo é um dos fatores para que os direitos sejam assegurados. Há uma necessidade social de informação e de um jornalismo que traga as informações que o cidadão tem o direito de receber para exercer seus direitos. Quando não se possibilita o acesso à informação, o exercício dos demais direitos fica prejudicado.

Por outro lado, contribuir para a consolidação de direitos dá sentido ao trabalho do jornalista e isso pode ser fonte de prazer. O papel do jornalismo na sociedade, assim, dá satisfação ao profissional que trabalha. Quando não há essa contribuição, e o trabalho perde a sua razão, pode emergir o sofrimento.

O sofrimento também pode vir das condições precárias de trabalho. O jornalista é portador de direitos trabalhistas, que incluem a saúde e segurança no trabalho, mas nem sempre são cumpridos. A saúde é um direito fundamental do ser humano, e o trabalho não deve ser fonte de adoecimento nem de acidentes. No percurso da cidadania, o direito a um trabalho seguro e saudável se consolida internacionalmente por meio de documentos e no âmbito brasileiro através da legislação trabalhista e da Constituição Federal. Observaremos essa construção para refletir sobre a relação entre a saúde do jornalista e as condições de trabalho enfrentadas por um lado, e a contribuição do jornalismo para a cidadania, do outro. 


\title{
2.2 - O significado da cidadania
}

"O simples nascer investe o indivíduo de uma soma inalienável de direitos, apenas pelo fato de ingressar na sociedade humana". É o que defende Santos (2007, p.19), pois ao se tornar "um ser no mundo", a pessoa é portadora de "prerrogativas sociais", como o "direito a um teto, à comida, à educação, à saúde, à proteção contra o frio, a chuva, as intempéries; direito ao trabalho, à justiça, à liberdade e uma existência digna”. Segundo o autor, "o respeito ao indivíduo é a consagração da cidadania, pela qual uma lista de princípios gerais e abstratos se impõe como um corpo de direitos individualizados".

Manzini-Covre (1993, p.11-15) também liga o fato de ser cidadão à própria existência humana quando explica que cidadania é o próprio direito à vida em sentido pleno, contemplando os direitos civis, sociais e políticos, os quais devem existir de forma interligada. Ela traz alguns exemplos de não cidadania que podem contribuir para a discussão sobre o direito ao trabalho. Cita exemplos de trabalhadores rurais tratados como escravos no Nordeste, ao que nós acrescentamos os casos de bolivianos em trabalho análogo à escravidão em confecções na cidade de São Paulo, que chegam a fornecer roupas para grandes redes.

\begin{abstract}
Ainda sobre o direito ao corpo, os direitos civis: quem disse que os trabalhadores escolhem onde vão colocar os seus corpos e em que condições e ritmos vão trabalhar? O capitalismo contemporâneo, com um sistema de produção baseado em tecnologia cada vez mais complexa, exige de corpos e mentes dos trabalhadores um esforço e um sofrimento desumanos. (MANZINI-COVRE, 1993, p.13)
\end{abstract}

Os direitos civis, segundo a autora, são os direitos de se dispor do próprio corpo e dependem da existência dos direitos políticos, que por sua vez, dependem de um regime democrático. Já os direitos sociais são aqueles que tratam do atendimento às necessidades humanas básicas como alimentação, habitação, saúde e educação. Os direitos políticos são os que abordam a deliberação do homem sobre sua vida e se relacionam com a convivência com outros homens em organismos de representações e deliberação dos direitos sociais e civis.

Essa divisão do conceito de cidadania em três partes - civil, política e social - é apresentada por Marshall (1967) no texto "Cidadania e classe social" de 1949. A 
história é o instrumento usado para pensar esses aspectos. Mais precisamente a história da cidadania na Inglaterra.

Chamarei estas três partes, ou elementos, de civil, política e social. O elemento civil é composto dos direitos necessários à liberdade individual - liberdade de ir e vir, liberdade de imprensa, pensamento e fé, o direito à propriedade de concluir contratos válidos e o direito à justiça. Este último difere do outro porque é o direito de defender e afirmar todos os direitos em termos de igualdade com os outros e pelo devido encaminhamento processual. Isto nos mostra que as instituições mais intimamente associadas com os direitos civis são os tribunais de justiça. Por elemento político se deve entender o direito de participar no exercício do poder político, como um membro de um organismo investido da autoridade política ou como um eleitor dos membros de tal organismo. As instituições correspondentes são o parlamento e conselhos do Governo local. O elemento social se refere a tudo o que vai desde o direito a um mínimo de bem-estar econômico e segurança ao direito de participar, por completo, na herança social e levar a vida de um ser civilizado de acordo com os padrões que prevalecem na sociedade. As instituições mais intimamente ligadas com ele são o sistema educacional e os serviços sociais. (MARSHALL, 1967, p. 63-64)

$\mathrm{O}$ autor coloca que os direitos civis se desenvolveram na Inglaterra no século XVIII, os políticos no XIX e os sociais no XX (Ibid., p.63). O direito a trabalhar é apontado como um direito civil básico, explicado como o direito "de seguir a ocupação de seu gosto no lugar de escolha, sujeito apenas à legítima exigência do treinamento técnico preliminar". Ele havia sido negado pela Elizabethan Statute of Artificers, "a qual destinava certas ocupações a certas classes sociais" e por regulamentos locais, "que reservam emprego numa cidade aos habitantes da cidade, e pelo uso do aprendizado como um instrumento de exclusão ao invés de recrutamento." (Ibid., p.67)

(...) na Inglaterra do século XVII, todos os homens eram livres. O status servil, ou servitude por sangue, tinha-se prolongado como um anacronismo patente nos dias de Elisabete, mas desapareceu logo depois. Essa mudança do trabalho servil para o livre foi descrita pelo Professor Tawney como 'um marco fundamental no desenvolvimento tanto da sociedade econômica quanto política'... (MARSHALL, 1967, p.68)

Em relação aos direitos políticos, explica que a formação na Inglaterra se iniciou no princípio do século XIX, "quando os direitos civis ligados ao status de liberdade já haviam conquistado substância suficiente para justificar que se fale de um status geral de cidadania”. Os direitos que eram apenas de alguns foram ampliados. A Lei de 1832, por exemplo, ampliou o direito de voto aos arrendatários e locatários de base econômica suficiente. O sufrágio universal veio somente em 1918 (Ibid., p.70). 
Como origem dos direitos sociais, Marshall (1967, p.70-71) aponta "a participação nas comunidades locais e associações funcionais", o que foi complementado e progressivamente substituído por uma "Poor Law" (Lei dos Pobres) e um sistema de regulamentação de salários. "A Poor Law elisabetiana era, afinal de contas, um item num programa de planejamento econômico cujo objetivo geral não era criar uma nova ordem social, e sim preservar a existente com um mínimo de mudança essencial." Mas foi dela, no entanto, que "se originou a ideia dos direitos sociais".

Marshall (1967, p.72-73) explica que "a Poor Law tratava as reivindicações dos pobres não como parte integrante de seus direitos de cidadão, mas como uma alternativa deles - como reivindicações que poderiam ser atendidas somente se deixassem inteiramente de ser cidadãos". Essa separação entre direitos sociais e o status de cidadania também apareceu nos primeiros Factory Acts, leis que regulamentavam as atividades fabris. Apesar de trazerem "uma melhoria das condições de trabalho e uma redução das horas" trabalhadas para todos trabalhadores das indústrias por elas regidas, negaram-se "a dar essa proteção diretamente ao homem adulto - o cidadão par excellence", pois as medidas protetoras "afrontavam o direito civil de efetuar um contrato de trabalho livre". Dessa forma, "a proteção se limitava às mulheres e crianças". Já a necessidade de um eleitorado educado e de trabalhadores qualificados levou ao "desenvolvimento da educação primária pública durante o século XIX”, o que constituiu "o primeiro passo decisivo em prol do restabelecimento dos direitos sociais da cidadania no século XX" (Ibid., p.74).

Tentei demonstrar que os direitos civis surgiram em primeiro lugar e se estabeleceram de modo um tanto semelhante à forma moderna que assumiram antes da entrada em vigor da primeira Lei de Reforma, em 1832. Os direitos políticos se seguiram aos civis, e a ampliação deles foi uma das principais características do século XIX, embora o princípio da cidadania política universal não tenha sido reconhecido senão em 1918. Os direitos sociais, por outro lado, quase que desapareceram no século XVIII e princípio do XIX. O ressurgimento destes começou com o desenvolvimento da educação primária pública, mas não foi senão no século XX que eles atingiram um plano de igualdade com os outros dois elementos da cidadania. (MARSHALL, 1967, p.75)

Para o autor (Ibid., p.76), "a cidadania tem sido uma instituição em desenvolvimento na Inglaterra pelo menos desde a segunda metade do século XVII" e o "seu crescimento coincide com o desenvolvimento do capitalismo, que é o sistema não de igualdade, mas de desigualdade". Como se deu essa convivência? No caso dos direitos civis, eles eram necessários para a economia de mercado competitivo instaurada 
(Ibid., p.79). Já os direitos políticos da cidadania "estavam repletos de ameaça potencial ao sistema capitalista", mas não havia "plena consciência da magnitude de tal ameaça" (Ibid., p.85). Os direitos sociais, por sua vez, “compreendiam um mínimo e não faziam parte do conceito de cidadania. A finalidade comum das tentativas voluntárias e legais era diminuir o ônus da pobreza sem alterar o padrão de desigualdade do qual a pobreza era, obviamente, a consequência mais desagradável" (Ibid., p.88).

O Estado garante um mínimo de certos bens e serviços essenciais tais
como assistência médica, moradia, educação, ou uma renda nominal
mínima (ou salário mínimo) a ser gasto em bens e serviços essenciais -
como no caso da lei que dispõe sobre a aposentadoria por velhice,
benefícios de seguro e salários-família. Qualquer pessoa capaz de
ultrapassar o mínimo garantido por suas qualidades próprias está livre
para fazê-lo. Tal sistema se assemelha, em sua aparência, a uma
versão mais generosa da supressão de classes em sua forma original.
Eleva o nível inferior, mas não limita automaticamente a
superestrutura. (MARSHALL, 1967, p.93)

Na avaliação de Marshall (1967, p.103), "a cidadania impôs modificações” no sistema de classes capitalista. "Os direitos sociais, em sua forma moderna, implicam uma invasão do contrato pelo status, na subordinação do preço de mercado à justiça social, na substituição da barganha livre por uma declaração de direitos”. No entanto, esses princípios já estão "arraigados no sistema de contrato em si”.

Os direitos políticos abriram na Inglaterra do século XIX "caminho para o desenvolvimento do sindicalismo ao tornar os trabalhadores capazes de se valerem de seus direitos civis coletivamente". As grandes greves, que antecederam a Primeira Guerra Mundial, traziam a reivindicação em comum por direitos sociais (Ibid., 104). A barganha também era comum.

O livro de Marshall (1967), "Cidadania, classe social e status", reúne outros artigos do autor, que trazem outras considerações importantes para entender a perspectiva apresentada por ele sobre cidadania. Uma é que ele já aponta a perspectiva de consumo na relação com a cidadania ao falar dos Estados Unidos, o que aparece na citação de um jornal local de 1925 no qual se afirma: "a maior importância do cidadão norte-americano não é mais a de cidadão, mas a de consumidor. $O$ consumo é uma necessidade nova" (Ibid., p.204-205).

Outro aspecto importante é a perspectiva individualista como "princípio do Estado do Bem-Estar Social". Assim afirma que "os benefícios monetários que oferece são reivindicados por direito individual, e em seus serviços de educação e saúde fazem 
o possível para dar a cada um o que cada um necessita para atender a suas necessidades individuais" (Ibid., p.220).

\section{3 - A construção da cidadania como processo conflituoso}

A construção da cidadania se dá, para muitos autores, em um processo conflituoso. Conflito esse que muitas vezes tem como ponto de partida o mundo do trabalho e a luta dos trabalhadores. Hirschman (1992, 11-13), por exemplo, retoma a forma como Marshall aborda a cidadania, para criticar a ausência de uma visão que mostre esse conflito. A divisão de Marshall em direitos civis desenvolvidos no século XVIII, políticos no XIX e sociais no XX com a ascensão do Welfare State é considerada simplista, pois as reações a cada uma delas são bem mais diversas e difusas.

Não é verdade que não só a última, mas cada uma das três investidas progressistas de Marshall fora seguida por contra-investidas ideológicas de força extraordinária? E que essas contra-investidas estiveram na origem de lutas sociais e políticas convulsivas que muitas vezes levaram a recuos dos programas progressivos pretendidos, e também a muita dor e miséria humanas? (HIRSCHMAN, 1992, p.12)

A "afirmação de igualdade perante a lei e dos direitos civis em geral" teve um movimento de oposição, por exemplo, à Revolução Francesa e suas obras. Já o sufrágio universal foi resultado de um crescimento gradual em muitos países, o que não impediu que encontrasse resistências.

...é possível interpretar um movimento ideológico contrário a partir de diversas correntes influentes, surgidas mais ou menos na mesma época em que as maiores conquistas na luta pela extensão do direito de voto foram feitas. Do último terço do século XIX até a Primeira Guerra, e depois dela, uma literatura vasta e difusa - que abarcava a filosofia, a psicologia, a política e as letras - acumulou todos os argumentos concebíveis para menoscabar as 'massas', a maioria, o regime parlamentarista e o governo democrático. Apesar de fazer poucas propostas de instituições alternativas, grande parte dessa literatura prevenia, explícita ou implicitamente, contra os perigos extremados que ameaçavam a sociedade como resultado da tendência à democratização. Com o benefício da visão retrospectiva, é fácil sustentar que tais escritos foram em parte responsáveis pela destruição da democracia na Itália e na Alemanha no período entre as duas guerras, e talvez também pela virada antidemocrática da Revolução Russa... (HIRSCHMAN, 1992, p.14) 
A terceira onda reacionária apontada por Hirschman (Ibid.) é a crítica contemporânea ao Welfare State e "a tentativa de recuar ou 'reformar' alguns dos seus aspectos". Diante dessas reações, o autor chega a três "teses reativo reacionárias principais": a tese da perversidade, a da futilidade e a da ameaça.

\begin{abstract}
De acordo com a tese da perversidade, qualquer ação proposital para melhorar um aspecto da ordem econômica, social ou política só serve para exacerbar a situação que se deseja remediar. A tese da futilidade sustenta que as tentativas de transformação social serão infrutíferas, que simplesmente não conseguirão 'deixar uma marca'. Finalmente a tese da ameaça argumenta que o custo da reforma ou mudança proposta é alto demais, pois coloca em perigo outra preciosa realização anterior. (HIRSCHMAN, 1992, p.15-16)
\end{abstract}

Para Hirschmann (1992, p.19-27), o avanço das formas políticas democráticas ocorreu em um clima de ceticismo e hostilidade na segunda metade do século XIX. As vozes que se levantavam contra o sufrágio universal usavam como argumento a tese da perversidade, que também foi usado para mostrar que a Revolução Francesa levou a tirania. Essa mesma argumentação foi retomada para criticar o Welfare State, quando se diz que "os programas causam o inverso dos resultados desejados" (Ibid., p.34). O autor ainda traz um exemplo relativo ao mundo do trabalho. Apesar de relatar um fato do século XIX, na Europa, esta argumentação já foi ouvida em nossa atuação como jornalista na área de segurança e saúde no trabalho:

Quando o seguro de acidentes foi introduzido nos principais centros industriais europeus, no fim do século XIX, houve muitas alegações, por parte dos empregadores e de diversos "especialistas", de que os trabalhadores estavam se mutilando de propósito, mas com o tempo descobriu-se que esses relatórios haviam sido altamente exagerados. (HIRSCHMAN, 1992, p.40)

Outro exemplo usado pelo autor fala sobre a crítica ao seguro desemprego nos Estados Unidos, que pode fazer com que o trabalhador não procure emprego e se acomode por algum tempo. Esse discurso aparece da mesma forma no Brasil. Assim como as falas que acusam trabalhadores adoecidos pelo trabalho que procuram a Previdência Social de estarem fingindo o adoecimento.

Na tese da futilidade, em que a tentativa de mudança é ilusória, pois a estrutura da sociedade permanece a mesma é exemplificada com uma frase do romance $\mathrm{O}$ Leopardo, de Giuseppe Tomasi di Lampedusa: "Se quisermos que tudo continue como está, é preciso que tudo mude". A afirmação de Tocqueville de que os "Direitos do Homem e do Cidadão" já existiam antes da Revolução Francesa é caracterizada como esse tipo de argumentação. (HIRSCHMAN, 1992, p.44-46) 
Tocqueville pode ser considerado o maior iniciador da tese de futilidade. No caso dele, a futilidade assumiu uma forma "progressista" especial. Tocqueville não se dedicou a negar que algumas mudanças sociais básicas haviam de fato sido alcançadas na França, no final do século XVIII; em vez disso, reconhecendo que tais mudanças haviam ocorrido, ele argumentou que isso acontecera em grande parte antes da Revolução. Considerando o imenso esforço da Revolução, tal posição era, repetindo, mais insultante e ferina à opinião pró-revolucionária que os assaltos diretos de um Burke, um Maistre ou um Bonald. (HIRSCHMAN, 1992, p.47)

Em relação ao Welfare State, o autor aponta como tese da futilidade as críticas que mostram que o pagamento de benefícios é desviado ou não chega a quem realmente precisa (Ibid., p.57). Argumento esse ainda ouvido no Brasil sobre programas como o Bolsa Família, em que pessoas recebem uma renda do governo.

Já a tese da ameaça propaga que a "mudança proposta, ainda que talvez desejável em si, acarreta custos ou consequências inaceitáveis" (Ibid., p.73). O direito ao voto para os trabalhadores e pobres, por exemplo, levaria a formação de uma maioria e de um governo que violaria o direito de acumular propriedade (Ibid., p.83). Outro argumento utilizado foi o de que a democracia colocaria em perigo o progresso econômico (Ibid., p.84). No caso do Welfare State, os apontamentos de que ele colocaria em risco as liberdades individuais e o governo democrático (Ibid., p.94). No Brasil, vemos a tese da ameaça no discurso contra a reforma agrária, por exemplo.

Essas três teses, apontadas por Hirschman (1992), são utilizadas para impedir a conquista e a implementação de direitos. Muitas vezes são reproduzidas pela cobertura jornalística, não com uma perspectiva crítica e sim naturalizando a argumentação como se fossem constatações verdadeiras. O jornalismo, assim, pode ajudar a difundi-las, não cumprindo o papel de proporcionar o acesso ao direito à informação, que, por sua vez, levaria ao exercício de outros direitos. Perversidade, Futilidade e Ameaça fazem parte do conflito que tenta estancar os progressos da cidadania. Para Hirschman (1992, p.77), Marshall não mencionou as forças reacionárias ocorridas no processo histórico, caracterizado apenas como somatório e ignorando o conflito existente. Essas "ondas" reacionárias bloquearam e até reverteram a ampliação do conceito de cidadania.

Como sabemos, T. H. Marshall usou esse mesmo material [histórico] para contar uma história edificante da progressiva expansão dos direitos de cidadania ao longo dos últimos dois ou três séculos, da dimensão civil à política e, com o tempo, à sócio-econômica. No entanto esse relato do progresso gradual e acumulativo é praticamente um convite ao ataque e à subversão, com base no argumento de que a passagem de um estágio a outro pode ser qualquer coisa, menos fácil. (HIRSCHMAN, 1992, p.75) 
A relação conflituosa na construção da cidadania também aparece em Saes (2000), que retoma Marshall e o clássico ensaio "Cidadania e classe social" para fazer uma crítica à concepção liberal de cidadania. Assim avalia que a definição do autor é considerada bastante vaga ${ }^{1}$ e que o que mais lhe interessa é "chegar rapidamente à caracterização dos diferentes modos pelos quais pode teoricamente se concretizar (e se concretizou historicamente) essa participação de todos os indivíduos na comunidade política" (Ibid., p.3). Ainda ressalta que Marshall não dispunha "de um esquema teórico preciso" que definiria "os papéis respectivos das classes trabalhadoras, das classes dominantes e da burocracia de Estado no conjunto do processo de criação de qualquer novo direito" (Ibid., p.6).

O autor retoma Marshall e sua análise sobre a Inglaterra para mostrar a relação entre o desenvolvimento do capitalismo e a evolução da cidadania. Os direitos civis, por exemplo, foram indispensáveis para a implantação do capitalismo, pois "sem tais direitos os homens não poderiam participar livremente do mercado, seja como compradores, seja como vendedores de força de trabalho" (SAES, 2000, p.8). O livre funcionamento do mercado gerou posições desiguais, o que criou a necessidade de direitos políticos e sociais para a diminuição da desigualdade. Mas, para que as transformações ocorressem, as revoluções tiveram papel importante, o que é subestimado por Marshall (Ibid., p.10).

Além disso, Saes (2000, p. 12) avalia que "a postura das classes trabalhadoras diante da cidadania, numa sociedade capitalista, tende a ser uma postura dinâmica e progressiva". No entanto, a liberdade civil, apesar de condição necessária, não era suficiente para que os direitos políticos fossem instaurados. "Na verdade, a instauração de tais direitos, defendida pelas classes trabalhadoras, é sucessivamente postergada, ao longo do século XIX, por obra das disposições antidemocráticas das classes dominantes" (Ibid., p.16) .

Essa postergação é exemplificada por Dejours (1992, p.14-18), que caracteriza o século XIX e início do XX como um período marcado por uma luta pela sobrevivência. As jornadas de trabalho iam de 12 até 16 horas por dia. Havia o emprego de crianças na produção, às vezes, a partir de 3 anos e com mais frequência, a partir de 7 anos. Os

\footnotetext{
1 “Cidadania, segundo Marshall, é a participação integral do indivíduo na comunidade política; tal participação se manifestando, por exemplo, como lealdade ao padrão de civilização aí vigente e à sua herança social, e como acesso ao bem-estar e à segurança materiais aí alcançados.” (SAES, 2000, p.3)
} 
salários eram muito baixos e não asseguravam condições mínimas de sobrevivência. Havia condições de trabalho adversas, falta de higiene, subalimentação e alta morbidade. Lutava-se para sobreviver, e essas condições foram denunciadas. Uma das respostas foi o movimento higienista. Já as greves que ocorriam para denunciar a situação eram reprimidas. A partir do movimento comunista e com a criação de sindicatos associações, federações e partidos políticos, as reivindicações operárias se politizaram. A grande questão era a redução da jornada de trabalho.

As lutas operárias marcarão todo o século. As discussões governamentais serão intermináveis. Entre um projeto de lei e sua votação é preciso, muitas vezes, esperar dez, vinte anos. Nove anos para a supressão da caderneta operária (1881-1890); treze anos para o projeto de lei sobre a redução do tempo de trabalho das mulheres e crianças (1879-1892); onze anos para a lei sobre a higiene e a segurança (1882-1893); quinze anos para a lei sobre acidentes de trabalho (1883-1898) (11 p.93); quarenta anos para a jornada de 10 horas (1879-1916); vinte e sete anos para o repouso semanal (18791906); vinte e cinco anos para a jornada de 8 horas (1894-1919); vinte e três para a jornada de 8 horas nas minas (1890-1913). (DEJOURS, 1992, p.17)

Mesmo antes disso, no período pré-industrial (de meados do século XVIII a meados do XIX para a Inglaterra e França), Martin-Barbero (2006, p. 141) aponta que "as classes populares são sujeito ativo de movimentos quase permanentes de resistência e protesto". Em relação às jornadas de 16 horas de trabalho, ele coloca que eram justificadas em nome do progresso. O capitalismo reduzia, assim, a vida à produção, e havia um conflito entre os modos populares de vida e a lógica emergente do capital.

As inovações, tanto econômicas como técnicas, eram experimentadas, sentidas pelas classes populares antes de tudo como isto: expropriação e dissolução de seus direitos. Fala disso a destruição das máquinas pelos luditas, um movimento que passou para a história com uma imagem caricatural elaborada pela direita, mas também os historiadores de esquerda engoliram até pouco tempo. A de que foi a ignorância misturada a preconceitos religiosos, a que impôs aos trabalhadores destruir as máquinas de trabalho, os teares mecânicos. Hoje sabemos sem dúvida que os organizadores do movimento ludita não foram os trabalhadores "mais primitivos", mas os mais instruídos e qualificados, aqueles mesmos que continuaram seu movimento para travar depois a primeira batalha pela jornada de dez horas. E não foram preconceitos religiosos, mas uma percepção aguda da relação entre as máquinas e as novas relações sociais, entre o formato do dispositivo mecânico e a organização do trabalho na fábrica, o que motivou a destruição das máquinas. (MARTIN-BARBERO, 2006, p. 143)

Heller (1989, p.114), por sua vez, considera que o movimento operário no século XIX ficou "mais ou menos isolado do conjunto da sociedade" e se interessou 
"unilateralmente pelos fatores econômicos". Assim a práxis e suas motivações ficaram de fora dos horizontes ideológicos dos trabalhadores.

A importância da história das lutas dos trabalhadores é defendida por Giannotti (2007). Ele relata que em 1820, a média de vida dos operários em Londres era 21 anos e que crianças de 5 anos já trabalhavam em fábricas (Ibid., p.31). O movimento operário inglês foi o primeiro a existir, havia manifestações e comícios (Ibid., p.32). A jornada de trabalho de 10 horas diárias passou a vigorar em $1^{\circ}$ de maio de 1848.

As reivindicações dos operários ingleses não visavam somente redução da jornada de trabalho e melhores salários. Passaram também a exigir o direito ao voto universal secreto e vários outros direitos sociais, como a escola gratuita para todos. Essas foram reivindicações apresentadas pelo chamado Movimento Cartista. Os trabalhadores exigiam uma Carta Constitucional que garantisse direitos no trabalho e no conjunto da vida de todos enquanto cidadãos. (GIANNOTTI, 2007, p.33)

O autor ainda relata o fuzilamento de milhares de trabalhadores franceses após 1845 (GIANNOTTI, 2007, p.34) e a luta pela redução da jornada para 8 horas de trabalho em diversos países. Nos Estados Unidos, cita uma greve de Chicago em 1886, na qual seis trabalhadores foram assassinados e que deu origem a criação do $1^{\circ}$ de maio em 1891 como Dia Internacional da Luta dos Trabalhadores, a ser marcado com greves e manifestações (Ibid., p.37).

No começo do século XX, a luta pelas 8 horas de trabalho continuou. "Mortes, prisões e perseguições marcaram todo o século XIX, mas as oito horas não eram alcançadas. Só começarão a vigorar na segunda metade da década de 1910” (Ibid., p.45). Em 1919, a recém-criada Organização Internacional do Trabalho (OIT), recomenda em sua Convenção $\mathrm{n}^{\circ} 1$ que todos os países regulamentem a jornada de trabalho de 8 horas. O direito no Brasil só será alcançado em 1933 para o trabalhador urbano na época do governo Vargas (Ibid., p.47).

Giannotti (2007, p. 49) afirma que a industrialização brasileira se iniciou cem anos depois dos países europeus ${ }^{2}$. No Brasil, em 1900, havia cerca de 80 mil trabalhadores urbanos. As primeiras fábricas foram as do setor têxtil. Entre 1844 e 1866, houve a instalação de nove tecelagens de algodão no país, e nos anos de 1890 eram 48 fábricas desse ramo (Ibid., p.51).

\footnotetext{
${ }^{2}$ Na Inglaterra, entre 1760 e 1770; na França, entre 1800 e 1815; na região da Alemanha e no norte da Itália, em 1830.
} 
As condições de trabalho para os primeiros operários e para os trabalhadores da construção civil eram péssimas. Exatamente iguais às de cem anos antes na Inglaterra. Jornada de trabalho sem limite: $12 \mathrm{~h}$, 14h, 16h ou mais. Nenhum descanso semanal. Nada de férias... ninguém nem conhecia essa palavra. Trabalho pesado, num ritmo que esgotava qualquer um.

$\mathrm{O}$ ambiente daquelas fábricas, movidas a vapor, era completamente nocivo à saúde. Insalubre. Umidade, fumaça de carvão, vapor vazando e uma alimentação de miséria eram o caldo ideal para a tuberculose e outras doenças infecciosas, como o tifo e a cólera. Em 1910, nas fábricas de São Paulo, a idade média de vida do trabalhador chegava a 19 anos. (GIANNOTTI, 2007, p. 55)

As primeiras greves no Brasil começaram na segunda metade do século XIX (Ibid., p. 59). Mas é entre 1900 e 1920, que para Giannotti, formou-se realmente a classe operária brasileira. A ideia de anarquismo é trazida por imigrantes espanhóis e italianos nesse período, já após a década de 20 se intensificou a influência comunista (Ibid., p.66). As lutas eram divulgadas nos jornais operários, os quais também eram impulsionados pelos imigrantes. Muitas das greves do período pediam redução da jornada para 8 horas diárias, descanso aos domingos, regulamentação do trabalho de mulheres e menores, liberdade de organização operária (Ibid., p.76).

As primeiras leis do Brasil foram a de acidentes de trabalho, de janeiro de 1919, dando o direito ao recebimento de indenização sob responsabilidade dos empregadores; uma lei de estabilidade de empregos em 1923; outra voltada a aposentadorias e pensões apenas para ferroviários nesse mesmo ano; extensão para os portuários em 1926; lei de 15 dias de férias para comerciários em 1925 e bancários em 1926; proibição de trabalho para menores de 14 anos em 1927. No entanto, essas leis eram negadas pelo patronato e não eram aplicadas na prática. (GIANNOTTI, 2007, p.107)

A elaboração de uma legislação trabalhista no Brasil ocorrerá, segundo o autor (Ibid., p.116) para racionalizar e regulamentar as relações de trabalho, possibilitando o desenvolvimento capitalista; para diminuir as pressões dos trabalhadores, e para atender às pressões da Organização Internacional do Trabalho - OIT. Em 1932, a Lei das Convenções Coletivas de Trabalho proporciona jornada de 8 horas e descanso semanal remunerado. Em 1934, é publicada uma lei sobre acidentes de trabalho, além de direitos de assistência e Previdência Social (Ibid., p.140). Já a publicação da Consolidação das Leis do Trabalho (CLT) só acontece em $1^{\circ}$ de maio de 1943 (Ibid., p.129). Na ditadura de Vargas, entre 1937 e 1945, as lideranças trabalhadoras foram presas e quase não havia greves (Ibid., p.142), o clima era de repressão ou cooptação. O movimento foi 
retomado a partir de 1944 até ser mais uma vez silenciado com a ditadura militar em 1964.

Em uma análise mais geral, Bobbio (1992, p.77) também reforça o papel da luta dos trabalhadores ao afirmar que o direito ao trabalho foi elevado a direito fundamental na sociedade dos países da primeira revolução industrial devido às reivindicações dos movimentos operários tanto que nas Declarações de Direito contemporâneas ele sempre aparece. A implementação do direito ao trabalho, no entanto, encontra outros entraves:

O direito ao trabalho nasceu com a Revolução Industrial e é estreitamente ligado à sua consecução. Quanto a esse direito, não basta fundamentá-lo ou proclamá-lo. Nem tampouco basta protege-lo. O problema da sua realização não é nem filosófico nem moral. Mas tampouco é um problema jurídico. É um problema cuja solução depende de um certo desenvolvimento da sociedade e, como tal, desafia até mesmo a Constituição mais evoluída e põe em crise até mesmo o mais perfeito mecanismo de garantia jurídica. (BOBBIO, 1992, p. 45)

O "processo de criação de direitos na sociedade capitalista", assim, "é necessariamente um processo conflituoso, embora não contraditório”. Isso porque "a perspectiva da maioria social é dinâmica e progressiva, e a perspectiva das classes dominantes é estagnacionista e regressiva". Outro aspecto é que os direitos sociais podem ser implantados sem a existência de um regime democrático como forma de compensação e busca de legitimidade de um governo ditatorial, como ocorreu na ditadura de Getúlio Vargas, de 1931 a 1934 e de 1937 a 1945. (SAES, 2000, p.18-19)

Bobbio (1992, p.1-6), no entanto, avalia que direitos "do homem, democracia e paz são três momentos necessários do mesmo movimento histórico", assim explica: "sem direitos do homem reconhecidos e protegidos, não há democracia; sem democracia não existem as condições mínimas para a solução pacífica dos conflitos”. Para ele, "a democracia é a sociedade dos cidadãos, e os súditos se tornam cidadãos quando lhes são reconhecidos alguns direitos fundamentais". Também defende "que os direitos do homem, por mais fundamentais que sejam, são direitos históricos, ou seja, nascidos em certas circunstâncias, caracterizadas por lutas em defesa de novas liberdades contra velhos poderes, e nascidos de modo gradual”.

...os direitos do homem constituem uma classe variável, como a história destes últimos séculos demonstra suficientemente. O elenco dos direitos do homem se modificou, e continua a se modificar, com a mudança das condições históricas, ou seja, dos carecimentos e dos interesses, das classes no poder, nos meios disponíveis para a realização dos mesmos, das transformações técnicas, etc. Direitos que foram declarados absolutos no final do século XVIII, como a 
propriedade sacre et inviolabre, foram submetidos a radicais limitações nas declarações contemporâneas; direitos que as declarações do século XVIII nem sequer mencionavam, como os direitos sociais, são agora proclamados com grande ostentação nas recentes declarações. Não é difícil prever que, no futuro, poderão emergir novas pretensões que no momento nem sequer podemos imaginar.... O que prova que não existem direitos fundamentais por natureza. $\mathrm{O}$ que parece fundamental numa época histórica e numa determinada civilização não é fundamental em outras épocas e em outras culturas. (BOBBIO, 1992, p.18-19)

O autor explica ainda que os direitos sociais foram chamados de direitos de segunda geração. Os de terceira geração constituem "uma categoria excessivamente vaga e heterogênea", que incluem, por exemplo, o direito de viver em um ambiente não poluído. Os de quarta geração são referentes aos "efeitos cada vez mais traumáticos da pesquisa biológica”. O grande problema, entretanto, é que muitos direitos não foram implementados:

a maior parte dos direitos sociais, os chamados direitos de segunda geração, que são exibidos brilhantemente em todas as declarações nacionais e internacionais, permaneceu no papel. O que dizer dos direitos de terceira e quarta geração? A única coisa que até agora se pode dizer é que são expressão de aspirações ideais, às quais o nome de "direitos" serve unicamente para atribuir um título de nobreza. (BOBBIO, 1992, p.9)

Um dos exemplos que utiliza é quando se fala do direito em viver em um mundo não poluído. Na verdade, fala-se sobre o desejo de se obter "uma legislação que imponha limites ao uso de substâncias poluentes”. Só que há uma distância entre a proclamação desse direito e a sua efetividade. O uso do termo "direitos" traz força às reivindicações dos "movimentos que demandam para si e para os outros a satisfação de novos carecimentos materiais e morais". No entanto, não deve ocultar a diferença entre o direito que é reivindicado e aquele reconhecido. Há uma massa "sem-direitos", uma grande parte da população mundial excluída de fato. (Ibid., p.10)

A construção conflituosa da cidadania também fica evidente nas colocações de Bobbio. "Não se pode afirmar um novo direito em favor de uma categoria de pessoas sem suprimir algum velho direito, do qual se beneficiavam outras categorias de pessoas". Por exemplo, "o reconhecimento do direito de não ser escravizado implica a eliminação do direito de possuir escravos". (Ibid., p.20)

$\mathrm{Na}$ história, "a ilusão do fundamento absoluto de alguns direitos estabelecidos foi um obstáculo à introdução de novos direitos, total ou parcialmente incompatíveis com aqueles". É o caso dos direitos sociais, adiados em nome dos direitos de liberdade, 
visto como um direito absoluto e usado para defender posições conservadoras. Com a Declaração dos Direitos do Homem, a questão dos fundamentos perdeu importância, pois a maioria dos governos concordou com o estabelecimento de determinados direitos, no entanto, ainda é necessário buscar implementar os direitos já proclamados. O grande problema é proteger esses direitos e torná-los efetivos, o que muitas vezes não depende apenas de boa vontade, mas de transformações econômicas. (Ibid., p.22-24)

Já Victor Gentilli (2005, p. 96) explica que a cidadania “é um conceito teórico cujo desenvolvimento teve como matriz de referência o ideal de emancipação liberal. Tem como base o reconhecimento a todos os membros plenos da sociedade de um 'status' de igualdade em relação a direitos e obrigações".

O autor aponta que os direitos civis "eram direitos de liberdade organizados contra o poder do Estado", mas surgiram em um mundo marcado pelas necessidades e acabaram ampliando as desigualdades sociais, pois legitimavam a exploração do trabalho juridicamente. Apesar disso, os direitos civis se universalizaram e se tornaram exercidos por todos. Os direitos políticos tiveram trajetória semelhante ao surgirem para atenuar o poder absolutista como um direito exclusivo dos proprietários, porém se ampliaram até chegar ao sufrágio universal. "As massas, por sua ação, vão se apropriando de prerrogativas que não foram concedidas para elas”. (Ibid., p. 108)

Em relação aos direitos sociais, caracteriza-os como os "que proporcionam aos seus beneficiários um certo nível de bem-estar material” e oportunidades e condições não possíveis pela classe social de origem da pessoa e pela desigualdade social capitalista. Cabe, então, ao Estado zelar por esses direitos, que partilham as conquistas da humanidade de forma mais igualitária. São direitos "à dignidade pessoal, ao trabalho, (e à proteção contra o desemprego), à saúde, à educação, à garantia de uma renda mínima, à aposentadoria, ao bem-estar". Trata-se de direitos de necessidades, tutelados pelo Estado, mas que fazem “surgir 'personagens como sujeitos de direito': o trabalhador, a mulher, a criança, o idoso, o doente, o deficiente físico, o consumidor." (GENTILLI, 2005, p. 104-105)

Bobbio (1992, p.72) também chama atenção para o surgimento de novos personagens como sujeitos de direito. Várias convenções são citadas: Convenção sobre os Direitos Políticos da Mulher (1952), Declaração da Criança (1971), Declaração dos Direitos do Deficiente Mental (1975), Declaração dos Deficientes Físicos (1982) (Ibid., p.69). Ainda aponta que a realização prática dos direitos sociais requer a proteção efetiva do Estado e a ampliação de poderes. Para esse autor (Ibid., p.61), o "Estado de 
direito é o Estado dos cidadãos", e a democracia é a "forma de governo na qual todos são livres para tomar as decisões sobre o que lhes diz respeito, e têm o poder de fazêlo".

Segundo Saes (2000, p. 24-25), as lutas populares instauram uma pressão objetiva sobre as classes dominantes e a burocracia estatal na sociedade capitalista para que haja "a instauração de direitos políticos e de direitos sociais (ambos contingentes quanto à reprodução do capitalismo)".

Assim podemos afirmar que a prática da reivindicação é fundamental para que a cidadania possa existir concretamente. É preciso, então, apropriar-se dos espaços e poder fazer "valer os direitos de cidadão". Para tanto, é preciso assegurar "o direito de reivindicar os direitos" e possibilitar que todos tenham esse conhecimento, para agirem como "sujeitos daquilo que podem conquistar". (MANZINI-COVRE, 1993, p. 10)

Trata-se da "nova cidadania" ou "cidadania ampliada", que foi formulada pelos movimentos sociais no final dos anos 1970 e ao longo da década de 1980. Eles se organizaram no Brasil "em torno de demandas de acesso aos equipamentos urbanos como moradia, água, luz, transporte, educação, saúde, etc. e de questões como gênero, raça, etnia, etc." A inspiração veio da luta anterior "pelos direitos humanos (e contribuindo para a progressiva ampliação do seu significado) como parte da resistência contra a ditadura, essa concepção buscava implementar um projeto de construção democrática, de transformação social”. (DAGNINO, 2004, p.103)

Um primeiro elemento constitutivo dessa concepção de cidadania se refere à noção mesma de direitos. A nova cidadania assume uma redefinição da ideia de direitos, cujo ponto de partida é a concepção de um direito a ter direitos. Essa concepção não se limita a provisões legais, ao acesso a direitos definidos previamente ou à efetiva implementação de direitos formais abstratos. Ela inclui a invenção/criação de novos direitos, que surgem de lutas específicas e de suas práticas concretas. (...)

(...) A nova cidadania requer - é inclusive pensada como consistindo nesse processo - a constituição de sujeitos sociais ativos (agentes políticos), definindo o que consideram ser seus direitos e lutando para seu reconhecimento enquanto tais. Nesse sentido, é uma estratégia dos não-cidadãos, dos excluídos, uma cidadania "desde baixo".

Um terceiro ponto é a ideia de que a nova cidadania transcende uma referência central no conceito liberal: a reivindicação ao acesso, inclusão, participação e pertencimento a um sistema político já dado. O que está em jogo, de fato, é o direito de participar na própria definição desse sistema, para definir de que queremos ser membros, isto é, a invenção de uma nova sociedade. (DAGNINO, 2004, p.104) 
Giannotti (2007) destaca o papel dos trabalhadores nessa época. Ele caracteriza os anos 1970 como um período em que houve "aumento da exploração, horas extras e aumento do ritmo de trabalho", e o Brasil se torna campeão mundial de acidentes e doenças do trabalho (Ibid., p.209). Tanto que o país sofre pressão internacional e chega a criar em 1978 as Normas Regulamentadoras, voltadas para as questões de saúde e segurança.

Por outro lado, os movimentos de trabalhadores voltam em cena com a explosão de greves a partir de 1978 em fábricas (Ibid., p. 225), que atingem diversas categorias em 1979 (Ibid., p.230). Nesse período, questões relacionadas à saúde do trabalhador passam a ganhar espaço (REIMBERG, 2012b, p.92). Um exemplo dessa ação foi a realização da I Semsat (Semana de Saúde do Trabalhador), organizada em 1979 por 49 sindicatos e seis federações do estado de São Paulo. Além do evento, que contou com a participação de 1.800 trabalhadores em um total de 13 encontros, foi produzido o Gibi dos Trabalhadores. Com ilustrações ${ }^{3}$, o material explicava os riscos das poeiras com sílica, de algodão, linho, cânhamo, sisal ou amianto no trabalho, que geravam doenças pulmonares, e como deveria ser feita uma proteção efetiva. A solução passava por medidas de engenharia como exaustão, umidificação e ventilação.

Outra ação ligada à Semsat foi a criação do Diesat (Departamento Intersindical de Estudos e Pesquisas de Saúde e dos Ambientes de Trabalho) em 1980. Inicialmente 16 entidades sindicais formaram a primeira diretoria. O órgão realiza estudos, assessora sindicatos para a melhoria das condições de trabalho e produz materiais de comunicação, sempre informando sobre o direito à saúde no trabalho ${ }^{4}$. Produziu o livro "De que adoecem e morrem os trabalhadores", em 1984, e, por 11 anos, a Revista Trabalho \& Saúde. Atualmente tem um informativo mensal, site ${ }^{5}, \operatorname{blog}^{6}$ e twitter ${ }^{7}$.

Os anos 1980 são aqueles em que houve o maior volume de greves do Brasil (GIANNOTTI, 2007, p. 233), período esse marcado pela recessão econômica (Ibid., p.253). O autor aponta que de 1980 a 2002, o país passou "de uma ditadura militar a um regime democrático conservador". A década de 80 foi um período de greves, greves

\footnotetext{
${ }^{3}$ As ilustrações foram feitas por Fausto e Laerte, já o jornalista responsável foi Sérgio Gomes, da Oboré.

${ }^{4}$ Outras Semsats também foram organizadas pelo DIESAT até 1995. No total, ocorreram doze edições da Semana de Saúde do Trabalhador.

5 www.diesat.org.br

6 http://diesat.blogspot.com/

7 @Diesat
} 
gerais, criação de central sindical, legalização de partidos de esquerda; já os anos 1990 foram marcados "pela implantação e consolidação do projeto neoliberal" (Ibid., p.85).

Canclini (2010, p.36-37) também aponta a "hipervalorização" da autonomia e da força dos movimentos sociais nos anos 1970 e 1980. A cidadania é pensada como estratégia política e se reivindica tanto o direito de pertencer ao sistema político e de participar na reelaboração desse sistema. A experiência dos movimentos sociais na América Latina leva a uma redefinição de cidadania, que compreende não apenas os direitos a igualdade como também os direitos à diferença.

Isto implicaria uma perda de substância no conceito de cidadania manipulado por juristas: mais do que como valores abstratos, os direitos são importantes como algo que se constrói e muda com as práticas e discursos. A cidadania e o direito não falam unicamente da estrutura formal de uma sociedade; indicam, além disso, o estado da luta pelo reconhecimento dos outros como sujeitos de "interesses válidos, valores pertinentes e demandas legítimas". (CANCLINI, 2010, p.36)

Mais adiante, o Brasil dos movimentos sociais que emergem na cena pública nos anos 80 passa a conviver com o projeto neoliberal que eclode no país a partir da eleição de Collor em 1989, com "um projeto de Estado mínimo que se isenta progressivamente de seu papel de garantidor de direitos através do encolhimento de suas responsabilidades sociais e sua transferência para a sociedade civil". Por outro lado, o país se encontrava em um período logo após a Constituição de 1988, que como veremos adiante, aprofunda a democracia participativa e as conquistas de direitos. Vive-se então "uma confluência perversa entre um projeto político democratizante, participativo, e o projeto neoliberal, que marcaria hoje (...) o cenário de luta pelo aprofundamento da democracia brasileira”. (DAGNINO, 2004, p.95-96)

Essa disputa entre projetos políticos ${ }^{8}$ distintos, segundo Dagnino (Ibid., p.97), também se dá no campo dos significados de palavras como participação, sociedade civil, cidadania e democracia. Por outro lado, há uma necessidade de interlocução entre os campos adversários. Esses dois projetos antagônicos apresentam a "coincidência na exigência de uma sociedade civil ativa e propositiva", além "de uma série de outras 'coincidências' no nível do discurso, referências comuns que, examinadas com cuidado, escondem distinções e divergências fundamentais" (Ibid., p.99).

\footnotetext{
${ }^{8}$ A autora usa "o termo projetos políticos num sentido próximo da visão gramsciana, para designar os conjuntos de crenças, interesses, concepções de mundo, representações do que deve ser a vida em sociedade, que orientam a ação política dos diferentes sujeitos.” (DAGNINO, 2004, p.98)
} 
O movimento de redefinição de sociedade civil no projeto neoliberal, por exemplo, marginaliza os movimentos sociais, e as relações entre Estados e ONGs configuram-se, muitas vezes, apenas como transferência de responsabilidades (Ibid., p.100-101). Já o termo cidadania tem o significado coletivo reduzido para um entendimento individualista e ligado ao mercado. "Tornar-se cidadão passa a significar a integração individual ao mercado, como consumidor e como produtor." Vemos a eliminação de direitos trabalhistas, "em nome da livre negociação entre patrões e empregados, da 'flexibilidade' do trabalho" e o fim de direitos sociais "garantidos pela Constituição Brasileira desde os anos quarenta eliminados sob a lógica de que eles constituem obstáculos ao livre funcionamento do mercado, restringindo assim o desenvolvimento e a modernização“ (Ibid., p.106). Essas visões são reproduzidas pelo jornalismo, que acaba tendo um papel contrário à cidadania, no sentido coletivo, democrático e participativo do termo. Ao mesmo tempo, os jornalistas vivenciam essa flexibilidade no ambiente de trabalho, com a supressão de direitos e a precarização, como veremos mais adiante.

Outro aspecto a ser pensado é a colocação de Canclini (2010, p.42): "Pela imposição da concepção neoliberal de globalização, na qual os direitos são desiguais, as novidades modernas aparecem para a maioria apenas como objetos de consumo, e para muitos apenas como espetáculo". O direito de ser cidadão e decidir sobre a produção, distribuição e utilização desses bens se restringe às elites. Desempregados e migrantes são excluídos de direitos humanos básicos como trabalho, saúde, educação e moradia.

Moretzsohn (2007, p.142) também chama atenção para o fato de que " "nas sociedades de mercado' os princípios fundamentais de cidadania transferem-se para a esfera do consumo". Nessa mudança, a concepção de cidadania "se esvazia de seu sentido político para vincular-se ao consumo, isto é, à capacidade de participar do mercado". Assim "não haveria cidadãos a esclarecer, e sim consumidores a satisfazer".

Posicionando-se contrariamente a esse sistema, a autora defende um jornalismo que pense contra os fatos, ou seja, aquilo naturalizado e aceito como verdade pelo senso comum sem maiores questionamentos, adequado à manutenção do mundo tal como é. "Para recolocar a questão nos trilhos, será preciso recuperar o referencial de autoridade do jornalismo como mediador implicado ao 'quarto poder', ainda que seja necessário desmistificar esse conceito e apontar o papel necessariamente político dessa mediação.” (Ibid., p.282-283) Complementa que o papel do jornalista como mediador deve ser preservado: 
A preservação desse papel remete ao conceito de "quarto poder", cuja crítica ao longo desse livro não sugere uma redenção, mas uma reelaboração capaz de expor as implicações políticas do trabalho de mediação. A revolução no jornalismo, portanto, não é dissolvê-lo no cotidiano, mas desmistificar o cânone da imparcialidade para fazê-lo assumir seu papel no jogo de forças que compõe a sociedade. Apenas desta forma o jornalismo pode de fato cumprir sua promessa de esclarecimento, esclarecendo previamente que todo discurso é ideológico e que não há informação independente de interpretação, apesar da ancestral aspiração do público pelo relato dos fatos "tais quais são": estaria aí, aliás, ao mesmo tempo o resultado e a legitimação do processo de "pensar contra os fatos".

(...) Noutras palavras, partir do fenômeno para conectá-lo ao processo. É nesse sentido que se poderá assumir o ideal iluminista de ousar saber e ousar ver, com a consciência de que esse processo será sempre um jogo de luz e sombra, que simultaneamente encobre e revela. (MORETZSOHN, 2007, p.288-289)

A relação entre consumo e cidadania também é pensada por Canclini (2010, p.13-14). Ele aponta que no modelo de sociedade norte-americano, "a participação social é organizada mais através do consumo do que mediante o exercício da cidadania". Para ele, deve-se refletir sobre o consumo como espaço para pensar, "no qual se organiza grande parte da racionalidade econômica, sociopolítica e psicológica nas sociedades". Assim tenta entender "como as mudanças na maneira de consumir alteram as possibilidades e as formas de exercer a cidadania” (Ibid., p.29).

Não é possível generalizar as consequências sobre a cidadania resultantes desta participação crescente mediante o consumo. As críticas apocalípticas ao consumismo continuam indicando que a organização individualista dos consumos tende a nos fazer desconectar, como cidadãos, das condições comuns, da desigualdade e da solidariedade coletiva. Em parte isto é correto, mas a expansão das comunicações e do consumo também podem gerar associações de consumidores e lutas sociais, ainda que em grupos marginais, melhor informadas sobre as condições nacionais e internacionais. (CANCLINI, 2010, p. 224)

O autor defende que as visões de consumo e cidadania deviam ser estudadas de forma conjunta, com instrumentos da economia e da sociologia política, e como processos culturais. Dessa forma, "ser cidadão não tem a ver apenas com os direitos reconhecidos pelos aparelhos estatais para os que nasceram em um território, mas também com as práticas sociais e culturais que dão sentido de pertencimento". "Ao pensar a cidadania em conexão com o consumo e como estratégia política”, o autor procura "um marco conceitual em que possam ser consideradas conjuntamente as atividades de consumo cultural que configuram uma dimensão da cidadania”. (Ibid., 2010, p.35-37) 
Podemos atuar como consumidores nos situando somente em um dos processos de interação - o que o mercado regula - e também podemos exercer como cidadãos uma reflexão e uma experimentação mais ampla que leve em conta as múltiplas potencialidades dos objetos, que aproveite esse "virtuosismo semiótico" nos variados contextos em que as coisas nos permitem encontrar com as pessoas.

(...)

Vincular o consumo com a cidadania requer ensaiar um reposicionamento do mercado na sociedade, tentar a reconquista imaginativa dos espaços públicos, do interesse pelo público. Assim o consumo se mostrará como um lugar de valor cognitivo, útil para pensar e atuar, significativa e renovadoramente, na vida social. (CANCLINI, 2010, p.71-72)

A questão do consumo realmente deve ser estudada, mas os direitos não podem ser observados apenas a partir da óptica do consumo, pois isso seria reduzir o sentido da cidadania. Santos (2007, p.47) acredita que "a grande perversão do nosso tempo (...) está no papel que o consumo veio representar na vida coletiva e na formação do caráter dos indivíduos". O “consumo instala a sua fé por meio de objetos", tanto pela promessa como pela esperança de tê-los. "O poder do consumo é contagiante, e sua capacidade de alienação é tão forte que a sua exclusão atribui às pessoas a condição de alienados. Daí a sua força e o seu papel perversamente motor na sociedade atual”, a qual é marcada pela competitividade (Ibid., p.48).

A glorificação do consumo acompanha-se da diminuição gradativa de outras sensibilidades, como a noção de individualidade, que aliás, constitui um dos alicerces da cidadania. Enquanto constrói e alimenta um individualismo feroz e sem fronteiras, o consumo contribui ao aniquilamento da personalidade, sem a qual o homem não se reconhece como distinto, a partir da igualdade entre todos. (SANTOS, 2007, p.49)

Para o autor (Ibid, p.54), "o chamado ao consumo busca retardar a tomada de consciência, mergulhando o consumidor numa atmosfera irreal, onde o futuro aparece como miragem". Uma consciência das possibilidades reais a partir de situações concretas possibilitaria o "confronto com um mundo incapaz de premiar os esforços individuais".

Ainda aponta que no Brasil existe uma cidadania mutilada, subalterna, na qual a profissionalização, por exemplo, é usada "para permitir aos indivíduos o acesso a direitos que deveriam ser indiscriminadamente assegurados" (Ibid, p.37). Coloca-se "no lugar do deveria ser o cidadão o seu substituto corporativo, pois as regalias são concedidas aos grupos profissionais enquanto grupos" (Ibid., p.38). Mais uma vez o que 
deveria ser visto como direito de todos passa a ser privilégios de alguns ou apenas objeto de consumo.

A crítica ao consumismo e a competitividade também aparece em outra obra do autor. Santos (2008, p.49-50) acredita que eles levam "à redução da personalidade e da visão do mundo" e ao esquecimento da "oposição entre a figura do consumidor e a figura de cidadão". No Brasil, a situação seria mais grave por jamais ter havido a figura de cidadão. "As classes chamadas superiores, incluindo as classes médias, jamais quiseram ser cidadãs; os pobres jamais puderam ser cidadãos. As classes médias foram condicionadas a apenas querer privilégios e não direitos."

A perspectiva marxista trazida por Agnes Heller (1989) nos ajuda a pensar a cidadania criticamente. Primeiramente é preciso considerar que a "humanidade se produz a si mesma a partir de um mundo que já existia antes dela” (Ibid., p.117-118). Como afirma a autora logo no início de sua obra, uma das teses fundamentais da concepção marxista da história é a de que "os homens fazem a sua própria história, mas em condições previamente dadas" (Ibid., p.1).

Para Heller (1989, p.116-117), "a consciência do direito a uma vida verdadeiramente humana está presente nos homens", e uma reorganização da sociedade para humanizar a vida depende de uma revolução permanente. Se antes havia uma consciência dos direitos às necessidades mais primárias, no século XX há exigências de “humanização da vida em geral". "É à luz dessas novas exigências que a consciência de classe deve propor iniciativas capazes de transformá-la numa força apta para mudar o mundo".

Marx disse que, transformando o mundo, os homens se transformam a si mesmos. Não modificamos substancialmente o seu pensamento se alterarmos a sua frase e afirmarmos agora que não podemos transformar o mundo se, ao mesmo tempo, não nos transformarmos a nós mesmos. (HELLER, 1989, p.117)

Heller nos ajuda a olhar para as pessoas como sujeitos históricos, que se transformam e podem transformar o mundo. Esses sujeitos de direitos ajudam a construir a cidadania ao lutar por sua efetivação. Para refletir sobre a cidadania, é preciso olhar para as condições econômicas, políticas, sociais e culturais. Isso inclui olhar para as questões de consumo e mercado com uma perspectiva crítica.

Essa construção de si e do mundo se dá no cotidiano, incluindo as relações sociais, a comunicação e o trabalho. "A vida cotidiana não está 'fora' da história, mas no centro do acontecer histórico", diz Heller (1989, p.20). Em sociedade, o ser humano 
se reconhece: "o homem, enquanto ser humano-genérico, não pode conhecer e reconhecer adequadamente o mundo a não ser no espelho dos demais” (Ibid., p. 84).

Santos (2007, p.136-137) também contribui para entendermos o cotidiano. De um lado, "há um cotidiano que se adapta à lógica hegemônica dos propósitos do Estado e das grandes firmas". Nele "a obediência se impõe como natural”. De outro, há o cotidiano "pelo qual o homem redescobre a consciência e busca ampliá-la".

Este cotidiano não se defende apenas pela letra de uma Constituição federal, mas igualmente (e mais frequentemente) pelas regras de convivência no lugar mesmo em que se vive. Essa consciência do homem, que faz dele um verdadeiro cidadão ou nele alimenta a vontade de sê-lo, também faz parte dos desígnios fundamentais e do longo prazo, porque diz respeito à própria essência humana. (SANTOS, 2007, p. 137)

Todos somos, assim, sujeitos de direito, sujeitos históricos que constroem o mundo no cotidiano, cidadãos que constroem a cidadania numa esfera de lutas sociais e discursos que disputam a hegemonia.

\section{4 - Jornalismo e cidadania}

O papel de mediação é muito utilizado no retrato do jornalismo. Traquina (2005, p.89) explica que o "direito e a obrigação do jornalista de mediar e simplificar, cristalizar e identificar os elementos políticos no acontecimento noticioso" é tomado como certo. Em outra obra também destaca a questão da ideologia profissional, que reúne crenças que dão sentido à experiência de trabalho, uma representação mitificada de si (TRAQUINA, 2008, p.22). Sobre a questão do que define a notícia, "produto" do trabalho jornalístico, questiona:

O que é notícia? A visão que os jornalistas apresentam desta questão o que é notícia? - é simultaneamente simplista e minimalista: a) simplista porque, segundo a ideologia jornalística, o jornalista relata, capta, reproduz ou retransmite o acontecimento. Segundo a metáfora dominante no campo jornalístico, o jornalista é um espelho que reflete a realidade. O jornalista é simplesmente um mediador; e b) minimalista porque, segundo a ideologia dominante, o papel do jornalista como mediador é um papel reduzido. (TRAQUINA, 2008, p. 62)

Moretzsohn (2007), por sua vez defende ser necessário politizar e problematizar a mediação, mostrando todos os aspectos implicados na produção da notícia. Assim 
seria possível ter um jornalismo voltado para a cidadania, no sentido coletivo, democrático e participativo do termo. Já uma visão mais ampla do termo mediações é dada por Jesús Martin-Barbero (2006, p.61), que o define como "as articulações entre práticas de comunicação e movimentos sociais".

A questão da mediação apareceu em pesquisa realizada por Abreu (2003) com 57 jornalistas em cargos de chefia ou responsáveis por colunas de prestígio. Foram percebidos três tipos de posicionamento frente à profissão. Os jornalistas se colocam como "mediadores entre a sociedade global e o indivíduo, ou entre a população e o poder público", ou seja, como "um intérprete da sociedade, com o papel de formar a opinião pública e defender o interesse público". Uma segunda vertente se posiciona como produtora e difusora da informação. Assim os jornalistas devem informar o que acontece para que a população faça seu julgamento. A terceira categoria vê o jornalista como "fiscal da sociedade", vigilante do poder, apto a fazer a denúncia social. (ABREU, 2003, p.35-36)

Gentilli (2005, p.143) aponta o jornalista como um mediador que dá visibilidade ao poder e ao mundo. No dia-a-dia, ele toma decisões e julga ao filtrar, selecionar e organizar os elementos para que o leitor tenha as informações necessárias e realize seu próprio julgamento. Realiza assim uma mediação ativa, pois a informação "é manipulada pelo jornalista, que faz as suas pré-escolhas, as suas pré-opções, a sua préfiltragem, o seu prejulgamento".

Proponho, assim, um jornalismo produzido em condições de oferecer, da melhor maneira possível, uma forma de conhecimento do mundo, que permita ao cidadão as condições de escolha quando se tratar de direitos políticos, que ofereça as informações básicas (jornalismo de serviços para o desenrolar cotidiano de suas atividades, que pense a práxis profissional no contexto amplo da ampliação da cidadania, do pluralismo, da liberdade, da democracia. (GENTILLI, 2005, p.143)

O pesquisador ainda destaca que o jornalismo como mediação não é contraditório ao jornalismo como representação. Como representante, busca a informação para um "outro" que tem interesse nela e é "uma das formas de ação da mediação". O trabalho do jornalista é "simultaneamente representar o leitor e mediar seu acesso à informação pública”. (Ibid, p.144-145)

Já para Chaparro (2007, p.143), o jornalismo deve buscar o "relato veraz", que se caracteriza por ser "visto, ouvido e sentido pelo mediador". A "razão ética primordial do jornalismo" seria a de "viabilizar, asseverando, o acesso ao direito de informação", até se chegar nesse "relato veraz". 
O jornalismo pode ser visto a partir de outras perspectivas. Ao falar da realidade, ele apresenta versões sobre determinado fato. Dessa forma, não faz a mediação de uma verdade absoluta, e o jornalismo pode, assim, também ser encarado como uma construção da realidade e nunca como reflexo da mesma.

Diante disso, Traquina (2005, p. 28) aponta que as notícias devem ser vistas como uma "construção" social, que resulta de interações "entre diversos agentes sociais que pretendem mobilizar as notícias como um recurso social em prol das suas estratégias de comunicação, e os profissionais do campo, que reivindicam o monopólio de um saber, precisamente o que é notícia". A notícia é vista como uma narrativa, o que apesar de não significar que seja ficção, encontra resistência por questionar "o conceito de notícias como espelho da realidade", o qual é criticado pelo autor (TRAQUINA, 2008, p.19).

Neste contexto, em que o jornalismo não é reflexo da realidade, mas pode contribuir para a ampliação de direitos por meio da informação, qual deve ser a ética do jornalista e a sua relação com a cidadania? Cláudio Abramo (1988, p.109) responde que não existe uma ética específica do profissional e sim uma ética do cidadão. "O jornalista não tem ética própria. Isto é um mito. A ética do jornalista é a ética do cidadão. O que é ruim para o cidadão, é ruim para o jornalista." Além disso, destaca que o jornalista precisa ter opinião para fazer opções e olhar o mundo.

O jornalista não pode ser despido de opinião política. A posição que considera o jornalista um ser separado da humanidade é uma bobagem. A própria objetividade é mal administrada, porque se mistura com a necessidade de não se envolver, o que cria uma contradição na própria formulação política do trabalho jornalístico. Deve-se, sim, ter opinião, saber onde ela começa e onde acaba, saber onde ela interfere nas coisas ou não. (ABRAMO, 1988, p.109)

O autor ainda define o papel do jornalista como "o de qualquer cidadão patriota, isto é, defender o seu povo, defender certas posições, contar as coisas como elas ocorreram com o mínimo de preconceito pessoal ou ideológico". Também afirma não dissociar o "jornalista de uma certa paixão", mas não pela profissão, o que considera "besteira" e sim para sentir as coisas como são (Ibid., p.113).

Nessa relação entre jornalismo e cidadania, pode-se considerar que em um cenário verdadeiramente democrático, o jornalismo pode ter um papel importante, cumprindo o dever de informar e respeitando o direito à informação que tem o cidadão, como mostra Gentilli (2005). Ter acesso à informação, dessa forma, é uma condição necessária à ampliação dos direitos. O jornalista, além de contribuir para essa ampliação 
com a informação, também é portador desses direitos, que inclui a saúde no trabalho, como veremos mais adiante.

Para Traquina (2005, p.22-23), a teoria democrática coloca nos jornalistas “o papel de informar os cidadãos" e "a responsabilidade de ser o guardião" do governo. "A democracia não pode ser imaginada como sendo um sistema de governo sem liberdade e o papel central do jornalismo, na teoria democrática, é informar o público sem censura”. Ele ainda define o jornalismo como uma atividade intelectual que sofre limitações.

Basta um olhar distraído aos diversos produtos jornalísticos para confirmar que é uma atividade criativa..., embora seja uma criatividade restringida pela tirania do tempo, dos formatos, e das hierarquias superiores, possivelmente do próprio dono da empresa. $\mathrm{E}$ os jornalistas não são apenas trabalhadores contratados, mas membros de uma comunidade profissional que há mais de 150 anos de luta está empenhada na sua profissionalização com o objetivo de conquistar maior independência e um melhor estatuto social. (TRAQUINA, 2005, p. 22)

Mais adiante Traquina (2005, p. 27) explica que a ideologia profissional desenvolvida ao longo do tempo define o jornalismo como um serviço público que fornece aos cidadãos "a informação de que precisam para votar e participar da democracia e age como guardião que defende os cidadãos dos eventuais abusos de poder". Por outro lado, desde antes do século XIX, “o jornalismo tem sido um negócio e as notícias uma mercadoria que tem alimentado o desenvolvimento de companhias altamente lucrativas". Esse pólo "econômico" convive com esse outro "ideológico", no qual "o jornalismo é visto como um serviço público em que as notícias são o alimento de que os cidadãos precisam para exercer os seus direitos democráticos” (Ibid., p. 126).

Seguindo essa linha, para Gentilli (2005, p.22-23), a informação pública realizada pelo jornalismo é um dos fatores para que os direitos sejam assegurados. Há uma necessidade social de informação e de "um jornalismo que ofereça aquelas informações que o cidadão tem o direito de receber para" exercer "plenamente todos os seus direitos". Quando não se cumpre o direito à informação o exercício dos demais direitos fica prejudicado.

Nas democracias de massas, marcadas pela expansão de direitos, o direito à informação constitui-se num direito "em si" e ao mesmo tempo é a porta de acesso a outros direitos. Neste sentido, a informação conforme seja a necessidade que dela se tenha pode ser entendida como direito social, como direito civil e como direito político. (GENTILLI, 2005, p.24) 
Nas sociedades modernas, o indivíduo é visto "como potencialmente capaz de exercer os direitos que lhes são reconhecidos, direitos conquistados de diversas maneiras". Mas o pesquisador alerta que o desafio nessa época de sociedade democrática de massa é ultrapassar a formalização dos direitos e alcançar a efetividade deles, produzindo uma verdadeira democracia. Mais do que reconhecer o ser humano como capaz de se emancipar, reduzindo-se a uma visão liberal e individualista, é preciso assegurar a extensão da cidadania às massas excluídas. (Ibid., p.92-93)

A liberdade de expressão e de manifestação do pensamento é um direito civil característico das sociedades democráticas, que surge "para permitir, na norma jurídica, a livre circulação de ideias através dos jornais e da imprensa em geral". Para que os procedimentos da democracia aconteçam são necessários "processos sociais de mediação". O direito à informação é, assim, "um direito-meio", um pressuposto para a realização dos outros direitos. (Ibid., p.118) Assim o jornalismo deve trazer “informações necessárias e imprescindíveis para a vida numa sociedade de massas, aí incluído o exercício pleno do conjunto de direitos civis, políticos e sociais" (Ibid., p.130).

O direito à informação, portanto, deve ser compreendido como um direito relacionado diretamente aos outros direitos, incluindo, obviamente, as contradições e os antagonismos destes. É um direito que fomenta o exercício da cidadania e permite ao cidadão o acesso e a crítica aos instrumentos necessários ao exercício pleno do conjunto dos direitos de cidadania.

Daí resulta a formulação da informação pública como um pressuposto indispensável ao exercício da cidadania e, portanto, um fator decisivo no processo de aprofundamento democrático. Como consequência do raciocínio, o entendimento de que o acesso à informação é uma porta de acesso a outros direitos: numa sociedade de massas modernas, o acesso à informação jornalística, por parte do cidadão, pode potencialmente vir a consistir num direito que assegura outros direitos, confere condições de equalização de sujeitos e oferece a visibilidade ao poder e ao mundo. (GENTILLI, 2005, p.128)

A informação pode existir como direito social, civil ou político. É social quando fala daquilo que é indispensável à vida em sociedade e para o uso coletivo das conquistas humanas no campo social. Já é um direito civil como liberdade de expressão e manifestação, o direito de dizer e o combate à censura. Enquadra-se na perspectiva política quando dá ao cidadão visão sobre as possibilidades de escolha na esfera pública, especialmente, para o "exercício pleno e consciente do direito de voto". (Ibid., p.131135) Outros autores também apontam essa contribuição do jornalismo para a cidadania. 
Ainda discutindo o papel do jornalista, saliento que ele tem uma função importante em termos de construção da cidadania, uma vez que é responsável pela transmissão de informações e a ideia de cidadania está subordina à informação. Não há cidadão sem conhecimento, é este que torna o indivíduo um cidadão, na medida em que as informações the possibilitam escolhas, avaliações e participação na sociedade. Sem isso, sua atuação ficaria restrita ou inexistente. (TRAVANCAS, 1993, p.107)

Abreu (2003, p.26) também acredita que "a informação é um dos elementos fundamentais para que o indivíduo possa exercer plenamente os seus direitos". A imprensa tem como "função dar visibilidade à "coisa pública" e, além de fornecer informações para os cidadãos, pode levar as demandas deles aos responsáveis pelas decisões.

No caso brasileiro, a autora destaca que a volta ao regime democrático trouxe novas orientações para os jornalistas, entre elas, a exploração da "utilidade social". Antes havia a noção de "responsabilidade social" da mídia, na qual o jornalista tem o dever de "assumir os efeitos e as consequências de seus atos profissionais junto ao público". O conceito de "utilidade social", por sua vez, coloca o jornalismo como capaz de atender aos interesses concretos dos cidadãos, assim, aborda preocupações relativas a emprego, habitação, educação, segurança pública, qualidade de vida, entre outros. É o chamado “jornalismo cidadão". (ABREU, 2003, p.30)

Esse tipo de jornalismo, segundo a mesma autora, surgiu nos Estados Unidos com as experiências do public e do civic journalism. O primeiro foi praticado inicialmente pela imprensa local, voltado às necessidades da população e à cobrança política, depois se estendeu para a nacional. O outro se iniciou nos anos de 1970 para enaltecer os valores democráticos, visando dar a palavra aos cidadãos comuns e responsáveis por associações e comunidades.

No caso brasileiro, Abreu (2003, p.31-33) aponta iniciativas como a prestação de serviço com seções para queixas e reclamações, que cresceram tanto em jornais populares como nos grandes jornais na década de 1990. Configura-se um espaço voltado para o direito do consumidor. Nesse caso, avaliamos que é uma abordagem da cidadania um pouco limitada, mais voltada para a perspectiva neoliberal individualista e de consumo.

Para Canclini (2010, p.38-39), os meios eletrônicos deslocaram o desempenho da cidadania para as práticas de consumo e fizeram com que as massas populares emergissem na esfera pública. "Desiludidos com as burocracias estatais, partidárias e 
sindicais, o público recorre à rádio e à televisão para conseguir o que as instituições cidadãs não proporcionam: serviços, justiça, reparações ou simples atenção". Com os avanços da internet, essa afirmação ganha ainda mais força.

“A cidadania, já não se constitui apenas em relação a movimentos sociais locais, mas também em processos de comunicação de massa" (CANCLINI, 2010, p. 110). O autor (Ibid., p.187) aponta a necessidade de se favorecer o acesso não apenas à comunicação de massa como também à produção de jornais, programas de rádio e vídeos comunitários. Essa é uma condição necessária para desenvolver formas democráticas de cidadania, considerando-se a capacidade para intervir nos processos de integração global e regional.

Martin-Barbero (2006, p. 21) também destaca o aspecto regional ao apontar que se recria a cidadania e se reconstitui a sociedade por "novas maneiras de estar junto". Como exemplo, cita associações de bairro, que solucionam pacificamente conflitos, e da comunicação comunitária, que recupera memória e tece laços de pertencimento ao território.

Segundo Canclini (2010, p.157), “os hábitos e gostos dos consumidores condicionam sua capacidade de se converter em cidadãos. O seu desempenho como cidadãos se constitui em relação aos referentes artísticos e comunicacionais, às informações e aos entretenimentos preferidos". Também é preciso repensar as políticas e formas de participação, o que em sua concepção significa ser cidadão e consumidor.

Além disso, o Estado deve se revitalizar "como representante do interesse público, como árbitro ou assegurador das necessidades coletivas de informação, recreação e inovação, garantindo que essas não sejam sempre subordinadas à rentabilidade comercial" (Ibid., p.217-218). Acrescentamos a isso o papel da sociedade como um todo e dos movimentos sociais que podem se mobilizar utilizando os recursos da comunicação e seus meios.

Voltando especificamente para a relação entre jornalismo e cidadania, Abreu (2003) também cita reportagens sobre temas como péssimo atendimento em hospitais, violência policial e corrupção que aparecem tanto na TV como no rádio e na mídia impressa. Há uma função do jornalismo como fiscalizador do poder público. O problema é quando ocorrem apenas denúncias "sem investigação ou evidências suficientes". Segundo a autora,

a prestação de serviços à população indica, de um lado, a existência de uma concepção de que o jornalista detém uma autoridade que lhe 
permite se apresentar como uma alternativa ao papel do Estado. Do outro lado, ele passa a desempenhar o papel de representante político da população, mas sem mandato efetivo.

O jornalismo cidadão deve ser entendido como um dos meios de o jornalista, na atualidade, preencher um papel de ativista político caracterizado pela defesa de valores como rejeição à corrupção, defesa dos direitos dos cidadãos, igualdade no tratamento e na aplicação das leis etc. É importante assinalar que nossa pesquisa indicou que um número significativo de jornalistas que atuou na imprensa a partir dos anos 1950 tinha um engajamento político e que muitos escolheram a profissão como forma de participação política e de intervenção na vida social.

Desse modo, seria simplificador interpretar o jornalismo cidadão de uma perspectiva econômica. (...) Com a redemocratização, a luta por justiça e cidadania se ampliou e encontrou, nas redações, entre os profissionais de imprensa, grande receptividade. (ABREU, 2003, p.30-31)

Um dos exemplos citados por Abreu (2003) como de utilidade pública é o jornal local da cidade de São Paulo, SPTV da Rede Globo, que atende reivindicações comunitárias e atua como intermediário entre a comunidade e autoridades. É o SPTV Comunidade. O contato pode ser feito pela página da internet do telejornal. Uma novidade aconteceu no ano de 2011, com mais uma versão desse modelo, o Parceiro do SP, na qual jovens moradores da periferia assumiram a função de repórter após passarem por uma seleção e preparação fornecida pelo telejornal. Eles mostraram os problemas locais e iniciativas culturais por 11 meses.

Outro exemplo retratado pela autora sobre a relação entre mídia, cidadania e denúncia é a morte do jornalista Tim Lopes, da TV Globo, em junho de 2002. Os moradores já haviam denunciado à polícia o aliciamento por traficantes de meninas menores de idade para exploração sexual da favela Vila Cruzeiro e nada fora feito. $\mathrm{O}$ caso foi levado ao jornalista Tim Lopes pelos moradores. Ele, então, esteve por lá quatro vezes, até desaparecer na última delas. Desse caso, levantamos mais uma questão, como fica a segurança do jornalista em um tipo de matéria como esse? Certamente esse quesito foi deixado de lado pelos editores e pela empresa. A questão dos riscos e da violência contra jornalistas será discutida no quarto capítulo. Mas a citação desse caso nos faz pontuar a seguinte questão: Se por um lado o jornalista pode contribuir para a cidadania ao informar direitos, por outro, ele pode não se ver como sujeito de direitos quanto o assunto é segurança e saúde no trabalho. 


\section{5 - Nas letras da lei}

As questões de segurança e saúde no trabalho estão inscritas nas letras da lei. No Brasil, a Constituição é o grande marco, e os movimentos sociais são atores fundamentais para a efetivação dos direitos. Com a Constituição de 1988, eles se legitimam juridicamente e, além de reivindicar, pressionar ou demandar, surge espaço para fazer, propor e participar (GOHN, 1997, p.288). Para Manzini-Covre (1993, p.10, p.17), a Constituição é um recurso importante, que permite o encaminhamento e conquistas mais igualitárias pelos cidadãos.

Dagnino (2004, p.95) considera a Constituição de 1988 o marco formal do processo de construção democrática do Brasil, pois ela consagrou o princípio de participação da sociedade civil com mecanismos de democracia direta e participativa, por exemplo, os Conselhos Gestores de Políticas Públicas. Foi um projeto construído desde o início dos anos 1980 para a cidadania e aprofundamento da democracia, que emergiu da luta contra o regime militar, com participação fundamental dos movimentos sociais.

Por um lado, a constituição dos espaços públicos representa o saldo positivo das décadas de luta pela democratização, expresso especialmente - mas não só- pela Constituição de 1988, que foi fundamental na implementação destes espaços de participação da sociedade civil na gestão da sociedade. Por outro lado, o processo de encolhimento do Estado e da progressiva transferência de suas responsabilidades sociais para a sociedade civil, que tem caracterizado os últimos anos, estaria conferindo uma dimensão perversa a essas jovens experiências. (...) $\mathrm{O}$ risco — real - que elas percebem é que a participação da sociedade civil nas instâncias decisórias, defendida pelas forças que sustentam o projeto participativo democratizante como um mecanismo de aprofundamento democrático e de redução da exclusão, possa acabar servindo aos objetivos do projeto que lhe é antagônico. (DAGNINO, 2004, p.97)

Já Giannotti (2007, p.264-265) reconhece que a Constituição de 1988 foi a "mais democrática de nossa História", ao expressar conquistas sociais dos anos 80 alcançadas por meio de greves e manifestações. No entanto a critica por "garantir a transição conservadora". Por um lado, as proibições impostas aos sindicatos são extintas, por outro, a Justiça do Trabalho fica com o poder normativo de decidir quem pode ou não fazer greve. Outros direitos são colocados na Constituição sem regulamentação, o que 
só viria a ser feito depois de "cinco, dez ou vinte anos, ou, quem sabe, no dia de 'São Nunca"”.

\begin{abstract}
Muitos dos direitos trabalhistas assinalados nessa Constituição são o resultado das lutas e reivindicações dos trabalhadores a partir das greves de 1978 e 1979. Entre eles citamos: jornada de 44 horas; ampliação da licença maternidade para 120 dias; criação da licença paternidade de cinco dias; $1 / 3$ adicional de férias; e seguro desemprego. Além dessas conquistas, a Constituição passa a garantir o direito de voto do analfabeto e os direitos dos índios de terem seus territórios reconhecidos, não sendo mais vistos como povos incapazes de se autogerirem. Sem dúvida alguma, esses e vários outros pontos positivos dessa Constituição, que refletia uma década de grandes lutas populares.

Infelizmente, a nova Constituição não alterou uma vírgula sequer a legislação que regia a propriedade de terra. (GIANNOTTI, 2007, p.265)
\end{abstract}

Se procurarmos o que levou ao estabelecimento de constituições na história, chegaremos até as revoluções burguesas. Foram elas que permitiram, especialmente a Francesa (1789), a criação de Cartas Constitucionais. Estabeleceu-se, dessa maneira, a igualdade para todos perante a lei e se instaura o Estado de Direito. Isso foi "proclamado principalmente pelas constituições francesa e norte-americana" e mais tarde "reorganizado e ratificado, após a II Guerra Mundial, pela Organização das Nações Unidas (ONU)", com a Declaração Universal dos Direitos Humanos, de 1948.

Bobbio (1992, p.85) conta que a Declaração dos Direitos do Homem e do Cidadão, da França, foi aprovada pela Assembleia Nacional, em 26 de agosto de 1789, após ser discutido por sete dias. Há um consenso de que "esse ato representou um daqueles momentos decisivos, pelo menos simbolicamente, que assinalam o fim de uma época e o início de outra". Ele considera a Declaração Francesa mais intransigente e individualista do que a Constituição Americana de 1787 (Ibid., p.90). A sociedade da época concebia o indivíduo de forma isolada, "independentemente de todos os outros, embora juntamente com todos os outros, mas cada um por si". Os "constituintes americanos relacionaram os direitos do indivíduo ao bem comum da sociedade" enquanto que "os constituintes franceses pretendiam afirmar primária e exclusivamente os direitos dos indivíduos".

Impulsionada pelas revoluções americana (1776) e francesa (1789), a liberdade torna-se um princípio sagrado. Reza o artigo 11 da Declaração do Homem e do Cidadão, aprovada em Agosto de 1789: "A livre circulação do pensamento e opinião é um dos direitos mais preciosos do Homem. Todos os cidadãos podem portanto falar, escrever e publicar livremente, excepto quando forem responsáveis pelo abuso dessa liberdade em casos bem determinados por lei". $\mathrm{O}$ 
Marquês de Mirabeau defendeu a declaração nos Estados Gerais, onde afirmou: "Que a primeira das vossas leis consagre para sempre a liberdade de imprensa. Esta é a mais intocável, a mais incondicional liberdade - sem a qual as outras liberdades nunca poderão ser asseguradas". (TRAQUINA, 2005, p. 45)

Traquina $(2005$, p.40) também aponta que a expansão da imprensa se alimentou da conquista de direitos fundamentais "como a liberdade, cerne de lutas políticas seculares que incendiaram revoltas e revoluções, valor central da emergência de um novo conceito de governo - a democracia”. No século XIX, na Europa, os jornais passam a ser vistos como um "meio de exprimir as queixas e injustiças individuais", e a legitimidade jornalística se dá na teoria democrática (Ibid, p. 47).

Por outro lado, Bobbio (1992, p.91) avalia que havia na França "uma 'imensa multidão' dos quais era composta de homens sem propriedade, que esperavam do governo mais a segurança do trabalho (a qual, por outro lado, os torna dependentes) do que a liberdade". No entanto, o olhar está voltado para o burguês: "os direitos tutelados pela Declaração eram os direitos do burguês, do homem (explicava Marx) egoísta, do homem separado dos outros homens e da comunidade", do homem fechado em si mesmo (Ibid., p.99).

O cidadão era apenas o burguês. Mas "há a afirmação de que os indivíduos têm direitos" e de que "o governo, precisamente em consequência desses direitos, obriga-se a garanti-los" (Ibid, p.101). Apesar de a Declaração de 1789 ter sido precedida pela norte-americana, "foram os princípios de 1789 que constituíram, durante um século ou mais, a fonte ininterrupta de inspiração ideal para os povos que lutaram por sua liberdade..." (Ibid, p. 129).

O jurista Dalmo de Abreu Dallari (2010) também apontou que a "Declaração dos Direitos do Homem e do Cidadão" de 1789 foi a primeira declaração da história nesses termos (informação verbal) ${ }^{9}$. No entanto, uma líder feminista propôs em assembleia a criação de outro documento - "Declaração dos Direitos da Mulher e da Cidadã" e foi considerada traidora da Revolução e condenada à guilhotina, por querer igualdade de direitos entre homens e mulheres. Já os operários, que ajudaram na tomada da bastilha, não eram considerados cidadãos ativos, então, começaram a se reunir e lançaram uma associação na qual a força do grupo superava a fraqueza do indivíduo. As condições de trabalho na Europa eram péssimas e há o cenário para o surgimento do

\footnotetext{
${ }^{9}$ Informação oferecida por Dallari em palestra - "Saúde do Trabalhador como Direito Humano Fundamental" - na ALESP (Assembleia Legislativa do Estado de São Paulo), no dia 06/05/2010.
} 
movimento socialista baseado em Marx. Percebe-se mais uma vez a base conflituosa na construção da cidadania.

Já sobre a Declaração Universal dos Direitos Humanos de 1948, Bobbio (1992, p.34) afirma que representa a consciência histórica sobre os valores fundamentais na metade do século XX, como "uma síntese do passado e uma inspiração para o futuro". Mais adiante, na página 128, coloca que por meio dela, todos os homens da Terra tornaram-se "idealmente sujeitos do direito internacional" e "adquiriram uma nova cidadania, a cidadania mundial". Dessa forma, possuem o "direito de exigir o respeito aos direitos fundamentais contra o seu próprio Estado".

A Declaração Universal dos Direitos do Homem pode ser acolhida como a maior prova histórica até hoje dada do consensus omnium gentium sobre um determinado sistema de valores. (...) acolhido como inspiração e orientação no processo de crescimento de toda a comunidade internacional no sentido de uma comunidade não só de Estados, mas de indivíduos livres e iguais. (...) pela primeira vez um sistema de princípios fundamentais de conduta humana foi livre e expressamente aceito, através de seus respectivos governo, peã maioria dos homens que vive na Terra. Com essa declaração, um sistema de valores é - pela primeira vez na história - universal, não em princípio, mas de fato, na medida em que o consenso sobre sua validade e capacidade para reger os destinos da comunidade futura de todos homens foi explicitamente declarado. (BOBBIO, 1992, p.27-28)

O autor avalia que a "Declaração Universal é apenas o início de um longo processo", um ideal a ser alcançado. Há dificuldades para garantir a sua implementação na comunidade internacional. Além disso, é preciso ter ciência de que os direitos humanos são direitos históricos, "emergem gradualmente das lutas que o homem trava por sua própria emancipação e das transformações das condições de vida que essas lutas produzem". (Ibid., p. 31-32)

As constituições dos países também podem ser apontadas como esse princípio. Para Manzini-Covre (1993, p.18), a constituição se caracteriza como um documento importante "que limita o poder dos governantes" e condensa a ideia dos direitos e da cidadania. As pessoas "de uma sociedade mantêm-se como cidadãos à medida que partilham as mesmas normas e podem lançar mãos delas para se defender".

Santos (2007, p.20) acredita na importância da legislação para a cidadania "ter eficácia e ser fonte de direitos". A cidadania "deve se inscrever na própria letra das leis, mediante dispositivos institucionais que assegurem a fruição das prerrogativas pactuadas" e, sempre que houver recusa no cumprimento, deve haver o direito de reclamar e ser ouvido. 
Na avaliação de Bobbio (1992, p. 102), qualquer constituição democrática deve pressupor "a existência de indivíduos singulares que têm direitos enquanto tais". A democracia moderna nasce da concepção individualista da sociedade. Não "como o 'poder do povo', e sim como o poder dos indivíduos tomados um a um, de todos os indivíduos que compõem uma sociedade". Assim "a democracia moderna repousa na soberania não do povo, mas de cidadãos". (Ibid., p. 119)

Abreu (2003, p.25) considera que a Constituição de 1988 foi a última etapa da transição para a democracia com a reconquista de liberdades que estavam suprimidas. A efetividade da cidadania, no entanto, encontra dificuldades como na atuação da justiça para garantir os direitos dos cidadãos, com "obstáculos econômicos, sociais e culturais" para o acesso dos mais pobres (Ibid., p. 28).

Ao longo da história, como já observado, a cidadania se desenvolve com o capitalismo e a visão burguesa. A valorização do trabalho, que vem com a ética protestante, foi o primeiro marco para a existência da cidadania. Quando a burguesia deixa de ser revolucionária para assumir o poder, vincula os direitos humanos aos que têm propriedade. É dessa forma que se explica a dominação da burguesia. Já uma cidadania mais efetiva, estende os direitos a todos. (MANIZINI-COVRE, 1993, p.2123)

No caso do Brasil, Carvalho (1996) avalia que a cidadania, durante o século XIX, foi construída de cima para baixo, com o predomínio de uma cultura política súdita, caracterizada pelo cidadão inativo, e até mesmo paroquial, em que o indivíduo é um não-cidadão. $\mathrm{O}$ autor ainda caracteriza no país uma centralidade do Estado, que não indica um "caráter público e universalista", pois "o Estado coopta seletivamente os cidadãos", os quais o buscam para atender seus interesses privados. Por outro lado, vimos que os movimentos sociais contribuíram para que a cidadania se inscrevesse na lei com a Constituição de 1988.

Por isso, vale o alerta de Manzini-Covre (1993, p.30-36), de que a cidadania não é uma categoria estritamente burguesa. Ela pode ser apropriada pelos trabalhadores, que devem usar os poderes executivo, legislativo e judiciário, assim como os meios de comunicação, para construir a cidadania e estendê-la a todos. O marxismo também contribuiu para a construção do conceito de cidadania ao criticar o uso dos direitos pela burguesia para dominar grupos. A força de trabalho, por exemplo, serve para pressionar e fazer valer os direitos. 
Não pode haver cidadania se não houver um salário condigno para a grande maioria da população. O Trabalhador, enquanto mercadoria, deve lutar para obter certa equivalência na troca estabelecida com o capitalista e o Estado. É preciso que ele tenha acesso aos bens que complementam sua vida (habitação, saúde e educação) e que compõem os chamados direitos sociais. Mas, antes é necessário que os trabalhadores tenham direitos políticos, e que existam mínimas condições democráticas para reivindicar o seu direito de ser cidadão e de, enquanto e tal, poder batalhar, por quaisquer de seus direitos. Por outro lado, é preciso que esses trabalhadores possam ser educados sobre a existência desses direitos, vendo dessa forma a amplidão do que há para construir em termos de uma sociedade sempre melhor. (MANZINI-COVRE, 1993, p.37)

Saes (2000) faz algumas considerações interessantes sobre o papel dos trabalhadores na construção da cidadania no sistema capitalista. Primeiro ele enfatiza a posição desigual entre o capitalista, que possui uma posição econômica de força, e o trabalhador, mais fraco economicamente, é constrangido pelo primeiro e precisa aceitar as condições impostas. Os trabalhadores continuamente vão reivindicar novas prerrogativas do Estado e procurar conquistar novos direitos e a instauração da realização de igualdade entre os homens, que não foi cumprida. "Da pressão das classes trabalhadoras pela satisfação dos seus interesses materiais, pode resultar um novo processo de corporificação da forma-sujeito de direito: a instauração de direitos políticos." Da mesma forma, "a defasagem entre aquilo que é proclamado e aquilo que é cumprido pelo Estado na aplicação da lei leva os trabalhadores à ação reivindicatória“" para a "a implantação de certos direitos sociais". Mas apenas um padrão mínimo será oferecido, abrindo espaço para novas reivindicações. Do outro lado estão as classes dominantes empenhadas em reduzir direitos. (Ibid., p.27-28)

Como afirmamos no início, entre os direitos inscritos na lei está a garantia de um trabalho seguro e saudável. No caso da Constituição Brasileira, os direitos sociais relacionados ao trabalho estão no Artigo $7^{\circ}$. No parágrafo XXII, aponta-se como direito dos trabalhadores a "redução dos riscos inerentes ao trabalho, por meio de normas de saúde, higiene e segurança". Outro direito assegurado, que tem reflexos sobre a saúde do trabalhador, trata da jornada de trabalho. No parágrafo XIII, defende-se que o trabalho normal não ultrapasse oito horas diárias e 44 horas semanais. Também se abre a possibilidade de redução de jornada a partir de Convenção Coletiva.

A CLT (Consolidação das Leis do Trabalho) é outro instrumento legal e traz um capítulo inteiro sobre segurança e medicina do trabalho: o capítulo $\mathrm{V}$, composto por 48 artigos, que falam dos deveres e direitos de empregadores, empregados e governo. Às 
empresas cabem cumprir as normas de segurança e saúde, instruir os trabalhadores visando à prevenção de acidentes e doenças do trabalho e facilitar a fiscalização. Os trabalhadores devem observar se as normas estão sendo cumpridas e colaborar com o cumprimento dos dispositivos do capítulo. Já o Estado deve fiscalizar o cumprimento, determinar reparos e impor penalidades.

Segundo Dallari (2010), a saúde no trabalho aparece como direito a partir dos movimentos socialistas/marxistas e da Encíclica Rerum Novarum (Das Coisas Novas), promulgada pelo Papa Leão XIII em 1891 (informação verbal) ${ }^{10}$. O documento da Igreja foi influenciado pelo movimento de dissidência na França chamado cristianismo social e afirmava que os operários não deviam ser tratados como escravo, e os patrões deviam respeitar a dignidade do ser humano. Também falava da necessidade de proteção do trabalho para operários, mulheres e crianças e da injustiça de exigências além da capacidade do trabalhador, assim, defendia o repouso e que o trabalho diário não excedesse a força de trabalho.

Bobbio (2004, p. 227) caracteriza a encíclica Rerum Novarum como uma mudança de rumo ao afirmar em relação aos direitos de tradições liberais o direito de associação, especialmente as associações de operários, base do pluralismo e da democracia. Já sobre os direitos sociais de tradição socialista, destaca o direito ao trabalho, o que inclui um salário justo, proteção às mulheres e às crianças.

Já Giannotti (2007, p. 104) vê na carta um "antimanifesto comunista". "Na encíclica, Leão XIII negava a luta de classe e defendia a convivência pacífica entre capital e trabalho. Estimulava os católicos a se organizarem separadamente dos partidos e sindicatos de esquerda".

O jurista Dallari ainda afirma que quem trouxe a ideia de que os trabalhadores têm direitos para o Brasil foram os imigrantes italianos. Já como marcos internacionais para a relação trabalho e direitos destaca o Tratado de Versalhes em 1919, com a criação da OIT (Organização Internacional do Trabalho). A situação dos trabalhadores após a Primeira Guerra teve um peso importante para isso. A criação da ONU (Organização das Nações Unidas) em 1945, após a Segunda Guerra Mundial, foi outro fato importante. Ela foi responsável pela constituição da OMS (Organização Mundial da Saúde) em 1948, e a saúde foi colocada como um estado de completo bem estar físico,

\footnotetext{
10 Informação oferecida por Dallari em palestra - "Saúde do Trabalhador como Direito Humano Fundamental” - na ALESP (Assembleia Legislativa do Estado de São Paulo), no dia 06/05/2010.
} 
mental e social, não apenas como ausência de doenças e enfermidades. É a saúde como direito fundamental das pessoas.

Ao mesmo tempo que foi definida como um direito positivo no marco dos Estados nacionais, ou seja, como direito dos cidadãos de cada Estado, a saúde foi erigida em direito fundamental do ser humano. O conceito de direitos fundamentais tem raízes na concepção de que todo ser humano nasce igual em dignidade e portador de uma sacralidade que não pode ser sacrificada em nome de conveniências políticas, razões de Estado ou interesses materiais. Isso significa que razões da saúde devem ter preferência sobre todas as outras. (KUCINSKI, 2005, p.35-36)

A ONU também construiu a Declaração Universal dos Direitos Humanos (1948), que no artigo XXIII, parágrafo 1, afirma que "toda pessoa tem direito ao trabalho" e "a condições justas e favoráveis de trabalho". Nos itens 2 e 3, asseguram-se igual remuneração por igual trabalho e "uma remuneração justa e satisfatória", que garanta "uma existência compatível com a dignidade humana". O artigo XXV aponta o direito que toda pessoa tem "a um padrão de vida capaz de assegurar a si e a sua família saúde e bem estar".

Outro importante documento da ONU é o Pacto Internacional sobre Direitos Econômicos, Sociais e Culturais, adotado pela XXI Sessão da Assembleia-Geral das Nações Unidas, em 19 de dezembro de 1966. Segundo Dallari (2010), a construção do texto foi liderada pela então URSS, já os Estados Unidos liderou o pacto sobre direitos civis e políticos, não aderindo ao pacto voltado aos direitos econômicos, sociais e culturais (informação verbal) ${ }^{11}$. O Brasil se tornou signatário dele em 6 de julho de 1992, a partir do Decreto n ${ }^{\circ} 591$, o que traz a obrigação jurídica de cumpri-lo, caso contrário, pode ser acionado em corte internacional.

O Pacto Internacional dos Direitos Econômicos, Sociais e Culturais reconhece no artigo 7 "o direito de toda pessoa de gozar de condições de trabalho justas e favoráveis", assim defende:

a) uma remuneração que proporcione, no mínimo, a todos os trabalhadores:

i) um salário equitativo e uma remuneração igual por um trabalho de igual valor, sem qualquer distinção; em particular, as mulheres deverão ter a garantia de condições de trabalho não inferiores às dos homens e receber a mesma remuneração que ele por trabalho igual;

ii) uma existência decente para eles e suas famílias, em conformidade com as disposições do presente Pacto.

\footnotetext{
${ }^{11}$ Informação oferecida por Dallari em palestra - "Saúde do Trabalhador como Direito Humano Fundamental" - na ALESP, no dia 06/05/2010.
} 
b) a segurança e a higiene no trabalho;

c) igual oportunidade para todos de serem promovidos, em seu trabalho, à categoria superior que lhes corresponda, sem outras considerações que as de tempo de trabalho e capacidade;

d) o descanso, o lazer, a limitação razoável das horas de trabalho e férias periódicas remuneradas...

Em relação à saúde, no artigo 12, os "Estados Partes do presente Pacto reconhecem o direito de toda pessoa desfrutar o mais elevado nível possível de saúde física e mental". No segundo parágrafo, apresenta as medidas que devem adotar, entre elas, " a melhoria de todos os aspectos de higiene do trabalho e do meio ambiente".

A saúde física e mental do ser humano é um pré-requisito para o exercício de seus demais direitos. E essa saúde exige um meio ambiente saudável, condições adequadas de vida e de trabalho, alimentação, moradia e educação - todos esses fatores também considerados direitos humanos fundamentais na constituição da Organização Mundial de Saúde (OMS) de 1948. (KUCINSKI, 2005, p.36)

$\mathrm{Na}$ avaliação de Bobbio (1992, p. 37), as convenções sobre o trabalho e a liberdade sindical adotadas pela Organização Internacional do Trabalho (OIT) são um desenvolvimento e uma determinação mais precisa da Declaração Universal. A Segurança e Saúde no Trabalho, por exemplo, é o tema das convenções 155 e 187 da OIT.

A Convenção 155 - Segurança e Saúde dos Trabalhadores - foi aprovada na $67^{\mathrm{a}}$ reunião da Conferência Internacional do Trabalho, em Genebra, no ano de 1981, e entrou em vigor no plano internacional no dia 11 de agosto de 1983. Ela abrange todos os trabalhadores e locais de trabalho. Sobre a questão da saúde, afirma que deve ser considerada não apenas como "ausência de afecções ou de doença", mas também em relação aos elementos físicos e mentais que a afetam e estão diretamente ligados à segurança e higiene no trabalho.

Outra necessidade apontada por essa convenção é a de cada país construir, com a participação de trabalhadores e empregadores, uma política nacional sobre segurança e saúde dos trabalhadores e meio ambiente de trabalho. O objetivo dela deve ser "prevenir os acidentes e os danos para a saúde que sejam consequência do trabalho, guardem relação com a atividade de trabalho ou sobrevenham durante o trabalho", de forma que se reduzam as causas dos riscos inerentes ao meio ambiente de trabalho ao mínimo possível. 
Ratificada pelo Brasil em maio de 1992, a Convenção 155 estimulou a construção da Política Nacional de Segurança e Saúde no Trabalho - PNSST, publicada por meio do Decreto $n^{\circ} 7.602$, de 7 de novembro de 2011. Essa discussão se iniciou com a criação do Grupo Executivo Interministerial de Saúde do Trabalhador - Geisat, em 1993, que preparou uma proposta de política concluída em 2005, mas que não chegou a ser publicada. Somente em 2008 a proposta foi retomada com a criação da Comissão Tripartite de Segurança e Saúde no Trabalho (CT-SST). Assim representantes do governo, dos empregadores e dos trabalhadores tiveram a atribuição de revisar e avaliar a proposta da PNSST elaborada anteriormente ${ }^{12}$.

Outro documento da Organização Internacional do Trabalho passou a ser também referência para esse processo, a Convenção 187, sobre a Estrutura de Promoção da Segurança e Saúde no Trabalho. Aprovada na 95 $5^{\text {a }}$ Conferência Geral da OIT em 2006 e ainda não ratificada pelo Brasil, reforça a necessidade de "desenvolvimento de uma política, de um sistema e de um programa nacional, em consulta com as demais organizações mais representativas de empregadores e trabalhadores", que devem ser revistos periodicamente. Deve-se desenvolver uma cultura de prevenção.

a) o termo política nacional se refere à política nacional de segurança e saúde no trabalho e meio ambiente de trabalho, elaborado em conformidade com os princípios estabelecidos no artigo $4^{\circ}$ da Convenção sobre a segurança e a saúde dos trabalhadores, $1981\left(\mathrm{~N}^{\circ}\right.$ 155);

b) o conceito de sistema nacional de segurança e de saúde ou sistema nacional refere-se à infraestrutura que compõe o marco principal para a execução de políticas e programas nacionais de segurança e saúde no trabalho;

c) o termo programa nacional sobre segurança e saúde ocupacional ou nacional refere-se a qualquer programa nacional que inclua os objetivos que devem ser alcançados dentro de um período determinado, assim como as prioridades e os meios de ação para melhorar a segurança e a saúde no trabalho, e os meios para avaliar os progressos realizados, e

d) A expressão cultura nacional de prevenção em matéria de saúde e segurança diz respeito a uma cultura em que o direito a um meio ambiente seguro e saudável trabalho é respeitado em todos os níveis, em que governo, empregadores e trabalhadores participam ativamente em iniciativas destinadas a assegurar um meio ambiente de trabalho seguro e saudável através de um sistema de direitos, responsabilidades e deveres, definidos e que seja atribuída a máxima prioridade ao princípio da prevenção. (CONVENÇÃO Nº 187 OIT)

\footnotetext{
${ }^{12}$ A história da construção da PNSST é contada por Reimberg (2011).
} 
A Política Nacional de Segurança e Saúde no Trabalho brasileira traz cinco princípios que devem nortear todas as ações: universalidade; prevenção; precedência das ações de promoção, proteção e prevenção sobre as de assistência, reabilitação e reparação; diálogo social; e integralidade. São sete diretrizes que devem ser seguidas:

a) inclusão de todos trabalhadores brasileiros no sistema nacional de promoção e proteção da saúde;

b) harmonização da legislação e a articulação das ações de promoção, proteção, prevenção, assistência, reabilitação e reparação da saúde do trabalhador;

c) adoção de medidas especiais para atividades laborais de alto risco;

d) estruturação de rede integrada de informações em saúde do trabalhador;

e) promoção da implantação de sistemas e programas de gestão da segurança e saúde nos locais de trabalho;

f) reestruturação da formação em saúde do trabalhador e em segurança no trabalho e o estímulo à capacitação e à educação continuada de trabalhadores; $\mathrm{e}$

g) promoção de agenda integrada de estudos e pesquisas em segurança e saúde no trabalho; (DECRETO N 7.602, DE 7 DE NOVEMBRO DE 2011)

Essas sete diretrizes foram transformadas em objetivos pelo Plano Nacional de Segurança e Saúde no Trabalho - Plansat, concluído em 2012. Ele indica as ações necessárias para a implementação de cada objetivo e quem são os responsáveis para executá-las. Também é atribuição da CT-SST propor o aperfeiçoamento do Sistema Nacional de Segurança e Saúde no Trabalho e conceber um programa nacional sobre esse mesmo tema.

A grande questão é como fazer com que todas as ações sejam efetivamente implementadas. Bobbio (2004, p.230) nos faz um alerta ao falar sobre a falta de implementação até mesmo de direitos consagrados na lei, que muitas vezes se apresentam como um ethos, um mundo do dever ser:

O mundo real nos oferece, infelizmente, um espetáculo muito diferente. À visionária consciência respeito da centralidade de uma política tendente a uma formulação, assim como a uma proteção, cada vez melhor os direitos do homem, corresponde a sua sistemática violação em quase todos os países do mundo, nas relações entre um país e outro, entre uma raça e outra, entre poderosos e fracos, entre ricos e pobres, entre maiorias e minorias, entre violentos e conformados. O ethos dos direitos do homem resplandece nas declarações solenes que permanecem quase sempre, e quase em toda parte, letra morta. 


\section{6 - Direitos do trabalhador jornalista}

A saúde e a segurança no trabalho também são direitos do trabalhador jornalista, que atua em uma empresa que tem seus próprios interesses. Cláudio Abramo (1988, p. 116) afirma que a grande imprensa é ligada aos interesses da classe que a mantém, e o papel de esclarecimento "vai até o nível dos interesses da própria grande imprensa", os quais são ligados a um complexo econômico, político e institucional. Mesmo assim ele acredita no exercício de um papel educativo.

O jornalismo é um meio de ganhar a vida, um trabalho como outro qualquer; é uma maneira de viver, não é uma cruzada. E por isso você faz um acordo consigo mesmo: o jornal não é seu, é do dono. Está subentendido que se vai trabalhar de acordo com a norma determinada pelo dono do jornal, de acordo com as ideias do dono do jornal. É como um médico que atende um paciente. Esse médico pode ser fascista e o paciente comunista, mas ele deve atender do mesmo jeito. $\mathrm{E}$ vice-versa. Assim, o totalitário fascista não pode propor no jornal o fim da democracia nem entrevistar alguém e pedir: "o senhor não quer dizer uma palavrinha contra a democracia?; da mesma forma que o revolucionário de esquerda não pode propor o fim da propriedade privada dos meios de produção. (ABRAMO, 1988, p.110)

Ribeiro (2001, p.54) avalia que "o velho espírito de missão” foi corroído. "Dentro dos jornais ocorreu um desencantamento do mundo, devido à eliminação dos elementos políticos e românticos, incompatíveis com uma produção cultural industrializada." O autor também traz o depoimento do jornalista Carlos Eduardo Lins da Silva, então diretor de redação da Folha, na época de sua pesquisa, o qual afirmava:

Muita gente ainda vê o jornalismo como um apostolado, uma missão evangélica, uma coisa quase religiosa. Mas o jornalismo é um negócio para se produzir um bem de consumo cuja venda se espera obter lucro; é feito em escala, em quantidades de massa; e acho que essa é a característica mais marcante do jornalismo.

(...) o efeito do jornal tem uma carga simbólica muito mais importante do que a carga material dele mesmo. A importância simbólica de um jornal é talvez maior do que a importância material.

(...) essa característica simbólica faz com que muitos profissionais não atentem para o fato de que, no fundo, eles são operários numa indústria, da mesma forma que são operários aqueles que trabalham num metalúrgica. (RIBEIRO, 2001, p.55-56)

Outro autor a olhar para o jornalista como trabalhador é Perseu Abramo (2007). Ele explica que os jornais se transformaram gradativamente em empresas regidas pelas mesmas regras de competição das relações econômicas da sociedade capitalista moderna. Dessa forma, passou a existir uma separação mais nítida entre "o proprietário 
do jornal, representante da classe burguesa, e o jornalista, profissional semiqualificado, geralmente recrutado entre as camadas da classe média urbana", ou seja, "um trabalhador assalariado que vende a sua força de trabalho para a defesa dos interesses da burguesia". No entanto, ele aponta que o jornalista nas "grandes empresas abdica de tomar consciência da classe social a que pertence" - a de trabalhador assalariado.

\begin{abstract}
Assim, o papel social do jornal como empresa, hoje é duplo: a) o jornal participa, indiretamente (através da tentativa de exercer influências), no poder político, ou, pelo menos, no poder político periférico, na defesa dos interesses políticos e econômicos gerais e específicos, do grupo social e da classe social a que pertencem os proprietários da empresa; b) promove a divulgação de informações e orientações necessárias ao funcionamento do sistema social, econômico e político da sociedade moderna.

Para o jornalista, porém, o problema de seu papel social coloca-se de maneira diferente. A contradição inerente à empresa jornalística, que a divide entre proprietário da empresa e jornalista assalariado (e que reflete a contradição essencial inerente à estrutura social, entre burguesia e proletariado), determina o papel real exercido pelo jornalista, que passa a ser, também, contraditório e é visto por ele e pelos demais como ambíguo, incongruente, impreciso, oscilante etc. Portanto, nesse campo é preciso distinguir entre o ser e o dever ser, isto é, a conduta efetiva dos jornalistas e a conduta que ele deveria ter ou pela qual deveria lutar. (ABRAMO, 2007, p.283-284)
\end{abstract}

A questão de se ver ou não como trabalhador foi levantada por alguns entrevistados deste estudo. Para Leonardo Sakamoto, “o jornalista não se vê como trabalhador". Pelo contrário, "muitas vezes se vê como parte integrante do capital porque ele convive com os mesmos espaços simbólicos e culturais desse capital". Ele também aponta a relação capital trabalho, que é ocultada: "Eles estão próximo dessa realidade dos proprietários dos veículos de comunicação, dos capitalistas nesse sentido. Só que ele não é um capitalista, ele não detém meio de produção, ele não detém esse processo, ele não detém esse know hall". Na avaliação do entrevistado, o jornalista só percebe que não é parte do capital quando é demitido: "ele é demitido sumariamente, sem explicações, às vezes, ah não, mas eu pensei que fazia parte da família, da família Abril, da família Folha, da família Estado, mas não tem família e esse é o ponto, é capital e trabalho". Considera ainda que o jornalista "fala muito dos direitos dos outros e trabalha com uma quantidade pequena de direitos e acha isso normal”. A solução: "Primeiro é o jornalista se considerar um trabalhador e reivindicar todos os direitos que ele tem como trabalhador." Na Repórter Brasil, coordenada por ele, todos são contratados conforme a CLT. "Isso é raro poder falar, bem raro. A gente pode não pagar os maiores salários do mercado, mas a gente é CLT”. 
Ao se reconhecer como trabalhador, o jornalista pode se perceber como portador de direitos trabalhistas e passar a questionar as relações de trabalho estabelecidas e a precarização. Além das longas jornadas, há jornalistas sem registro em carteira, que cumprem jornadas como se fossem celetistas, são chamados de frila fixo. Há casos em que são obrigados a dar nota como se fossem uma empresa, mas cumprem jornada como um trabalhador, nesse caso, são as conhecidas PJs, abreviação para pessoa jurídica. O que para alguns pode ser algo provisório, para outros é uma situação constante, presente em diferentes meios de comunicação, como será discutido adiante. São formas de flexibilizar e mascarar as contratações. Ainda há os profissionais que fazem matérias para diferentes veículos, os freelancers propriamente dito, que podem ter ou não empresa para dar nota, mas não cumprem jornadas nos locais de trabalho.

Eu acho que é uma condição de trabalho precária, em estado de precarização. Eu comecei em 93, o jornalismo no Brasil era altamente formalizado, apesar de eu ter trabalhado um ano como frila fixo, não havia vaga na revista naquele momento, mas eles me queriam lá, fui contratado logo que foi possível. Os jornalistas que eu conhecia, praticamente todos eram contratados, seja no Estado, no Globo, na Folha, nas revistas da Abril, pelo menos em São Paulo, você tinha um grau de formalização, direitos trabalhistas, plano de saúde, maior do que se tem hoje. Eu vejo, não estou falando nem tanto por mim que estou contratado e tenho todos esses benefícios, mas eu vejo muitos colegas, muitos mesmo, trabalhando de maneira autônoma, seja por opção, seja por falta de alternativa mesmo, tendo que ser freelancer, fazer diversas matérias por mês, pagar seu próprio plano de saúde. Eu acho que de fato o momento para o jornalismo, para o trabalhador da notícia, digamos assim, é bem difícil - Ivan Marsiglia.

Para Maria, falta união de classe para "brigar pelo registro de todos os profissionais e acabar com a PJ". Para a jornalista, "nós somos uma classe trabalhadora", mas não nos vemos como tal: "A gente se acha o máximo. A gente não se entende como trabalhador, operário". Durante a entrevista, ela relembrou a greve realizada pelos trabalhadores da EBC em 2013, que possibilitou que eles se enxergassem como trabalhadores:

Lá na EBC a gente fez uma greve ano passado, uma das maiores greves de jornalistas dos últimos tempos, mas ninguém falou sobre isso. A empresa tem 2000 funcionários, e a gente conseguiu parar mais ou menos 700 e ali a gente conseguiu entender que a gente era peão. A empresa fez questão de dizer nas negociações e tratar a gente como peão, e a gente era peão mesmo, fazia greve e não ia trabalhar. A gente ia fazer piquete, chamava sindicato. Foi bem interessante por ser também uma greve com muita gente nova, de 25 a 35 anos, que é uma galera que não viveu nenhuma outra história de militância política assim da categoria. E acho que a própria regulamentação do trabalho vai garantir condições de saúde, já vem tudo junto. Eu acho 
que o caminho tinha que ser pelo registro CLT, enquadrando a gente como qualquer trabalhador comum e batalhar. Nós já somos cidadãos, e a gente vai batalhar pelo SUS [Sistema Único de Saúde] também. Se não tem convênio médico, a gente vai ter que fortalecer o SUS. A gente vai ter que se entender não como categoria privilegiada... Maria.

A greve realizada pelos trabalhadores da EBC não conseguiu alcançar as reivindicações salariais. "A gente ganhou meio por cento de aumento real, mas a gente não teve retrocesso de direitos. A empresa queria tirar muitos direitos, e a gente conseguiu manter todos. A gente não conseguiu avançar, mas evitou um retrocesso", considera Maria. Para a jornalista, o maior ganho da greve foi possibilitar a identificação dos trabalhadores:

Acho que a EBC perdeu muito, essa direção não negociando com a gente, ficamos 15 dias, e a gente ia pra porta da empresa todos os dias. Não era greve de pijama. E a gente fazia churrasco, fazia atividade, eu dei aula sobre o meu mestrado. Tinha outras pessoas que faziam mestrado também em comunicação, falaram também sobre seus mestrados. Demos palestras. Chamamos gente de fora. Então foi um momento de integração entre os funcionários e quando a gente está oprimido a gente se une mais. Então a gente foi cada vez mais sendo deixado de lado pela empresa nesse processo, e a gente foi criando uma identificação que eu vejo muito presente. Faço um paralelo com a minha vida porque meu pai era metroviário daqueles dos anos 80 , e eles tinham uma identidade muito forte. Metroviário adora o metrô, adora ser metroviário e se defende. E aí nasceu nessa greve a identificação dos funcionários. No movimento, a gente falava muito em toque bar, expressão que virou uma hashtag. Naquelas discussões que não acabavam mais, alguém levantava o papelzinho e começava o 'toque bar'. Aí começou a chamar o movimento 'toque bar'. Até hoje a gente usa, que é uma expressão de identificação que remete a esse tempo de luta. Então hoje a gente consegue buscar os trabalhadores como nunca. Por mais que a gente não tenha conseguido aumento salarial, hoje a gente consegue ter muito mais gente interessada nas questões trabalhistas, por isso que eles odeiam mais quem estava na liderança. As pessoas não ficam mais quietas, elas já sabem que podem falar e não estão sozinhas, então se criou essa identidade. Acho que eles não perceberam, são pessoas despreparadas politicamente na direção para não ver esse impacto - Maria.

Também da EBC, Aline Scarso já se deparou com atrasos de salários em outros locais que trabalhou e considera isso "um atraso na vida do trabalhador, porque o jornalista é um trabalhador". Ela sempre trabalhou muito e hoje se considera menos precarizada, se comparada a outras situações que vivenciou, mas vê a precarização de forma aguda presente na vida dos colegas.

O jornalista hoje aceita trabalhar por qualquer salário. Isso é um comportamento geral de toda a categoria e muitas vezes incentivado pelo próprio sindicato, no sentido de não ser forte na categoria, no 
sentido de muitas vezes precarizar nossas condições, de aceitar as coisas, ou seja, a gente aceita, e o nosso órgão representativo de classe aceita também. Então fica muito complicado. O jornalista hoje trabalha muito e ganha extremamente pouco. Fica morrendo de medo de perder o emprego. Nas horas vagas, então faz contatos justamente para não perder o emprego ou para conseguir outro emprego. Fica fazendo frilas para complementar a renda. Fica vendo pautas fora do horário de trabalho, ou seja, ele é um trabalhador 24 horas, mas ao mesmo tempo ele não recebe o suficiente pra isso. Ele recebe muito pouco - Aline Scarso.

A insatisfação com a questão salarial apareceu várias vezes nas falas dos jornalistas até 45 anos. É o que diz Pedro: "Eu acho que é sempre um salário muito baixo em relação ao mercado e em relação à jornada de trabalho e ao quanto você trabalha. Isso eu acho que gera uma insatisfação natural". Há uma combinação de muito trabalho, ritmo acelerado e baixa remuneração. No caso da Folha, os repórteres que trabalhavam em sua equipe recebiam o piso da categoria ${ }^{13}$, mas trabalhavam mais tempo do que o estabelecido pela legislação: "Eu tenho amigo economista, que fala, assim, eu estou fazendo um sacrifício de dois anos pra ter uma grana pra guardar; no caso do jornalista, trabalha a mesma coisa e não tem nada, não tem um retorno em relação a isso". A visão é compartilhada por outro entrevistado:

Nos grandes jornais existe uma filosofia que sempre existiu, mas que é assim, se você já vai trabalhar na Folha, você não precisa de salário, se você vai trabalhar no Estadão, se você vai trabalhar na Veja, você não precisa de salário. Então pra entrar nesses veículos você precisa abrir mão de qualquer pretensão salarial e de qualidade de vida, porque você já está num grande veículo e você vai catalisar outras coisas no futuro. Você vai ter melhores condições de emprego porque você trabalhou na Folha, você vai ter um currículo bom, por ser um jornalista da Folha, do Estadão, você vai ser um jornalista de grife, de pedigree (risos) - Antonio.

As longas jornadas, os plantões, o não recebimento de hora extra ou um banco de horas inadequado, os baixos salários são fontes de sofrimento para os jornalistas, especialmente, para os mais jovens. "A maioria dos profissionais não está nos veículos grandes, eles estão espalhados pelo Brasil ganhando uma merreca sem direito de greve", afirma Leonardo Sakamoto. Mesmo para quem está na grande imprensa, a remuneração é considerada baixa, como mostra Pedro: "O salário é muito baixo em relação ao

\footnotetext{
${ }^{13}$ Segundo a Convenção Coletiva 2013/2014, do Sindicato dos Jornalistas Profissionais de São Paulo, para jornal e revista da capital, o salário normativo para os trabalhadores da categoria profissional a partir de $1^{\circ}$. de junho de 2013 era de $\mathrm{R} \$ 2.342,40$ para a jornada de 5 horas diárias. Para jornada de 7 horas, chegava a $\mathrm{R} \$ 3.747,84$. Os pisos salariais para $2014 / 2015$ ficaram em $\mathrm{R} \$ 2.500,00$ para 5 horas e $\mathrm{R} \$$ $4.000,00$ para 7 horas.
} 
mercado, a questão de falta de hora extra, é um problema sério. Eu também não sei como eles não pagam hora-extra, porque por lei deveriam pagar também”.

O sofrimento aparece, por exemplo, na fala de Vivian Fernandes, que trabalha no tabloide Brasil de Fato, e não é registrada. "Se o cara começar a pensar no futuro, estou aqui ganhando mal, fudido, mal pago, precarizado, tem muita gente que não paga aposentadoria. Eu por exemplo não pago aposentadoria. Aí se você pensar a longo prazo, que droga de vida eu estou construindo?" Mas essa situação de trabalho precarizado que a faz sofrer ocupa o mesmo espaço do prazer. O trabalho jornalístico que realiza na publicação alternativa lhe dá satisfação.

Estou me satisfazendo agora, fazendo uma parada que eu gosto, de certa forma eu estou sofrendo por isso, mas está valendo a pena. Aí você vai ficando mais velho ou vai pensando em constituir família e você pensa - onde é que isso vai me levar? Eu acho que é esse sofrimento da perspectiva do futuro, é um sofrimento emocional Vivian Fernandes.

Aline Scarso também demonstra ter preocupação com seu futuro profissional. Como funcionária pública da $\mathrm{EBC}$, tem contrato celetista, não estatutário, e considera o Plano de Cargos e Carreiras, que está sendo discutido, muito fraco. "Ele não fortalece o concursado a continuar lá. Hoje meu salário é acima do mercado, daqui há 10 anos eu não sei se vai ser, quando eu tiver filho, tiver família”. Outros problemas são relatados:

Hoje pra mim está ok, mais pra frente, eu não sei como vai ser e ao mesmo tempo eles não condições monetárias pra você ficar. Hoje a maioria dos chefes é trazida de fora, não são pessoas que prestaram concursos, mas são pessoas que têm ligações de contato, ligações políticas, são pessoas de confiança. Eu acho isso bem complicado Aline Scarso.

Fica clara a necessidade do jornalista se reconhecer como trabalhador para reivindicar os direitos trabalhistas e melhores condições de trabalho. Por um lado, para ser mediador do direito à informação, o jornalista precisa pautar o seu trabalho no interesse público e em notícias que contribuam para a efetivação dos direitos sociais, políticos e econômicos. Por outro, ele sente os efeitos de estar inserido em uma empresa que além de ter seus interesses próprios nem sempre vê o jornalista como um trabalhador portador de direitos.

Além disso, a divisão explicitada por Abramo (2007), entre capital e trabalho, dono de jornal e jornalista, não é tão clara assim atualmente pela própria forma que a organização do trabalho se dá no pós-fordismo. Cada vez mais as empresas se apropriam de discursos que defendem a participação e a autonomia. No entanto, essa é 
uma forma de controlar a subjetividade dos trabalhadores, como aponta Heloani (2003a), e utilizá-la a favor do capital. Ele fala da gestão da produção, o que pode ser estendido para a empresa jornalística, que produz e vende informação "O reordenamento da subjetividade no interior do processo laboral serve não só para otimizá-lo dentro do quadro de globalização do capital, mas também para garantir, em outras bases, seu domínio sobre a força de trabalho. Assim, o autor avalia que no pósfordismo, "a expropriação da capacidade intelectual do trabalhador é tão importante quanto foi o domínio sobre sua capacidade física no modelo taylorista-fordistafayolista" (Ibid., p.175).

Embora não seja possível analisar aqui todas as experiências da gestão da produção, há uma característica fundamental, comum a todas elas, que queremos ressaltar: a tentativa de 'harmonizar' um maior grau de autonomia dos trabalhadores, para organizar um setor de produção, com o desenvolvimento de controles mais sutis, que objetivam colocar o trabalho numa posição de 'dependência' ou 'incapacidade' em relação ao capital. Com esses novos mecanismos, revela-se, a nosso ver, uma notória modificação na organização de poder dentro do espaço fabril - a formulação de uma gramática de dominação que, nas palavras Max Pagès, age pela extensão dos mecanismos de poder, chegando à 'manipulação do inconsciente'... (HELOANI, 2003a, p.102) (grifo nosso)

Essas questões relativas à organização do trabalho serão aprofundadas no terceiro capítulo desta tese. Procuramos apenas introduzir o tema, já que a flexibilização dos direitos trabalhistas têm relação direta com a forma como o trabalho é organizado na atualidade, e no mundo do trabalho dos jornalistas não é diferente. Apresentamos assim como se configuram os direitos trabalhistas dos jornalistas. Ter condições de trabalho adequadas que preservem a saúde do trabalhador é um direito presente na lei e em documentos internacionais, como já vimos anteriormente, mas nem sempre esse direito é contemplado. No caso do trabalho do jornalista, a organização do trabalho é marcada por cargas horárias excessivas e ritmo de trabalho acelerado. Os depoimentos mostram situações de longas jornadas, insegurança nas formas de contratação, horas extras não remuneradas e bancos de horas questionáveis, que podem ser fonte de sofrimento e ter reflexos na saúde do jornalista e no trabalho realizado. 


\section{7 - Formas de contratação}

Os depoimentos colhidos para a tese mostram que houve uma mudança nas formas de contratação dos jornalistas. Se antes ser contratado conforme a CLT era a regra, hoje não seria exagero dizer que cada vez mais ser registrado é exceção. O que se vê é a precarização das relações trabalhistas no mundo do jornalismo.

Para os jornalistas com mais experiência, ter registro em carteira era uma realidade. Clóvis Rossi, 71 anos, por exemplo, sempre foi CLT. Já Alberto Dines, 82 anos, nem considera a passagem pela Cena Muda seu primeiro trabalho: "A Cena Muda era uma coisa muito diletante, amadora. Aqui [na Visão] não, era emprego, carteira assinada, horário, função". O fato de ser registrada possibilitou que Paula Puliti, 50 anos, ao ter que se afastar do trabalho por conta de sua doença, pudesse ter um salário durante o afastamento. A jornalista sempre foi CLT.

Ter a carteira assinada também foi a realidade de Aureliano Biancarelli, 63 anos, até ser demitido da Folha em 2004. Lúcio Flávio Pinto, 65 anos, deixou de ser CLT em 1989, quando saiu da grande imprensa para ser um profissional autônomo: "Como eu hoje sou um profissional autônomo, até agora não deixei de pagar a Previdência... Não só o Jornal Pessoal é pobre, eu virei pobre, eu sou o Jornal Pessoal, então, eu vivo de alguns trabalhos extras que eu faço".

A trajetória de Ricardo Kotscho, 66 anos, ilustra bem como se configuraram as formas de contratação dos jornalistas ao longo das últimas décadas. Ele começou em 1964 nos jornais de bairro Folha Santamaraense e depois Gazeta de Santo Amaro: "Era engraçado que nos dois jornais e isso era comum na época, eu era repórter num período e vendia anúncios no outro, aí tinha comissão dos anúncios. Ganhava mais vendendo anúncio do que como repórter. O salário de repórter era pequeno". Certa vez ele recebeu o salário em sapatos por meio de um vale para gastar numa loja de calçados que era anunciante da Gazeta de Santo Amaro, já que o jornal não pôde pagá-lo em dinheiro: "Então eu tinha muito sapato e não tinha dinheiro no bolso (risos)".

Foi em 1967 que Kotscho recebeu o seu primeiro registro em carteira no jornal O Estado de S. Paulo: "era CLT, como todo mundo". E assim recebeu vários registros, tanto que sua carteira de trabalho se transformou em uma espécie de prêmio, que lhe dava muito orgulho: 
É uma coisa curiosa, nesse meio tempo, eu trabalhei também nas campanhas do PT e era registrado pela CLT como funcionário do partido até o dia que entre uma eleição e outra perderam minha carteira no PT (risos). Não fica bem o Partido dos Trabalhadores perder a minha carteira de trabalho (risos). Fiquei chateado porque carteira de trabalho é quase um troféu que a gente tem, né, dos registros, por onde você passou, aquele negócio todo, e perder, eu tive que tirar a segunda via que não é a mesma coisa - Ricardo Kotscho.

Kotscho começou a trabalhar como pessoa jurídica na televisão, exceto na primeira passagem pela TV, na Globo, onde trabalhou no Globo Rural e foi CLT. "Mas no SBT Repórter já era contrato de microempresa, esse negócio. Depois foi assim também na CNT/Gazeta, na Bandeirantes". Atualmente ele tem contrato de trabalho como pessoal jurídica com a Record para participar como comentarista no Jornal da Record News, na televisão, e para escrever no blog Balaio do Kotscho, que fica no Portal R7. Ele faz seus textos de casa. Além disso, quando escreve para a revista Brasileiros recebe por matéria como freelancer.

Fernanda Cirenza também trabalha na Brasileiros como prestadora de serviços: "Eu venho todo dia ou quase todo dia, mas eu tenho muito mais flexibilidade de horário". Com 49 anos de idade, ela foi por muito tempo CLT, relação trabalhista que começou a ter no Sesc Pompeia e durou até a Marie Claire. Fernanda deixou a Editora Globo para fazer matérias jornalísticas como frila por um tempo. Em sua avaliação, ser CLT tem suas vantagens e desvantagens.

Pra maternidade, por exemplo, é uma grande vantagem você ser CLT e se tornar mãe nesse esquema, porque você tem sua licença maternidade, continua recebendo o seu dinheiro, depois tinha na minha época licença aleitamento... Então eu fiquei seis meses com os meus filhos, cuidando deles, isso é legal, isso é bacana. Muito difícil alguém que não é CLT, ter essa possibilidade, que eu acho super justa. As empresas precisam abrigar as mulheres que vão ter filhos, mas não é obrigada se você não é CLT. Eu não sei como vai ser pra essa geração que chega, quem não é CLT, que esteja como prestador de serviço, ficar grávida. Aqui eu mesma já tive coisas do tipo, minha mãe foi internada e eu não vim trabalhar dias e não me descontaram evidentemente. Ou eu tenho férias. A gente tem um contrato bacana pra mim também, não é uma coisa monstruosa, dá pra tirar férias, dá pra eu cuidar da minha mãe que é uma senhora, problemas com filhos... - Fernanda Cirenza.

A situação vivenciada por Kotscho e Fernanda Cirrenza levanta uma questão: quando ser PJ e freelancer é uma opção, que pode significar boa remuneração e reconhecimento, e quando é precarização do trabalho, ferindo os direitos do trabalhador jornalista? Bob Fernandes, 58 anos, por exemplo, reconhece a precarização que atinge a 
categoria, mas no caso dele, afirma sempre ter conseguido "ótimos contratos". Em parte da carreira, nos anos 1980 e início dos anos 1990, ele era CLT, a partir de 1993 se tornou PJ:

Da Carta Capital pra cá, sempre PJ. Eu acho que tem vantagens, tanto que eu prefiro ser PJ do que trabalhar em empresas que um monte de gente trabalhou, Jornal do Brasil, Gazeta Mercantil, que depois não existe, e o cara não recolheu o FGTS. Claro, eu já tenho que embutir no salário o meu seguro médico e tal. Só que eu não posso ser cego, e achar que essa é a condição de trabalho de todo mundo, acho que não, é uma precarização das condições de trabalho de maneira geral pra todo mundo. Reconheço que alguns poucos, e eu me incluo entre esses poucos, tiveram oportunidade, chance, sorte de escapar disso, sei lá por que condições, destino, sorte, mas a maioria é muito mal paga Bob Fernandes.

Bob Fernandes, quando fazia a revista Terra Magazine, tinha um escritório e contratava outras pessoas para trabalhar com ele. As contratações ocorriam como pessoa jurídica em ambos os casos:

$\mathrm{Eu}$, aliás, desconfio que boa parte delas [das relações de trabalho] deve ser modificada mesmo, deve ter outro acordo de trabalho que seja justo para todas as partes. Eu, por exemplo, recebo como PJ e pago como PJ. Eu não teria uma redação com seis pessoas se eu fosse pagar de uma forma que não fosse PJ, diante da situação, teria três porque o custo é o dobro, entende. Então você tem uma meleca grande que tem que ser resolvida nisso. Se você não resolve, você só tem condições precárias pra todo mundo - Bob Fernandes.

Marilu Cabañas, 51 anos, também começou a carreira como CLT e agora é pessoa jurídica na Rádio Brasil Atual. "O resto foi tudo CLT. Eu trabalho registrada desde os 14 anos". No entanto, nesse trabalho encontrou apoio que não havia recebido quando era celetista. Desde julho de $2013^{14}$, estava cuidando da mãe com câncer e trabalhando. "Até que chegou um momento que não dava mais. O Colibri falou: - vai cuidar da sua mãe. - Como é que fica? - Vai lá. Foram meses e eu recebi tudo. O que é que eu vou falar?”. Quando era funcionária da Rádio Cultura, era CLT e ao pedir uma semana para cuidar da mãe que havia sido operada, obteve uma negativa:

- Só se você descontar das suas férias.

- Não quero que desconte das minhas férias. Não dá pra gente ver uma forma? Se me liberam? Uma licença?

- Não.

- Então tá, bota falta aí. Pode descontar, desconta do meu salário.

E descontaram. Entendeu a diferença? Agora meses recebendo tudo, e lá uma semana que eu tinha que ficar com minha mãe, ela não podia

\footnotetext{
${ }^{14}$ A mãe da jornalista faleceu em janeiro de 2014.
} 
andar porque tinha operado as duas pernas e não quiseram acordo Marilu Cabañas.

$\mathrm{Na}$ avaliação de Marilu, se a empresa entende quando um funcionário tem um problema de saúde na família, a pessoa se dedicará muito mais ao trabalho. "Você precisa estourar o horário, claro, imagina que eu não vou ficar. Claro que eu vou fazer, é uma relação humana com o colega e as pessoas que representam a empresa."

Quando trabalhava na Rádio Cultura, Marilu Cabañas chegou a questionar a questão dos PJs. Na época que Mário Covas era governador, os funcionários eram CLT. Com Geraldo Alckmin, começaram a contratar jornalistas como pessoa jurídica. Depois com José Serra no governo, foram escolhidos representantes dos funcionários para passar à direção o que estava se passando nos setores. A jornalista foi escolhida para representar a rádio $\mathrm{AM}$ e $\mathrm{FM}$ e a internet.

Eu ficava inconformada.

- Pô, você não tem um ticket, caramba, você não tem convênio.

$\mathrm{Eu}$ verbalizava demais e na hora que tiveram que escolher, me escolheram. Não queria. No primeiro contato com o João Sayad, eu encaminhei todas as questões, de condições de trabalho dos colegas. E eu falei para o Sayad:

- Você sabe que tem PJtinha e PJtão.

A Marília Gabriela tinha acabado de ser contratada por uma fortuna. Ele disse:

- Pjtinha?

- É, PJtinha, o povo que ganha pouco e nem consegue pagar um convênio. Já o PJtão nem quer ser contratado, nem quer ser CLT.

Aí foi isso e teve também uma matéria que eu fiz, uma série sobre a Jureia, e bati de frente com a Secretaria do Meio Ambiente. As crianças caminhavam mais de uma hora e eram picadas por cobras. Que isso? Cobrei. Não sei o motivo exato da demissão, mas foi depois dessa série sobre meio ambiente, sobre a Jureia, sobre a mata atlântica porque tinha os impactos além da situação ecológica, e também casualmente foi no período em que eu estava como representante, que eu fui demitida - Marilu Cabañas.

Antonio, 40 anos, vê a situação de PJ como precarização, principalmente, quando se cumpre jornada como funcionário, sem direito a nenhum benefício, nem férias. Miguel, 39 anos, viveu essa precarização algumas vezes ao longo de sua carreira. Quando começou a trabalhar na agência de notícias de um grande jornal, por dois anos trabalhou sem registro em carteira. Era frila fixo. Cumpria jornada como se fosse um funcionário contratado e não tinha que dar nota fiscal:

Sem direito a décimo terceiro, sem direitos trabalhistas. Eu consegui na época tirar, juntei 10 ou 15 dias de folgas, porque eu trabalhei muito feriado, nos plantões, consegui descanso depois de um ano e 
meio que eu estava lá. Depois que eu voltei desse período de folga, eu fiquei uns 4, 5 meses, aí sim fui registrado - Miguel.

Após essa experiência, Miguel voltou a ser precarizado trabalhando para uma agência de conteúdo que produzia materiais jornalísticos para um portal. Foram mais dois anos sem registro e sem direitos trabalhistas. Saiu do trabalho quando quiseram que ele emitisse nota como PJ. Abrir uma empresa para isso geraria muitos gastos, e ele considerou que não valia a pena. "Não queria chegar a esse ponto, virar PJ. Lá eu trabalhava de segunda a sexta, era um pouquinho mais tranquilo, não tinha plantão, mas era também um ritmo puxado". O seu terceiro trabalho mudou essa realidade, foram quatro anos como CLT na CBN. Outra experiência como CLT foi quando trabalhou em um portal de notícias no interior do estado de São Paulo, mas isso não significa que deixou de vivenciar sofrimentos no local em relação às questões trabalhistas:

Tinha algumas coisas que eu não podia decidir também, que eu imaginava que quando eu chegasse a ser editor de um veículo eu poderia decidir. A relação trabalhista da própria equipe, dos próprios subordinados. As repórteres que tinham lá eram contratadas como auxiliares de redação, uma coisa absurda, ganhando menos que o piso. Nós ganhávamos o piso, os editores. E os estagiários ganhavam valor de estágio. Então uma coisa muito precária, me angustiava fazer parte daquilo - Miguel.

$\mathrm{Na}$ época da entrevista, trabalhando em um grande portal de notícias na capital paulista, Miguel voltou a ser frila fixo: "Uma negativa é o fato de não ser registrado, mas eu também não fui obrigado a fornecer nota nem a ser PJ. É o frila fixo de novo (risos), só que pelo menos agora eu me vejo numa situação em que há certa valorização salarial pelo menos". O entrevistado não percebia essa valorização salarial na época do outro portal e da agência de notícias. Agora ele consegue pagar o INSS por conta própria. "Na época que eu fui frila fixo eu não tinha condição de me preocupar com essas coisas, agora é um salário mais interessante, não é nenhuma fortuna, mas dá uma certa folga". Para ele, essas relações trabalhistas vivenciadas no jornalismo são inconcebíveis:

Tem uma quantidade grande de pessoas que é obrigada a montar sua própria empresa e fornecer nota fiscal, eu que fui fugindo disso sempre. Acho isso um absurdo. Frila fixo é absurdo também, mas eu ainda acabo aceitando ele, não tem impostos e quando você aceita ser pessoa jurídica é quase você abrir mão de algum dia você voltar a ser registrado - Miguel.

Pedro, também da faixa dos 30 anos como Miguel, chegou a ser frila fixo na Folha por seis meses até ser registrado. Antes disso, atuou como freelancer: "No 
começo da carreira, eu achei muito difícil encontrar trabalho, principalmente porque eles queriam pessoas experientes e por encontrar dificuldade também de ter um vínculo empregatício pra quem eu estava trabalhando". Para ele, essa dificuldade persiste:

Acho que é até hoje assim, é um esquema que não existe mesmo vínculo, e as pessoas às vezes não cumprem muito bem a CLT. Você não tem os seus direitos de férias remuneradas, principalmente nesse período que você trabalha como frila. Isso pra mim dá uma instabilidade muito grande na profissão - Pedro.

Maria, do mesmo grupo etário, também vivenciou a precarização trabalhando para o movimento social. No MST (Movimento dos Sem Terra), não era registrada:

Eu tinha essa noção, de não me registrar, e no momento em que eu achei importante ser registrada, eu nem exigi isso deles, eu levantei e saí, porque eu sabia que eles não poderiam, eu estava ali pela experiência, pra aprender, por estar em um movimento social que eu admirava, mas eu via muito essa situação de exploração no dia a dia. Era muito complicado isso, porque é muito difícil de lidar, porque você tem que trabalhar o tempo inteiro, se é uma militância, você não tem folga. Se é trabalho tem que acabar às 5 . Mas é militância, você não tem final de semana, você não tem vida pessoal, mas então se eu quiser ir ao cinema, não pode, porque tem gente que não pode ir ao cinema porque está lá no acampamento. Era uma crise quase que existencial o tempo inteiro. A hora que eu saí de lá fiquei contente. Amo eles de paixão, todos, mas chegou um limite que eu falei, quero ser amiga de vocês, me chamem para projetos esporádicos, essa relação de trabalho eu não suporto mais e aí eu saí - Maria.

Vivian, 27 anos, vivencia uma angustia parecida ao trabalhar em um veículo alternativo com o qual se identifica, o grupo Brasil de Fato, mas não ser registrada. Ela tem alguns benefícios como férias e décimo terceiro, mas a empresa não recolhe INSS. Os acordos são verbais. A situação mostra como o prazer de trabalhar em um jornal no qual se acredita faz com que se suporte a situação de precariedade, o que não significa que se concorde com ela. O sofrimento e o questionamento das situações estão presentes.

Nessa trajetória interna deu pra aprender muita coisa da profissão dentro de um meio alternativo e ao mesmo tempo muitos dos problemas que o meio alternativo sofre, tanto a parte de precarização do trabalho, não ter contrato, não ter nada. Esse é um mal que persegue a mídia alternativa de onde eu estou, que eu acho que nunca teve. Há 10 anos o jornal foi criado e há 10 anos ninguém teve nada acrescido lá dentro por parte dos jornalistas. Os outros funcionários têm. Faxineira tem. A secretária tem. Mas os jornalistas não têm. Então é encarado como uma forma de militância, também por isso que também se relega essa parte da carteira de trabalho pra lá. Você é um militante, logo, tudo bem pra você não ter carteira assinada e não ter o resto dos benefícios trabalhistas. Mas é uma coisa que hoje eu vejo com olhar mais crítico do que eu via no começo, sabe. Acho que no 
começo tudo era alegria, que legal o trabalho, a parte boa supera todas as partes ruins. Hoje em dia eu acho que eu consigo ver de uma forma mais equilibrada o que é bom de trabalhar em uma imprensa alternativa, que eu acho que é uma liberdade maior para escrever as matérias, que eu concorde mais, mas tem essa parte ruim que é uma precarização muito grande - Vivian.

Bruno Torturra, 35 anos, não trabalhava no meio alternativo, mas também enfrentava a precarização. Na Trip, era PJ. "Eu dava nota, mas sempre estava no expediente da revista. Quase todo mundo lá é assim”. Ivan Marsiglia, 43 anos, também foi PJ na mesma revista, saindo da Editora Abril por vontade própria, onde era CLT: "Foi por uma opção de trabalho, de criatividade. Eu queria trabalhar com aquelas pessoas que eu achava interessantes, criativas, e exercitar também a minha liberdade naquele ambiente. Então eu abri mão de uma segurança profissional em favor disso". Antes disso, já havia sido frila fixo na Abril antes de ser contratado, situação que se repetiu em O Estado de S.Paulo, ficou três anos como frila fixo e estava há dois como CLT na época da entrevista.

Já Torturra, ao sair da revista, fez frilas. Atuando como jornalista independente, com a Mídia Ninja, não tinha renda. A ideia dele na época da entrevista era desenvolver um novo projeto jornalístico que pudesse ter apoio dos leitores por microassinaturas:

Eu me sustento hoje com a festa que eu faço mensalmente, alguns jobs que eu faço de roteiro, vídeo, tal, mal tenho tempo de fazer, e contei nos últimos meses com muita ajuda de amigos, gente que me empresta um dinheiro, me dá alguma coisa que eu preciso. Mas estou lutando muito para daqui muito pouco tempo lançar aqui uma campanha de microassinaturas pra quem está a fim de apoiar o Fluxo, dar 5 reais no mês e tal. Vou ver se eu consigo uma base de assinantes pra pelo menos pagar o aluguel do espaço, sustentar o espaço físico e depois talvez se a gente conseguir entregar um material de qualidade, sustentar as pessoas que vão trabalhar aqui também - Bruno Torturra.

Os outros jovens de 20 e poucos anos entrevistados pela pesquisa - Aline Scarso da EBC, João que relatou a experiência em revista de informação e Priscilla Nery em revista segmentada (Proteção e Emergência) - eram celetistas. Priscilla, quando estagiária em uma empresa de conteúdo que prestava serviços para portais de notícias, tinha contrato de estágio com direito a seguro de vida. No entanto, apesar de lá constar trabalho de segunda a sexta, por seis horas diárias, ela tinha que fazer plantão em alguns finais de semana. Já Aline foi a que enfrentou mais precariedades nas formas de contratação: "Esse é meu primeiro trabalho com carteira assinada, então, eu valorizo muito isso. Porque eu estou há cinco anos formada e é a primeira vez que eu tenho carteira assinada, e eu gosto também de onde eu trabalho". Na FIA, por exemplo, em 
que produzia conteúdo sobre direitos da criança para a internet, ela foi obrigada a abrir uma empresa para ser contratada como pessoa jurídica.

Teve a questão do Ano Novo, do Natal, das férias. Eles queriam me dar 10 dias de férias, ou seja, eu sou uma empresa teoricamente, mas eu não escolho quando eu vou parar, eu estou submetida a um chefe, tenho que está lá todo dia, tenho jornada pra cumprir, então, acho que assim, foi uma experiência que eu acho que existem muitas no mundo dos jornalistas - Aline Scarso.

Para Aline, trabalhar em uma empresa pública dá uma estabilidade maior do que trabalhar em empresas privadas. "Acho que o medo de perder o emprego é muito maior, muito mais do que a gente. Isso com certeza as pessoas que trabalham nesses veículos devem sofrer muito mais, com problemas inclusive mentais mesmo". A crítica à precarização das relações trabalhistas, de forma geral, também aparece na fala dela e de outros jovens entrevistados.

Eu acho que isso é uma culpa nossa mesmo, por exemplo, tinha um dirigente sindical na nossa universidade lá em Bauru, que ele era um professor muito bacana, só que no dia da formatura de alguns colegas ele disse que ser PJ, pessoa jurídica, era uma realidade do mercado e que a gente deve aceitar isso. Então eu acho que é complicado quando um dirigente sindical, que deve lutar pelo menos pelas manutenções dos direitos..., dizer que você deve aceitar não ganhar férias, que você deve aceitar contribuir à parte com a sua Previdência, aceitar trabalhar abaixo do piso, porque quando ele diz que é PJ, a realidade do mercado é exatamente essa, você estar submetido a um sistema de precarização quase que total - Aline Scarso.

Acho que é uma carreira que está sendo precarizada pelo mercado. As pessoas acham muito bacana às vezes não ter patrão, mas acho que tem essa parte toda da questão dos benefícios, porque eu vejo muitos amigos meus que trabalham hoje como PJs e isso é muito grave. Até a própria empresa que eu trabalho hoje tem pessoas trabalhando como pessoa jurídica. Eles falam que é uma empresa, mas é uma pessoa e acho isso muito ruim porque o jornalista não consegue pensar que um dia ele vai ter que parar de trabalhar. Então a pessoa vira PJ por uma situação de mercado, mas também não pensa que era bom pagar o INSS de repente facultativo, porque eu acho que a gente também não pensa, a gente entra nesse trator, um dia vai ter que parar de trabalhar e não vai conseguir.

(...)

A PJ é um mal que se estende, e o jornalista tem muito medo de brigar, porque a gente acha que nosso nome é nosso patrimônio e aí se você entrar com uma ação trabalhista, se você brigar, você nunca mais vai conseguir trabalho algum, e eu sinceramente questiono muito isso. Acho que isso é muito desculpa, mas desculpa que outra coisa. Acho que há momentos que a gente pode se expor, há momentos que não pode, se a gente não brigar pela categoria, está lascado. Então acho que em relação ao trabalho é o registro pra gente ter os benefícios que todo trabalhador tem - Maria. 
Aquela coisa de frila fixo, frila fixo é o funcionário da empresa, que ela faz isso para fugir dos custos trabalhistas, na verdade, o cara tem que bater cartão, obedecer ordens, e ter que bater cartão mesmo não estando na empresa, e ter que obedecer ordem, produzir diariamente, ele é funcionário da empresa, só que ela não quer pagar os direitos trabalhistas - Leonardo Sakamoto.

\section{8 - Jornada de Trabalho}

Estudos como o de Heloani (2003b) e Ribeiro (2001) relatam jornadas excessivas no trabalho do jornalista. No entanto, a Consolidação das Leis do Trabalho CLT, que coloca como limite uma jornada de trabalho de 44 horas semanais ou de acordo com a convenção coletiva da categoria, aborda, na seção XI do Capítulo I - Das Disposições Especiais sobre Duração e Condições do Trabalho, os jornalistas profissionais e estabelece uma jornada de trabalho diária de 5 horas, que pode ser elevada a 7, "mediante acordo escrito, e em que se estipule aumento de ordenado, correspondente ao excesso do tempo de trabalho, em que se fixe um intervalo destinado a repouso ou a refeição" (Art.304).

A questão também aparece em Convenção Coletiva de Trabalho. No caso do Sindicato dos Jornalistas Profissionais no Estado de São Paulo - SJSP, a convenção define 5 horas de trabalho e regulamenta a realização de duas horas extras diárias, o que daria uma jornada de 7 horas por dia ou 42 horas semanais. Mas na prática, vemos uma realidade diferente, em que é comum não se ter horário para deixar o trabalho. Heloani (2003b) encontrou relatos de até 60 horas semanais.

Travancas (1993, p.83-86) também recolheu relatos de jornalistas que afirmam que "a jornada de trabalho do jornalista de cinco horas, com possibilidade de mais duas extras no contrato, raramente é cumprida à risca. São inúmeros e frequentes os casos de jornada de nove ou dez horas, muitas vezes sem o pagamento adequado." Nesse quadro, em que reconhecem "a extensa carga horária", a autora percebe a existência de "uma importante dose de prazer" no exercício profissional. "São muitos os que permanecem ligados ao trabalho 24 horas por dia, independentemente do fato de estarem ou não na redação, o que é inerente à profissão".

O problema ainda permanece. Notícia publicada no site Comunique-se em março de 2011 relata casos de jornalistas trabalhando no Agora SP, do Grupo Folha, de 
12 a 15 horas por dia, sem banco de horas ou horas extras (VASCONCELOS, 2011). Apesar de a empresa negar as irregularidades, a matéria afirma ter ouvido fontes que confirmaram. O sindicato, por sua vez, disse desconhecer as irregularidades, mas não se surpreender com elas, e que apuraria.

Os depoimentos colhidos por esta pesquisa mostram que a flexibilização dos direitos trabalhistas ocorre no jornalismo de forma frequente. As longas jornadas são naturalizadas como uma necessidade da profissão e não se respeita o que está na CLT e na Convenção Coletiva dos jornalistas. Por outro lado, em algumas situações é necessário prorrogar a jornada devido à intensidade da cobertura.

A cobertura da agonia do presidente Tancredo Neves, em 1985, começava de manhã cedo. Você se plantava no Centro de Convenções Rebouças, onde tinha sido montada a sala de imprensa, para acompanhar o paciente que estava no Incor, até à noite, até a hora em fechava o jornal. Não havia rotina. Até houve um período quando ficou evidente que o presidente ia morrer, eu trabalhava com um olho no noticiário do dia, um olho no fechamento, um olho no timetable das companhias aéreas, porque eu já estava escalado para cobrir o enterro em Brasília. Então tinha que estar prestando atenção em todas essas coisas para poder pegar o primeiro voo possível, fechar o material do dia em que ele morresse e viajar para Brasília, o que de fato aconteceu, só que ele morreu em um domingo, e eu acabei viajando no dia seguinte de manhã - Clóvis Rossi.

Quando está muito envolvido com uma reportagem, por mais sofrimento que a sua elaboração traga, há prazer em ver o texto terminado, em conseguir vencer as dificuldades, obter as informações, finalizar sua obra. Assim se trabalha a mais. O problema é isso não ser tomado como uma exceção diante da complexidade de uma reportagem, seguida de folga ou pagamento de hora extra, torna-se a regra trabalhar a mais sem compensação. E isso não é um problema de agora, como mostram as falas dos jornalistas com mais tempo de profissão:

Uma coisa comum em redação de jornal é que geralmente não se considera a rigidez dos horários. Há lei que estabelece o período de cinco horas de trabalho, mas raramente isso é respeitado, e na maioria das vezes pelo próprio jornalista. Primeiro porque o próprio jornalista quer, ele tem interesse, o jornalista apaixona, e segundo porque as empresas se beneficiam dessa coisa. Se o sujeito vai além do horário pra elaborar melhor uma matéria quando ela fica pra outro dia, esse tipo de coisa, a empresa acha muito bom porque raramente se pensa em hora extra em redação. Na revista, essa coisa, o limite de tempo, praticamente não existe, o tempo é aquele exigido pela busca da matéria, apuração, etc. - Audálio Dantas.

Eu sempre trabalhei, sem exagerar, em média, um dia de trabalho era um dia de 12 horas. Tem até uma coisa também interessante que eu acho que horário de jornalista por lei é cinco horas, mais duas horas 
extras, 7 horas no máximo, e aconteceu em alguns lugares de o fotógrafo virar e falar pra mim, meu horário venceu. Se você quiser, você continua fazendo, porque eu estou indo embora, e eu não me conformava com isso, eu acho que o jornalista não admitia isso Ricardo Kotscho.

Audálio Dantas também trabalhou em revistas nas décadas de 1960 e 1970: “o horário na redação não existe, na redação de revista, revista mensal, não tem esse negócio de horário, de entrar, sair, etc. e tal, cada um faz o seu horário”. Em 1975, seu discurso de posse no Sindicato dos Jornalistas, em São Paulo já falava de precariedade:

Eu começava o meu discurso dizendo, nós somos os que morremos mais cedo, isso em função exatamente dessa pressão. Por definição, a profissão é estressante e isso obriga os jornalistas, além desse estresse natural na busca da informação, a cumprir horários que vão além. Ele mesmo termina indo. Vão além daquilo que é estabelecido, que seria o ideal, que seria o tempo de trabalho mais curto pra que ele não sofresse tanto - Audálio Dantas.

Alberto Dines recorda que na época em que esteve à frente do Jornal do Brasil, criaram-se categorias de repórteres que ganhavam progressivamente. Os repórteres exclusivos trabalhavam em tempo integral, mais por tarefas do que por horário. Para ele, a jornada de 5 horas "era um avanço sob o ponto de vista laboral, mas tinha um defeito, se o jornalista precisasse trabalhar $10 \mathrm{~h}$ durante dois, três dias, pra fazer uma matéria especial ele não podia". Na época da entrevista, aos 82 anos, o jornalista continuava mantendo uma longa jornada, trabalhando pelo menos 10 horas por dia.

Aureliano Biancarelli, nos anos 1970, 1980, 1990 e início de 2000, trabalhou em grandes veículos como Veja, Jornal da Tarde e Folha de S.Paulo. Cobriu grandes tragédias como os incêndios nos edifícios Joelma e Andraus, o assassinato dos presos no Carandiru, a queda do Boeing da Tam, a explosão do Shopping de Osasco. "Aí não tinha horário". Em dias normais, sua jornada era respeitada, mas isso não era visto como um direito de todos os jornalistas e sim como privilégio de um profissional com mais experiência.

"Com o tempo fui ganhando certos privilégios, eu entrava a uma da tarde, logo depois do almoço, já chegava almoçado, e geralmente saía 9 da noite. E nos pescoções como a gente dizia, aí podia ficar até 3, 4 da manhã. Eventualmente num acontecimento que envolvesse as pessoas, que fosse um acontecimento que fugia do esperado, aí você poderia ser chamado 9 horas da manhã e ficava até o fechamento final" - Aureliano Biancarelli. 
Quando foi entrevistado, Biancarelli prestava serviços para o Conselho Regional de Medicina do Estado de São Paulo - Cremesp. Antes recebia por trabalho realizado. Depois foi contratado por um período de 5 horas:

\begin{abstract}
Ah, o meu ritmo hoje é completamente atabalhoado, porque eu estou trabalhando como contratado aqui no Conselho. (...) Tem períodos que eu não trabalho essas cinco horas, como agora que eu estou esperando três trabalhos, quando eles chegarem eu vou trabalhar 10 horas por dia, porque não é o mesmo chefe, digamos, para me passar material. (...) Então é bastante instável. O diferente é que eu trabalho em casa, não saio de casa, venho aqui duas ou três vezes por semana, não mais que isso. Aqui tem uma mesa que eu nunca usei - Aureliano Biancarelli.
\end{abstract}

Lúcio Flávio Pinto, do grupo de 60 anos como Biancarelli, também trabalha em casa. Ele pode, por exemplo, passar cinco, seis dias lendo o relatório anual de uma empresa como a Vale e nem sempre isso vai render matéria. Vivencia um envolvimento grande e uma dedicação total.

Já a rotina de Bob Fernandes, 58 anos, sempre envolveu trabalhos noturnos e de madrugada. "Nunca tive esse tipo de problema de trabalhar muito, trabalhar pouco, porque eu sempre fiz meus horários. Sempre que faço algo grande, texto grande, seja o que for, eu estava escrevendo um livro o ano passado, eu escrevia até as 5 horas da manhã, 6". Mesmo para fechar a edição de revista, ele preferia a madrugada, podia assim acordar mais tarde, fazer exercícios físicos.

Durante muito tempo com isso eu fugia dos engarrafamentos, essas coisas que todo mundo tem que ter. Como sempre tem uma equipe, você pode escolher o horário que você quer fazer e eu prefiro fazer esses horários. Tem a hora que você como jornalista pega as pessoas para almoçar, pra jantar, pra conversar, pra relaxar, tomar vinho, então rende muito mais. É muito difícil você ter informações preciosas e grandes revelações por telefone durante o dia, fica no plano do feijão com arroz. As coisas pra valer não são assim, são normalmente de outra forma, com mais tempo. Claro, hoje você faz tudo por telefone, por computador, mas o que é importante, um trabalho de investigação profunda, não é uma conversa de telefone, e essas costumam ser mais no período noturno, no meu caso, que faço revista há quase 20 anos, à noite - Bob Fernandes.

Quando trabalhava em Brasília, nos anos 1980, os jornalistas saíam dos jornais entre $19 \mathrm{~h} 30$ e $20 \mathrm{~h} 30$ e iam para o boteco beber. "Eu devo ter ido uma ou duas vezes nesses lugares porque eu preferia ir para um lugar chamado Tarantela, que depois virou Piantella, porque ali estava o poder da época. Era Ulisses e sua turma toda, Tancredo, Fernando Henrique, toda a política circulava ali." Lá ele encontrava a pauta do dia 
seguinte. Mesmo na época de Veja, no início da carreira, preferia escrever à noite. Matérias especiais também exigem longa jornada e disponibilidade de tempo:

Quando eu estava cobrindo o Chávez, o golpe, eu chegava às 6 e meia, 7 da manhã no Palácio e saia às $2 \mathrm{~h}$ da manhã nos dias seguintes ao golpe, porque ali estava a notícia, e para você ter a notícia depois de um golpe de Estado, você tinha que estar fisicamente no lugar. Eu acompanhei com ele o "no", referendo revogatório do mandato ${ }^{15}$... Nesse dia ${ }^{16}$ [em 2004] e no dia da reeleição ${ }^{17}$ dele em 2006, eu fiquei umas 16, 18 horas, esperando ter a chance e tinha lá centenas de jornalistas do mundo todo. Assim como depois do golpe, todo mundo ficou no hotel, a pessoa fica para aquela hora que vai ter uma coletiva dele, então, vai para o hotel e espera ser chamado. Eu falei - não vou para o hotel, vou ficar dentro do palácio esperando. Às $22 \mathrm{~h}$ ele me chamou para dentro da sala dele, porque se há uma coisa que o jornalismo exige é absoluta determinação - Bob Fernandes.

Para Paula Puliti, a madrugada fazia parte da jornada de trabalho quando estava na equipe do pescoção, período em que se adianta o jornal de domingo, trabalhando-se de sexta para sábado. Atuando com temas como saúde no início da carreira e depois com economia, sua jornada na revista Saúde e na Agência Estado costumava ser de 8 horas. Só em jornal diário que a jornada costumava ultrapassar as 8 horas.

Marilu Cabañas, da mesma geração de Paula, começou a jornada intensa na época da faculdade, pois entrava no trabalho na rádio Guarujá às $7 \mathrm{~h}$ da manhã e ia direto estudar à noite. Continuou trabalhando muito na Rádio Bandeirantes, mas o prazer do trabalho compensava.

Eu emagreci 10 quilos nessa fase [na Guarujá], porque eu tinha que trabalhar e estudar. Eu pegava um ônibus da minha casa até a balsa, depois pegava a barquinha, depois outro ônibus, era puxado. Depois de um ano e pouco, dois, eu estava com a moto. Minha mãe ficava preocupada porque eu parecia uma caveira, era bastante trabalho. Depois em São Paulo, eu não precisava estudar, quando acaba a faculdade dá aquele alívio. Pelo menos à noite, estava livre. Trabalhava bastante, umas 10 horas, de 8 a 10 , por mais que sejam sete horas de trabalho, mas eu me lembro que eu trabalhava muito. Quando tinha que cobrir férias, eu dobrava, aí que ficava bem pesado. Era um ritmo que sinceramente eu não sentia. Porque era muito gostoso, muito prazeroso... E lá eu tive muito prazer em trabalhar,

\footnotetext{
${ }^{15}$ Consulta popular que permite a destituição ou não do presidente na Venezuela. O instrumento consta na Constituição Bolivariana aprovada em 1999 pelo próprio Hugo Chávez. Para que o plebiscito ocorra, são necessárias as assinaturas de $20 \%$ dos eleitores do país, que na época correspondiam a 2.436 .083 pessoas. Um total de 2.451.821 assinaturas foi considerado válido em junho de 2004 pelo Conselho Nacional Eleitoral.

${ }^{16} \mathrm{O}$ referendo foi realizado em 15 de agosto de 2004, um domingo, e o resultado divulgado na madrugada de 16 de agosto, com a vitória do "no", que era favorável a permanência de Chávez na presidência.

${ }^{17}$ As eleições foram realizadas em 3 de dezembro de 2006, um domingo.
} 
porque tinha muito essa possibilidade humana, foi uma escola para mim - Marilu Cabañas.

No SBT e na Rádio Cultura, Marilu não tinha problema de horário de trabalho. Atualmente na Rádio Brasil Atual também classifica sua jornada como normal. A exceção é a realização de matérias especiais: "Fui ao Paraguai, cobri eleições, cobri o golpe, aí quase não durmo, porque você fica o dia inteiro colhendo material, depois têm que editar para o dia seguinte. Você entra ao vivo e dormiu uma média de duas, três horas por noite nessas coberturas grandes". O mesmo ocorre em grandes eventos como na cobertura do Fórum Universitário do Mercosul - FoMerco: “É violento porque a gente trabalha o dia inteiro, edita, eu coloco tudo que eu posso, depois trago todo o material, porque é impossível colocar todas as entrevistas, então eu vou pondo nos outros dias quando volto, vou fazendo as matérias como a gente pode”. Isso porque no retorno precisa conciliar a continuação da especial com as matérias do dia a dia.

Você tem que ir driblando, entendeu, porque não tem como, é muita coisa e pouca gente, poucos repórteres. Então você tem que fazer. É esse o preço? Então tá bom, eu pago esse preço. Eu quero fazer, quero saber como os índios estão, quero ouvir as questões da América Latina. É mais envolvimento, eu brigo mesmo para poder ir. No caso dos guaranis, o próprio Colibri ${ }^{18}$ falou você tem que ir pra lá, porque eu estava fazendo por telefone. Ele falou, a Marilu tem que estar lá. Imagina, bom jornalista é bom diretor - Marilu Cabañas.

Outra realidade vivenciada por alguns jornalistas é o aumento da jornada nos dias de fechamento. Antonio, 40 anos, em uma revista segmentada que trabalhou, vivenciou isso: "nas primeiras semanas você sai mais cedo, porque a edição ainda está começando, mas nas duas últimas, no fechamento, é aquela história de duas da manhã, três da manhã". Priscilla Nery, 25 anos, costuma trabalhar nas revistas Proteção e Emergência 8 horas diárias, essa jornada aumenta quando é fechamento das revistas. Já Vivian Fernandes, 27 anos, costuma ter mais liberdade de horário: "Existe uma pressão do fechamento do jornal, mas quando você precisa faltar tudo bem, você precisa estudar, ok, tem os prós e os contras sempre". No dia após o fechamento, ela costuma trabalhar menos horas. No fechamento, que é semanal, a jornada aumenta:

Lá no Brasil de Fato hoje em dia, o trabalho começa numa edição. Ele começa na sexta-feira, com a pauta já mais certa, mas aí eu tenho menos trabalho ou tenho reunião com Conselho Editorial ou mando email pros colaboradores. Dou uma checada na pauta. Mas é bem mais leve. Segunda-feira ainda é mais leve o trabalho porque eu recebo um ou outro texto. Aí na terça-feira já recebo muitos textos de

\footnotetext{
${ }^{18}$ Oswaldo Luiz Colibri, diretor da Rádio Brasil Atual.
} 
colaboradores, desde horóscopo, receita, colunista. Na quarta-feira a gente fecha a maioria das reportagens, eu trabalho mais tempo. Como se na sexta, segunda e terça eu trabalhasse umas cinco horas por dia de tarde. Posso trabalhar de lá ou posso trabalhar de casa, o ideal é que esteja lá. Quarta-feira eu já trabalho bem de lá mesmo e aí eu fico trabalhando, não tenho horário pra começar, não tenho horário pra terminar. Às vezes eu começo de manhã e termino à noite, às vezes eu começo à tarde e termino às 10 da noite, e aí na quinta-feira eu vou pra lá às 9 da manhã, sento com o diagramador e fico até as 18 horas, que é o horário de entrega da gráfica. Então uma rotina de trabalho que começa pequena e vai aumentando e sufocando até quinta-feira com fechamento bem estressante, às vezes nem consigo almoçar porque tem que fechar todos os textos, às vezes atrasou um, caiu outro, então é meio que essa a rotina, ela não é tão fixa - Vivian Fernandes.

Vivian relata que se cobra pra cumprir essa possibilidade de na sexta trabalhar menos horas e depois trabalhar mais no fechamento. "Coisa que eu falo isso também pros estagiários, pros repórteres. A gente não tem horário, a gente não tem ponto. Não marco horário de entrada e saída. Cada um sabe mais ou menos que tem o compromisso de fazer aquela rotina de umas seis, sete horas por dia". Dessa forma, quando se trabalhou mais num dia, abate-se do outro. "As pessoas se controlam, eu não gosto desse papel de controlar o horário dos outros. Eu acho que todo mundo consegue fazer isso. Então é tranquilo assim”.

Antonio já vivenciou uma jornada intensa de trabalho também no Nordeste. "Nunca se teve uma situação tão ruim, que pode piorar, eu não conheço ninguém que trabalhe em redação que trabalhe menos de 12, 14 horas, por dia. Segundo não há políticas de incentivos", afirma destacando essa intensidade nos jornais impressos. Outro problema, para ele, é que são raros os que conseguem passar um mês fora de férias. "Você não tem horário, eu fiquei 10 anos sem tirar 30 dias de férias, mas aí depois eu voltei a tirar, mas já estou há 3 anos sem tirar de novo”, concorda Leonardo Sakamoto. O ritmo de trabalho dele chega a atingir até 80 horas semanais, o que é suportado pela satisfação que o trabalho lhe dá:

Hoje o ritmo fora da estrutura é bem maior que o ritmo dentro da estrutura, só que hoje o prazer que eu tenho gerado é bem maior também. O ritmo de hoje é insuportável, se você for pegar, a gente faz essas contas de hora trabalho, tem semana que eu bato 70, 80 horas/ trabalho. Só que aí que está, se eu for contar todos os aspectos da minha vida, tem dia que eu começo às 8 da manhã e termino às $11 \mathrm{~h} 30$ da noite e tem dia que continuo. É uma coisa que não existe hora semanal cravada, mas eu não deixo de trabalhar todos os finais de semana, eu estou trabalhando também. Só que o conceito de trabalho acabou mudando, que parte do meu trabalho é desterritorizado, ele não tem um locus de trabalho, É uma desterritorização mais complexa, 
porque eu tenho três atividades jornalísticas, elas são complementares, então é qualquer lugar, qualquer momento. (...) Isso na verdade, por um lado aumenta a produção, e por outro lado acaba com a vida da pessoa, a minha vida ela é extremamente maluca por conta dessa desterritorização, mas é uma rotina totalmente diferente, essa rotina de hoje é uma rotina muito mais aberta e mais intensa. Se eu tivesse um capitalista me explorando, se não fosse eu mesmo no caso me explorando, eu diria que hoje ele ganha mais valia minha do que o pessoal da Abril, da Gazeta, do DCI e de outros lugares pelos quais eu passei, por curtos ou maiores tempos - Leonardo Sakamoto.

Fernanda Cirenza, 49 anos, e Pedro, 32 anos, que trabalharam na Folha sabem bem o que é trabalhar várias horas seguidas diariamente. "Então a gente trabalhava muito no jornal, na Folha, bastante. Mais de 7 horas por dia sem dúvida... Não existe, ninguém trabalha 7 horas numa redação, nem numa redação específica como a Marie Claire, por exemplo, impossível”, avalia Fernanda. Para Pedro, a exigência era pesada:

O ritmo de trabalho, aí eu falo principalmente da Folha, é uma coisa que me incomodava muito no período todo que eu fiquei, porque eu achava que ele extrapolava o bom senso de trabalho. Então, em termos de horário eu entrava 10, 11 horas, e às vezes saía 11 da noite, meianoite, uma hora, dependendo do fechamento, tal. E isso não mudava muito ao longo da semana. Era um horário que eu cumpria quase todo dia - Pedro.

Mas por que suportar uma rotina tão intensa? O sentido do trabalho para o jornalista explica isso. Quando falamos das formas de contratação, ficou claro que as jornalistas Vivian e Maria se sujeitaram a não ter registro por acreditarem no trabalho que faziam e no projeto social em que estavam envolvidas, como mostra a fala sobre o MST:

Quem trabalhasse diretamente com você era um pouco ruim porque era difícil as pessoas entenderem o que é militância e o que é profissional, e eu acho que essa bagunça favorecia muito a exploração. Então se a pessoa quer te explorar ela não fala que quer te explorar, fala que se chama espírito de sacrifício, que vem até da história da culpa católica, cristã. Eu que não sou ateia sentia uma culpa diária que era muito complicada. É óbvio que você não vai tratar alguém do movimento social como você trata uma empresa - Maria.

Pedro também acreditava no trabalho que realizava na Folha e sentia prazer em fazer parte da equipe e trabalhar naquele jornal. Era reconhecido por isso e também tinha uma satisfação pessoal que justificava tanto envolvimento e tantas horas trabalhadas:

Eu acho que o que me segura também, apesar de nem todo mundo assumir isso, mas você ainda tem um glamour na profissão. Então quando você fala que você é jornalista da Folha, as pessoas gostam de ouvir isso e ficam perguntando, que legal. Eu acho que isso dá para o 
jornalista um enobrecimento da pessoa, que às vezes eu acho que segura e faz com que ele aceite algumas condições por ser um jornalista da Folha, que está numa empresa grande e tal. Eu tive ao longo desse tempo todo que eu trabalhei, como eu te falei, frustração em relação aos direitos, que o jornalista tem, eu acho que isso não é cumprido, a jornada de trabalho é muito puxada. Eles exigem você estar na redação e estar disponível inclusive no final de semana, que não é uma coisa legal, então, durante muito tempo eu fiquei bitolado dentro de um jornal para cumprir uma jornada de trabalho que pra mim era insana, mas eu fazia o sacrifício de cumprir pra decolar minha carreira. Eu acho que a profissão trouxe por outro lado uma oportunidade muito grande de eu conhecer mais a cidade, de entrar em contato fazendo entrevistas com artistas, com pessoas da cultura que me trouxeram muito conhecimento na área. Então eu acho que nesse sentido é uma profissão muito fascinante - Pedro.

Segundo Aline Scarso, para estar em um veículo de destaque e pelo medo de perder o emprego, alguns jornalistas aceitam certas situações, como trabalhar 12 horas. Se o jornalista trabalha até o horário normal, os colegas acham estranho. Trabalhando na Brasileiros, Fernanda Cirenza entende esse estranhamento. As longas jornadas são colocadas de tal forma como uma necessidade da profissão, que acabam naturalizadas.

Tem um pessoal novo do site, que acha que tem fazer 7, 8 horas. Eu acho inacreditável, isso é uma discussão. Eu não acho que é injusto, pelo contrário, acho que é super justo as pessoas trabalharem o que elas têm que trabalhar por hora, mas quando a pessoa fala deu meu horário, sai e vai embora, pra mim é um choque, entendeu, embora eu continue achando que é isso. Eu tenho dois funcionários na casa em que eu vivo, eles cumprem horário e passou daquele horário, eu pago. Não é por conta da lei das domésticas. Há anos é assim na minha casa. Eles trabalham sábado, eu pago. Mas eu mesma me submeto a essas arbitrariedades - Fernanda Cirenza.

A situação em uma empresa pública de comunicação pode ser um pouco melhor. Maria contou que na EBC tinha contrato de 5 horas mais duas horas de prorrogação contratual. Assim trabalhava 7 horas por dia. Em sua chefia, encontrou também uma relação mais humana, em que tem flexibilidade para resolver imprevistos com a devida compensação de horas. "Não quer dizer privilégios, mas sim um entendimento de que a vida do funcionário não é só está ali, cumprir ordens e pronto, tem uma preocupação maior”. Aline Scarso que também trabalha na EBC tem a mesma jornada, mas quando está na função de repórter é comum fazer extra, que pode ser tirada em folga depois, o que requer negociação, como veremos mais adiante.

A intensidade esteve presente no trabalho de Bruno Torturra, Miguel e João. No caso de João, por exemplo, na revista em que trabalhava tinha uma sensação de descoberta. "Era uma coisa nova e acho que você mesmo acaba se dedicando mais do 
que você deveria, se doando mais, fazendo muitas horas a mais, deixando-se ser exigido". Mesmo quando era estagiário trabalhava mais de seis horas. Em uma ocasião, empolgado por ajudar em uma matéria de capa, trabalhou das 9 da manhã às $21 \mathrm{~h}$.

Já Bruno Torturra tinha um expediente com carga horária mínima para cumprir, mas com certa flexibilidade. Não havia um horário rigoroso a ser cumprido, mas a intensidade do trabalho era grande. "Eu podia chegar mais tarde desde que eu entregasse tudo que eu precisava fazer, mas sempre foi uma carga horária bastante puxada perto dos fechamentos, muita madrugada, muito final de semana." Isso significava que não havia horário para terminar o trabalho. Por outro lado, ele podia escrever textos de sua casa.

Miguel, por sua vez, teve um trabalho intenso desde o início da carreira na agência de notícias. Na cobertura dos jogos olímpicos de Sidnei, por exemplo, trabalhou em São Paulo cobrindo o que passava na TV durante a madrugada. "Eu lembro que o maior número de madrugadas seguidas que eu trabalhei foram 17”. A jornada nesse período ia da meia-noite até 11 horas da manhã. Mas essa cobertura, sofrível pelo horário e a jornada, foi fonte de prazer pelo reconhecimento que o trabalho teve. "Um bom trabalho dentro do que a própria agência tinha de experiência de eventos desse tipo anteriores, copas, olimpíadas. Foi um momento bom, apesar do sacrifício todo de madrugada, mas teve consequências de muito cansaço.” Geralmente a agência mandava um carro buscar os jornalistas para ir ao trabalho, devido ao horário, no entanto, em alguns dias, Miguel foi trabalhar de carro. Quando voltava para casa, sol do meio-dia, o cansaço e o sono eram tantos que ele bateu o veículo. "Não cheguei a dormir ao volante, mas eu estava com os reflexos muito prejudicados. A batida não foi tão séria, mas enfim". Em coberturas normais, cumpria-se a jornada de 7 horas.

Já no primeiro portal em que Miguel trabalhou, como terceirizado de uma agência de conteúdo, costumava trabalhar pelo menos 9 horas e às vezes extrapolava isso. Na CBN, tinha uma jornada bem definida de 7 horas, mas era um trabalho pesado, especialmente, quando fazia o boletim que entrava de meia em meia hora. Em um dia de trabalho de 7 horas, tinha que fazer 14 boletins, ouvindo a rádio, acompanhando TV e notícias na internet. "Eram sete horas de atenção total". Quando trabalhou em TV no interior, fazia-se muita hora extra. "Eu fiquei muito impressionado como não havia qualidade de vida pras pessoas que estavam no interior, eu também fui para o interior pensando que teria mais qualidade de vida. Era chocante isso. As pessoas trabalhavam demais." Em seu trabalho atual, em um grande portal de notícias, a jornada é de 9 horas, 
contando uma hora para o almoço. Muitos jornalistas não fazem o horário de almoço, comem um lanche ou marmita na própria mesa, para sair uma hora mais cedo.

\section{9 - Plantões}

Os relatos sobre plantões feitos pelos jornalistas mostram que muitas vezes se emenda a semana de trabalho com plantão e outra semana de trabalho, fazendo com que o jornalista trabalhe por muito tempo sem descansar, o que acaba gerando cansaço e desgaste.

Paula Puliti costumava trabalhar um final de semana por mês. Marilu Cabañas só fez plantões na época em que trabalhava na Rádio Bandeirantes. "Sou privilegiada, porque é raro isso. $\mathrm{Na}$ Cultura não tinha, porque não tinha um jornal no sábado e domingo, nem agora eu tenho jornal de sábado e domingo. Mas eu me culpo um pouco, as pessoas dizem não se culpe, mas é uma coisa mais pessoal”.

A fala de Marilu sobre culpa ilustra bem o sentimento que é alimentado pelo jornalista e estimulado pelas empresas para extrair produtividade e aumentar o envolvimento com o trabalho. Se o jornalismo tem uma função social, quando o jornalista não trabalha, deixa de cumprir esse papel que contribui para a efetivação da democracia, para a informação de direitos ou à denúncia de problemas e tantos outros sentidos que são atribuídos para o trabalho do jornalista, que no passado era comparado ao sacerdócio e visto como missão.

Ivan Marsiglia em O Estado de S. Paulo faz plantão de final de semana uma vez por mês, trabalhando sábado e domingo. "Embora o meu caderno seja semanal, ele não tem uma contribuição de final de semana pra fazer, no meu caso, ajudo no mesão, que é a editoria de primeira página." Já quando trabalhava em revistas, trabalhar nos finais de semana "dependia muito do grau da organização e dos tamanhos das equipes".

Na Playboy eu me lembro de ter trabalhado bastante, mas nunca exageradamente, nunca ter que ir num final de semana trabalhar como chegou a acontecer na Trip, mas um pouco talvez por falta de organização de fluxo e de pessoal. Então muitas vezes a gente era obrigado no final de semana que antecedia o fechamento a ficar até altas horas da noite, inclusive viramos noites algumas vezes. Quando o projeto gráfico mudou, mais de uma vez isso aconteceu, trabalhar no sábado e domingo no momento do fechamento por acúmulo [de trabalho] e falta de pessoal. Mas eu sempre achei que se tivesse bem 
organizada, a coisa poderia ser feita de maneira mais razoável - Ivan Marsiglia.

Pedro, quando trabalhava na Folha de S.Paulo, também fazia plantão um final de semana e ficava livre os três finais de semana seguintes. "Eu trabalhava sábado e domingo, durante seis horas mais ou menos cada dia. Algumas vezes, dependendo do feriado, eles acumulavam de você trabalhar dois finais de semana seguidos." Quando isso acontecia, Pedro questionava a situação: "Várias vezes eu briguei, não aceito isso, não dá para a pessoa trabalhar direto assim. Então a questão de trabalhar no final de semana eu também acho que é um problema."

Miguel vivenciou plantões na agência de notícias. "O esquema era de trabalhar um fim de semana e descansar dois, era meio apertado, a gente acumulava folgas, mas tinha que negociar muito pra conseguir tirá-las." No portal que trabalhou via agência de conteúdo não se trabalhava de fim semana, só se houvesse algo excepcional. "Em dois anos que eu trabalhei lá, eu devo ter ido uns 4 ou 5 domingos em plantão.” Já na CBN trabalhava um e descansava três:

Nos plantões eu mudava de função, eu era chefe do plantão. Não no começo, mas depois de uns seis meses pra um ano, eu passei a ser chefe do plantão. Aí na maioria das vezes eu entrava de manhã, muito cedo, eu tinha certa dificuldade em trabalhar de manhã, então tinha que entrar 5 da manhã no sábado, 6 da manhã no domingo. Eram 10 horas seguidas, era muito chato, muito desgastante, muito ruim. No último ano, houve certa mudança na orientação do trabalho lá, não sei o que mudou, o chefe de reportagem também acumulava a função de redator do Repórter $\mathrm{CBN}$, então, era muita coisa pra fazer e eu não conseguia quase almoçar nesse último ano que eu trabalhei lá. Era muito difícil. Não era uma questão minha. Não sei o que tinha acontecido de mudança nos plantões que levou a isso. Muita gente estava tendo essa dificuldade de almoçar, quem estava na chefia principalmente. Então eram 10 horas seguidas bem puxadas. E o plantão também gerava certo atrito com as pessoas. Eu não recebia nada a mais por ser chefe de plantão, não recebia nenhum acréscimo de salário, era um acréscimo só de responsabilidades (risos). E na relação com os colegas você era visto como se estivesse tendo um benefício daquilo - Miguel.

O jornalista Miguel também vivenciou plantões na TV em que trabalhou, nos quais havia uma jornada extensa. No portal do interior do estado, primeiro fazia um plantão por três finais de semana sem trabalhar, depois de cortes de pessoal, tiveram que fazer um plantão a cada dois finais de semana descansados. "Uma situação bem desgastante também." No portal de notícias da capital em que trabalhava quando concedeu a entrevista, trabalhava um e descansava cinco ou seis finais de semana. “Como no plantão, não existe a função de repórter, a equipe é bem mais enxuta, então, 
eu tenho que fazer outras coisas no plantão." Isso inclui, por exemplo, trabalhar com imagens, vídeos e outras funções. Ele também avalia negativamente os plantões:

Acho que no começo eu fiz meus primeiros plantões, cobria esporte, e eu não me incomodava, mas depois foi ficando cada vez mais pesado, mais desconfortável. Se o trabalho do jornalista fosse de segunda a sexta, seria muito bom não precisar fazer plantão. Acho que é uma coisa que as redações, os donos, quem está na condução dos veículos deveriam pensar muito bem na organização do trabalho, e no que os leitores e os internautas procuram no fim de semana. Acho que há um exagero de procurar produzir notícias no fim de semana, não sei se é tão necessário assim. O plantão vira um tormento para as pessoas. Em alguns lugares não se consegue tirar folga, já passei por isso, emendar 12 dias. Aí se você emenda seu plantão normal com um plantão excepcional de carnaval, ano novo, você passa 19 dias seguidos... Vi muitos colegas que postam no facebook, estou trabalhando há tantos dias, tem uma coisa das empresas, mas um pouco do jornalista mesmo, masoquista, que quer sofrer mesmo, e a saída não é essa. É as pessoas se organizarem e participarem da organização do trabalho, terem mais atuação dentro daquilo que influencia o dia a dia dela Miguel.

Aline Scarso já chegou a trabalhar 12 dias diretos, devido ao plantão, o que considerava muito cansativo, mas a situação deixou de ocorrer na $\mathrm{EBC}$, que passou a cumprir a CLT e o acordo coletivo. Já Priscilla Nery teve que fazer plantões enquanto era estagiária, o que nem era previsto no contrato, em um ritmo pesado, no qual trabalhava um fim de semana sim, um não. Além disso, tinha que cobrir celebridades, um assunto com o qual não tinha afinidade, para um site que não era o mesmo em que ela trabalhava durante a semana.

O Vila Mulher tinha as demandas de segunda a sexta, não tinha nada de final de semana, mas como eles precisavam pra outros lugares como MSN e como tinha cobertura de reality show, tipo Big Brother, eles tinham plantão de final de semana. Então a gente trabalhava um sim, um não. Aí quando você trabalhava no final de semana você pegava folga, por exemplo, vou trabalhar final de semana que vem, aí eu peguei folga na segunda agora. Fiquei sábado, domingo e segunda em casa e só vou folgar na sexta da outra semana. Isso era meio livre pra gente que trabalhava no Vila Mulher, no site do Terra, então, normalmente nós pegávamos no meio da semana a folga, pra compensar, pra não ficar tantos dias, a gente pegava terça, quartafeira, mas era assim, eu trabalhava sábado e domingo, aí no outro você folgava sábado e domingo - Priscilla Nery.

Olhando-se para esses últimos depoimentos, percebe-se que, muitas vezes, no jornalismo trabalhar muito, extrapolar limites, acaba sendo visto como competência profissional. O bom jornalista trabalha muito, está sempre disponível, não tem horário. Fazer tudo isso é sinal de que se é um jornalista de verdade. Quando que na verdade um 
ritmo menos acelerado e plantões seguidos de descanso poderiam contribuir não só para a qualidade de vida do trabalhador jornalista como para a construção de um texto melhor e mais bem apurado.

\subsection{0 - A compensação de horas e a não remuneração de hora extra}

Eu trabalhava no sábado e no domingo e eu tinha direito a um dia de folga, que não era tirado imediatamente também. A gente costumava acumular folgas, então nesse período que eu trabalhei na Folha eu acumulei, sei lá, mais de 30 dias de folga, é uma praxe lá - Pedro.

A gente tem direito por esse sábado e domingo trabalhado a tirar um dia de folga na semana, que não é o ideal..., na prática jornalística, tanto aqui quanto na Folha, o normal é trocar por folga, mas subavaliadas, menos tempo de folga do que você trabalhou extra Ivan Marsiglia.

Os relatos do que os jornalistas acima vivenciaram ilustram bem como funciona o nebuloso mundo de banco de horas no jornalismo. Como vimos, conforme a CLT, a jornada de trabalho do jornalista deve ser de cinco horas (artigo 303) com elevação para 7 horas mediante acordo escrito (artigo 304). Isso também está nas convenções coletivas dos jornalistas, como a de São Paulo, por exemplo. No entanto, no parágrafo único do artigo 304, abre-se espaço para ampliação da jornada:

Parágrafo único - Para atender a motivos de força maior, poderá o empregado prestar serviços por mais tempo do que aquele permitido nesta Seção. Em tais casos, porém o excesso deve ser comunicado à Divisão de Fiscalização do Departamento Nacional do Trabalho ou às Delegacias Regionais do Ministério do Trabalho, Indústria e Comercio, dentro de 5 (cinco) dias, com a indicação expressa dos seus motivos. (CLT, 2014)

O próximo artigo, de número 305, define que as horas de serviço extraordinário, sejam aquelas oriundas de acordo, sejam as relativas ao parágrafo anterior, "não poderão ser remuneradas com quantia inferior à que resulta do quociente da divisão da importância do salário mensal por 150 (cento e cinquenta) para os mensalistas, e do salário diário por 5 (cinco) para os diaristas, acrescido de, pelo menos, 25\%"19.

${ }^{19} \mathrm{O}$ artigo 306 exclui as funções de redator-chefe, secretário, subsecretário, chefe e subchefe de revisão, chefe de oficina, de ilustração e chefe de portaria dos dispositivos dos artigos 303, 304 e 305. 
Já no artigo 307 da CLT, ainda na Seção XI dos Jornalistas Profissionais, estabelece-se que a cada seis dias de trabalho efetivo deve haver um "dia de descanso obrigatório, que coincidirá com o domingo, salvo acordo escrito em contrário, no qual será expressamente estipulado o dia em que se deve verificar o descanso".

Vale ainda destacar o artigo 316 da CLT, que afirma: “a empresa jornalística que deixar de pagar pontualmente, e na forma acordada, os salários devidos a seus empregados, terá suspenso o seu funcionamento, até que se efetue o pagamento devido".

Percebe-se assim que o que está na CLT não é cumprido em relação ao trabalho dos jornalistas. No tópico anterior, vimos jornadas que ultrapassam as 7 horas como regra e não como exceção acordada. Com os plantões, jornalistas relataram que chegam a trabalhar 12 dias seguidos e até houve casos de 19 dias, quando havia algum feriado e se fazia mais plantão. Também não se costuma pagar hora extra. $O$ único relato que ouvimos sobre o pagamento foi o de Miguel, na época em que trabalhou na TV do interior. Os jornalistas costumavam fazer muita hora extra já que o salário era baixo.

A Convenção Coletiva de Trabalho 2013/2014 do Sindicato dos Jornalistas Profissionais no Estado de São Paulo estabelece na cláusula décima segunda as regras para pagamento de hora extra: acréscimo de 50\% em relação à hora normal de trabalho, para as duas primeiras horas de segunda a sábado e 60\% para as demais horas extras eventuais. Horas extras e adicionais noturnos devem ser considerados para a remuneração de férias e décimo terceiro. Também se coloca a possibilidade de compensação de horas:

PARÁGRAFO $2^{\circ}$ :: Poderá ser compensado o trabalho em dias úteis intercalados com fins de semana e feriados, de forma a que os empregados tenham um descanso prolongado. A compensação poderá ser acertada diretamente entre a empresa e os empregados, e as horas compensadas não poderão ser consideradas horas extras.

PARÁGRAFO $3^{\circ}$ :: As empresas poderão, desde que haja concordância do empregado, compensar esses dias no período de férias.

PARÁGRAFO $4^{\circ}$ :: A compensação de horas extras só ocorrerá quando houver interesse do empregado, manifestado por escrito. (CONVENÇÃO COLETIVA DE TRABALHO 2013/2014)

Essa compensação de horas, conhecida popularmente como Banco de Horas, está regulamentada na CLT no artigo 59, parágrafo segundo, que possibilita a compensação do excesso de horas de trabalho em um dia pela correspondente diminuição em outro dia, desde isso esteja documentado em acordo ou convenção 
coletiva, e "que não exceda, no período máximo de um ano, à soma das jornadas semanais de trabalho previstas, nem seja ultrapassado o limite máximo de dez horas diárias".

Outro exemplo é o acordo coletivo da EBC, em que cada hora extra trabalhada equivale a 1 h40 de folga. Nem sempre é fácil tirar essas folgas, como mostra o depoimento de Aline Scarso: "Não é algo assim que eu chegue num dia e é certeza que eu vou ter, às vezes, você precisa dialogar bastante pra conseguir. Eu acho que é um reflexo da precarização mesmo do mundo do trabalho do jornalista. Isso reflete lá, com menos peso, mas reflete também." O acordo também prevê o pagamento de hora extra, mas ele não ocorre:

Eu gostaria que por ser uma empresa pública a gente tivesse mais respeito às normas trabalhistas. A gente tem um acordo coletivo que prevê que o trabalhador e a empresa têm que chegar a um comum acordo em relação às horas extras e que eu posso escolher tirá-las em folga ou em dinheiro, um ponto de vista bem interessante poder ganhar esse dinheiro, ela vale mais, seria muito interessante, mas eles não pagam. Pelo menos a [TV] Brasil São Paulo não paga hora extra Aline Scarso.

A Comissão de Funcionários da EBC costuma intermediar as reivindicações de compensação de horas. "Então a gente não vai cobrar hora extra de cara limpa, a gente passa a demanda pra essa Comissão, e essa Comissão vai fazer esse papel, que eu também acho que é um avanço em relação às outras redações", avalia Aline. Para a jornalista, o fato de não ter medo de perder o emprego, já que são concursados, e de existirem pessoas eleitas para cobrarem direitos possibilita que a situação não seja tão ruim. Por outro lado, a dificuldade de a empresa cumprir o acordo coletivo e o estresse da cobrança desanimam.

Os depoimentos dos outros jornalistas mostram uma situação ainda pior em outros veículos. A hora extra a ser compensada não vale tempo a mais. A compensação nem sempre ocorre da maneira acordada pela convenção coletiva dos jornalistas nem respeitando os direitos estabelecidos pela CLT. Em muitos casos, as horas nem chegam a ser compensadas, já que trabalhar a mais diariamente se torna uma rotina e isso nem chega a ser computado.

Miguel, por exemplo, na agência de notícias acumulava muitas folgas e tinha que negociar muito para conseguir tirá-las. Antonio também tinha dificuldades em compensar as horas a mais trabalhadas na revista especializada em crítica de mídia: "Eu 
brigava e acabava dando uma folga, duas folgas, logo após o fechamento da edição". Na agência de notícias científica, ele recebia as folgas corretamente.

Marilu Cabañas, por sua vez, faz banco de horas na rádio Brasil Atual e costuma compensar quando trabalha a mais: "Você tem essa compensação. Então tranquilo, você trabalha com prazer”. Priscilla Nery, que trabalha nas revistas Proteção e Emergência, também costuma compensar as horas extras em folga, mas quando há muitas horas acumuladas, a empresa paga uma parte. "Normalmente eles cumprem certo, algumas vezes demora alguns meses (risos). Você sabe, porque não dá, é uma coisa em cima da outra. Mas eles cumprem. No meio do ano, como eu estava com muitas horas acumuladas, eles pagaram uma parte e me deram uma semana de folga".

Nos jornais diários, a situação varia a partir da experiência de cada jornalista, uns tiram logo em seguida, outros tem horas acumuladas e juntam com o período de férias. Não houve relatos de pagamento de hora extra. "É normal trabalhar além do horário, isso é tido no jornalismo como algo usual e também é usual você não ser remunerado pelas suas horas extras, infelizmente, essa é uma realidade", afirma Ivan Marsiglia. Aureliano explica como essa questão foi evoluindo com o tempo, mas recentemente há uma nova deterioração:

A gente fez muitas conquistas. No começo a gente tinha uma espécie de banco de horas pra repor, pra repor nas férias, dias que você acabava trabalhando a mais. No começo isso era muito difícil, era quase que desconsiderado. Depois foi passando, as próprias chefias foram concordando com isso, e foram mantendo, e chegou-se a ter esse banco mais organizado, o número de horas que você passava além do seu horário, e você cobraria em férias ou folgas. No final de semana, você teve que trabalhar, então você estava dispensado na segunda. Nesse sentido, houve uma conquista. O que eu acho no jornalismo especialmente, deve acontecer em algumas outras profissões, mas à medida que o mercado foi ficando mais árido, mais difícil, com mais procura que oferta, o nosso lado acabou perdendo força em negociação. Não estou dizendo em negociação sindical, as pessoas trabalham e trabalham e acham que tudo bem, porque se ela for trabalhar menos, ele vai acabas perdendo o posto dela. Já é um privilégio poder trabalhar..., e as pessoas estão em uma fase que carregam o jornal nas costas. São pessoas que estão dispostas a trabalhar um número enorme de horas, e se o jornal quiser pagar, paga. Se não quiser pagar, não paga. Na Folha foi se ampliando essa civilidade, que no começo era bastante pequena - Aureliano Biancarelli.

Fernanda Cirenza conta que certa vez, em um ano de trabalho na Folha, acumulou horas e tirou mais de 50 dias de férias. Já quando saiu do jornal, eles pagaram as horas que ela tinha a compensar. "Na Marie Claire, existia esse banco de horas, mas 
era bem diferente do da Folha, era mais informal, mas a gente tinha outras vantagens. Entre Natal e Ano Novo, ninguém trabalhava e você ainda tirava os 30 dias de férias." Como na prática as pessoas tinham 40 dias de férias, não havia um cálculo das horas. "Rolava na informalidade, ninguém ficava anotando."

Pedro tirava folga, mas nem sempre na semana do plantão. "Mas não era, por exemplo, que trabalhava naquele final de semana e tirava naquela semana. Muitas vezes eu tinha um trabalho muito puxado e se eu tirasse folga, eu me ferrava. As coisas iam acumular ainda mais e eu não ia conseguir entregar o que me pediram". Dos horários que trabalhava a mais durante a semana, não recebia nada.

A condição de trabalho é ruim (risos) em vários aspectos [riso nervoso]. É ruim em termos de horário, é ruim. Vou dar minha experiência de vida ali. A gente não tinha horário. Muita gente ficava muito além do horário sem ganhar hora extra. Um problema. O nosso vale alimentação, que é um direito, imagino que seja por lei isso, eles pagavam $10 \%$ e você pagava $90 \%$, era descontado $90 \%$, eles davam $10^{20}$. Não sei como eles conseguem isso. Uma coisa que é bizarra na Folha, mas que existe. As folgas expiram na Folha, que eu também acho que é totalmente antilei. Você recebe um comunicado, sua folga vai expirar em 15 dias. Como assim gente? (risos) E o pior, eu imagino que eles não tenham nem medo de fazer isso porque eles mandavam um e-mail, então, ficava registrado isso. Agora eu não sei que tipo de amparo da lei que eles têm. Eu não sei que viagem é essa Pedro.

\subsection{1 - O longo caminho para a efetivação dos direitos}

Ao longo desse capítulo, vimos que a luta por uma jornada de trabalho compatível com a saúde do trabalhador remete ao século XIX. Essa mobilização continuou no início do século XX e várias regras foram inscritas nas letras da lei sejam por meio das constituições nacionais, legislações específicas como a CLT e até mesmo

\footnotetext{
${ }^{20}$ A afirmação sobre os descontos e a expiração de folgas se baseia exclusivamente no depoimento e memória do jornalista. Não tivemos acesso a documentos ou e-mails que comprovassem. De acordo com matéria publicada no jornal Unidade, edição de setembro de 2014, $\mathrm{n}^{\circ} 370$, do Sindicato dos Jornalistas Profissionais no Estado de São Paulo - SJSP, “o vale refeição não poderá ser inferior a R $\$ 10,00$ (empresas com até 20 jornalistas) e $\mathrm{R} \$ 15,00$ (empresas com mais de 20 jornalistas) para salários de até R\$ 4 mil é limitado a $20 \%$ do benefício concedido. Para salários acima desse valor, a empresa poderá estabelecer uma escala, com descontos superiores a 20\%. Segundo a legislação do Programa de Alimentação do Trabalhador (PAT), da qual a concessão de vale refeição faz parte, a cobrança é permitida, desde que o montante global da participação dos empregados seja igual ou inferior a $20 \%$ do custo direto global do benefício."
} 
Convenções Internacionais. No caso do jornalista, os limites estão dados pela CLT e pelas convenções dos sindicatos de trabalhadores da área. No entanto, esses direitos não estão efetivados. Há uma grande distância entre o que é escrito e o que ocorre na prática. É o que mostram os depoimentos colhidos pela pesquisa, mas também notícias específicas sobre a área de comunicação.

Segundo informações publicadas no site do Sindicato dos Jornalistas Profissionais no Estado de São Paulo - SJSP em 9 de dezembro de 2014, essa organização sindical "denunciou ao Ministério Público do Trabalho (MPT) fraudes trabalhistas promovidas pelas empresas de comunicação no Estado de São Paulo" em 19 de novembro.

O titular da Comissão de Registro e Fiscalização do Exercício Profissional (Corfep), Vitor Ribeiro, e o secretário geral, André Freire, ambos do Sindicato, afirmaram aos procuradores que as empresas utilizam o frila-fixo e a PJ para "fugir da formalização do vínculo empregatício, terceirizar a atividade fim, descumprir a legislação trabalhista e a convenção coletiva, além de submeter os jornalistas a extensas jornadas de trabalho". Participaram do encontro na sede do MPT a procuradora-chefe, em São Paulo, Claudia Regina Lovato Franco e o coordenador nacional de Combate às Fraudes nas Relações de Trabalho, José de Lima Ramos Pereira.

Durante a reunião ficou acordado que o Sindicato e a Corfep passarão a protocolar denúncias individualizadas das empresas que cometem irregularidades. Várias denúncias já foram formalizadas. Entre elas, contra a Folha de S. Paulo, Editora Abril, Agora São Paulo, UOL, TV Record, TV Bandeirantes e a produtora Cuatro Cabezas. Novas denúncias estão sendo preparadas e serão protocoladas. (SINDICATO DOS JORNALISTAS PROFISSIONAIS NO ESTADO DE SÃO PAULO, 2014b)

A notícia pode significar um avanço para que haja mudanças efetivas nas relações trabalhistas, que devem ir ao encontro do que já está na lei e na convenção coletiva. Outra informação que pode levar a mudanças foi noticiada em 11 de dezembro de 2014 pelo site do sindicato: "Produtores de conteúdo de internet serão regularizados como jornalistas". Isso se dará por meio de Convenção Coletiva do Trabalho, a ser assinada com o Sindicato de Empresas de Internet do Estado de São Paulo (Seinesp), processo iniciado em 2011, mas que não tinha avançado.

Trata-se da primeira vitória para fazer com que os produtores de conteúdo de internet sejam considerados jornalistas, uma vez que empresas como Terra e IG, entre outras, não os reconhecem dessa forma e, por isso, esses profissionais têm jornadas de trabalho superior a legal, salários e benefícios inferiores e diferentes da categoria que 
atua em outros veículos como jornais e revistas. (SINDICATO DOS JORNALISTAS PROFISSIONAIS NO ESTADO DE SÃO PAULO, 2014a)

Claro que a realidade de jornais e revistas também incluem longas jornadas e todos os problemas discutidos até agora, mas a questão da internet, além de ter esses problemas, não conta com um amparo de convenção coletiva. Essa precarização que atinge trabalhadores de rádio, $\mathrm{TV}$, jornais, revistas e internet são de conhecimento da categoria e do próprio sindicato, como mostram textos do jornal sindical Unidade e outras matérias publicadas pela internet.

$\mathrm{Na}$ notícia "Sindicato protesta contra demissões na Editora Abril", de 7 de dezembro de 2012, afirma-se que os jornalistas "enfrentam grande precarização das condições de trabalho, com o desrespeito à jornada de trabalho, o não-pagamento de horas-extras, o acúmulo de funções e a sonegação de registro em carteira - com a proliferação de PJs ou frilas-fixos".

No jornal Unidade, do SJSP, essas questões chegaram a aparecer algumas vezes. Em 2012, na edição 353, do mês de outubro, uma nota relatava a fiscalização do Ministério do Trabalho e Emprego na Rádio Eldorado, a partir de solicitação do sindicato, que foi multada por não cumprir a jornada de 7 horas, não pagar hora extra, não conceder 1 dia de descanso a cada seis trabalhados, entre outros. Já a edição de setembro de 2012, número 352, publicou a "Carta de Caraguatatuba", fruto do XIV Congresso Estadual dos Jornalistas de São Paulo “Audálio Dantas", em que se afirmou:

O XIV Congresso reafirma a luta em defesa dos direitos trabalhistas e rechaça qualquer forma de retirada ou flexibilização de direitos, demissões, e precarização das condições de trabalho.

Exigimos o fim das fraudes no trabalho travestidas de estágio, de contratação como pessoa jurídica (pejotismo, de frila fixo, não registro em carteira, excesso de jornada, acúmulo de função, assédio moral. Em suma, não aceitamos que as empresas jornalísticas descumpram as leis trabalhistas do país - que representam um mínimo de conquistas dos trabalhadores, fruto da luta de gerações e gerações. (UNIDADE, Set/2012)

Nos materiais de divulgação das chapas, que concorreram às eleições do SJSP, publicados no Unidade 346, de março de 2012, a questão da precarização foi apontada. A Chapa 1, da situação, que acabou ganhando, afirmou que os jornalistas estão "trabalhando sem parar em jornadas sem fim, nos finais de semana, sem receber horasextras, muitas vezes sem vínculo empregatício". Já a Chapa 2, de oposição, afirmou:

O Sindicato está enfraquecido e os patrões sabem disso. A maior parte da categoria está fora do Sindicato. Cientes disso, os barões da mídia 
pintam e bordam. Fraudam as contratações aumentam ilegalmente as jornadas, praticam assédio moral, deixam de pagar horas-extras, não cumprem as convenções coletivas... (UNIDADE, Mar/2012)

O blog Jornalismo Freelance, neste mesmo ano, no mês de abril, destacou notícia do site Comunique-se, em que se relatava a condenação da revista Isto é a pagar "R\$ 10 mil para jornalista que virou PJ para trabalhar como frila fixo". Na avaliação do jornalista João Marcos Rainho, que faz o blog, o Sindicato dos Jornalistas "tem sido omisso nessas questões e faz uma defesa fraca quase parando para perder a ação. Já aconteceu comigo". Esse descrédito em relação ao sindicato costumava aparecer quando apresentávamos essa pesquisa em congressos na área de comunicação. Também esteve presente na fala de alguns jornalistas entrevistados, como na avaliação de Kotscho, que relembra a atuação forte dos profissionais dentro da própria redação nos anos 80 :

É outro ponto que houve uma mudança muito grande, quando você fala em condições de trabalho, quem lutava muito por isso era o Sindicato dos Jornalistas. Como em qualquer profissão é o sindicato. Eu me lembro nos anos 80 na Folha de S.Paulo nós criamos o Conselho Consultivo dos Representantes da Redação, não sei quantos, 10 mais ou menos, representantes que eram eleitos em votação direta pela redação para representá-los junto à direção da empresa e junto ao sindicato e tal. Eu lembro que eu fui um dos eleitos. Então a gente tinha uma participação muito maior em todo o processo de relações de trabalho. Tanto de contratações, que a gente era consultado, de demissões, quando mandavam embora alguém injustamente, a gente ia lá reclamar, respeito ao horário de trabalho, mas não aquele respeito burro de você largar seu trabalho no meio porque venceu o seu horário, mas se repetidamente te colocam todo dia pra trabalhar de manhã, à tarde e à noite, alguma coisa está errada. Então essas coisas eram levadas ao sindicato, o sindicato às vezes representava a delegacia do trabalho, e as coisas ocorreriam. Hoje há um esvaziamento enorme do sindicato, quase ninguém mais vai. Os jornalistas mais jovens não sabem nem onde fica o sindicato, e isso tem a ver com essa tendência geral da individualização do trabalho jornalístico, uma coisa muito egoísta, muito fechada, muito individual mesmo - Ricardo Kotscho.

Outras ações foram relatadas pelo SJSP por meio do jornal Unidade. Em 2013, houve ainda mais matérias do que em 2012, relatando casos de precarização do trabalho. A edição de março de 2013, número 356, relatou ação de fiscalização do Ministério do Trabalho e Emprego no Diário do Comércio, na Editora Abril, Editora Três, TV Record, TV Cultura, entre outras. Esses veículos foram obrigados a registrar em carteira seus jornalistas. $\mathrm{Na}$ edição seguinte, 357 , foi publicada entrevista com o psicólogo Roberto Heloani, que será citada ao longo da tese, por falar das pesquisas por ele realizadas em relação ao trabalho do jornalista. "Aquele estilo de vida do jornalista 
do interior, que era mais tranquilo, acabou... A cobrança é muito semelhante", afirma Heloani (2013), que também destaca a terceirização e quarteirização na área e os horários "malucos".

A situação dura no interior também é relatada na edição de julho de 2013, número 360. Matérias falam sobre manifestação em Americana devido às longas jornadas no jornal Todo Dia e mesa redonda com a TV Record de Santos com a Superintendência Regional do Trabalho por causa de desrespeito à Convenção Coletiva. A publicação cita ainda casos de negociação sindical para compensação de horas em Araçatuba, Araraquara, Marília e Presidente Prudente. Já da edição de agosto, 361, destacamos matéria e editorial sobre PL da terceirização. O editorial "Não à pejotização e não à terceirização" afirma:

Todos sabemos que o jornalista exerce uma das profissões que mais sofre com o processo de terceirização - que na nossa categoria atende pelo nome de pejotização, já que os trabalhadores são contratados como Pessoas Jurídicas. É uma velha prática dos patrões para surrupiar direitos trabalhistas e muitos profissionais, acreditando ter um bom negócio, são enganados e sofrem consequências nefastas como a dificuldade para obter aposentadoria ou para garantir direitos mínimos como pagamento de férias, $13^{\circ}$ salário, FGTS, entre outros. (UNIDADE, Ago/2013)

Mais precarização é noticiada na edição de outubro de 2013, no 363, em relação aos jornais Diário de SP e Bom Dia. Essas publicações são notícias novamente na edição seguinte, 364, dos meses de novembro e dezembro, focando no home office, em que os jornalistas arcam com gastos de telefone, internet e deslocamento. A edição anterior ainda falou sobre a negociação com o Portal R7 para mudar a escala de dois finais de semana de folga por um trabalhado para $3 \times 1$.

Nas edições de Unidade de 2014, a precarização continuou em pauta. A primeira edição do ano, de janeiro e fevereiro, 365, trouxe uma matéria com a professora da USP Roseli Fígaro, que estuda o trabalho do jornalista. Ao avaliar as novas diretrizes curriculares da formação em jornalismo, a pesquisadora falou sobre a precarização e a organização do trabalho na área.

A edição de junho de 2014 do jornal Unidade, 367, traz matéria crítica ao home office na Rede Bom Dia e, em outra matéria, relata casos em que a Justiça reconheceu vínculos trabalhistas de PJs. O texto deixa claro que "o trabalhador é obrigado a constituir uma empresa e, assinando um contrato de prestação de serviços, passa a trabalhar para a empresa como empregado, mas, formalmente, como prestador de serviços autônomo". 
Também noticia a campanha do sindicato para o estabelecimento de uma convenção coletiva para os jornalistas que atuam na internet. Tema esse retomado na edição 370 de setembro, em que se relata desrespeito à jornada dos jornalistas e salários abaixo do piso da categoria. Relata-se ainda que jornalistas declararam ter medo de procurar o sindicato, para não ficar queimado no mercado. Os jornalistas de empresas de internet são considerados por elas como trabalhadores do ramo da informática, respondendo a outro sindicato. Assim o Sindicato dos Jornalistas Profissionais de São Paulo tentava negociar uma convenção com o setor.

Outra edição que aborda a questão dos direitos trabalhistas é a 368, de julho de 2014, em que se fala da precarização do trabalho para repórteres fotográficos e cinematográficos. Já uma nota noticia a negociação de jornada de trabalho para os assistentes de artes do jornal Lance.

Mesmo assim percebe-se a necessidade de uma maior mobilização sindical que conte com o apoio dos jornalistas para que os direitos trabalhistas sejam efetivados. Ações concretas com a denúncia ao MPT são importantes. Mas também é necessário que os jornalistas se mobilizem, denunciem as condições precárias e defendam o respeito às leis trabalhistas, reconhecendo-se como classe trabalhadora.

A legislação ainda traz recomendações da CLT que também podem servir para o direito de um ambiente de trabalho saudável para o jornalista, como a necessidade de iluminação adequada à natureza da atividade (Art. 175), ventilação natural ou artificial que possibilite o conforto térmico (Art. 176) e a obrigação de "assentos que assegurem postura correta ao trabalhador, capazes de evitar posições incômodas ou forçadas sempre que a execução da tarefa exija que trabalhe sentado" (Art. 199).

Entre as Normas Regulamentadoras do Ministério do Trabalho e Emprego, a NR 17, voltada para os aspectos ergonômicos, afirma que as condições de trabalho devem se adaptar as características psicofisiológicas dos trabalhadores. As orientações contidas nessa norma também podem contribuir para um ambiente de trabalho mais saudável para o jornalista. Há recomendações para o mobiliário do posto de trabalho e equipamentos, visando, por exemplo, proporcionar boa postura, evitar fadiga visual ou tensão no pescoço. No caso de digitação, coloca-se a necessidade de pausas, que seriam importantes para os jornalistas. Sobre a organização do trabalho, devem ser consideradas questões como o ritmo de trabalho e o conteúdo das tarefas.

Alguns aspectos ergonômicos, por exemplo, foram considerados, de forma bem limitada, na época do Projeto Folha, entre maio de 1984 e fevereiro de 1987, mas 
apenas aqueles que tratavam dos aspectos físicos e ambientais. Em 27 de fevereiro de 1987, a redação passou a contar com um sistema de ar condicionado central. No período que antecedeu o Projeto, foram instalados computadores e houve a tentativa de usar as mesmas mesas: "foram necessárias semanas de argumentação e dezenas de comunicados para que se resolvesse pela fabricação de novas mesas, as quais ainda assim têm um 'design' que nem de longe oferece funcionalidade e conforto a seus usuários" (SILVA, 1988, p.61-62). As paredes, que eram cobertas com pastilhas coloridas que dificultavam a visão, foram cobertas com tom neutro (Ibid., p.83).

Já a questão de adaptação do trabalho ao homem não foi sequer pensada, pelo contrário, os relatos de Silva (1988) mostram que se buscava tirar o máximo de cada trabalhador. Esse sistema, marcado por um ritmo intenso e alta rotatividade, chegava a ser chamado por Frias Filho, diretor do jornal, “de 'seleção natural': algumas pessoas simplesmente não aguentam o ritmo e pulam fora" (Ibid., p.158).

O único problema é que ao acelerar o ritmo do 'grupo que faz a ponte ${ }^{, 21}$, a direção de redação acaba perdendo alguns dos integrantes desse grupo, que não aguentam e o empuxo e preferem desistir no meio do caminho. Em setembro de 1986, dois casos desse ocorreram. Todo o esforço despendido na formação desses dois quadros foi perdido antes que eles tivessem rendido para o projeto tudo que deles podia se esperar.

A decisão mais difícil é saber até onde é possível puxar a corda que é sustentada por essas pessoas sem que elas resolvam solta-las. (SILVA, 1988, p.97)

Esse ritmo intenso, no entanto, atingia todos os jornalistas. Em fevereiro de 1985, 50 jornalistas da Folha se reuniram no sindicato da categoria em São Paulo e elaboraram um abaixo-assinado, que recebeu a adesão de 155 profissionais, $65 \%$ da redação, incluindo repórteres especiais. Criticavam os métodos adotados pelo Projeto, a alta rotatividade e as condições de trabalho:

Afirma o abaixo-assinado que "não é possível ignorar o fato de que várias editorias trabalham num limite de profissionais muito inferior ao volume e a importância das tarefas a serem executadas. Mesmo assim, todos são cobrados dura e injustamente por falhas do esgotamento físico e mental de quem trabalha nessas condições. A perdurar essa limitação, dificilmente as metas recentemente estabelecidas e os horários cada vez mais curtos de fechamento serão cumpridos com eficiência e qualidade". (SILVA, 1988, p.86)

\footnotetext{
${ }^{21}$ Aqueles envolvidos em tarefas prioritárias e totalmente envolvidos com o projeto. Silva (1988, p.96) afirma que de um total de 360 jornalistas em fevereiro de 1987, de 30 a 60 compreendiam integralmente o projeto e desses, Frias Filho afirmava que o "grupo que deve fazer a ponte não chega a doze pessoas".
} 
Não se pode deixar de lado, quando se fala em ergonomia, a variabilidade existente entre as pessoas e é preciso deixar uma margem de manobra para que o trabalhador faça as adequações necessárias. Deve-se considerar que a "ergonomia foi criada para adaptar o trabalho às características humanas" e não o contrário. Como nos mostram Abrahão, Sznelwar, Silvino, Sarmet e Pinho (2011, p.61), "planejar uma situação de trabalho considerando que o trabalhador se comporta sempre da mesma maneira" pode impor "uma organização de trabalho que, em longo prazo, acarretará prejuízos à empresa/instituição e problemas ao trabalhador."

A preocupação com meio ambiente de trabalho também está presente na atuação da Comissão de Funcionários da EBC. "São tantas coisas que a gente pede, desde [a mudança de] ambientes fechados sem ar condicionado, chegamos ao cúmulo de não ter nem ventilação na sala, nem ventilador, do gestor pegar dinheiro do bolso e comprar, entendeu?", relata Maria. Outras lutas em São Paulo são por um espaço de convivência dos funcionários e pela a construção de um ambulatório. "O que a empresa chama de ambulatório hoje, arrumou um cantinho, não tem regra nenhuma. Isso é junto com a Cipa, o EPI também, a gente une forças". A reivindicação do ambulatório foi parcialmente aceita depois de uma pessoa ter morrido na empresa em 2014 após passar mal e não ter havido tempo para socorrê-la.

Pela legislação não é obrigada a ter ambulatório. Mas, poxa, é uma empresa pública, do governo federal, você tem outra compreensão, vamos dar o exemplo. Aí depois que morreu esse chefe, era um gerente, dentro da empresa, resolveram fazer um ambulatório. Eles chamam de ambulatório, mas é um espacinho que eles fecharam, inventaram de colocar um ventilador lá dentro, esse espaço não foi vistoriado por ninguém. A cabeça do gerente administrativo fez, e eles chamam de ambulatório, e a gente chama de guarda macas, porque ambulatório pra gente tem profissional pra atender. A gente cobrou o presidente da empresa e ele falou - vocês também querem tudo. Uma coisa de cada vez. O dia que eles colocarem uma placa lá chamada ambulatório, nós vamos tirar... Óbvio se tivesse um médico ali, de repente, poderia prestar um primeiro socorro. Em Brasília, existe médico do trabalho. É tudo uma questão de contratação de pessoal, não querem gastar, não querem contratar, vai ter questão trabalhista, entendeu? Aí fica assim. O que a gente conseguiu é que se alguém passar mal lá, a gente pode usar um carro da reportagem pra levar. Isso no acordo coletivo. Isso é o básico - Maria.

A Convenção Coletiva de Trabalho do SJSP também traz outros direitos ligados à saúde e ao trabalho. Na versão 2013/2014, há cláusulas sobre segurança e saúde do trabalhador: a 18, estabelece regras para a complementação do auxílio-doença; a 37 , aborda o assédio moral e o sexual e recomenda que as empresas façam campanha de 
conscientização contra essas práticas; e a 39 é sobre a estabilidade do acidentado do trabalho:

Ficam garantidos, aos empregados vítimas de acidente de trabalho, emprego e salário, nos termos da legislação vigente.

PARÁGRAFO $1^{\circ}$.: Na hipótese de recusa, pela empresa, da alta médica dada pelo INSS, arcará ela com o pagamento dos dias não pagos pela Previdência Social, compreendidos entre 0 reencaminhamento e a confirmação da alta pelo INSS.

PARÁGRAFO $2^{\circ}$ : : As empresas se comprometem, sendo possível, a reaproveitar os empregados acidentados, após a respectiva alta, em funções compatíveis com suas condições físicas.

PARÁGRAFO $3^{\circ}$ :: Será garantida aos empregados acidentados no trabalho que apresentem redução da capacidade laboral e incapacidade para desempenharem a função que antes executavam e que tenham sido reabilitados pelo INSS, a exercer outra função, e estando em condições de exercer qualquer outra atividade compatível com seu estado físico após o acidente, a manutenção na empresa, sem prejuízo da remuneração antes recebida, pelo prazo de 180 (cento e oitenta) dias além do previsto em lei.

PARÁGRAFO $\mathbf{4}^{\mathbf{0}}$ :: Estão abrangidos por esta garantia os já acidentados no trabalho com contrato em vigor nesta data.

PARÁGRAFO $5^{\circ}$.: Demonstrando o empregado que é portador de doença profissional, como tal definida nos termos da Lei, atestada pelo INSS, e que a adquiriu em seu atual emprego ou nele a teve agravada, passará o mesmo a gozar das garantias previstas nesta cláusula, à exceção dos 180 dias adicionais concedidos aos acidentados no trabalho, previsto no Parágrafo $3^{\circ}$. Acima. (CONVENÇÃO COLETIVA DE TRABALHO 2013/2014)

A cláusula 47 traz orientações sobre condições de trabalho, afirmando que empresas devem oferecer "ambiente adequado de trabalho aos jornalistas, principalmente quanto à iluminação, ao ruído, ao equipamento, ao espaço, mobiliário e à ventilação, visando à preservação da saúde de seus empregados, conforme Normas Regulamentadoras vigentes". No primeiro parágrafo, estabelece-se que as empresas "promoverão regularmente seminários e/ou palestras com especialistas em doenças tais como AIDS, LER, alcoolismo, dependência química, etc.”. No parágrafo seguinte, coloca-se a necessidade de uma "política de orientação, treinamento e conscientização dos profissionais" sobre "prevenção de doenças profissionais", "obrigatoriedade do uso regular de equipamentos de segurança" e "procedimentos de segurança a serem observados durante a execução de suas atividades". Já o parágrafo $3^{\circ}$ aponta que "as empresas poderão ceder espaço para que os jornalistas promovam palestras sobre doenças profissionais e sua prevenção desde que o horário de exposição das mesmas não venha a interferir com o horário de produção e fechamento normal das redações". 
A cláusula 48 versa sobre as eleições da Cipa (Comissão Interna de Prevenção de Acidentes), 50 sobre atendimento médico em situações de emergência no trabalho noturno e a 51 abrange a emissão de Comunicado de Acidente de Trabalho (CAT) conforme a lei. Também se consideram "acidentes de trabalho, para todos os efeitos legais, toda e qualquer agressão física sofrida por jornalista a serviço da empresa", mediante apresentação do Boletim de Ocorrência Policial.

Se por um lado existem instrumentos para um ambiente de trabalho mais saudável, como normas, lei e itens da Convenção Coletiva, por outro falta o cumprimento desses direitos e uma organização do trabalho que realmente olhe para as necessidades do ser humano que executa a atividade. Muitas vezes não se vê o jornalista como trabalhador, e as condições ruins são aceitas como inerentes à profissão. Para que esses direitos não sejam letras mortas, é preciso apostar em uma saída coletiva, que requer a mobilização dos trabalhadores jornalistas. Não se trata de não se considerar as necessidades do trabalho dos jornalistas e sim de se olhar para as necessidades do ser humano por trás do trabalho. Ser humano esse que é um sujeito de direitos. Se a construção da cidadania, ao longo da história, tem se dado de forma conflituosa, com a efetivação dos direitos não é diferente.

É preciso se mobilizar e essa mobilização requer a união de diversos atores sociais. Os próprios jornalistas que precisam se reconhecer como trabalhadores, sindicato, Ministério Público do Trabalho e a fiscalização do Ministério do Trabalho e Emprego. É possível organizar o trabalho de tal forma que direitos básicos sejam respeitados, como uma folga a cada seis dias trabalhados, compensação de horas consensuada e pagamento de hora-extra. A Pessoa Jurídica deve existir apenas para aqueles casos que caracterizam realmente prestação de serviço, como empresas ou profissionais que fornecem textos para vários lugares sem caracterização de vínculo empregatício, e não como opção para driblar a legislação trabalhista. Há um longo caminho a ser percorrido. 



\section{Capítulo 3}

\section{A organização do trabalho jornalístico}

\section{1 - A centralidade do trabalho}

Após falar sobre os direitos dos trabalhadores, vamos discutir o papel do trabalho no mundo atual e como ele se organiza. Primeiramente, ao abordar o trabalho, deve-se considerar a sua complexidade e se reconhecer sua centralidade. Os sujeitos se constroem por meio do trabalho e não podem ser separados do objeto, ou seja, não podem ser tratados a despeito das condições objetivas (materiais) do desenvolvimento social, nem é possível pensá-lo sem considerar os aspectos históricos de sua época. O ser humano se constrói no trabalho ao mesmo tempo em que utiliza a sua subjetividade e o seu corpo para realizar a atividade.

Quando afirmamos que sujeito e objeto não podem ser separados, estamos recorrendo à relação sujeito/objeto da filosofia de que trata "A Ideologia Alemã", de Marx e Engels (2007). Eles desenvolveram o materialismo histórico dialético. Sader (2007) explica que o homem é apontado como um ser histórico, e o trabalho colocado no centro das condições de vida e consciência humana. Quando esse trabalho é alienado, a pessoa não se reconhece no que produz, no mundo que transforma.

"Se o trabalho é processo de autocriação, quando, no entanto, ele passa a ser regido por uma lógica que independe do sujeito que o realiza, este trabalho passa, no entender de Marx, a ser um meio de alienação do sujeito", complementa Figaro (2008, p.46). Assim "o trabalho alienado subtrai o sujeito de si mesmo". É furtada a vida genérica da pessoa, a "sua objetividade real como ser genérico" (MARX apud FIGARO).

A consciência emerge, para Marx e Engels (2007, p.32-34), do embate com o real, da ação transformadora. A base é a práxis. Os autores afirmam que a produção da vida no trabalho aparece como uma relação dupla - social e natural. A conexão entre os homens depende das necessidades e dos modos de produção. Assim como, para eles, "todas as colisões na história têm sua origem na contradição entre as forças produtivas e a forma de intercâmbio" (Ibid., p.61). 
Já em “O Capital”, Marx (1985, p. 45-53) estabelece conceitos primordiais relacionados ao mundo do trabalho. Um deles é o de mercadoria, que "pelas suas propriedades satisfaz as necessidades humanas", independentemente de se originarem no "estômago" ou na "fantasia" (Ibid., p.45). O valor de uso, por sua vez, constitui "o conteúdo material da riqueza"(Ibid., p.46) e tem "utilidade determinada pelas propriedades do corpo da mercadoria" (Ibid., p.45). O valor de troca é uma relação quantitativa, "a proporção na qual valores de uso de uma espécie se trocam contra valores de uso de outra espécie" (Ibid., p.46).

As mercadorias são produtos do trabalho, no entanto, nelas restam uma "objetividade fantasmagórica, uma simples gelatina do trabalho humano indiferenciado, isto é, do dispêndio de força de trabalho humano, sem consideração pela forma como foi despendida" (Ibid., p.47). Um bem possui valor "porque nele está objetivado ou materializado trabalho humano abstrato". Afinal "a própria quantidade de trabalho é medida pelo seu tempo de duração".

Na produção da mercadoria, deve-se consumir o tempo de trabalho socialmente necessário ${ }^{1}$, o qual se transforma de acordo com a mudança na força produtiva de trabalho. Essa é determinada pelas habilidades dos trabalhadores, meios tecnológicos, “combinação social do processo de produção e as condições naturais". É importante ainda destacar que para se produzir mercadoria é necessário produzir "valor de uso para outros" (Ibid., p.49).

No texto, percebe-se claramente a centralidade do trabalho:

Como criador de valores de uso, como trabalho útil, é o trabalho, por isso uma condição de existência do homem, independente de todas as formas de sociedade, eterna necessidade natural de mediação do metabolismo entre homem e natureza e, portanto, vida humana. (MARX,1985, p. 50)

Todo trabalho é, por um lado, dispêndio de força de trabalho do homem no sentido fisiológico, e nessa qualidade de trabalho humano igual ou trabalho humano abstrato gera o valor da mercadoria. Todo trabalho é, por outro lado, dispêndio da força de trabalho do homem sob forma especificamente adequada a um fim, e nesta qualidade de trabalho concreto útil produz valores de uso. (Ibid., p.53)

Marx e Engels colocam a primazia das relações de trabalho para entender a realidade. Essa primazia se mantém, pois como afirma Figaro (2008, p. 28), “a

\footnotetext{
1 “Tempo de trabalho socialmente necessário é aquele requerido para produzir um valor de uso qualquer, nas condições dadas de produção socialmente normais, e com o grau médio de habilidade e intensidade de trabalho.”(MARX, 1985, p.48)
} 
globalização e a revolução tecnológica, entre outras transformações, estão intrinsecamente ligadas à centralidade da categoria trabalho".

O trabalho também é central para o ser humano na abordagem de Braverman (1981). Ele problematiza o trabalho humano, que é consciente e proposital, diferenciando-o do animal, que é instintivo. Se o trabalho é produto da espécie humana, essa também é produto do trabalho, afirma o autor, retomando Marx: “Ao agir assim sobre o mundo externo e transformá-lo, ele ao mesmo tempo modifica a sua natureza" (Ibid., p.52).

A separação entre sujeito e objeto é vista como impossível. Da mesma forma, o trabalho é constitutivo do ser humano, que tem a capacidade de planejamento e a de execução, essa última chamada por Marx de "força de trabalho". Nas relações capitalistas de produção, há a compra e venda dessa força de trabalho. O processo de trabalho serve à expansão do capital. No entanto, o trabalho "é uma propriedade inalienável do indivíduo humano", o capitalista compra "a força para trabalhar por um período contratado de tempo" (Ibid., p.56). Por outro lado, o controle sobre o processo de trabalho passa para as mãos do capitalista, sendo alienado do trabalhador.

Antunes (2009) é outro autor que defende a centralidade do trabalho. Ele parte da perspectiva de que o trabalho é "referencial ontológico fundante da práxis social" (Ibid., p.139). O autor analisa a obra de Lukács para apontar que por meio do trabalho há "um processo que simultaneamente altera a natureza e autotransforma o próprio ser que trabalha. A natureza humana é também metamorfoseada a partir do processo laborativo, da existência de uma posição teleológica e de uma realização prática" (Ibid.,p.142). Além disso, coloca que o trabalho "é a forma fundamental, mais simples e elementar daqueles complexos cuja interação dinâmica constitui-se na especificidade do ser social" (Ibid., p.141).

Também procura mostrar "como as relações entre trabalho produtivo e improdutivo, manual e intelectual, material e imaterial bem como a forma assumida pela divisão sexual do trabalho, a nova configuração da classe trabalhadora" colocam e dão "concretude à tese da centralidade (e da transversalidade) da categoria trabalho na formação societal contemporânea" (Ibid., p.133-134):

Posso, portanto, afirmar que, em vez da substituição do trabalho pela ciência, ou ainda da substituição da produção de valores de troca pela esfera comunicacional, da substituição da produção pela informação, o que vem ocorrendo no mundo contemporâneo é maior inter-relação, maior interpenetração, entre as atividades produtivas $\mathrm{e}$ as improdutivas, entre as atividades fabris e as de serviços, entre 
atividades laborativas e as atividades de concepção, entre produção e conhecimento científico, que se expandem fortemente no mundo do capital e seu sistema produtivo. (ANTUNES, 2009, p. 134)

No caso do trabalho do jornalista, podemos afirmar que é um trabalho produtivo. Como explica Marx (2010b, p.151-152) o trabalho produtivo se determina a partir do ponto de vista da produção capitalista, é aquele que se troca por capital e cria maisvalia. Já o improdutivo é aquele que "não se troca por capital, troca-se diretamente por renda - isto é, por salário ou lucro", ele apenas consome o lucro.

"O escritor é um trabalhador produtivo não porque produz ideias, mas porque enriquece o editor que publica as suas obras; consequentemente, é produtivo enquanto trabalhador assalariado de um capitalista" (Ibid.). Da mesma forma o jornalista, ainda que freelancer, está gerando lucro para a indústria de comunicação, pois seu trabalho fará parte de um produto, que será comercializado.

Outro aspecto importante é a questão da subjetividade no trabalho, que aparece em Schaff (1967) ao discutir a concepção de indivíduo no marxismo. O ponto de partida de Marx é o indivíduo e seus problemas, o homem vivo e real, que mesmo inserido na sociedade, "continua, até certo ponto, autônomo" (Ibid., p.54). O homem é um ser social, que parte sempre de si, dentro das condições sociais. Assim caracteriza como estereótipo dizer que no marxismo não há lugar para o indivíduo.

Ao olhar para o indivíduo humano, Marx alia natural e social, especialmente, às propriedades históricas. "A descoberta de Marx, estreitamente ligada à evolução do materialismo histórico, de acordo com a qual o indivíduo humano seria uma parte da sociedade, entrelaçado em relações inter-humanas concretas - em particular, em condições de produção" (Ibid., p.65). Marx também vê a origem do homem no trabalho, na práxis humana, em que o ser humano transforma a realidade objetiva e assim transforma a si próprio (Ibid., p.75). O indivíduo é também fruto dessa autocriação. Mas a alienação deforma e limita a evolução dos indivíduos (Ibid., p.95).

Podemos dizer que a questão da autocriação se relaciona com a ergologia. Segundo Schwartz (2006), há uma tendência de sempre se renormatizar o meio de vida e de trabalho. O trabalho, como atividade industriosa, envolve o debate de normas, o que amplia a diferença entre trabalho prescrito e real. Os conceitos de trabalho prescrito e real remetem à ergonomia e são retomados pela ergologia de Schwartz e pela Psicodinâmica do Trabalho de Dejours.

O trabalho prescrito é, muitas vezes, associado ao conceito da tarefa e a sua concepção está relacionada à necessidade de se estabelecerem 
métodos de gestão com o objetivo de definir e medir a produção.(...) Essa forma de prescrição desconsidera as competências adquiridas ao longo do tempo e, principalmente, as variabilidades intra $\mathrm{e}$ interindividuais e da situação.

(...)

O trabalho real é determinado, por um lado, pelas características dos trabalhadores e, por outro, pelas regras de funcionamento da empresa e o contexto das ações. Ele é perpassado pelo status dos trabalhadores e pelo seu salário, objeto de negociações via contrato. Nele, a dimensão prescrita é detalhada e a real resulta de um compromisso entre os objetivos da produção, suas características e o reconhecimento social, gerando um resultado positivo e/ou negativo para a produção e para a saúde. (ABRAHÃO, SZNELWAR, SILVINO, SARMET, PINHO, 2011, p. 37-38)

Os autores ainda explicam que a atividade de trabalho "significa o que efetivamente é feito pelo trabalhador, a forma como ele consegue desenvolver as suas tarefas. Ela resulta das definições dos objetivos e metas, das características pessoais, da experiência e do treinamento formal" (Ibid.). Segundo Falzon (2007, p.9), "a atividade é o que é feito, o que o sujeito mobiliza para efetuar a tarefa. A atividade é finalizada pelo objetivo que o sujeito fixa para si, a partir do objetivo da tarefa." Já a tarefa é o que se deve fazer, o que é prescrito pela organização.

Para nós, a partir do olhar clínico, o trabalho é o que implica de uma perspectiva humana, o fato de trabalhar: os gestos, os saber-fazer, o engajamento do corpo, a mobilização da inteligência, a capacidade de refletir, de interpretar e de reagir a diferentes situações, é o poder de sentir, de pensar, de inventar etc. Em outros termos: para o clínico, o trabalho não é, em primeira instância, a relação salarial ou empregatícia, é o "trabalhar", ou seja, um modo específico de engajamento da personalidade para enfrentar uma tarefa definida por constrangimentos (materiais e sociais). (...) mesmo se o trabalho é bem concebido, mesmo se a organização do trabalho é rigorosa, mesmo se as indicações e os procedimentos são claros, é impossível atingir a qualidade caso se respeite à risca as prescrições. Pode-se observar que as situações de trabalho ordinárias são impactadas por acontecimentos inesperados...

Em verdade, sempre haverá uma lacuna entre o prescrito e a realidade concreta da situação. Este hiato entre o prescrito e o efetivo encontrase em todos os níveis da análise entre tarefa e atividade, ou ainda entre organização formal e organização informal do trabalho. Trabalhar é vencer, preencher o hiato entre o prescrito e efetivo. Ora, o que se deve colocar em ação para vencer esse hiato não pode ser previsto de antemão. O caminho a ser percorrido entre o prescrito e o efetivo deve ser a cada momento inventado ou descoberto pelo sujeito que trabalha. Assim, para o clínico, o trabalho define-se como o que o sujeito deve acrescentar às prescrições para poder alcançar os objetivos para os quais foi designado; ou ainda, o que o trabalhador deve acrescentar de si para fazer frente ao que não dá certo quando ele se atém escrupulosamente à execução das prescrições. (DEJOURS, 2012b, p.24-25) 
A ergologia complementa essa visão ao trazer a ideia de uso de si por si e uso de si pelos outros, mostrando que mesmo em uma situação de constrangimento, há transgressão. As normas são renormatizadas pelo sujeito, que na ergologia é chamado de corpo-si. Isso porque esse sujeito que tem a subjetividade solicitada, mas também o corpo, é um ser social, histórico e biológico.

Quando falei pela primeira vez na expressão 'uso de si', em 1987, era para transmitir a ideia de que, mesmo numa situação de maior constrangimento, como no trabalho em linhas de montagem, existe atividade, transgressão, 'renormatização' das normas. Isso nos afasta da ideia de pura execução e nos conduz à ideia de uso de si, porque, mesmo nas linhas de montagem, encontramos uso de si - seja 'por si mesmo', seja 'pelos outros'. Podemos então falar que, no trabalho, o uso de si envolve o 'uso de si pelos outros' e o 'uso de si por si mesmo'...

(...) esse uso de si é sempre uma arbitragem a ser feita, passando sempre pelo uso de si pelos outros, tornando-se uma variável comum, em especial no trabalho. E acrescentaria: dramáticas do uso de si e também 'uso do corpo-si', porque o corpo nos pareceu bastante solicitado... (SCHWARTZ, 2006, p.460)

Figaro (2009, p.36-37) mostra que para Schwartz, "trabalhar é gerir", ou seja, "administrar-se como sujeito em atividade", fazendo uso de si tanto como corpo físico quanto como corpo-si (sujeito). Já o termo "dramática" é usado porque há "o movimento entre norma prescrita, infidelidade do meio, renormalização e atividade singular". No estudo "O perfil do jornalista e os discursos sobre o jornalismo", coordenado por Roseli Figaro entre 2009 e 2012, afirma-se:

A gestão de si por si mesmo e de si por outros se dá pelo embate entre normas, protocolos e leis; e pelo ineditismo da atividade real, cuja efetivação re-normaliza cada ato desempenhado pelo ser que trabalha, bem como transforma sua relação de comunicação com o outro, com a sociedade. Deste encontro, forjam-se a experiência e os novos conhecimentos, os novos protocolos e a mudança nas relações de comunicação.

A abordagem ergológica permite compreender a presença da dimensão de escolhas e de valores na atividade de trabalho. (FIGARO, 2009-2012)

Segundo Schwartz (2000, p. 41), "os atos de trabalho não encontram o trabalhador como uma massa mole onde se inscreveria passivamente a memória dos atos a reproduzir". Há "micro-escolhas" no uso de si que se revelam no cotidiano do trabalho, "há negociação de aceitação entre o que as condições de trabalho de nós exigem e o uso de nós que estamos dispostos a fazer" (Ibid., p.45). As adaptações do prescrito, a negociação e a "gestão" do trabalho pelo trabalhador ocorrem em diferentes 
situações, inclusive para a preservação da saúde. Outra importante questão levantada por Schwartz e ressaltada por Figaro é que a singularidade está presente em toda situação de trabalho:

Yves Schwartz afirma que "toda a situação de trabalho é singular". Dessa forma, o uso que o sujeito faz de si no trabalho é singular. A consciência da singularidade do uso de si próprio permite a objetivação e a desnaturalização das atividades de trabalho. O sujeito no trabalho coloca-se por inteiro em atividade. Ele põe em movimento a energia de seu corpo, seus sentidos, sua experiência física e intelectual - o corpo em relação ao meio, aos instrumentos e técnicas. Ele também aciona suas relações com o meio social, seus parceiros de trabalho, os colegas, os chefes e superiores. Convoca também as relações com seu grupo social: a família, o bairro, sua história de vida. (FIGARO, 2009, p.35)

A autora defende, dessa forma, que "o trabalho é atividade humana que comporta uma herança cultural e história das técnicas, da experiência das gerações passadas e da experiência pessoal o que permite ao homem uma transcendência criativa".

Esta contradição inerente $a$ toda a atividade de trabalho, própria da vida, é potencializada com o conflito entre as diferenças sócioeconômicas, pela apropriação mercantil do trabalho, pela exploração, pela desvalorização do trabalho. A contradição e o conflito são geridos e negociados a todo o momento, isso é a atividade humana de trabalho, é o corpo-si, expressando-se na dimensão dialética do micro/macro-social. (FIGARO, 2009, p.15-16)

Para Dejours (1992, p.51), não existe neutralidade dos trabalhadores em relação ao que eles produzem, e a tarefa nunca é neutra em relação ao meio afetivo do trabalhador. O trabalho é central para o ser humano, e a subjetividade é mobilizada pelas relações de trabalho e não apenas estruturada pela sexualidade.

O trabalho, por isso mesmo, pode ser para a subjetividade uma provação essencial, por meio da qual ela se revela a si mesma e pode sair fortalecida. Mas se esta provação terminar em um impasse, então a subjetividade pode sofrer danos profundos. Essa provação pode ser tão desastrosa que, ao final de contas, levaria o sujeito ao suicídio. A centralidade do trabalho para a subjetividade não é uma formulação retórica e (...) a teoria psicanalítica ganharia se estivesse apta a integrar uma teoria do trabalho. Esta discussão tem por objetivo mostrar ainda que as relações entre a sexualidade e o trabalho só podem ser amalgamadas em uma arquitetura do corpo que não é nada menos do que a própria condição imanente da vida.

$\mathrm{O}$ resultado das relações entre o trabalho e a vida, que percorrem o caminho que vai da felicidade à infelicidade, não depende apenas de uma economia individual. $\mathrm{O}$ trabalho é também uma relação social perpassada pela dominação. $\mathrm{O}$ sucesso frente à provação individual do trabalho em relação à subjetividade depende das condições sociais do trabalho. O trabalho pode gerar violência, e pode mesmo ser colocado 
a serviço da violência organizada. Em que condições o trabalho pode servir ou tornar-se agente capaz de reunir os seres humanos? Em que condições, em sentido oposto, fomenta a desagregação e a destruição? É a questão que provoca o surgimento de outra característica da centralidade do trabalho: a centralidade social do trabalho. (DEJOURS, 2012a, p. 32)

O autor (Ibid., p.38) afirma que "trabalhar é preencher a lacuna existente entre o prescrito e o efetivo". Assim "o trabalho se define como aquilo que o sujeito deve acrescentar às prescrições para atingir os objetivos que lhe são confiados" e também como "o que ele deve dar de si mesmo para fazer frente ao que não funciona quando ele segue escrupulosamente a execução das prescrições". Além disso, o trabalho não se encerra no local onde ocorre concretamente, pois toda a subjetividade é colonizada por ele (Ibid., p.51). Outra questão é que o trabalho em si não é mensurável:

Não se pode mensurar o trabalho com objetividade. Mensura-se, certamente, mas o que se mede é o resultado do trabalho, nunca o trabalho em si. Ora, não há qualquer proporcionalidade entre o visível e o invisível, entre o resultado da produção e o trabalho vivo necessário para a obtenção deste resultado. Por exemplo: o pesquisador é alguém que fracassa o tempo todo. Os resultados não têm qualquer proporcionalidade com o trabalho e os sofrimentos subjetivos que ocorrem antes de o produto final ser alcançado. (DEJOURS, 2012a, p. 54)

Isso não significa que as prescrições são dispensáveis: “A métis só se revela plenamente em um jogo sutil de subversão das prescrições". Sem elas, "toda a dinâmica da inteligência astuciosa ficaria paralisada" (Ibid., p.55).

Dejours (2012a, p.72) ainda diferencia a concepção freudiana de trabalho como "exigência de trabalho imposta ao psiquismo" do trabalho de produção, poiesis, que é "ação dos indivíduos sobre o mundo" visando à sua transformação, definição oriunda das ciências econômicas e sociais. No entanto, essas visões se complementam, pois o real do trabalho só se faz conhecer pelo fracasso, que se torna um enigma que requer uma solução. A busca dessa solução traz a exigência de um trabalho psíquico, que levará ao nascimento de habilidades profissionais, as quais vêm dessa transformação de si, consequência da resistência ao fracasso. Assim “o 'trabalhar' (poiesis) adquire seu sentido inventivo a partir do instante em que sucede de um segundo trabalho de si sobre si (Arbeit)" e "trabalhar não é apenas produzir, é ainda transformar-se a si próprio".

Quando o sujeito engaja sua subjetividade para enfrentar a resistência do real, "novos registros de sensibilidade", que não estavam presentes no $\mathrm{Eu}$, podem surgir. Dessa forma, existe a possibilidade de o trabalho ampliar a subjetividade da pessoa por 
meio da experiência inédita dada pelo trabalho. Ao afirmar isso, Dejours (2012a, p.8485) retoma a clínica do trabalho para destacar o poder do trabalho em relação à subjetividade. "O acréscimo do corpo subjetivo pelo exercício do trabalho é efetivamente a fonte de prazer que, desta forma, não seria possível não fosse a mediação do trabalho". E mais adiante completa que "o trabalho oferece realmente uma via original e insubstituível ao desenvolvimento da subjetividade".

O trabalho é a um só tempo oportunidade e mediação de uma ampliação de subjetividade que se inscreve na dinâmica da sublimação. Uma descoberta inesperada essa de que o trabalho, contrariamente ao que reza a teoria convencional, não se presta apenas como canalização possível à excitação, mas pode contribuir, como contrapartida, à expansão do repertório erótico do corpo e à acomodação da economia pulsional em seu conjunto (e a ainda ao enriquecimento do patrimônio pulsional) ${ }^{2}$. (DEJOURS, 2012a, p.113)

Dejours (2012b, p.20) coloca o trabalho - poiesis como uma promessa de ampliação da subjetividade - Arbeit, que "abre caminho para a realização de si mesmo". No trabalho psíquico, “a assimilação de uma nova habilidade passa por um processo de apropriação complexo que impõe um remanejamento da arquitetura subjetiva como um todo". Para adquirir a habilidade, exige-se uma evolução da personalidade, disso vem a afirmação de transformar-se a si próprio ao trabalhar, pois o enigma do real leva à exigência de trabalho para o psiquismo. No entanto, a "promessa de ampliação da vida subjetiva contida no trabalho vivo não pode materializar-se sem que estejam reunidas algumas condições sociais e políticas precisas" (Ibid., p.21).

O trabalhar pode ser a provação eletiva de revelação da vida para si mesma. Mas a relação com o trabalho só oferece essa possibilidade se for reconhecida e respeitada a parte que no trabalho diz justamente respeito à subjetividade.

A evolução contemporânea das formas de organização empresarial, do trabalho e de gestão, com a tendência neoliberal, repousam em

\footnotetext{
${ }^{2}$ Dejours (2012a, p.116-117) explica que “a pulsão é busca de excitação sexual” e "sua trajetória não se interrompe no gozo", que "possui um poder de desestabilização da organização tópica". A pulsão ultrapassa o gozo "pelo abalo tópico que provoca" e procura em um segundo momento "uma reestruturação econômica" para oferecer certa estabilidade ao aparelho psíquico. "A desestabilização econômica induzida pelo gozo convocaria um novo trabalho de ligação (para aceder à nova estabilidade em pauta), que pode levar a uma reestruturação tópica e a uma ampliação da subjetividade fundadas na integração da experiência (inédita) do corpo, no teclado dos registros da sensibilidade. Este segundo tempo da pulsão, levando a novas ligações, passa por um trabalho, por uma elaboração, melhor, pela 'perlaboração' [possibilidade de elaborar] da experiência do corpo, Mas também pelo trabalho muito particular do pensamento que toma a via onírica: 'o trabalho do sonho'. Desta feita, a pulsão agiria em dois tempos distintos: desligamento-ligação; gozo-trabalho; excitação-pensamento. A pulsão seria, de qualquer forma, bifásica, pulsátil: sístole (abalo), de uma parte; diástole (retomada ou reestruturação), de outra.
} 
princípios que sugerem precisamente o sacrifício da subjetividade em nome da rentabilidade e da competitividade.

(...)

Mas é necessário frisar, uma vez ainda, que nenhuma organização, nenhuma empresa, nenhum sistema funciona por si, automaticamente, pelo gênio de uma lógica interna qualquer. Todo sistema necessita, para funcionar, não apenas da obediência dos homens e das mulheres, mas também de seu zelo, de sua dedicação, em outros termos, de sua inteligência. A evolução contemporânea da organização do trabalho não é uma fatalidade. Ela releva da vontade - e do zelo - dos homens e das mulheres que o fazem funcionar. Se o trabalho pode gerar o pior, como hoje, no mundo humano, ele também pode gerar o melhor. Isso depende de nós e de nossa capacidade de pensar, graças a uma renovação conceitual, as relações entre subjetividade, trabalho e ação. (DEJOURS, 2012b, p.42-43)

Dejours (2012a, p.175) ainda faz outras importantes considerações sobre o trabalho, que "exige a implicação do corpo por inteiro no desempenho da tarefa". Além da questão do fracasso na realização do trabalhar, o real do trabalho traz o ineditismo ao sujeito, que precisa enfrentá-lo (Ibid., p.178). Trabalhar é "confrontar a resistência do real material" e " a resistência do inconsciente", mas também "reencontrar as relações sociais e a dominação, pois o trabalho não se faz conhecer apenas no mundo objetivo e no mundo subjetivo, ele se revela também no mundo social” (Ibid., p.183). Segundo o autor, “o 'trabalhar' constitui uma segunda oportunidade depois da infầncia, para ampliar os poderes do corpo de experimentar-se a si próprio de gozar de si” (Ibid., p.200).

O psicanalista coloca o trabalho como direito à existência da vida. Como atividade individual, o trabalho possibilita a constituição da identidade e do corpo erótico por meio da inteligência do corpo. Já como atividade coletiva, pela cooperação, torna possível o viver junto de "indivíduos movidos por interesses egocêntricos e de contrabalancear as tendências individualistas por causa da possibilidade de compartilhar a experiência coletiva de participação de uma obra comum", de caráter pré-político. (DEJOURS, 2012b, p.101)

O autor ainda coloca que o trabalho deve ser reconhecido como objeto da política e da filosofia. Se há uma centralidade epistemológica do trabalho, também existe uma centralidade política do trabalho. (Ibid., p.175). O espaço político pode se concretizar no espaço de deliberação, "que nasce das dificuldades encontradas diante do real do trabalho":

...trata-se do lugar onde, melhor que em qualquer outra parte, podem se expressar as opiniões que açambarcam $o$ real e a vida (o trabalho vivo) sem outra mediação que a palavra viva. É nesse sentido que o 
espaço de deliberação consagrado ao trabalho, por permanecer de forma constante o mais perto possível da maneira como a experiência da vida se revela pela praxis, pode legitimamente ser habilitado não apenas como espaço político por excelência, como também espaço gerador do político, tal como tentamos aprender aqui as características: o político a um só tempo inoculado na vida e intérprete desta mesma vida até no amor do mundo. (DEJOURS, 2012b, p.179180)

No espaço de deliberação, trabalhadores e trabalhadoras "podem formular e defender suas concepções sobre os modos de trabalhar" (Ibid., p.83). Estruturado como um espaço público, a atividade de deliberação leva à formação de regras de trabalho. Ela pode ocorrer em espaços informais, onde se dá a convivência dos trabalhadores, como o cafezinho, por exemplo, e nos espaços formais de reuniões (Ibid., p.84). Assim "trabalhar não é apenas produzir, é também viver junto" (Ibid., p.85).

O trabalhador tem um engajamento do corpo e subjetivo, que configura um envolvimento total - psíquico, afetivo e corporal - para produzir um trabalho de qualidade. As habilidades e o zelo necessários à produção passam "por um engajamento do corpo, de sua sensibilidade, e finalmente de sua subjetividade como um todo, incluindo-se mesmo o envolvimento da atividade mais privativa, a do sonho" (Ibid., p.198).

O trabalho é ainda e sempre será a origem da riqueza. Ao contrário do veredito prospectivista, não há qualquer possibilidade de término, um fim do trabalho em nosso horizonte.

O trabalho é e sempre será um mediador insubstituível na luta pela realização de si mesmo e na produção das obras da cultura.

Estes poderes gigantescos, o trabalho os recolhe da inteligência do ser humano - a sua engenhosidade - e da mobilização desta inteligência o seu zelo.

(...)

O zelo, ou seja, a liberdade de mobilizar a sua inteligência, é assim decisivo para o sucesso de todas as organizações, até para as piores entre todas. Se novas formas de organização de trabalho que se mostram prejudiciais para a condição humana e para o futuro de nossas sociedades perduram, é porque elas contam com algum consentimento e com a colaboração da maioria daqueles e daquelas que trabalham. Assim, o ser humano pode levar o seu zelo a organizações que se voltam contra o "ser genérico do homem" e vão

\footnotetext{
${ }^{3}$ Segundo Dejours (2012a, p.50-51), a insônia, o sonho, o pesadelo relacionados ao trabalho também são partes integrantes do trabalho: "Incorporar a destreza do seu trabalho, isso implica ser por ele tomado até mesmo em sonho. E é graças a todo esse trabalho interno que se obtém toda esta familiaridade. $\mathrm{O}$ trabalho do sonho é a parte interna do remanejamento da personalidade que impõem os constrangimentos e o real do trabalho àquele que apresenta esta qualidade: a obstinação de prosseguir ante o insucesso. Encontrar soluções, inventar novos caminhos, isso passa por uma transformação de si, profunda. O trabalho não cessa no ateliê, na fábrica ou no hospital. Ele coloniza toda a subjetividade.
} 
doravante até conduzir certos indivíduos ao suicídio. O zelo pode assim passar insensivelmente sob o primado da alienação...

Se o trabalho é assim capaz de produzir o pior, e disso estamos certos, pode também produzir o melhor... (DEJOURS, 2012b, p.207-208)

Esse melhor perpassa por uma mudança na organização do trabalho, que inclua o reconhecimento, espaços de deliberação e possibilidades para o prazer e à emancipação. O trabalho é central para a constituição do sujeito, que se constrói enquanto trabalha. $\mathrm{O}$ sujeito transforma a si e pode ter a subjetividade ampliada. O sofrimento, que faz parte do trabalho, pode ser transformado em prazer. Do fracasso e do inédito do real, surge o trabalho em si.

No entanto, o modelo de organização do trabalho atual, como veremos adiante, flexível e polivalente, subtrai a subjetividade do trabalhador para obter mais produção, com o aval de um discurso que prega criatividade e autonomia, o que na verdade ocorre de forma controlada e limitada. Além disso, muitas vezes, desconsidera-se o trabalho real que contribui para a realização da tarefa e da atividade e as renormatizações, limitando-se a vangloriar o prescrito.

Apesar de todos esses fatores, o sujeito está lá, transgredindo, renormatizando, fazendo a atividade de trabalho acontecer, colocando seu corpo e sua subjetividade no trabalho, ainda que o trabalho lhe seja alienado. É preciso reconhecer esse sujeito e criar condições para a ampliação da subjetividade e à emancipação, o que só pode ser alcançado por meio de uma mobilização coletiva de fundo político e histórico, e a construção de uma nova organização do trabalho.

\section{2 - Organização do trabalho: conceitos e história}

Dejours (1992, p. 25) define a organização do trabalho como "a divisão do trabalho, o conteúdo da tarefa (na medida em que ele dela deriva), o sistema hierárquico, as modalidades de comando, as relações de poder, as questões de responsabilidade etc.”. Já Seligmann-Silva (2011, p.163) aponta que a “organização do trabalho pode ser definida preliminarmente como a forma de conceber os conteúdos das atividades de trabalho, bem como a sua divisão entre os trabalhadores". 
Seligmann-Silva (2009b, p. 23) coloca "a estruturação hierárquica, o controle, a divisão das atividades, a estrutura temporal do trabalho, as relações interpessoais e intergrupais" como aspectos da organização do trabalho. Segundo a autora, a divisão social e técnica do trabalho incorpora relações de poder, que inclusive podem ocorrer em um mesmo escalão hierárquico. Isso porque tanto "o conhecimento formal quanto a experiência (saberes da prática) podem significar poder. Trata-se de uma questão micropolítica que trará reflexos para a saúde mental" (Ibid., p.22).

Dejours (1992, p.51-52) também chama atenção para o fato de que "a organização do trabalho, concebida por um serviço especializado da empresa, estranho aos trabalhadores, choca-se frontalmente com a vida mental e, mais precisamente, com a esfera das aspirações, das motivações e dos desejos".

O psiquiatra e psicanalista explica que o trabalho artesanal, existente antes da organização científica do trabalho e presente atualmente em tarefas muito qualificadas, permite que parte da organização do trabalho esteja nas mãos do trabalhador, o qual pode escolher técnicas e materiais empregados, ainda que com limitações, e adaptar o trabalho às suas aspirações e competências.

Em termos de economia psíquica, essa adaptação espontânea do trabalho ao homem corresponde à procura, à descoberta, ao emprego e à experimentação de um compromisso entre os desejos e a realidade. Em tais condições, podemos perceber um movimento consciente de luta contra a insatisfação ou contra a indignidade, a inutilidade, a desqualificação e a depressão, graças aos privilégios de uma organização do trabalho deixada, em grande parte, à discreção do trabalhador. Num trabalho rigidamente organizado, mesmo se ele não for muito dividido, parcelado, nenhuma adaptação do trabalho à personalidade é possível. As frustrações resultantes de um conteúdo significativo inadequado às potencialidades e às necessidades da personalidade podem ser uma fonte de grandes esforços de adaptação...

(...) Via de regra, quanto mais a organização do trabalho é rígida, mais a divisão do trabalho é acentuada, menor é o conteúdo significativo do trabalho e menores são as possibilidades de mudá-lo. Correlativamente, o sofrimento aumenta. (DEJOURS, 1992, p.52)

Percebe-se, assim, que da mesma forma que o trabalho pode contribuir para a ampliação da subjetividade e à construção do sujeito, uma organização de trabalho rígida pode levar ao sofrimento, que não encontrará possibilidades para ser transformado em prazer. Ao longo das entrevistas realizadas com os jornalistas, constatamos que muitas vezes a organização do trabalho com seu ritmo acelerado, longas jornadas e pressão levava os jornalistas ao sofrimento. É o conteúdo significativo do trabalho que permitia que se chegasse ao prazer como veremos adiante. No entanto, 
se houvesse menos rigidez da organização, haveria mais possibilidades de satisfação e até para a construção de matérias com mais qualidade, em que se tivesse mais tempo para construí-las.

\begin{abstract}
A livre organização do trabalho é apenas uma estruturação do modo operatório, que leva em consideração, as atitudes individuais, as necessidades de personalidade, onde cada gesto harmoniza-se espontaneamente com as defesas comportamentais e caracteriais. A organização do tempo em fases de trabalho e em fases de descanso respeita as necessidades da economia psicossomática, protege o corpo contra uma sobrecarga comportamental, que poderia ser prejudicial, e possibilita ao sujeito meios de canalizar suas pulsões durante o trabalho.

Deste modo, a livre organização do trabalho torna-se uma peça essencial do equilibrio psicossomático e da satisfação. Ao inverso da livre estruturação do modo operatório, que caracteriza o trabalho artesanal, a organização do trabalho rígida e imposta, que caracteriza a maior parte das atividades industriais, aparece, inicialmente, como um obstáculo à livre estruturação da tarefa. A organização do trabalho, fixada externamente pelas chefias, pode, em certos casos, entrar em choque com o compromisso operatório favorável, que o trabalhador teria instituído espontaneamente. A organização do trabalho, neste sentido, pode comprometer imediatamente o equilibrio psicossomático. (DEJOURS, 1992, p.127-128)
\end{abstract}

Para Spink (1996, p.186), “o dia-a-dia organizacional é onde se trabalha, parte esta cujo horizonte - ou limite - é socio-tecnicamente configurado (pelo espaço físico, maquinaria, tarefas, horários, pressupostos de controle e práticas de interação)". Ele explica que essa concepção apresenta uma ordem negociada. Mais adiante aponta que "a organização enquanto algo concreto é muito mais produto de contradições e conflitos deste mesmo cotidiano do que é produtora" (p.188). Assim a organização pode ser entendida como representação.

Se a organização enquanto um todo não é mais que um rastro da atividade que já passou, uma sombra pálida de um fenômeno multidimensional que desaparece quando a luz é acesa, segue que estes empreendimentos diversos de todos os tipos funcionam não porque as pessoas são administradas e direcionadas, mas porque a concentração de processos que seus cotidianos representam serve de ímã para 'O uso das caixas coletivas organizativas mundanas desenvolvidas ao longo da história social. Em última análise, pessoas sabem se virar. A estrutura de uma firma, hospital, escritório, ou ONG é uma representação de ação congelada; de pouca importância no diaa-dia de negociação de significado. Ela pode apoiar ou restringir a ação processual pelo seu efeito simbólico enquanto mecanismo de mediação, mas não a produz nem a reproduz... (SPINK, 1996, p.188)

A organização do trabalho não pode ser respeitada totalmente. Para que ela funcione, deve ser transgredida. Por isso, Dejours (2012b, p.37) afirma que para o 
processo de trabalho funcionar, "é necessário reajustar as prescrições e desenvolver a organização do trabalho efetiva, o que é diferente da organização do trabalho prescrita".

Desde o tempo das tradições taylorianas, as organizações do trabalho são essencialmente consagradas à divisão social e técnica do trabalho, dando a cada um tarefas, atribuições e prerrogativas limitadas. Mas, aí também, se os trabalhadores respeitassem à risca as diretrizes dos engenheiros de métodos e dos gestores de produtividade, nenhuma produção seria possível. (DEJOURS, 2012b, p.37)

Vale ressaltar ainda que a forma como o trabalho está organizado tem a ver com as condições históricas e econômicas da época que se vive. Atualmente vemos técnicas nascidas no taylorismo/fordismo conviverem ao lado de novas formas de organização, como as trazidas pelo toyotismo. Isso também acontece na indústria da comunicação. Segundo Heloani (2003a, p.23), "as relações entre capital e trabalho muitas vezes se desenvolvem em movimentos circulares, e velhas ideias adquirem nova roupagem...”.

O autor coloca, por exemplo, como marcas da administração taylorista, "tudo o que esteja ligado à maximização de recursos no tempo": robôs em linhas de montagens, fast food, lazer planejado e sistematizado (excursões), currículos de escolas, cursinhos pré-vestibulares. São buscas por um melhor aproveitamento do tempo, pela recompensa e prosperidade.

Há inclusive uma relação direta entre a forma que o trabalho é organizada e a maneira que se realiza e enxerga a comunicação. Figaro (2010) explica que no modelo taylorista-fordista, o homem é "um corpo forte e resistente que deve ser usado no máximo de sua capacidade produtiva"; já a comunicação é vista como "transmissão da informação de um polo a outro" (Ibid, p.101). No toyotismo, "a organização do processo produtivo a partir da demanda" foi possível devido à "intensificação dos usos da comunicação na organização de trabalho".

Nesse novo paradigma, a apropriação do saber-fazer, da criatividade, da participação do sujeito, na forma de polivalência e de flexibilização das funções no trabalho, requer estratégias comunicativas simuladoras da horizontalidade das relações entre as equipes de trabalho e os diferentes níveis hierárquicos. (FIGARO, 2010, p.102)

A Organização Científica do Trabalho, construída por Frederick Taylor, responde "à necessidade de uma redefinição do trabalho, para que pudesse atender à velocidade e ao novo ritmo de produção das fábricas, onde se introduziram novos instrumentos de trabalho". Ele chegou a trabalhar como operário para "entender a objetividade do processo de produção e a subjetividade do trabalhador”. Em 1911, lançou o livro "The principles of scientific management", em que defende ser preciso 
“descobrir a 'melhor maneira' para atingir o máximo de eficiência”. Os tempos e movimentos dos operários eram registrados e analisados. $\mathrm{O}$ trabalhador não participava da formulação dos processos e recebia salário melhor se otimizasse seu desempenho. Havia no taylorismo uma concepção positivista, que via o progresso mediante a ordem e não aceitava conflitos. Valorizava-se a hierarquia, a disciplina e o controle. (HELOANI, 2003a, p.25-26)

Heloani (2003a, p. 31-33) ainda destaca a apropriação do saber operário e a divisão entre o trabalho manual e intelectual, pois, para Taylor, o trabalhador não tinha tempo para descobrir as melhores formas de trabalhar, já que o tempo era absorvido pelo trabalho manual. Além do que, ainda que descobrisse, guardaria as descoberta para si por interesse pessoal. Defendia-se a premiação e recompensas financeiras para os trabalhadores mais eficientes e que cada trabalhador fizesse apenas uma tarefa, o que foi aperfeiçoado por Ford com a linha de montagem. "O trabalhador deve se submeter ao sistema cientificamente planejado, que modela a subjetividade do trabalhador, reconstruindo sua percepção a partir dos interesses do capital”.

Paralelamente à consolidação do taylorismo, que se dá na década de 20 , Henry Ford desenvolve o processo de linha de montagem. O fordismo repassava ganhos de produtividade aos salários dos trabalhadores por convenções coletivas. A ideia era transformá-los em consumidores do produto que produziam. Assim se construiu um modelo de carro que se ajustasse ao maior número possível de compradores. Há o barateamento do custo da produção com linha de montagem. Para se ter uma ideia das proporções, de 1914 a 1923, a produção passou de duzentos mil para 2 milhões de veículos na Ford. (HELOANI, 2003a, p.50-51) A absorção das ideias de Taylor pelas linhas de montagem do fordismo possibilitou que "o grau de intensificação dos ritmos de trabalho e o nível de parcelamento das tarefas" atingissem "pontos extremamente elevados” (SELIGMANN-SILVA, 2011, p.38).

...entendemos o fordismo fundamentalmente como a forma pela qual a indústria e o processo de trabalho consolidaram-se ao longo deste século, cujos elementos constitutivos básicos eram dados pela produção em massa, através da linha de montagem e de produtos mais homogêneos; através do controle dos tempos e movimentos pelo cronômetro taylorista e da produção em série fordista; pela existência do trabalho parcelar e pela fragmentação das funções; pela separação entre elaboração e execução no processo de trabalho; pela existência de unidades fabris concentradas e verticalizadas e pela constituição/consolidação do operário-massa, do trabalhador coletivofabril, entre outras dimensões. Menos do que um modelo de organização societal, que abrangeria igualmente esferas ampliadas da 
sociedade, compreendemos o fordismo como o processo de trabalho que, junto com o taylorismo, predominou na grande indústria capitalista ao longo deste século. (ANTUNES, 2007, p.25)

Figaro (2001, p.173-175) completa que o taylorismo se caracterizava "pelo estudo pormenorizado das tarefas e da movimentação dos trabalhadores na produção". Já o fordismo, pela "cadência, o ritmo de trabalho e a linha de montagem". Buscavam obter o controle sobre o trabalho e se desenvolveram a partir dos anos 20 do século passado. Os modelos começam a se esgotar no final dos anos 60. Segundo Heloani (2003a, p.83), havia uma insatisfação dos trabalhadores, que não conseguiam se adaptar “às constantes acelerações de cadência do trabalho, dentro de uma rígida disciplina, que também já dava sinais de esgotamento. Daí as altas taxas de absenteísmo, de turnover (rotatividade), e o crescimento de refugos, que põem à mostra as limitações do fordismo".

a crise do fordismo-keynesianismo em meados da década de 1970 significou a incapacidade de constituição de um novo modo de desenvolvimento capitalista na época da decadência histórica do capital, colocando-se a necessidade de recomposição da forma de subsunção real do trabalho ao capital. ...constituiu-se um novo regime de acumulação flexível, cujo momento predominante é o toyotismo que, como o fordismo, procurou constituir, de modo original, nas condições da crise estrutural do capital, uma nova hegemonia capaz de articular coerção capitalista e consentimento do trabalhador. (ALVES, 2011, p.99)

O toyotismo, surgido no Japão, com Círculos de Controle de Qualidade e técnicas como o Just in time, celularização da produção e kanban, passa a ganhar espaço (FIGARO, 2001, p.173-175). Antunes (2007, p. 24) explica como a organização do trabalho foi se modificando: "o cronômetro e a produção em série e de massa são 'substituídos' pela flexibilização da produção, pela 'especialização flexível', por novos padrões de busca de produtividade, por novas formas de adequação da produção à lógica do mercado". A chamada gestão participativa e a busca pela qualidade total do modelo japonês, toyotismo, ganham o mundo.

O toyotismo penetra, mescla-se ou mesmo substitui o padrão fordista dominante, em várias partes do capitalismo globalizado. Vivem-se formas transitórias de produção, cujos desdobramentos são também agudos, no que diz respeito aos direitos do trabalho. Estes são desregulamentados, são flexibilizados, de modo a dotar o capital de instrumental necessário para adequar-se à sua nova fase. Direitos e conquistas históricas dos trabalhadores são substituídos e eliminados do mundo da produção. Diminui-se ou mescla-se, dependendo da intensidade, o despotismo taylorista, pela participação dentro da ordem e do universo da empresa, pelo envolvimento manipulatório, 
próprio da sociabilidade moldada contemporaneamente pelo sistema produtor de mercadorias. (ANTUNES, 2007, p.24)

O toyotismo, que surge no Japão nos anos 50, segundo o autor (Ibid., p. 31), tem causado grande impacto não só pela revolução técnica que causou na indústria japonesa, como pela expansão em escala mundial de seus pontos básicos. Um dos ideais é produzir o necessário no menor tempo possível. A produção é voltada para a demanda, além de ser diversificada para suprir o consumo, que determina o que será produzido.

Desse modo, a produção sustenta-se na existência do estoque mínimo. O melhor aproveitamento possível do tempo de produção (incluindose também o transporte, o controle de qualidade e o estoque) é garantido pelo just in time. O kanban, placas que são utilizadas para a reposição das peças, é fundamental à medida que se inverte o processo: é do final, após a venda, que se inicia a reposição de estoques, e o kanban é a senha utilizada que alude à necessidade de reposição das peças /produtos. (ANTUNES, 2007, p. 34).

Para atender às demandas do mercado, mais individualizadas, em menor tempo e com mais qualidade, há necessidade de flexibilizar a produção de modo que um mesmo operário opere várias máquinas. Nasce, assim, o trabalhador polivalente, tão requisitado nos dias atuais. A organização do trabalho também precisa ser flexibilizada. "Deve haver agilidade na adaptação do maquinário e dos instrumentos para que novos produtos sejam elaborados”. Outra marca do sistema é a horizontalização, onde se estende às empresas terceirizadas "a produção de elementos básicos que no fordismo são atributo das montadoras". Os métodos e procedimentos acabam se espalhando para fornecedores: "kanban, just in time, flexibilização, terceirização, subcontratação, CCQ, controle de qualidade total, eliminação do desperdício, 'gerência participativa', sindicalismo de empresa, entre tantos outros elementos, propagam-se intensamente". (Ibid., p. 34-35)

Figaro (2008, p.25-26) destaca que a base central do modelo toyotista é o "tripé filosófico-ideológico-comunicacional kaizen-kanban-just-in-time”. Com ele, eliminamse hierarquias e postos de trabalho. Também se desenvolve a autodisciplina e se incorpora o saber do trabalhador, visando ao aumento dos lucros. $\mathrm{O}$ cenário de novas tecnologias possibilitou "o fluxo e a disseminação de conhecimentos".

O primordial do chamado modelo japonês, o kaizen, ou seja, mudar para melhor, é o centro discursivo ideológico das reformas implantadas na gestão de pessoas e, portanto, na organização da produção. Enaltecer a capacidade do trabalhador para que ele disponibilize o conhecimento sobre o trabalho que realiza em função das metas da empresa é a estratégia que orienta os discursos da gestão de pessoas, a organização dos fluxos de mercadorias e matérias 
primas, bem como todas as operações de comunicação relativas à corporação. (FIGARO, 2008, p.26)

Antunes (2007, p.22) explica que a "classe-que-vive-do-trabalho", aqueles que vivem do trabalho assalariado e vendem sua força de trabalho, sofreu repercussões na sua subjetividade, que afetam sua forma de ser. A produção em série e massa do taylorismo/fordismo é substituída pela flexibilização da produção. O modelo japonês expande novos padrões de gestão, caracterizada por "participativa" e pela busca de qualidade. Mas na verdade o que se busca é o controle da subjetividade do trabalhador em favor do capital:

a sujeição do ser que trabalha ao 'espírito' Toyota , à 'família' Toyota, é de muito maior intensidade, é qualitativamente distinta daquela existente na era do fordismo. Esta era movida centralmente por uma lógica mais despótica, aquela, a do toyotismo, é mais consensual, mais envolvente, mais participativa, em verdade mais manipulatória.

(...) O estranhamento próprio do toyotismo é aquele dado pelo 'envolvimento cooptado', que possibilita ao capital apropriar-se do saber e do fazer do trabalho. (ANTUNES, 2007, p.42)

Heloani (2003a) completa que no período pós-fordista, mesmo com um discurso adotado pelas empresas de autonomia e participação dos trabalhadores, o que se pretende é manipular a subjetividade do trabalhador em favor do capital. Considera, assim uma utopia acreditar que o modelo pós-fordista é "libertário e emancipatório do ser humano", pois tem fundamentos muito parecidos com o taylorismo. Apesar de mais sutis, são mais perigosos porque compartilha a sua dominação.

Minha teoria, então, é a de que o pós-fordismo veio não só como uma resposta do capital à "crise do sistema de regulação", mas também como forma de buscar outros meios de dominação da classe trabalhadora. O progresso tecnológico pode então ser visto como um movimento contraditório e conflituoso inserido num processo histórico de luta de classes. Nesse contexto, a chamada "gestão participativa" foi de fato uma resposta interessada do capital - que, num momento de dura crise na produtividade do trabalho no Ocidente, voltou-se para uma nova forma de "envolvimento" do trabalhador no processo de produção.

(...)

Ao contrário do que apregoam os apologistas da sociedade do lazer, sociedade pós-industrial e congêneres, que veem na lógica amplamente utilizada pelo modelo pós-fordista um elemento libertário e emancipatório do ser humano, não acreditamos nessa utopia. Isso porque os fundamentos e preceitos do pós-fordismo são, em sua essência, muito semelhantes aos da lógica taylorista. Apenas mais sutis, mais bem maquiados e, portanto, mais perigosos, pois de certa maneira agora o trabalhador compartilha a própria dominação. (HELOANI, 2003a, p.175) 
Para Seligmann-Silva (2011, p. 101), as empresas "absorvem o tempo, o pensamento, as energias e desejos dos empregados a tal ponto que se tornam, por inteiro, reféns" das mesmas. Os "objetivos da empresa e o desejo de ser reconhecido e mantido no seio desta passam a ser o motor da mobilização subjetiva e, às vezes, da própria existência, sobrepondo-se a valores, afetos e pertencimentos anteriores”. Há uma imposição da cultura da excelência, que oculta uma relação de subordinação:

As exigências de dedicação total são assim disfarçadas, mas, gradualmente, a empresa e suas metas passam a ocupar o lugar dos próprios desejos ao se apossarem da vida mental e do tempo do novo empregado. A absorção do colaborador pela empresa o sequestra de outros espaços - a vida familiar, o círculo de amizades, as práticas de lazer e outras formas de participação social. Ocorre o sacrifício do repouso e mesmo do horário antes dedicado ao sono. Quando a empresa se torna dona e o centro de sua vida, a percepção da fadiga e o temor de não conseguir manter a própria excelência significam horror e podem ser a véspera de um horror maior - perda de prestígio, ser barrado na competição interna ou até ser despedido. (SELIGMAN-SILVA, 2011, p.495)

O panorama traçado pela autora se aplica à organização do trabalho jornalístico, na qual a adesão é total, e o tempo do trabalho ocupa todo o tempo da vida, como já vimos no capítulo anterior sobre a falta de direitos e as longas jornadas, e veremos mais adiante nas discussões sobre ritmo e envolvimento. Da mesma forma, as demissões em massa que ocorrem nas empresas de comunicação, os passaralhos, deixam o aviso você pode ser o próximo e assim não há espaço para questionar a forma como o trabalho se organiza. Simplesmente se adere sem questionar para ser aceito e permanecer.

Outros paradigmas da excelência citados por Seligman-Silva (2011, p. 497) ilustram bem as características da organização do trabalho na atualidade: flexibilidade permanente, mudança continuada, polivalência, agilidade enxuta - que remete ao corte de pessoal e despesas, rapidez e inovação. A flexibilidade exacerba a competitividade e leva à precarização do trabalho, além disso, "contribui para incrementar a tensão e a fadiga dos trabalhadores, por causa dos esforços de adaptação continuada às sucessivas mudanças de todo tipo".

A palavra flexibilidade era utilizada de modo a evocar a ideia de liberdade e sugeria uma promessa: a de que a rigidez e o controle autoritário contidos no taylorismo-fordismo seriam deixados no passado e que começava agora uma era de liberdade no mundo do trabalho.

Faziam parte das diretrizes vinculadas à produção flexível implementada com a ajuda do toyotismo: a polivalência (todos deveriam ser capazes de fazer tudo) e a eliminação de desperdícios - 
de tempo, de materiais e de insumos humanos. (SELIGMAN-SILVA, 2011, p.172)

Harvey (1992, p. 140) explica que a acumulação flexível se caracteriza pela "flexibilidade dos processos de trabalho, dos mercados de trabalho, dos produtos e padrões de consumo". Em um cenário que se caracterizava pelo enfraquecimento do poder sindical e pelo excedente de mão de obra, as empresas impuseram regimes e contratos de trabalho flexíveis (Ibid., p.143).

A nova organização do trabalho, na medida em que se fundamenta exclusivamente no aspecto econômico, quebra as relações e os contratos de trabalho, legitima a competição acirrada em todos os níveis, individualiza as culpas e os prejuízos pelo não atendimento de metas descabidas, torna facilmente a empresa em uma pessoa jurídica nômade sem responsabilidades locais, eleva o ritmo e a flexibilidade do trabalho, coloca a guerra econômica como álibi para justificar a sobrevivência da empresa a qualquer custo e gera um ambiente de trabalho em que a violência começa a fazer morada permanente. Mais do que isso, essa nova organização do trabalho faz parecer que os que têm emprego devem se submeter à degradação do clima de trabalho sem pestanejar, visto que eles são privilegiados; ter um emprego passa a ser motivo para ser chantageado com a ameaça do desemprego. (FREITAS, HELOANI, BARRETO, 2008, p.35)

Heloani (2003a, p.106) completa que no pós-fordismo, caracterizado por ser um sistema competitivo e flexível, a empresa estimula iniciativa, capacidade cognitiva, raciocínio lógico, potencial de criação para obter respostas imediatas aos problemas. As regras de funcionamento são incorporadas pelos funcionários como se fossem suas próprias percepções. Busca-se o "reordenamento da subjetividade dos trabalhadores". Assim a subjetividade é manipulada para que o trabalhador acredite que ela foi reconhecida.

O taylorismo elaborou a primeira tentativa de administração da percepção dos trabalhadores num contexto de produção em massa. De sua parte, as chamadas 'teorias da qualidade' que constituem, até certo ponto, o arcabouço ideológico (ou superestrutura ideológica, por que não?) do modelo japonês e, em consequência, dos Programas de Qualidade, conseguem reordenar a subjetividade do trabalho num mundo globalizado, cuja produção flexibilizada demanda outro tipo de 'atitude mental' (lembram-se de Taylor?). (HELOANI, 2003a, p.128)

Alves (2011, p. 15-16) vai ao encontro de Heloani (2003a) ao considerar que "a acumulação flexível, que surgiu em meados da década de 1970," não é "uma 'ruptura' com o padrão de desenvolvimento capitalista passado, mas uma reposição de elementos essenciais de produção capitalista em novas condições de desenvolvimento capitalista e de crise estrutural do capital". No entanto, há "uma nova materialidade do capital da 
produção, um novo espaço-tempo para a exploração da força de trabalho adequado à nova fase do capitalismo global sob o regime de acumulação financeirizado". Nos anos 80 e 90, desenvolvem-se as inovações capitalistas para a flexibilização e se prolifera a precarização do trabalho (Ibid., p.20-21). As redes informacionais se revolucionam ${ }^{4}$ e encurtam as distâncias (Ibid., p.37-38). Para o autor, "a rede informacional do capital é intrinsecamente rede controlativa a partir da qual se constitui a 'captura' da subjetividade no trabalho" (Ibid., p.75).

A questão do controle da subjetividade do trabalhador também aparece na análise de Figaro (2008, p. 28). A autora avalia que as "profundas mudanças" do mundo do trabalho não buscam superar a exploração e sim aumenta essa condição, pois procuram "controlar e domesticar a subjetividade do trabalhador". É preciso aderir intelectualmente em prol da inovação e da concorrência. Os postos de trabalho, as funções e os perfis profissionais são reorganizados, exigindo-se "maior polivalência", multiespecialização, "atualização e disponibilidade" dos trabalhadores.

Nesse processo, as metamorfoses do mundo do trabalho, segundo Antunes (2007, p. 49-63), incluem incorporação das mulheres; "subproletarização intensificada" - trabalho parcial, precário, temporário, terceirizado; diminuição do tempo de trabalho necessário e aumento do trabalho excedente; intelectualização do trabalho por um lado e desqualificação de outro.

Em "Os sentidos do trabalho", Antunes (2009) também defende essa noção ampliada da classe trabalhadora com a expressão "classe-que-vive-do-trabalho", abrangendo tanto trabalhadores produtivos quanto improdutivos. Mais uma vez reforça o aumento significativo do trabalho feminino - que ocorre também no jornalismo, a expansão do terceiro setor e das formas de trabalho em domicílio.

Os desafios do trabalho atualmente são transnacionais e não é possível aceitar a ciência como principal força produtiva, pois ela interage com o trabalho sem se sobrepor ao valor, é parte do mecanismo. Entre as tendências, aponta uma redução do trabalho improdutivo e a crescente imbricação entre trabalho material e imaterial. Nesse contexto, o estranhamento do trabalho ainda é preservado, "a subjetividade que emerge na fábrica ou nas esferas produtivas contemporâneas é a expressão de uma existência inautêntica e estranhada" (Ibid., p.130). É preciso buscar a emancipação.

\footnotetext{
${ }^{4}$ Alves (2011, p. 70-71) fala em Quarta Revolução Tecnológica ou "revolução das redes informacionais".
} 
No processo mais profundo de emancipação do gênero humano, há uma ação conjunta e imprescindível entre os homens $e$ as mulheres que trabalham. Essa ação tem no capital e em seu sistema de metabolismo social a fonte de subordinação e estranhamento. Uma vida cheia de sentido, capaz de possibilitar o afloramento de uma subjetividade autêntica, é uma luta contra esse sistema de metabolismo social, é ação de classe do trabalho contra o capital. A mesma condição que molda as distintas formas de estranhamento, para uma vida desprovida de sentido no trabalho, oferece as condições para o afloramento de uma subjetividade autêntica e capaz de construir uma vida dotada de sentido. (ANTUNES, 2009, p. 110)

Além disso, é preciso reconhecer o aspecto político da organização do trabalho e a importância do espaço de deliberação interno à organização, que é um espaço prépolítico reservado ao debate de opiniões. "A tolerância e a manutenção de um espaço de deliberação no trabalho só são possíveis se a direção da empresa assumir a decisão de conceder aos trabalhadores uma parte do poder sobre o ajuste e o controle da organização do trabalho" (DEJOURS, 2012b, p.102).

Se fosse necessário recapitular o que implica a tese da centralidade do trabalho, poderíamos dizer que toda organização do trabalho faz surgir por seu próprio funcionamento a questão do espaço de deliberação coletiva dedicado à expressão das opiniões (sobre as diferentes maneiras de tratar o real do trabalho). Toda organização do trabalho leva ao tema da pluralidade do trabalho vivo. E os desdobramentos que lhe são imputados nunca são neutros: ou a equidade entre a palavra e a escuta é assegurada e a deliberação participa da aprendizagem e da manutenção da democracia, ou a deliberação é manipulada e vipendiada e se aprende então a se subtrair da deliberação e a desconfiar de toda implicação em uma praxis que pode desqualificar o pensamento, pensamento justamente inspirado pelo trabalho vivo. (DEJOURS, 2012b, p.179)

Os trabalhadores precisam ocupar o espaço político da organização do trabalho, e o trabalho pode ser um mediador da emancipação. Ao retomar Marx, Dejours (2012b, p.186-187), destaca que apesar de muitos autores se focarem na ideia de alienação do trabalho, que "remete às incidências de despersonalização do trabalho sobre a subjetividade daquele e daquela que consente em dobrar-se diante de uma organização do trabalho pensada, decidida e controlada por outro", alguns compreendem que "o trabalho é uma condição imanente de todo conhecimento possível”, outros poucos percebem no pensamento marxista "o trabalho como provação de revelação a si mesmo dos poderes do ser humano, de uma parte; o 'trabalho social' como viés da emancipação, de outro". 
Mais uma vez vemos que o trabalho que escraviza e aliena, também pode ser espaço de libertação e emancipação, mas para tanto outra organização é necessária, que valorize os sujeitos, seus saberes e o seu empoderamento. Para Dejours (2012b, p.208210), "a organização do trabalho apresenta-se sempre com um lugar de aprendizagem da implicação ou da deserção dos espaços políticos". Nesse cenário, é preciso "uma teoria do trabalho que também seja uma teoria do ser humano, da inteligência individual e da inteligência coletiva", que ele chama de uma teoria do "trabalho vivo". A mudança inclui uma reorientação da organização do trabalho sobre seus pressupostos e encaminhamentos. E a emancipação abrange tanto "escapar da alienação mental" quanto o retorno à arena política.

\section{3 - A organização do trabalho no jornalismo ao longo da história}

A partir dessas considerações sobre organização do trabalho, passaremos a observar de que forma essas características aparecem na indústria que gera os produtos jornalísticos. É possível a emancipação? O que se vê é um cenário semelhante ao de outras indústrias: flexibilização do trabalho, aumento do ritmo e da produtividade, exigência de polivalência, adesão intelectual do trabalhador jornalista. Tudo isso convivendo com heranças do taylorismo/fordismo como veremos a partir de alguns estudos consultados.

Primeiramente é importante considerar que "os meios de comunicação são meios de produção". A afirmação de Raymond Williams (2011, p.69) se baseia no fato de que “a comunicação e os seus meios materiais são intrínsecos a todas as formas distintamente humanas de trabalho e de organização social”. Dessa forma, constituemse "em elementos indispensáveis tanto para as forças produtivas quanto para as relações sociais de produção".

$\mathrm{Na}$ esfera econômica a comunicação corresponde a duas figuras. Uma tradicional: a do veículo de informação para o mercado, isto é, o processo de circulação do capital que precisa de informação permanente a cerca de todos os fenômenos da vida social que possam incidir sobre seus fluxos e ritmos. E outra pós-industrial: a informação como matéria-prima da produção não só das mercadorias mas da vida social. (Martin-Barbero, 2004, p.226) 
Outra questão importante a ser considerada é que os "meios de comunicação, tanto como produtos quanto como meios de produção, estão diretamente subordinados ao desenvolvimento histórico", pois "possuem relações históricas variáveis com o complexo geral das forças produtivas e com as relações sociais gerais" (Williams, 2011, p.69).

Se olharmos para a história do jornalismo no Brasil, vemos que ele não nasce ligado ao projeto de empresas e sim a projetos individuais, como uma imprensa artesanal baseada na opinião. Sodré (2011) conta essa história fazendo a seguinte divisão: imprensa colonial, imprensa da independência, o pasquim, imprensa do império e grande imprensa. A imprensa no Brasil nasce em 10 de setembro de 1808 com a vinda da corte portuguesa ao país. Da imprensa oficial nasceu a Gazeta do Rio de Janeiro: "era um pobre jornal impresso, preocupado quase que tão somente com o que se passava na Europa", dirigido pelo frei Tibúrcio José da Rocha, que não ganhava nada "para ser gazeteiro" (Ibid., p.41-42). Três meses antes, no entanto, em $1^{\circ}$ de junho de 1808 , foi lançado no Brasil o Correio Brasiliense, feito por Hipólito da Costa em Londres e enviado ao país. Aproximava-se de uma "revista doutrinária" e pretendia ter impacto na opinião pública, já a Gazeta era um “embrião de jornal”, mais informativa (Ibid., p.45). Vale ressaltar que Hipólito descreve o seu trabalho de redação como incansável, "recaído sobre um só indivíduo", que precisava recorrer a outras ocupações para sobreviver (Ibid., p.47). Desde o início, no trabalho jornalístico, ganhava-se pouco (ou até mesmo nada) e se trabalhava muito.

Nas primeiras duas décadas do século XIX, essa imprensa artesanal se desenvolve com exigências materiais reduzidas. São várias experiências relatas por Sodré (2011, p.54-73) em locais dos mais variados, como Pará e Minas Gerais, por exemplo. Ele chama de imprensa áulica. Em seguida, vem a imprensa da independência. "Para o desenvolvimento da imprensa brasileira, o movimento de 1820 teve consequências favoráveis. Foi em função delas que o processo da Independência prosseguiu, mudando a sua qualidade, mas encontrando um mínimo de imprensa para nele influir" (Ibid., p.85). O autor (Ibid., p.87) considera o Diário do Rio de Janeiro, de $1^{\circ}$ de junho de 1821 , o primeiro jornal informativo do Brasil. Nesse período, a imprensa tem um papel político e sofre perseguições, inclusive com atentados aos jornalistas. $\mathrm{O}$ decorrer dos anos de 1820 foi marcado pela censura. Para enfrentá-la, desenvolveu-se a imprensa panfletária - o pasquim, numa luta por liberdade que persiste até a década de 1850 (Ibid., p.135-270). 
A referida forma [o pasquim] traduz, entretanto, com exemplar fidelidade, o que a época tinha de melhor, de mais expressivo, de mais genuíno, de mais popular, de mais democrático. Corresponde, por outro lado, ao período artesanal, em que era possível alguém fazer um jornal sozinho. Encerrada essa fase, o jornal passará a ser empresa pequena empresa, de início, para chegar às proporções de grande empresa, como se apresenta em nossos dias [anos 1960 ]. As inovações técnicas que se esboçam no fim da primeira metade do século XIX e definem-se na segunda metade encerram as possibilidades da imprensa artesanal que, a partir de então, e até hoje, refugia-se no interior, nos pequenos jornais das pequenas cidades onde, entretanto, inexistem as condições políticas que salvaram os precursores de se tornarem inócuos. O papel do pasquim, na história da imprensa brasileira, foi, assim, muito ao contrário do que tem sido indicado, de inequívoca e fundamental importância (SODRÉ, 2011, p.270).

Antes de falar da grande imprensa, Sodré (2011, p.273-368) fala como o golpe da maioridade refletiu na imprensa do império: "Triunfava, realmente, no início da segunda metade do século XIX, o jornalismo conservador, de que o Jornal do Comércio foi expressão singular" (Ibid., p.285). Nos anos de 1870, uma nova fase de mudanças se impõe com a necessidade de reformas políticas, que leva a imprensa mais uma vez à agitação (Ibid., p.301). São lutas pela abolição da escravatura e pela república. "A mudança do regime não alterou o desenvolvimento da imprensa. Os grandes jornais continuaram os mesmos, com mais prestígio e força os republicanos, com mais combatitividade os monarquistas" (Ibid., p.371). De novidade, em 1891, nasceu o Jornal do Brasil, e A Província de São Paulo, nascida em 4 de janeiro de 1875 (Ibid., p. 336), mudou de nome, em $1^{\circ}$ de janeiro de 1890 , passando-se a chamar O Estado de São Paulo (Ibid., p.357).

Sodré (2011, p. 384) avalia que no final do século XIX “a imprensa artesanal estava sendo substituída pela imprensa industrial. Assim na virada para o século XX, ocorre a transição à grande imprensa, caracterizada pela divisão do trabalho (ainda que insipiente), atração de capitais, estrutura específica com equipamentos gráficos. O que faz parte das transformações do país com a ascensão da burguesia. O jornal como empreendimento individual e aventura isolada quase desaparece ${ }^{6}$ (Ibid., p.405-406). O

\footnotetext{
${ }^{5}$ Isso porque o livro de Sodré foi lançado pela primeira vez em 1966.

${ }^{6}$ Sodré (2011) faz a ressalva que iniciativas individuais ficavam relegadas ao interior na época em que ele escreve. Vale ressaltar que com a internet essas iniciativas ganham espaço, tanto de forma individual, como coletiva, por exemplo, a Mídia Ninja. Há ainda iniciativas de resistência que independem da internet, como o Jornal Pessoal, de Lúcio Flávio Pinto, criado na década de 1980 e que continua em plena produção de uma pessoa só em 2014.
} 
início do século XX ainda vai ter o desenvolvimento da imprensa operária. Já em 1938 Getúlio Vargas assina a lei do dos jornalistas profissionais (Ibid., p.454).

Pensando na organização do trabalho, vamos selecionar alguns fatos que fazem pensar como essa organização se deu no jornalismo ao longo dos anos. O ritmo de trabalho, por exemplo, poderia ser aumentado devido a um fato excepcional, como ocorreu com a revolta dos marinheiros em 1910 que fez com que o Jornal do Brasil tivesse de cinco a seis edições diárias (Ibid., p. 506). Já a fala do jornalista Alcindo Guanabara ao jornalista Gilberto Amado mostra o sofrimento do jornalista no trabalho no começo do século XX: "Vão fazer com você o que fizeram comigo. Sugar... tirar tudo de dentro de você... e manter você sempre em situação subalterna. Defenda-se. Preserva-se. Senão você se perde" (AMADO apud SODRÉ, 2011, p.512). Em 19 de fevereiro de 1921 surge a Folha da Noite (SODRÉ, 2011, p. 521) e em $1^{\circ}$ de julho de 1925 (Ibid., p. 534), a Folha da Manhã em São Paulo, que dão início a empresa Folha. Nesse mesmo ano, 1925, Irineu Marinho funda O Globo no Rio de Janeiro (Ibid., p.544). Também na década de 1920, Assis Chateaubriand começa o seu império, comprando O Jornal (Ibid., p. 528). Para Sodré (2011, p. 573), no fim da primeira metade do século XX a passagem para a grande imprensa está consolidada:

... a imprensa industrial da fase capitalista é bem diversa da imprensa artesanal que a antecedeu; nela, a divisão do trabalho ampliou-se consideravelmente, e a divisão de classes tornou-se clara. Numa empresa jornalística operam elementos de três camadas ou classes sociais: os proprietários, que pertencem à burguesia; os trabalhadores intelectuais, que pertencem à classe média ou pequena burguesia; e os operários, que pertencem à classe operária, ao proletariado. Embora assalariados, os elementos intelectuais não têm situação proletária e sofrem as injunções e vacilações de sua posição intermediária, que se presta à ambiguidade. (SODRÉ, 2011, p.609-610)

Bahia (2009) também fala sobre a história da imprensa no Brasil ${ }^{7}$, dividindo-a em fase inicial - em 1808, fase de consolidação - que começa em 1880, fase moderna a partir de 1920, e fase contemporânea. Ele destaca a função política da imprensa (Ibid., p.42) nessa fase inicial. Da segunda fase, aponta, em termos de organização do trabalho, a passagem da tipografia para a indústria gráfica, com inovações mecânicas, a divisão do trabalho, a especialização, a racionalização de custos e a conquista de mercado

\footnotetext{
${ }^{7}$ Outra referência sobre a história da imprensa no Brasil é Martins e Luca (2012), que reúne artigos de diversos autores, analisando desde os primórdios da imprensa aos dias atuais. Já Ribeiro (1998) apresenta a história da imprensa de São Paulo a partir de depoimentos dos próprios jornalistas e das lutas dos trabalhadores por meio do Sindicato dos Jornalistas Profissionais no Estado de São Paulo, de 1937 a 1997.
} 
(Ibid., p.112). “Antes de ser profissão, o jornalismo é um bico, um subemprego que procura compensar o baixo salário com o prestígio da letra de forma. Porém essa situação é menos grave nesses 20 anos do que no passado", diz o autor ao se referir aos primeiros 20 anos do século XX (Ibid., p.143). Da fase moderna, o autor (Ibid., p.211) enfatiza a organização racionalizada das empresas editoras de jornais. "Os jornalistas boêmios, pouco a pouco, cedem lugar aos jornalistas profissionais".

Das experiências particulares dos veículos de comunicação, algumas se tornaram referências em organização do trabalho. Hime (1997) relata a história de Cásper Líbero e os progressos trazidos por A Gazeta, em São Paulo. O jornal oferecia "as melhores condições possíveis, naqueles tempos, para jornalistas, fotógrafos, gráficos, enfim, toda a equipe envolvida na elaboração do jornal, que realizava o seu trabalho", além da modernização de maquinário e instalações (Ibid., p. 165). A primeira etapa para modernizar o jornal ocorreu em meados da década de 1920: "Tal processo inclui tanto a aquisição de maquinário capaz de acelerar e aprimorar a produção do jornal, como também a reforma das instalações para torná-las mais adequadas à acomodação desse maquinário e principalmente da redação" (Ibid., p.172).

Já no final da década de 1930 Cásper Líbero inaugurou “o primeiro edifício planejado especificamente para abrigar um jornal do Brasil", com um arquivo que era considerado o melhor das redações da América Latina (Ibid., p.178-179). Também investia em salários e melhores condições de trabalho: "Seus funcionários tinham gabinetes espaçosos e arejados, móveis elegantes, telefone, arquivo e biblioteca à disposição e um bom salário. Ou quase. Apesar de trabalharem em um dos jornais que pagava melhor, para se manter muitos funcionários d'A Gazeta tinham dois empregos" (Ibid., p. 181). Os jornalistas que trabalhavam com ele o apontavam com um amigo e ressaltavam seu espírito empreendedor.

\footnotetext{
Antecipando qualquer política de Recursos Humanos, Cásper busca criar um clima de envolvimento no jornal, em que todos se sentem peças fundamentais do processo, um não é mais importante que o outro, ninguém pode ser desprezado. Tal política é esboçada por ele próprio em diversas ocasiões. Destaca que $A$ Gazeta é produto de uma colmeia. No exercício da profissão, compreendeu que nada pode ser feito individualmente, sem partir de um trabalho conjunto. Esse espírito é assimilado por todos os que com ele trabalham como demonstram os depoimentos de antigos funcionários. (HIME, 1997, p. 237)
}

Outro destaque foi o a cadeia de comunicação de Assis Chateaubriand, considerado por Bahia (2009, p. 259) um império jornalístico sem precedentes na 
América Latina entre as décadas de 1930 e 1970. A partir dos anos 70, as empresas se tornam cada vez mais diversificadas, como um sistema de comunicação (Ibid., p.268). Já Dines (1986) destaca outro jornalista e empresário que marcou a organização do trabalho no jornalismo:

Aqui, convém ressaltar o mérito de Samuel Wainer na modernização da imprensa brasileira, especialmente a vespertina, alterando o quadro de então. Para competir com a Última Hora, os jornais buscaram a modernização de seu equipamento, da sua aparência, maior qualificação profissional, novas técnicas promocionais, novas faixas de cobertura. $O D N$, como aliás toda a cadeia dos 'Diários Associados', fundada por Assis Chateaubriand, não acompanhou a modernização. (DINES, 1986, p.50)

Dines (1986, p.51) também aponta o papel do Jornal do Brasil na modernização do jornalismo brasileiro. Ele assumiu o "cargo de editor-chefe no dia 6 de janeiro de 1962, uma segunda-feira", com o compromisso de fazer "um jornal diferente dentro de poucos anos". O jornal "implantou, em 1963, e desenvolveu em 1964, o primeiro departamento de pesquisa. Não era apenas a busca da memória, mas a necessidade de estender a notícia, de satisfazer em profundidade a sede recém-despertada pela TV" (Ibid., p.70). Para Ribeiro (1998, p.194), a reforma do Jornal do Brasil "mudou a cara e a alma de quase todos os jornais brasileiros".

Alberto Dines falou sobre a experiência de trabalho no Jornal do Brasil durante a entrevista que concedeu para esta pesquisa, ressaltando os principais aspectos organizacionais que vivenciou na época: "Tentei fazer algumas inovações muito tempo atrás pra tornar mais organizado o trabalho na redação". As mudanças no Jornal do Brasil começaram antes da chegada de Dines, mas com ele foram aprofundadas.

O jornal rodava tarde, não alcançava as bancas, tinha esses problemas industriais e mecânicos que complicavam, aí eu comecei a refletir um pouco sobre a organização do trabalho. Eu tinha experiências de dois jornais diários, mas que eram jornais muito bagunçados. Um era a Última Hora, que era um jornal inovador, mas foi muito louco, como tudo que o Samuel Wainer fez. O jornal era central e depois tinha as edições regionais que eram feitas centralmente (risos) também. Era um jornal muito criativo, mas não havia recursos pra fazer uma coisa bem pensada. (...) No Jornal do Brasil não, eu não sei por que, eu achei que havia a possibilidade de fazer um trabalho sistemático, metodológico, operacional - Alberto Dines.

No comando do JB, criou uma reunião diária de pauta com o comando do jornal, redatores e responsáveis pelas opiniões e editoriais para discutir a página dos editoriais. Também fazia a reunião de pauta para planejar o jornal, que chegou a ocorrer duas 
vezes por dia. "Vinha com a ideia de que um jornal precisa ser minimamente planejado, não fazia sentido que ele fosse acontecendo num prazo tão rápido, tão veloz, dava grandes improvisações", recorda Dines. Também criou novos cargos e editorias, inclusive o seu, de editor chefe, que levou dois anos para aparecer no expediente do jornal. "Eu centralizava o trabalho noticioso." Das novas editorias, destaca a de fotografias e a de pesquisa:

\begin{abstract}
A editoria de pesquisa, isso foi realmente novo. Quando eu cheguei, o jornal não tinha arquivo, não tinha biblioteca, referências, não tinha nada. Até arquivos fotográficos não tinha. Os fotógrafos faziam as suas fotografias e levavam os negativos ou deixavam lá numa gaveta. Eu criei a editoria de pesquisas, criamos uma base, nós chamávamos de base de dados, nós compramos livros de referências importantes, começamos a assinar revistas estrangeiras e colecionar pra ter referências. E começamos a preparar, mas isso foi um processo progressivo, uma coisa inédita. Preparamos matérias, primeiro disponibilizamos pra todos os repórteres e redatores, em seguida, avançamos, começamos a preparar dossiês sobre determinados assuntos para que o repórter saísse à rua minimamente preparado. Depois convertemos esses dossiês em matérias a serem publicadas já impressas no jornal com a assinatura, com o crédito de editoria de pesquisa. Foi uma evolução.(...) Também concentramos na editoria de pesquisa tudo aquilo que tinha a ver com experimentações. Nessa editoria criamos o comitê que chamava o jornal do futuro (...), que poderia nos ajudar a estabelecer uma discussão e quem sabe encontrar caminhos novos, foi uma coisa muito importante e ao mesmo tempo começamos a disciplinar, a organizar o trabalho dos repórteres Alberto Dines.
\end{abstract}

O curso que fez na Universidade de Columbia é considerado por ele muito importante, por ter aulas com "profissionais altamente categorizados" e por possibilitar "uma pequena vivência dentro de jornais que cada um escolhesse". Dines anotava o que os professores falava e relaciona com o ele pensava sobre cada questão. "Eles falavam já sobre organização de jornais e as nossas visitas aos jornais foram muito importantes. Como é que esses jornais se organizavam? Como é que funcionavam?” Assim ele pôde conhecer procedimentos que a imprensa brasileira não tinha, pois apenas a técnica do lide ${ }^{8}$ havia sido incorporada nos anos 1950 por iniciativa de Pompeu de Souza, que também havia ido aos EUA em um programa de visitas às redações.

Outro ponto relembrado por Dines foi a consultoria de uma empresa chamada Montreal, contratada pela direção do JB. "Era uma empresa de engenharia de métodos e

\footnotetext{
${ }^{8}$ Primeiro parágrafo do texto noticioso que deve responder as questões: o quê, quem, quando, como, onde, por quê.
} 
sistemas e eles eram muito competentes". Um consultor mergulhou na administração da empresa, e se criou um convívio positivo, que possibilitou a organização da redação.

As ações de Dines incluíram colocar televisões na redação e nas salas das editorias: "Você não podia fazer o jornal do dia seguinte sem saber o que estava sendo dado, isso hoje parece uma providência de caráter de conforto, mas não é, foi uma revolução". As discussões de pauta também foram descentralizadas: "O Armando [Nogueira] trouxe ideias de que as pautas podiam ser menos autoritárias, no sentido de ser autoral, de ser de uma pessoa. A pauta podia ser da redação, do corpo de repórteres, de redatores". Também se desenvolveu um corpo de correspondentes nacionais e de sucursais pelo Brasil. Eram correspondentes pagos em todas as capitais, contratados, que frequentemente visitavam a sede.

Dines define a experiência vivenciada no Jornal do Brasil como um trabalho colegiado e integrado, de muita discussão e participação. Quando o jornalista relembra essas histórias passa a impressão de que no jornal se vivenciou o espaço de deliberação de que fala Dejours. Não era uma organização do trabalho fechada. "Esse ritual das reuniões e tudo isso criava um ambiente de convivência que é muito importante", avalia o jornalista.

Mesmo no período da ditadura, Alberto Dines acredita que entre 1964 e 1967 não houve transformações na forma do trabalho: "Não houve grande mudanças na nossa vida, porque os jornais sempre foram comandados pelos donos dos jornais mesmo, só saía o que eles queriam". Em 1968, houve censura "e logo depois numa decisão infeliz da direção, a autocensura, que durou de 69 até quando eu fiquei em 73, mais até, porque quando eu saí, continuou". Apesar disso, as mudanças organizacionais para ele passaram a fazer parte das rotinas e influenciaram outros jornais.

Para Bahia (2009, p.244), "no último quarto do século XX, a grande imprensa brasileira concilia as empresas tradicionais e as empresas modernas". Dessa forma, as primeiras são restritas a algumas áreas de comunicação, já as outras se diversificam como conglomerados de comunicação. Não há dúvida que as empresas de comunicação compartilham técnicas de organização do trabalho de empresas de outros segmentos.

Segundo Nassif (2003, p.3-4), no fim “dos anos 60, a imprensa descobriu o jornalismo econômico. No início dos anos 70, o jornalismo de negócios. No fim dos 70, o jornalismo crítico. Nos anos 80, o jornalismo de serviços. Nos anos 90, o jornalismo denunciatório. Nos anos 2000, falta à imprensa se descobrir”. Mais adiante ele reforça que ela se viu "como um produto, que tem que responder às expectativas do seu 
público”. Completamos que nos anos 2000, ela é tudo isso misturado. A flexibilidade atinge a produção, os produtos gerados, as formas de produzir, as relações de trabalho no setor da comunicação. Já Nonato (2013) aponta três grandes marcos do jornalismo brasileiro:

O primeiro ocorreu nos anos 1950, depois da Segunda Guerra Mundial, com a chegada da televisão e de uma cultura audiovisual, momento em que ocorre uma modernização dos jornais. A segunda mudança ocorreu nos anos 1960, com a obrigatoriedade do diploma, a criação das faculdades de jornalismo e a consolidação da Indústria Cultural no país. A terceira mudança foi nos anos 1980, com a introdução das novas tecnologias, fusão e surgimento das novas mídias. Hoje, essas mudanças que se acumularam nas duas últimas décadas cristalizaram o perfil...: os jornalistas são jovens, individualistas, estão preocupados com o produto e têm a clara ideia de que o marketing está inserido na informação (NONATO, 2013, p. 199)

\section{4 - O uso de técnicas fordistas, tayloristas e pós-fordistas no trabalho jornalístico}

Há frequentes comparações com resquícios de um tipo de organização taylorista/fordista nas empresas de comunicação, que se configurou a partir da década de 1980. Marcondes Filho (2000, p.81-82), ao abordar a TV, relata a busca pela rapidez e a superficialidade das notícias. Caracteriza os jornalistas como "funcionários de uma linha de montagem acelerada em que rapidamente selecionam, por padrões viciados e em geral imutáveis" com os mesmos enfoques e caracterizações. O jornalismo se torna assim "uma máquina de produzir sempre o mesmo, qualquer que seja o conteúdo diferente do dia-a-dia". Selecionam-se os mais rápidos e não os mais capazes.

A dureza das condições organizacionais é relatada por Heloani (2003b), que estudou a qualidade de vida do "trabalhador-jornalista" no mundo contemporâneo, considerando a relação entre trabalho e sintomas psicológicos. Ele apontou problemas como a obrigação dos jornalistas se adaptarem às novas tecnologias "freneticamente"; o efeito colateral danoso das práticas organizacionais; a falta de identificação coletiva; manipulação das informações; humilhações no trabalho; o enxugamento das redações (Ibid., p.78-80).

Apesar do "glamour", do fetiche pelo jornalismo, como já vimos, alguns buscam outras saídas pois, ao contrário de outros colegas, não suportam mais adiar a felicidade e temem não mais aguentarem o ritmo de trabalho por muito tempo, ou melhor, até a aposentadoria. 
Isto fica evidente pelas seguintes falas: "hoje a redação é uma padaria, é uma linha de montagem..." (HELOANI, 2003b, p.80)

Ribeiro (2001, p.66) também utiliza o termo linha de montagem para caracterizar o trabalho dos jornalistas. "A nova racionalidade - que se pretendia secular e regida por critérios de desempenho, produtividade e rentabilidade - caracterizou decisivamente a empresa de notícias como indústria e como comércio...” (Ibid., p.54).

Não é só tempo que falta aos jornalistas para realizarem suas matérias de forma que possam ouvir todos os lados, checar a veracidade dos fatos, compreender a realidade que buscam retratar. A comparação com a linha de montagem também remete à falta de autonomia, algo fundamental para o exercício de um trabalho reflexivo.

$\mathrm{Na}$ análise de Ribeiro (2001, p.156-157), o taylorismo ${ }^{9}$ está presente nas redações com a "cobertura científica dos fatos", "a imposição do deadline, de planos de metas, produção computadorizada, controles de erros, avaliações mensais dos jornalistas, planilhas do volume de produção". Acrescentamos a isso os manuais de redação, que tentam uniformizar não apenas a linguagem, mas a atividade de trabalho, trazendo regras e as "melhores" formas de fazer.

Marcondes Filho (2009, p.164) fala na adoção de "processos hipertaylorizados na utilização da mão de obra jornalística", que são coerentes com "a alta velocidade de informações em todo sistema". Assim "o homem-máquina tem de trabalhar à velocidade do próprio sistema". Percepção essa presente entre jornalistas, como um entrevistado de Travancas (1993, p.94): "Não comungo com a ideologia da empresa, mas sou parte da engrenagem. E é fácil conviver com isso. Eu alugo minha força de trabalho, não minha cabeça. (...) Procuro fazer o melhor possível." Em sua pesquisa, conclui que a "movimentação e tensão presentes na redação contaminam toda a empresa" (Ibid., p. 101).

Kucinski (2005, p.107), por exemplo, acredita que o jornalismo atual "perdeu sua centralidade no mundo da cultura e das ideias". Ele também avalia que "a competição feroz pelo emprego determina um ethos de individualismo extremado". O jornalista deixa de lutar "pela verdade ou pelo interesse público", pois a batalha é "para garantir o seu emprego".

\footnotetext{
${ }^{9}$ Segundo Harvey (1992, p.121), para Taylor, “a produtividade podia ser radicalmente aumentada através da decomposição de cada processo de trabalho em movimentos componentes e da organização de tarefas de trabalho fragmentadas segundo padrões rigorosos de tempo e estudo do movimento".
} 
(...) nas empresas jornalísticas, o fazer tornou-se mais importante que o saber fazer. A quantidade tornou-se o critério da aprovação do trabalho, e as pautas deixaram de ser um exercício de criatividade para se tornar uma ordem de trabalho. O jornalista comum, hoje, é um trabalhador de uma linha de montagem, cuja esteira corre com velocidade cada vez maior, não deixando tempo nenhum para a individualização. Logo que pode, ele larga a profissão. (KUCINSKI, 2005, p.109-110)

Piernes (1990, p. 39) completa que o progresso foi impondo um ritmo intenso ao jornalismo. Em relação à produção de bens materiais, isso pode ser visto positivamente, no entanto, alerta que "resulta nocivo e altamente perigoso quando, por obrigação do progresso tecnológico, tem-se de produzir mais ideias, mais opiniões, mais noticiais, como se fossem salsichas, para dar de comer a uma máquina cada vez mais faminta".

Para Kucinski (1998, p. 17), “a atuação do jornalista no Brasil é constrangida por um modo autoritário de controle da sua produção, falta de garantias à liberdade de expressão jornalística e dimensões restritas do mercado de trabalho". Outro problema é rotatividade nas redações, que faz "das demissões um instrumento rotineiro de intimidação ou controle social" (Ibid., p.27).

A tensão, segundo Ribeiro (2001, p.157), é outro instrumento utilizado no jornalismo para gerar mais produção. "Inerente aos ritmos e procedimentos da própria tarefa", essa tensão é "estimulada e, então, canalizada para a obtenção de resultados específicos - trata-se da mais-tensão, a tensão fabricada com o objetivo de extrair produtividade". Era assim no cenário dos anos 1980 e início dos 1990 desenhado por Ribeiro (2001) continua assim no cenário sobre os anos 2000, trabalhado por Marcondes Filho (2009).

A organização do trabalho e os adoecimentos estão ligados às condições históricas e sociais em que vivemos. Harvey (1992) mostra que a racionalização e a divisão do trabalho pensada por Henry Ford $^{10}$ foram substituídas depois pela acumulação flexível, a qual é caracterizada pela "flexibilidade dos processos de trabalho, dos mercados de trabalho, dos produtos e padrões de consumo", assim como pela "inovação comercial, tecnológica e organizacional". O autor relata que (Ibid., p.177) muitos acreditam em uma "segunda divisão industrial" e que "novas formas de

\footnotetext{
${ }^{10}$ Segundo Harvey (1992, p. 121), Ford racionalizou velhas tecnologias e detalhou a divisão do trabalho pré-existente. Com uma posição fixa do trabalhador, ganhou produtividade. Reconhecia que a "produção de massa significava consumo de massa" e tinha uma visão para uma nova política de controle e de gerência do trabalho.
} 
organização do trabalho" transformaram "radicalmente a face do capitalismo no final do século XX". Em tempos de acumulação flexível, as relações de trabalho também são flexibilizadas, e o favorecido continua sendo o capital (Ibid., p.211).

Essa precarização atinge também os jornalistas, com longas jornadas sem hora extra, contratações como pessoa jurídica, menores salários, redações enxutas, mais demanda com menos profissionais e tantas outras flexibilizações. Como descreve Marcondes Filho (2000, p. 36), "bom jornalista passou a ser mais aquele que consegue, em tempo hábil, dar conta das exigências de produção de notícias do que aquele que mais sabe ou melhor escreve"; o processo de trabalho se virtualiza, e o ambiente humano da redação desaparece, por exemplo, "a consulta ao colega, a conversa relaxante, os eventuais apoios ou críticas, em suma, o clima - inconscientemente solidário da atividade" (Ibid., p.50-51).

Isso significa que o bom jornalista hoje é aquele capaz de dar conta das exigências de tempo, produzindo textos jornalísticos razoáveis e com grande maleabilidade redacional ou editorial. Ele deve ser uma peça que funciona bem, acoplável a qualquer segmento do sistema de produção de informações. A eficiência sobrepõe-se à questão da qualidade (originalidade, personalidade) do texto.

Por outro lado, a alta rotatividade dos ingressantes na carreira jornalística nas grandes empresas informatizadas faz com que, por um mecanismo quase de "seleção natural", permaneçam na redação somente aquelas pessoas que dão conta das demandas hipertaylorizadas de trabalho e com uma diversidade redacional adaptável a todas exigências momentâneas da produção de jornal. (MARCONDES FILHO, 2009, p.164)

Vale ressaltar que essa flexibilidade e polivalência em se adaptar não se resumem aos jornais. Com as novas tecnologias, novas habilidades e mais rapidez são solicitadas. Todos os meios estão na internet, e o que era só texto e foto para o jornal, voz para o rádio e texto e imagem para $\mathrm{TV}$, alcança todas essas dimensões na internet. A reportagem de TV também se torna texto escrito na web, com fotos, além do vídeo. O texto do jornal ganha versão em vídeo e assim se dá uma convergência, na qual todos tentam sobreviver e oferecer cada vez mais em menos tempo.

O quarto e último jornalismo, o do fim do século 20, é o jornalismo da era tecnológica, um processo que tem seu início por volta dos anos 70 . (...)

No âmbito das relações entre comunicação e tecnologias, as novas tecnologias agem em dois planos: virtualizam o trabalho jornalístico impresso e interferem radicalmente nos conteúdos (tanto explícitos, quanto subentendidos nas novas técnicas). Em relação ao trabalho, o homem da redação, acostumado a escrever sobre o papel, a participar fisicamente do ambiente com os colegas, a ver seu produto "realizado" como um objeto jornal, passa a se submeter à lógica 
imaterial da tecnologia (mais difundida nos meios visuais) e a se adaptar à completa volatização do ambiente de trabalho, do seu trabalho e do produto final "jornal". Isso tanto aumenta a sobrecarga de trabalho do jornalista, quanto o reduz cada vez mais a si mesmo. Além disso, a tecnologia imprime seu ritmo e sua lógica às relações de trabalho, definindo os novos profissionais, a nova ética de trabalho, em suma, um outro mundo, que mal deixa entrever os sinais do que se convencionou chamar no passado de "jornalismo". (MARCONDES FILHO, 2009, p.36-37).

Todas essas mudanças, que no nosso entender são mais frutos de um desenvolvimento histórico do que uma ruptura totalmente diferente do passado, têm muito a ver com um processo de racionalização do trabalho jornalístico que começa com o Projeto Folha na década de 1980, que tem suas raízes nos anos 70 com Cláudio Abramo $^{11}$ e é retratado por Silva (1988). Demissões, regras, a chegada do computador e a informatização das redações. Mudanças essas que alcançarão toda a imprensa, tanto as organizacionais quanto as editoriais.

No final dos anos 80 o "Estadão" procedia à sua reforma editorial, e "O Globo" saía da toca para disputar o mercado do jornalismo de opinião. Todos buscavam seguir os princípios consagrados pela "Folha", como um time mais diversificado de colunistas e um apelo às manchetes fortes, o "Estadão" menos, o "Globo mais, embora sem a quantidade e a abrangência de posições dos colunistas da "Folha". (NASSIF, 2003, p.16)

De um ponto de vista histórico, é preciso olhar para a reestruturação do trabalho jornalístico a partir da experiência do Projeto Folha, que Silva (1988, p.20) assume ter tido um custo humano não desprezível, mas que procurou elevar o nível da qualidade no jornalismo. Um discurso de caráter organizacional. "Sou favorável à ideia de que a adoção das técnicas e métodos de organização é importante para a obtenção de um bom produto jornalístico nas sociedades de mercado" (Ibid., p.36).

Segundo Silva (1988, p.47), em 1984, “o documento do Conselho Editorial 'A Folha depois das diretas-já' consolida o projeto editorial do jornal e define questões

\footnotetext{
${ }^{11}$ Segundo Kucinski (1998, p.65), Cláudio Abramo é o formulador do Projeto Folha e dele afastado em 1977 ao ser demitido do jornal, "morrendo amargurado e marginalizado da grande imprensa". Mais adiante afirma: "O Projeto Folha começou com Cláudio Abramo, fato que Carlos Eduardo procura ignorar em seu livro Mil dias: os bastidores da revolução em um grande jornal. O livro póstumo de Cláudio Abramo, A regra do jogo, revela um jornalista extremamente contraditório, um homem não realizado e até infeliz. Um homem fiel ao paradigma da esquerda humanista, mas ao mesmo tempo com raiva das esquerdas. Cláudio Abramo desperdiçou energias tentando inutilmente reeducar os donos da imprensa brasileira, fazer deles uma elite educada para o espaço público republicano e o compromisso social. (...) Cláudio Abramo não só não conseguiu reeducar sua burguesia como parecia esmagado pelo crescimento do monstro que ajudara a criar com o seu projeto de reforma da Folha de S. Paulo de 1978" (Ibid., p. 73-74).
} 
técnicas e organizacionais como prioridade da redação". Assim abordava temas como "problemas de estrutura jornalística", "críticas ao fluxo interno" e "preocupação com o cumprimento dos cronogramas industriais". Também reclamava da falta de "mecanismos de controle" e pedia intransigência técnica aos jornalistas e desenvolvimento profissional.

Outros documentos importantes para o projeto, apontados por ele, foram: "Levantamento de pontos indicativos de posição editorial e avaliação sintética do momento político" de 1978; "A Folha e alguns passos que é preciso dar" de 1981; "A Folha em busca do apartiarismo, reflexo do profissionalismo" de 1982; "Projeto Editorial da Folha - 1985-1986" de 1985; e "Projeto Editorial da Folha - 1986-1987" de 1986 (Ibid., p.68).

Já Ribeiro (2001, p.66) destaca que o documento da consolidação, o de junho de 1984, falava da necessidade de substituição de profissionais, pois não haveria "tempo nem condições materiais para adestrá-los". Como jornalista, afirma ter vivenciado "uma tarefa mental submetida a normas industriais, um ritmo de trabalho frequentemente embrutecedor e relações tensas" (Ibid., p.14). É interessante notar o uso do verbo adestrar, tirando a dimensão humana e subjetiva dos profissionais, que perdem a necessidade de reflexão e podem ser treinados como animais.

$\mathrm{Na}$ entrevista que nos concedeu, Ricardo Kotscho também fez uma análise crítica do que vivenciou no Projeto Folha:

Eu peguei o começo, foi em 1984, logo depois da Campanha das Diretas e me rebelei. Eu fui um dos, vários outros também se rebelaram naquela época. Eu me recusei a ler o manual de redação que a gente chamava de manoel da redação, eu não li. E aconteceu o seguinte, foi realmente uma demonstração de força da nova direção, do Otávio Frias Filho, que assumiu o comando da redação, aliás, do jornal era o pai dele. Um jornal que era um jornal de autor, quase todas as matérias eram assinadas, e o estilo de cada um era respeitado, passou a ser um jornal padronizado e sem assinatura nenhuma, de um dia pro outro. Até foi engraçado porque na semana que isso aconteceu uma jovem repórter chegou e falou pra mim - Kotscho, vem cá, essa matéria aqui foi você que fez, não foi? Falei - Fui, mas como você sabe, não está assinado? Porque o que você fez, do jeito que você fez, se fosse eu, tinha sido mandada embora, você não, você, eles publicaram. Mas algum tempo depois eu achei que era hora de ir embora, anos depois eu acabaria voltando. Ali foi realmente uma ruptura, foi uma padronização do texto. Aquilo que hoje se generalizou na imprensa brasileira, o pensamento único. A imprensa do pensamento único. Então você tem pouca diferença entre O Globo, entre os grandes jornais, o Estadão e a Folha, que são os três jornais nacionais, pouquíssimas diferenças nas revistas, nas televisões, é um pensamento único e antes era muito mais variado. Dentro de cada 
empresa, cada um de nós tinha o seu espaço, o seu jeito de trabalhar, que era respeitado assim e de uma empresa pra outra. Era bem diferente - Ricardo Kotscho.

O próprio estabelecimento de avaliação de desempenho levou às demissões. Em 10 de julho de 1984, 27 jornalistas, que correspondiam a 10\% do efetivo jornalístico do jornal em São Paulo, foram demitidos e trocados por pessoas de fora (SILVA, 1988, p.77). A justificativa era a de que eles estavam abaixo das exigências de qualificação do jornal. Já o enxugamento devido à modernização pôde ser visto, por exemplo, em 1983, quando 72 jornalistas da equipe de revisores foram demitidos após a instalação de terminais de computadores, de forma pioneira (Ibid., p. 57).

Na Folha, havia uma Secretaria de Produção que implantou uma planilha "para o acompanhamento da evolução de cada reportagem ao longo do dia". Era função dessa secretaria "normatizar o trabalho jornalístico" e discipliná-lo. Contabilizava-se "o número de erros por edição e por redator, gerando um relatório diário, apelidado de pelourinho ou superego". Os jornalistas eram avaliados individualmente e recebiam notas numa reunião mensal dos editores. Também se estabelecia um Plano de Metas Trimestrais. (RIBEIRO, 2001, p.69)

A Filosofia quantitativa da FSP atingiu um ponto alto em 1984, com a implantação de fichas, nas quais os jornalistas recebiam avaliações $\mathrm{A}$, B ou C, em fevereiro de 1987, essas notas ganharam gradações: A1, A2, B1, B2 e C. A reunião em que era feita a avaliação foi-me descrita por um editor como 'sessão de tortura'. Verifiquei, em minha experiência, que essas fichas não serviam de base para demissões ou promoções - sua finalidade alegada - e seu conteúdo rarissimamente era informado aos interessados, o que leva à conclusão que tinham a função ritual de instrumento de pressão. (RIBEIRO, 2001, p.120)

A avaliação individual continuou sendo usada na Folha, com pequenas variações ao longo do tempo, conforme relatado pelos entrevistados para a pesquisa, o que será mostrado no tópico sobre pressão e ritmo de trabalho baseado nas entrevistas. A rotatividade de profissionais que marcou o projeto é algo que também se perpetuou no jornalismo assim como o fantasma da ameaça das demissões e a culpabilização do indivíduo - se ele foi demitido é porque não era capaz. Até mesmo o discurso sobre o prestígio de trabalhar na Folha, que foi relatado por nossos entrevistados, remete àquela época, assim como outros argumentos questionáveis sobre liberdade editorial e salários superiores. Tudo para justificar a adesão total que é exigida:

Os jornalistas da Folha ouvem com frequência nas reuniões periódicas das equipes que as condições de trabalho no jornal são provavelmente 
mais difíceis do que em outros veículos de comunicação. Os secretários de redação e editores repetem sempre, diante do lamento dos jornalistas, que as condições dadas na Folha são essas: ganha-se um salário hoje superior ao pago pelos outros jornais diários, desfrutase de liberdade editorial sem similar na imprensa contemporânea deste país, participa-se de um projeto jornalístico de envergadura, adquirese prestígio profissional pessoal, mas paga-se o ônus das dificuldades de infraestrutura, das exigências redobradas, da cobrança dura, do ritmo mais acelerado, das padronizações obrigatórias. (SILVA, 1988, p.112)

Todo esse processo vivenciado pela Folha assume a influência da racionalização do trabalho, oriundas do taylorismo e do fordismo. Silva (1988, p.135141) relata que em 1985 foi estabelecido o Plano de Metas Trimestrais, que foi influenciado pelo livro "Iacocca: uma autobriografia", de Lee Iacocca, que trabalhou na Ford e na Chrysler. Outra influência foi a do pedagogo americano Robert Mager, que teorizava sobre planejamento educacional. No Plano, cada editoria se reunia para fixar suas metas e depois avaliava se foram cumpridas. Passou-se a contabilizar os erros e estabelecer metas para gráficos e horários de fechamento.

$\mathrm{Na}$ avaliação de Oliveira (2007, p.175-177), a Folha tentou fazer com que os jornalistas desenvolvessem uma disciplina fabril com a adoção de novos hábitos de trabalho. Além de impor um novo ritmo, a disseminação dos valores do projeto visava “mudar a 'mentalidade' e auto-representação dos jornalistas em relação ao próprio ofício, migrando de uma concepção romântica para outra, compatível com os requisitos da produção moderna e industrial". Assume-se uma concepção mercadológica em que o jornalismo é um negócio, o que sofria certa resistência na época. A autora percebe uma mudança de paradigma nos anos 1990, no documento editorial de 1997, com um discurso de qualificação, aprimoramento técnico e intelectual. Podemos dizer que as técnicas toyotistas passam a ser valorizadas:

Se na década de 1980, Frias Filho, sem meias palavras, fazia referência ao "taylorismo" implantado na redação, o discurso da Folha, no texto de 1997, reverencia explicitamente os programas de qualidade dos paradigmas emergentes de organização do trabalho e assume a necessidade dessas iniciativas - que se converteram em "imperativo de gerência empresarial" - serem adaptadas à esfera das redações. (OLIVEIRA, 2007, p. 176)

A década de 1990 é o período em que o neoliberalismo ganha força no Brasil. A flexibilização começa a galgar seus espaços, e a empresa de comunicação vai aderir a esse processo. Lembrando que o pós-fordismo não traz uma ruptura. São as técnicas 
para gerar adesão que se aperfeiçoam, e o sentido que o trabalho tem para os jornalistas facilita a aplicação dessa nova organização.

Heloani (2005, p.149-152) afirma que há uma necessidade de se adaptar às novas tecnologias implementadas pelas empresas, trabalha-se por mais horas sem receber nada a mais por isso, vive-se em ambientes de submissão e isolamento, em que o rompimento de vínculos desencadeia para o assédio moral. Esse cenário que permeia os ambientes de trabalho, no geral, está presente no jornalismo.

Ao entrevistar 44 jornalistas (24 homens e 20 mulheres) e depois realizar entrevista em profundidade com metade dessa amostra, Heloani (2005, p.157-161) aponta que os jornalistas reclamam de falta de tempo para a família, falta de dinheiro, condições penosas de trabalho, acúmulo de funções e enxugamento das redações.

Da fala desses narradores podemos inferir que, principalmente no início da carreira, as condições de trabalho são bastante desfavoráveis e penosas, sendo que quase todos profissionais da área jornalística apresentam elevado turnover (às vezes 7 a 8 empregos) na busca de novas oportunidades e melhores condições de trabalho.

(...)

Observamos a diversidade de funções e ocupações dentro da área do jornalismo. Ademais, um depoente nos tenta alertar para os perigos da polivalência e multifuncionalidade que caracterizam o "jornalismo pós-fordista" ou "pós-reestruturação produtiva". Parece-nos evidente que as mudanças no mundo do trabalho, em termos tecnológicos, impactaram de forma negativa a qualidade de vida dos trabalhadores jornalistas... (HELOANI, 2005. p. 159)

O autor (Ibid., p.165) conclui a deterioração da qualidade de vida no trabalho se naturalizou. Em sua avaliação, o trabalhador-jornalista se vê obrigado a negociar sua força de trabalho para sua subsistência. "As organizações, pressionadas pelo processo de globalização, substituem cada vez mais o homem pela máquina, implementam novas tecnologias e obrigam o jornalista a adaptar-se freneticamente a elas". O resultado afeta corpo e mente, corroborando a "consideráveis níveis de estresse".

Grisci e Rodrigues (2007, p.48) também falam do pós-fordismo no jornalismo industrial. Eles consideram a compressão do tempo com o encurtamento e a supervalorização do tempo de confecção do produto jornalístico, o alongamento da jornada de trabalho e o desmantelamento dos limites entre as funções como características pós-fordistas nas rotinas de produção jornalística.

Para esses autores, "a sobreposição/supressão de funções e o processo multimídia permitem diminuir a alienação do trabalho e das fronteiras, solicitando iniciativa, cooperação, domínio do processo, tomada de decisão, envolvimento afetivo, 
mobilidade" (Ibid., p.52). Essa afirmação, no entanto, deve ser relativizada, pois esse é o discurso que a organização do trabalho pós-fordista se utiliza para ter a adesão dos trabalhadores. Na prática, significa trabalhar mais, ter mais funções a desempenhar, menos tempo para refletir.

Também não significa que não haverá um estranhamento em relação ao produto final. Ter ou não o trabalho alienado tem muito mais a ver com o sentido que se atribui ao trabalho realizado e com se reconhecer no produto finalizado. Participar de mais etapas não significa automaticamente esse reconhecimento. Ao fazer o trabalho o mais rápido possível e exercer várias funções sem tempo para refletir pode haver alienação.

Vemos que há uma relação direta da produção em comunicação com as forças produtivas e o trabalho. Williams (2011) traz uma perspectiva materialista histórica, a qual é obscurecida quando se reduzem os meios de comunicação a apenas meios de produção social. Também critica o "determinismo tecnológico", uma posição ideológica na qual:

usos e relações sociais são determinados tecnicamente pelas propriedades de meios diversos, desconsiderando o todo complexo das forças produtivas e relações sociais dentro das quais eles são desenvolvidos e empregados. Assim, os meios de comunicação são reconhecidos como meios de produção, mas de modo abstrato, e são de fato projetados ideologicamente como os únicos meios de produção nos quais será produzida a "retribalização", a suposta restauração da "aldeia global"... (WILLIAMS, 2011, p.72)

Williams (Ibid., p.80) destaca que ocorrem "alterações nos meios de produção de comunicação que tanto afetam as relações de classe dentro dos processos quanto conduzem a alterações". A tecnologia avançada se desenvolve dentro das relações sociais configuradas em um sistema capitalista. Percebe-se
a necessidade de enfrentar o pensamento único que legitima a ideia de que a tecnologia é hoje o grande mediador entre os povos e o mundo, quando o que a tecnologia medeia hoje mais intensa e aceleradamente é a transformação da sociedade em mercado, e deste em principal agenciador da mundialização (em seus múltiplos sentidos contrapostos). (MARTIN-BARBERO, 2004, p. 229)

Como vimos, processos de trabalho de jornais e meios de comunicação de massa têm se transformado. Segundo Castells (2009), há redes globais de empresas multimedia que possuem alianças estratégicas, não sendo totalmente global nem excepcionalmente locais. Ao mesmo tempo, a propriedade dos meios está cada vez mais concentrada. Para o autor (Ibid., p.110), a digitalização da comunicação impulsionou a difusão de um 
sistema de meios de comunicação tecnologicamente integrado em que os produtos e os processos se desenvolvem em formas distintas de conteúdo e expressões midiáticas dentro da mesma rede de comunicação global-local.

Scolari (2008, p.200-201), por sua vez, avalia que novos modelos de comunicação participativa trazidos pela internet trazem transformações para a produção de conteúdos: tanto os blogs como os "wikis" desafiam o modelo tradicional de produção de conteúdos de comunicação nos mesmos termos em que o sistema de código aberto questiona a produção centralizada de software. As novas tecnologias não substituem as anteriores e sim transformam o sistema ao atuar entre si e dar lugar a novas configurações.

O autor (Ibid., p.202-204) também acredita que houve um remodelamento da força de trabalho da área de comunicação com a mudança de rotinas produtivas. Houve profunda transformação das rotinas de trabalho dos jornalistas. Os limites que separavam os campos de trabalho se diluem. Há uma convergência profissional. Vive-se uma transição da lógica produtiva.

Essas novas lógicas produtivas requerem "uma força de trabalho flexível, capaz de reinventar-se constantemente para seguir o ritmo do desenvolvimento tecnológico". Os contratos de trabalho são flexibilizados. As práticas realçam a competição, e as velhas leis capitalistas seguem vigentes. (Ibid., p.208-210)

Figaro (2010, p.100) aponta que o potencial da internet está conformado pelas condições objetivas da sociedade: "História e processo produtivo engendram a lógica do papel das tecnologias na sociedade". Do lado das organizações, há uma busca pelas "novidades sem romper com os fundamentos que as estruturam" em um sistema econômico centralizador.

A flexibilização das relações de trabalho e produção caracteriza o pós-fordismo e permeia todas as áreas produtivas, inclusive a indústria da comunicação. Scolari (2008, p. 245) avalia que, na economia pós-fordista em que vivemos, os meios não podem apostar em audiências massivas. Devem-se reconfigurar para abarcar o usuário. Outra marca é a exigência de um jornalista "multiplataforma polivalente".

Assim o autor (Ibid., 206-207) reforça que a digitalização está modificando o contorno laboral e os atores nele envolvidos. Figuras como o revisor tendem a desaparecer, novos perfis como o gestor de conteúdo ou media manager aparecem e profissões como a de jornalista estão sendo modificadas. $\mathrm{O}$ redator deve dominar a produção informativa para um meio caracterizado por hipertextos, que é multimídia e 
requer a gestão de espaços colaborativos. Por outro lado, ele aponta que é cada vez mais difícil encontrar um jornalista que trabalhe em um único meio tanto em grandes grupos como em pequenas empresas, como uma rádio local com sua página na internet. Ao jornalista, exige-se o domínio de diferentes meios e linguagens, e eles assumem funções antes desempenhadas por outros profissionais.

Estudos realizados por Figaro (2010, p.104-106) mostram que o mundo dos comunicadores é "um território em constante transitoriedade". Ela também destaca a exigência do profissional de comunicação ser polivalente e "capaz de transitar por diferentes áreas e competências (das técnicas, das linguagens e das artes)". As empresas exigem habilidades "para produzir enunciados de acordo com os requisitos de diferentes plataformas e dos objetivos de consumo". Outra característica atual é a opção por profissionais de comunicação cada vez mais jovens, que não vivenciaram os processos de trabalho que envolviam tecnologias analógicas. Noções de marketing e comunicação estão entre as exigências para os comunicadores. Há uma tendência em se trabalhar com pequenas equipes multiprofissionais.

No estudo O perfil do jornalista e os discursos sobre o jornalismo, realizado entre 2009 e 2012, coordenado por Figaro, na fase quantitativa, 340 jornalistas ligados ao Sindicato dos Jornalistas Profissionais no Estado de São Paulo responderam a um questionário fechado. No relatório, revela-se que a vida dos entrevistados se dá no espaço de trabalho. A sociabilidade com outros grupos de amizade, além do trabalho, é rara. Nas conclusões gerais da pesquisa, afirma-se:

Os jornalistas estão conscientes de que a profissão mudou muito nos últimos anos, principalmente a partir da introdução das novas tecnologias. Mudaram também os processos de organização do trabalho, que resultaram, para $38,2 \%$, em aumento do ritmo de trabalho e de produtividade, além da redução da mão de obra. A precarização do trabalho, para eles, é causada pela busca do lucro empresarial, o que faz com que as empresas paguem salários menores e economizem em encargos sociais. Com relação ao futuro, $85,9 \%$ acham que a precarização vai aumentar.

Hoje as equipes de trabalho são pequenas ou os profissionais trabalham sozinhos. No exercício da função, sentem falta de conhecimentos técnicos e atualizados, embora se considerem atualizados no desempenho das atividades. (FIGARO, 2009-2012)

Sobre a questão de flexibilidade do trabalho, a pesquisa mostrou entre os jornalistas sindicalizados um total de $42,6 \%$ com registro em carteira, $20,9 \%$ de outra modalidade de vínculo, 19,7\% como pessoa jurídica e 10,3\% de freelancer fixo. 
Em outra pesquisa coordenada por Figaro, "As mudanças no mundo do trabalho nas empresas de comunicação", realizada entre 2005 e 2008, foram entrevistados profissionais de comunicação de uma agência de publicidade e da Editora Abril. Nessa última, 142 questionários foram validados. Também houve uma fase qualitativa com profissionais de outros meios de comunicação.

$\mathrm{Na}$ editora, foi constatado que 31,6\% dos respondentes têm até dois anos de empresa, enquanto $28,2 \%$ estão há mais de 10 anos. Também se percebeu o trabalho em pequenas equipes e dependência de relacionamentos pessoais, apesar da necessidade onipresente de internet. As respostas mostraram aumento das jornadas e do ritmo de trabalho. "A lógica do sistema de trabalho não é a de expansão do número de postos de trabalho, mas sim a de aumento da produtividade, seja pelo número de horas; seja pela aceleração do ritmo, da polivalência e do autocontrole de qualidade."

Os estudos coordenados por Roseli Figaro no âmbito do Centro de Pesquisa em Comunicação e Trabalho da Escola de Comunicações e Artes - ECA/USP também foram apresentados por Figaro, Nonato e Grohmann (2013). Figaro (2013, p.14) reforça a exigência de um profissional "multiplataforma e polivalente": "Dele é exigido que tenha domínio dos mais variados meios e linguagens, assumindo funções desempenhadas antes por outros profissionais (editores, revisores, repórteres, diagramadores, pauteiros)".

Grohmann (2013) olhou para o jornalista como receptor. Já Figaro (2013) apresentou pesquisa, a partir de quatro amostras diferentes ${ }^{12}$, que constata ritmo acelerado e equipes pequenas (Ibid., p.35). O tempo das rotinas produtivas é comprimido (Ibid., p.126). Também falta tempo para refletir (Ibid., p.135). No jornalismo, a maioria é de mulheres, brancas, sem filhos, até 35 anos, multiplataformas e com vínculos precários (Ibid., p.133).

$\mathrm{Na}$ fase qualitativa da pesquisa, a autora (Ibid., p. 50-111) detalha 20 entrevistas, são relatos de precarização do trabalho, trabalho multitarefa e ritmo intenso. O tempo é um fator de pressão, e a agilidade de acesso aos fatos caracteriza o valor notícia, além disso, o ritmo de trabalho e os desafios das novas plataformas aumentam a tensão profissional (Ibid., p.112). A produção de conteúdos é terceirizada e até quarteirizada.

\footnotetext{
${ }^{12} \mathrm{Na}$ fase quantitativa, a amostra contou com 538 respostas de jornalistas de forma consolidada. Os grupos eram de jornalistas captados por redes sociais (26), do Sindicato dos Jornalistas do Estado de São Paulo (340), de empresa editorial (90).
} 
A reestruturação produtiva ocorrida no mundo do trabalho, principalmente a partir dos anos 1990, transformou as relações de trabalho. Foi a partir dessa década que aumentou o número de jornalistas contratados sem registro em carteira profissional, abrindo caminho para novas formas de contratação, como a terceirização, contratos de trabalho por tempo determinado, contrato de pessoa jurídica (PJ), cooperados e freelancers, entre outros. São os jovens, não sindicalizados, que mantêm vínculos precários, trabalham entre oito e dez horas por dia e em ritmo acelerado. O fato de a maioria dos freelancers receberem pagamento a partir de nota fiscal fornecida por um terceiro e trabalharem no setor de revista e Internet dá indicações claras de onde estão os problemas contratuais. (FIGARO, 2013, p.45)

Nonato (2013), por sua vez, apresenta os resultados de pesquisa realizada junto aos jornalistas do Sindicato dos Jornalistas de São Paulo, com a participação de 340 entrevistados da fase quantitativa e de 10 na qualitativa. Também fala do aumento de ritmo e da produtividade e da redução da mão de obra (Ibid., p. 182) e aponta o crescimento do home office -"o sujeito perde a referência do local de trabalho como troca de sociabilidades e autoestima" e "o lar deixa de ser um local prazeroso, de descanso e lazer" (p.195), das PJs e autônomos (p.192).

Já Mick e Lima ${ }^{13}$ (2013) apresentam um perfil sobre os jornalistas brasileiros a partir de pesquisa realizada no Programa de Pós-Graduação em Sociologia e Política da Universidade Federal de Santa Catarina (UFSC). Eles avaliam que nos últimos 20 anos a profissão de jornalista sofreu muitas metamorfoses, e as possibilidades de atuação profissional se reconfiguraram. Figaro $(2013$, p.7) também faz essa mesma afirmação sobre as duas últimas décadas: “As mudanças tecnológicas apropriadas no fazer jornalístico redesenharam as maneiras de trabalhar. As redações ganharam outro formato, outro ritmo, muitas profissões desapareceram".

Os pesquisadores da UFSC também destacam a passagem do jornalismo para o pós-fordismo e a intensificação do trabalho. Entre 1980 e 2010, a partir de dados do Ministério do Trabalho e Emprego, a pesquisa estimou que 145 mil jornalistas obtiveram seu registro profissional (MICK e LIMA, p.28-29). O estudo aponta ainda que $54,5 \%$ dos jornalistas brasileiros trabalham na mídia - "produção de notícias em veículos clássicos, como jornais diários, revistas, telejornais ou radiojornais, ou em novas mídias via internet”.

Dos jornalistas atuantes na mídia, 59,8\% têm carteira assinada... Outros dados demonstram o quanto variadas formas de contratação

\footnotetext{
${ }^{13}$ A amostra mantida para a pesquisa foi de 2674 respostas de jornalistas espalhados por todo o Brasil (MICK e LIMA, 2013, p.30)
} 
têm sido experimentadas no âmbito midiático, o que tem relação com a flexibilização da carreira. Ao somar o número de freelancers $(11,9 \%)$ com os jornalistas que possuem contrato de prestação de serviço $(8,1 \%)$ e os que firmaram contrato de pessoa jurídica, os PJ's $(6,8 \%)$, teremos $26,8 \%$ de todos os trabalhadores de mídia. (MICK e LIMA, 2013, p. 51)

Heloani (2013), que realizou estudos sobre os jornalistas em 2003, 2005 e 2012, destaca a desregulamentação da profissão. O jornalista "é terceirizado, quarteirizado, é contratado por uma equipe que presta serviços para outros". Questões essas trabalhadas no segundo capítulo desta tese, na perspectiva de direito, mas que também são características da organização do trabalho na atualidade, marcada por flexibilizações.

Mesmo aqueles que são freelancers estão submetidos ao ritmo acelerado e à pressão que marca o jornalismo, ainda que trabalhem em casa. Para se conseguir uma renda razoável, é preciso aceitar vários trabalhos ao mesmo tempo. Isso acrescido de outras pressões como a instabilidade salarial, a falta de pagamento e ter que se submeter às condições do contratante, inclusive constrangimentos organizacionais. Se o jornalista contratado é ameaçado pelo fantasma da demissão, o frila é instigado a não dizer "não" a nenhum trabalho, sob a pena de não ser chamado novamente em caso de recusa.

O jornalista freelancer também está exposto à pressão do tempo, ao direcionamento da matéria, às relações com a chefia - no caso o contratante, longas jornadas e irregularidades de horário - ainda mais trabalhando em casa, onde não há fronteira entre a vida pessoal e o trabalho. Figaro (2013, p.135) afirma que "os freelancers são os que mais demonstram sofrer com a falta de prescrições e com a insegurança sobre o quê e como ele trabalhará amanhã". Muitos dos problemas vivenciados por esses profissionais são contados por Oliveira (2010), ainda que o objetivo dele seja mais fazer um manual de sobrevivência aos frilas, é possível inferir do texto questões organizacionais.

...é importante desmistificar a imagem romântica que se faz do jornalista freelancer como um sujeito que sai pelo mundo pautado por si próprio e tem o resultado do seu trabalho disputado por vários clientes em potencial. Não digo que esse estágio seja impossível de alcançar, mas apenas por profissionais que conquistaram um alto nível de reconhecimento - ou por aqueles que receberam uma bela herança e não têm que se preocupar com contas. $O$ normal é trabalhar predominantemente sob demanda, cumprindo missões definidas pelo contratante. Nesse meio-tempo, consegue-se emplacar uma ou outra ideia própria.

Quem é frila em tempo integral e precisa correr atrás de dinheiro para pagar as contas não pode se dar ao luxo de fazer apenas o que quer. (OLIVEIRA, 2010, p.13) 
O cenário de trabalho do jornalismo também conta com um aumento de ritmo gerado pela convergência entre mídias clássicas e novas mídias. Segundo Mick e Lima (2013, p.54), há uma pressão para que o jornalista produza para as novas mídias, “cuja linguagem e know how ainda estão em desenvolvimento", o que gerou uma necessidade de adaptação rápida ao trabalho em sites, podcasts, videocasts, blogs, entre outros, sem especialização ou aprofundamento. Também perceberam um acúmulo de funções, o que vai ao encontro do discurso de profissionais polivalentes:

Dos jornalistas que trabalham em mídia no Brasil, 84,3\% fazem reportagem, $83,1 \%$ fazem redação, e $67,9 \%$ fazem edição, embora só $46,5 \%$ sejam contratados como repórteres e $20,6 \%$ como editores. Têm, como parte da atividade, a produção de pautas $70,6 \%$ dos jornalistas de mídia, enquanto $35,4 \%$ fotografam, $18,1 \%$ diagramam, $16,5 \%$ fazem assessoria de imprensa, $14,1 \%$ fazem cinegrafia, $14 \%$ estão envolvidos com a gestão e $4,2 \%$ com atividades de ensino e formação de outros profissionais. Nota-se aqui, claramente, que captar imagem ou vídeo deixou de ser uma função exclusiva de repórteres fotográficos e cinegrafistas. (MICK e LIMA, 2013, p. 58)

Nos próximos tópicos, retrataremos o que os 21 entrevistados desta pesquisa falaram sobre organização do trabalho. Elegemos seis temas a serem retratados em três tópicos: pressão e ritmo de trabalho; impacto das novas tecnologias; rotinas, relações e limitações do trabalho do jornalista.

\section{5 - Pressão e ritmo de trabalho}

A pressão do tempo e do fechamento, o ritmo de trabalho intenso, a tensão constante são características que marcam o trabalho do jornalista. Ribeiro (2001, p.100) ouviu de seus entrevistados que o ritmo de trabalho e a interiorização "de procedimentos de reportagem e redação criam uma segunda natureza, que desestimula a experimentação de possíveis formas de expressão". Há um misto de aliciamento do trabalhador jornalista com coerção, mantida por ritmo, exigências e métodos de produção industrial e de exploração comercial (Ibid., p.154). O ritmo de trabalho também "é marcado por uma tarefa movida a solavancos e arranques, entremeados de fases de marasmo" (Ibid., p.136). É no fechamento que o ritmo de trabalho se acelera (Ibid., p.178). 
O trabalho jornalístico é condicionado pela pressão das horas de fechamento, pelas práticas levadas a cabo para responder às exigências da tirania do fator tempo, pelas hierarquias superiores da própria empresa e, às vezes o(s) próprio(s) dono(s), pelos imperativos do jornalismo como um negócio, pela brutal competitividade, pelas ações de diversos agentes sociais que fazem a "promoção" dos seus acontecimentos para figurar nas primeiras páginas dos jornais ou na notícia de abertura dos telejornais da noite. (TRAQUINA, 2005, p.25)

Os entrevistados desta pesquisa, de forma geral, apontaram que o ritmo e a pressão se intensificam no fechamento ou quando realizam uma cobertura especial. Essas questões também foram relacionadas, em alguns momentos, ao sofrimento assim como havia ocorrido com as longas jornadas e a falta de cumprimento de direitos, sendo esse último ponto especialmente destacado entre os jornalistas com até 45 anos. A pressão e o ritmo intenso também fazem parte da memória dos jornalistas com mais experiência. Já a questão da polivalência e da multitarefas apareceu na fala de alguns entrevistados. De certa forma, a pressão, que é internalizada, aparece como parte do trabalho jornalístico. Há pressão do tempo, dos prazos apertados, das chefias, da exposição, da audiência, de não errar, do próprio conteúdo do trabalho e do inédito do real - pensando nas colocações de Dejours.

Entre os mais velhos, as coberturas de fatos que marcaram a história são lembradas como momentos em que o ritmo se intensificou. Clóvis Rossi, por exemplo, na cobertura da doença de Tancredo Neves trabalhou pelo menos três semanas, durante todos os dias, de manhã até a noite. "No último dia, no último fim de semana que ele acabaria morrendo, o jornal resolveu me dar uma folga, porque achou que corria mais risco de eu morrer do que ele, de tanto trabalho, tanto cansaço, porque eu era um pouco coordenador da cobertura em campo", recorda. Ele buscava compensar os excessos de trabalho tirando uma folga ou diminuindo o ritmo: "Pisava no breque, trabalhava menos nos dois ou três dias seguidos a uma grande cobertura".

O ritmo também foi intenso nos momentos que exerceu a função de correspondente internacional: "Como correspondente, você tem que estar 24 horas por dia alerta, atento". No período em que trabalhou em revistas, não sentiu diferença de ritmo, o que justifica por uma característica pessoal: "Eu trabalhava com a mesma volúpia, o mesmo ritmo, mas por vício, não por necessidade imposta pelo ritmo da revista".

Os jornalistas de certa forma são condicionados a trabalhar muito e isso é naturalizado como uma necessidade da profissão. Seguir o ritmo é uma exigência para 
ser aceito e se manter trabalhando, além disso, é um reconhecimento de ser bom profissional. Isso é internalizado, como mostra a declaração de Rossi, e o jornalista exige muito de si: “A pressão foi sempre minha mesmo, eu sempre me pautei para fazer o melhor que eu pudesse fazer e sempre exigi de mim muito". Ele conta que sempre trabalhou com a perspectiva de que algo na cobertura poderia dar errado: "Então me agoniava permanentemente. Saía para todas as coberturas como se fosse a primeira vez, inseguro, achando que um dia podia fazer uma besteira, não conseguir todas as informações necessárias". As afirmações mostram o quanto o sofrimento está presente no trabalho do jornalista, na defrontação com o fracasso e com o inédito do real, presente em cada cobertura.

O jornalista do dia a dia sofre uma pressão muito grande no exercício da profissão, porque ele está sujeito à pressão dos fechamentos, aos prazos de fechamento, a corrida atrás da notícia, e hoje, um trabalho cada vez mais complicado, porque as redações estão cada vez mais enxutas e isso obriga que um jornalista, um repórter cumpra pautas que vão além até daquilo que se esperava para um trabalho perfeito. $\mathrm{Na}$ maioria das vezes, os temas são abordados por telefone, o que é uma coisa lamentável, não é absolutamente recomendável, e algumas vezes, o que é pior ainda, pela internet. Isso prejudica evidentemente uma apuração mais detalhada, mais apropriada da coisa - Audálio Dantas.

Das suas experiências no passado, Dantas, que começou no jornalismo na década de 1950, recorda que o ritmo também era grande no passado porque havia os jornais vespertinos. "A Folha da Noite fechava por volta das $11 \mathrm{~h} 30$, meio-dia, porque saía quase no final da tarde. Isso obrigava uma corrida muito grande. Raramente se faziam matérias por telefone". Era preciso ir "ao encontro dos fatos, dos acontecimentos, das entrevistas e era uma corrida permanente inclusive na cobrança em relação ao horário, de entrega, essa cobrança era feita". O secretário de redação costumava gritar com os repórteres: "Como é? Sai ou não sai? Uma pressão muito forte". Esses primeiros anos de trabalho na Folha são caracterizados por ele como um período de "uma angustia muito grande". Ele conta uma dessas histórias:

$\mathrm{Eu}$ fui fazer uma solenidade qualquer no Palácio do Governo do Estado, que era por sinal pertinho da Folha, na Barão de Limeira, era no Palácio dos Campos Elíseos. O governador era o Jânio Quadros, um sujeito complicado. Ele anunciou qualquer coisa, nem me lembro o que era. Aí eu voltei correndo a pé, botando o coração pela boca, e cheguei em cima do fechamento. Faltavam 15 minutos, então tinha que fazer aquela notícia, era notícia importante, e eu fui pra máquina de escrever, com muita, muita angústia, claro. Bom, terminei e botei um título assim - Jânio diz que, qualquer coisa desse tipo, e entreguei. E o cara gritando - E o seu texto não vem? Entreguei e voltei pra mesa 
e ele gritou - Aqui nesse jornal enquanto eu for o secretário, governador é senhor, hoje em dia, até eu me vanglorio, acho que eu estava adiantado no tempo, porque imagine - o senhor Jânio Quadros diz. Mas essa era a norma. Aí eu disse - Tá bom, faça o título você. Foi um negócio assim, uma discussão brava. Saí, fui pro banheiro, e daqui a pouco ele chega (risos), no ato do xixi - Eu sou um cavalo. Eu disse - É mesmo (risos). Você tem razão, você é um cavalo (risos). Quer dizer, essas discussões em redação eram muito comuns naquela fase. Hoje em dia eu não sei, eu estou longe. Segundo o Joel Silveira, as redações viraram coisas assépticas, silenciosas, nos computadores. São redações bem mais comportadas - Audálio Dantas.

Para Alberto Dines, a pressão seria insuportável se você não fizesse o trabalho "com prazer, com devoção, com empenho". "Você ficar trabalhando em jornalismo, dentro do ritmo e das exigências profissionais, se você não gostar e estiver empenhado naquilo, fica insuportável, agora se você gosta, é um vício, você não consegue largar”. O sentido do trabalho e o prazer que o jornalista obtém fazem com que suporte a pressão e o ritmo acelerado.

O jornalista de 82 avalia que as empresas jornalísticas limitam a qualidade do trabalho do jornalista, que não pode perder tempo com a matéria e "não pode gastar muito dinheiro senão estoura orçamento". O trabalho em jornal diário é muito estressante. Mesmo jornalistas chamados bem sucedidos, na visão de Dines, que trabalham para vários veículos, como rádio e TV, trabalham como loucos. "Eles ganham muito bem, mas são literalmente sugados pelas empresas”.

Aureliano Biancarelli recorda que os momentos mais pesados eram os fechamentos e havia a pressão do horário diariamente no jornal para que a matéria estivesse na mão do editor a tempo. Já na Veja, em meados dos anos 70, a revista fechava de sexta para sábado: "Você começava de manhã como repórter, mas depois você tinha que esperar o fechamento que ia até de manhã no outro dia". Na Folha, ele também viveu o pescoção: "Dependia muito do editor esse ritmo que era imposto. Tinha editor que fazia questão de dizer que enquanto não amanhecesse o sol do sábado ninguém saía. Era um prazer você poder tomar café na esquina do jornal”. A pressão maior para ele era do controle de qualidade do jornal. Eram mecanismos que criavam um clima muito tenso, o que será discutido mais adiante.

Havia um mural onde algumas matérias eram expostas. No começo chegavam a tirar o nome da pessoa, mas a gente sempre sabia quem tinha feito o erro que estava lá exposto. Então tinha essa questão de exposição pública da sua falha, que pesava como uma pressão muito grande. O resto, essa coisa de ser chamado a qualquer hora do dia ou da noite, acontecia também comigo que trabalhava numa área mais específica, mas isso ainda continua, o jornal tenta chegar primeiro ou 
pelo menos a tempo de recolher o mínimo de informação de um fato que está começando a acontecer. Eu trabalhei por acaso nas grandes tragédias que São Paulo viveu, a começar pelo edifício Joelma, aqui no Centro, em 1974, estava no meu primeiro ano de trabalho, estava na revista Veja. Depois passando pelo Andraus, pelo Carandiru, pela queda do boeing da Tam, pela explosão do shopping de Osasco, que eram dias especiais, você realmente tinha que seguir outro ritmo. Todo mundo entrava nessa história. E havia muito cruzamento de informação, havia falta de comunicação, depois as coisas foram mudando com celular. Hoje o editor pode monitorar onde você está e refazer a pauta que distribuiu pros repórteres cobrirem o mesmo fato, em diferentes locais, diferentes funções. Quando não tinha o celular ainda era às escuras, o que a gente tinha no final do dia, começo da noite - Aureliano Biancarelli.

Para Biancarelli, "há uma pressão natural que independe do jornal querer ou não, o jornal tem que ser fechado em tal horário e, muitas vezes, o fato em si se expande e você tem que interromper a sua matéria em algum momento". Na avaliação dele, hoje há mais recursos para o jornalista se informar sobre o tema que vai cobrir, como a internet e o celular. Por outro lado, o repórter precisa alimentar o noticiário on-line e se preocupar em obter imagens.

Lúcio Flávio Pinto também vê uma pressão constante no jornalismo, quando se trabalha com a "linha de frente", o que inclui matérias exclusivas fruto de investigação e que vão contra os interesses hegemônicos. No caso dele, até com ameaças e agressões físicas, tanto quando trabalhava em jornal diário quanto no alternativo, o Jornal Pessoal. Ele já chegou a fazer 10 matérias em um dia, pois sempre teve um ritmo intensificado. Já sobre a pressão atual ele destaca os 33 processos na Justiça que precisa enfrentar e que considera uma tentativa de intimidação ao seu trabalho.

Trabalhar e escrever muito é característica de outro jornalista da antiga geração: Ricardo Kotscho. "Sempre fui muito caxias. Então mesmo quando eu terminava o trabalho, eu continuava na redação, me oferecia pra ajudar. Saía da redação e continuava discutindo jornalismo. A gente ia pros bares, hoje não tem mais isso". Ao longo da carreira, vivenciou vários tipos de pressão: da censura e do governo militar, das chefias, do tempo, que inclui chegar a locais de difícil acesso e voltar a tempo de escrever o texto.

Eu gosto sempre de dar um exemplo, chegaram a me pedir uma vez uma matéria na Folha de S. Paulo contra determinado personagem. Eu sabia que aquela coisa não era verdadeira, e eu não iria fazer a matéria. Pediram pra outro repórter que se recusou também. Pediram pra um terceiro que se recusou, o quarto fez. Então tem isso, a pressão depende do jornalista também. Eu não quero dar uma de herói. No 
meu caso eu até sou bastante medroso, mas eu sempre procurei impor os meus princípios. E em último caso, quando não era possível, eu pedia demissão. Eu brincava, eu demitia a empresa. Eu não aceitava imposição, pressão, escreva isso, isso aqui pode, isso aqui não pode, eu nunca aceitei. Muitos colegas meus aceitavam e até gostavam disso, porque mostravam serviço e achavam que assim subiriam na carreira mais depressa. Os carreiristas sempre existiram. Eu acho que eles se disseminaram hoje, virou uma coisa mais generalizada o que antes era uma exceção - Ricardo Kotscho.

Outro relato de ritmo intenso em jornal diário foi o de Paula Puliti. O início da carreira nos anos 1990 na Folha e no Estado era tão pesados que ela chegou a pensar em desistir do jornalismo. "Na Folha de S. Paulo era muito intenso, eu era repórter de saúde. E eram todo dia duas ou três matérias. Era cansativo. Algumas caíam. Era muito puxado. Por isso que o jornalismo está cheio de gente mais moça, porque tem energia". $\mathrm{Na}$ época, havia a pressão da competência, era a palavra da moda, além das pressões já relatadas de horário, fechamento e produtividade.

Fernanda Cirenza começou a trabalhar um pouco antes na Folha, em 1988, e caracteriza a pressão vivenciada em jornal diário como industrial. O jornal tem horário para fechar e não pode atrasar para cumprir a complexa logística de ir para gráfica e sair a tempo de ser distribuído para todo o país. "Na Folha, você é pressionado pelo relógio, porque você tem que colocar o jornal pra rodar naquele horário, porque senão ele não vai chegar ao Acre e isso vai dar um prejuízo financeiro para a empresa que você trabalha. Isso é uma pressão bem complicada”. Nos anos 2000, já na revista Marie Claire, ela avalia que o ritmo era diferente, apesar de também haver a ebulição da redação. A variedade de temas abordados pelo jornal fazia com que o clima fosse mais intenso.

Também com experiência em jornais e revistas Bob Fernandes avalia que a pior pressão é a que ele chama de "power games", disputas inúteis de poder, que são para ele o que estressam no trabalho. "O meu foco é produzir, fazer. Você pode ser um chefe duro, brigar, mas o joguinho é o que atrapalha tudo, o joguinho estraga uma redação, derrete o ambiente". A competição também pode funcionar como pressão no trabalho. “Um lugar onde o terror é a norma, um vigia o outro, a competição é ultra estimulada, isso pode funcionar nas cabeças doentias, eu sou contra. Isso tolhe a liberdade de produzir, isso na verdade é um instrumento de dominação ideológica". Para o jornalista, ninguém arrisca nesse tipo de ambiente. "No fundo, vira um aprisionamento grotesco. 
Então essas são as questões desgastantes. Eu tenho um prazer extraordinário com coisas legais, se tiver um ambiente legal, para mim o ambiente vem em primeiro lugar".

O ritmo e a pressão também podem variar com a gestão em um mesmo local. Foi isso que Marilu Cabañas vivenciou em diferentes fases na rádio Cultura. Momentos de autonomia e criatividade que foram cortados quando se mudou a gestão da emissora, por exemplo, após a morte de Mário Covas. Da qualidade, passou-se para o padrão quantidade. Outro tipo de pressão é aquela natural do rádio, a tensão da notícia, de entrar ao vivo. $\mathrm{Na}$ Bandeirantes, por exemplo, ela cobria um sequestro, em que a vítima podia ser resgatada a qualquer momento. A jornalista estava em frente à casa da pessoa, mas saiu para fazer outra matéria e perdeu a chegada. "Eu fiquei mal pra caramba, eu chorava. Fui lá, pedi pra empregada chamar o cara. Não adiantou, lógico". Já no SBT havia uma pressão do tipo de jornalismo praticado, como em uma cobertura de um enterro de uma criança vítima de uma explosão de carro, em que ela se recusou a filmar escondido como a chefia queria, já que não houve a autorização da família, que estava incomodada com o canal de TV, que havia filmado a cena da explosão e a transmitia várias vezes ao dia como chamada do Aqui Agora. "Pressão nesse sentido, que você quer de um jeito, o chefe quer de outro. Ele acha que você tem que estar de um lado, você acha que não, que tem que mostrar o que está rolando lá, enfim, tem pressão".

O ritmo também tem se acelerado devido às redações terem menos jornalistas e pelo estresse gerado por estar ligado a várias mídias - jornais impressos, redes sociais, blogs - na avaliação de Antonio, de 40 anos. Ele também fala da competição estimulada pelas empresas com suas avaliações, das pressões da chefia e da empresa por produtividade e qualidade, "sem oferecer nada em contrapartida". A pressão do público é algo novo que ele acrescenta que não foi relatado pelos jornalistas com mais de 45 anos. A multitarefa também aparece nessa fala, do jornalista que se pauta, escreve, edita e fotografa.

Para Ivan Marsiglia, 43 anos, a multifuncionalidade é uma falácia. Se um jornalista tem que fazer tudo, o resultado final será pior. O ideal, para ele, seria cobrir uma quantidade menor de temas e focar na qualidade. Mas o cenário que tem acompanhado nos últimos quatro anos é o de acúmulo de funções, não só oriundo dos cortes de pessoal, mas também da "sinergia com o digital, que é exigida do jornalista do papel”. Assim o jornalista deve fazer contribuições para a internet, para o rádio, para a TV, para todas as mídias que o jornal produz. 
Marsiglia também fala da pressão interna de si mesmo, como Clóvis Rossi. O jornalista é um profissional que se cobra muito. Em relação ao ritmo, considerando a experiência de amigos, afirma que o jornalismo de revistas semanais é complicado porque se exigem reportagens de fôlego. No jornalismo diário, apesar do ritmo intenso, "você mata um leão por dia" e "não dorme com sua matéria".

Estou agora nos últimos seis, cinco anos, num ritmo de jornalismo semanal, que é pesado, ele é muito concentrado no final da semana, próximo do fechamento do caderno ele é desgastante, mas no geral você tem mais tempo para trabalhar os temas e isso me traz mais alegria. (...) O ritmo mensal eu acho que é o mais interessante do ponto de vista da qualidade de vida, porque te permite fazer coisas em profundidade, mas também te dá um espaço de reflexão, que eu acho que é o que falta às vezes, que é o que faz você sofrer - Ivan Marsiglia.

Também com experiência em jornal diário, Pedro, que trabalhou na Folha até o início de 2014, não tem dúvidas ao afirmar: "Existe pressão no meu trabalho, definitivamente, existe (risos)". Assim destaca pressões já apontadas por outros entrevistados: do tempo, do tempo de fechamento, do horário para entregar as coisas, dos prazos apertados, da cobrança de não haver erro. As chefias também costumavam cobrar muito os repórteres, que viviam "sob a pressão do chefe". Havia casos em que até extrapolavam na exigência, gritando com o repórter e exagerando na forma de cobrar o profissional. Outra cobrança, ainda que velada, era para se estar disponível ao jornal a qualquer hora:

Se acontecesse alguma coisa na sua área, por exemplo, um final de semana que você não está [de plantão], você vai lá e você trabalha um dia normal. E se você não for, e falar, não, é o meu dia de folga, não é que você vai ser cobrado ali, mas as pessoas vão olhar com maus olhos. É como se você tivesse que estar disponível a todo momento para o jornal. Eu acho insano isso porque você não tem vida, você já trabalha muito e nos momentos que você está livre, você ainda tem que estar disponível, você fica com a cabeça lá, entendeu. Eu dava uma olhada no site, fazia uma ronda para ver se ia acontecer alguma coisa - Pedro.

Miguel não teve experiência em jornal diário, mas passou por todos os outros veículos de grande mídia. A pressão, para ele, vinha de uma necessidade de agilidade e precisão, de não cometer erros, como na agência de notícias que era ligada a um grande jornal e na internet. $\mathrm{Na} \mathrm{CBN}$, além dessas, havia uma pressão do conteúdo do trabalho e da exposição que o rádio traz. "Apesar de notar que havia um risco, uma pressão maior, eu me dei bem sempre com a pressão mesmo na rádio, acho que teve só uns momentos como repórter que me incomodou mais". Isso ocorria quando ele precisava entrar no ar 
ao vivo em pouco tempo sem ter se preparado o suficiente para falar. Na TV, viveu um ambiente mais carregado, não havia descontração. Outra pressão é a de se ter audiência, que vivenciou mais intensamente nos três portais de internet em que trabalhou.

Ao longo da carreira, Maria lidou com diferentes tipos de pressão. Na época da Radiobras, ela considerava muito estressante cobrir a cada dia um ministro diferente. "A pressão do editor sobre você é muito maior, porque ele sabe que ali tem uma matéria de ministro. E aí você tem a pressão do tempo, que é uma agência de notícias. Tem a sua cobrança porque você não entende daquele assunto". A época do Correio da Cidadania também foi um momento de ritmo intenso e muita aprendizagem, mas muita pressão, por estar em início de carreira e ser a única jornalista do veículo. Atualmente na $\mathrm{EBC}$ ela edita matérias para a radioagência e falta tempo para a demanda de trabalho existente.

Outro jornalista do grupo de 30 e poucos anos, assim como Pedro, Miguel e Maria, Bruno Torturra avalia que a rotina dele como jornalista independente é ainda mais massacrante do que quando atuava em revista. "Eu realmente trabalho 24 horas por dia, porque eu tenho que não só dar conta de uma redação quase que sozinho, mas na época que eu estava articulando com o Fora do Eixo, com a Pós-TV, com a Mídia Ninja, era um trabalho full time". São centenas de e-mails todos os dias e um celular que não para. "Hoje eu trabalho muito mais do que em qualquer época da minha vida em que eu tive um emprego ou um salário". Na Trip, a pressão maior era a dos prazos que precisava cumprir. Também sentiu uma pressão interna muito grande na época em que era diretor de redação. "Me sentia muito mal em ser chefe dos repórteres e dar uma bronca, em falar não, muita dificuldade em não dar um aumento quando me pediam, eu não tinha o controle financeiro da situação, nem poderia ter, era mais nisso". Já na atualidade outras pressões que sofre vêm da ansiedade de seus projetos darem certo e do ataque a sua imagem e pessoa. "Muita gente tenta me prejudicar do ponto de vista de imagem pública, de julgamentos que fazem sobre minha pessoa. Sofri e sofro ameaças de polícia, por conta de trabalhos que eu fiz na Mídia Ninja. Então, eu me sinto sob mais pressão hoje".

Leonardo Sakamoto também sofre pressão pelo trabalho da Repórter Brasil, muito pautado em denúncias, como a do trabalho análogo à escravidão. Essa pressão se manifesta por meio de processos jurídicos. "Quando você está num veículo grande, num veículo de comunicação convencional, a pessoa está te processando, o veículo te abraça e vamos embora. Aqui não, você tem que constituir advogado, você tem que fazer tudo. 
Então é sempre mais complicado". Já das experiências que teve em veículos tradicionais ressalta a "pressão por produtividade, por prazo, por otimização de gastos e por qualidade". Ele também fala da pressão de si mesmo: "uma pressão que você impõe contra você mesmo, então esse tipo de pressão é extremamente violenta".

Dos jornalistas do grupo de 20 e poucos anos, Aline Scarso destacou ter vivido diferentes tipos de pressão nos locais em que trabalhou. Na FIA, onde produzia conteúdo para internet, sofria pressão da chefia. No Brasil de Fato, era uma pressão salarial. O estresse vinha das incertezas de quando cairia o pagamento. Na EBC, há um pouco da pressão da lógica empresarial. Um problema é que, quando trabalha de produtora, as pautas muitas vezes chegam em cima da hora e ela precisa acelerar o ritmo para dar conta.

Assim como Aline, João avalia que falta planejamento, muitas vezes com o recebimento de pautas de última hora. Na revista em que trabalhava vivenciou algumas situações de pressão da chefia, culpabilização por erros que não cometeu - “O diretor de redação nunca tinha dirigido a palavra a mim... Eu falei que eu não cuidava dessa parte... Eu nem consegui falar direito, fiquei muito nervoso, desestabilizado" e de direcionamento de matérias. Houve um caso em que teve que refazer uma matéria inteira. "Isso me causava um stress psicológico enorme. Em cima da hora, não é normal. Tudo bem que é redação, é jornalismo, a gente sabe de todas as pressões, mas tinha coisas assim...”. Ele define o ritmo de trabalho como intenso. As pessoas tinham medo de questionar as ordens, e as broncas eram naturalizadas. Para ele, os que permanecem nas redações sofrem cada vez mais com as exigências. "Se antes tinham três que faziam, agora tem um que faz. Para o jornalista que está dentro de uma redação, a condição não é muito promissora".

Já Priscilla, como estagiária, produzia de cinco a oito matérias por semana para a internet. Os piores momentos eram os plantões, em que havia número de notas a entrar. Rapidamente era preciso pegar as informações, checar e escrever. "Era um ritmo muito acelerado. Você tinha uma quantidade de notas por dia. Eu não lembro quantas notas eram, mas eram bastantes. Por exemplo, você tinha que entregar uma a cada meia hora". Já nas revistas que trabalha atualmente o ritmo acelera nos fechamentos, que são dois por mês, e quando há acúmulo de trabalho. "Fico bem cansada mentalmente".

Em geral, eu acho que tem pressão, eu acho não, eu tenho certeza absoluta, que tem muita pressão (risos). No meu trabalho lá na Proteção agora eu separaria em dois momentos. Enquanto nos outros períodos eu consigo fazer minhas horas normalmente, no período de 
fechamento, no final de ano, que a gente tem que adiantar o fechamento, e com a feira em que acumula mais material, é muita pressão. Eu não sinto pressão, por exemplo, por parte dos colegas, da chefia, mas é a própria demanda que me pressiona. Por exemplo, no dia que eu passei mal com dor de cabeça. Ficava na minha casa passando mal, preocupada, pensando, amanhã eu tenho que levantar porque eu tenho um monte de coisa pra fazer. Eu acho que isso piora, agrava. Então tem dois momentos distintos, acho que nesses momentos de fechamento, chega a pressão da profissão, que a gente vê a maioria dos colegas, principalmente o pessoal de jornal diário que vive essa correria, essa pressão diariamente. Eu não diria que eu vivo diariamente, mas nesses momentos é muita pressão - Priscilla Nery.

Por fim, Vivian Fernandes relata que no começo de seu trabalho no tablóide Brasil de Fato, de São Paulo, ela "ficava meio paranóica" e trabalhava 24 horas. Havia uma pressão de si mesma para o projeto dar certo, por ser algo novo, e também da expectativa dos movimentos sociais. "Hoje em dia eu acho que o ritmo ainda é um pouco puxado, a equipe ainda precisaria ser maior pra não sobrecarregar ninguém, mas a gente já sabe o que tem que ser feito". Conforme o fechamento, que é semanal, se aproxima, o ritmo de trabalho aumenta. Já quando trabalhou na radioagência havia uma pressão do aprendizado, por ser seu primeiro trabalho. Ela costumava fazer três matérias por dia e se esforçava para fazer o dia render.

O jornalista ainda tem muito aquele glamour de estar cobrindo a notícia..., só que ao mesmo tempo sofre uma precarização absurda. Pelo menos acho que agora os jornalistas estão se ligando disso. Eu acho que a precarização e a pressão vêm tanto da própria empresa, no nosso caso, não a empresa, mas os próprios movimentos sociais pressionam que a gente escreva uma ótima matéria. Aí a gente tem que escrever essa ótima matéria numa situação em que a gente não tem gravador funcionando direito, o telefone dá problemas, você não consegue falar com o entrevistado, você não consegue apurar da melhor forma porque o tempo é muito curto... Eu acho que os jornalistas se cobram muito ou porque estão numa competição real de emprego ou em uma competição hipotética, tipo, eu tenho sempre que ser o melhor jornalista... Então ele tem uma autocobrança muito grande. Ele é toda hora visado pelos colegas, ele é visado pela empresa ou movimentos sociais, e o público hoje em dia está muito mais crítico.... Isso tudo não alterou a condição de trabalho diária, os jornalistas não ganham mais, os jornalistas não têm mais segurança, os jornalistas não trabalham menos horas, os jornalistas não têm tempo a mais para escrever uma boa matéria. A pressão aumentou, e as condições de trabalho, em minha opinião, de certa forma até pioraram... - Vivian Fernandes.

O último aspecto da pressão no trabalho do jornalista que analisaremos é o sistema de avaliação, um instrumento presente em algumas empresas jornalísticas, especialmente, na Folha de S.Paulo. Segundo Silva (1988, p.147), o jornal iniciou a 
avaliação dos profissionais em 1983, o que provocou um conflito entre os jornalistas e a direção. "O objetivo da avaliação era tornar mais transparente e criterioso o julgamento de valor que toda chefia faz de cada subordinado em qualquer agrupamento humano hierárquico."

Pelos depoimentos colhidos nesta pesquisa, esse objetivo de transparência de critérios nunca foi alcançado. As diferentes gerações de jornalistas entrevistados, que passaram pelo jornal ou que conhecem o sistema, posicionaram-se de forma crítica. Os critérios não eram claros, há uma exposição dos jornalistas e uma pressão desnecessária que recai sobre o trabalho, e eles não se sentem a vontade nem em julgar nem em ser julgado.

Os critérios de avaliação estabelecidos em 1984 foram: "domínio de linguagem, empenho, confiabilidade técnica, exatidão, rapidez, senso crítico, disciplina, formação cultural, concisão, iniciativa, criatividade e identificação com o projeto" (SILVA, 1988, p. 148). Em fevereiro de 1985, foram efetivadas "promoções salariais por mérito em função da avaliação do desempenho profissional do beneficiado de acordo com o sistema" (Ibid., p.149). Nesta mesma época, o abaixo assinado dos jornalistas da Folha criticava a forma de avaliação, em que não se sabia quem decide o que era bom e o que era ruim, nem se ouvia o avaliado, além disso, estimulava-se uma competição interna. Em 1987, os conceitos A, B e C passaram a ser divididos em A1, A2, B1, B2 e C (Ibid., p.150).

Aureliano Biancarelli, um de nossos entrevistados que trabalhou na Folha entre 1989 e 2004, relata que havia uma equipe para ler o jornal e verificar os erros. "O repórter recebia um boletim no final do mês com uma nota. Nós éramos avaliados como se estivéssemos na escola, além do português, tinha a questão da informação". Essa tentativa de controle da produção jornalística era criticada pelo jornalista na época. Aqueles que mais fizessem tudo corretamente conforme o manual eram premiados com viagens. "Se você não arriscasse nada, você ficava premiado. Mas eu sempre critiquei”". Houve momentos em que chegavam a ligar para a fonte para confirmar as informações. "A Folha sempre se pautou por esse rigor, que na verdade se mostrou ineficiente. Você via gráficos de queda de número de erros, mas o número de erros nunca caia." Havia ainda um controle sobre a quantidade de matérias produzidas.

Paula Puliti, que trabalhou no jornal no início dos anos 90, via a avaliação como uma forma de pressão para o repórter. "Vai muito se o editor gosta do repórter ou não 
gosta. Eu era uma repórter média." Já Fernanda Cirenza vivenciou o sistema de avaliação por 12 anos:

Tive avaliações melhores, avaliações piores, a Folha, eu não enxergava assim na época, mas ela é uma indústria de informação... Fui avaliada e avaliei muita gente. Os subordinados uma hora passaram a avaliar os editores também... Mas é uma indústria, tipo você produziu x centímetros de texto no mês, está muito, está pouco. E isso era cobrado como é na indústria de parafuso... Elas têm uma meta, e isso acontecia na Folha de fato. Naquele momento, que eu estava lá, eu só me incomodava quando eu era mal avaliada (risos). Era muito chato você receber avaliação. Evidente, se você recebe uma boa avaliação você fica contente, mas de qualquer maneira era tenso, receber a avaliação, abrir o papelzinho, avaliar os colegas. Por mais que você esteja num papel de liderança de equipe, aquele sujeito é teu colega, quer dizer, é muito complicado... Eles computavam o tanto de produção que cada um de nós tinha no decorrer de determinado período, aquilo era discutido, quantos erros de português, gramática, ortografia, concordância, tudo isso era detalhado na sua nota... Depois teve a chegada do ombudsman, que também foi muito ameaçador na época porque tinha uma coluna interna... Depois teve uma época do didatismo... Tinha um mural logo na entrada da redação, exemplos e contra-exemplos, era riscar matéria e eventualmente o mau exemplo era você, era o seu texto. E mesmo quando não era, era ruim, eu não gostava disso - Fernanda Cirenza.

Em seus últimos momentos em Marie Claire, Fernanda vivenciou um sistema de avaliação na Editora Globo. O jornalista também se autoavaliava e avaliava o seu superior. Ela não via sentido nesse tipo de avaliação em uma redação de 20 pessoas. "Na Folha eu ainda via um pouco mais de sentido, porque nós éramos muitas pessoas." Mas depois conclui: "Acho tudo isso uma bobagem".

Já Bob Fernandes critica a impessoalidade da grande corporação e também discorda dos sistemas de avaliação, que considera um fator de estresse e emburrecimento, porque o jornalista é aprisionado. O jornalista fala de um local, sem nominar, em que se estabelece uma tática do medo e do terror. Já de outra empresa afirma: "Todo mundo dá nota pra todo mundo, isso significa que se estabelece uma situação de acordos que inevitavelmente levam a mediocridade".

Entre os mais jovens, João vivenciou um sistema de avaliação na revista de informação. Na época de estagiário, achava importante. Já como profíssional achava que era mais uma encenação para constar. Já Pedro vivenciou o sistema de avaliação da Folha até o início de 2014.

O que é cobrado na Folha é quantidade de erros. Isso eu sempre achei um terrorismo desnecessário. Então, toda edição, eles marcam os erros. E eles associam os erros ao repórter que cometeu o erro pra depois numa avaliação que era feita trimestralmente, eu acho que 
agora é quadrimestral, se não me engano... Essa cobrança de não errar é muito puxada na Folha. Acho que é uma pressão desnecessária Pedro.

Pedro explica que no último ano em que esteve na Folha houve uma mudança no sistema de avaliação. Quando ele entrou, havia uma escala com conceitos como ótimo, muito bom, bom, regular e ruim. "Não me lembro se tinha ruim ou não. Também nunca recebi um ruim, mas se eu recebesse, eu estava fora do jornal (risos)." O jornalista explica como se dava a avaliação na prática:

O editor fazia uma primeira avaliação e escrevia para o repórter tudo que ele tinha feito durante esse período, levantando os pontos positivos, relatando os pontos negativos... Os erros mais graves, menos graves, que ele tinha cometido. Fazia uma avaliação por escrito. Essa avaliação ia pro repórter para ele fazer uma autoavaliação. Então o repórter rebate algumas coisas, não foi bem isso, minha atuação foi boa por causa disso, disso, disso, eu sugeri pauta. Tinha se não me engano, três campos que você tinha que responder, você dizia se o seu trabalho com a equipe foi bom e por que, quais os problemas que você encontrou no jornal, o que te atrapalha no trabalho - Pedro.

Essa autoavaliação voltava para o editor, que dava a nota. Tudo ficava computado, e o repórter tinha um histórico de avaliação. A premiação em viagens continuava ocorrendo. Com a mudança no sistema, as notas passaram a variar entre $0 \mathrm{e}$ 10, podia-se usar decimais e não se podia repetir notas entre os repórteres de uma mesma equipe. Como já foi tanto repórter como editor, Pedro esteve dos dois lados:

Eu me sentia mal nos dois, por diferentes motivos, mas eu me sentia constrangido nos dois lados. Eu tive uma sorte ou não sei se realmente eu fui competente no período que eu fiquei como repórter, mas enfim, de ter boas avaliações, mas ao mesmo tempo eu achava injusto, por exemplo, o editor às vezes esquecer alguma coisa que eu tinha feito ou exigir uma coisa que eu achava que não estava correta. A questão da escala é muito subjetiva, então, pra mim não fazia sentido. Eu não sabia, por exemplo, se eu recebesse um bom se estava bom ou se estava ruim, porque eu não sabia também se as pessoas tinham recebido muito bom, ótimo, enfim. Então eu ficava sempre com receio da nota que eu havia tirado... E eu discordo desse tipo de avaliação tanto como editor ou como repórter, avaliando ou sendo avaliado, porque eu acho que avaliação tem que ser feita diariamente através de conversas com o repórter e não distribuindo nota, que eu acho uma bobagem... - Pedro.

Como avaliador, às vezes tinha que dar uma nota baixa para um repórter que não merecia porque no histórico dele estava computado algum erro que o jornal colocava como grave. "Eu não concordava com os critérios que estavam sendo adotados, porque eu acho que ele tinha se destacado de outras maneiras, sendo criativo, sugerindo pautas 
boas e trabalhando corretamente." Quando o chefe recebe a avaliação a ser preenchida, os erros que a pessoa cometeu no período já estão computados. "Não é que existe uma definição, por exemplo, a cada erro, a pessoa vai perder um ponto. Mas como aparecia ali eu usava como critério, tipo, a pessoa que cometeu três erros vai ter que ganhar uma nota um pouco menor do que a pessoa que cometeu dois." Eram erros como grafia incorreta de nome, informação incorreta, problemas de gramática, erros de remissão de página. Pedro via nisso ainda uma lógica "bizarra", pois havia uma equipe para ver os erros, mas não havia para fazer revisão antes da publicação. Para ele, o sistema funcionava como uma forma de terrorismo contra os jornalistas.

Eu acho que ele impunha uma tensão exagerada em vários aspectos que eu não concordava. Então o repórter ficava com receio, ele fazia um tipo de checagem com umas coisas, que eu achava que ele podia perder tempo com outras coisas. Então eu acho que esse tipo de cobrança ia pra direção errada. E acho que estimula uma paranoia, a verdade é essa, as pessoas ficam paranoicas com erros... Até pra não ficar falando que é só um erro, um problema isso, em alguns aspectos, ajudava a ter um repórter mais cuidadoso com a matéria - Pedro.

Segundo Dejours (2012b, p.87), a "avaliação individual de desempenho contribui de forma determinante, na primeira década deste século, a desestruturar as solidariedades". A concorrência é estimulada com gratificações ou para se proteger do risco de punições. "A desconfiança entrou em cena trazendo consigo o medo ao mundo do trabalho."

É interessante notar que o sistema de avaliação da Folha ao longo da história mostra essas duas faces. Primeiro surge como ameaça de demissão. Depois se desenvolvem mecanismos de premiação. Mas um não anula o outro. A fala de Pedro mostra isso, quando ele diz nunca ter tirado um conceito ruim e completa que se tivesse tirado estaria fora. $\mathrm{O}$ fantasma da punição continua presente, uma tensão que permanece o tempo todo como forma de controle do trabalho. E mesmo com as gratificações em viagens, os jornalistas de diferentes gerações se mostraram incomodados em avaliar e ser avaliado, sentem-se expostos, não concordam com os critérios, defendem uma relação mais pessoal entre editor e repórter, que seria mais humana e mais produtiva. Por outro lado, os sistemas podem aprisionar e inibir a criatividade.

Criticar os sistemas de avaliação da forma como são instituídos, não significa ser contra a qualquer avaliação, já que da avaliação vem o reconhecimento, e do reconhecimento, o prazer no trabalho. "A avaliação constitui um trabalho específico, mas ela é parte integrante do trabalho propriamente dito e constitui uma etapa na 
evolução e no ajustamento da organização do trabalho", mas o problema vem dos “métodos devastadores da avaliação individual” (DEJOURS, 2012b, p.94).

É preciso buscar caminhos que valorizem o diálogo, a troca de saberes, o reconhecimento, a coletividade e a solidariedade. Só assim o trabalho será um espaço para ampliação da subjetividade e à construção de si. Dessa forma, mesmo com toda pressão inerente ao trabalho do jornalista, o sofrimento poderá ser transformado em prazer. Já em relação ao ritmo intenso, ele poderia ser amenizado se fossem cumpridos os direitos trabalhistas como folgas e respeito à jornada. Uma maior quantidade de profissionais também ajudaria. Nos casos excepcionais, o próprio conteúdo do trabalho, apesar do sofrimento gerado pela tensão da cobertura, leva ao prazer. Além disso, se depois da cobertura intensa houvesse a folga, o jornalista poderia se recuperar do cansaço e da fadiga do trabalho. Mais uma fez fica clara a necessidade de se mudar a organização do trabalho, visando à autonomia do sujeito.

\section{6 - Impacto das novas tecnologias}

Durante as entrevistas, os jornalistas falaram sobre o impacto que as novas tecnologias tiveram em seu trabalho. Mais do que falar sobre a internet, os mais velhos relembraram como era mais difícil depender do telex, do orelhão e da máquina de escrever. Já os mais jovens focaram nas possibilidades da comunicação em rede e nos novos caminhos que se abrem, por um lado, e na intensificação do trabalho por outro. Alguns reforçaram que o jornalismo passa por uma transformação. Outros destacaram a imposição do jornalista multimídia e a perda de qualidade do trabalho.

Para Kucinski (2005, p.79), a internet abre uma nova era, possibilitando a terceirização no jornalismo e decretando "a morte da fábrica de notícias que é a grande redação". "Os grandes jornalistas passam a trabalhar em suas casas, e qualquer um pode produzir seu jornal, seu boletim, sua revista". Assim defende a possibilidade de uma "comunicação libertária", ao que acrescentamos uma possibilidade de democratização da informação, ainda que se possa discutir quem realmente tem espaço e destaque na rede.

O autor destaca que o jornalismo on-line prima pela "velocidade sobre outros atributos da informação, tais como precisão, contextualização e interpretação" (Ibid., 
p.97-98). Essa questão ilustra bem o noticiário on-line, mas isso é relativo já que os blogs passam a ser espaços de interpretação, análise ou opinião, ocupados por jornalistas que fizeram carreiras em outros meios. Entre nossos entrevistados Ricardo Kotscho possui blog no portal R7, Leonardo Sakamoto no Uol e Clóvis Rossi, coluna na Folha on-line. Outro exemplo de textos analíticos é o site do Observatório da Imprensa, de Alberto Dines. Além disso, há iniciativas de grandes reportagens viabilizadas pela internet, como fazia Bob Fernandes na revista digital Terra Magazine e como faz a ONG Repórter Brasil, coordenada por Sakamoto. Isso só para ficar nos exemplos dos jornalistas ouvidos para esta pesquisa.

Há outro tipo de impacto, não como meio de divulgação, mas na forma de fazer o trabalho. Clóvis Rossi conta que quando foi correspondente internacional, na Argentina, por exemplo, e precisava saber o crescimento da economia no país em determinado ano, tinha que ir até um instituto de pesquisa e lidar "com aquela burocracia infernal do serviço público" que manda a pessoa de um prédio para outro, de uma instituição para outra, de um andar para outro, até descobrir algo que ocuparia meia linha de uma matéria. Com a internet, "você entra no site do instituto argentino de estatísticas e tem todas as informações". Em sua avaliação, a coleta de informações foi facilitada. "Hoje o seu trabalho é muito mais de interpretar, juntar as peças do quebracabeça do que recolher essas peças na rua como se fazia antigamente. A vida é mais fácil sem dúvida nenhuma com a internet".

O problema, para Clóvis Rossi, é que se induziu a uma "preguiça” em que alguns jornalistas não buscam "complementos próprios". Bob Fenandes também falou sobre a preguiça em apurar com a internet e que é preciso criar anticorpos de desconfiança, luta e determinação como jornalista, mas acredita que "os ganhos são maiores do que as perdas".

Já sobre os computadores, Rossi conta como eles facilitaram a vida do jornalista: "Você não precisar refazer texto, jogar uma lauda fora, começar tudo de novo, simplesmente, corre o cursor para cima, e muda o seu texto". Quando era correspondente na Argentina, por exemplo, precisava ir até uma oficina de telex para enviar a matéria e ali perdia uma hora para transmitir 60 linhas.

Ainda havia o risco de a matéria ir parar no endereço errado. Em 1969, Audálio Dantas fazia uma matéria de turismo para a revista Quatro Rodas ${ }^{14}$. Era um roteiro de

\footnotetext{
${ }^{14}$ Dantas (2004, p.28-33) conta a história dessa cobertura.
} 
automóvel até o México. Quando chegou a Honduras, soube que o país estava sendo atacado por El Salvador. A pauta mudou. Ele entrou em contato com a Veja, que publicaria a reportagem depois, mas com mudanças:

A Veja fechava sexta-feira, ou excepcionalmente sábado, não sei se hoje é assim, e a pressão de chegar de volta a Tegucigalpa, onde havia na cidade só, além dos telex oficiais, havia um telex no hotel em que nós estávamos. Não tinha mais. A essa altura já tinha chegado algumas dezenas de jornalistas estrangeiros, e havia uma fila pra passar as matérias por telex. Isso é a maior angústia porque primeiro a angústia de chegar, depois a angústia de escrever a matéria... Escrevi uma matéria de 8, 10 laudas e entrei na fila do telex. Eu estava exausto, estava dois dias sem dormir, quando chegou a minha vez, o operador do telex recebeu a matéria, passei o endereço e fui dormir. No outro dia, um telefonema da revista, pô, onde é que está a matéria? Esse foi o momento mais bravo e de frustração também. Não chegou a matéria? Mas eu mandei! Mas não chegou. Aquela coisa. Então, perdi o furo, que era furo internacional. Depois a semana seguinte é que se foi saber. O sujeito do telex errou o endereço, ao invés de ser o endereço que eu dei, foi cair numa fábrica em Santo André, e na segunda-feira cedo o pessoal da fábrica ligou... Mas aí a matéria foi liquidada da maneira que eu tinha visto no original, mas saiu... Foram várias frustrações - Audálio Dantas.

Alberto Dines comprou seu primeiro computador em 1983 para escrever um livro. É na década de 1980 que as máquinas de escrever são aposentadas. Nesse início, os jornais e as revistas utilizavam entre "sete a dez CPUs, de três a cinco fotocompositoras e terminais de vídeo", compostos de monitor e teclado, assim as matérias eram enviadas dos terminais às fotocompositoras, "já com as medidas exatas para ocupação dos espaços em páginas pré-determinadas” (BAHIA, 2009, p.432)

Antes mesmo que os computadores chegassem às redações, o Sindicato dos Jornalistas Profissionais no Estado de São Paulo realizaram em outubro de 1981 um seminário, cursos e palestras durante uma semana com o tema "Quem tem medo de computador?":

O Sindicato conseguiu prever essa tendência quando juntou, em 1981, os mais respeitados pesquisadores e especialistas em informática no Quem Tem Medo do Computador? O material discutido foi editado e impresso no livro Que é isso, Computador?...

A tese básica era aquela: já que o computador ia chegar para valer, o que poderíamos fazer, não para vencê-lo, mas para vencer com ele? Uma das orientações era a de que cada jornalista, na medida de sua possibilidade e ambição, fosse buscando cursos de informática e atualização. Assim estaria pronto para assumir novas funções no jornal ou nas editoras. E foi o que aconteceu, em muitos lugares. (RIBEIRO, 1998, p.158) 
Tão rápida quanto à adaptação de Dines ao computador foi a sua adaptação à internet. Quando os participantes do Laboratório de Estudos Avançados em Jornalismo - Labjor, projeto da Unicamp, decidiram criar o Observatório da Imprensa, o jornalista Mauro Malin sugeriu que se usasse a via digital. Assim nasceu esse veículo jornalístico focado na crítica da mídia, com presença regular na internet desde abril de 1996, época do início da internet no Brasil.

Vale lembrar que foi em 1995, através da Portaria Interministerial $n^{\circ} 147$, de 31 de maio de 1995, que foi criado o Comitê Gestor da Internet no país para acompanhar a disponibilização de serviços de internet, estabelecer recomendações como estratégia de implantação e interconexão de redes, e coordenar a atribuição de endereços IP (Internet Protocol) e o registro de domínios.

Quando nós decidimos fazer uma coisa chamada Observatório da Imprensa, eu nunca tinha pensado em usar o computador pra fazer o veículo. Nós resolvemos fazer o Observatório, e a experiência foi tão bem sucedida no ponto de vista conceitual que o Comitê Gestor da Internet, do Ministério da Ciência e Tecnologia, falou - É isso que nós queremos que a internet seja no Brasil, um fator de democratização, de socialização, de discussão... Eu nunca pensei que a internet um dia desbancaria a mídia impressa, mas aceitei fazer o nosso projeto em via digital, porque era mais barato, mais fácil, mais tudo... E aí quando surgiu a ideia de fazer televisão, ninguém falava em interatividade, mas eu achava que tinha que ter... Eu naturalmente me deixo levar pelas inovações, se elas são boas. Eu só não acho que o ser humano pode se dar ao luxo de jogar fora coisas que lhe são úteis: o livro, o papel, o jornal, tão importantes no desenvolvimento das civilizações humanas, é uma pena você desperdiçar isso. E não vai desperdiçar, vai diminuir um pouco a importância do papel, mas ele vai ser mais sedimentado, mais bem organizado, mais denso, enquanto a internet vai ficar cada vez mais fragmentada, pulverizada. Então eu convivo muito bem com as inovações, só não sou um fanático por elas, porque eu acho que o ser humano é muito mais do que essa tecnologia Alberto Dines.

Para Aureliano Biancarelli, a internet, ao propiciar um noticiário rápido, apresenta uma limitação na narrativa dos fatos e relatos superficiais. Apesar de haver experiências interessantes, que usam fotografia, vídeo e texto, ele sente falta de texto. “Agora nessa fase atual de mudança, está havendo perdas, perda de qualidade, perda de informação, perda de foco. Mas são danos que eu acho que vão ser recuperáveis de alguma maneira". Já em relação aos modos de fazer jornalismo avalia que os profissionais passaram a ser mais exigidos, pois precisam atender a mais de uma mídia. Por outro lado, "a pressa está sacrificando a qualidade da informação". 
Ricardo Kotscho também fala do jornalista multimídia, que faz foto, vídeo, texto, escreve para o impresso e a versão da internet. "Essa tecnologia permite isso. Se de um lado é bom pra empresa, menos gente faz mais coisa, de outro lado, torna o trabalho, o resultado do trabalho muito superficial". Os equipamentos mais modernos não geram um jornalismo melhor. "Tanto que às vezes a mesma matéria que você viu na internet, amanhã você vai ver no jornal sem muita diferença. Quer dizer, não há tempo pra aprofundar os assuntos, pra buscar um outro ângulo, contar uma coisa que os outros não contaram."

Vou dar um exemplo, aquela matéria das mordomias ${ }^{15}$ deu uma repercussão muito grande, foi a primeira matéria de denúncias ainda durante o regime militar. Eu levei três meses pra fazer e com o auxílio de um monte de gente. Isso hoje é inimaginável. E hoje o que acontece? A maioria dos repórteres faz três matérias por dia. Então fica superficial. É aquele negócio feito por telefone. E tem a questão também do trânsito, que antes era mais fácil chegar aos lugares... Claro, é melhor escrever no computador do que na máquina de escrever. É melhor você ter um notebook do que ir à fila enfrentar um telegrama. Isso tudo facilita. Mas não acho que o jornalismo tenha melhorado em função disso - Ricardo Kotscho.

Já Lúcio Flávio Pinto destaca o papel de mobilização da internet. Em uma ocasião, um oficial da Justiça Federal chegou com um mandado que o proibia de falar de um processo do Ministério Público Federal sobre desvio de incentivos fiscais. Como não havia segredo de justiça, o jornalista avaliou que o mandado era ilegal, fez uma nota sobre o caso e disparou "pro mundo" e recebeu "uma enxurrada" de mensagens de apoio. O juiz acabou indeferindo o mandado.

Sem internet, eu jamais teria conseguido. Eu acho fundamental, mas o mundo não é internet. Tenho um amigo, que toda vez ele me liga Lúcio, soubeste o que aconteceu na Nova Zelândia? Eu disse - Não. Mas que diabo de jornalista é tu que não sabes o que aconteceu? Aí eu disse - É verdade. Sabes o que aconteceu ainda agora em Carajás? Ele disse - Não. Que diabo de cidadão tu és que sabe o que aconteceu na Nova Zelândia e não sabe o que aconteceu em Carajás? Tu podes fazer alguma coisa na Nova Zelândia? Aqui tu podes e aqui tu não sabes nada. Então esse é o excesso da internet, a pessoa achar que o mundo está lá dentro... Pra mim [a internet] é uma pauta, nunca é a verdade, nunca é o ponto final da pauta. A maioria das coisas que eu sei não é da internet. Então eu acho que a internet é uma ferramenta, vai depender de quem usa, se tem competência ou não pra usar. Bem usada é maravilhosa - Lúcio Flávio Pinto.

\footnotetext{
${ }^{15}$ Ricardo Kotscho conta que quando O Estado de S. Paulo ficou livre da censura, ele foi encarregado de fazer uma série de reportagens sobre as mordomias que políticos e sua cúpula tinham durante a ditadura militar. Para tanto, contou com o apoio da equipe de sucursais e correspondentes do Estadão. A série foi publicada em agosto de 1976, e o jornalista também fala sobre essa história em Kotscho (2006, p.54-56).
} 
A jornalista Paula Puliti destaca outro aspecto da tecnologia: você poder escrever seu texto de qualquer lugar e não precisar voltar para a redação. No caso da agência de notícia, o celular facilitou bastante o trabalho. Mas as tecnologias fizeram com que o jornalista trabalhasse mais.

O celular também é considerado muito importante para Marilu Cabañas, que trabalhou a maior parte da carreira em rádio: "Imagine cobrir reintegração de posse na Zona Leste, com uma pancadaria violenta. Você tinha que gravar. Depois podia reproduzir, mas na hora como você ia reproduzir? Não tinha como. Você tinha que achar um orelhão e você narrava". Ela também destacou os avanços em relação aos gravadores e a facilidade em mandar a matéria por e-mail, quando está fazendo cobertura fora.

Fernanda Cirenza, por sua vez, recorda o impacto que foi chegar à Folha em 1988, onde tudo era informatizado. "Eu acho muito legal você ser multitarefado, isso é uma cultura da própria Folha, que já tinha muito isso nesse período que eu vivi lá.... Ir pra rua, entrevistar, voltar, escrever uma matéria, fechar o texto, se exigia isso de um jornalista lá atrás, na Folha." Sem internet, costumava-se consultar o banco de dados do jornal:

Era um negócio surreal... Tinha pasta de tudo quanto era coisa e tinha gente trabalhando no banco de dados, que pegava o jornal, cortava o jornal e colocava lá. De todas as personalidades, e as pessoas consultavam esses papéis se não sabiam o assunto que era exigido... Isso mudou e melhorou muito, quer dizer, a gente tem uma base de informação que é o google e todos os sites que estão na rede, com a possibilidade de você checar inúmeras informações como uma agilidade monstro. E você tem o outro lado, as empresas de comunicação usando esses instrumentos pra também disseminar informação... Eu acho que ninguém sabe muito bem o que vai acontecer... - Fernanda Cirenza

$\mathrm{Na}$ revista Brasileiros, onde trabalhava quando nos concedeu entrevista, Fernanda vivencia o trabalho em múltiplas plataformas. A revista está nas plataformas digitais, e os jornalistas trabalham para todos os suportes. "O cara que tem que fazer uma matéria pra revista, também está publicando no site, também está publicando no Inova BR, que é uma plataforma sobre inovação, então a gente é meio multitarefado.”

Um ponto levantado por vários entrevistados foi a intensificação do trabalho trazida pelas novas tecnologias. "Se achava que com as novas tecnologias o jornalista teria mais tempo para produzir uma coisa de melhor qualidade ou trabalhar menos, ledo engano, mas acho que teve uma potencialização do estresse como nunca", como afirma 
Antonio. "As tecnologias, ao mesmo tempo em que nos ajudam, elas acabaram fazendo a gente trabalhar mais, principalmente na nossa profissão, que foi muito impactada", completa Priscilla Nery. Assim você nunca se desliga do seu trabalho.

A fantasia do trabalhador multitarefas é de fato autoenganação. Acho que não tem condições de se fazer um bom trabalhando chutando pra todo lado, atirando pra todo lado... Essa ideia de integração, do jornalista multitarefas, é muito mais uma maneira de economizar, cortar custos dos jornais pra sobreviver à crise, do que pensar numa nova natureza, numa dinâmica da profissão, que é uma ilusão que muitos jovens jornalistas têm - Ivan Marsiglia.

A intensificação aparece na fala de Pedro: "Elas aumentaram a quantidade de coisa pra gente fazer (risos). Basicamente quadruplicaram o ritmo". Além do jornal, é preciso dar conta do conteúdo do site e das redes sociais - como twitter e facebook. "O cara que era repórter só do impresso, virou repórter do on-line. Ele precisa cuidar dessas plataformas móveis também.” As redes sociais servem ainda como fonte de informações para o jornal, mais ágeis do que o contato das assessorias. "Acho que dinamizou muito mais o trabalho e dificultou também porque você precisa ficar muito atento a uma infinidade de informações, que vão sendo bombardeadas e, muitas vezes, você não dá conta das quantidades de coisa."

Maria também foca na precarização do trabalho que as novas tecnologias possibilitaram, porque as pessoas passaram a trabalhar o tempo todo. "Essa história do celular, do tablet, tudo isso, as empresas são muito mais espertas do que nós. A gente acha legal ter um smartphone, mas eles acharam mais legal ainda a gente ser acionado em qualquer lugar." Do lado positivo, ela aponta uma aproximação com o público e conteúdos integrados que atraem mais pessoas, por exemplo, os programas de rádio disponibilizados pela internet. "Muita gente fala hoje que não escuta rádio, mas você tem o programa na web, e a pessoa está ouvindo rádio e nem percebe. Eu acho que é um impacto na profissão bom."

Essa dualidade aparece na fala de Aline Scarso, que vê produtos mais interessantes, com a possibilidade de uma matéria na internet trazer áudio, texto e vídeo, mas ao mesmo tempo isso significa a precarização da profissão. "Se houvesse um aumento salarial, por você acumular funções, eu acho que isso seria uma compensação pra você ter esse produto melhor." Por outro lado, ao se exercer várias funções, a qualidade fica prejudicada.

Eu já tive experiência no Brasil de Fato de às vezes estar tirando foto e fazendo texto, é muito complicado, porque eu acho que você não consegue fazer nenhuma função muito bem, porque o fotógrafo vai ter 
determinada situação pra observar, ele tem que ficar pensando sempre em imagem. O repórter vai pensar no que ele está vendo, no texto, ele não vai se preocupar em guardar imagens, mas viver o ambiente, ver e ouvir, mas principalmente ouvir - Aline Scarso.

Outro desafio, para Antonio, é o jornalismo e o jornalista descobrirem o seu papel, já que não é só ele que produz comunicação. Questão essa que apareceu na fala de outros jornalistas, como Bruno Torturra, que destaca a "quebra do monopólio da produção e difusão de informação", dessa forma, "a sociedade inteira hoje é comunicadora" e "consegue compartilhar informação e consumir o jornalismo de uma forma muito rápida, dinâmica, grátis, conectado".

Além disso, é muito mais fácil filmar, gravar, fotografar e publicar conteúdo hoje em dia, usando apenas um smartphone. "Isso empodera pequenas iniciativas, isso empodera muito mais o indivíduo ao invés do veículo", acredita. No entanto, para ele, "a essência do jornalismo não muda": "O jornalismo continua sendo jornalismo". Mostrando o celular, afirma:

Mais que uma redação, isso aqui é uma produtora. Filma, fotografa, edita, publica, escreve, distribui, checa, compartilha. Isso tem um impacto profundo. Eu sou suspeito pra falar, minha vida mudou profundamente a partir do momento que eu peguei um smartphone na mão. Criei a Mídia Ninja sem um real, uma rede nacional de jornalismo independente, que causou muito impacto - Bruno Torturra.

Leonardo Sakamoto também acredita que o jornalismo está passando por uma transformação devido ao desenvolvimento tecnológico. "O jornalista perde esse pedestal sagrado de ser o intermediador de informação, o veiculador de informação, e as pessoas, os próprios produtores de informação, começam a veicular informação, seja população em geral, empresas, governo." Para ele, a internet "é uma plataforma de construção e reconstrução da realidade". Também chama atenção para a geração que nasceu com o computador em casa e que vai transformar ainda mais o jornalismo do ponto de vista digital.

Miguel, por sua vez, destaca que a internet $\mathrm{e}$ as novas tecnologias potencializaram uma instantaneidade que já existia com o rádio e a TV, mas isso aumentou o risco de falar e escrever bobagem, pois o jornalista não vai à rua e "corre o risco de ter menos noção do que está acontecendo de verdade”. Há mais velocidade, que gera mais erros e menos qualidade.

João acredita que muitos jornalistas veem a internet como uma ameaça e acabam produzindo conteúdo para o on-line da mesma forma que fazem para as outras mídias. 
"Em vez de mudar a forma como você produz conteúdo, não, você continua fazendo do mesmo jeito, só que num novo meio.” Para ele, há possibilidades de fazer o jornalismo viver por muitos anos, o que é compartilhado por outros colegas:

$\mathrm{Eu}$ acho que as novas tecnologias revolucionaram o jornalismo, e a gente não está entendendo a dimensão dessas mudanças, nem como lidar com elas. As experiências do CMI [Centro de Mídia Independente] foram pioneiras nisso. Acho que o fato da jornada de junho ter impulsionado o Mídia Ninja mostra a força que tem a tecnologia e o fácil acesso às tecnologias por pessoas que não são jornalistas inclusive. $\mathrm{O}$ jornalismo profissional ainda não sabe como lidar muito bem... O Brasil de Fato de Minas teve uma assessoria com um analista de redes sociais pra aprender como publicar as coisas no facebook, porque não é só colocar o link lá e carregar. Tem toda uma teoria por trás, a questão do horário e tal. Eu acho que tem um potencial de democratização muito grande colocado na internet, mas está muito confuso ainda, pouco explorado. Mas que mudou o jornalista mudou. Tem até aquela entrevista recente da Ivana Bentes que ela fala isso, que o jornalismo não morreu. Mas ele está por um processo de crise e de se revolucionar ao mesmo tempo. O jornalismo não morreu, tanto que eu acho que cada vez mais as pessoas querem produzir discursos e discursos jornalísticos porque têm credibilidade Vivian Fernandes.

\section{7 - Rotinas, relações e limitações do trabalho jornalístico}

Ao falar de outros temas que emergiram das entrevistas, algumas rotinas de trabalho foram retratadas, dessa forma, buscaremos focar em quatro pontos neste tópico: algumas características das rotinas, funções ou veículos de trabalho levantadas pelos jornalistas, a falta que a cobertura de rua faz ao jornalismo, as relações com colegas de trabalho e chefia, e as limitações enfrentadas. Como são várias questões, não faremos uma descrição de todas as falas e sim vamos eleger as mais representativas, que de certa forma resumem os principais aspectos levantados durante as 21 entrevistas.

Audálio Dantas, por exemplo, que trabalhou em revistas nos anos 1960 e 1970, avalia que as revistas semanais de informação têm prazos massacrantes, porque os textos requerem mais apuração e uma exigência maior do que os jornais. Já as revistas de reportagens como eram $\mathrm{O}$ Cruzeiro e Realidade exigiam ainda mais apuração e preparação das matérias, mas havia mais tempo para fazê-las. "Eu tive matéria como o Vale do São Francisco, que eu fiz pra Realidade, que só na apuração, na viagem pra fazer isso, foram gastos 45 dias (risos). Isso hoje parece impossível." A corrida contra o 
tempo começava na volta para a elaboração do texto, o que lhe dava uma angústia muito grande.

Já Clóvis Rossi relata os procedimentos que seguia quando era chefe em $\mathrm{O}$ Estado de S. Paulo, onde trabalhou nos anos 1960 e 1970 ${ }^{16}$. Ele chegava entre meio-dia e uma da tarde, pois no dia anterior já havia deixado as orientações para o pauteiro, que trabalharia nisso pela manhã, para o chefe de reportagem e para o editor. Então, recolhia a pauta, lia o que tinha que fazer e quais eram as sugestões, via o que já estava em andamento e o que precisava ser feito de novo, dava orientações, e, depois, a partir do meio da tarde, recebia os repórteres de volta, e corrigia com eles as matérias que seriam editadas. Nessa época, não havia computador, a correção era manual. "De preferência, ao lado do repórter para que ele pudesse discutir comigo o que ele tinha feito, o que ele achava, o que eu achava, quais as correções que deviam ser feitas, o que faltou em uma determinada matéria, etc..” À noite sabiam o espaço definitivo da editoria no jornal.

Esse diálogo Aureliano Biancarelli vivenciou nos anos 1980 quando trabalhou no Jornal da Tarde: "Ainda era possível fazer, o que depois desapareceu completamente das redações, a conversa do repórter com o editor ou com o chefe de reportagem. Normalmente você chega à redação e encontra hoje no computador a sua pauta". Depois, na Folha, nos anos 1990 e início de 2000, a relação foi mudando conforme acumulou anos de casa:

Fiquei mais autônomo dentro dos temas que eu trabalhava. As minhas pautas geralmente eram pensadas por mim mesmo. Então eu era mais dono do meu tempo e do meu espaço. Tinha esses privilégios, do tempo, da idade, do fato de estar mais tempo numa mesma área, em determinado tema, em ser menos absorvido pelo dia a dia. A não ser plantão, final de semana, feriado..., você tinha que fazer aquilo que o dia oferecesse, mas no geral eu escapava um pouco desse cotidiano que eram pequenos acidentes, uma morte aqui, uma coisa ali, que o repórter do cotidiano tem que fazer, o chamado cobrir buraco de rua Aureliano Biancarelli.

Como correspondente internacional, na Folha, Clóvis Rossi trabalhou na Argentina de 1980 a 1986 e na Espanha em $1992^{17}$. A rotina era ler e acompanhar os jornais, rádio e TVs locais. "A partir daí você via o que estava acontecendo, se tinha

\footnotetext{
${ }^{16}$ Em relação à censura da ditadura militar, que ocorria na época, Clóvis Rossi afirma que cobriam os fatos com se não houvesse censura, a qual depois cortava as matérias e cumpria o seu papel. Ricardo Kotscho fez o mesmo tipo de afirmação.

${ }^{17}$ Rossi (1999) fala sobre seus trabalho como correspondente internacional.
} 
uma greve, se tinha uma reunião do sindicato, se tinha uma reunião de oposição, se tinha marcha das Madres da Plaza de Mayo que a gente acompanhava sempre..."

Para Ricardo Kotscho, nesses 50 anos que tem de jornalismo, mudaram as relações e os instrumentos de trabalho. "Era mais difícil transmitir por telegrama do que escrever a matéria". Hoje ele avalia que se dá ao jornalista o "prato feito". "É o jornalismo de tese. O jornal, a revista, a televisão têm uma tese sobre determinado assunto, chamam o repórter e entregam a pauta pra ele num horário determinado, com espaço determinado, então, o repórter se tornou um cumpridor de pauta."

$\mathrm{Na}$ televisão, o diferencial é que a imagem é fundamental e o trabalho envolve diversos profissionais. "Mais do que jornal, mais do que revista, eu senti que televisão é um trabalho de equipe, de confiança, de lealdade, porque exige muito das pessoas. A pressão do tempo é maior ainda na televisão", avalia Kotscho.

Aline Scarso, que trabalha na TV Brasil, e já exerceu funções como produtora e repórter, considera que na televisão o trabalho "é muito fragmentado, como se fosse uma linha de produção": o produtor pensa a pauta, o repórter e o cinegrafista executam e o editor fecha. "Às vezes pra fazer uma matéria de dois minutos, são dez pessoas envolvidas num mesmo processo".

Tem uma coisa específica de TV, que é o produtor, a função que eu exercia. Ele fica dentro da redação e tem que orientar o repórter. É como se eu fosse cego, e o repórter lá na rua, ele enxerga, e eu cego, dentro da redação, tenho que orientá-lo... O repórter de rádio ou de jornal vai pra rua e vê as coisas e pronto. Lógico que quem está na redação influencia a pauta também, mas não é a mesma coisa de TV, o produtor é quase babá do repórter. Isso pra mim era meio inconcebível, eu achava muito estranho - Miguel.

Miguel trabalhou em diferentes tipos de veículos. Na agência de notícias, havia tanto o trabalho de fazer notas com o material do jornal diário, que era mais mecânico, quanto a produção de matérias próprias, especialmente de economia. Paula Puliti, que trabalhava com jornalismo econômico na Agência Estado, explica que forneciam notícias em tempo real, principalmente, para o mercado financeiro (serviço de broadcast). Fazia-se muita entrevista com especialistas, e havia jornalistas trabalhando 24 horas.

Em relação ao trabalho em rádio, Miguel relata que o trabalho de redator do Repórter CBN era desgastante, fazer notas apresentadas de meia em meia hora, acompanhando $\mathrm{TV}$, rádio e internet. $\mathrm{Na}$ reportagem em rádio, não há editoria fixa, então, cobre-se assuntos bem diferentes: "Você chega lá e pode ser designado para 
acompanhar o ministro da Fazenda e no dia seguinte você vai falar de um crime que aconteceu na periferia." $\mathrm{Na}$ internet, a rotina de trabalho era marcada pela rapidez e a necessidade de concentração.

O mundo digital também foi abordado por Fernanda Cirenza, que avalia que colocar uma informação em qualquer plataforma digital é mais simples do que publicar no meio impresso. A internet dá a possibilidade de mudar o texto a qualquer momento, no impresso, depois que o material foi para a gráfica, é impossível.

Fernanda também vivenciou a experiência de freelancer. Devido ao trabalho e aos contatos acumulados da Folha e da Marie Claire, ela costumava receber muitas propostas de frilas. "Eu fiz muito frila, de tudo quanto é valor, dos mais baratinhos aos mais recheadinhos, foi uma delícia reencontrar colegas que me ajudaram e foi uma experiência legal trabalhar em casa, trabalhava com notebook na mesa da sala de jantar." A opção possibilitou que ficasse mais próxima dos filhos. "Foi muito legal receber meus filhos na volta da escola. Dava para parar uma hora e fazer um lanche com eles e ouvir as histórias fresquinhas." O penoso era dar conta de diversas funções e lidar com a questão dos pagamentos: "É penoso sim com esse negócio da grana, porque você é tudo, você é o gerente, você é o repórter, o editor, o cara que liga pra cobrar, ô, você não me pagou".

Pedro, antes da Folha, também foi freelancer. Não foi uma escolha pessoal e sim devido às dificuldades de encontrar o primeiro trabalho. $\mathrm{O}$ lado bom era ter uma rotina com horários flexíveis, que permitia tocar projetos pessoais. "Eu conseguia dividir mais meu tempo. No período que eu fiquei contratado, é o que eu te falei, eles exigem ali uma jornada de trabalho muito intensa e eu praticamente passava todo o tempo na redação." O principal problema de ser frila era a insegurança em relação aos pagamentos.

Mesmo quando era CLT, a rotina de trabalho de Bob Fernandes era marcada pelo período vespertino, noturno e da madrugada, especialmente, quando trabalhou em revistas. No jornal, a questão do horário para a escrita não era flexível, porque havia o deadline do fechamento, mas mesmo assim ele costumava fazer muitos contatos com fontes no final da tarde e à noite, adiantando a pauta do dia seguinte. Na experiência da internet, com a Terra Magazine, vivenciou o trabalho não presencial com a rede de colaboradores. Tendo atuado também em rádio e TV, avalia que as diferenças entre veículos se devem mais "a mecânica da plataforma”, já a essência do jornalismo e do trabalho é a mesma. 
Maria, por exemplo, na radioagência Nacional, edita as matérias feitas pelos repórteres das oito emissoras da $\mathrm{EBC}$ e as disponibiliza no site. A rotina de produção é industrial, mas ela sente muita satisfação pelo material gerado, que é utilizado por rádios comunitárias, mas também pode ser acessado por qualquer cidadão. São em média 60 mil downloads por mês de áudios, que incluem reportagens, entrevistas e até rádio-novela.

\begin{abstract}
A gente consegue entender o nosso impacto um dia que a gente fica fora do ar. O telefone não pára, porque as emissoras, o que acontece, elas montam as grades de programação, e nosso pico de acesso é das 3 da manhã às 7 da manhã... É o horário que chegam à rádio, baixam tudo, pra montar a grade. Então o que a gente põe durante o dia, não tem tanta pressão de ter que colocar, porque a gente sabe que isso vai ser usado na madrugada, quando eles vão baixar - Maria.
\end{abstract}

Vivian Fernandes, também trabalhou em uma radiagência, mas de uma rede de comunicação alternativa - Brasil de Fato. Como repórter, havia uma meta de produção diária de duas ou três matérias, que eram feitas, geralmente, da redação. Mas se por algum motivo não desse certo, era possível adaptar com uma nota lida. Já no tablóide Brasil de Fato de São Paulo ela vê mais complexidade no fechamento. "No impresso, existe uma demanda muito complexa de fechar 16 páginas na semana na quinta-feira às 18 horas. Eu não tenho a opção de não entregar essas matérias editadas. Eu tenho que entregá-las porque não pode sair página em branco." O financiamento para os veículos vem da publicidade e dos movimentos sociais. Para viabilizar o tablóide, também foram feitos empréstimos, e o jornal tem um endividamento.

Manter financeiramente a mídia alternativa é uma dificuldade. Outro veículo de comunicação alternativa tocado pelos jornalistas entrevistados é o Jornal Pessoal, de Lúcio Flávio Pinto. Ele tenta se manter com as vendas avulsas do periódico em banca. “O jornal surgiu com o compromisso de não ter publicidade, um jornal que vive da venda avulsa. Ele não tendo publicidade, que é a principal fonte de receita de uma empresa jornalística, ele tem um capital muito baixo." Lúcio, que já atuou em outros jornais alternativos, como Opinião, da época de resistência à ditadura, afirma: "A empresa jornalística alternativa, a imprensa alternativa, não consegue ter uma organização empresarial alternativa, é por isso que acaba falindo." Assim em um cenário com cada vez menos bancas de jornais, sem estrutura de distribuição e sem publicidade, sentencia: "Isso garante que o jornal vai ser pobre sempre." Das rotinas de trabalho, relata: 
Mesmo sendo só eu no jornal, eu procuro manter a rotina do que era o trabalho coletivo. Então quando sai o jornal, eu faço a avaliação dos erros e muitos erros de digitação porque é feito tudo muito às pressas. Em seguida, eu faço a pauta... Então ele é um jornal amadorístico, mas feito com condições profissionais, porque eu era um profissional que já tinha testado todas as maneiras até em coberturas internacionais e sempre me saí bem, porque eu sei fazer jornalismo... O fato é que o jornal publica coisas que são relevantes, que não saem na imprensa, e que não são desmentidas - Lúcio Flávio Pinto.

Outra experiência alternativa é a Mídia Ninja, que segundo Bruno Torturra, tinha o objetivo de quebrar a narrativa da grande mídia, o que eclodiu nas manifestações de junho de 2013, em que os materiais produzidos pelos participantes eram difundidos rapidamente pelas redes sociais da internet. No entanto, não era uma iniciativa com financiamento nenhum. O objetivo de Torturra é criar uma nova iniciativa - um coletivo chamado Fluxo. Para mantê-lo pretende lançar campanha de microassinaturas.

As formas de financiamento para produção e circulação de notícias foram discutidas no evento "Quem mexeu no meu jornalismo?", realizado na Faculdade Cásper Líbero, em 7 de maio de 2014. No evento, Leonardo Sakamoto defendeu modelos de redações menores e a formação de coletivos. $O$ financiamento pode vir por meio de doações, crowdfunding (financiamento coletivo por pessoas interessadas na iniciativa), prestação de serviços e editais de fundo para ONGs, que não devem visar ao lucro e ter objetivos claros.

É o caso da ONG Repórter Brasil, que Sakamoto coordena, uma Organização Não Governamental de jornalismo. Ele também levantou algumas dessas questões durante a entrevista que concedeu a esta pesquisa. "Por mais que você tenha coordenações, estruturas internas, ela é uma situação muito mais horizontal do que uma redação", assim, participa-se de todo o processo de trabalho, da pauta à veiculação, e se tem muito mais prazer com o trabalho, que "não é alienado". Em um cenário de demissões e enxugamento das redações, ele acredita que o jornalismo precisa se reinventar. "Pode ser cooperativas, grupos, organizações não governamentais, pequenos veículos de comunicação, o jornalismo trabalha de forma celular, sozinho, blogs, por exemplo, trabalhando como interpretador da realidade..."

Ricardo Kotscho via no passado um trabalho mais coletivo. "Você escrevia o lide, escrevia cinco linhas e tal e ia mostrar pro cara do lado, aí outro dava palpite, a gente saía do jornal e ficava até tarde no bar discutindo pautas pro dia seguinte (risos)." Também destaca, na atualidade, o trabalho realizado em casa e a distância. O que não 
mudou para ele é a necessidade de se descobrir uma boa história pra contar, nova e original.

Um ótimo lugar para se descobrir histórias é vivenciar a rua, entendida como os ambientes externos às redações. Essa questão foi abordada pelos jornalistas entrevistados. Um dos principais pontos levantados foi que muitas vezes se deixa de ir aos locais do acontecimento, por contenção de custos, por falta de carro, por falta de tempo, por conta do trânsito, em função da quantidade em vez da qualidade. Assim se perde a dimensão da realidade e se deixa de olhar os problemas enfrentados pela população com os próprios olhos.

Você pode falar sobre a operação da polícia em determinado bairro, ouvindo duas pessoas: o que a polícia fez lá na operação - a própria polícia contando e ouvindo o presidente da Associação do Bairro. Ele vai dar a versão dele e dos moradores. Aí você tem duas fontes que você pode ouvir pelo telefone, provavelmente, eles têm telefone. Agora se você for lá e observar como as pessoas estão reagindo diante do fato, como a própria polícia está reagindo, você tem muito mais riqueza de detalhes. Hoje não dá tempo em uma cidade congestionada como a nossa. Não há tempo hábil pra você ir. Se isso tivesse acontecido em uma periferia qualquer, agora são 4 horas, pra se deslocar daqui até lá na hora do rush, eu não vou conseguir. A única maneira é usar o telefone. Às vezes você até faz de conta que esteve o mais próximo possível da notícia. Aí o presidente da Associação de Bairros indica um morador, que é vizinho dele... Como foi pro senhor? Tudo bem, a sua casa, as suas crianças? Você que teve um filho que se queimou, não sei o quê, tal. E tenta dar vida pra uma reportagem que é limitada ao telefone - Aureliano Biancarelli.

Os jornalistas até levantam que em alguns casos é possível ouvir mais pessoas por telefone, mas há um consenso de que é essencial ter uma vivência externa e o contato com a realidade. Pessoalmente, as entrevistas são mais ricas, é possível captar os detalhes do ambiente e nas ruas se encontram os fatos.

Antes era uma coisa comum o repórter, o fotógrafo, o motorista, todo mundo participava do processo de produção da pauta. Hoje o repórter trabalha isoladamente, o fotógrafo vai sozinho aos lugares, motorista de reportagem não tem mais, então eu acho que isso enfraqueceu muito a cobertura jornalística, porque antes, os assuntos vinham da rua pra redação... Hoje o processo é inverso... - Ricardo Kotscho.

O e-mail também é uma ferramenta criticada, mas necessária em alguns casos. Antonio conta que quando trabalhava em agência de notícias científicas, os pesquisadores preferiam responder as questões por e-mail. O jornalista afirma que faziam isso para provar o que tinham dito. 
Mais do que isso, pode-se concluir que em assuntos técnicos a resposta escrita pode trazer uma riqueza de informações e detalhes. O ideal é que ela seja complementada depois por uma conversa, seja por telefone ou pessoalmente, sendo essa última opção sempre mais rica, mas usada com limitações devido aos prazos do jornalismo e as dificuldades colocadas anteriormente.

Para Alberto Dines, a dificuldade de ir ao local é dramatizada demais. "O problema não é esse, às vezes, não precisa ir até o local, o problema é você ter a liberdade de desenvolver o seu raciocínio, e permitir que a matéria vá numa determinada direção."

Lúcio Flávio Pinto, por sua vez, sente falta de os jornalistas terem fontes de “carne e osso", que são essenciais, pois não é possível estar presente em todos os acontecimentos. "Se você tiver uma diversidade de fontes nos lugares estratégicos, e essas fontes têm um compromisso com a informação e a verdade, inclusive contra os interesses dela, aí sim você é um grande jornalista." Já fazendo apenas matérias pelo telefone e pela internet, perde-se "a capacidade de revelar as transformações reais e não aquilo que o editor cria".

Fernanda Cirenza, no início de seu trabalho na Folha, fazia muita matéria na rua, depois começaram os cortes e a dificuldade em conseguir carro. A impressão de Pedro, que trabalhou mais recentemente no jornal, é de que dependia da editoria. Jornalismo de serviços era mais feito da redação. Já reportagem cultural, por exemplo, era feita fora da redação. Ivan Marsiglia, no Estado, percebe que ainda há espaço para o trabalho externo, mas isso tem mudado: “A gente tenta se manter fazendo isso, manter o contato com a realidade, com a rua. Mas com o acúmulo de funções e as equipes reduzidas eu senti que nos últimos anos há mais gente editando, fechando texto, do que repórteres nas ruas, em todos os veículos".

Vivian conta que no tablóide Brasil de Fato (SP) a prioridade é a rua, na radioagência era redação: “os técnicos sempre achavam ruim a qualidade do áudio que a gente trazia do gravador, os gravadores não eram potentes. Então a gente tinha que fazer tudo por telefone porque era um som mais limpo que ia sair, o que eu achava bem ruim, saia pior a matéria".

A carreira de Bob Fernandes foi marcada por matérias fora da redação. Já Antonio avalia que $80 \%$ de sua produção foi em redação e $20 \%$ fora dela. Leonardo Sakamoto se recorda que notícias mais curtas eram feitas na redação, mas as reportagens, na rua. 
Priscilla escreve mais da redação, mas em coberturas de acidentes e grandes ocorrências, vai ao local do fato: "quando você vai até o local, você tem as suas impressões. Eu acho particularmente que a matéria fica muito melhor. Você vê vários detalhes que você não ia conseguir pegar porque as fontes não vão lembrar depois". João, na revista de informação, trabalhava mais na redação.

Na Agência Brasil, em São Paulo, Maria avalia que muita matéria é feita da redação, por exemplo, cobrir marcha dos sem tetos que vem do interior do estado para a capital paulista, telefonando para saber onde eles estão. "Isso é uma decisão absolutamente da chefia de reportagem. Os repórteres querem ir pra rua, e a chefia não quer deixar porque se você manda o repórter pra lá, ele não pode fazer uma notinha sobre a inflação da Fipe" (Fundação Instituto de Pesquisas Econômicas). Marilu Cabañas vivenciou isso em uma das gestões da rádio Cultura. Quando se privilegiava quantidade, o repórter tinha que fazer mais matérias por telefone. Atualmente na Rede Brasil Atual a rua tem bastante espaço.

Já para Aline, que trabalha em TV, a rua é uma necessidade para coletar imagens. Em outros trabalhos, sentiu "pouco espaço pra sair às ruas, numa lógica produtivista, de produzir o maior número de matérias possíveis, mas de dentro da redação":

Falta estímulo pra você ser um bom repórter de fato, investigativo, por exemplo. Se pelo menos a gente ficasse dentro da redação investigando algo, usando o tempo pra isso, mas não é isso que acontece, as pautas não são extremamente criativas, isso em qualquer lugar você pode ver o resultado. A imprensa hoje cobre fundamentalmente agendas: agendas do governo, agendas do empresariado, agendas dos movimentos, não sai muita coisa além daí. Agora lógico por ser TV, quando eu sou repórter, a televisão precisa de imagem, então você tem que ir pra rua... Isso é muito legal da TV, você ter que mostrar e ter que sair a campo sim e na rua é onde as melhores coisas acontecem. É na rua onde eu mais me sinto viva. $\mathrm{Na}$ redação eu me sinto um pouco subaproveitada... Na rua, eu olho as coisas acontecerem, eu vejo com os meus próprios olhos pra fazer uma afirmação, não é alguém que me disse... Você tem um pouco mais de liberdade e acho isso muito importante, e o jornalismo não podia perder isso assim - Aline Scarso.

Miguel também sente falta de espaço para fazer reportagens com investigação e aprofundadas. Para ele, existe espaço para a reportagem de rua, especialmente no rádio, mas isso não significa automaticamente que a matéria será mais profunda. Parte é rotina, por exemplo, cobrir o que o governador faz. 
Os depoimentos mostram que é preciso buscar um equilíbrio e dar mais espaço para as matérias realizadas nos locais do acontecimento, às entrevistas feitas pessoalmente e à realidade vista com os próprios olhos. Isso não significa que telefone, e-mail, skype, whatsapp, redes sociais e outras tecnologias ou aplicativos que surjam não possam ser usados. Pelo contrário, todas essas ferramentas auxiliam o fazer jornalístico. Mas isso não significa que substituem o contato pessoal com a realidade e possam preencher a falta que a rua faz.

Outro tema abordado durante as entrevistas com os jornalistas foi a relação de trabalho com os colegas e as chefias. De maneira geral, os jornalistas relataram ter vivenciado uma competitividade sadia com os colegas, em um ambiente que também possuía muita solidariedade. Com as chefias, na maioria do caso, houve uma convivência cordial. As exceções, com casos de assédio moral, inclusive, serão relatadas no quarto capítulo, como parte do sofrimento no trabalho.

Essa competitividade sadia foi vivenciada por Audálio Dantas especialmente nas revistas O Cruzeiro e Realidade. Ele recorda ainda que as chefias das redações mais antigas, nos anos 50 e um pouco nos anos 60, resolviam as coisas no grito. "Era muito comum o grito. Mas eu tive, com exceções, sempre chefes excelentes, que me ajudaram muito. Havia uma espécie de troca." No início da carreira, seus chefes perceberam sua vocação para o texto e lhe confiaram trabalhos importantes.

Tanto Alberto Dines quanto Clóvis Rossi foram chefes muito jovens. A primeira chefia, Dines assumiu aos 25 anos na revista Manchete. Para ele, o fundamental é saber ouvir. Já Rossi assumiu a chefia em O Estado de S.Paulo de 22 para 23 anos. "Nunca tive problemas de relacionamento com a chefia nem quando eu era chefe, nem quando eu era subordinado." Ele conta que sempre teve uma vivência boa, mesmo com os chefes menos experientes, porque senão estaria negando sua própria história. Sobre os colegas de trabalho, o jornalista da Folha afirma que cada um fez o "melhor possível", "sem pisar no pescoço do outro".

Dos jornalistas de 60 e poucos anos, Aureliano Biancerelli destaca que havia "uma alta rotatividade e a cada mudança o novo editor vinha com gana de querer botar todo mundo pra trabalhar mais do que trabalhava". Por outro lado, havia chefes muito jovens, que sabiam que ele estava há muito tempo na área, então, existia um respeito. Ele vivenciou a solidariedade entre os colegas, mas acha "que existe uma competição muito grande por conta das pressões que existem nas redações", que deixam as pessoas 
inseguras. Já Lúcio Flávio Pinto destaca que havia uma competitividade para fazer o melhor, para ver quem teve mais manchetes, mas de forma saudável.

Ricardo Kotscho se recorda que a solidariedade e a cumplicidade entre os colegas era muito grande na época da ditadura. "Hoje há uma competição muito grande pra você subir mais rápido na carreira, ganhar mais...”, compara. Com as chefias, o único problema que tinha era escrever demais: "Eu sempre queria escrever mais do que o espaço permitia. Hoje eu tenho consciência de que eu exagerava. Tudo bem você brigar pela sua matéria, mas você não pode achar que ela é a única..." Do passado, Kotscho guarda lembranças do clima de descontração que viveu no começo da carreira:

Uma mudança que é até auditiva. As redações eram muito barulhentas e bagunçadas. Pra você ter uma ideia a gente parecia moleque, fazia guerra de bolinha de papel. A gente fazia bola de futebol com papel e durex e jogava no corredor, cantava, falava alto, sacaneava os outros. $\mathrm{Eu}$ por exemplo tinha mania de latir para as moças que estavam fazendo matérias por telefone... Eu vinha por trás e imitava um cachorro e latia, aí a moça jogava o telefone pra cima. Então esse tipo de coisa tornava mais leve o ambiente, mais leve o trabalho. Isso acabou. Hoje é tudo muito silencioso. Até as máquinas de escrever obrigavam a gente a falar mais alto. Aquele barulho da máquina, mais ou menos como chão de fábrica... E era muito bagunçado, entrava qualquer pessoa na redação, não tinha esse negócio de segurança. Era uma zona. Iam artistas, os amigos dos jornalistas, aquele negócio todo. E hoje me lembra mais quando você vai a uma redação, uma repartição pública da receita federal. Por quê? Porque cada um tem o seu computador, os que vão à redação, porque muitos não vão, não há um diálogo assim direto, uma conversa direta. O cara manda recado pro editor dele numa distância às vezes de 5 metros. $\mathrm{O}$ editor responde aquele recado. Ele termina de escrever e vai embora. Foi esse silêncio que mais me chamou atenção - Ricardo Kotscho.

Entre os jornalistas do grupo de 50 anos, Paula Puliti encontrou competição, mas também solidariedade, para ela, dependia da pessoa, apesar de ter visto muita gente competitiva e chefes estimulando isso. Marilu Cabañas vivenciou os dois tipos de situação, mas prevaleceu a solidariedade. Já Bob Fernandes avalia que a competitividade é da natureza humana, o problema é quando ela é "suja": "Quem põe esse ritmo são as pessoas, mas na verdade quem determina esse rumo é a empresa. A empresa que define qual é a lógica que ela vai ter de funcionamento. Tem empresas que estimulam a disputa, e o resultado disso não é legal".

Dos jornalistas de 40 e poucos anos, Antonio levantou outra questão que é o fato de o jornalista precisar de indicação para conseguir trabalhos. Já Ivan Marsiglia fala mais de sua experiência. Teve chefes exigentes, mas compreensivos, que contribuíam com o trabalho. "Tem digamos uma dinâmica de pesos e contrapesos, pressões e 
compreensões de parte a parte e que você consegue fazer seu trabalho de maneira digna se você tiver vontade de fazê-lo." Entre os colegas, viveu em ambientes de solidariedade: "Não passei por nenhum veículo que eu sentisse que realmente a coisa ali era uma guerra generalizada, como eu já ouvi histórias de pessoas que abriram o computador do outro pra roubar ideias de pauta...". Fernanda Cirenza, por sua vez, conta que na Folha teve relações mais afetuosas, na Marie Claire, em geral, respeitosas, e na Brasileiros, muito boas. Para ela, "trabalhar em equipe não é simples":

Exige um refinamento afetivo, porque as pessoas têm todos os problemas que você também tem... Quando você está redatora chefe, você tem que lidar com esses problemas também e eu procuro ser, na medida do possível, muito compreensível com as demandas das pessoas. Mas no fechamento eu sou meio insuportável, eu confesso que sou (risos), eu ouço pouco dos colegas que estão abaixo. Se eu tenho uma dificuldade, em geral, no fechamento, a maioria das pessoas já está muito exausta, então, se você quer mudar um texto de última hora, aquele cara que está abaixo de você fala - essa mulher é uma velha chata, nojenta, está mudando porque, eu sei que rola isso... Já aconteceu comigo também de um redator chefe chegar e falar - Fê, nã nã ni nã não, nos 42 do segundo tempo. Você fala, puta, que inferno... Eu sei que as pessoas ficam irritadas, me xingam internamente, e eu no fechamento não estou nem aí, peço pra fazer até chegar no limite... e muitas vezes eu mesma faço o que tem que fazer ou porque a pessoa foi embora ou porque está se saco cheio Fernanda Cirenza.

Pedro, na Folha, em uma das equipes que trabalhou, viveu um ambiente saudável em que se divertiam muito fazendo o jornal, já em outra sentiu mais vaidade e uma falta de ajuda mútua. Tanto como chefe quando foi chefiado, vivenciou uma relação de proximidade e menos autoritária, inclusive com estímulo para sugerir mudanças. No entanto, "às vezes o estilo de cobrança e de exigência era mais por causa da política da Folha, do que por causa da pessoa ali”.

Maria atualmente tem na EBC um ambiente de solidariedade, especialmente com sua chefia. Aline Scarso, da mesma empresa, também tem essa impressão, mas vê dificuldade com algumas chefias em relação ao cumprimento de direitos. Já o reconhecimento é positivo: "Uma coisa muito legal lá é a gente elogiar matérias uns dos outros... Quando me elogiam, eu divido com as pessoas que participaram, porque eu sou repórter, mas teve o cinegrafista, o editor de áudio, o editor de vídeo, então, acho que trabalhar em equipe é isso...” Aline afirma ter uma competição consigo mesma, sempre tentando fazer "um trabalho melhor do que o anterior".

Miguel avalia que há bastante coleguismo e que as pessoas ajudam umas as outras. Por exemplo, se você chega atrasado em uma cobertura, o colega fala o que 
ocorreu, o que é mais difícil quando há um grupo que sempre cobre aquele mesmo assunto, como em política, e chega alguém de fora. "Como o repórter de rádio não é especialista, ele sempre é um peixe fora d'água numa cobertura." Em relação às chefias, teve experiências boas e ruins.

Leonardo Sakamoto também fala do hábito dos colegas se ajudarem em cobertura, o que também havia sido relatado por Aureliano Biancarelli. Para Sakamoto, "há uma quantidade maior de solidariedade do que de competitividade agressiva". Com as chefias, já teve relacionamentos conflitantes, mas avalia que houve casos em que a voz mais firme da chefia era necessária.

Na Trip, Bruno Torturra nunca sentiu competitividade, e as pessoas que tinham esse comportamento "eram rapidamente expelidas, porque ficava insuportável, era um clima muito solidário". Agressividade dos colegas de profissão, ele sentiu quando estava na Mídia Ninja: "Eles me agrediam muito como se eu estivesse tentando derrotálos e eu nunca estive". Também critica, a partir de fatos vivenciados por amigos, grandes organizações que tendem a ter o ambiente competitivo e encorajam essa competitividade com políticas internas de promoção e aumento de salário em função do tipo de destaque que o jornalista consegue ganhar dentro do veículo. "Acho péssimo pra saúde mental e à saúde da profissão como um todo."

Trabalhando em uma grande corporação, João percebia diferenciação no tratamento dado aos jornalistas. "Se você é um repórter especial tem muitos louros, tem vários benefícios, você ganha bom dia. Aconteceu de eu entrar várias vezes dentro do elevador com o diretor de redação, e ele não olhar pra minha cara." Para ele, existe muita competição no mundo corporativo, mas ele prefere ambientes colaborativos: “todo mundo trabalhando junto, por objetivos comuns". Só que se vê como minoria: "Você acaba sendo engolido em certas situações".

Já Priscilla, em uma pequena editora, não vive um ambiente competitivo e se sentiu bem acolhida desde o início. Quando trabalhou com internet, sentia uma competitividade entre sites, quem daria a notícia primeiro, especialmente na cobertura de reality show. Mas entre os jornalistas, de maneira geral, um ajudava o outro.

Vivian, por sua vez, avalia que cada equipe da rede Brasil de Fato tem muita solidariedade entre si, mas "uma competiçãozinha entre os veículos", por exemplo: "Pra qual que os movimentos vão dar mais atenção? A gente consegue menos verba que o outro..." Ela também vê às vezes uma disputa entre pensamentos políticos. 
As reflexões apresentadas pelos jornalistas entrevistados mostram que é possível ter um ambiente em que as relações de trabalho são baseadas na solidariedade e que os profissionais preferem isso. No entanto, algumas empresas estimulam a competitividade e valorizam posturas agressivas como se isso gerasse mais produtividade. Se em um primeiro momento pode levar a uma maior produção, ambientes competitivos desestruturam a coletividade e encorajam situações assediadoras, que propiciam um sofrimento que pode levar à descompensação e ao adoecimento.

Os jornalistas também falaram sobre as limitações que os incomodam no trabalho. Apareceram questões como a limitação do tempo, condições precárias de apuração, falta de autonomia, autocensura, falta de preparo do jornalista e condições de trabalho precárias. Outras limitações foram as de pensamento, de pesquisa, de quantidade de trabalho, de recursos financeiros e materiais, salarial e de pessoal.

Clóvis Rossi vê o fechamento como a única limitação que o incomoda no jornalismo. Ter uma hora determinada para entregar o texto sem que o considere o ideal. Já Audálio Dantas se incomoda com a censura institucionalizada que existe em toda redação em nome da técnica e dos interesses dos proprietários dos veículos de comunicação.

Dantas cita dois casos que ocorreram em Realidade. Uma matéria sobre mortalidade infantil no Nordeste ${ }^{18}$, que tinha a foto de um pai sozinho levando o caixão de uma criança. A equipe queria que a foto fosse capa e teve que negociar muito para conseguir que ela saísse dentro da revista. Em outra matéria, sobre a caça de caranguejos ${ }^{19}$, a chamada era "A vida na lama" e foi transformada em "Vida Corajosa". "Eu me considerei frustrado com isso, não só eu, mas a redação inteira, mas o fato é que era durante a ditadura, e achavam que aquilo poderia despertar a raiva dos ditadores."

Alberto Dines avalia que encontrou barreiras para se expressar conforme foi se desenvolvendo na carreira. "Hoje eu posso escrever o que eu quero porque eu criei o meu emprego, eu criei o Observatório da Imprensa, mas não são muitos que têm essa oportunidade. Isso é muito doloroso. Você passa a vida se aprimorando, e a sociedade não quer te aproveitar”.

\footnotetext{
${ }^{18}$ A matéria foi publicada com o título "Doença de menino" na revista Realidade de fevereiro de 1970 e pode ser lida em Dantas (2012b, p. 97-116).

${ }^{19}$ A matéria foi publicada com o título "Povo Caranguejo" na revista Realidade de março de 1970 e pode ser lida em Dantas (2012b, p. 117-129).
} 
Aureliano Biancarelli se incomoda como a superficialidade dos relatos e a falta de cor local às matérias. Faltam grandes reportagens ao jornalismo. Lúcio Flávio Pinto, por sua vez, vê "limitações ao exercício independente do jornalismo" no Brasil. Para ele, as empresas fazem autocensura, e os jornalistas se acovardaram: "Eles não esperam pela censura interna, pelo conflito com os patrões, com os editores. Eles se antecipam a isso, deixando de fazer, e eu entendo não só como uma covardia pessoal, mas por causa das circunstâncias, salários muito baixos, cada vez mais restritos." Já Ricardo Kotscho não vivenciou limitação de não poder fazer o que queria ou alguma limitação da empresa. Para ele, hoje, as limitações são de saúde: "Eu ando hoje cinco quarteirões e fico cansado. Dói tudo, dói o joelho, doem as costas.”

Marilu Cabañas aponta uma precariedade que também surgiu em outras falas de jornalistas que atuam em pequenas empresas e mídia alternativa: a falta de recursos financeiros. Ela vivenciou essa limitação nas rádios Cultura e Brasil Atual. Bruno Torturra também lamenta não ter mais tempo e dinheiro para tocar seus projetos jornalísticos. Quando trabalhava em revista, sentia falta de ler e pesquisar mais sobre os assuntos que cobria.

A questão financeira apareceu ainda nas falas de Vivian Fernandes e Priscilla Nery. Vivian conta que o tablóide Brasil de Fato (SP) ainda não tem caixa positivo e há dificuldades estruturais, como o gravador que não funciona e a internet muito lenta. Para a diagramação, há apenas um computador. "Se precisar usar dois, a gente não teria, porque são versões diferentes e aí o mesmo arquivo não abre no outro. Você tem essas limitações estruturais." Além disso, a equipe é pequena - dois repórteres e um estagiário. "Não dá pra fazer sempre a matéria da melhor forma possível." Ela gostaria, por exemplo, de ter feito uma matéria em uma comunidade indígena na zona sul de São Paulo, mas ainda não foi possível. "É uma matéria que a gente quer fazer, mas não necessariamente a gente tem um motorista pra nos levar. Então assim pra ir de ônibus é muito difícil. Isso me incomoda."

A falta de estrutura também incomoda Priscilla, que conta com uma equipe pequena nas revistas. Houve uma época em que a internet caía direto. "Teve um dia que era fechamento e caiu (risos)... Minha casa não é longe, mas até eu me deslocar, abrir as coisas e finalizar, prejudicou bastante." Outra limitação é ter que agradar a fonte ou "ficar cheia de dedos quando vai publicar alguma coisa". "Isso me incomoda porque isso restringe minha liberdade pra escrever". 
Para Leonardo Sakamoto, se tivesse mais recursos financeiros, a Repórter Brasil poderia ampliar seu trabalho. Antonio foi outro jornalista que enfrentou condições precárias de materiais de trabalho. Ele conta sobre a revista que trabalhou: "Mal se tinha um computador, acesso à internet, essas coisas, não tínhamos carro de reportagem, fazíamos matérias de táxi quando dava, quando não dava, de outra forma. E se pagava muito pouco, plano de saúde não existe." Também enfrentou limitações parecidas quando trabalhou em jornal no nordeste.

Fernanda Cirenza, na editora da Brasileiros, não enfrenta limitações de equipamentos tecnológicos. "Aqui a gente tem boas máquinas de computadores. Em geral, as empresas investem nesses suportes." Mas às vezes há problemas. "Isso é histórico no jornalismo, na própria Folha e Globo, que são fortes, teve momento de você esperar motorista ir te buscar horas, porque mandaram os motoristas embora, então, era esquema de rádio táxi." Ela contou casos de colegas que tiveram que usar o próprio carro, pagaram estacionamento e não foram reembolsados; de outros que usam seus próprios equipamentos como notebook e máquina fotográfica. "Tem um desprezo pelo profissional em geral, pelo jornalista, que é grande."

Com experiência em jornal diário, Pedro vê como limitação a quantidade de trabalho e a insatisfação salarial. Ivan Marsiglia, por sua vez, acha muito desgastante se deslocar todos os dias para o Estado. "O jornalista não precisaria vir todos os dias. Ele poderia estar melhor na rua apurando ou escrevendo seu texto em casa com mais tranquilidade." Pedro manifestou essa mesma opinião.

Miguel levanta outra questão: o jornalista "sempre estar sujeito a tratar de um assunto que não conhece e ter pouco tempo para falar ou escrever alguma coisa sobre aquilo”. Bob Fernandes, por sua vez, avalia que faltam pessoas mais bem preparadas, com visão holística. Também critica o fato dos jovens não aceitarem críticas.

Essa não aceitação às criticas, de forma geral, apareceu na fala de Maria. Ela apontou ainda a limitação de pensamento e a falta de se pensar em um projeto maior na EBC. "As pessoas não aceitam você dar outra opinião, elas personalizam. Coisas que são fáceis de resolver, não se resolvem pela inabilidade, inoperância e aí não é só da direção, de uma gestão, mas também dos terceiros e quartos escalões. Isso me frustra profundamente." Mas ela afirma que não desiste. Para Aline, que é da mesma empresa, incomoda não ser pública de fato. "A gente é muito ligada ao governo, porque no final a EBC responde à Secretaria da Presidência da República... É complicado porque se muda 
o governo, muda tudo." Além disso, ela critica o Plano de Cargos e Carreiras e o fato de a maioria dos chefes serem trazidos de fora.

Por fim, João levantou a falta de planejamento ao jornalismo como limitação. Para ele, é preciso pensar, discutir, desenvolver, testar, voltar, dando consistência ao que é feito. Falta tempo para "fazer as coisas com mais significados".

Vimos que essas limitações são ligadas na maioria das vezes à organização do trabalho. Isso reforça a necessidade de se buscar uma nova organização, que valorize os sujeitos, a coletividade, o diálogo e a autonomia, mas também olhe para os recursos materiais e a pressão do trabalho no jornalismo. Reconhecer a centralidade do trabalho, e o jornalista como trabalhador também é fundamental. 


\section{Capítulo 4}

\section{Sofrimento e prazer no trabalho do jornalista}

\section{1 - A Psicodinâmica do Trabalho como referencial teórico}

Nos três primeiros capítulos, ao retratar os entrevistados e refletir sobre a falta de cumprimento de direitos trabalhistas e a organização do trabalho no jornalismo, foi adotada a perspectiva de sofrimento e prazer, a partir da Psicodinâmica do Trabalho (PDT). O sofrimento faz parte do trabalho, mas pode ser transformado em prazer, o que no jornalismo ocorre muito em razão do conteúdo significativo do trabalho e do sentido que o mesmo tem para os profissionais. A discussão sobre o sofrimento e o prazer no trabalho do jornalista será aprofundada neste quarto capítulo, no qual apresentaremos a história e os fundamentos da PDT, para depois mostrar o que os jornalistas consideram sofrimento no jornalismo e outros sofrimentos retratados nas entrevistas como o assédio moral, o estresse, o trabalho como fonte de dor e adoecimento, os riscos e a violência no trabalho do jornalista, e o consumo de álcool e drogas. Após falar sobre os sofrimentos, abordaremos o sentido do trabalho, considerando o que é ser jornalista para os entrevistados, e a relação entre trabalho e vida pessoal. Em seguida, exploraremos o que os jornalistas apontam como prazer no trabalho e discutiremos também a questão da autonomia e da criatividade.

Antes, no entanto, vamos entender os fundamentos da psicodinâmica do trabalho. O artigo de Uchida, Sznelwar e Lancman (2011) aponta Christophe Dejours como principal autor da psicodinâmica do trabalho, a qual se inspira em conceitos da psicanálise, como os mecanismos de defesa, e da ergonomia, por exemplo, a relação entre trabalho prescrito e real. Para explicitar qual a especificidade da PDT, os autores retomam a herança da psicopatologia do trabalho, surgida nos anos 1950, que foi retrabalhada por Dejours, a partir de 1980, e deu origem a essa nova abordagem.

Após a II Guerra, havia um debate para explicar as causas das doenças mentais, destacando-se três matrizes: organogênese, psicogênese e sociogênese. Em relação à organização do trabalho, na França, o modelo preponderante era o taylorista-fordista. Um artigo de 1952, escrito por Sivadon e denominado "Psicopatologia do Trabalho", definiu o nome da disciplina. Outro pesquisador que se tornou referência no tema foi Le 
Guillant. A questão era se o trabalho podia adoecer, relacionando a doença mental e o trabalho. Nesse início, a visão que predominava era a da sociogênese. Le Guillant não considerava o sujeito em suas análises, já que seguia as orientações do Partido Comunista Francês e negava as contribuições freudianas. Ele "pensava que a conduta psicopatológica apresentada pelos trabalhadores era exclusivamente devida aos efeitos patogênicos da situação de trabalho, referendando uma visão mecanicista de causa e efeito" (Ibid., p.3).

Dejours (1992, p.23) relata que após 1968, período marcado por várias mudanças de paradigmas e comportamento, há uma luta pela proteção da saúde mental e se coloca o sofrimento mental como resultado da organização do trabalho. O sofrimento psíquico permanecia quase não analisado, por outro lado, havia o esgotamento do sistema taylorista/fordista, com greves, paralisações da produção, absenteísmo, rotatividade. A Organização Científica do Trabalho passou a ser considerada desumanizante. Assim começam a ser buscadas alternativas como a reestruturação das tarefas. Nascem debates sobre objetivo do trabalho e a relação homem-tarefa. Acentuase a dimensão mental do trabalho industrial. Ao mesmo tempo se desenvolve o setor terciário e crescem as atividades de escritório. "A sensibilidade às cargas intelectuais e psicossensoriais do trabalho" prepara "o terreno para as preocupações com a saúde mental".
A "libertação da palavra": se 1968 aparece como uma data representativa na história da relação saúde-trabalho, é primeiramente em razão do desencadeamento verbal ocorrido durante os acontecimentos de maio de 68 . No centro do discurso de maio de 68 encontramos a luta contra a sociedade de consumo e contra a alienação. (...) o trabalho foi reconhecido como causa principal da alienação, inclusive pelos estudantes. (DEJOURS, 1992, p.24)

$\mathrm{O}$ autor afirma que sua pesquisa se coloca contra uma visão centrada no comportamento humano, que aparecia na psicopatologia do trabalho. Ele caracteriza a dominação da vida mental do trabalhador pela organização do trabalho e a ocultação de seus desejos. O sofrimento mental como resultado da organização do trabalho aparece nas falas de telefonistas, por exemplo, que têm as estratégias defensivas contra o sofrimento utilizadas por essa mesma organização. Elas afirmam que quando estão nervosas, querem que o assinante desligue, então, passam a responder as questões o mais rápido possível, mas já têm que atender outro chamado e assim vão trabalhando mais depressa e atendendo mais pessoas (Ibid., p.100). 
Essas colocações são apresentadas por Dejours (1992) em seu primeiro trabalho, publicado na França em 1980, com o título Travail, Usure Mentale, e publicado no Brasil pela primeira vez em 1987, com o título "A Loucura do Trabalho". A obra nasce dentro da tradição da psicopatologia do trabalho, no entanto, adota também a psicanálise e coloca "o sujeito e a questão da subjetividade na relação entre a organização do trabalho e o trabalhador". Assim afirma que as pessoas não eram passivas diante dos constrangimentos organizacionais, pois elas sofriam, mas podiam construir estratégias defensivas individuais ou coletivas (UCHIDA, SZNELWAR, LANCMAN, p.4). Essa obra é considerada um marco para o desenvolvimento da psicodinâmica do trabalho, pois apesar de ainda não trazer o novo nome, coloca os seus fundamentos.

\begin{abstract}
A PDT nasce de uma prática de ação no campo e de um diálogo entre a psicopatologia do trabalho, a ergonomia, a psicanálise, a sociologia, a fenomenologia, a antropologia e a filosofia. Ela tem como pedra mestra o livro publicado em 1980, na França, intitulado Travail, usure mentale, de autoria do Christophe Dejours. Nesse livro, ainda que a psicodinâmica do trabalho não seja assim nomeada, o autor esboça as premissas norteadoras da teoria. $\mathrm{O}$ autor propõe a clínica do trabalho, cujo objetivo é compreender o conflito entre a organização do trabalho e o funcionamento psíquico do trabalhador. A PDT questiona como as pessoas, apesar de submetidas a diversos constrangimentos relacionados às condições e à organização do trabalho conseguem trabalhar sem adoecer psiquicamente. Como fazem os trabalhadores do ponto de vista psíquico para realizarem suas atividades laborais, apesar de todas as dificuldades que enfrentam no trabalho? A partir deste questionamento é elaborada a complexa categoria normalidade sofrente que informa as estratégias defensivas, construídas individual ou coletivamente, contra o sofrimento patogênico vivenciado no trabalho. Tal categoria pode ser considerada um divisor de águas entre a PDT e a psicopatologia do trabalho. (SEGNINI, LANCMAN, 2011, p.45)
\end{abstract}

Segundo Dejours (2011a), a mudança de nome ocorreu no início da década de 1990, caracterizada por três dimensões: a expansão da clínica do trabalho; a teoria e prática específica elaborada a partir de 1980, dialogando com a teoria psicanalítica do sujeito a partir de Freud e a teoria da sedução de Laplanche, com a sociologia e com as ciências do trabalho, especificamente a ergonomia francesa; e o método de investigação, que analisa o "trabalho psíquico imposto ao sujeito pelo conflito entre os constrangimentos da organização do trabalho e os próprios constrangimentos do psiquismo".

A partir da conceituação da Psicodinâmica do Trabalho e com o lugar que o sujeito vai ocupar nessa nova teoria, Dejours, no nosso entender, vai dialeticamente conservar, ultrapassar e transformar este campo de investigação. Se a Psicopatologia do Trabalho entendia como seu 
objeto a "análise do sofrimento psíquico resultante do confronto dos homens com a organização do trabalho", a PDT, em 1993, passa a entender o seu campo com uma nova perspectiva: "a análise psicodinâmica dos processos intersubjetivos mobilizados pelas situações de trabalho". Não será à toa que a centralidade do trabalho vai passar a ser defendida em um momento em que se apregoa a produção sem o ser humano: a tese agora passa a ser que o trabalho é o mediador privilegiado entre o inconsciente e a sociedade. $\mathrm{O}$ trabalho aqui entendido como trabalhar, como atividade de um sujeito que, ao mesmo tempo, é intersubjetivo. O sujeito entendido inicialmente como alguém que se adapta, passa a ser compreendido como um sujeito ativo que transforma o sofrimento em prazer e que tem um potencial de transformação do real, agindo no mundo, em cooperação com outros. (UCHIDA, SZNEWAR, LANCMAN, 2011, p.5)

O Colóquio Internacional de Psicodinâmica e Psicopatologia do Trabalho, realizado em Paris no ano de 1997, foi importante para a consolidação da área. Nele foi decidido criar a revista Travailler para difundir as investigações científicas deste campo. A primeira publicação aconteceu em 1998. O título faz referência ao "trabalhar", que consiste na mobilização do corpo, da inteligência, da pessoa, para uma produção com valor de uso. O trabalhar é apontado como consubstancial ao humano, e o trabalho tem a ambiguidade de poder gerar saúde e acréscimo de vida ou a doença e a morte. $\mathrm{O}$ trabalho tem o poder de ordenar o mundo, objetivar a inteligência e produzir a subjetividade. Como sujeito inacabado, eu me construo enquanto trabalho. (DEJOURS, 2011b)

Para Segnini e Lancman (2011, p.45), a psicodinâmica do trabalho não vê "o sofrimento no trabalho como produto de uma relação de causa e efeito das relações de poder vivenciadas na esfera da exploração do trabalho" e analisa "o sofrimento e as defesas contra os aspectos nocivos à saúde mental da organização do trabalho". Também não vê o trabalhador como passivo aos constrangimentos organizacionais, pois pode se proteger por meio de estratégias defensivas ${ }^{1}$.

A normalidade representa o resultado de um compromisso, de uma luta entre o sofrimento provocado pelos constrangimentos organizacionais e as estratégias de defesa inventadas pelos trabalhadores para conter esse sofrimento e evitar a descompensação. Mas tais estratégias de defesa, estritamente ajustadas aos constrangimentos exercidos pela organização do trabalho sobre o funcionamento psíquico, têm a marca específica e reconhecível da organização do trabalho em causa. Podemos assim descrever estratégias individuais e colectivas cuja riqueza e diversidade

\footnotetext{
1 "Segundo a psicanálise, a defesa e os mecanismos de defesa se constituem em processos inconscientes que tem por função evitar o desequilíbrio psíquico", assim, o ego tem "certo controle" em relação às forças pulsionais (representações e afetos inaceitáveis a ele) (SEGNINI, LANCMAN, 2011, p.45).
} 
constituem a matéria-prima de uma clínica apelidada de «clínica do trabalho». (DEJOURS, 2011a, p.13)

A questão das estratégias defensivas é trabalhada por Dejours (1992). Logo na introdução de "A Loucura do Trabalho", ele afirma que procurará "divulgar aquilo que, no afronto do homem com sua tarefa, põe em perigo sua vida mental". Também aponta que quer chamar a atenção para a especificidade da vivência operária. O ponto de vista dinâmico é colocado como prioritário. (Ibid., p.11-12) O livro foi construído em torno da seguinte hipótese:

a organização do trabalho exerce, sobre o homem, uma ação especifica, cujo impacto é o aparelho psíquico. Em certas condições, emerge um sofrimento que pode ser atribuído ao choque entre uma história individual, portadora de projetos, de esperanças e de desejos, e uma organização do trabalho que os ignora. Esse sofrimento, de natureza mental, começa quando o homem, no trabalho, já não pode fazer nenhuma modificação na sua tarefa no sentido de torná-la mais conforme às suas necessidades fisiológicas e seus desejos psicológicos - isso é, quando a relação homem-trabalho é bloqueada. (DEJOURS, 1992, p. 133)

Acreditamos que essa hipótese de Dejours pode ser aplicada ao trabalho do jornalista. Uma pessoa que deseje poder e status se sentirá bem trabalhando em grandes veículos de comunicação que representem esse poder, como a revista Veja ou a TV Globo, por exemplo. Já uma pessoa que vê a linha editorial desses veículos ir contra os seus princípios pode vivenciar um cenário de sofrimento devido ao choque de seus desejos enquanto sujeito e um trabalho contrário ao que acredita. Uma organização do trabalho mais fechada, que enquadre o jornalista em um padrão de texto sem espaço para a criatividade, também pode bloquear essa relação com o trabalho.

As entrevistas que fizemos para a pesquisa, de certa forma, indicam como é importante essa identificação com o trabalho. Os depoimentos mostraram, por exemplo, que tanto a jornalista da mídia alternativa, que não é registrada, quando o jornalista que trabalhava na Folha e tinha uma longa jornada, suportavam o desrespeito ao direito regulamentado porque acreditavam no trabalho em que faziam, como já foi discutido anteriormente.

Se o sofrimento faz parte do trabalho, ele pode variar conforme a organização do trabalho (Ibid.). No trabalho repetitivo, surge a insatisfação, que é a "porta de entrada para a doença" e podem ocorrer descompensações mentais ou doenças somáticas. Já as tarefas perigosas resultam no medo. Para lidar contra esse medo ou contra a 
insatisfação, os trabalhadores elaboram estratégias defensivas, e o sofrimento é disfarçado.

Em relação aos efeitos do trabalho repetitivo sobre a atividade psíquica, Dejours (1992, p.43) explica que a atividade intelectual engajada, que era característica do operário-artesão, desaparece. Antes "o corpo obedecia ao pensamento", o qual "era controlado pelo aparelho psíquico, lugar do desejo e do prazer, da imaginação e dos afetos". Com o sistema de Taylor há uma "subtração do estágio intermediário, lugar da atividade cognitiva e intelectual". Quebra-se, nesse contexto, a atuação coletiva.

Uma vez conseguida a desapropriação do know-how, uma vez desmantelada a coletividade operária uma vez quebrada a livre adaptação da organização do trabalho às necessidades do organismo, uma vez realizada a toda poderosa vigilância, não restam senão corpos isolados e dóceis, desprovidos de toda iniciativa. A última peça do sistema pode ser induzida sem obstáculos: é preciso adestrar, treinar, condicionar esta força potencial que não tem mais forma humana. (DEJOURS, 1992, p.42)

Cabia, então, a psicopatologia do trabalho estudar o que ocorria "com a vida psíquica do trabalhador desprovido de sua atividade intelectual pela organização científica do trabalho". Nesse contexto, o indivíduo com uma "história personalizada" se chocava com a organização do trabalho "despersonalizante" e desse embate surgia uma vivência e um sofrimento a serem esclarecidos (Ibid.., p.43). A organização do trabalho pode induzir uma paralisia mental e quando os trabalhadores enfrentam a monotonia das tarefas com possibilidades defensivas individuais menos eficazes, o sofrimento é agravado (Ibid., p.45).

O sofrimento do trabalhador dá lugar a uma semiologia que é chamada de "ideologia defensiva da profissão" na construção civil ou nas indústrias químicas, de "síndrome subjetiva da fadiga nervosa" ou de "síndrome de contaminação pelos comportamentos condicionados", nas tarefas taylorizadas. (Ibid, p.134)

O sofrimento é um tema bastante analisado por Dejours (1992, p.48-62), sendo tema do capítulo 2 e permeando todos os outros textos do livro. Há "dois sofrimentos fundamentais organizados atrás de dois sintomas: a insatisfação e a ansiedade”. No discurso dos trabalhadores, percebe-se um sentimento de vergonha de ser robotizado, de ser uma extensão da máquina, "de não ter mais inteligência ou imaginação, de estar despersonalizado". Vivencia-se um sentimento de inutilidade e não se reconhece o significado do trabalho em relação ao todo da empresa. O cansaço não vem apenas dos esforços musculares. A vivência depressiva se alimenta da sensação de adormecimento 
intelectual. O sofrimento começa quando a evolução da formação da imagem de si em relação ao trabalho é bloqueada.

O sujeito pode ter suas capacidades subempregadas na adaptação do conteúdo das tarefas às competências reais do trabalhador. O conteúdo significativo do trabalho em relação ao sujeito abrange "a dificuldade prática da tarefa, a significação da tarefa acabada em relação a uma profissão" e o estatuto social do posto de trabalho. Também há o conteúdo em relação ao objeto, "exterior e real por um lado", interiorizado por outro. Toda atividade tem os dois termos, e o essencial da significação do trabalho é subjetivo. Vale ressaltar ainda que não há neutralidade dos trabalhadores sobre o que eles produzem. Ser colocado em um posto considerado duro, por exemplo, tem uma significação para ele e para os outros.

Quanto mais a organização do trabalho é rígida, e a divisão do trabalho é acentuada, o conteúdo significativo do trabalho e as possibilidades de mudá-lo são menores. Quando o conteúdo ergonômico da tarefa (exigências físicas, químicas e biológicas) não se adapta às necessidades da estrutura mental também ocorre insatisfação, sofrimento ou um forte estado de ansiedade. O sofrimento impacta primeiro sobre o corpo, e essa insatisfação é uma carga de trabalho psíquica. Já a insatisfação em relação ao conteúdo significativo da tarefa traz um sofrimento que impacta mentalmente, mas também pode levar às doenças somáticas. (Ibid., p.61-62)

Se a violência da organização do trabalho pode, mesmo na ausência de nocividade dos ambientes de trabalho (por exemplo nos empregos de escritórios), criar doenças somáticas e não apenas psíquicas é porque o aparelho mental não é um "compartimento do organismo, simplesmente justaposto à musculatura, aos órgãos sensoriais e às vísceras. A vida psíquica e, também, um patamar de integração do funcionamento dos diferentes órgãos. Sua desestruturação repercute sobre a saúde física e sobre a saúde mental. (Ibid., p.134)

Apesar dessa constatação, já neste primeiro livro Dejours (1992) fala que o trabalho pode ser favorável ao equilíbrio mental e a saúde do corpo. Assim afirma que a boa adequação entre organização do trabalho e estrutura mental se apoiam numa "análise precisa da psicodinâmica da relação homem/trabalho". Essa situação é alcançada quando "as exigências intelectuais, motoras ou psicossensoriais da tarefa" vão ao encontro das necessidades do trabalhador, assim, o exercício da tarefa se origina de uma descarga ou de um "prazer de funcionar". Outra possibilidade ocorre quando o “conteúdo do trabalho é fonte de uma satisfação sublimatória. Nesse caso, concepção do conteúdo, do ritmo de trabalho e do modo operatório são deixados em parte nas 
mãos do trabalhador. A organização do trabalho pode ser modificada conforme seu desejo ou suas necessidades e até variar "com seus próprios ritmos biológicos, endócrinos e psicoafetivos". Essas características são possíveis para artesãos, profissionais liberais e responsáveis de alto níveis. Cita ainda o caso de artistas e pesquisadores, apesar de sacrifícios materiais os fazerem sofrer, o prazer do trabalho é a melhor defesa que possuem. (Ibid., p.134-135)

Essas afirmações podem ser estendidas aos jornalistas, pois nessa área o conteúdo do trabalho pode levar ao prazer, quando há essa identificação com o local em que se trabalha e o tipo de material que se produz, e o prazer também funciona como defesa que faz suportar todo o sofrimento anterior, seja motivado pelo inédito do trabalho, por condições organizacionais ou mesmo por descumprimento de direitos. $\mathrm{O}$ prazer do trabalho realizado e o sentido que se atribui a esse trabalho, supera o que faz sofrer. Se o jornalista tiver espaço para exercer sua criatividade e autonomia, podendo adequar as pautas aos seus desejos e necessidades, como assuntos que têm afinidade, que atribui relevância ou que tem a ver com o que acredita ser jornalismo, haverá prazer, pois se afere um valor positivo ao trabalho realizado.

O prazer no trabalho também tem relação direta com o reconhecimento. Dejours (2012b, p.39) explica que "o que mobiliza a inteligência não é apenas a retribuição material, o salário, mas uma retribuição simbólica, ou mesmo 'moral'. Essa retribuição toma uma forma extremamente precisa: o reconhecimento". Esse reconhecimento é colocado tanto como gratidão quanto como reconhecer a "contribuição do sujeito que trabalha", assim, ele passa por julgamentos:

O julgamento de utilidade. Utilidade econômica, social ou técnica da contribuição própria do trabalhador. O julgamento é proferido pela hierarquia. $\mathrm{O}$ desejo de ser útil é psicologicamente crucial. Esta é a razão de ser tão perigoso para a saúde mental o ato de "pendurar as chuteiras" ou de ficar desempregado: o sujeito torna-se inútil para o outro.

O julgamento de beleza. Este se anuncia sempre em termos estéticos... Este julgamento só pode ser proferido por aqueles que conhecem a fundo o trabalho, os colegas, os pares. Ele credencia um retorno de pertencimento a um coletivo, a um ofício, a uma comunidade. (DEJOURS, 2012b, p.40)

O autor coloca ainda que "o reconhecimento como retribuição simbólica pela contribuição" trata da qualidade do trabalho e não da pessoa em si, focando assim o fazer. Esse julgamento do registro do "fazer" pode, no entanto, alcançar o "ser" em um segundo momento. Dessa forma, o sujeito pode ser transformado pelo reconhecimento 
ao se realizar. "O reconhecimento pode transformar o sofrimento em prazer. O reconhecimento a imprimir ao trabalho o seu sentido subjetivo" (Ibid.). A questão do reconhecimento é muito importante para o jornalista, como veremos adiante, tanto o reconhecimento de seus pares, como de seus leitores.

...a psicodinâmica do trabalho completa a análise dinâmica do sofrimento e das estratégias defensivas pela análise dinâmica do sofrimento e sua transformação em prazer pelo reconhecimento. O trabalho atua junto com o sofrimento e o reconhecimento. Se o reconhecimento não aparece, os sujeitos engajam-se em estratégias defensivas para evitar a doença mental, com consequências sérias para a organização do trabalho. (DEJOURS, 2012b, p.110)

Outra questão abordada por Dejours (1992, p.136) é quando o sofrimento auxilia a produtividade através do uso que se faz dos mecanismos de defesa usados contra ele. Casos que ocorrem na construção civil em que as defesas coletivas da profissão são usadas para a produtividade e das telefonistas em que a ansiedade contribui para a aceleração das cadências. A exploração passa pelo aparelho mental, assim como a exploração do corpo depende de uma neutralização da vida mental. A submissão vem a partir da ação sobre os processos psíquicos. Assim a carga psíquica do trabalho é uma etapa necessária para que o corpo se submeta. Contra esse sofrimento, essa ansiedade e insatisfação são construídos os sistemas defensivos. Eles escondem o sofrimento, e a dor fica desconhecida.

No caso das telefonistas ${ }^{2}$, as falas das trabalhadoras mostram a frustração - "o trabalho nos deixa idiotas". Vivenciam o controle e a tensão do trabalho - seja porque são vigiadas ou porque devem ficar caladas diante dos insultos, não se admite a variação no vocabulário. A sensação de ser controlada é tanta que criam um autocontrole, "pois ter medo de ser vigiado é vigiar-se a si mesmo". Nesse contexto, há uma relação entre a "tensão nervosa" e a produtividade. Quanto mais tensa a telefonista fica e mais agresssiva se sente, deve intensificar a autorrepressão. Essa agressividade reativa é explorada pela organização do trabalho. A energia é orientada para a tarefa. Proibida de responder agressivamente, de desligar, de fazer o cliente esperar, só é permitido reduzir o tempo da comunicação, levando o outro a encerrar a ligação. Então precisam trabalhar mais de pressa para se livrar da situação, mas logo um chamado é terminado, outro cai no atendimento. "O sofrimento produz o trabalho", mas se o limite pessoal for

\footnotetext{
${ }^{2}$ Em 1980, quando lança a obra, Dejours fala em telefonistas. As reflexões podem atualmente ser estendidas aos trabalhadores de telemarketing.
} 
ultrapassado, a descompensação pode vir como uma crise nervosa, por exemplo. (Ibid, p. 96-103)

O que é explorado pela organização do trabalho não é o sofrimento, em si mesmo, mas principalmente os mecanismos de defesa utilizados contra esse sofrimento. No caso das telefonistas, o sofrimento resulta da organização do trabalho "robotizante", que expulsa o desejo próprio do sujeito. A frustração e a agressividade resultantes, assim como a tensão e o nervosismo, são utilizados especificamente para aumentar o ritmo do trabalho. (DEJOURS, 1992, p. 104)

A ansiedade também é explorada nas indústrias químicas, onde há ignorância sobre os processos. Há apenas dicas de um saber descontínuo, que não forma um conhecimento coerente. O saber do trabalhador se constrói de forma operatória, e o saber possível circula pelo companheirismo dos colegas. Os macetes dos trabalhadores permitem o funcionamento da fábrica, e eles têm conhecimentos que o saber especializado das chefias desconhecem. A exploração do medo aumenta a produtividade ao estimular a criação de macetes que fazem a fábrica funcionar. Com ele, a atenção aumenta e o medo partilhado cria uma solidariedade na eficiência. (Ibid.., p. 105-115)

Dejours (1992, p. 63-74) explica que o medo está presente em todas as atividades profissionais. Ele "responde por um aspecto concreto da realidade e exige sistemas defensivos específicos". O medo pode advir dos ritmos ou dos riscos oriundos de más condições de trabalho e destrói a saúde mental dos trabalhadores. A ideologia ocupacional defensiva é uma forma de enfrentar esse medo. Na construção civil, o aparente desprezo pelo risco, na verdade, significa que o medo é vivenciado pelos mecanismos de defesa, os quais o neutralizam, só assim os trabalhadores podem executar sua tarefa. A bravura e a falsa ideia de que criam o próprio risco mostram o domínio da situação. Nessa ideologia defensiva da profissão, ninguém pode ter medo ou demonstrá-lo. E se acontece o acidente, é porque o trabalhador exagerou, o que atenua o medo e coloca o risco como algo que foi procurado e não como parte do processo de trabalho. Essa ideologia ocupacional defensiva permite a continuidade do trabalho mesmo com alto risco como determina a seleção pessoal.

O desprezo pelo risco também está presente no trabalho do jornalista, que precisa neutralizar o medo para fazer determinados tipos de cobertura, como matérias investigativas, reportagens em áreas de conflito ou em regiões violentas. Enfrentar o risco e o medo é condição para realizar o trabalho. Não utilizamos a metodologia da psicodinâmica do trabalho, que permitiria desvelar as defesas psíquicas dos jornalistas. 
No entanto, podemos apontar que há indícios de que a neutralização do medo também funcione como uma ideologia ocupacional defensiva para os jornalistas.

Por outro lado, o sentimento de medo em si também pode ser usado no jornalismo para se extrair produtividade, como o medo de ser demitido, diante das constantes demissões na área, e das avaliações individuais, retratadas no capítulo anterior, nas quais permanece o medo e a tensão de não ser bom suficiente. Mesmo os jornalistas que não passam por sistemas de avaliação carregam esse peso da competência e a insegurança de não alcançá-la.

Já em relação às ansiedades, o autor (Ibid.., p.75-76) destaca as relações hierárquicas, nas quais as supervisões devem mantê-las para o rendimento do trabalhador no caso das indústrias. No setor de serviços, é mantida pela falsa esperança de promoção e por sistemas de avaliação, que também existem no cotidiano de trabalho jornalístico. Ocorre ainda uma manipulação psicológica em que informações sobre a vida do funcionário são usadas como pressão. A rivalidade é usada como uma forma de controle.

Dejours (1992, p.77-78) define três formas de ansiedade. A primeira, "ansiedade relativa à degradação do funcionamento mental e do equilíbrio psicoafetivo", gera dois tipo ansiedade: uma "resulta da desestruturação das relações psico-afetivas espontâneas com os colegas de trabalho" ou das relações violentas e agressivas da hierarquia, provoca a contaminação das relações fora da empresa e às vezes é atenuada com bebidas alcoólicas; a outra abrange a desorganização do funcionamento mental, fruto dos efeitos da organização do trabalho e da despersonalização.

Acreditamos que esse primeiro tipo de ansiedade pode estar presente no ambiente jornalístico. Em Heloani (2003b), vemos relatos de jornalistas que mostram a relação agressiva da chefia. Um dos entrevistados afirmou: "Sei de colegas que ouviram coisas horríveis. Uma garota na minha sala foi falar sobre o aumento de salário e o chefe respondeu assim: ah, vocês vão continuar tomando no cu até o fim do ano" (Ibid.., p.61). Em relação aos nossos entrevistados, problemas de relações de trabalho que culminaram até em assédio moral serão retratados adiante. De qualquer forma, quando existe essa dureza nas relações, cria-se um ambiente em que qualquer questionamento é bloqueado. Ribeiro (2001, p.157) conta ter presenciado "subeditores normalmente cordiais transformarem-se em indivíduos possuídos pelo nervosismo que, no ápice, amaldiçoavam sua vida e apresentavam taquicardias frequentes”. Ele também relaciona a questão da ansiedade com o trabalho do jornalista a partir de Dejours (1992): 
A precariedade aumenta a margem de entropia e a possibilidade de erro, obrigando o profissional a compensá-la através do investimento em tempo extra e na aquisição de conhecimentos. Daí decorrem a ansiedade e o pânico de errar, que resultam em esgotamento progressivo e, com frequência, se somatizam em doenças alérgicas e até cardíacas. O sofrimento mental é administrado pelas empresas - e, portanto, tornado produtivo - por meio de mapas de erros personalizados, de ameaças e sanções; seu objetivo é a submissão e a indução ao autocontrole. Daí a afirmação de Christophe Dejours de que 'ter medo de ser vigiado é vigiar-se a si mesmo. O medo e a ansiedade são os meios pelos quais se consegue faze respeitar os preceitos hierárquicos'. Dessa forma, obedecer é proteger-se da ansiedade originada pelo risco de cair em erro." (RIBEIRO, 2001, p.158-159)

O segundo tipo relatado por Dejours (1992, p. 78-79) é a “ansiedade relativa à degradação do organismo", que resulta das ameaças à integridade física, seja por causa do risco de acidentes ou doenças relacionadas ao trabalho. A terceira é a "ansiedade gerada pela 'disciplina da fome", que se caracteriza por trabalhar, apesar do sofrimento mental, como exigência da sobrevivência.

Outro grupo abordado pelo psicanalista é o de pilotos de caça em que se explora a questão do prazer no trabalho (Ibid.., p. 80-89). A ideologia da profissão é necessária para manter "um moral feito de orgulho, de insolência e de agressividade". Características importantes para enfrentar as condições de trabalho. O piloto também precisa manter a "vigilância e suas faculdades psicossensoriais para observar" todas as informações visuais ou sonoras, apesar de dores de ouvido e abdominais, náuseas, suores, cefaléias, perturbações visuais e neurovegetativas.

A situação de funcionamento homem-máquina exige a perfeição. São desenvolvidas técnicas para adaptar o trabalho ao homem e cada acidente gera pesquisa. Também é realizada preparação técnica para missões e psicológica para incidentes. Duas ações importantes para defesa na luta contra o medo e a ansiedade. Há um esforço para o domínio do risco. Além disso, os pilotos se veem como uma elite admirada por todos. A tarefa complexa exige a associação perfeita das qualidades intelectuais, psicológicas e físicas. Essa profíssão mostra como os efeitos do medo provocados pela organização do trabalho podem ser atenuados pela satisfação no trabalho. O prazer vem da relação com o conteúdo significativo da tarefa. "Voar sozinho é o supremo prazer em que o piloto deixa-se levar pelo gozo narcísico. (...) verdadeira reconciliação entre o eu adulto e as aspirações arcaicas de ideal (ideal do ego), fonte de um sentimento de bem estar, de vitória e de exaltação". 


\begin{abstract}
A boa qualidade da relação motivação-satisfação e, particularmente, o prazer proveniente do conteúdo significativo e simbólico do trabalho são absolutamente necessários à manutenção da performance "ergonômica" e à atenuação do medo. Para ser perfeita, a adequação homem trabalho exige não apenas um conteúdo excepcionalmente interessante da tarefa mas também uma seleção rigorosa entre os candidatos da profissão, a excepcional adaptação do prazer tirado do trabalho ao desejo do piloto de caça permite-lhe enfrentar a cada dia as condições de trabalho particularmente nocivas e a tolerar um medo, que seja do nosso conhecimento não acontece em nenhum outra situação de trabalho. A estrutura mental muito particular dos pilotos de caça contém talvez "um grão de loucura" que não inútil para ousar desafiar assim a morte a cada dia. (DEJOURS, 1992, p.95)
\end{abstract}

Também vemos no jornalista a possibilidade de existência de um prazer proveniente do conteúdo significativo e simbólico do trabalho. Alguns depoimentos colhidos por Ribeiro (2001) mostram isso ao retratar jornalistas que consideram a profissão "uma missão". "Exige-se uma adesão ideológica enorme e uma dedicação que não é de um mero profissional. Você tem de ficar no jornal um número de horas muito maior do que em qualquer outro lugar", afirmou Carlos Eduardo Lins da Silva ao autor (Ibid., p.131).

A dedicação de nossos entrevistados ao jornalismo segue o mesmo sentido. Apesar de não falarem na missão do jornalismo, eles chegam a utilizar o termo paixão, e suas falas deixam claro o envolvimento com a profissão e o sentido que ela dá à vida. A mística permanece no imaginário dos profissionais e na importância que dão ao trabalho do jornalista, como sendo, por exemplo, essencial para a democracia.

Há uma necessidade de ser jornalista 24 horas, que aparece em outros estudos e permanece nas falas de nossos entrevistados, tanto os mais velhos quanto os mais jovens. Esses sentidos do trabalho serão discutidos adiante, mas é possível supor que o sentido e a importância que os jornalistas dão ao seu trabalho podem funcionar como uma ideologia defensiva para enfrentar as longas jornadas e estar sempre pronto a trabalhar, o que deixa de ser visto como um trabalho, já que o espectro da missão e da paixão permanece presente. Isso é utilizado pelas empresas para explorar o profissional e obter mais produção e dedicação ao trabalho. Você só é reconhecido como jornalista se você trabalhar muito e se estiver sempre disponível.

Por outro lado, como vimos no segundo capítulo, alguns entrevistados, especialmente os mais jovens, com menos de 45 anos, levantaram a necessidade do jornalista se ver como trabalhador. A importância da coletividade também apareceu na 
fala dos mais velhos. O que nos remete à cooperação no trabalho, que vai ao encontro de algumas colocações de Dejours.

A cooperação fundada sobre acordos normativos e regras de trabalho passa por uma atividade deôntica cujos objetivos são de libertar-se, pelo menos de forma parcial, da dominação, para reapropriar-se individual e coletivamente de uma parte de autonomia, não apenas pelo gosto da liberdade, da transgressão ou da indisciplina, mas porque esta margem de autonomia é indispensável para o exercício da inteligência, para a formação das habilidades e do prazer da "subversão poiética". (DEJOURS, 2012b, p.96-97)

Vale lembrar que essa cooperação é afetada pelas avaliações individuais. Segundo Dejours (2011a), a forma como a avaliação individual tem sido desenvolvida leva a destruição das possibilidades de trabalho coletivo, de cooperação e solidariedade. Esse tipo de organização do trabalho está relacionado com os "processos de servidão voluntária e de deterioração da saúde mental no trabalho". Dessa forma, o sujeito fica sozinho frente à dominação, à injustiça e ao assédio.

Outra limitação trazida à tona por Dejours (1992, p.137) é a “alienação", tanto no sentido de Marx, como "tolerância graduada segundo os trabalhadores de uma organização do trabalho, que vai contra os seus desejos, suas necessidades e sua saúde", quanto no sentido psiquiátrico, "de substituição da vontade própria do Sujeito pela vontade do Objeto". A fadiga é necessária, pois é mais fácil alienar os trabalhadores cansados. A alienação, por sua vez, é necessária à sujeição do corpo.

(...) trata-se de uma alienação, que passa pelas ideologias defensivas, de modo que o trabalhador acaba por confundir com seus desejos próprios a injunção organizacional que substituiu seu livre arbítrio. Vencido pela vontade contida na organização do trabalho, ele acaba por usar todos os seus esforços para tolerar esse enxerto contra a sua natureza, ao invés de fazer triunfar sua própria vontade. Instalado o circuito, é a fadiga que assegura a sua perenidade, espécie de chave, necessária para fechar o cadeado do círculo vicioso. (DEJOURS, 1992, p.137)

Com essas últimas considerações, o autor (Ibid.., p.138-139) conclui que os mecanismos da alienação devem ser desmantelados para um projeto de transformação social, ainda que isso seja insuficiente para que ela ocorra. É preciso considerar a "vivência operária" e ler o sofrimento dela no seu próprio discurso e nos sistemas defensivos. Deve-se "compreender que as resistências individuais ao prazer acompanham resistências coletivas, no centro das quais se encontram, precisamente, as ideologias coletivas de profissão". Da transformação da organização do trabalho e da dissolução dos sistemas defensivos "pode nascer uma evolução da relação saúde 
mental-trabalho". Por fim, devemos encontrar soluções para acabar com a desestruturação das pessoas pelo trabalho.

Outros aspectos apontados por Dejours (2012a, 2012b) foram discutidos no capítulo anterior, quando falamos da centralidade do trabalho e da organização do trabalho, como a importância da constituição de espaços de deliberação - fundamentais nesses tempos de pós-fordismo em que há uma falsa sensação de autonomia e coletividade que tem mais a ver com a adesão total à empresa, a dimensão política do trabalho e a possibilidade de ampliação da subjetividade. Dejours (2012a, p.204-205), afirma que pensar na centralidade política do trabalho, ou seja, na "força de transformação contida no trabalho em relação à evolução da sociedade e do vir a ser da polis", "supõe pensar a emancipação e seus limites". Isso é possível por meio da cooperação, que ocorre quando se oferece aos indivíduos a possibilidade de se mobilizar em uma construção coletiva.

Uchida, Sznelwar, Lancman (2011) destacam a importância de se "pensar o trabalho como mediação entre o inconsciente e o social" e da proposta de emancipação trazida pela PDT, que possibilita a reconstrução por meio das palavras e recuperação das vivências, revertendo a banalização da organização do trabalho que legitima a dominação e pasteuriza os desejos.

O trabalho de produção - poiesis - é uma provação para toda a subjetividade, de onde podem emergir novas habilidades, isso com a condição que esta provação seja completada por um segundo trabalho - Arbeit - de si sobre si, ou de transformação de si.

(...)

O trabalho é uma provação da qual a identidade pode sair fortalecida, ao ponto que uma vida de trabalho pode abrir um verdadeiro processo de realização de si, de emancipação. (DEJOURS, 2012b, p.210)

Mas o autor (Ibid.., p.211) explica que os seres humanos possuem uma identidade incerta e por essa razão precisam de confirmação e reconhecimento pelo outro. Se trabalhar é viver junto, o trabalho é o espaço para essa realização. Por outro lado, "a busca pelo reconhecimento é a fraqueza a partir da qual grande número de homens e de mulheres podem ser levados a engrossar as fileiras dispostas ao pior, para não perder este reconhecimento e para não se encontrar sozinho quando todos os demais consentem em colaborar".

O trabalho, por tudo isso, é um ponto central da fragilidade constitutiva do ser humano. Da provação do trabalho ele pode sair engrandecido em dignidade ou diminuído pela experiência da traição, a de consentir em se deixar instrumentalizar, bem como de instrumentalizar o outro. 
Assumir politicamente tanto a fragilidade constitutiva do ser humano como a indeterminação axiológica da inteligência no trabalho é pinçar desta antropologia do sujeito e do trabalho os elementos a permitirem conceber a organização do trabalho, de maneira que ela ofereça aos homens e às mulheres que trabalham os caminhos que assegurem a articulação entre o trabalho ordinário e o desenvolvimento da civilidade, do viver junto e das obras da cultura. Nessas condições, pode-se uma vez mais esperar que volte o entusiasmo ali onde se instalou a desolação, mas também que o trabalho possa ser colocado, a serviço das solidariedades e da emancipação. (DEJOURS, 2012b, p.212)

\section{2 - O trabalho como fonte de sofrimento}

Ao longo dos três primeiros capítulos, em diversos momentos, pontuamos a questão do sofrimento, seja usando o referencial de Christophe Dejours, seja apontando o descumprimento dos direitos trabalhistas e a forma como o trabalho é organizado como fontes de sofrimentos para os jornalistas. Desde a introdução, quando relatamos a entrevista que Dejours nos concedeu na época em que trabalhávamos na revista Proteção, fica claro que o sofrimento sempre está presente no trabalho, a questão é se ele terá a possibilidade de ser transformado em prazer.

Para Dejours (2012b, p. 25), "o real se deixa conhecer pelo sujeito por sua resistência aos procedimentos, aos saber-fazer, à técnica, ao conhecimento, isto é, pelo fracasso imposto ao domínio sobre ele - o real". O sujeito é confrontado pelo mundo real, de modo afetivo, e se depara com o fracasso. Ao provar a resistência do mundo, a afetividade se manifesta ao sujeito. "Assim, é nessa relação primordial de sofrimento no trabalho que o corpo realiza a um só tempo a experiência do mundo e de si mesmo". Mas esse não é o fim e sim o começo de uma ação que pode levar à ampliação da subjetividade:

O sofrimento é também um ponto de partida. Nesta experiência, concentra-se a subjetividade, o sofrimento torna-se um ponto de origem visto que esta condensação da subjetividade sobre si mesma anuncia um tempo de dilatação, de desdobramento, de reexpansão que lhe sucede. O sofrimento não é apenas uma consequência última da relação com o real, é ainda proteção da subjetividade rumo ao mundo em busca de meios para agir sobre o mundo, para transformar este sofrimento encontrando os meios de superação da resistência do real. Assim o sofrimento será ao mesmo tempo impressão subjetiva do mundo e origem do movimento de conquista do mundo. O sofrimento, enquanto é afetividade absoluta, está na origem desta inteligência que 
parte em busca do mundo para experimentar-se a si próprio, para transformar-se, para ampliar-se.

Neste movimento que parte do real do mundo como resistência à vontade ou ao desejo, para completar-se como inteligência e em poder de transformação do mundo, neste movimento, portanto a subjetividade transforma-se, amplia-se e revela-se a si mesma. (DEJOURS, 2012b, p.26)

As colocações mostram um sujeito ativo com possibilidades de ação. Ele pode transformar, mas a dureza da organização do trabalho pode limitar esse sujeito. É a discussão colocada no tópico anterior quando se aponta que a organização do trabalho pode ir contra os desejos e as necessidades do sujeito e bloquear esta expansão.

Heloani (2006, p.194), ao avaliar os resultados encontrados a partir de 44 entrevistas com jornalistas, chega a discutir a questão do sofrimento no trabalho desses profissionais. Para ele, há "um claro indicador de que as práticas organizacionais trouxeram, como efeito colateral danoso, não apenas a corrosão de certos valores básicos, mas, principalmente, a cisão da ideia de qualidade de vida e excelência no trabalho". Os jornalistas postergam a felicidade, o tempo para a família, para os filhos, para o lazer e para o amor. "Alguns chegam a alegar que fora do ambiente de trabalho só fazem o imprescindível, faltando tempo para namorar".

O autor analisa que o sofrimento que, para Dejours, "deveria ser uma expectativa com relação à auto-realização, um estado mental que implicasse um movimento da pessoa sobre sua existência, passa a ser relegado à condição de estado temporário, dentro da ilusão de que o curto prazo torna tudo plausível". Desse modo, Heloani (Ibid.) aponta que "o próprio significado de vida mostra-se deteriorado pelo predomínio do efêmero" e que as iniciativas em prol da qualidade de vida "parecem estar muito mais alinhadas com aspectos da profissão do que com uma genuína emancipação".

A questão é de identidade. Continua sendo uma profissão glamourizada. E isso cria uma relação ambígua de amor e ódio. Ao mesmo tempo que se vêem como Dom Quixote, se vêem lá embaixo. Isso é muito esquizofrênico e produz um sofrimento muito grande. Jornalistas postergam a felicidade. "Ah, tudo bem, eu vou dar um duro danado aqui, mas daqui cinco ou seis anos eu vou melhorar. Então, mudam muito de emprego, mudam, mudam, mudam, pensando que no próximo vai ser melhor, vai dar certo. Mas o que acontece? Você tem uma cobrança social, uma cobrança da família que você não cumpre. Esse é o mecanismo que enlouquece. Como ele investiu muito, não pode desistir. Já investiu muito, já sofreu muito, a dívida com ele mesmo é muito grande. (HELOANI, 2013, p.7) 
Grisci e Rodrigues (2007, p. 51), que entrevistaram seis jornalistas do Rio Grande do Sul, também chegam a pontuar a questão do sofrimento psíquico a partir da reflexão dos entrevistados sobre organização do trabalho e mostram alguns "pontos de conflito entre vida e trabalho indicados pelos participantes: sensações de desconforto físico e psíquico -, taquicardia, decepção com a profissão, reivindicações caladas, inspirações frustradas, impactos na vida social”.

Ferraciolli (2000), por sua vez, entrevistou 19 jornalistas do Paraná, para a sua dissertação de mestrado, em que avaliou o sofrimento no trabalho desses profissionais. O autor aponta o sofrimento gerado pela organização do trabalho, nem sempre é percebido pelos jornalistas, os quais são tão envolvidos pelo trabalho, que não chegam a refletir sobre suas próprias condições de vida (Ibid., p.7). Há uma naturalização da velocidade do processo produtivo (Ibid., p.61). Outras fontes de sofrimento são os baixos salários, a falta de possibilidade de planejar o futuro e a ausência de reconhecimento pelos outros (Ibid., p.89). Até mesmo o fato de alguns entrevistados se considerarem naturalmente jornalistas (nasceram para isso) gera sofrimento, pois há "um comprometimento intrínseco com a profissão que, quando não é mantido, faz com que o sofrimento apareça na forma de insuficiência com as atividades que realiza" (Ibid., p.99).

O fenômeno sofrimento aparece vinculado nas condições de trabalho quando referem-se às situações a que estão submetidos no cotidiano do trabalho (velocidade na realização das tarefas, excesso de trabalho, trabalho ininterrupto, escassez de tempo decorrente da vida ocupada pelo trabalho e as pressões por produtos presentes nas atividades que realizam, problemas de saúde, salários baixos), nos sentimentos relatados (desamparo, não-reconhecimento, menos-valia da profissão, depreciação, medo, relacionamento afetivo, solidão, tristeza, insatisfação com a formação). O sofrimento aparece, também, como natural do envolvimento com a profissão na forma de fatalismo e nas diversas contradições encontradas nos relatos (tudo é ruim, mas não largo a profissão; ritmo frenético é atraente, porém, queixam-se por falta de tempo livre; para trabalhar tem que ter cabeça boa, porém, todos ficam com a cabeça ruim; a profissão não interfere na família, porém, descrevem de forma vívida os problemas familiares, apresentam conceitos amplos de saúde, porém, relatam vividamente os problemas de saúde gerados no trabalho). (FERRACIOLLI, 2000, p. $\mathrm{X}-\mathrm{XI})$

A questão do sofrimento no trabalho do jornalista também foi tratada durante as entrevistas realizadas para esta pesquisa de doutorado. Nesse primeiro tópico apresentamos o que os próprios entrevistados consideram sofrimento, a partir da 
pergunta: "O que vê como sofrimento no [ $\left.\mathrm{seu}^{3}\right]$ trabalho de jornalista?" Também entram nessa análise outros itens apontados no decorrer das falas, quando houve o uso do termo sofrimento ou algum equivalente. Dessa forma, é a própria percepção do sujeito sobre sofrimento que aparece. Outros sofrimentos, que vieram de questões específicas feitas durante a entrevista, serão relatados nos próximos tópicos. São os seguintes temas: dores e adoecimento, assédio moral, estresse, riscos e violência, álcool e drogas.

Os jornalistas convivem diariamente com o sofrimento no trabalho. Há um grande envolvimento com a profissão e não há separação entre trabalho e vida pessoal. O trabalho dá sentido à vida, e o envolvimento e a mistificação da profissão fazem com que se aceitem as condições organizacionais, como o excesso de trabalho, longa jornada, ritmo e pressão, ainda que essas condições sejam fatores de sofrimento.

Nas entrevistas realizadas para a tese, esse sofrimento atrelado à organização do trabalho aparece nas falas dos jornalistas entrevistados. As condições de trabalho e a precariedade, as jornadas exaustivas, a pressão contra o relógio e pelo prazo do fechamento, o desgaste físico e emocional, o próprio trabalhar e suas etapas foram citados na questão sobre sofrimento no trabalho. Outros itens considerados sofrimento foram: o fechamento; fazer o trabalho em tempo curto e não ter as melhores condições para realizá-lo; baixa remuneração (não conseguir pagar as contas com seu trabalho); trabalhar fim de semana; a falta de reconhecimento.

Também apareceram questões ligadas à subjetividade, autonomia e realização profissional. Assim foram apontados como sofrimento no trabalho: tratar de temas para os quais você não está preparado; falta de espaço para reflexão; cobrir o que não gosta; perseguição e não poder desenvolver o seu trabalho; frustração de não poder dizer tudo; frustração de não trabalhar no que queria; frustração em relação à matéria; fazer pauta sem identificação; não ter liberdade para se expressar; não conseguir fazer o jornalismo em que acredita.

Pelas falas é possível perceber que o sofrimento faz parte do trabalho como mostra a psicodinâmica. A própria escrita foi citada como um processo doloroso pelo jornalista Ivan Marsiglia - "Escrever a matéria é o mais difícil e desgastante pra mim, porque tem as questões das suas exigências, o que você quer fazer, o que você quer publicar, você quer colocar no material. Esse é o momento mais dramático mesmo, mais

\footnotetext{
${ }^{3} \mathrm{O}$ pronome seu foi usado na maioria das entrevistas.
} 
cansativo". As reportagens mais longas são as que mais causam sofrimento, mas, ao mesmo tempo, as que mais lhe trazem alegria depois.

Ivan Marsiglia se recorda de um caso que lhe causou muito sofrimento psicológico. Foi uma reportagem sobre o cotidiano de um médico num pronto socorro de periferia. Ele passou uma semana no local. "Foi uma matéria muito dura. Vi quatro pessoas morrerem na minha frente. Então foi muito intenso, impactante. Ali eu trabalhei com certa tranquilidade, mas depois tive pesadelos na semana seguinte."

Produzir um bom texto, o ato de escrever, é sofrimento para Fernanda Cirenza. "É uma construção. Conseguir pra mim é sofrer. Não é eu fui lá, que delícia, estou escrevendo... Texto de revista é muito diferente de jornal, é pedra sobre pedra, é palavra por palavra..." As condições de trabalho também podem causar sofrimento: o contratante não lhe pagar pelo serviço, você não ter carro para fazer a cobertura, "o seu computador quebrar e ninguém arrumar, isso é sofrido”. O não reconhecimento também a faz sofrer: "o que é sofrido mesmo é você achar que fez um bom texto e alguém olhar e falar não, está tudo errado. Isso dói, às vezes a pessoa melhora o seu texto e às vezes não melhora, isso é sofrível".

O sofrimento na elaboração da matéria também apareceu no depoimento de Audálio Dantas, que se definiu como um sofredor do texto. Para ele, "o jornalista é um angustiado". Com a pressão do tempo, aliada à preocupação dele com a elaboração do texto, sentia uma angústia muito grande. "Eu estou incluído entre aqueles jornalistas que se chamam o sofredor do texto. É o jornalista que busca a elaboração do texto mais aperfeiçoado possível”.

Outro sofrimento relatado por Audálio "é a frustração que certamente existiu e continua a existir de você não poder dizer tudo que você vê". Na avaliação dele, os jornais atualmente são editorializados, e muitos fatos buscados pelos repórteres não são noticiados. Essa frustração é compartilhada por Lúcio Flávio Pinto, o que ele completa com a falta de repercussão de fatos importantes:

É não poder divulgar a informação e, divulgando, que ela não tenha compreensão sobre sua importância. Essa é a principal fonte de sofrimento. Por isso eu criei um jornal que eu sei que vai ser minha fonte permanente de novos sofrimentos, porque tem momentos que eu gostaria que meu jornal tivesse duas mãos pra pegar o leitor e puxar ele pela lapela e dizer, o seu desgraçado, isso aqui é importante. Eu tenho a seguinte diretriz, se eu fizer determinado tipo de matéria, o jornal vende - matéria política, matéria de fofoca, bastidores do poder, todo mundo quer ler. Mas Carajás ninguém quer ler... O jornalismo não é apenas pra reproduzir os fatos, mas também pra mostrar pro leitor a importância daquele fato, para a ação do leitor como 
personagem da história. Então tem uma função didática importantíssima, pedagógica.... Então esse é um momento que você vê a história passando, você alerta, vamos fazer, vamos fazer, e você está falando pro deserto - Lúcio Flávio Pinto.

Para Clóvis Rossi, sofrimento é não conseguir fazer a matéria que tinha na cabeça quando começou a trabalhar nela ou quando não se tem o espaço suficiente para publicar a matéria, no tamanho que considera ideal, ou ainda "não ter nem espaço para publicar nada", o que às vezes acontece. Já para Alberto Dines sofrimento é "fazer o que você não gosta, escrever o que você não gostaria de escrever, não conseguir colocar a sua energia, a sua vitalidade".

Há ainda aqueles sofrimentos que marcam a trajetória de uma pessoa. Para Alberto Dines, as demissões que sofreu foram dolorosas. Ele calcula cerca de dez demissões, que trouxeram punição pelo que ele expressava: "Você está defendendo o ponto de vista que são aqueles que você acredita melhores pra democracia, pra vida brasileira, e de repente você leva um soco na cara desse..." Um dos episódios mais duros que sofreu foi a saída do Jornal do Brasil:

Eu fui saído, e foi saído também o meu substituto, houve um corte muito brusco na cadeia de comando, mas mesmo assim o jornal manteve... A minha saída foi uma das coisas mais sórdidas que eu já assisti alguém fazer, por sorte eu estava muito bem amparado, já fazia análise naquela época, mesmo assim eu tive o baque, porque mudou minha vida... - Alberto Dines.

A demissão de Aureliano Biancarelli da Folha também lhe causou sofrimento. "Eu me senti muito injustiçado. Eu fui mandado embora nas férias, na minha primeira semana de férias, só me avisaram, quando eu voltasse das férias eu estaria demitido". Ele conta que sentiu "um baque muito grande", porque tinha seu espaço, seu horário, autonomia, credibilidade: "Eu tinha um nome no meio que circulava e tendo o jornal como porta voz, meio de divulgar, eu ganhava muita força, era um jornalista da Folha de S. Paulo". O trabalho lhe dava a possibilidade de transformar pequenos temas em assuntos com destaque, como questões sobre diversidade e transexualidade. "Foram temas que eu comecei”.

E tinha essa sensação, não que nunca fosse sair da Folha, mas de que nesse veículo eu não seria cortado dessa maneira. E aí eu fiquei tão surpreendido com isso, que eu acho que eu não lidei da melhor maneira, eu deveria ter aproveitado esse momento pra fazer contatos com as redações e retomar meu posto em outra redação, mas como eu já estava há muitos anos lá, tinha sido chefe de redação, eu tinha um bom salário, que os outros não iriam me oferecer... - Aureliano Biancarelli. 
Biancarelli passou a fazer trabalhos como freelancer. Foram trabalhos ligados aos temas que cobria como uma publicação sobre crianças com câncer. Mas ele que sempre quis apenas ser repórter, apesar de ter sido chefe duas vezes, sente falta do jornal e do reconhecimento que esse trabalho trazia:

Agora passaram dez e eu continuo fazendo essas coisas. Se me perguntasse se eu gosto de fazer essas coisas que eu estou fazendo, eu diria que não. Claro que é melhor do que muita coisa que anda sendo feita por aí, em qualquer publicação, em qualquer veículo, mas na reportagem, no texto, com visibilidade, com repercussão, tenho certeza que não vou ter mais chance de fazer. E acho que eu perco muito com isso, acho que o outro lado perde também - Aureliano Biancarelli.

Marilu Cabañas também passou pelo sofrimento da demissão no SBT. Ela já havia tido problemas éticos em relação a algumas coberturas, com os quais não concordava. Lá chegou a ouvir que tinha um lado na história. Em outra ocasião queriam que ela filmasse escondido um velório de uma criança vítima de explosão:

Até que um dia teve uma fatalidade. Um carro explodiu, um cinegrafista estava passando e filmou a explosão desse carro. Tinha uma mãe, que tinha resgatado uma filha, e quando foi pegar o menino, explodiu com o filho dentro. E eles colocavam de tempo em tempo, o $\tan \tan \tan$, assista ao Aqui e Agora, com aquela imagem. E me falaram assim:

- Você vai cobrir o velório.

- Mas cobrir o velório? Pra quê?

- Não, vamos cobrir o caso.

- Mas qual o sentido?

- Não, é pra cobrir.

A falta de identificação com a pauta e o questionamento sobre o sentido do trabalho já ilustram quando o sofrimento aparece. A jornalista foi com a equipe até o local e pediu que eles a aguardassem. Ela preferiu tentar contato com a família sozinha. Para a tia da criança falou que estava lá em nome do SBT e perguntou no que podia ajudar. "Foi a única coisa que eu consegui falar". A tia pediu que retirassem a imagem sensacionalista do ar. Marilu repassou o pedido ao seu chefe:

- A família não quer falar e pediu para tirar a imagem do ar. Eu dei a minha palavra, por favor, retire agora.

- Espera um pouco.

Ele foi falar com alguém acima. Não sei quem. Ele voltou e falou para mim:

- Marilu, a ordem é para você filmar escondido.

Eu falei:

- Como é que é?

- É para você filmar escondido. 
- Eu estou com tanto nojo do que você está falando, que eu nem vou voltar para pegar o meu carro no estacionamento. Vou de metrô pra casa. Tchau. E fui embora.

No dia seguinte eu voltei para pegar o carro, entrei na redação, não me deram nenhuma matéria - Marilu Cabañas.

Depois desse episódio, Marilu foi trabalhar no Jornal do SBT e acabou sendo demitida como toda a equipe, quando a apresentadora Lílian Witte Fibe foi para a TV Globo. "Eu fiquei muito mal. Já tinha todo um problema no Aqui Agora, questões éticas... Quando eu fui demitida, bom, não sei te definir se fiquei em depressão, mas fiquei dois anos parada”. Ela nunca havia sido demitida. Durante o período, foi fazer análise. Chegou a receber convite para trabalhar na então TV Manchete, mas não quis.

$\mathrm{Na}$ avaliação de Marilu Cabañas, a perseguição e a falta de liberdade em relação à pauta são os maiores sofrimentos que se pode ter no trabalho. Já Aureliano Biancarelli aponta os sofrimentos cotidianos oriundos do confronto com o real do trabalho:

Você esperar e não conseguir falar com a pessoa. Não conseguir achar a fonte que você está procurando. Não conseguir confirmar alguma coisa que você tem como suspeita. Acompanhar a trajetória de pessoas que estão sofrendo injustiças e você não conseguir fazer nada, está conseguindo apenas relatar, você está envolvido de certa forma com isso - Aureliano Biancarelli.

Outra questão levantada por Aureliano é o luto. Para ele, falta preparo psicológico do jornalista para fazer coberturas de tragédias e lidar com a morte: "Você recebe uma pauta e diz, caiu um avião, pode ter muitos mortos, mas como você vai absorver isso? O jornal não te dá nenhuma retaguarda. Não é uma preocupação do jornal como é que você vai lidar com isso". Ele recorda como foi a cobertura da queda do avião da Tam:

O jornalista acaba no momento do fato tão envolvido com a coisa que, geralmente, ele segura as emoções. Eu vi 100 corpos juntos do avião fokker da Tam no chão. Não me lembro de ter ficado caído em prantos, eu tinha que pegar a informação, quantos corpos eram, se tinha sobrevivente, se não tinha, e depois no dia seguinte você continuava tocando as coisas. Não que você deixasse de sentir Aureliano Biancarelli.

O sofrimento que o trabalhador sente quando se depara com o inédito do real também aparece na fala de Ricardo Kotscho. "Sofrimento é uma coisa permanente, porque qualquer matéria que você for fazer, importante ou não, grande ou pequena, você nunca sabe o que vai encontrar, o que você vai conseguir". O jornalista precisa encontrar a personagem, chegar ao local, obter as informações para contar a história. "É um desafio diário, permanente, que você só termina quando você entrega a matéria, e a 
matéria é editada no jornal." Para ele, o sofrimento faz parte, e "a insegurança é uma coisa a favor do jornalista", porque, quem se sente seguro e acha que sabe tudo não é surpreendido por uma boa matéria. "Acho que nesse sentido é sempre bom ser foca a vida inteira... E claro que quando você não consegue, você fica frustrado como qualquer ser humano".

O jovem João, assim como Kotscho, detém-se ao ato de trabalhar quando fala dos sofrimentos: o fechamento, conseguir aquela fonte, fazer o texto mais completo, reunir as melhores opiniões, esgotar todas as possibilidades. "Então se você tem que ouvir todos os lados, ir ouvir todos os lados. E fazer tudo isso em um tempo curto, com condições nem sempre as melhores, acho que isso é o grande sofrimento da profissão."

O próprio fazer jornalístico continua aparecendo em algumas falas sobre o sofrimento no trabalho do jornalista assim como as questões organizacionais. Para Paula Puliti, a pressão contra o relógio é o sofrimento maior. Já Bob Fernandes aponta "as eventuais condições precárias" e um ambiente de trabalho ruim. Ivan Marsiglia, por sua vez, considera a jornada de trabalho extensa e a quantidade de trabalho simultâneo que é preciso realizar como fontes de sofrimento.

Para Antonio, o jornalista sofre para produzir a matéria, para o resultado agradar a direção e aos chefes imediatos e com a repercussão entre os leitores. "Se você não cria uma casca pra aquilo, se você não cria métodos pra se desligar ou pra se imunizar disso, eu acho que isso me causa certo sofrimento". Ele também acrescenta a esse ciclo de produção as condições ruins de trabalho, que fazem com que o jornalista nunca se desligue, ou seja, obrigado a se desligar quando adoece ou porque tomou remédio. "Isso é o que causa maior sofrimento. E numa perspectiva futura saber que aquilo não tem condições de melhorar a não ser que eu saia dessa atividade, que as coisas só vão piorar em termo de condições de trabalho."

O sofrimento no trabalho, com condições ruins e "descompensação da chefia", aliado à doença na família fez com que Maria deixasse um dos locais em que trabalhou. "Eu não tinha condição emocional de aguentar aquilo." Sobre a situação atual que vive, Maria fala sobre o sofrimento que é fazer parte da Comissão de Empregados e trabalhar em uma empresa pública, com a sensação de que você está "numa empresa privada fazendo matéria tipo Globo". Ela coloca como sofrimento "a própria missão do jornalismo. Você não conseguir fazer o jornalismo que você acreditou na faculdade. Eu acho que isso é um sofrimento que eu vejo em muitos colegas..." A jornalista ainda destaca a jornada de trabalho muito pesada com pouco retorno financeiro. 
Em termos de direitos sociais e de tudo é muito ruim pra vida do jornalista. E isso é sofrer. Então, você trabalha, hora extra, não pagam. Você ter que fazer 10 matérias no dia, e o chefe não quer saber, você tem que fazer de qualquer jeito. Você tem essa pressão, principalmente quem é do mercado, se você não fizer, tem um exército de reserva prontinho pra ocupar sua vaga. Isso eu acho muito cruel... A regulação da profissão do jornalista pelo mercado vai afetar a vida pessoal e causar sofrimento, ela já causa, embora muita gente não perceba que essa é uma relação com o capital, acha que é só uma relação com a sua chefia, no seu microcosmo - Maria.

A questão das longas jornadas de trabalho também foi apontada como sofrimento por Pedro. "Não conseguir ter uma vida social fora do trabalho, ter plantões excessivos no final de semana, ser muito exigido, são esses problemas que eu falei. Não sei se tem algum outro tipo de sofrimento. É isso.” Já para Leonardo Sakamoto "a maior violência é você não poder exercer sua profissão por problemas causados internamente na redação ou externamente na sociedade, (...) e ser tratado da uma forma indigna como um trabalhador".

Miguel também coloca como sofrimento a precariedade do trabalho e as limitações de organização das redações, que obrigam o jornalista a ter jornadas exaustivas, tratar de coisas para as quais não está preparado ou não tem conhecimento suficiente pra tratar. Como Aureliano Biancarelli, levanta o sofrimento de lidar com a morte, a cobertura de grandes tragédias e dos problemas sociais do país. "É um desafio você trabalhar no jornalismo, pensar nisso, e tentar fazer a sua parte." Ele ainda relata que quando trabalhou na TV e no portal de notícias do interior, teve que fazer cobertura policial, assunto com o qual não tem afinidade e isso lhe causava angústia.

Fazer pauta com a qual não se identifica também é causa de sofrimento para Aline Scarso. Outro sofrimento apontado pela jornalista é não ter liberdade para se expressar, apesar de afirmar não passar por isso. "Mas eu acho que é muito triste você não conseguir fazer algo porque alguém te impede". Ela ainda fala sobre o sofrimento da precarização e de ter que trabalhar nos finais de semana e feriado. "Ontem, por exemplo, eu só tive o dia. Minha mãe emendou, minha irmã emendou, então é triste, eu queria estar com elas e não posso por conta da minha profissão."

Bruno Torturra, por sua vez, vê como sofrimento a falta de recursos para viabilizar seu projeto jornalístico e as injustiças do mundo. "Isso me oprime, me deixa muito triste, me massacra. Ver o que a polícia faz com as pessoas, essa coisa de direitos humanos me afeta muito, me deixa muito revoltado." Para ele, o jornalismo se conecta 
com esses problemas intensamente, porque "é uma forma de você lutar por um mundo mais justo, mas também é uma forma de você trabalhar dentro do esgoto".

Priscilla Nery foca o sofrimento na organização do trabalho. A pressão é o grande problema, seja quando ocorre devido à chefia, seja quando vem da própria demanda do trabalho, o que ocorre no seu caso. Deixar de publicar algo por interesses comerciais ou ser injusto com a fonte podem ser outros sofrimentos. Ela fala sobre uma situação que vivenciou quando trabalhou com internet, que foi contra a idealização que se tem da profissão:

Não era uma coisa super séria, que ia prejudicar, mas era algo que eu achava que deveria ser dito. Então foi uma omissão, que eu achava importante e me causou sofrimento psicológico. A gente tem uma profissão idealizada de que a gente vai poder sempre falar a verdade, desmascarar as coisas erradas... Eu acho que a maioria dos jornalistas acredita nisso ainda. Aí você chega numa empresa e às vezes dá mais espaço para uma coisa que você acredita que não faz diferença nenhuma e dá menos espaço para algo importante, relevante ou você não poder ouvir alguma fonte. Eu acho que tudo isso causa um sofrimento - Priscilla Nery.

Vivian Fernandes é outra entrevistada a abordar questões organizacionais como fontes de sofrimento, mas também foca no trabalhar. Há um sofrimento físico oriundo das longas jornadas, de se passar muito tempo usando o computador. "Eu acho que é algo que o corpo sente. É uma forma de sofrimento, que às vezes é combatido com álcool ou com medicamentos, dorflex da vida, acho que tem esse sofrimento físico." Existe o sofrimento emocional, que é a cobrança de o jornalista ter que fazer uma matéria que agrade, escrever um bom texto, conseguir apurar e falar com as pessoas. "Essa dependência do outro, de ter que conseguir, de ficar em um ambiente competitivo, tal, causa um sofrimento emocional muito grande, um stress, aquele sufoco do dia a dia, que acaba sendo naturalizado, mas que ele ocorre, ele ocorre."

\section{3 - Dores e adoecimento}

Dejours (1992, p. 119-132) relaciona a organização do trabalho e a doença. Saber se a exploração do sofrimento pode ter repercussões sobre a saúde dos trabalhadores é a questão colocada. A exploração mental é fonte de mais-valia nas tarefas desqualificadas. As estratégias defensivas podem controlar o sofrimento e 
impedir que ele se transforme em patologia. A diminuição da pressão organizacional também faz com que as manifestações do sofrimento desapareçam. No entanto, há casos em que os ritmos de trabalho são mantidos ao nível máximo de tolerância. Se esse limiar coletivo é passado, algum trabalhador pode não conseguir manter os ritmos de trabalho ou o equilíbrio mental. Uma das soluções é mudar de empresa, o que explica a rotatividade. Outra é o absenteísmo. "O sofrimento mental e a fadiga são proibidos de se manifestarem numa fábrica. Só a doença é admissível” (Ibid.,p.121). Esse sofrimento mental acaba sendo disfarçado pela medicalização.

Em relação às doenças mentais, o autor explica que a "exploração do sofrimento pela organização do trabalho não cria doenças mentais específicas", pois "as descompensações psicóticas e neuróticas dependem, em última instância das personalidades". No entanto, a fadiga faz com que o aparelho mental perca a versatilidade; "o sistema frustração-agressividade reativa" reprime a energia pulsional; e a "organização do trabalho, como correia de transmissão de uma vontade externa, que se opõe aos investimentos das pulsões e às sublimações". Sintomas subjetivos também podem impedir o retorno ao trabalho. A síndrome subjetiva pós-traumática pode vir depois de um acidente de trabalho, pois ele comprova a ineficácia da ideologia ocupacional. O trabalhador passa a enfrentar sozinho o perigo e o medo. (Ibid., p. 122124)

Quando as defesas caracteriais e comportamentais, que não são psiconeuróticas e são menos flexíveis que as defesas mentais, não são exercidas durante o trabalho, há risco de acúmulo de energia pulsional, que não se descarrega. Já se ocorre uma contribuição exagerada dessas defesas pode ocorrer uma desorganização. A doença somática aparece quando as defesas caracteriais e comportamentais são neutralizadas. É importante ainda saber que a livre organização do trabalho é fundamental para o equilíbrio psicossomático e da satisfação. Já a organização do trabalho rígida e imposta pode comprometer o equilíbrio psicossomático, pois pode bloquear os esforços do trabalhador na adequação do modo operatório às necessidades da estrutura mental. Outro ponto é que "o conflito entre a economia psicossomática potencializa os efeitos patogênicos das más condições físicas, químicas e biológicas do trabalho”. (Ibid., p. 126-128)

Nós propomos a seguinte hipótese: a organização do trabalho e, em particular, sua caricatura no sistema taylorista e na produção por peças é capaz de neutralizar completamente a vida mental durante o trabalho. Nesse sentido, o trabalhador encontra-se, de certo modo 
lesado em suas potencialidades neuróticas e obrigado a funcionar como uma estrutura caracterial ou comportamental. Efetiva-se assim, artificialmente, pelo choque com a organização do trabalho, o primeiro passo para uma desorganização psicossomática experimental.

Em nossa opinião, uma das maiores causas da doença somática é o bloqueio contínuo que a organização do trabalho - e, em especial, o sistema taylorista - pode provocar no funcionamento mental. (Ibid, p. 129)

Seligmann-Silva (2011, p.539-541) afirma que "atividades em que a tensão gerada é constante e elevada, especialmente quando não ocorrem apoio social e reconhecimento" provocam sofrimento mental, que pode levar ao "surgimento de depressões e de diferentes processos mórbidos associados à tensão continuada", como "hipertensão arterial, úlcera péptica, gastrite nervosa".

Outra questão retratada pela autora é que "a fadiga mental é indissociável da fadiga física", trata-se de um "cansaço geral", que também pode ser chamado de "fadiga crônica", quando esse cansaço se acumula ao longo do tempo (Ibid., p. 140-141). Essa última é marcada por distúrbios do sono, irritabilidade, desânimo, dores diversas e perda de apetite.

As longas jornadas, a tensão e pressão vivenciadas pelos jornalistas podem levar à fadiga. A vida mental do jornalista também pode ser neutralizada pela padronização existente da atividade e uma organização do trabalho fechada, que inibe a criatividade e autonomia, regida por manuais de redação, avaliações individuais e por pouca liberdade de atuação.

Alguns estudos chegam a abordar a questão da saúde do jornalista. Heloani (2006, p.191) afirma que dos 44 jornalistas pesquisados, 40 apresentaram fracasso no quadrante relativo à saúde no Inventário de Qualidade de Vida ${ }^{4}$. Outro problema apontado por Heloani (2003b, p. 20) é que a partir da implantação de novas tecnologias nas redações, os jornalistas se deparam cada vez mais com o adoecimento:

Pesquisas da Organização Internacional do Trabalho (OIT), junto a sindicatos de jornalistas, demonstram uma tendência nada promissora para essa profissão: devido às doenças insidiosas e, portanto, de difícil diagnóstico precoce, parte significativa desses profissionais não alcança sequer a aposentadoria... Ademais, a partir da implantação de novas tecnologias nas redações nacionais, os usuários - jornalistas em sua maioria - se vêem cada vez mais diante dos "Distúrbios Osteomusculares Relacionados ao Trabalho" (DORT). (HELOANI, 2003b, p.20)

\footnotetext{
${ }^{4}$ O autor se baseou em Lipp e Rocha (1996, p.191).
} 
Esse adoecimento chegou a ser abordado em reportagem da revista Imprensa, de outubro de 2006, produzida pelos jornalistas Alex Sander Alcântara e Otávio Grillo: “Quando o jornalismo provoca DORT”. Na matéria, destaca-se a rotina exaustiva dos jornalistas e que muitos aprendem a conviver com a dor, chegando a omiti-la para não ficar marcado. Um dos casos apresentados é de uma jornalista que teve tendinite, bursite e tendinose crônica. $\mathrm{O}$ texto mostra a relação que há entre LER/DORT ${ }^{5}$ com fatores psicossociais como estresse, pressão e assédio moral, indo além da questão dos movimentos repetitivos. Outra autora a falar sobre o adoecimento do jornalista é Travancas (1993).

As doenças mais frequentes entre os jornalistas são úlcera, cardiopatias e outras ligadas ao alto consumo de álcool. Mais recentemente, com a chegada dos computadores à redação dos grandes jornais, têm surgido também doenças de visão. Algumas dessas doenças estão relacionadas com o estilo de vida boêmio do jornalista e com a tensão muito própria do ofício. Nesse contexto de trabalho, o consumo de álcool e de drogas está presente, em escalas diferentes, é claro, mas refletem um tipo característico de sociabilidade do grupo estudado. Segundo pesquisa realizada pelo jornalista Silvio Júlio Nassar sobre doenças profissionais entre jornalistas, ocorre que 'na verdade o profissional nunca está desligado totalmente. Na prática, o trabalho não tem limites. O próprio fascínio da profissão leva a essa situação'. (TRAVANCAS, 1993, p.31)

Ribeiro (2001, p.157) afirma que é comum, entre os jornalistas, a queixa de problemas nervosos: "A tensão está cotidianamente presente nos comentários de colegas que se queixam de problemas nervosos, ou dos que, ao entrar de férias, demoram a desarmar mecanismos de trabalho, ou daqueles que têm pesadelos com computadores, com chefes". O autor destaca ainda que a "ansiedade e o pânico de errar" resultam "em esgotamento progressivo e, com frequência, se somatizam em doenças alérgicas e até cardíacas" (Ibid., p.158). Ele presenciou a dispensa de vários colegas por problemas de saúde, após acumularem duas jornadas para se antecipar a edição de domingo do jornal (Ibid.,p.94).

Outra manifestação de formidável grau de prioridade da área comercial sobre a editorial é o pescoção, horário implantado no Estado nas noites de sexta-feira e madrugadas de sábado. Trata-se de uma estratégia cujo objetivo é, logo em seguida à exaustiva jornada de

\footnotetext{
${ }^{5}$ Segundo publicação do Ministério da Saúde de 2005, o termo LER/DORT (Lesões por Esforços Repetitivos / Distúrbios Osteomusculares Relacionados ao Trabalho) "se refere aos distúrbios ou doenças do sistema músculo esquelético, principalmente de pescoço e membros superiores, relacionados, comprovadamente ou não, ao trabalho". Entre as características estão fadiga neuromuscular causada por trabalho em posição fixa ou com movimentos repetitivos, principalmente dos membros superiores, falta de flexibilidade de tempo e ritmo elevado de trabalho; além de sintomas como dor, formigamento, dormência, choque, peso, fadiga precoce.
} 
trabalho, antecipar a produção da edição de domingo, que normalmente seria concluída na tarde de sábado. A justificativa é que assim se antecipa a distribuição de domingo.

(...) A acumulação de duas jornadas, a quebra do ciclo biológico (não é raro equipes saírem do jornal às $5 \mathrm{~h}$ da manhã de sábado), provocaram problemas de saúde e motivaram o pedido de dispensa de vários profissionais. Ergonomistas sustentam que as mudanças de horário têm consequência sobre a saúde dos trabalhadores, pois alteram o seu ritmo circadiano (que inclui sono, tensão arterial, temperatura, consumo de oxigênio). (RIBEIRO, 2001, p.94)

$\mathrm{O}$ adoecimento tem influência do trabalho e de outros fatores. Segundo Ribeiro (2010, p.307-308), pessoas com condições sociais de vida e trabalho semelhantes podem adoecer de maneiras diferentes. "As formas de reação orgânicas e psíquicas aos agravos revelam modos particulares de sentir o mundo...". O trabalho "cada vez mais medido e controlado" e a capacidade de produzir, no entanto, são vistos como um "divisor de águas" entre a saúde e a doença. Essa última é percebida a partir da "dor que dificulta ou impede o fazer".

(...) as doenças não se manifestam de modo igual; primeiro porque os sujeitos, mesmo quando irmãos univitelinos, não são clones, apesar de terem constituintes orgânicos e inorgânicos parecidos ou comuns; segundo porque os agravos a que se vêem obrigados a se expor no trabalho e fora do trabalho diferem qualitativamente, quantitativamente, no tempo e no lugar; terceiro porque as alterações anatômicas, fisiológicas, psíquicas e afetivas ocorridas com os adoecidos raramente guardam relação simétrica com tais agravos...

Por isso o que faz adoecer alguns pode não adoecer outros, e os que adoecem o fazem de modos diferentes; isto é, cada sujeito tem um modo particular de reagir, de adoecer ou não adoecer. (RIBEIRO, 2010, p.309)

No caso das LER/DORTs, Ribeiro (2010, p.312) aponta que os números e prevalências desse tipo de adoecimento têm aumentado em um cenário de trabalho intensificado e de rígido controle. Crescem também os transtornos mentais e comportamentais, como apontou a psiquiatra Edith Seligman Silva, em entrevista à publicação especializada em saúde e segurança no trabalho, a revista Proteção de fevereiro de 2009. São 12 tipos de transtornos mentais relacionados ao trabalho reconhecidos pelo Ministério da Saúde, como a depressão. Muitas vezes um adoecimento acarreta outro.

Entre os adoecimentos físicos que tem ligação com o sofrimento ou adoecimento mental, destaco as LER/DORTs. Muitos estudos sobre as lesões de esforços repetitivos mostram que elas são acompanhadas de transtornos como depressões. Chamamos isso na medicina de comorbidade. Nós temos frequentemente associações de doenças do trabalho com transtornos psíquicos e isso é bastante compreensível. 
Quando as pessoas percebem que estão limitadas fisicamente, que foram adoecidas pelo trabalho e não podem mais desempenhar a profissão que amavam, para qual muitas vezes tinham vocação, elas vivenciam um sentimento intenso de perda. (SELIGMANN-SILVA, 2009a, p.11-12)

Segundo publicação do Ministério da Saúde de 2005, o aumento de casos de LER/DORT está relacionado a mudanças na forma como o trabalho é organizado. São fatores como inflexibilidade, ritmo de trabalho intenso, realização de movimentos repetitivos em grande velocidade, sobrecarga muscular, ausência de controle sobre o modo e ritmo de trabalho, a não existência de pausas, exigência de produtividade, mobiliário e equipamentos desconfortáveis.

As organizações, pressionadas pelo processo de globalização, substituem cada vez mais o homem pela máquina, implementam novas tecnologias e obrigam o jornalista a adaptar-se freneticamente a elas. Assim sendo, o seu corpo, que é o seu instrumento de trabalho, se "ressente" e a sua mente se "surpreende" como se pode inferir através da observação dos consideráveis níveis de stress. Afinal, como responderam dois de nossos depoentes, "isso é uma fábrica de loucos", "o ambiente era tão pesado que as pessoas morriam... de câncer". (HELOANI, 2003b, p.78)

Ferraciolli (2000, p.77-79) aborda os problemas de saúde relatados pelos 19 jornalistas de sua pesquisa. As doenças mais enfatizadas foram as LER/DORTs e o alcoolismo, além de problemas devido ao estresse. Os entrevistados apontaram ainda problemas como azia e dor de estômago, respiratórios e oftalmológicos. Entre os repórteres cinematográficos, houve queixas de dores nas costas e nas articulações, principalmente nos joelhos, devido ao peso dos equipamentos que carregam.

Já Kilesse e Machado (2009b), a partir de um questionário aplicado a 44 jornalistas de uma empresa jornalística de Minas Gerais, levantaram alguns sintomas vivenciados frequentemente pelos profissionais. Os que mais apareceram foram ansiedade (19 jornalistas), irritabilidade (14 jornalistas), dor de cabeça (13 jornalistas), dor no pescoço (11 jornalistas), dor lombar (11 jornalistas) e dor nas costas (10 jornalistas). Dez jornalistas afirmaram ainda ter dificuldades para dormir. Metade dos entrevistados relatou que raramente (50\%) toma algum medicamento, contra $42 \%$ que o fazem frequentemente e $8 \%$ que responderam nunca. Perguntados sobre como classificam seu estado de saúde, $2,3 \%$ disseram ser ruim, 34,1\% regular e $63,6 \%$ bom.

Os resultados encontrados mostram que os principais ingredientes relacionados negativamente ao estado geral de saúde dos profissionais são: percepção do trabalho como pesado, como rígido e como estressante, trabalho em finais de semana, irritação sentida durante apuração e redação de notícia, consumo de álcool, cansaço excessivo 
depois de uma jornada de trabalho, sedentarismo. (KILESSE, MACHADO, 2009b, p.9)

Em nossa pesquisa, as dores e os adoecimentos foram abordados a partir de uma questão semiaberta: "Já houve alguma situação de trabalho que o levou a ter algum tipo de dor, por exemplo, dor de cabeça, dor nos pulsos, lombar. Se sim, é comum isso acontecer? Com que frequência? Em que situações?”. O objetivo era que os próprios jornalistas refletissem sobre situações que tivessem relação com o trabalho.

Os entrevistados relataram problemas como síndrome do pânico, dor emocional, cansaço, ansiedade, insônia, dor na coluna, dor de pescoço, dor de cabeça, dor de garganta, faringite, ronquidão, infecção genital, LER, dor no braço, dor nos dedos, dor na mão, pressão alta, queda de cabelo, artrite, hérnia de disco, sobrepeso, sedentarismo, colesterol alto, triglicérides alto, ácido úrico alto.

Entre os mais jovens, de maneira geral, a lista de dores e sintomas foi maior do que entre os mais velhos. Mas os jornalistas com mais experiência também relataram casos. Percebe-se que a situação piora quando há maior quantidade de trabalho, mais pressão e mais tensão. $\mathrm{O}$ trabalho também pode fazer com que a pessoa deixe de comer ou de ir ao banheiro, o que apareceu em alguns relatos. Muitas vezes as dores são avisos de que o jornalista está passando do limite. O desgaste físico e mental também apareceu durante as entrevistas.

Alberto Dines recordou que quando trabalhava na Última Hora, nos anos 1950, e dirigia as edições matutina e vespertina, ele dormia muito pouco. Acordava às $4 \mathrm{~h}$ da manhã e ia para o jornal, de onde só saía entre $7 \mathrm{~h}$ e $8 \mathrm{~h}$ da noite. Isso todos os dias, com exceção do domingo, quando a publicação não ocorria. “O sono é uma coisa muito importante pra sua recuperação diária... Foi muito duro, foi fisicamente muito difícil, daí eu fui ao médico, o médico falou, não, não, duas vezes na semana você vem fazer fisioterapia, ginástica, mas foi terrível” (risos). O jornalista de 82 relatou ter tido inúmeras dores ao longo da carreira.

Como você está empenhado, como você está intensamente envolvido com o trabalho, com as emoções decorrentes do trabalho, porque você não é uma máquina, é um ser humano, você evidentemente sofre os desgastes, o desgaste emocional, o desgaste físico, porque um comunica com o outro, então eu tenho aí um monte de doenças, que não tem nada a ver com a idade, tem a ver com fatores de risco mesmo - Alberto Dines.

Para Dines, "está tudo incorporado, uma coisa ligada a outra, e não é só comigo, com os outros da minha geração e até de gerações mais novas, as pessoas vivem esse 
stress". Quando ele foi demitido do Jornal do Brasil, por exemplo, ele teve um deslocamento de um cálculo renal, que o levou a tomar morfina de tanta dor. Ele reflete que pode haver uma relação de causa e efeito com o estresse brutal que a demissão causou.

\begin{abstract}
Desenvolvi essa hipótese de que o deslocamento do cálculo renal e sua saída, muitas vezes, são causados por um estresse, por uma coisa emocional, já tenho conversado com médicos, não tem nada que comprove, mas é uma hipótese válida, e a minha foi profissional, fui demitido, e eu fui demitido por razões políticas, não fui demitido porque era mau jornalista, então ao longo da minha vida eu acumulei esse tipo de acidente de trabalho (risos) - Alberto Dines.
\end{abstract}

Audálio Dantas não se recorda de doenças, mas afirma ter vivido momentos de grande sofrimento, de dor espiritual e emocional. Já Clóvis Rossi se lembra que teve dois ou três ataques de pânico provavelmente devido ao trabalho. "Tive piripaques algumas vezes provavelmente em função, mas nunca se sabe, porque síndrome do pânico não é uma coisa que tem explicação, acontece, você nunca sabe a causa. Mas muito provavelmente foi essa tensão do trabalho." Rossi destaca a tensão permanente vivida na Argentina, na época da ditadura, em que ele fazia matérias sobre direitos humanos.

Ainda mais porque quando eu fui para a Argentina, o embaixador da Argentina no Brasil, quando a sucursal de Brasília foi pedir a ele para facilitar o meu visto de trabalho, visto de permanência, ele disse que não ia dar visto porque eu não era jornalista, era militante. Militante morria na Argentina naquela época. Então era permanente tensão Clóvis Rossi.

Aureliano Biancarelli avalia que quando era mais jovem tinha mais saúde e resistência. Os plantões de final de semana e os pescoções resultavam em muito cansaço, impedindo outras atividades. Lúcio Flávio Pinto, pelo contrário, afirma que teve: "Toda a enciclopédia de dor. Todas. Eu já tive todas. Já tive desmaio em plena redação".

Lúcio Flávio Pinto também destaca a tensão da profissão para falar do adoecimento: "Eu já tive todos os tipos de doenças, de distúrbios, e continuo sujeito a elas cada vez mais, minha situação se agravou com os processos judiciais, porque eu tive um problema adicional, eu não consegui ninguém que me defendesse." Isso porque esses processos eram movidos pelo grupo O Liberal, com grande poder local. Acabou contando com a ajuda de um amigo advogado que não exercia a profissão, e o próprio jornalista passou a pesquisar as questões jurídicas. "Tive muito tempo desviado nisso. 
Isso me sobrecarregou. Eu sou uma pessoa que tenho sequelas que vão ser definitivas na minha saúde." São problemas como insônia e ansiedade. "Ansiedade que se tornou patológica. Durante muito tempo a ansiedade foi boa pra mim, porque ela me fazia trabalhar cada vez mais, mas hoje ela já começa a ser um complicador." O desgaste físico que sente é muito grande.

Ricardo Kotscho conta que muitas vezes deixou a saúde de lado em prol de uma cobertura jornalística. Uma das vezes viajou com uma ferida na perna para cobrir a visita do Papa João Paulo II em um leprosário em Manaus. "Ela foi piorando durante a viagem. Eu não conseguia mais andar, uma dor filha da puta, e o fotógrafo falou, agora chega, vamos ao pronto socorro e me mandaram pra um hospital”. De lá, teve que voltar para São Paulo, onde foi operado. "Estava tudo infeccionado."

Eu nunca deixei de fazer uma reportagem por problema de saúde, mas deixei de cuidar da saúde por causa de reportagem. Isso tem um preço a pagar. Eu senti mais isso a partir do ano passado pra cá, eu estava muito cansado pra fazer reportagem, pra subir morro (risos), eu falava pro fotógrafo, vai você, tira as fotos depois você me conta. Aconteceu isso. O Campos Mello, que é o dono da revista Brasileiros, é fotógrafo e é meu amigo. Meu chefe. A gente estava no Recife na campanha municipal, acompanhando os candidatos. À noite, depois de andar o dia inteiro, subi o morro, quando eu vi o lugar da igrejinha lá em cima, aí eu falei pro fotógrafo (risos), nós temos a mesma idade, um dia de diferença, ele é um dia mais novo que eu. Eu falei: - Você que é o mais novo, você vai lá. Dá uma de repórter fotográfico. Não vai acontecer porra nenhuma, a não ser que matem o candidato. Eu não fui. Nesse dia eu vi que eu tinha chegado ao meu limite. Isso aí foi em $2012 \ldots$ - Ricardo Kotscho.

O jornalista diz que se sente muito cansado. "Minha mulher fala pra mim, parece que você tem 80 anos (risos). Eu estou com 66, mas eu me sinto realmente cansado como se eu tivesse 80." Para ele, isso se deve às características que a profissão tinha no passado. "A gente saía toda noite. Era época dos festivais de música, da bossa nova, a maioria de nós era de solteiros. A gente saía pra gandaia até 3, 4, 5 horas da manhã. Fumava muito, bebia, uma hora você tem que pagar o preço."

Eu ando hoje cinco quarteirões e fico cansado. Dói tudo, dói o joelho, doem as costas. Tem uma frase do Antônio Maria, grande jornalista, compositor, poeta, foi casado com a Danuza Leão. Um dia o pegaram e esmagaram as mãos dele de porrada, porque ele tinha esculhambado com alguém, um bicheiro no Rio. Os caras bateram, e ele criou a seguinte frase: "Que bobos, eles pensam que os jornalistas escrevem com as mãos". Ele quis dizer que o jornalista escreve com a cabeça. Eu descobri agora com esse acidente ${ }^{6}$ que os jornalistas escrevem com

\footnotetext{
${ }^{6}$ Ricardo Kotscho caiu na rua, quando voltava da casa de uma de suas filhas, Carolina, e machucou o braço direito no final de janeiro. Teve que passar por uma cirurgia, colocar pinos e placas no braço para
} 
as mãos sim, e além das mãos, nós precisamos de pernas. São dois instrumentos de trabalho fundamentais para o jornalista. Mais importante que o celular, que o laptop, mais importante que a tecnologia mais moderna, mais hi tech, é ter pernas e braços... É um trabalho braçal também - Ricardo Kotscho.

Bob Fernandes também fala sobre as limitações físicas que a idade traz aos jornalistas. "Você é que nem jogador de futebol. Quando vai ficando mais velho você vai aprendendo a encurtar os espaços ou você se arrebenta, por isso o jornalista tem uma expulsória, é raro gente da minha idade, eu tenho 58 anos, ainda estar no jornalismo." Em relação a problemas de saúde, ele se recorda de dois episódios em que fazia reportagens investigativas, que traziam muita tensão e riscos, e chegou a ter uma esofagite aguda em um deles. Quando cobriu a guerra da Somália, teve uma diarreia e perdeu cinco quilos.

Paula Puliti relata que muitos sentiam dor na coluna, mas relativiza que isso é comum a partir de certa idade. "Eu ficava muito tensa, o ombro muito duro, mas será que se eu tivesse outra profissão eu também não ia ficar estressada? Não sei... Não posso afirmar que é a profisssão ou a forma como você lida com a profissão.”

Marilu Cabañas se recorda de uma reportagem na época da rádio Cultura no acampamento do Movimento dos Sem Terra no Pontal do Parapanema. Ela chegou a acampar e voltou de ônibus: "Peguei uma baita infecção genital, sofri de lá até São Paulo, com essa coceira... Devia ter ligado para o ginecologista de lá. Falta de experiência total. Ele me passou um remédio". Era comum também ficar com a garganta inflamada. Teve uma grave faringite, na época da rádio Bandeirantes. Ficava pior quando trabalhava bastante, mas faz questão de ressaltar que era um trabalho muito prazeroso. Outro problema foi após a demissão do SBT:

Eu acho que caí em depressão, não sei, porque na depressão você fica prostrada. Não fiquei. Na verdade, não fui diagnosticada com depressão, foi uma profunda tristeza, decepção com a profissão. Fiquei muito decepcionada, até que surgiu a Cultura e me levantou também. Fiquei muito decepcionada nesse período. Fiquei profundamente triste. Parei de trabalhar porque tinha que arrumar a casa [que estava construindo], não sei se usei isso como desculpa, pode ser - Marilu Cabañas.

reconstituir o cotovelo, que foi imobilizado. Em 3 de fevereiro, Mariana Kotscho escreveu no blog do pai, Balaio do Kotscho, que ele ficaria afastado do trabalho por 4 semana por recomendação médica, mas conhecendo o pai, ele voltaria antes. Em 26 e 27 de fevereiro, ele nos concedeu a entrevista. Ainda não havia se recuperado, mas já estava trabalhando. 
Fernanda Cirenza tem dores de cabeça eventualmente, no período pré-menstrual e menstrual, e costuma tomar analgésico. Chegou a ter LER, que foi tratada com exercícios. Antonio também teve LER. As dores costumam ocorrer quando a pressão e a carga de trabalho aumentam. "Já teve momentos em que eu tive uma carga excessiva de trabalho, mas eu não tive tanta pressão, então eu não sentia dores, mas com certeza, a dor assim na omoplata é a maior." Outro problema é a dificuldade para dormir.

A LER já afetou Ivan Marsiglia, que em seu período final na Abril, teve um início de tendinite. Dois dedos da mão direita foram afetados pelo uso do mouse. Após tratamento com fisioterapia, ele melhorou. "Essa lesão voltou um pouco aqui nesse período no jornal, senti algum tempo, comecei a tomar cuidado, fazer atividade física, a trocar o mouse de mão, mas é claramente relacionado à minha atividade profissional." Para ele, escrever, observar as redes sociais, mexer no computador o dia inteiro, ficar diante de uma tela causam um desgaste físico evidente.

Um pico de sofrimento de trabalho que eu tive foi na mudança do projeto gráfico na Trip. A gente trabalhou mais de 30 horas seguidas, passou um dia, amanheceu e continuou trabalhando, eram 32 horas seguidas pra fechar a edição no último dia. Foi muito cansativo. No final, estava todo mundo bravo, cansado. As pessoas começam alucinar. Existe um estado como se estivesse um pouco bêbado, sabe. É bem cansativo. Depois você fica estragado por dias. Eu sinto muito cansaço depois de fechar uma contracapa aqui do Aliás, que é um texto maior, uma reportagem de fôlego que a gente faz em dois ou três dias. Tem em torno de 10 mil caracteres de texto, muita coisa, uma página inteira de jornal. Sempre quando chega sexta-feira e eu tenho que escrever, eu lamento amargamente, sofro pra fazer. No domingo quando sai a edição eu fico satisfeito, mas é sempre desgastante ao ponto de você pensar duas vezes quando você vai pegar uma matéria dessa de novo... - Ivan Marsiglia.

Maria também viveu momentos difíceis no trabalho. "Eu ficava muito doente, porque eu somatizava todas aquelas doenças. Eu era muito jovem e lidava com um jornal que era muito importante pra esquerda naquele momento." A fala resume o que ela passou no Correio da Cidadania, que considera muito importante para sua aprendizagem, mas tinha dificuldade em lidar com a pressão que sentia, acrescida de fazer dois cursos universitários ao mesmo tempo.

Eu era tratada como se fosse uma profissional formada. Tem o lado bom nisso, a questão do respeito, mas tinha o lado ruim que eu não tinha preparo emocional pra aguentar isso. Tanto que eu pedi demissão por questão emocional, aí pedi pelo amor de Deus pra ficar. Fiquei mais um ano. No dia que eu fui embora, eu fui internada. Era isso, era somatização, tanto que isso me ajudou nessas outras decisões de vida depois, que eu não podia ficar num ambiente ou deixar o trabalho, a pressão me absorver de uma maneira que afetasse a minha 
saúde. Se uma capa saísse com uma letra errada, eu absolutamente absorvia isso como uma questão de incompetência minha, e não era. Não era pra eu fazer a capa do jornal porque afinal de contas eu era uma estagiária - Maria.

Bruno Torturra sofre com a ansiedade. Pedro já teve problemas como pressão alta, taquicardia, irritação, mau humor. "Nos períodos mais intensos na Folha eu tive essas manifestações, meu corpo se manifestando pra eu dar uma acalmada. E foi um dos motivos, entre outros, que eu decidi sair da Folha pra cuidar um pouco da minha vida também." Ele recorda ainda dores pontuais que sentia, por exemplo, dor no pescoço quando tinha muito material para revisar. "Eu ficava muito com o pescoço pra baixo, e isso me deu uma travada... Eu tive um problema de coluna meio sério. Tive que pedir pra mudar a cadeira, mas eu acho que tudo tem a ver com o nervosismo, com tensão." Nos piores momentos, chegou a ter dor por um mês, mas normalmente elas aconteciam uma vez ou outra por semana, coincidindo com os períodos em que havia mais trabalho.

Leonardo Sakamoto já teve problemas como queda de cabelo, cansaço, dor de cabeça, dor lombar, artite, LER/DORT, hérnia de disco, sobrepeso, colesterol alto, triglicérides alto, ácido úrico alto, sedentarismo. "Você pode passar o que quiser, eu tenho." Miguel, por sua vez, recorda que no início da carreira sentia muita dor no braço e na cabeça. Nos períodos em que fazia reportagem, ficava mais cansado fisicamente. Quando trabalhou em rádio, teve problemas como ronquidão e inflamação na garganta com mais frequência.

Aline Scarso teve dor de cabeça em dias que o trabalho é mais intenso, por exemplo, quando precisa "brigar" por uma pauta. Quando chega a sua casa nem sempre consegue se desligar do trabalho. As dores costumavam ocorrer com mais frequência antes de tirar férias. "Eu fiquei um ano e nove meses sem férias, eu emendei trabalho e antes mesmo quando eu tinha férias, eu não tinha dinheiro pra fazer uma viagem... Teve férias, por exemplo, que eu trabalhei. Por conta do dinheiro faltar, então, eu fui procurar um frila..." Também vê um desgaste físico maior na atuação como repórter, já como produtora acredita que o desgaste é mental.

João conta que já teve problemas para dormir, dor nas costas e dor de cabeça. "Mas nada de ficar doente assim de ir parar no médico. Acho que é uma coisa meio natural, dor de cabeça, você fica muito tempo olhando pro computador fazendo uma coisa." Isso ocorre quando a intensidade do trabalho é grande e ele está muito cansado, mas vê como frequente. 
Priscilla Nery relata que nos últimos tempos sentiu muita dor de cabeça, pelo menos uma vez por semana, e principalmente quando o ritmo de trabalho era mais forte. “Às vezes na minha casa mesmo me dá uma crise, começa a doer forte. Já me impediu de fazer algumas atividades que tenho depois do trabalho, porque geralmente é no final do dia, que estou mais cansada." A dor forte fez com que ela desmarcasse a aula de inglês ou deixasse de ir à igreja, por exemplo. Certa vez, em que escreveu muito, sentiu dor nos dedos e nas mãos.

Vivian Fernandes também relata dores, principalmente, nas costas. "Eu fico tão concentrada, que esqueço da minha postura, na hora que eu reparo, eu tenho que alongar e sentar melhor. Depois que eu virei editora do jornal eu sinto com muito mais frequência." Não sente exatamente toda semana, mas pelo menos todo mês. "Eu já cheguei a ter que tomar dorflex pra dar uma relaxada no músculo pra conseguir dormir. Mas hoje em dia eu sinto menos." A jornalista avalia que quando consegue fazer uma caminhada, melhora. Às vezes, sente dor de estomago. Nas quintas, quando o jornal está em fechamento, não tem tempo para almoçar. "Só que eu não sinto fome, porque eu acho que minha adrenalina está lá em cima, aí quando dá 18 horas, eu entrego o jornal, aí eu vejo que eu estou morrendo de fome, com pressão baixa e com dor de estômago."

\section{4 - Quando o trabalho é cenário para o assédio moral}

Outro problema ligado ao trabalho que pode afetar o jornalista é o assédio moral, que ocorre "quando a dignidade de alguém é atacada de modo repetitivo, sistemático e deliberado durante um período prolongado, geralmente de vários meses" (SELIGMANN-SILVA, 2011, p.502). Essa "prática desmoralizante recebe adesões dos demais e se propaga de modo a isolar cada vez mais a pessoa visada". Segundo a autora, “o objetivo é excluir, desqualificar profissionalmente e desestabilizar emocionalmente alguém que, por motivos os mais diversos, tenha se tornado indesejável para o/a perpetrador/a do assédio" (Ibid.. p. 503).

O tema foi abordado pelo jornal Unidade, do Sindicato dos Jornalistas Profissionais do Estado de São Paulo, de maio de 2011, em reportagem de Ana Paula Carrion. Um dos casos apresentados é de um jornalista que sofreu assédio moral e teve uma síndrome depressiva, seguida de problemas no intestino e próstata. Um processo 
movido pelo sindicato contra o empregador, a Federação Espírita de São Paulo, seria julgado em última instância.

A reportagem ainda afirma ter aumentado a procura por orientações sobre assédio moral no sindicato e apresenta entrevistas com especialistas no formato pinguepongue. Um box é dedicado à médica do trabalho e doutora em psicologia social, Margarida Barreto, que destaca alguns problemas vivenciados pelos jornalista como a alta demanda, "jornadas prolongadas, a carga excessiva de trabalho, em ritmo intenso, baixos salários, com pouco tempo para o lazer e convívio com a família e amigos". Também afirma que os jornalistas adoecem mais atualmente e que se queixam de "dores difusas, de ansiedade e angústias", além de trabalharem mesmo quando estão "doentes, cansados, esgotados mental/fisicamente". O outro entrevistado, o desembargador Valdir Florindo, falou sobre processos em caso de assédio moral.

O rompimento de vínculos de relações fundamentais para a manutenção e fortalecimento da subjetividade humana atua de forma a desencadear o assédio moral, que tem sido compreendido, atualmente, como a exposição dos trabalhadores a situações humilhantes e constrangedoras, repetitivas e prolongadas, durante a jornada de trabalho. Consequentemente, as relações ficam mais desumanas e antiéticas e nelas predominam os desmandos, a manipulação do medo, a competitividade desenfreada e os programas de Qualidade Total associados à produtividade e dissociados da QVT [Qualidade de Vida do Trabalho]. (HELOANI, 2003b, p.14)

Magalhães (2006, p.83) define o assédio moral "como a exposição de trabalhadores a situações humilhantes e constrangedoras, repetidas e prolongadas, durante a jornada de trabalho e no exercício de suas funções". Coloca ainda que ocorre "principalmente em relações hierárquicas autoritárias e assimétricas, de forma a desestabilizar o estado emocional da pessoa, fazendo com que ela se veja forçada a desistir de seu emprego". No entanto, também "os funcionários subalternos de uma dada organização podem solapar a posição de um colega, pela desestabilização ostensiva de suas condições sociais de trabalho" (BIRMAN, 2006, p. 49).

Nas organizações, a violência e o assédio nascem do encontro da inveja do poder do outro e da perversidade. Esse poder pode ser real ou imaginário, mas ele incomoda o agressor, sendo que o atributo que o expressa pode ser sustentado em qualquer fonte, como conhecimento, beleza, relacionamento social ou competência. Para Hirigoyen, o assédio pode ocorrer em todas as direções, ou seja, partindo tanto de chefes e colegas como vindo de subordinados. Não existe necessariamente um conflito entre o agressor e a vítima, podendo mesmo o assédio ocorrer de forma subterrânea, na qual o agressor vai minando aos poucos o ambiente da vítima sem que ela se dê conta. Aliás, os conflitos geralmente fazem emergir as divergências 
e as discórdias, possibilitando sua negociação ou resolução. Nos casos de assédio, contudo, a vítima pode ignorar o problema por bastante tempo, uma vez que, frequentemente, as pessoas à sua volta assistem em silêncio ao desenrolar da trama. Aliás, o agressor conta com o fato de que, geralmente, as pessoas evitam se envolver em situações desagradáveis e se posicionar sobre temas que possam redundar em prejuízos para si. Aqui as condições organizacionais exercem uma influência, podendo combater ou incentivar essas ocorrências... (FREITAS, HELOANI, BARRETO, 2008, p.25-26)

Segundo Dejours (2010, p.12), o assédio moral não é uma questão nova no mundo do trabalho. O que mudou atualmente é a solidão. O assediado fica sozinho. "Ninguém se mexe, ninguém faz nada, ninguém fala, ninguém protesta. Não é só a questão do assédio, mas a questão da traição dos colegas também. Eles não falam, eles recusam o testemunho." Mais uma vez o problema pode levar aos transtornos mentais e comportamentais. "Isso é extremamente perigoso psicologicamente, e o resultado é o aumento considerável das descompensações, ou seja, crises psicopatológicas ligadas ao assédio."

Koubi (2006, p.21) também aponta que o assédio moral "não é um fenômeno recente" e "existiu em todos os tempos", caracterizando-o "pela repetição, frequência ou persistência, pela sua sucessão e continuidade, pela obstinação e tenacidade, pela duração: ele é sempre o resultado de uma certa visão das relações sociais, é sempre produto de uma gradação, uma progressão...." (Ibid., p.19). Ainda destaca que "no plano das relações pessoais, não existe assédio individual de um sobre o outro sem a cumplicidade dos outros, testemunhas silenciosas ou coniventes com o fenômeno e atores implícitos ou explícitos da dominação ou de seu agravamento....” (Ibid., p.29).

Fica claro o aspecto organizacional do assédio no trabalho. Se ele existe é porque a organização dá espaço ou até estimula esse tipo de situação. De Gaulejac (2006, p.72) aponta que a pressão pelo tempo, pelos resultados e pelo medo proporciona um estresse estrutural e "uma cultura do assédio da qual é difícil se defender, pois os sofrimentos provocados devem permanecer escondidos; se forem expressos corre-se o risco de se encontrar no olho da rua". Diante disso, o autor destaca a importância de se focar nos processos que o geram e não focalizá-lo, como geralmente ocorre, como problema de comportamento das pessoas (Íbis, p.79).

Direcionar o sentimento de assédio sobre uma pessoa é tranquilizador, como se bastasse que esta pessoa mudasse seu comportamento para resolver o problema. Este procedimento oculta um fato maior: na empresa hipermoderna todo mundo é colocado sob pressão. Cada um sofre e exerce pressões no interior de uma cadeia sem fim onde cada 
elo pode se encontrar na posição de assediador ou assediado. (DE GAULEJAC, 2006, p. 80)

Segundo Freitas, Heloani e Barreto (2008, p. 35-45), analisar essa violência como um problema das organizações "pode abrir espaço para o resgate de um ambiente mais colaborativo, mais honesto e mais saudável para as pessoas e os negócios", pois a violência vista como normal pela organização, naturalizada, "desintegra o vínculo social, fortalece o individualismo predador, corrói a cooperação e a confiança, derrota a solidariedade e retira do homem a sua humanidade".

\begin{abstract}
Entendemos que é preciso ter em mente que o assédio moral é em si um problema organizacional simplesmente porque ocorre dentro do ambiente de trabalho, entre pessoas que são parte da estrutura organizacional. $\mathrm{O}$ assédio moral detém prerrogativas a partir de papéis organizacionais e encontra respaldo em questões ou aspirações organizacionais, o que torna a empresa co-responsável ou não isenta pelos atos culposos ou dolosos que ocorrem em seu interior. Explicitando aqui o conceito de que, para nós, o assédio moral é uma conduta abusiva, intencional, frequente e repetida, que ocorre no ambiente de trabalho e que visa diminuir, humilhar, vexar, constranger, desqualificar e demolir psiquicamente um individuo ou um grupo, degradando as suas condições de trabalho, atingindo a sua dignidade e colocando em risco a sua integridade pessoal $e$ profissional. (FREITAS, HELOANI, BARRETO, 2008, p.37)
\end{abstract}

Já Birman (2006, p.48) destaca que quando o assédio moral ocorre, a pessoa tem sua segurança identitária prejudicada e é esvaziada "nas suas potencialidades sociais e psíquicas de ser". O assédio leva a uma "condição de paralisia mental e à impossibilidade de agir, na medida em que suas reações são esvaziadas de qualquer sentido pelos demais participantes da trama" (Ibid., p.50).

Koshiyama (2005) aponta que há uma rotina de assédio moral no jornalismo ao retratar o assassinato da jornalista Sandra Gomide, editora de economia de O Estado de S. Paulo, pelo seu ex-namorado, Antonio Pimenta Neves, diretor de redação do mesmo jornal em agosto de 2000. A pesquisadora avalia que na época alguns veículos, como a Folha, tentaram preservá-lo "como um homem culto, viajado e competente executivo de jornais. E que fora tomado de uma paixão por uma mulher mais jovem, sua subordinada na empresa, que o estava deixando" (Ibid., p.5). Já o Estado colocava o fato como uma tragédia, e o Sindicato dos Jornalistas Profissionais no Estado de São Paulo, em um primeiro momento, como problema privado, o que era defendido por alguns jornalistas. Por outro lado, ela cita aqueles que promoveram um debate como os sites Observatório da Imprensa e Profisssão Repórter do jornalista Luiz Maklouf, que divulgou um abaixo- 
assinado, que descreve o crime, organizado por grupos feministas e de jornalistas mulheres.

Neste debate, provocado pela morte de Sandra Gomide, apareceram precisas descrições sobre rotinas de trabalho em jornalismo nos textos dos jornalistas Nivaldo Manzano e Cláudia Rodrigues. Ambos abordam o campo de arbitrariedades vigentes e do qual é parte o caso de Sandra. É o ângulo dos profissionais que aproveitaram o momento para desmistificar a lenda do grande e competente chefe, Pimenta Neves, organizando o campo das redações.

Nivaldo Manzano em "Por que medram Pimentas", condena a cultura organizacional que avaliza o autoritarismo e arbitrariedade e propunha criar mecanismos para limitar o poder dos chefes de redação. Observava que há dois anos atrás, o Observatório da Imprensa publicou um artigo dele intitulado "Carta aberta aos jornalistas - Os novos bárbaros", no qual chamava atenção para "a expansão avassaladora do poder imperial, por parte dos chefes, no ambiente das redações." O que o levou a sugerir "a criação de critérios explícitos e de instrumentos de decisão que removam o poder absoluto dos chefes." (KOSHIYAMA, 2005, p.7-8)

A autora defende, assim, a hipótese, de que na redação chefiada por Pimenta Neves, trabalhadores e trabalhadoras vivenciavam situações de assédio moral e não o coloca como uma exceção. "Faz parte da cultura das organizações jornalísticas modernas conviver com chefias arbitrárias e centralizadoras, algumas vezes com poderes ilimitados sobre a vida profissional dos subordinados" (Ibid., p.9).

Relembrar esse caso é importante para refletir sobre a prática de assédio moral, muitas vezes, naturalizada nas redações. As histórias viram lendas e servem de exemplo para que outros profissionais não ousem e sejam submissos. Em estudo concluído em 2012, foram encontrados casos significativos de assédios moral e sexual entre jornalistas (HELOANI, 2013, p.6).

Nesta pesquisa, perguntamos: Você já vivenciou ou presenciou alguma situação de assédio moral? Dos 21 entrevistados, seis vivenciaram e presenciaram casos de assédio moral, três apenas presenciaram, três não usam o termo, mas relatam situações que podem ser assediadoras, e três ouviram histórias de amigos ou no local em que trabalhavam. Também ouvimos três relatos de assédio sexual.

Entre os jornalistas com mais de 60 anos, não houve nenhum relato de assédio moral, mas houve três falas que podem indicar posições assediadoras. Audálio Dantas falou em cobrança excessiva e que ouviu histórias de mulheres que saíam da redação chorando. Aureliano relatou ter visto chefes gritarem com repórteres e humilhações, mas que isso era comum no passado: "Já foi mais comum. Na Folha, por exemplo, a gente teve editores chefes que tinham um perfil bastante agressivo, não diria agressivo, 
mas que expunham as pessoas, que não se importavam, colocavam até humilhações em algumas pessoas”. Já Ricardo Kotscho afirma que antes não existia essa palavra, mas havia "chefes que não gostavam de determinadas pessoas e sacaneavam". Também fala em autoritarismo de alguns antigos chefes de redação.

Dos que vivenciaram, Marilu Cabañas conta o caso mais emblemático, que mostra como realmente o assédio moral é uma questão organizacional. Em uma das gestões da rádio Cultura, houve perseguição aos profissionais e um direcionamento de pautas. Em uma das reuniões, ela chegou a ouvir: "Eu quero deixar claro uma coisa, matéria com pobre e sobre pobre é uma bobagem". O então chefe falou isso olhando para ela. Prezava-se a quantidade em vez da qualidade, fazia-se um direcionamento político das matérias e se perseguia as pessoas que já trabalhavam no local e não faziam parte da equipe contratada por ele.

Era tão aterrorizante, porque ele provocava assédio moral coletivo, pegava um para cristo e ficava torturando as pessoas. Tanto que quando ele saiu, a turma dele saiu, fizemos uma festa com todos da rádio, técnicos, apresentadores. $\mathrm{E}$ faltou a gente fazer um processo de assédio moral coletivo. Ninguém fez. Para você ter ideia do nível que era, a gente tinha tanto pavor desse cara, que, por exemplo, eu, para não cruzar, porque se você fosse embora e passasse por ali, ele te chamava, te torturava, era um horror, tinha uma janela na redação, e eu pulava a janela para ir embora. Outro colega jogava a mochila, porque só podia sair por uma porta, e se ele visse a mochila sabia que estava indo embora, então ele jogava a mochila e saía como se fosse voltar. Todo mundo tinha um esquema para fugir desse cara. Era um horror, ele ficava pegando no pé de uma forma que eu nunca vi na minha vida. Ali havia profissionais de ponta, gente, o que é isso, foi um período muito, muito triste - Marilu Cabañas.

A equipe contratada por ele também costumava perseguir os outros profissionais. Após o desentendimento com uma dessas pessoas e afirmar que iria até o superintendente da época, outro profissional da equipe dele chegou a agarrá-la pelo braço como intimidação. "Eu falei - Larga meu braço. Larga meu braço. Assim, nesse nível. Quer conversar vamos, mas não encosta no meu braço. Ele saiu, me intimidando."

Em um período de eleições presidenciais, não passavam matéria para Marilu fazer. Em outra situação, ela chegou a se negar a fazer uma matéria de educação. "Fiquei com tanto trauma dele, eu me neguei a fazer, porque ele ia ver a matéria, ia me encher o saco, me torturar, eu não quis." Marilu preferia devido à situação fazer matérias culturais. Ela se sentia muito mal, e o prazer no trabalho, quando existia, era sua defesa: "Eu ia trabalhar com medo, ansiedade, porque já não era mais prazeroso. Às 
vezes era prazeroso pelo tipo de matéria e você fugia daquela realidade. Ali você se envolvia com a matéria e se sentia melhor". Essa violência durou entre dois e três anos, dos 16 anos que Marilu trabalhou na rádio Cultura, atingindo outros colegas que já atuavam na rádio antes da chegada desse chefe.

Outro jornalista a vivenciar o assédio moral foi Antonio. "Quando querem colocar pra fora, seu texto não serve mais, sua apuração tem problemas, seu texto tem problema, isso é rotineiramente." Ele conta que o mesmo já aconteceu com um amigo que trabalhou na Veja. "Era tudo uma maravilha. Quando eles queriam colocar pra fora, o texto dele começou a ter problemas..., de coisas que não eram apontadas até então. É clássico, humilhações públicas." Para ele, esse é um modelo que vai sendo reproduzido, e as chefias escolhidas são aquelas que as empresas acham que manterão o perfil exigido.

Fernanda Cirenza também vivenciou como presenciou situações de assédio moral. Em certa ocasião, teve uma chefia que pedia para ela fazer vários textos, os quais não eram publicados. "Essa pessoa quis me fritar naquela equipe... Eu levei essa situação pra pessoa acima dessa pessoa que fazia isso comigo. Também vi colegas serem humilhados na frente da equipe toda e já fui humilhada na frente dos outros." Ela conta ainda que no início da carreira na Folha havia "uma chefia bastante barulhenta", mas que devido ao seu temperamento forte conseguiu manter certa distância. Fernanda avalia que depois as relações nas redações melhoraram.

Leonardo Sakamoto é outro profissional que viu e viveu o assédio moral. "É super comum, só que jornalista não considera que está sendo assediado, ele acha que é normal, faz parte da profissão. Não, não faz parte da profissão gritar com uma pessoa..." O jornalista também afirmou saber de casos de mulheres jornalistas que sofreram assédio sexual. "É uma coisa que dá pra ser combatida com conversa, com penalização, com demissão..."

Miguel vivenciou e presenciou o assédio moral no início da carreira em uma agência de notícias. Havia um chefe que tratava alguns jornalistas com ironia, sacarmos, menosprezo e desrespeito. Um colega, que era mais questionador, passou a ser perseguido até ser demitido.

Já Aline Scarso vivenciou uma situação no passado em que não lhe passavam o trabalho ou faziam isso no final do dia ou lhe cobravam por algo que não tinham passado. "Eu já chegava nervosa no trabalho porque eu sabia o que eu ia passar. Foi um período horrível da minha vida, que eu entrei em depressão, eu engordei, eu fiquei 
muito mal, eu pensei até em voltar pra minha cidade natal e recomeçar de novo." No trabalho atual, presenciou colegas serem "colocados na geladeira".

Maria conta que ouve muitos relatos de assédio moral, por fazer parte da Comissão de Funcionários da EBC. Muitos casos relatados ocorreram na TV Brasil de São Paulo e abrangem desde intimidação por cobrança de folga até chefes xingarem funcionários.

Isso é uma coisa que a Comissão de Funcionários briga muito, que a empresa ignora absolutamente, acha que são todos uns "reclamões" e não capacita os gestores. Tem muito gestor que é da velha guarda do jornalismo, do autoritarismo... Acham que seguram seus funcionários na base da ameaça, da advertência, dessas coisas... - Maria

Bruno Torturra também já acompanhou um caso de uma redação vizinha a que ele trabalhava. "Já ouvi gritaria, você é burra, só fala merda, fora daqui, tipo demissão sumária humilhando a pessoa e era claramente por uma diferença pessoal, não tinha nada a ver com o trabalho, mesmo se tivesse, não era justo que se fizesse isso."

Bob Fernandes é outro jornalista que já viu cenas de assédio moral, mas em poucas ocasiões, já que sempre buscou trabalhar em ambientes com melhor convivência. "Mesmo lá no jornal que tinha quarenta e tantas pessoas contando repórter e fotógrafo, o Jornal do Brasil, tinha confusão, mas era tudo na boa." Em outras ocasiões viu humilhação coletiva, não relativa ao trabalho de uma pessoa especificamente, mas no geral. Para ele, o pior constrangimento é o corporativo estabelecido como regra e que deve ser enfrentado.

Entre os jornalistas que já ouviram histórias sobre assédio moral está Ivan Marsiglia. "Acho que tem ambientes de grandes redações que são muito duros com os repórteres, o que eu mais ouvi durante minha época na Abril, não sei como é hoje, é a revista Veja, por exemplo, em que é muito duro." Ele fala sobre "um ambiente competitivo, exigente no mal sentido", em "pressões o tempo inteiro sobre o repórter".

Pedro não viveu ou viu nenhum episódio na Folha. "Na equipe que eu estava a gente tinha na medida do possível uma relação mais saudável. Mas no jornal eu escutei histórias de um editor gritando muito e xingando, e o repórter sair chorando de lá.” Já Vivian Fernandes ouviu a história de amigos, por exemplo, ser xingado no meio de toda redação de retardado.

Já o assédio sexual, que acabou aparecendo nos relatos de três pessoas entrevistadas, é juridicamente compreendido no Brasil, segundo Magalhães (2006, p. 83), "como o ato de 'constranger alguém com o intuito de obter vantagem ou 
favorecimento sexual, prevalecendo-se o agente da sua condição de superior hierárquico ou ascendência inerente ao exercício de emprego, cargo ou função'."

Um dos casos relatados nesta pesquisa se enquadra nesta definição, pois o chefe assediava a jornalista subordinada e a demitiu por não querer nada com ele. A pessoa relata que se sentia muito nervosa e pressionada com a situação. Os outros dois casos não se encaixam diretamente na definição, mas tanto na nossa percepção quanto das pessoas que relataram pode ser visto como um tipo de assédio sexual. Em um deles, o entrevistado tentou abraçar a jornalista, a qual saiu e desistiu da entrevista. No outro, um colega de trabalho piscava e fazia gestos para a profissional.

Os depoimentos mostram que assédio moral e assédio sexual podem fazer parte das rotinas de trabalho do jornalista. Alguns jornalistas apontaram que se deve enfrentar a situação e tentar se impor. Por outro lado, o que se percebe é que quando a situação acontece a pessoa se vê sem força para reagir ou as relações são naturalizadas a tal ponto que se impede a reação, pois há a conveniência organizacional. Algumas situações de humilhação parecem ser usadas no jornalismo como uma forma de extrair produtividade ou como forma de controle para limitar as ações do outro e o fazer obedecer. A humilhação também serve para controlar o outro, que passa a se vigiar e a se submeter para não ser o próximo.

\section{5 - O estresse no trabalho do jornalista}

Alguns estudos mostram como o estresse faz parte do trabalho do jornalista, o que está relacionado com o aparecimento de sintomas físicos e até o adoecimento. Heloani (2003b, p.77) constatou em sua pesquisa com 44 jornalistas, que 34 tinham estresse. Em um segundo grupo amostral de 22 jornalistas com estresse, 16 estavam em fase de resistência e seis em fase de quase exaustão (Ibid., p.75). Foram colhidos depoimentos como - "Sinto, sinto estressada pela carga de trabalho. Fico chateada, brava, rôo a unha de monte, aí fico com mais dor de estômago, com dor de cabeça, o corpo grita." - identificada na pesquisa como Sujeito 17 (Ibid., p.74). Em outro artigo, o mesmo pesquisador aponta que "dos 44 sujeitos pesquisados 24 apresentaram clara sinalização de sintomas de estresse em fase de exaustão e resistência. Os outros 20 
jornalistas, "aprenderam" a suportar os elementos estressores" (HELOANI, 2006, p.192).

Heloani (2003b, p.19) explica que a primeira fase do processo de estresse "é a de alerta e começa quando a pessoa se confronta inicialmente com um estressor", e o organismo reage como "fuga ou luta". Sabendo administrá-la, essa fase pode ser produtiva. Já a segunda fase é a de resistência, "quando o estressor é de longa duração. O organismo tenta restabelecer o equilíbrio interno mediante ação reparadora. Toda a energia adaptativa é utilizada na tentativa de equilíbrio". Se há "sucesso nesse intento, os sintomas iniciais desaparecem, o que gera a sensação de melhora". Se a pessoa continuar "nesse estágio por muito tempo, o organismo torna-se mais vulnerável às doenças em geral e o stress avança para a última fase", a de exaustão, que "é o estágio mais perigoso" e "ocorre quando outros estressores surgem concomitantemente ou quando existir uma evolução do processo de stress". Nessa fase, surgem doenças com mais frequência, tanto físicas quanto psicológicas. "O enfraquecimento fisiológico é de tal ordem que patologias latentes se manifestam, comprometendo a saúde da pessoa, às vezes de forma irremediável".

Em entrevista ao jornal Unidade, do Sindicato dos Jornalistas Profissionais no Estado de São Paulo, Heloani $(2013$, p.6) relata que seus estudos com jornalistas se iniciaram em 2002, com a primeira fase sendo concluída em 2003. A segunda parte da pesquisa, em 2005, mostrou "a quase incompatibilidade da profissão com vínculos estáveis". A última fase, finalizada em 2012, mostra que há ainda mais estresse na profissão.

Hoje os jornalistas enfrentam um grau de estresse que beira a exaustão, bem diferente do apurado na primeira pesquisa que já existia, mas não no grau de hoje. $\mathrm{E}$ a quase exaustão propicia, se não cuidada, os AVCs. É um estresse que fugiu do controle, está cronificado. Então, você já vê pessoas usando de tal maneira o seu organismo para mostrar que ainda é produtivo, que é melhor do que o outro, que vão ter consequências físicas e psíquicas, em curto, médio e longo prazo.

(...)

Então, existe uma discrepância entre uma identidade que é idealizada e uma real e isso produz um nível de estresse extremamente forte, para não dizer transtorno mental, porque você já percebe que algumas pessoas estão descompensadas e qualquer um estaria na situação delas. Por isso, você vai ver um jornalista que virou mendigo, outro que tentou suicídio. Isso porque ele não aguenta mais ter que pagar aquela dívida psíquica consigo mesmo. Então, o jornalista acaba sendo o seu pior inimigo. (HELOANI, 2013, p.7) 
Kilesse e Machado (2009a) também estudaram a ocorrência do estresse entre 44 jornalistas de uma empresa jornalística de Minas Gerais e apuraram que quase um terço da amostra, 31,8\%, passou por situação de estresse no mês anterior à pesquisa ${ }^{7}$. Eles apuraram que nas últimas 24 horas, dois jornalistas se encontraram em fase de alerta do estresse; na última semana, 13 apresentaram sintomas que os colocaram na fase de resistência; e em relação ao último mês nove estavam em fase de exaustão.

Para Marcondes Filho (2000, p.50-51), os “jornalistas estão hoje mais entregues a si mesmos", sozinhos com a tela do computador, são exauridos por ela. "Neste sentido, o trabalho informatizado e isolado eleva sobremaneira a 'exploração da maisvalia': os jornalistas trabalham mais pelo mesmo dinheiro, se esgotam mais e estão mais sujeitos ao estresse, à estafa."

Já Kucinski (2005, p. 118) avalia que o estresse se tornou "a doença ocupacional típica do jovem jornalista". O mais triste da situação é que como aponta De Gaulejac (2006, p.76), “na empresa 'performática', o stress não é considerado uma doença profissional, mas um dado quase natural ao qual convém se adaptar”. Esse autor explica que se difundiu a ideia de que "a 'resistência ao stress' é exigida como uma qualidade necessária para se ter sucesso". Dessa forma, "em vez de se interrogar suas causas, aprende-se a 'geri-lo'."

Essa gestão consiste em domesticá-lo através de exercícios ou dispositivos variados: relaxamento dos ombros, respirações abdominais, alongamentos, meditação, massagens, bolas de borracha 'anti-stress'... Não se procura resolver o problema atacando suas causas. O stress é considerado um mal necessário ao qual convém se adaptar, canalizando-se os seus efeitos mais nocivos. (DE GAULEJAC, 2006, p. 76)

$\mathrm{Na}$ avaliação desse mesmo pesquisador, "o stress é banalizado ou apresentado como a consequência de comportamentos individuais, da mesma forma que o assédio moral". Ainda chama atenção para o fato de que o estresse é a causa de $24 \%$ das crises cardíacas, "favorece o câncer, provoca o consumo excessivo de tabaco, álcool e uma má alimentação", além de ser "uma das maiores causas de depressão, levando, às vezes, ao suicídio" (Ibid., p.77).

\footnotetext{
${ }^{7}$ Segundo os autores, "considerando que cada jornalista que ultrapassou o limiar de estresse da primeira fase pode também ter atingido as duas outras fases, o mesmo valendo para todos que apresentaram sintomatologia de estresse, e objetivando criar uma única variável reveladora do risco de estresse da amostra, procedeu-se a contagens que mostraram que, entre os 44 jornalistas, 30 (68.2\%) não ultrapassaram os limites e $14(31,8 \%)$, ou seja, perto de um terço, já entraram em uma ou mais fases" (KILESSE, MACHADO, 2009a, p.9).
} 
De certa forma, o estresse esteve presente em todas as falas dos 21 entrevistados ao responderem a questão: "Você considera a sua profissão estressante? Pode dar algum exemplo de situações desse tipo?". O intuito da pergunta foi avaliar se os jornalistas percebiam a profissão como estressante e que destacassem o que vivenciaram, dando vazão as suas percepções e subjetividades. Não pretendíamos fazer análises como as de Heloani (2003b, 2006) e Kilesse e Machado (2009), que utilizaram o Inventário de Sintomas de Stress de Lipp (ISSL) ${ }^{8}$ e obtiveram dados objetivos.

Apenas dois afirmaram que não a consideram estressante. Mas isso não significa que não exista estresse no trabalho para eles. Alberto Dines, apesar de responder a questão negativamente, acredita que há um estresse da própria atividade, naturalizando a questão. Já Ricardo Kotscho afirma nunca ter tido outra profisssão para comparar e que nunca reclamou de estresse. Ele não acha que todos os jornalistas são estressados, mas afirma que se dedicava "do fundo da alma aos trabalhos" e que ficou doente várias vezes porque sempre teve a saúde frágil, para logo depois completar que claro que o trabalho afetou a saúde. No fim, conclui que depende da personalidade, da natureza, de cada jornalista.

Fernanda Cirenza, por sua vez, relata ter vivenciado várias situações de estresse, mas não considera "a profisssão de jornalista hiperestressante". O estresse para ela vem da responsabilidade que o trabalho do jornalista traz. Entre os momentos estressantes da carreira, ela cita a cobertura de uma greve em vários setores e do sequestro do empresário Abílio Diniz, ambos em 1989. Outro momento foi a cobertura da morte da princesa Diana em 1997: “A morte da Lady Di foi um momento muito importante, de muito stress, porque eu estava na primeira página, no sábado, esperando pra trocar a chamada do futebol, e a princesa morreu". Ela conta que a pequena equipe teve que parar de rodar o jornal e mudar a manchete. "Isso tudo foi muito estressante, mas pelo lado positivo, porque a gente conseguiu fazer." A época que fez cobertura em delegacias - "perdi muito quilos fazendo isso, porque aquilo me abatia, não conseguia comer" - e cobriu tragédias também foram duras.

Mas a situação mais marcante, que a levou a se afastar do jornal, não foi ocasionada por nenhuma matéria específica e sim pelo estresse causado pelo trabalho em si. Em um período na Folha passou a sentir palpitações e transpirar muito, passava

\footnotetext{
${ }^{8} \mathrm{O}$ objetivo do ISSL é avaliar, por meio de questionário, se os sujeitos têm ou não estresse, o tipo de sintoma (somático ou psicológico) e em que fase se encontravam (HELOANI, 2003b, p.31).
} 
mal quando ia escrever. "Eu tive uma trava, passei mal mesmo, e o Caio [Túlio] foi um cara muito legal comigo, que me mandou tirar 20 dias de folga e eu fui ao médico esquece a caneta, esquece o computador, vai fazer argila que você está estressada..." Ela conta que isso ocorreu em uma época em que o estresse não era comum como hoje. Depois da folga, ela voltou ao jornal, onde trabalhou por muitos anos.

Para Clóvis Rossi, coberturas como a da morte de Tancredo Neves e de situações de guerra e manifestações foram muito estressantes em sua carreira, mas o dia a dia também tem sua carga de estresse: "Mesmo quando não há conflito, violência envolvendo a cobertura, a preocupação de fazer um bom trabalho, para mim, é tremendamente estressante. Volto a dizer apesar de ter 51 anos de profissão, eu entro em cada cobertura como se fosse a primeira." O jornalista afirma ser inseguro e sempre ter "medo de que não vai dar certo".

Já Audálio Dantas considera a profissão de jornalista “essencialmente estressante". Ele avalia que há uma diminuição do número de pessoas nas redações, e o aumento da carga de trabalho e a pressão do tempo causam estresse. Uma das situações mais estressantes que viveu foi a cobertura da guerra em Honduras, quando chegou à capital Tegucigalpa. "A cidade estava em blecaute e bombardeio. Uma situação muito estressante em si, porque de repente você podia ser atingido por aquela coisa, e o rádio anunciou que os carros tinham que parar... Ali começou o grande stress.”

Aureliano Biancarelli, que se considera uma pessoa ansiosa, viveu muitas situações de estresse, especialmente na cobertura de catástrofes. Em uma delas conta que devido a um princípio de hipertensão, ele teve que ficar com um aparelho no braço 24 horas para fazer um exame. "Depois você só anota os fatos importantes pra checar qual o reflexo que esse fato teve na sua pressão arterial." Era um dia tranquilo até chegar ao jornal, quando soube da explosão em um shopping de Osasco: "Morreram 40 pessoas na véspera do dia dos namorados, e foi uma tensão muito grande. Primeiro, pra chegar lá, porque o trânsito começou a engarrafar as marginais." No local, havia muitas máquinas trabalhando e se tentava resgatar vítimas sob os escombros. A polícia era agressiva:

Você tentava se aproximar e era quase agredido, e eu tentava. Estava fazendo as anotações e de repente, começava a inflar o meu braço. Aí eu tinha que manter meu braço abaixado, mas eu não conseguia porque estava anotando. $\mathrm{O}$ resultado do teste foi anulado praticamente (risos), porque tinha momentos de pico que não dava pra explicar também e não dava pra ficar anotando, 13h05, o policial militar me empurrou - Aureliano Biancarelli. 
A vigilância em torno do profissional também é vista por ele como fator de estresse. Além do medo do furo, na Folha, havia o controle de erros, e os textos diários do ombudsman para os jornalistas. "Nós estávamos cercados, nada passava... Diariamente ele dizia, olha, tal jornal deu isso e aquilo, nós não demos... Isso aumentava o estresse próprio da profissão... Era o que me estressava, mas era o que eu queria fazer... Sobrevivi”, avalia Biancarelli.

No caso de Lúcio Flávio Pinto, ele destaca que o estresse costuma atrapalhar seu sono: "Fico um dia, dois dias, três dias com sono ruim, às vezes, mais tempo." Para Paula Puliti, o estresse vem da corrida contra o tempo e do próprio trabalho cotidiano ao lidar com o chefe, com as fontes, na hora de escrever. Já Marilu Cabañas considera estressante não saber o que pode acontecer quando faz determinada cobertura.

Bob Fernandes acredita que a profissão de jornalista é estressante. A questão da velocidade é ainda mais presente com a internet. As condições ruins de trabalho também podem ser causa de estresse. Para ele, "as condições são proletarizadas, o que não impede que as pessoas encontrem suas maneiras de ter prazer e sofrer menos ou não sofrer". Os casos mais estressantes na sua carreira foram matérias investigativas e a cobertura da Guerra da Somália em 1992, que o deixou mal por cerca de três meses ao retornar aos Estados Unidos, onde trabalhava como correspondente da Isto é. "Você vê as piores situações que os humanos podem ter e às vezes são estresses emocionais. Por exemplo, eu acompanhei a campanha do Tancredo toda..., quando acabou, eu não conseguia ouvir falar de política por muito tempo."

Os jornalistas com menos de 45 anos da pesquisa ressaltaram o fato de a profissão ser muito estressante. Apenas João desenvolveu uma linha de raciocínio um pouco diferente ao afirmar que as pessoas fazem dela estressante. Ele concorda que algumas coberturas, como tragédia ou guerra, e a pressão do tempo são fontes de estresse, mas avalia que muitos problemas poderiam ser resolvidos com planejamento e diálogo. Para ele, o estresse gera marcas emocionais e cansaço.

Antonio relata que nunca ficou muito tempo em jornal diário devido à loucura do fechamento e por preferir textos mais trabalhados como os de revistas, mas recorda que viveu nesses curtos períodos no Nordeste situações como ir cobrir um fato sem saber nada sobre a pauta, o que era fonte de muito estresse. A falta de infraestrutura também o angustiava. 
Para Ivan Marsiglia, o estresse vem do excesso de atividades simultâneas e paralelas de que é preciso dar contar, além do volume de trabalho, que é comum em outras profissões também. "Isso é muito cansativo, você não poder parar, se concentrar numa coisa só, fazer, terminar e passar pra outra. Isso é uma característica do jornalista que me desgasta, estimula certa ansiedade, que eu já tenho.” O jornalismo, para ele, joga a pessoa para a ansiedade. "Essa coisa de tudo ao mesmo tempo agora, eu acho que é o elemento de maior stress no jornalismo, que vem se agravando violentamente pela exigência de ser multitarefa".

A força do estresse está na fala de Maria: "Eu acho totalmente estressante, em nível de 10, 10". Ela já vivenciou estresse por não aceitar as condições de trabalho no passado. Na EBC, ela considera estressante a falta de infraestrutura física e pessoal. "Você põe as matérias no ar e você vê que a cada dois dias o site fica fora do ar, porque a empresa não tem uma estrutura de internet. Isso te estressa. Quando você vê que tem muito material bom e você não consegue aproveitar porque você não tem tempo..."

Para Bruno Torturra, o estresse lhe traz problemas para dormir e muita ansiedade. Ele reforça o fato de o mundo atual ser muito estressante. Ainda acrescenta que para os jornalistas das mídias convencionais é estressante a crise existencial do jornalismo e sua perda de credibilidade, o medo de perder o emprego e o acúmulo de trabalho. "Com demissões, quem fica, fica no ficaralho... Quem fica também se ferra, quem fica também se fode na hora desses novos reajustes editoriais das grandes redações."

Já Pedro considera a profissão muito estressante. "Eu tive uma fase meio paranoica mesmo, de não conseguir me desligar porque eu tinha que entregar, de dormir pensando nisso, de ter problemas do tipo pressão alta,..., do coração bater muito acelerado...".

Leonardo Sakamoto também destaca os problemas de saúde devido ao estresse. "No meio de uma investigação jornalística pesada, que durou quase um ano, eu tive alopecia areata, perda grande de cabelo..." A cobrança social em torno do jornalista também é fonte de estresse. "Você tem uma imagem a zelar... É diferente de alguém que faz uma burrada, que só você e o chefe ficam sabendo... Você está nu na frente do público e agora com a internet mais nu ainda."

Outro jornalista a relacionar problema de saúde com o estresse é Miguel, que chegou a desenvolver uma alergia na pele no começo de sua carreira na agência de notícias. O médico que o tratou levantou a hipótese de causa emocional relacionada com 
o trabalho. No mais, ele viveu momentos "de muita irritação, muita insatisfação, descontentamento", mas não chegou "a ter um estresse total".

Para Aline Scarso, na rua, em que se trabalha com equipe na TV, o jornalista está mais sujeito ao estresse, são vontades diferentes e há o fator trânsito para atrapalhar. "Mas eu acho que em relação aos meios privados, a gente não sofre tanto stress." Ela avalia, a partir de relatos de amigos, que nesses locais há mais pressão, tensão e competitividade. "Eu acho que isso não ocorre na TV pública, a gente não fica competindo com o outro. Eu acho isso muito legal. O nosso grupo é muito unido. Isso ajuda bastante. A gente se ajuda."

Priscilla Nery, por sua vez, reforça a questão do estresse: "Com certeza é estressante, com certeza é estressante.” Uma dessas situações ocorreu quando fez hora extra durante todo o mês. Na semana do fechamento, ela teve que cobrir uma premiação pela revista em um dia que tinha matéria para fechar e não conseguia falar com o entrevistado. Para piorar, ela não achava a cobertura essencial e foi designada de última hora. No mesmo dia ainda apareceu um gasto que não era seu na sua conta bancária.

$\mathrm{Na}$ hora que eu voltei do almoço veio essa situação de que eu teria que ir ao Prêmio, e o povo não tinha respondido ainda, não tinha me dado entrevista. Começaram a acumular as coisas. Me deu uma dor de cabeça, e eu comecei a chorar. Fui pro banheiro chorar um pouco pra descarregar. Esse dia foi bem estressante. Eu me considero uma pessoa bem tranquila, eu nunca tinha ficado daquele jeito com o trabalho... - Pricilla Nery.

Vivian Fernandes também considera a profissão "bem estressante" e seus momentos mais sofríveis ocorrem no fechamento do jornal semanal. "Eu vivo toda quinta-feira uma situação estressante, porque a gráfica tem um horário rígido pra gente entrar com o material." $\mathrm{Na}$ primeira edição, o computador estava com programa desatualizado e não foi possível fazer a diagramação corretamente. "Eu sei que a gente fechou 5 horas da manhã. $\mathrm{O}$ jornal só ficou pronto tipo sexta-feira à tarde, sabe. Aí já cagou com a distribuição, foi aquela droga." Com as novas edições, foram conseguindo chegar ao horário previsto de fechamento, mas a pressão do tempo continua a ser um fator de estresse.

É uma engrenagem que funciona muito perfeita, se alguma coisa falha nessa engrenagem, ferrou. Então eu me sinto estressada toda quintafeira. É raro quando eu não fico estressada. Eu tenho prazo. Eu tenho que fazer o jornal perfeito pra não ser criticado. Eu tenho o prazo da gráfica. Vai que acaba a luz, até quando começa chover, eu penso, se acabar a luz eu estou ferrada. São paranoias assim... - Vivian Fernandes. 
Os depoimentos mostram como os jornalistas vivenciam o estresse no seu cotidiano de trabalho, independente de trabalharem na grande mídia, na pequena empresa ou na mídia alternativa. A pressão do tempo está presente em todos os locais. $\mathrm{O}$ estresse se intensifica nas situações de fechamento, em coberturas especiais, mas mesmo no dia a dia está presente como mostra a fala da maioria dos entrevistados, sejam mais jovens ou mais velhos.

\section{6 - Os riscos do trabalho jornalístico}

No segundo capítulo, chegamos a mencionar o assassinato do jornalista Tim Lopes, que ocorreu em junho de 2002, enquanto fazia reportagem investigativa sobre o aliciamento por traficantes de meninas menores de idade para exploração sexual da favela Vila Cruzeiro para a TV Globo. Moretzsohn (2003) afirma em "O caso Tim Lopes: o mito da 'mídia cidadã"” que o assassinato do jornalista provocou entre os profissionais da área "uma esperada reação corporativa", na qual se discutiu em debates a segurança no exercício da profissão e se acusou, em alguns casos, "a negligência e autoritarismo" da Rede Globo.

Do lado do público, a autora avalia que houve um reforço da "mistificação" que a "imprensa promove em torno de si", o que foi reforçado pelo noticiário, sedimentando a imagem da emissora "como defensora dos valores e direitos da cidadania". Eram frases, por exemplo, destacando que a imprensa não recuaria e cumpriria o seu papel. Como raro, colocou o comentário de Fritz Utzeri, do JB, que denunciou a "imprudência quase criminosa das chefias de jornalismo da TV" para se conseguir imagens de algo sabido, "em nome do voyeurismo". Na maioria das vezes, não se discutiu os limites profissionais:

O Fórum Tim Lopes Nunca Mais, de 5 a 9 de agosto, foi o ponto alto de um movimento que expressava ao mesmo tempo a indignação dos jornalistas e sua incapacidade de enfrentar questões que fugissem ao estrito âmbito corporativo da segurança no trabalho, das responsabilidades dos empregadores e da relação de poder nas redações. Salvo exceções já citadas aqui, não se discutiam métodos, limites, enfim, o sentido da atividade profissional. O Fórum sintetizou esse quadro, a partir mesmo da pergunta que, escrita numa faixa, dominava o auditório do $7^{\circ}$. andar da $\mathrm{ABI}$, e depois seria transferida para o hall de entrada do prédio: “Onde está Elias Maluco?". Qualquer perspectiva de discussão séria já estaria descartada a partir dali, pois, 
se a questão era saber onde estava o traficante, uma vez que ele aparecesse o assunto estaria encerrado. $\mathrm{Na}$ abertura dos debates, o discurso da viúva reiterava aquela impossibilidade, pois qualquer crítica tenderia a ser vista como um atentado à memória do companheiro morto. (MORETZSOHN, 2003, p.25)

Já em novembro de 2011, o repórter cinematográfico Gelson Domingos da Silva, da TV Bandeirantes, foi atingido por um tiro de fuzil enquanto cobria uma operação policial na favela de Antares, em Santa Cruz, zona oeste do Rio de Janeiro. Ele usava um colete à prova de balas de nível II-A. A maior proteção possível a um civil é o nível III-A, que funciona contra revólveres, pistolas e submetralhadoras. Já contra fuzil seria necessário um colete à prova de balas de nível III, que necessita de uma autorização especial do exército para a utilização. Mais do que debater a autorização de uma proteção mais potente, o que seria necessário a todos que estavam lá, inclusive moradores, é preciso refletir sobre a cobertura jornalística em locais de alta periculosidade e fazer uma discussão mais ampla sobre a questão da segurança pública. Se for de interesse público noticiar o fato, a empresa deve oferecer segurança no trabalho, discutindo como isso deve ser feito com os próprios profissionais e especialistas em segurança, além de se debater quais os limites da cobertura.

Travancas (1993, p.82) coloca que se exige do jornalista, principalmente dos que trabalham em editorias como Geral e Cidade, o contato com áreas marginalizadas da vida urbana, "o que supõe correr riscos". Deve-se "acompanhar a polícia em perseguições a bandidos, obter informações de criminosos ou indivíduos que levam uma vida não só à margem da sociedade, como também clandestina". Assim a pesquisadora ressalta querer mostrar "que o risco está presente no exercício da carreira jornalística".

Se isso é uma realidade para os diferentes tipos de mídia, na TV, existe uma pressão ainda maior por imagens para que uma matéria realmente possa ser transmitida. Por outro lado, há um imaginário em torno da profissão de jornalista, construído socialmente. Autores que entrevistaram jornalistas encontraram falas em que são usados termos como missão, sacerdócio e comparação ao exercício da medicina. Tudo para alimentar uma ideia de dedicação total à profissão. Isso apareceu na pesquisa de Travancas (Ibid.), que constatou que "a profissão é elemento fundamental na vida" de seus entrevistados. Há "um vínculo afetivo com o trabalho" e "é difícil sair dele".

A ideia de missão e sacerdócio também apareceu entre os entrevistados de Ribeiro (2001). Esse imaginário sobre o papel do jornalista acrescido do prazer, apesar dos sofrimentos, que a profissão provoca, pode alimentar uma busca incessante pela 
notícia, com a naturalização do risco e das condições adversas que o jornalista enfrenta, o que como já dissemos pode ser uma defesa do profissional. Não se pode negar que quando o jornalista faz esse tipo de matéria, ele sente cumprir o seu dever de informar e mostrar o outro lado da questão. O medo está ao lado do prazer.

No caso Tim Lopes, os depoimentos contidos no documentário "Tim Lopes Histórias de Arcanjo", roteirizado por Bruno Quintella, filho do jornalista, e dirigido por Guilherme Azevedo, indicam essa mistura entre medo e prazer. São mostradas outras reportagens dele, desde a época em que trabalhava em jornal, em que chegou até a morar na rua para fazer uma reportagem. Sobre a matéria que causou sua morte, um dos irmãos dele fala que o jornalista sabia dos riscos, mas se sentia no dever de mostrar o que estava acontecendo. Isso não significa culpar o jornalista nem isentar os veículos, que não refletem sobre a segurança dos profissionais, mas reconhecer a complexidade desse tipo de cobertura e o envolvimento dos jornalistas nela.

Outro caso com repercussão na mídia foi a morte do cinegrafista da TV Bandeirantes Santiago Ilídio Andrade, de 49 anos. Ele foi atingido em 6 de fevereiro de 2014 por um rojão lançado por manifestantes durante um protesto no centro do Rio de Janeiro e morreu dias depois, em 10 de fevereiro. Tratava-se de uma cobertura de manifestação, como tantas outras feitas pelo país desde junho de 2013.

Em São Paulo, também cobrindo manifestações, o repórter fotográfico Sérgio Silva perdeu a visão do olho esquerdo, que foi atingido por uma bala de borracha disparada pela polícia militar, em 13 de junho de 2013. O jornalista chegou a ser entrevistado pelo jornal Unidade, do Sindicato dos Jornalistas Profissionais no Estado de São Paulo, de setembro de 2013, em que relatou o que aconteceu:

A polícia foi a primeira a atirar nos manifestantes que protestavam pacificamente. Fez um cerco na rua da Consolação, esquina com a Maria Antonia e começou a disparar bombas de gás lacrimogêneo e efeito moral. Ao mesmo tempo, as balas de borracha eram disparadas para todos os lados. Imediatamente procurei abrigo para minha segurança atrás de uma banca de jornal e, mesmo assim, depois de vários minutos de ataque, estando distante da maioria dos manifestantes e dos outros colegas da imprensa, fui atingido no olho esquerdo depois de fotografar os policiais atirando contra as pessoas. Fui alvo do ataque covarde que a polícia cometeu.

(...)

Daqui para frente minha vida profissional será $100 \%$ prejudicada. Mesmo com um olho, sei que poderei fotografar, mas não como antes. Perdi a noção da profundidade de campo, da nitidez e foco da fotografia, o que para todo e qualquer profissional, é fundamental para o bom desempenho do trabalho fotográfico. Eu amo a fotografia e jamais deixarei de fotografar, mas profissionalmente será bastante 
difícil ter o mesmo desempenho que eu tinha antes de ser atingido, além de ter o direito de competir igualmente com os outros profissionais. A visão do meu olho esquerdo foi arrancada de mim. Ela era um dos meus maiores instrumentos para a execução do meu trabalho. (SILVA, 2013)

Segundo dados da Associação Brasileira de Jornalismo Investigativo - Abraji, de 10 de maio de 2013 até 13 de julho de 2014, 210 jornalistas foram agredidos. Há casos de prisão, agressões com cassetete, socos, bala de borracha, spray e bombas de gás lacrimogêneo, e até atropelamentos pela polícia. Também existem ocorrências de hostilização e agressões físicas realizadas contra jornalistas por manifestantes.

Antes mesmo das manifestações de junho de 2013, os casos de agressões aos jornalistas já eram noticiados. Segundo matéria publicada na Folha de S.Paulo no mês de abril de 2012, dados do Comitê para a Proteção dos Jornalistas (CPJ), com sede em Nova York, apontam para o assassinato de 909 jornalistas de 1992 até a data da matéria. Ainda se afirmou que o Brasil ocupava a $11^{\mathrm{a}}$ posição no ranking, com 21 mortos. Já notícia do site Comunique-se (PATROCÍNIO, 2012) colocou que, segundo a Press Emblem Campaign (PEC), o Brasil ocupava o $5^{\circ}$ lugar no ranking de países em que jornalistas mais foram assassinados naquele ano. Os dados mostravam que 72 jornalistas foram mortos em 21 países durante o primeiro semestre de 2012. Ainda citava o relatório da Associação Brasileira de Emissoras de Rádio e Televisão, que contabilizava o assassinato de quatro profissionais no período no Brasil. Um dos casos noticiados em 2012 foi o do jornalista Décio Sá, repórter do jornal Estado do Maranhão. Ele foi executado a tiros no mês de abril em um bar, na cidade de São Luís.

Em julho de 2012, a Unesco - Organização das Nações Unidas para a Educação, a Ciência e a Cultura colocou em consulta pública um plano de ação para melhorar a segurança dos jornalistas e combater a impunidade nos crimes cometidos contra esses profissionais. Entre as questões abordadas está a prevenção de ataques contra jornalistas. Essa ação foi um desdobramento do Plano de Ação das Nações Unidas sobre a segurança dos jornalistas e a questão da impunidade, adotado em 12 de abril daquele ano pela junta de chefes executivos das Nações Unidas.

O jornal Unidade também costuma abordar com frequência os casos de violência sofridos por jornalistas no estado. Na edição de junho de 2012, por exemplo, a matéria de capa tratou do tema violência contra os jornalistas com o título - Basta, "A dor da gente não sai no jornal". A matéria noticiava um documento do sindicato solicitando às “autoridades judiciárias e legislativas 'salvaguardas necessárias para que a imprensa 
possa exercer sua função de informar o cidadão'." Também apoiou o Projeto de Lei 1078/2011 do deputado federal Protógenes Queiroz que possibilita a participação da Polícia Federal na investigação de crimes contra a atividade jornalística, após 90 dias, quando houver ineficiência ou omissão do poder estadual e municipal.

A reportagem relata um caso de profissional que foi assaltado e perdeu parte de seus equipamentos, que não eram da empresa, e ainda foi agredido com um corte na orelha. Outro repórter fotográfico foi agredido por manifestantes. Foram relatados roubos assim como ameaças e perseguições para intimidar dois jornalistas que cobriam a morte de uma pessoa em São Paulo, até seus celulares e telefones foram grampeados. Em relação às mortes, foram relatadas quatro ocorridas durante o primeiro semestre de 2012.

O relatório anual da organização Repórteres sem Fronteiras (RSF) afirma que cinco jornalistas foram mortos no Brasil em 2013 (FERNANDES, 2014). Todos são casos de execução. Já o relatório "Segundo tempo para a imprensa brasileira - a justiça prevalecerá sobre a censura e a violência?" da entidade internacional Comitê para a Proteção dos Jornalistas (CPJ), divulgado em 6 de maio de 2014 durante o $6^{\circ}$ Fórum Liberdade de Imprensa e Democracia, em Brasília, apontou que 12 jornalistas foram mortos desde 2011 no Brasil "em represália direta por seu trabalho" e que outros cinco foram mortos em circunstâncias obscuras. O primeiro caso relatado é de Luciano Leitão Pedrosa, da TV Vitória e Rádio Metropolitana FM, assassinado em 9 de abril de 2011, em Vitória de Santo Antão, Pernambuco. O último caso colocado no relatório, de 13 de fevereiro de 2014, foi o de Pedro Palma, do jornal Panorama Regional, de Miguel Pereira, subúrbio ao sul do Rio de Janeiro, que circulava nos municípios próximos.

Um último caso, que vamos relatar, foi apresentado pelo jornal Unidade de outubro de 2014 e teve repercussão em outros veículos e mídias sociais, com a mobilização \#somostodosculpados em que as pessoas se fotografavam com um tapaolho em solidariedade ao repórter fotográfico Alex Silveira. Ele levou um tiro de bala de borracha no olho esquerdo, dado pela polícia militar, enquanto cobria um protesto de professores na Avenida Paulista, no ano 2000. O Tribunal de Justiça de São Paulo o considerou culpado por ter se colocado em risco. A sentença anterior condenava o Estado a lhe pagar indenização de 100 salários mínimos. Com a nova decisão, fundamentada pelos desembargadores Vicente de Abreu Amadei e Sérgio Godoy Rodrigues e pelo juiz Maurício Fiorito, o jornalista, além de não receber nada, deveria pagar as custas do processo. 
Ao apresentar esses casos não tivemos como objetivo esgotar o tema nem tratálo em profundidade. Apenas pontuamos alguns fatos e dados disponíveis para mostrar que o risco e a violência estão presentes no trabalho do jornalista. Introduzimos essa discussão para mostrar o ponto de vista de nossos entrevistados sobre os riscos que eles já vivenciaram na profissão. A questão que fizemos foi: "Você já vivenciou algum tipo de violência por ser jornalista?" Obtivemos relatos de dez profissionais que vivenciaram os riscos e possibilidades de violência da profissão. Desses, sete têm mais de 50 anos, sendo uma mulher, os outros três estão na faixa dos 30 aos 39 anos, dois homens e uma mulher.

Um dos casos mais emblemáticos é o do jornalista Lúcio Flávio Pinto, que foi agredido em 2005, quando estava almoçando, por Ronaldo Maiorama, um dos donos do jornal Liberal, do Pará. "Ele veio por trás e me deu um murro, por sorte eu virei um pouquinho, bateu raspando, aí deu um chute, eu caí, e os dois seguranças, que eram policiais militares, partiram pra cima de mim me chutando". O fato ainda abala Lúcio, que após um silêncio, continua:

Essa experiência que é a mais próxima da morte, no sentido da agressão, ela mostra o seguinte, quão valiosa é a vida e quão sem valor ela se tornou. Então você tem na pele um retrato da impunidade, do mal que a impunidade faz, porque eu me senti impotente. O cara pegou, me agrediu, foi embora, fiz o boletim de ocorrência, foi pra Justiça e no final ele foi condenado a pagar 50 salários mínimos de cestas básicas para uma instituição, uma das quais era apoiada pela família dele. Então se ele pensava que ia me intimidar, hoje eu tenho a plena convicção que eu não tenho medo de nada que possa me ameaçar, nada. Eu cumpri a minha função e eu cumpro automaticamente, não pensando em heroísmo, em nada, simplesmente, no jornalismo. O que você está fazendo? Eu faço jornalismo. Os outros não fazem jornalismo? Fazem. Cada um faz da maneira que sabe fazer. Eu só sei fazer assim, não sei sair disso, por mais que eu tentasse - Lúcio Flávio Pinto.

A fala de Lúcio deixa claro o envolvimento que ele tem com a profissão e o compromisso que tem em fazer um jornalismo combativo. Parte da ansiedade que sente se deve a essas ameaças latentes. "Ando de ônibus, normalmente. Ando na rua. Então estou exposto. Os guarda costas que me agrediram um dia vão querer acertar as contas. Eu não limito as minhas coisas, mas eu estou atento." Com a voz embargada, diz que seus amigos estão na retaguarda, só ele atua "na linha de frente". Para ele, os jornalistas que estão na grande imprensa têm a figura institucional da empresa que ele não tem. "Sempre aqueles que eu desagrado têm esse raciocínio. Se acabar com ele, acaba com o jornal." 
Lúcio já recebeu várias ameaças de morte por telefone. "A primeira vez que você recebe você fica abalado, com o tempo você vai se acostumando, e eu nunca me considerei na lista de ameaçados de morte. Nunca. O que eu faço? Ajo como jornalista. Eu vou saber de onde parte..." Assim ele investiga com a rede de fontes que tem se as ameaças têm procedência, para conseguir desfazê-las. Em uma das vezes chegou a ligar para o então governador Jader Barbalho porque descobriu um esquema para assassiná-lo de pessoas ligadas a ele.

Audálio Dantas conta ter vivenciado várias situações de risco e violência. "Uma vez eu me vi morto porque era uma grande manifestação..., isso antes do golpe militar, nos anos 1960, e eu fui cobrir." Ao ouvir o barulho de tiros perguntou a um policial o que havia ocorrido. O policial respondeu que nada, podia ficar despreocupado, era tiro de festim. As lojas fecharam, e Audálio ficou em frente a uma porta de aço, mas acabou saindo por causa de um movimento qualquer. "Logo que saí, tombaram duas ou três pessoas naquele lugar, podia ser eu, eu considerei esse fato, mas continuei fazendo a cobertura porque aí é a exigência profissional."

Em outro caso, ao cruzar a fronteira de Honduras, em 1969, soube pelo rádio que o país tinha sido atacado por El Salvador. "O que devia acontecer com o repórter? (...) era ir pra guerra e foi o que fizemos, eu e o meu colega, o fotógrafo Oswaldo Maricato e fomos cobrir." Eles foram até uma das frentes de batalha: "Vimos aquela guerra terrível, porque era uma guerra quase primitiva. Esses bombardeios eram feitos com aviões $\mathrm{C}$ 47, eram jogadas as bombas manualmente, uma coisa triste.” Eles viram várias pessoas mortas à beira da estrada, muitos jovens.

O jornalista fala de outro tipo de violência, a psicológica, que sentiu ao fazer uma reportagem sobre o hospital psiquiátrico do Juquiri, para a revista O Cruzeiro, de 30 de março de $1963^{9}$. "Eu passei uma semana acompanhando aquilo e sofrendo barbaramente aquele estado de coisas porque aquilo, literalmente, era um campo de concentração, não era um hospital." Ele recorda ter visto cenas de terror . "Tudo isso é coisa que o repórter tem que enfrentar, se não ele não faz."

Os riscos também podem ter um caráter de aventura, o que Audálio chama de "momentos de ousadia ou irresponsabilidade", que o repórter precisa ter, muitas vezes, na busca da matéria. "Eu tenho vários momentos desses, e um deles foi indo fazer uma matéria sobre garimpo no Alto Rio Jarí na Amazônia." A região ficava quase na

\footnotetext{
${ }^{9}$ A história dessa reportagem e a matéria podem ser lidas em Dantas (2012b, p. 45-59)
} 
fronteira com as Guianas, tinha uma grande cachoeira e um longo trecho de corredeiras. "A subida foi um sofrimento muito grande porque a gente veio num barco de motor de popa desde Macapá. Subiu um pedaço do Amazonas, um pedaço do rio Jarí, tudo isso é muito fascinante pro repórter, pra mim, e nada paga esses momentos." Para enfrentar as corredeiras era preciso usar cordas, amarrá-las no barco e nas árvores. Na volta, havia duas opções:

Tem um trecho do rio chamado sete pancadas, porque são degraus, e os barcos descem por ali, para a destruição ou para vencer aquele espaço em 15 minutos, compensando o que arrastou o dia inteiro o barco na subida. Era motor de popa, na volta, tinha o barqueiro e um proeiro que é o cara que conhece os meandros do rio, sabe que por aqui é bom. Aí o cara disse, olha, pra descer, amarrando o barco pela margem a gente vai demorar não o dia inteiro, mas vai demorar umas oito horas, mas a gente pode também arriscar descer aqui porque é aquela corrente e vai. O motor de popa tem uma particularidade, ele tem um pino, uma coisinha assim frágil, que é o que gira. Se a hélice, se aquele pino arrebentar num galho de árvore ou uma pedra e tal, aí não tem barco que sobre porque ele se arrebenta, ele perde o rumo... Aí pensei, pensei, pensei, e vamos lá. Eu acho que foi uma grande irresponsabilidade. Esses 15 minutos foram de absoluta tensão, um medo. Mas depois foi uma vitória - Audálio Dantas.

Já a ameaça da violência pode vir da luta pela liberdade. Foi isso que viveu Audálio Dantas quando assumiu a presidência do Sindicato dos Jornalistas Profissionais no Estado de São Paulo em 1975. Ele recorda que naquela época a "violência era a regra e atingia indiscriminadamente qualquer pessoa que se opusesse ao regime militar". A ida ao sindicato foi com o compromisso de "uma gestão de luta contra o regime militar". Em julho, dois meses após tomar posse, chegou a ser chamado para falar com o comandante do segundo exército.

Eu sabia que estava visado, mas ali era uma questão de determinação. Não era uma coisa heróica, mas era uma decisão de luta e havia muito medo, havia muita ameaça. Antes do Herzog foram presos 11 jornalistas. Cada um a gente acompanhou, protestou, quer dizer, foi um processo, e a morte do Herzog precipitou as ameaças, mas ao mesmo tempo ela contribuiu para que houvesse uma tomada de consciência da sociedade contra a ditadura e foi um divisor de águas, sem dúvida. E ali eu devo dizer que passei os dias mais angustiantes da minha vida, os dias mais difíceis, mais complicados. Mas não era só eu - Audálio Dantas.

A maior pressão e ameaça de violência que Ricardo Kotscho sofreu também remete ao período da ditadura militar logo após ter feito a já citada matéria das mordomias e uma matéria sobre a morte do operário Manoel Fiel Filho em circunstâncias parecidas com a de Vladimir Herzog. "Ele apareceu morto na cela e 
falaram que foi suicídio." O jornalista conseguiu levantar todos os detalhes do caso, e a matéria teve que sair assinada por exigência do diretor do jornal O Estado de S. Paulo, Júlio de Mesquita Neto. Um jornalista que cobria a área militar avisou Kotscho: "Os homens estão putos com você, acho melhor você dá um tempo". Nessa época, ele recebeu um convite para ser correspondente do Jornal do Brasil na Europa. "Como eu te falei antes, eu não sou nenhum herói, corajoso, mais que depressa eu aceitei o convite e caí fora." Além desse caso, ele se recorda de ameaças veladas, de ser mordido por um cachorro, de truculências da polícia. "Nos conflitos que havia na época das greves, como agora acontece, a polícia entra batendo nos manifestantes e não sabe quem é jornalista, quem não é jornalista. Eu procurava sempre ficar mais a distância pra evitar isso." Para ele, "quando existe uma violência contra um jornalista, ou contra um veículo, é na verdade uma violência contra a sociedade. Nós representamos a sociedade. Nós estamos em lugares onde as pessoas não podem ir pra contar o que aconteceu".

Um dos maiores riscos para Clóvis Rossi, que cobriu a guerra em El Salvador em 1982 e a do Golfo em 1991 de Jerusalém, foi ter caído no meio de um tiroteio quando voltava para a capital de El Salvador. Essas experiências são relatadas, respectivamente, em Rossi (1986, 1999). Em seus livros, ele mostra os dilemas e medos do repórter frente ao risco e à violência.

Estava na Nicaragua quando ocorreu o episódio do assassinato de quatro jornalistas holandeses pelo Exército salvadorenho, quando eles se preparavam para um contato com guerrilheiros. (...) Por isso mesmo, meu jornal (a Folha de S. Paulo) me deixou escolher entre ir ou não a El Salvador. Passou a ser uma decisão estritamente pessoal. Minha mulher pressionou para que eu não fosse, alguns jornalistas brasileiros, que já haviam deixado El Salvador, também. Mas não havia, na verdade, escolha: ou ia e corria o risco ou falhava como profissional.

Fui e tive de enfrentar, já em El Salvador, outra escolha difícil: muitos jornalistas preferiam cobrir a guerra exclusivamente da capital, menos conflitiva e mais segura, portanto. (...)

Fui de novo e de novo escapei por pouco. Na volta, em plena estrada, havia uma caminhonete parada no acostamento, com homens armados em volta. Avisaram-nos (havia outros dois jornalistas no táxi e mais dois táxi, atrás, com jornalistas) de que a guerrilha dificilmente ataca os veículos que levam a bandeira branca e o dístico "Prensa Internacional" nos pára-brisas, para evitar que haja uma propaganda negativa contra ela.

Resolvemos seguir adiante. Mal o nosso carro - que era o primeiro do comboio de três - avançou uns metros, começou uma fuzilaria que nem dava para perceber direito de onde partia. Não tive dúvidas: com meus quase dois metros de altura, consegui enfiar-me no pequeno espaço livre entre o banco e o porta-luvas do Toyota que nos levava e ali fiquei até cessar os tiros. (ROSSI, 1986, p. 34-35) 
$\mathrm{Na}$ entrevista, Rossi conta que as coberturas de manifestações no Chile também costumavam ser tensas. Mas a perseguição que sofreu da repressão na Argentina foi a que lhe causou mais tensão psicológica. "Entraram na minha casa e claramente foi coisa da repressão, porque pegaram as notas de 100 e de 50 dólares e deixaram as de 20, 10 . Nunca fui preso, nem torturado, mas o simples fato de você saber que está sendo vigiado e perseguido é estressante." Também chegou a seguido na rua e pediam cópias de suas matérias ao serviço de telex.

Evidentemente não era para saber o que eu estava escrevendo, porque a embaixada informava, era para que eu ficasse sabendo que eles estavam me vigiando. Tudo isso é extremamente estressante em uma ditadura como a argentina em que fazer desaparecer as pessoas era a coisa mais fácil do mundo. Você fica realmente em pânico permanentemente - Clóvis Rossi.

Para Aureliano Biancarelli os riscos vieram de coberturas como de desocupação, em "que as pessoas ficam muito agressivas com a imprensa". Outro caso que lhe causou apreensão foi uma matéria sobre vítimas da polícia militar e famílias que estavam denunciando essa violência. "A família começou a receber recados. Eu recebi telefonemas, dizendo que sabiam onde eu morava, que eu tomasse mais cuidado. Esse caso foi um caso concreto de policial militar que estava se valendo do telefone pra me ameaçar.” O carro do jornal passou a acompanhá-lo até a sua casa, pois ele recusou ser acompanhado pela polícia militar, que colocou uma viatura a sua disposição. "Mas depois de duas semanas esse policial disse que não era isso, que era um mal entendido."

Marilu Cabañas relatou três agressões, que lhes causaram ferimentos superficiais. Em uma reintegração de posse, ela presenciou um policial cortando a costa de um sem teto. "Eu falei para o policial, não faça isso. Os repórteres todos estavam atrás da polícia, e eu estava junto com a galera no terreno que estava sendo desocupado, e o policial jogou uma bomba em mim, que estourou nos meus braços, nas minhas costas, os estilhaços." Em outra cobertura, ela estava com sem tetos em um prédio ocupado na rua Líbero Badaró, do extinto Banco Nacional, no centro de São Paulo.

A tropa de choque entrou, os jornalistas lá fora, e eu dentro, e começou a jogar gás lacrimogêneo. Eles vinham de baixo e jogavam gás para afetar quem estava no andar de cima. Nossa, afetou para caramba. Todo mundo tossindo. Aquele gás todo. Em manifestação também. Sempre com a polícia. A polícia sempre é o ator principal da violência. Na manifestação dos professores, bomba de gás lacrimogêneo também me atingiu. Tem repórter fotográfico que já 
perdeu a visão, mas felizmente comigo, graças a Deus, só foram ferimentos superficiais - Marilu Cabañas.

As colocações de Marilu Cabañas são importantes para fundamentar uma discussão sobre os limites de uma cobertura. Muitas vezes quando o jornalista é atingido em coberturas desse tipo, como manifestações, algumas pessoas culpam o jornalista pelo risco, como se vê em alguns comentários de leitores na internet e até mesmo na resolução do Tribunal de Justiça de São Paulo no caso do repórter fotográfico Alex Silveira. Pergunta-se o que o jornalista estava fazendo junto aos manifestantes e não do lado da polícia. Para contar uma história que se aproxime da realidade não se pode ficar limitado aos relatos oficiais. É preciso ir ao outro lado. Essa é a essência do jornalismo.

O mesmo vale para o dilema acima relatado por Clóvis Rossi entre cobrir a guerra de San Salvador ou ir para a área de conflito. A história que se conta ouvindo fontes da capital pode não ser a mesma do que estar na área de risco e ver com seus próprios olhos e ouvir as pessoas que estão no local.

Bob Fernandes já foi assaltado ao sair de madrugada do palácio do governo no dia da reeleição de Hugo Chávez, enfrentou os riscos de cobrir guerra e da cobertura de muitas passeatas. Antes de chegar à guerra na Somália, passou pela Angola - que estava em trégua, Ruanda, que vivia um início de guerra, e Quênia. O jornalista se recorda de outros riscos. Certa vez, em uma de suas primeiras matérias na Veja sobre Eunápolis, um povoado com 100 mil pessoas, ele entrevistou um matador. "Ele foi a última pessoa que falei. Falei e na hora saí, você está num brejo, com um cara que mata.” Em outra ocasião, em 1987, ficou 25 dias em Letícia, na Colômbia, com o fotógrafo Luciano Andrade. O objetivo era entrevistar Evaristo Porras Ardila, que era o braço direito, no sul da Colômbia, do chefe do tráfico de cocaína Pablo Escobar. O resultado foi uma matéria de duas páginas no Jornal do Brasil.

Por que a gente ficou 25 dias? Porque se a gente chegasse dizendo assim, eu quero falar, o cara matava a gente com 10 minutos. Todas as noites durante 20, 21 dias, a gente foi ao mesmo restaurante, que tocava o mesmo disco do Roberto Carlos, porque o dono era tio do Evaristo Porras Ardila... O contato tinha que ser uma coisa casual. Aí um dia eu falei, cara, ou a gente arrisca ou, então, não vai dar certo Bob Fernandes.

Conversando com o tio de Ardilas, começou a criticar os americanos: "Os caras ficam dando 3 bilhões de plano Colômbia, porque eles não dão máquina de plantar, sementes, implementos agrícolas." O homem respondeu que era a mesma coisa que o 
sobrinho dele dizia. Era a deixa que o jornalista precisava, perguntou quem era o sobrinho e ao ouvir o nome, falou que gostaria de conversar com ele. "Aí o velho acertou, chegamos à casa do cara, cheia de metralhadora, fizemos a matéria. Ele se deixou fotografar sentado em uma cadeira de costas."

Outros casos de riscos emergem de sua memória. Também enfrentou perigo em um rio. Era um braço do Solimões, na região da tríplice fronteira Brasil, Colômbia e Peru. Na volta, no escuro, sem lanterna, uma batida em qualquer tronco viraria a lancha. "Eu não sabia nadar direito, um rio mega.. A gente voltou no escuro com o barqueiro dizendo: vocês estão correndo um risco." Em Abrolhos, arquipélago no sul da Bahia, enfrentou uma tempestade e ficou 12 horas no mar. "Coisa que você faz quando você é moleque, irresponsável, não está nem aí, cara. É isso, mil encrencas, mas eu nunca dei conta dessas coisas (risos).”

Bruno Torturra relata que já sofreu ataques em manifestações quando fazia a cobertura para a Mídia Ninja. "Já recebi muito gás lacrimogêneo. Já apontaram arma na minha cara duas vezes quando eu fui fotografar. Já recebi recados de associações de direitos humanos dizendo que havia milícia de policiais interessados em me pegar, não sei o quanto isso é crível ou não." Ele conta ainda que seu telefone foi grampeado, que já jogaram bomba de efeito moral no seu pé e já miraram bala de borracha nele, mas não acertaram. "Black bloc já me agrediu, me empurraram na parede, só pararam de me agredir quando alguém disse que eu era da Mídia Ninja.”

Leonardo Sakamoto, por sua vez, recebeu ameaças veladas e vivenciou riscos na cobertura de trabalho escravo, de trabalho infantil e de guerra. Também costuma receber e-mails ameaçadores. "Mas eu sempre levei tudo isso na boa. Só uma pessoa muito idiota pra fazer alguma coisa contra, por quê? Porque você gera um mártir, ainda mais no corporativismo jornalístico... É diferente de alguém que está lá no meio do mato cobrindo e não é conhecido..." Ele se incomoda mais com tentativas de destruir a sua credibilidade. Sobre a cobertura de guerra, ele afirma que o trabalho é menos romântico do que as pessoas pensam.

Primeiro você tem que fazer um trabalho muito grande de apuração. Sem fontes você não é nada lá... Encontrar as pessoas certas pra poder chegar lá e se cumprir um plano... Estar bem preparado pra tudo, saber as consequências de ir para algum lugar, as consequências de não ir para algum lugar... E, é claro, preparado para determinada situação de conflitos. Se estiver sozinho, tem momento que vendo a natureza humana, sofrimento, dores, vendo as coisas acontecendo, você com mais frequência vai se colocar em xeque... O jornalista deveria fazer mais reflexão sobre si mesmo, sobre o que ele sente dentro de todas as 
coisas que ele passa.... Eu cresci muito nas vezes que cobri conflitos armados, como jornalista e como pessoa... - Leonardo Sakamoto.

Dos riscos que correu, Sakamoto se recorda que a resistência Timorense fez uma identidade falsa, como se ele fosse indonésio, pra ele sair do Timor e ir até a penitenciária de Cipinang em Jacarta, capital da Indonésia, entrevistar Xanana Gusmão, líder revolucionário que depois se tornou presidente do Timor. "Se eu fosse pego, seria preso e ficaria por lá." Ele avalia que o "risco faz parte em determinadas atividades da nossa profissão, só que não é o risco maluco, é o risco ponderado", ou seja, cercado de planejamento.

Maria conta que vivenciou uma situação que não chegou a ser violência, mas que a deixou nervosa. Ela estava fazendo um programa especial sobre o dia da criança e adolescente em uma ocupação do Movimento dos Sem Terra e do Movimento dos Trabalhadores Sem Teto da Odebrecht na Marginal Pinheiros, em São Paulo. "Tem criança no acampamento e eu estava lá. Não era pra cobrir o protesto." No meio do protesto, souberam que a Odebrecht estava no local, fecharam a entrada e começaram a tirar os jornalistas. "Eu conheço o MST, o MTST, não tenho medo deles, nem nada. Mas por duas vezes vieram em mim, você é jornalista, não sei o que, já pegou meio pelo braço, e eu falava que eu era da revista Sem Terra." Por já ter trabalhado na revista, ela conseguiu ficar. "Foi uma situação que me deixou nervosa, eles não iam me bater, só iam me tirar, mas acho que hoje a gente sofre muito por ser jornalista, principalmente em situações de protesto."

A jornalista relata que na EBC a Comissão de Funcionários batalhou para que a empresa disponibilizasse aos jornalistas colete balístico, capacete e máscara apropriada para gás. Não houve treinamento, mas tiveram uma palestra sobre como se comportar em situações de conflito, tratando inclusive das condições emocionais e de como os gestores devem lidar com a questão. "Os gestores mesmo não foram ouvir isso, entendeu? Só os funcionários." Em relação ao uso do equipamento, é o jornalista que decide se deve ou não usar. "Tem colegas meus que não querem sair com colete balístico pra não ser diferenciado. Se diferenciar pode ser uma coisa ruim, se tem os Black Blocs."

Os depoimentos mostram que o risco de ser submetido a uma violência faz parte do fazer jornalístico, e o envolvimento dos profissionais com o jornalismo faz com que os riscos sejam naturalizados para se fazer a cobertura. $\mathrm{O}$ medo existe, mas o dever do jornalismo é maior do que ele, assim como o prazer de sentir que se cumpriu o papel de 
jornalista. Outros riscos apareceram nas falas como o da violência psicológica e até um senso de aventura. Eles não se veem como heróis. Isso apareceu na fala de cinco entrevistados, mas por uma boa história podem esquecer que há limites. Quais são eles? Não estão dados, devem ser criados a partir da reflexão dos próprios profissionais. Por outro lado, as empresas devem assumir as suas responsabilidades. E todo esse debate deve ser feito em um contexto mais amplo, social e histórico, que incluem as limitações do próprio Brasil.

\section{7 - Álcool e drogas}

Uma reflexão que tentamos fazer com os nossos entrevistados foi sobre o uso de álcool e drogas entre jornalistas e se haveria relação com o trabalho. A questão já foi tratada na revista Imprensa e no jornal Unidade, na já citada entrevista com o pesquisador José Roberto Heloani.

O álcool é uma droga lícita e sempre foi utilizado no meio, até porque o álcool tem duas funções. O pessoal diz que ele é depressor, mas ele é, ao mesmo tempo, um excitante e um ansiolítico porque baixa a ansiedade e é também um desinibidor. Então o álcool é uma droga que começa ser utilizada muito cedo.

Então você começa a beber quando é estagiário em pequenas doses. $\mathrm{O}$ problema é que primeiro você começa a beber para se desinibir, depois um uísque para dormir e assim vai. É sabido que existe o efeito de tolerância. Isso é um mecanismo do nosso organismo que faz com que a atuação da droga diminua. Então, você passa a precisar cada vez de doses mais elevadas para sentir o mesmo efeito. Ele começa a recorrer, até para não ficar bêbado, a outras drogas e a tomar anfetaminas. Toma medicação lícita, mas geralmente sem acompanhamento e psicológico. Toma para dormir e depois entram os antidepressivos para ficar acordado.... E começam a usar de forma mais ou menos camuflada e, aos poucos, vão ficando dependentes também. Chega uma hora que não vai mais conseguir baixar a ansiedade. Aí ele volta para o álcool e vai chegar um ponto que vai ficar tão mal no dia seguinte, que não consegue ter o mesmo desempenho, porque a cobrança é louca. Aí, ele parte para as drogas ilícitas e uma das preferidas é a cocaína. (HELOANI, 2013, p.7)

Já a reportagem “As drogas no jornalismo", da revista Imprensa de novembro de 1993, escrita por Luís Fernando Colombini, contou com 27 entrevistados que tomaram drogas nas redações ou presenciaram o fato. O álcool, a maconha e a cocaína foram apontados como as drogas mais consumidas.

O texto traz relatos de uso de cocaína em banheiros de redações de jornais e TVs. Os depoimentos colhidos falavam no uso para relaxar a tensão e para se criar uma 
realidade diferente da que se vivia. Fechamentos e pescoções apareciam como cenários. Já sobre a maconha, devido ao odor, afirma-se que já chegavam "fumados". Abordavase ainda a questão do vício e levantava-se a questão do crime organizado.

A mesma revista retomou o tema em outubro de 2006 em reportagem de Alex Sânder Alcântara. O texto afirma que "muitos jornalistas buscam 'saída' nas drogas, principalmente no álcool, na cocaína e na maconha, para aliviar o estresse”.

Travancas (1993, p.31) chega a citar o consumo de álcool e drogas entre jornalistas. Já Ribeiro (2001, p.157) apresenta o depoimento de um redator de economia sobre o consumo de drogas, que ocorria, "porque a droga faz você trabalhar muito mais, além de dar uma sensação de poder, que se traduz na sua capacidade de ser mais eficiente, redigir mais depressa, ordenar melhor as ideias. Para mim, isso foi um desastre total; mas parei".

Na nossa pesquisa, os jornalistas com mais de 45 anos não presenciaram o uso no trabalho. Duas pessoas disseram que sabiam ou percebiam que colegas usavam drogas ou álcool. Uma delas cita um caso de alcoolismo em que o jornalista teve apoio para se tratar, pois já estava prejudicando seu trabalho. A outra pessoa entrevistada não acredita que o trabalho leve a pessoa a usar.

Nessa mesma linha, um entrevistado disse não ver números significativos no jornalismo. Outros três falaram que era comum ir ao bar tomar uma cerveja, mas como diversão. Três também é o número dos que citam ter tido colegas que se tornaram alcoólicos, mas não sabiam dizer se havia alguma relação com o trabalho no adoecimento.

Entre os jornalistas com menos de 45 anos, há diferentes percepções sobre o tema. A questão das drogas ilícitas foi abordada em sete relatos. Em um deles, falou-se do caso de um chefe que chegava alterado: "Chegava tremendo, tomava lexotan, porque passou a noite toda cheirando, pra poder suportar a agenda, coisas que tinha que fazer". Em outro depoimento se apontou o uso no trabalho: "Eu acho que usar químicos recreativamente é divertido, mas agora cheirar nos banheiros da redação é uma merda, sabe? Mas tem gente que faz".

Outra pessoa disse ter ouvido falar sobre a questão: “É um assunto corrente nas redações... Eles falam assim - Nossa, que tem gente que cheira cocaína pra fazer grandes jornadas, mas nos ambientes de trabalho que eu frequento, com os colegas de profissão que eu tenho, não conheço nenhum que faz isso." 
Há os que não relacionam com a profissão: "Eu não uso droga ilícita, só o álcool. Mas sei que muitos colegas meus fumam maconha. Isso é muito comum, mas acho que não é da profissão, é da geração. Eu não acho que é por ser jornalista que a pessoa fuma maconha". Em outro depoimento: "Não sei se é uma coisa da profissão. Eu acho que jornalista abusa mesmo de drogas assim, alguns que eu conheço sim.” Já outra pessoa avalia que o uso de drogas ocorre em menores proporções do que o de álcool.

Sete relatos também falam sobre o uso de álcool, dos quais quatro apontam o uso para relaxar, dois citam uma boemia relacionada ao jornalismo, dois relacionam ao estresse no trabalho. Ainda há dois desses que dizem não saber se dá para relacionar, outro que depende da dinâmica da pessoa, mas outro vê uma relação com a natureza do trabalho. No geral, afirma-se que as pessoas já gostavam de beber antes. Um depoimento apenas diz já ter visto uma pessoa que não gostava de beber, ter bebido por causa do estresse. Selecionamos partes de alguns desses relatos:

Eu sempre gostei de beber mesmo antes de trabalhar, gosto de tomar cerveja, mas eu vejo que quando eu estou estressada no trabalho, eu vou mais pro bar logo em seguida.

Às vezes eu chego cansada e eu quero tomar uma cerveja sabe. Eu acho que todos os trabalhadores sentem um pouco isso. (...) Posso afirmar que eu vejo um padrão de comportamento de que há relação sim entre a rotina agitada e o uso pra poder relaxar. Mas eu não sei se isso é uma exclusividade do jornalista. Eu acho que não.

Acho é da dinâmica da pessoa. Eu bebia muito, parei, mas teve uma época da minha vida que saía da redação, enchia a cara... Em fechamento eu levava cachaça muitas vezes, a gente comprava cerveja, dava 10 horas a gente começava tomar e ia sair na rua pra fumar maconha, mas não era afogar as mágoas. Era reduzir a pressão, sim, sem dúvida, e muito vinculado a ser uma boemia assim. A gente era uma turma do trabalho, saía já à noite, tipo, onde é que vamos beber. Mas não necessariamente por excesso de trabalho, era no fechamento muito, mas quando não fechava também, então era parte da vida. Hoje eu não uso quase nada por conta disso, eu não tenho tempo nem saúde pra beber.

Outras duas pessoas entrevistadas centraram suas respostas em não conhecem casos no trabalho. Um depoimento foi de que na redação em que trabalhava não percebia qualquer uso: "Eu nunca vi. Todo mundo muito quadradinho. Bem coxinha (risos). Não vi nada nesse sentido não." O outro de que o trabalho não intensifica e nunca percebeu uso na redação, afirmando: "Eu não acho que seja um meio que aconteça mais isso do que a sociedade em geral. Não acho que intensifica". 


\section{8 - O sentido do trabalho}

Suportar esses sofrimentos e ter prazer no trabalho, apesar deles, tem muito a ver com o sentido que o trabalho tem para os jornalistas e o grande espaço que ele ocupa em suas vidas. Acreditamos ser possível perceber uma identidade coletiva ${ }^{10}$. As condições de trabalho são criticadas, como foi demonstrado nos capítulos anteriores, mas a visão idealizada da profissão é mantida, o que tem relação direta ao sentido que os jornalistas dão ao trabalho e ao significado que permeia o jornalismo.

O trabalho pode ter diferentes conotações como mostra Coutinho (2009, p. 192), que utiliza a classificação de Blanch: "polo negativo, centro do contínuo e polo positivo". O primeiro vê o trabalho como "maldição, castigo, jugo, estigma, coerção, esforço, penalidade". O segundo o coloca como instrumento para sobrevivência, e a terceira visão é do trabalho como "missão, vocação, caminho, valor, fonte de satisfação e auto-realização". No jornalismo, prevalece essa terceira visão. Ribeiro (2001), Heloani (2003b) e Travancas (1993) apontam, a partir das entrevistas que realizaram, sentidos como missão, paixão e adesão.

Ribeiro (2001, p. 140) avalia que “o elevado teor místico do ambiente jornalístico, que se cristaliza em torno de temas como missão e sofrimento, é alimentado pelas empresas e assimilado pelos jornalistas", alertando que isso não corresponde mais à realidade de uma atividade que se industrializou. Para ele, "essa mística pode tanto ser fator de resistência profissional como, transformada em fantasmagoria, contribui para uma gloriosa extração da mais-valia". Nos depoimentos que colheu, salientou-se "uma tênue consciência de que o jornalismo tem uma missão superior a cumprir. Nas palavras de Raul Drewnick, 'é comum se dizer que o jornalismo é um sacerdócio. O jornalista se dedica tanto à profissão que ela acaba sendo uma religião".

Augusto Nunes também reconhece um forte elemento místico no jornalismo: "Nossa profissão tem elementos de seita; é uma certa

\footnotetext{
${ }^{10}$ Segundo Coutinho (2009, p.193), "as reflexões teóricas sobre os processos identitários frequentemente tomam como referência conceitos de identidades pessoais e coletivas. O primeiro corresponderia ao ... 'sentido de si mesmo que se constrói, reflexiva e narrativamente, e que orienta para as ações significativas de cada indivíduo...' (Stecher, Godói \& Díaz, 2005, p. 89). Já o segundo é compreendido de modo indissociável ao primeiro, pois '... as identidades pessoais supõem sempre as identidades coletivas, isto é, os indivíduos sempre definem o que são como decorrência do reconhecimento de seu pertencimento a certos coletivos ou categorias sociais com as quais se identifica...' (p.89, grifos no original, tradução da autora)."
} 
forma saudável de loucura. Você não ganha tanto para ser tão obstinado e tão apegado à integridade, como ocorre aqui”. Ao afirmar, no entanto, que a mística é mais forte que as condições de trabalho, ele toca a ideologia empresarial: "Os jornalistas desmentem a história de que falta de dinheiro corrompe pois, mesmo com salários muito baixos, eles resistem à atração do poder. Isso tem alguma coisa de missionário...".

A mística comporta uma forte dose de ascetismo e de valorização do sofrimento, que confere um glamour à exploração sofrida. $\mathrm{O}$ psicoterapeuta e jornalista Rui Fernando Barbosa afirma que "faz parte do meio profissional e é muito valorizada a situação de sofrimento; se o cara chega cedo, tem horários, ele já fica angustiado, porque o bonito na profissão é sofrer". A analista Regina Mascarenhas avalia que a mística do "sacerdócio da notícia" é uma forma sutil de violência: "Os jornalistas trabalham 24 horas por dia. Numa festa, no bar, no cinema; há sempre uma pauta que pode sair desse ou daquele contato. A profissão ocupa tanto tempo que a pessoa não pode exercer seus papéis de homem, mulher, pai, mãe, amigo". (RIBEIRO, 2001, p.142)

O autor (Ibid., p.130) mostra o uso do termo missão no Manual da Folha, na época do seu estudo, que foi realizado no início dos anos 1990: "Estando ou não em missão jornalística, os jornalistas são os ouvidos e os olhos do leitor”. Na fala de outros jornalistas, como Márcia Glogowski, que afirma: “...o jornalista tem uma ideia da sua missão, mas precisa amoldar-se à empresa” (Ibid., p.142).

O depoimento que Ribeiro (2001, p 141-142) colhe de Kotscho mostra que se alimenta uma paixão pela profissão. A paixão pela profissão também aparece nos resultados colhidos por Heloani (2003b, 2005). "O que se conclui pelos depoimentos é que a maioria desses sujeitos simplesmente ama seu trabalho, são apaixonados pelo que fazem, fetichizam sua profissão" (HELOANI, 2005, p.166). Isso é mostrado nas falas colhidas pelo pesquisador:

"Eu adoro. Eu adoro vir para o trabalho. Eu adoro e adoro mesmo. Então, eu acho que isso ameniza o meu sono." (Sujeito 15)

(...)

"Eu amo o que eu faço e nunca mais eu largo ela (profissão) (...) Eu não consigo ver a $S$. sem ser a $S$. jornalista e eu não consigo ver a jornalista sem ser a S. pessoa (...) Para ser jornalista tem que ter o dom, tem que gostar, gostar muito do que se está fazendo (...)” (Sujeito 1)

(...)

"Eu gosto de Redação, apesar de sofrer. Eu acho que é que nem cachaça. Você vicia (...) O nivel de adrenalina é muito forte, assim, e você vicia. Fica escravo dessa coisa." (Sujeito 6)

(HELOANI, 2003b, p.55-56)

As entrevistas com jornalistas realizadas por Travancas (1993, p. 83-85) também mostraram uma centralidade do trabalho na vida das pessoas. "Vários entrevistados 
salientam que apesar do desgaste e corre-corre do dia-a-dia a carreira é gratificante, não só pela sua responsabilidade social sempre enfatizada, como pelas relações que ela possibilita." Também falam de paixão, vício e adesão: "exige adesão de quem a escolhe. É como o vício, dá prazer a quem a ele se entrega". A comparação com o sacerdócio e a medicina (especialmente os mais velhos) aparece nas falas dos entrevistados. A autora também alimenta essa mistificação e o afastamento de uma visão que olhe para os jornalistas como trabalhadores:

Essas atitudes são plenamente justificadas se levarmos em conta que não se trata de um simples ofício ou trabalho assalariado, mas uma ocupação de 'outra esfera'. Por isso exige como 'pré-requisito' uma disponibilidade eterna e constante. Este ponto me remete a ideia de missão do jornalista, que estaria ligado a algo divino, a uma função concebida por algo exterior a ele, da ordem do sagrado. (TRAVANCAS, 1993, p. 86)

Para refletir sobre o sentido do trabalho para os jornalistas, perguntamos aos nossos entrevistados: “O que é ser jornalista para você?”. Nas falas, não aparece a palavra missão, mas dois entrevistados da faixa dos 60 anos usam a palavra paixão e uma entrevistada na faixa dos 20 anos usa a palavra amor à profissão.

De forma geral, percebe-se que o imaginário sobre a profissão continua idealizado. Os sentidos de missão, vocação, papel a cumprir à sociedade estão implícitos nos discursos e gestos dos entrevistados durante toda a entrevista. Continua havendo uma adesão à profissão, e o trabalho dá sentido à vida dos jornalistas.

Para os jornalistas de mais de 60 anos, ser jornalista é atuar para a melhoria da humanidade, é ser testemunha da história, de seu tempo e dos mais fracos, promover a mudança pela informação, perguntar, contar uma história, ser auditor do povo, olhos e representante da sociedade, denunciar, buscar a verdade pela inteligência e ser apaixonado pelo que faz.

Alberto Dines define ser jornalista como "estar empenhado em retransmitir aquilo que a vida te dá". Falar em vida, para ele, é falar da humanidade. "É uma das profissões mais humanistas que eu conheço, eu acho que não existe outra..., você está trabalhando para a melhoria da humanidade."

Para Audálio Dantas, "ser jornalista é ser testemunha, é ser testemunha do fato, é ser testemunha do seu tempo, e ser, principalmente, testemunha dos mais fracos". Ele afirma que o jornalista que toma partido do mais forte, "deixa de ser jornalista, passa a ser um traidor da profissão". 
A palavra repetida por Dantas também aparece na fala de Clóvis Rossi: "É ser testemunha ocular do meu tempo. Essa é a graça da profissão”. E de certa forma está presente no raciocínio de Aureliano Biancarelli, que coloca ser jornalista como "ter a chance de acompanhar os fatos, ter o privilégio de tentar estar mais próximo das coisas que estão acontecendo, e de poder relatar, não a sua maneira, mas de qualquer maneira, com as suas palavras." Ele também acha que o jornalista deve conservar o sonho de que é capaz de contribuir com alguma coisa, mudar algo.

Tem uma coisa que é muito clara pra mim que jornalismo é a profissão que eu queria de fato ter seguido... Estar em contato com temas diferentes, isso foi o principal, o que me cativou dentro do jornalismo é um sentimento que tem um fundo cristão, que é: dentro do jornalismo você teria como contribuir de alguma forma pro mundo em geral. Eu achava na minha juventude, que ser um comerciante, comprar uma coisa pra vender para o outro, não tinha sentido. $\mathrm{O}$ jornalismo tinha uma função na medida em que corria atrás de um fato, fazia uma denúncia, exibia uma situação que poderia ser modificada. Eu sempre acreditei nessa mudança pela informação Aureliano Biancarelli.

Lúcio Flávio Pinto considera que "o jornalista é o auditor do povo. Ele se confunde com o trabalho do policial, que é sempre investigação e se distingue por não precisar usar a violência. O jornalista tem que usar a inteligência”. Ele sente falta da preocupação ética da profissão e se vê como um servidor público. "O jornalista tem que ter paixão", e a experiência é fundamental para o exercício da atividade. "O jornalismo é a verdade baseada no exercício livre da inteligência", conclui.

A paixão também aparece na fala de Ricardo Kotscho. "Não só no meu caso, eu acho que no caso da minha geração, era um negócio de paixão mesmo, de compromisso, e o jornalismo aos poucos foi se transformando numa profissão como qualquer outra." Para ele, uma das definições é que o jornalista é aquele ser que pergunta. "Tem que perguntar sempre." Mas critica o jornalismo atual em que "o jornalista muitas vezes já tem a resposta quando vai fazer a matéria e nem presta atenção no que o cara responde".

Outra definição, dada por Kotscho, é ser os olhos da sociedade, o representante dela nos lugares para contar para as pessoas o que aconteceu. "Eu me coloco muito no lugar das pessoas. $\mathrm{O}$ que as pessoas gostariam de saber sobre aquilo? $\mathrm{O}$ que eu gostaria de saber?” E conclui: “O repórter pra mim é um contador de histórias. Histórias que você tem que descobrir, apurar e contar".

As definições que aparecem no grupo de 50 anos são parecidas com a do grupo anterior: contar histórias de dentro delas (ser testemunha), conhecer a alma humana, dar 
voz a quem não tem, fazer algo pelas pessoas e ser útil. Uma que se diferencia é ser intermediário entre o público e a fonte.

Paula Puliti considera o jornalista "um intermediário entre a fonte, que pode ser uma autoridade ou um especialista, e o público. Ele é uma ponte entre um e outro... Ele traduz um fato que pode ser de difícil entendimento". Uma definição bem próxima ao trabalho que realizava em jornalismo econômico.

A definição de Marilu Cabañas também se aproxima do tipo de cobertura que faz, voltada para temas sociais. Ser jornalista é: "Em primeiro lugar, ser útil. Tentar fazer alguma coisa pelas pessoas, dar voz a quem não tem voz. Isso pra mim é fundamental, dar visibilidade para os que sofrem". Ela se recorda de uma fala de dom Pedro Casaldáliga, bispo emérito de São Félix do Araguaia (MT), que lhe concedeu entrevista e disse: "Vocês jornalistas têm muita responsabilidade, porque os ricos têm advogados, os pobres têm jornalistas".

Bob Fernandes, assim como Kotscho, reforça o lado contador de história do jornalista. "Eu gosto é de contar como os humanos se movem, vivem, agem em relação ao futebol, à política, à economia, tudo. Acho que é você ter a extraordinária e prazerosa oportunidade para conhecer a fundo a alma humana nas mais diversas situações." Ser testemunha da história também aparece em sua fala: "Você tem a oportunidade como jornalista de ver aquilo dentro. Copa do mundo, eu era menino fanático por futebol, depois você está lá contando o que é uma copa do mundo".

Entre os jornalistas da faixa de 40 anos, repetem-se as definições de mediação, dar voz a quem não tem, transformação da realidade, denúncia. Novos conceitos aparecem, mas que vão ao encontro do que foi dito anteriormente, manutenção da democracia, aprendizado de responsabilidade, curiosidade pelo mundo e pelas pessoas, interferir nos poderes constituídos.

Antonio afirma que "o jornalista é o profissional que faz a mediação dos conteúdos especializados, mas isso não é permeado apenas por uma técnica", inclui uma conduta, uma ética. É papel do profissional se preocupar com as implicações desse material simbólico à sociedade, ao leitor, sendo "fundamental nas sociedades democráticas e não democráticas também, apesar de tudo". "Na minha opinião, o jornalismo é um elemento importante pra manutenção do princípio democrático num papel mais amplo. É o jornalista que dá voz a quem não tem voz, embora ele esteja também do lado do poder. É essa a dialética." A denúncia de privilégios é outra característica que ele aponta do jornalismo. 
Para Fernanda Cirenza, ser jornalista é aprender a ter muita responsabilidade. "Você tem que tomar muito cuidado com a informação, ela pode ser uma coisa explosiva. Eu acho que ser jornalista é um aprendizado de responsabilidade."

Já Ivan Marsiglia afirma que ser jornalista “é ter curiosidade pelo que acontece no mundo e pelo que sentem e pensam as pessoas" e ter "a possibilidade de interferir nos poderes constituídos, não estando neles". Ainda complementa que é "ser uma esfera de participação política e de transformação em algum nível da realidade". Por outro lado, ele critica o fato de o jornalismo estimular uma postura cínica diante da vida. "Esse é um lado que eu achei sempre ruim da profissão, como se você tivesse que se dessensibilizar sobre qualquer tragédia humana ou você não pudesse jamais se emocionar por alguma coisa."

O grupo de 30 e poucos anos também traz definições parecidas com as dadas anteriormente ou que complementam o que foi dito antes. Ser jornalista é ser cidadão que leva outros cidadãos a conhecerem seus direitos, expandir a consciência pública, não ter ideias pré-concebidas, saber ouvir, ajudar a sociedade a se entender, exercer um papel político e social, mediação e uma experiência com a vida.

Maria acredita que ser "jornalista é se entender primeiro como cidadão, não como um ser acima de ninguém". Depois "se entender como um cidadão que pode ajudar outros cidadãos a entender seus direitos, entender o seu contexto na sociedade e melhorar a sua vida pessoal e da sociedade".

Bruno Torturra diz que o jornalismo veio para ele como uma possibilidade de dar vazão à sua curiosidade e vontade de se expressar, mas com o tempo começou a entender a função social dele e um sentido coletivo, social e político. "É deliberadamente buscar a expansão da consciência pública. Fazer disso a sua profissão. Resumindo é isso jornalismo pra mim."

Pedro avalia que ser jornalista é "tirar qualquer tipo de preconceito da sua cabeça, de ideia formada, e se abrir pra ouvir uma pessoa e tentar passar isso da forma mais honesta possível para outra pessoa". Ele diz buscar mais ouvir do que comunicar e tentar não fazer um pré-julgamento.

Leonardo Sakamoto afirma que "ser jornalista é ajudar a sociedade a se entender". Para ele, o jornalista é um ator político, social e econômico acessório, que garante informação e análise para a sociedade entender o que está acontecendo a sua volta. 
Miguel também fala que o jornalista exerce um papel político e social, trazendo à tona temas para que a sociedade conheça, debata e trate. Ele retoma o conceito de mediação, que já havia aparecido nos grupos de 40 e 50 anos, acrescentado que é cada vez maior com a internet. Considera ainda que ser jornalista é uma experiência muito forte com a vida, por lidar com grande diversidade de assuntos, inclusive a morte e a tragédia. "Uma profissão, que apesar de todo desgaste, tem certo encanto por te dar a oportunidade de participar politicamente de discussões sobre certos temas e por te dar certa autonomia, que não é ideal ou total, mas é uma autonomia."

Os jornalistas da faixa dos 20 anos consideram o jornalista defensor da democracia, dos direitos, um dos promotores de transformações sociais, um ser curioso, questionador, aberto ao aprendizado, que ama a profissão, um idealista, que quer mudar o que é injusto e fazer algo para além de si mesmo.

Aline Scarso ressalta que o jornalista é a pessoa que vê algo e conta o que viu. "É um defensor da democracia”, que deve ser contra qualquer violação dos direitos. Já João aponta não ter a visão romântica de que o jornalista vai mudar a sociedade, mas sim é um dos agentes que pode ajudar a promover transformações sociais.

Para Priscilla Nery, ser jornalista é ser uma pessoa curiosa, questionadora (no sentido de buscar o conhecimento), aberta ao aprendizado. "Tem que ser uma pessoa analítica, que pare pra pensar, pra você levar uma informação de qualidade, de um lado que não foi explorado pro seu leitor.” Deve traduzir a informação e querer transformar o seu meio de atuação.

Se você não quiser transformar o seu meio de atuação, você perde a razão da profissão. Na verdade, essa utopia nossa, essa idealização contribui pra gente melhorar o nosso trabalho, levar informações de qualidade, que façam as pessoas pensarem. Ser jornalista é isso: ser questionador, ter esse amor pela profissão, esse idealismo e querer transformar o seu meio de atuação - Priscilla Nery.

A idealização do jornalista também aparece na fala de Vivian Fernandes. "Jornalista é meio quixotesco, tem aqueles sonhos impossíveis e fica lá tentando." Ela conta que desde a faculdade percebia que a maioria das pessoas pensava em mudar alguma coisa, fazer algo para além de si mesmo, mudar algo injusto.

Aí você vai vendo que não é possível ou pelo menos que é muito difícil ou que é muito lento esse processo. E mesmo assim você não desiste, você fica lá. Acho que o jornalista tem algo de diferencial das outras profissões, que é esse lado de querer mudar e dar a cara pra mudar... Acho quixotesco, mas é fundamental pra sociedade. Não teria como ter democracia na sociedade sem jornalismo e sem jornalistas Vivian Fernandes. 
Não se vê rupturas nos conceitos apresentados pelos jornalistas, em nenhum momento se contradizem, pelo contrário, complementam-se. Mesmo quando dizem não ter a visão romântica, reconhecem um papel de transformação. Os sentidos profissionais apresentados mostram a importância do jornalismo para relatar a história, desvelar o ser humano, informar a sociedade sobre direitos, questões sociais e políticas, dar voz a quem não tem e até ajudar a promover mudanças. $\mathrm{O}$ papel do jornalismo para democracia se repete em várias falas. Todos esses ideais dão sentido ao trabalho, mais do que isso, dão sentido à vida.

O sentido que o trabalho tem para a vida dos jornalistas também fica claro na pesquisa de Heloani (2003b, p.52) ao mostrar que "o 'mundo da vida', a esfera particular... se confunde com a própria atividade profissional". Ele apresenta vários relatos de jornalistas que caracterizam o sentido do trabalho jornalístico para essas pessoas: "Eu sou jornalista o tempo inteiro. Vida pessoal e vida do trabalho, elas se interpõem"; "Eu acho que a minha vida profissional e o meu trabalho não são coisas díspares (...) A minha motivação de viver ta relacionada ao orgulho que tenho do que faço" (Ibid., p.53).

Por outro lado, o trabalho do jornalista influencia outras esferas de sua vida. Heloani (2006, p.184) encontrou fracasso no quadrante afetivo do Inventário de Qualidade de Vida. "Dos 44 sujeitos pesquisados, 30 se sentem 'fracassados afetivamente'." Já no quadrante social, 30 dos 44 depoentes apresentaram sucesso (Ibid., p.185).

Também perguntamos aos nossos entrevistados "Você acha que o seu trabalho afeta a sua vida pessoal de alguma forma?" Quisemos com isso que os jornalistas refletissem sobre o espaço que o jornalismo ocupa em sua vida e se isso influenciava a esfera pessoal. Selecionamos ainda outras falas que mostram o envolvimento do jornalista com o trabalho, que emergiram em outras questões.

Se na discussão sobre sentido do trabalho a palavra paixão apareceu nas falas de Lúcio e Kotscho, e a palavra amor na de Priscilla Nery. Na discussão sobre trabalho, vida e envolvimento, encontramos o termo paixão para se referir ao trabalho na fala de mais jornalistas: Alberto Dines, Audálio Dantas, Ricardo Kotscho, Marilu Cabañas, Maria e João. Ivan Marsiglia, Paula Puliti, Vivian Fernandes e Pedro usam a palavra gostar. Maria e Leonardo Sakamoto recorrem ao verbo adorar. Aparecem ainda termos 
como viciante e fascínio. Todos os depoimentos mostram muito envolvimento com o trabalho de jornalista e ele ocupa uma grande esfera de suas vidas.

Alberto Dines afirma que foi se envolvendo com o jornalismo porque ele é apaixonante. Trata-se de "uma atividade de caráter existencial, porque você está acompanhando a vida, isso é de uma força extraordinária." Quando a pergunta é se o jornalismo afetou sua vida pessoal, ele afirma que não só a dele, mas a maioria dos jornalistas. "Porque não é só o trabalho, porque o trabalho se relaciona com a vida, então o movimento da vida afeta o trabalho, que afeta a sua pessoa", justifica. Para ele, mesmo aos 82 anos, o jornalismo até hoje é um fator de grande envolvimento: "Se você não se envolve, não mete a cabeça, se você não participa, eu acho que você está fazendo o trabalho pela metade." E continua:

Envolvimento esse que seja talvez meu atributo maior. Eu sempre me envolvi, eu acho que você não tem o direito passar raspando pela vida, você tem que entrar... O jornalismo sempre foi muito prazeroso pra mim, a ponto de se incorporar a minha própria fisiologia, minhas próprias rotinas, hábitos, negócios de prazos, que tem hora de fechar o jornal, tem hora de sair, tudo isso, isso criou em mim coisas que eu nunca vou perder até hoje. Mesmo porque até hoje eu tenho prazos, tenho compromissos que não podem atrasar... - Alberto Dines.

Para Audálio Dantas, o trabalho afetou bastante a sua vida pessoal. "Alguns definem como sacerdócio, eu não concordo, é uma profissão como outra qualquer que exige principalmente ética. Agora o jornalismo é paixão para a maioria das pessoas que se volta para a profissão.” Essa paixão o levou a recusar um cargo de direção da Abril na região Norte e Nordeste. Ele preferiu continuar sendo repórter, e essa atuação com dedicação fez com que tivesse "prejuízos muito graves em relação à família". "Por exemplo, aquela viagem para o México para fazer o roteiro, me levou três meses fora de casa. O meu primeiro filho cresceu praticamente sem a minha presença.”

Clóvis Rossi também avalia que sua vida pessoal foi afetada profundamente. "Sacrifiquei mulher, filhos, sem dúvida nenhuma." Para ele, as novas gerações parecem ter uma noção mais realista de como trabalhar e conseguem dividir o seu tempo de forma a atender tanto a família e a vida pessoal quanto à vida profissional. "Mas a minha geração, inclusive, porque os meios mecânicos à disposição eram mais complicados, tudo era mais demorado para fazer, realmente, sacrificou muito a vida pessoal.” Ele avalia que eles vestiam a camisa e se matavam de trabalhar.

Aureliano também vê esse reflexo do trabalho em sua vida pessoal. "Eu acho que sim. Eu não percebia tanto, mas até hoje minha mulher e meus filhos dizem que eu 
só vivia pro jornal. [Silêncio] Deve ter algum fundamento. [Silêncio] E falam que eu também só falava no jornal, que o jornal que tinha importância pra mim.”

O impacto do trabalho também marcou a vida pessoal de Lúcio Flávio Pinto, que investiu tudo que tinha no Jornal Pessoal, inclusive o seu carro e o Fundo de Garantia que recebeu do Estadão, mesmo tendo sido dele a iniciativa de deixar a publicação.

Afetou minha família, eu perdi meu casamento, porque foi um período muito ruim. Meus filhos, nenhum é jornalista. De sete irmãos, seis homens, 4 foram jornalistas. $\mathrm{E}$ isso não passou pra ninguém porque desde cedo eles aprenderam que essa profissão é muito ruim. Eles sofreram com isso, então, foi realmente um dano considerável. Mas eu acho que valeu a pena - Lúcio Flávio Pinto.

Ricardo Kotscho conta que sua esposa sempre diz que ele se casou com a profissão, não com ela. "A maior concorrente dela é a profissão. Eu sou um cara apaixonado pelo jornalismo." Ele avalia que o trabalho afetou sua vida pessoal mais quando era jovem do que hoje, pois atualmente ele trabalha mais em casa e tem a vida mais organizada.

Mas nos meus 30 anos de profissão, a grande prioridade da minha vida era o trabalho. Saía pra trabalhar, voltava tarde da noite, tinha pouco contato, pouco convívio com as filhas e com a mulher, mais no fim de semana, que é uma coisa que eu batalhei muito pra não trabalhar fim de semana. E hoje eu tenho uma convivência maior com os netos, que são cinco, do que eu tive com as minhas filhas que são duas. Outro momento da vida. E vou dizer uma coisa, eu acho que o pessoal que entrou depois de mim, mais novo, está certo de cuidar mais de sua vida pessoal, cuidar mais da vida familiar, acho que está certo. Eu acho que tem que ter um equilíbrio, nem como era no meu tempo, não era só eu, a maioria era assim, priorizar muito a profissão, o trabalho. Também não é tocar o jornalismo como se fosse uma profissão qualquer, cumprir horário, cumprir tabela, cumprir a pauta. Eu acho que tem que encontrar uma solução intermediária, tanto pra preservar o jornalista quanto pra preservar o jornalismo - Ricardo Kotscho.

Paula Puliti também mostra envolvimento com a profissão e afirma sempre ter gostado do seu trabalho e ter feito a escolha certa. Em relação à vida pessoal afirma que afetou e vai além: "Meu trabalho é também a minha vida pessoal. Eu sou o que o meu trabalho quer. Minha casa é tudo fruto de uma coisa só." Além disso, a pessoa leva a tensão do trabalho para casa. Ela avalia ainda que houve época em que o trabalho afetava muito, pois ela queria ficar mais em casa, mas tinha que viajar bastante, o que deixou de fazer quando seu filho nasceu.

Já Marilu Cabañas, ainda que não falasse nenhuma palavra, deixaria claro o seu envolvimento com o jornalismo e com a reportagem: “Ah, que delícia! [suspiro e risos] 
Eu adoro! [mais risos] Eu gosto muito de ser repórter." O brilho em seus olhos e a animação com que fala sobre a carreira são contagiantes. Ela dá vários exemplos de como as matérias que fez deram guinadas em sua vida, como a cobertura de um congresso de saúde pública em Águas de Lindóia:

Eu falei com o Paulo Elias, da Faculdade de Medicina da USP, aqui do HC. Eu correndo, esbaforida, para entrar ao vivo e ele perguntou:Você já tomou seu café da manhã? E eu falei: - Não. Ele falou: Olha, vou fazer o seguinte, eu já fiz minha caminhada, vou tomar meu café da manhã, um suco de laranja, comer alguma coisa, depois eu te dou a entrevista. E eu lá, pateta esperando, ao invés de tomar o café também. Mas a minha tensão era tão grande, a minha adrenalina é tão grande para fazer o que eu gosto, que pouco importava café da manhã. $\mathrm{Eu}$ já fiquei 24 horas sem tomar água, sem comer e sem ir ao banheiro, de tanto prazer que eu sentia nesse começo de carreira na Bandeirantes, quando eu cobria eleições. Eu falo isso, e as pessoas não acreditam, e é verdade. Não tinha essa coisa de computador, era tudo ali, eleição no papelzinho, na contagem. Eu lembro disso, no ar, direto. Direto no ar e sem nada. Depois, eu pensei acho que vou comer alguma coisa. Mas não tinha nem fome. Era uma loucura isso. Eu lembro desse comprometimento, desse envolvimento. Tem que ter paixão. Quando beira a loucura, é paixão mesmo. E eu lembro que nessa cobertura de Águas de Lindóia, eu mudei. Comecei a fazer caminhada, meu ex-marido também fazia caminhada. Eu comecei a tomar café da manhã. Ele explicou a importância disso, tudo isso no ar, e pá, foi para mim. Imagino que se foi para mim, deve ter sido bom para os ouvintes - Marilu Cabañas.

Marilu conta que a Bandeirantes era como uma família. Lá ela conheceu o exmarido e se casou. "Eles fizeram uma festa surpresa num salão de prédio. A gente não tinha dinheiro para fazer festa. Foi muito engraçado. O marido de uma amiga nossa levou a gente para o local, e a gente não sabia o que era. E era a festa surpresa. Era muito prazer."

Pode todo mundo falar, nossa jornalismo, não dá dinheiro, tem muita manipulação, não adianta. Quando você gosta e eu tenho uma boa estrada e nunca me arrependi, por mais problemas que tivessem, mas não desisti, porque é minha vida praticamente, eu queria muito dar esse orgulho para minha mãe - Marilu Cabañas.

Por outro lado, ela tentou sempre estar ao lado de sua mãe. "Eu sei o quanto é importante o meu trabalho, mas eu sei o quanto é importante também minhas relações humanas, com a minha família. Nunca deixei minha mãe.” Ela costumava ir todos os finais ao Guarujá ficar com sua mãe.

Bob Fernandes também procurou preservar a sua vida familiar. "Eu nunca deixei de estar com as minhas filhas nos almoços e jantares. Reconheço que pode afetar a vida de muita gente. Mas eu tenho a vida e a família de uma forma que compatibiliza." No 
entanto, eventualmente, alguma coisa do seu trabalho pode interferir na sua vida pessoal: "Eu fico 40 dias fazendo copa do mundo e olimpíadas, todo mundo tem saudade e tal, mas eu não acho que isso seja afetar a vida, acho que isso é parte da vida. Você pode resolver sofrer ou encarar isso como prazer".

Fernanda Cirenza diz conseguir manter uma rotina fora da redação. "Eu tenho dois filhos, marido, mãe, cachorro, tenho uma vida fora da redação, também há muito tempo, não é uma vida nova e eu cuido bastante dessa minha vida fora da redação." Nos fechamentos, ela sai da rotina, chega mais tarde e apela para a pizza no jantar.

Ela teve seus dois filhos enquanto trabalhava na Folha: "Voltar a trabalhar com meu primeiro filho foi difícil? Foi. Deixar na mão de um funcionário foi super difícil, mas eu adorei por outro lado voltar pro jornal". E eles se acostumaram em ver a mãe chegar tarde.

O lado positivo é que como jornalista ela leva as notícias para dentro de casa e toda a empolgação que elas trazem, como quando foi entrevistar o Chico Buarque de Holanda para a Folha. O filho e a filha também cresceram com muito contato com os jornais e revistas que ela sempre recebeu em casa. No mais, costuma dividir com a família quando tem algum problema de relacionamento no trabalho. "A gente aprendeu a lidar com isso, vai tudo meio no rolo, eles participam bastante, tanto meu marido quanto meus filhos, muito da minha vida profissional há anos. E eu participo da vida deles. Se eu não jantei com eles ontem, hoje eu estou almoçando..."

Antonio, por sua vez, avalia que o trabalho de jornalista tem um impacto negativo na vida familiar. "A maioria dos jornalistas ... tem um péssimo relacionamento familiar, porque dá pouca atenção aos filhos, dá pouca atenção às mulheres. Eu conheço várias pessoas que já estão no segundo, terceiro casamento, porque dormiam na redação praticamente."

Para Ivan Marsiglia, o trabalho afeta a vida pessoal porque não permite "planejamento de horários, da hora que você pode estar livre, do que você pode fazer". Outro ponto que ele sente que afeta é o excesso de informação. "Essa doença moderna de você ter que saber de tudo, ler tudo, muito jornalista fala isso... Você tem que ler o que é bom, o que interessa, no tempo que você tenha pra assimilar."

Ivan também demonstra o envolvimento com a profissão na entrevista. "O que eu gosto no jornalismo é essa possibilidade de você ter uma atividade que tanto é de reflexão, tem um conteúdo intelectual, exige um pensamento, mas também tem ação, te 
põe no centro do debate público, te faz conviver com pessoas." Também sempre o fascinou a possibilidade de escrever.

Se Ivan usou o verbo fascinar, Maria usa o adorar e o substantivo paixão. "Meu trabalho é um trabalho que eu adoro fazer, que é trabalhar com rádio, que é uma paixão da minha de vida, então, fico muito feliz hoje de poder aliar um trabalho público, de fazer algo para a sociedade". Ela diz fazer o que gosta e lhe dá prazer.

Em relação à vida pessoal, ela acha que o trabalho influencia $100 \%$ sua vida pessoal. "Essa história de dividir trabalho, trabalho não pode afetar a vida é uma balela, acho até bonito falar isso, mas quando meu trabalho não está bom, minha vida pessoal fica ruim, e quando a minha vida pessoal fica boa, também meu trabalho tende a ser melhor. Não dá pra separar." Ela diz perceber que está exagerando na dose quando fica monotemática e só fala do trabalho. "Quando começo a só falar do trabalho tem alguma coisa errada, que é isso, se está afetando demais minha vida pessoal, meu namorado não quer mais me ouvir, fica quase uma obsessão."

Bruno Torturra vai além e afirma: "Meu trabalho é minha vida pessoal... Eu não quero ter vida e trabalho. Eu quero ter uma vida onde o trabalho é parte integral dela." Da época da Trip, recorda que eram uma turma de amigos. "Lá misturava muito a minha vida pessoal com o trabalho, se tornava minha turma, minhas namoradas, minhas festas." Da atualidade, ele avalia que falta tempo para cuidar de sua avó como gostaria, para família, para leitura e para lazer. "Mas eu não considero lazer mais vida pessoal do que trabalho." O trabalho costuma tomar grande parte do seu dia. Ele sempre tem texto atrasado e costuma receber mais de 1000 e-mails por dia. "Eu estou o dia inteiro em função disso, raríssimos os momentos que eu paro pra ver um filme, ir ao cinema... É muito cansativo."

Pedro também viveu momentos cansativos na Folha e de muito envolvimento, que trouxe reflexos para a vida pessoal. "É um trabalho muito desafiador que me estimulou a ser jornalista. Eu sempre gostei muito de escrever, então pra mim foi o caminho, por isso que me formei nisso." No entanto, o ritmo intenso do trabalho prejudicou o relacionamento com a sua esposa.

Eu trazia muito problema do trabalho pra casa, chegava de mau humor e às vezes descontava na minha esposa, ficava bravo sem necessidade. Em termos de horários, nos períodos mais críticos, que acumulava o fechamento, por exemplo, de cadernos especiais, eu não tinha vida social, eu não saia pra fazer outras coisas. Uma coisa que eu tentei fazer foi conciliar nesse período uma academia com o trabalho e eu 
nunca consegui fazer. Eu pagava a academia e não conseguia ir, porque não tinha tempo - Pedro.

Envolvimento e excesso de trabalho também fazem parte da vida de Leonardo Sakamoto. "Eu adoro meu trabalho, ainda mais que eu dirijo uma ONG jornalística. Eu adoro a ideia de ser professor de jornalismo também, de estar trabalhando com essa molecada, de estar discutindo a profissão." As atividades lhe dão prazer:

Não é você trabalhar para sobreviver... Isso é uma coisa muito viciante, na verdade, a gente vê que gera transformação social, que o seu trabalho gera impacto, gera consequências fortes, então, às vezes, a gente pergunta pra que parar? Então, eu não paro, por exemplo, eu tento escrever post todos os dias. Tem coisas que na Repórter Brasil, mesmo final de semana, estou fazendo, mesmo no final do ano, recesso todo mundo para, o Repórter não para... Eu sei que isso, na verdade, causa impacto pra nossa estrutura física... Só que eu me divirto, eu não reclamo, "ahhh, estou cansado, não aguento", não, aqui eu gosto desse ritmo, dessa sobreposição maluca de coisas, fazendo tudo ao mesmo tempo - Leonardo Sakamoto.

Miguel avalia que o trabalho de jornalista afeta sua vida pessoal. "A relação com as pessoas é muito desgastante, porque ter um relacionamento ou uma família e você fazer plantão. Isso é muito decepcionante." Para ele, a vida pessoal do jornalista também é prejudicada pelas longas jornadas. "Você não tem mais hora pra sair, e a consequência é o desgaste físico. Quando você consegue descansar, você não consegue fazer nada a não ser descansar, dormir, se alimentar e conseguir um pouco de energia para continuar trabalhando depois."

Aline Scarso acredita que o trabalho afeta totalmente a vida pessoal, a ponto de determinar a rotina de sua vida. Além disso, há o fato de ser jornalista 24 horas. Ela afirma não se desligar do trabalho nem nas horas livres. "Eu me sinto muito jornalista, sempre estou de olho nas coisas, mesmo fora do trabalho, tenho essa preocupação de estar olhando, de ver o que pode ser notícia. Às vezes você está numa conversa, alguém fala alguma coisa legal, você vai lá e anota, ou pega a fonte." Ela se define como "uma pessoa bem movida a trabalho" e que está tentando resignificar o trabalho em sua vida para ter saúde e poder gastar sua energia com outras coisas fora do trabalho.

O envolvimento também está presente na fala de João, que tem uma grande paixão pelo jornalismo. Em relação à vida pessoal, avalia que sempre "leva alguma coisa que aconteceu durante o dia pra casa, não só para fazer, mas alguma coisa que ficou na sua cabeça mal resolvida ou que você vai ter que resolver no dia seguinte”. O 
smartphone faz com que sempre olhe o e-mail da empresa, e a longa jornada pode fazer com que deixe de sair com os amigos.

Priscilla Nery avalia que o trabalho de jornalista afeta a sua vida pessoal. No final de ano, por exemplo, em que houve um aumento do ritmo do trabalho para que todos pudessem sair de recesso, ela teve que desmarcar compromissos. "É a época que todo mundo quer se encontrar, e eu estou no trabalho. Eu não consigo ir. Não consigo comparecer em algumas coisas que são importantes pra mim.” Em muitos finais de semana, o cansaço fez com que ela não quisesse fazer nada. "Queria ficar na minha casa dormindo, porque eu estava cansada, esgotada." Mas ela acha também que afeta positivamente. "Você acaba sendo uma pessoa mais bem informada. Eu acredito que eu sou uma pessoa mais maleável pelo fato de ter que lidar com as fontes, a dificuldade de cada um, com prazos, com pessoas. A profissão ajuda bastante nisso.”

Vivian Fernandes também vê o trabalho afetar a sua vida pessoal. "Antes eu não via problema nisso, em trabalhar muito ou não ter tempo para fazer outras coisas... Primeiro emprego é assim mesmo até eu me acostumar." Depois ela percebeu que não era questão de se acostumar.

Eu não estava lidando bem com isso e quando eu não lido bem, as outras pessoas meio que respondem na mesma moeda. Eu até comecei a fazer análise de uns tempos pra cá porque eu sentia essa necessidade de entender melhor esses processos, que alguns são pessoais, mas outros estão muito relacionados ao trabalho. Tanto que boa parte das minhas sessões de análise foi pra discutir questões de trabalho. Vira e mexe eu não consigo falar da minha vida pessoal. Eu não consigo nem chegar à minha vida pessoal. $\mathrm{O}$ trabalho toma conta de tudo assim. Meio que minha função no mundo é ser jornalista às vezes, sabe. Eu comecei a ver de uma forma muito ruim. Acho que eu tenho que separar as esferas da minha vida e não deixar que uma interfira tanto na outra. Se não eu não consigo nem ir ao cinema, porque eu tenho que trabalhar. Ou se eu vou ao cinema e já estou pensando em escrever uma matéria sobre aquele filme. Isso é meio neurótico. Eu acho que eu estou tentando controlar isso agora Vivian Fernandes.

Para Vivian, essa quase obsessão que o jornalista tem pelo trabalho ocorre porque ele gosta muito de ser jornalista. "Por gostar demais da profissão, acreditar demais nela ou acreditar muito nos veículos que eu construo, eu me empolgo e não vejo os riscos que isso me traz, deixar de fazer muita coisa da minha vida pessoal por questão de trabalho." São as "alegrias e tristezas da profissão" nas quais ela se "afunda".

Os depoimentos mostraram que os jornalistas com mais de 60 anos avaliam que o trabalho afetou muito a vida pessoal, em alguns casos, com prejuízos à família, que 
sofreu com ausência deles. Os entrevistados de 50 anos relatam a busca de um equilíbrio entre vida familiar e trabalho, discurso que inclui a entrevistada de 49 anos, mas mesmo para eles o trabalho é visto como parte da vida e a influencia.

Diferentemente do que pensam alguns jornalistas mais velhos, de que os mais jovens conseguem cuidar mais da vida pessoal, os jornalistas com menos de 45 anos desta pesquisa enfatizam que o trabalho afeta bastante a vida pessoal, que trabalham muito e que falta tempo para o lazer e para a vida familiar.

Não se pode deixar de destacar que alguns entrevistados levantaram que o trabalho também afeta positivamente as suas vidas, seja mudando seus hábitos por causa de matérias, seja fazendo do jornalista uma pessoa informada. Outra questão que apareceu foi a de que o trabalho tem relação direta com a vida pessoal ou que o trabalho é a própria vida.

Todos os entrevistados demonstram grande envolvimento com o jornalismo. Essa adesão à profissão aliada ao sentido que o trabalho tem, com todos os ideais da profissão, ainda que nem sempre se consiga cumpri-los, ajudam a transformar $\mathrm{o}$ sofrimento no trabalho em prazer.

\section{9 - O trabalho como fonte de prazer}

Como vimos no tópico anterior, o prazer está ligado ao envolvimento que o trabalhador jornalista tem com a profissão e ao sentido que atribui ao jornalismo. $\mathrm{O}$ reconhecimento de seu trabalho, tanto pelo outro como por si próprio, quando aferi um sentido positivo ao trabalho realizado, faz com que o sofrimento possa ser transformado em prazer.

Segundo Dejours (2012b, p.105-106), a retribuição esperada pelo sujeito no trabalho é de natureza simbólica: o reconhecimento, tanto no sentido de constatação "reconhecimento da realidade que constitui a contribuição do sujeito à organização do trabalho", quanto no de gratidão pela contribuição dada.

O reconhecimento passa pela construção rigorosa de julgamentos. Esses julgamentos ocorrem a partir do trabalho realizado. São proferidos por atores específicos, engajados diretamente na gestão coletiva da organização do trabalho. É possível fazer a distinção entre os diferentes tipos de julgamento que compõem o reconhecimento: o julgamento de utilidade, produzido essencialmente pelo outro sobre a 
linha vertical, ou seja, os superiores hierárquicos e subordinados, às vezes por clientes; e o julgamento de beleza, proferido essencialmente na linha horizontal pelos pares, os colegas, os membros da equipe ou os membros da comunidade profissional.

Esses julgamentos têm em comum uma peculiaridade: estão focados no trabalho realizado, ou seja, sobre o fazer e não sobre a pessoa que faz. Mas, em contrapartida, o reconhecimento da qualidade do trabalho realizado pode inscrever-se em relação à personalidade em termos de ganho no registro da identidade. Para dizê-lo de outra forma: a retribuição simbólica conferida pelo reconhecimento pode fazer sentido em relação às expectativas subjetivas quanto à realização de si mesmo. (DEJOURS, 2012b, p.106-107)

Tanto o julgamento de utilidade, no qual o cliente é o próprio leitor/ouvinte/internauta/telespectador, quanto o de beleza faz parte do reconhecimento do trabalho do jornalista. As falas encontradas mostrarão isso quando entrevistados citam o reconhecimento de seu público como fonte de prazer ou em momentos já citados na tese em que falaram do reconhecimento dos colegas de trabalho. Além disso, há o prazer proveniente do próprio conteúdo do trabalho, que discutimos no início do capítulo, e o que vem do sentido do trabalho jornalístico, falado anteriormente.

Grisci e Rodrigues (2007, p.55) retomam Dejours para dizer que "o sofrimento não exclui o prazer”. Eles avaliam que os jornalistas gostam do que fazem, apesar de serem "submetidos a ritmos incessantes dentro da redação". A adrenalina do fechamento "foi indicada por alguns como prazerosa e intrínseca à profissão, o que parece revelar um fator de construção de identidade ligado ao tempo". Nas entrevistas, constataram um "exagero na hora de falar da paixão pelo jornalismo - expressão usada pelos seis entrevistados - como justificativa para suportar o ritmo frenético, a jornada comprida e o salário minguado", o que para os autores pode ser uma estratégia coletiva de defesa.

Nas entrevistas para esta tese, perguntamos - "O que é prazer para você no trabalho de jornalista?". Nas respostas mais uma vez aparecem palavras que reforçam o grande envolvimento com o trabalho, como adorar (Clóvis Rossi), felicidade (Bruno e Pedro), delícia (Marilu e Fernanda), apaixonante e viciante (Antonio).

O trabalho é apontado como fonte de prazer quando se consegue realizar um trabalho bem apurado e bem feito; trata-se de temas com os quais se tem afinidade; há autonomia. Características apontadas quando falam sobre o que é ser jornalista também são colocadas como fonte de prazer.

Os entrevistados consideraram prazer: o próprio resultado do trabalho; a matéria que dá certo; ter o nome no jornal; ver a matéria publicada com o seu nome ainda que o 
leitor nem repare nisso; ter o reconhecimento dos leitores (casos em que escrevem para a redação agradecendo pela utilidade da matéria); trabalhar no local em que você gostaria de trabalhar (por exemplo, jornalista que cita a vaidade de trabalhar na Folha); ver o texto terminado e achar que ficou bom; o alívio de entregar uma matéria e ter ficado legal; sentir-se participando do mundo; ter contato com as pessoas e aprender com elas; ajudar a transformar uma situação; a possibilidade de influenciar a sociedade e ter impacto na vida das pessoas; acesso ao conhecimento; conhecer diferentes realidades; mostrar o que existe; fazer a pauta e ter reconhecimento; ver que o trabalho tem resultado; a intensidade do trabalho e das entrevistas; o prazer de conseguir a informação; a apuração rigorosa; o prazer de contar histórias e de ser lido.

Alberto Dines, ao longo da entrevista, ressalta que o trabalho coletivo do jornalismo é extraordinário e altamente gratificante. Ele também cita ser um grande prazer colaborar com o El País, por ser um jornal que sempre acompanhou. Já quando a questão é "O que é prazer para você no trabalho de jornalista?", responde: "Fazer o que eu estou fazendo, é escrever, olhar, observar, acompanhar, participar”.

O prazer também apareceu diversas vezes na fala de Audálio Dantas. Ele citou o prazer que o jornalista tem em conseguir a informação, o prazer do repórter ao buscar o tema, apurar rigorosamente as pautas e "depois evidentemente o prazer de contar a história”. Assim conclui: "O repórter é um contador de histórias e ao contar história ele se realiza".

Quando responde à questão da pesquisa, afirma que o prazer maior da profissão é a oportunidade que ela dá de acesso ao conhecimento. "Mesmo que você não queira, você está aprendendo no dia a dia com a profissão ao entrevistar, ao tomar conhecimento dos fatos." O jornalista também aprende ao ser obrigado a estudar para ser um bom jornalista, lendo jornais, revistas e livros. "Você termina tendo uma bagagem considerável."

Clóvis Rossi responde que adora o que faz, então, o trabalho em si é uma fonte de prazer. "Se não, eu não teria sobrevivido 51 anos na profissão. Eu gosto do que eu faço, portanto, faço com prazer. Me divirto fazendo o que eu faço. É o trabalho do jornalista, o prazer do trabalho."

O próprio conteúdo do trabalho e o reconhecimento pelo trabalho feito são fontes de prazer para Aureliano Biancarelli. "Prazer maior era ver a matéria no dia seguinte, escrita sem alterações, nos espaço que você tinha imaginado, e melhor ainda, se tiver alguma manifestação das pessoas envolvidas." Saber que a matéria possibilitou 
uma mudança também satisfaz o jornalista: "Você perceber que teve algum efeito, uma denúncia, que o governo se prontificou a tomar alguma atitude, enfim, você percebe que a notícia teve alguma repercussão".

Para Lúcio, o reconhecimento do público proporciona prazer no trabalho. "Um dos maiores prazer, por exemplo, que eu tive foi uma vez eu fui ao ônibus, e o cobrador estava lendo o Jornal Pessoal, olha eu quase choro, quase dou um beijo no cobrador." O jornalista ficou perto do cobrador observando e quando foi passar na catraca, o homem levantou os olhos e falou: "Você é o Lúcio Flávio, do Jornal Pessoal! Que prazer!". Em outra ocasião, o porteiro de um prédio ligou para o jornalista, queria contar que estava fazendo um jornal para o condomínio baseado no Jornal Pessoal. "Isso me dá uma alegria enorme porque eu estou atingindo um público que eu nem devia atingir [a voz embarga, quase chora], porque o jornal é caro, cinco reais. Por que ele é caro? Porque não tem publicidade."

Ricardo Kotscho falou do prazer ao longo da entrevista. "Não é só você sentir o prazer de contar uma história, mas sentir o prazer de que essa história seja lida e que possa influir de alguma maneira pra consertar alguma coisa, pra incentivar as pessoas." Uma matéria que possibilitou isso foi a que fez sobre o desemprego na década de 1980. O desemprego na cidade de São Paulo alcançava alto índice, e a pauta era mostrar como vivia uma família de desempregados.

"Como eu tinha muitos contatos na igreja, então, não foi difícil encontrar um bairro onde tinham muitos desempregados e me indicaram uma família." O trabalho foi feito em dupla com o repórter fotográfico Jorge Araújo. "Havia duplas de repórteres e fotógrafos, geralmente trabalhavam juntos e muitas vezes também com o mesmo motorista. O motorista também tinha função jornalística, porque dependia dele chegar a tempo nos lugares e voltar a tempo.” A foto mostrava a família envolta da mesa, sem nada em cima, um olhando para o outro.

Essa matéria provocou uma grande repercussão de pessoas querendo ajudar essa família, mas foi tamanha a ajuda, oferecer emprego, comida, roupa, que um bairro inteiro acabou sendo beneficiado. Mandaram essas coisas pra igreja que distribuiu. E esse casal pôde escolher onde queria trabalhar. Não que essa seja a função do jornalismo ou do jornalista. Jornalista não é assistente social, mas quando pelo seu trabalho, você consegue sensibilizar pessoas a ajudar outras pessoas e resolver problemas de algumas famílias, é muito gratificante - Ricardo Kotscho. 
Quando a pergunta é específica sobre o que é prazer no seu trabalho de jornalista, Kotscho fala que prazer é ver a matéria publicada no jornal. "A gente ficava até tarde na oficina, esperando o jornal rodar pra ver a matéria publicada, o seu nome. A gente adorava assinar matéria. O leitor nem liga pra isso. Acho que o leitor nem lê quem escreveu aquilo, mas a gente ligava.” Ele chama esse desejo de vaidade saudável. "Claro, você quer ser lido, quer ser reconhecido, e quando você consegue, por exemplo, a manchete do jornal é a grande alegria. Eu acho que todo jornalista tem que batalhar diariamente para conseguir a manchete do jornal." O prazer para ele vem de ser bem sucedido na maioria das vezes.

Para Paula Puliti, prazer é entregar uma matéria que você gostou de fazer. Já Marilu Cabañas vê como prazer o contato com as pessoas - "é uma delícia" - e aprender com elas. "Eu acho que essa experiência, essa troca. Nem sei se é troca, mais eu que recebo mesmo. E às vezes poder também ter um final bom para as pessoas." Dá como exemplo uma matéria sobre crianças que trabalhavam em um lixão no Vale do Paraíba na época em que trabalhava na rádio Cultura. A população foi retirada de lá, e as crianças passaram a estudar. "Isso é bastante prazeroso. Muito feliz quando a gente vê que teve um resultado assim positivo, concreto..."

Outra fonte de prazer, segundo Marilu, é quando as pessoas entram em contato com ela agradecendo pela matéria e dizendo que foi importante. "Eu faço pra isso, para modificar alguma realidade, tentar ser útil, e tentar modificar. Nem sempre a gente consegue, na maioria das vezes não, mas a gente tenta."

Bob Fernandes também suspira ao responder a questão: "Ah, tudo isso que eu te falei, que eu contei, tudo isso é prazer." Mais uma vez o próprio conteúdo do trabalho aparece como fonte de satisfação. "Prazer é você contar uma história que ninguém vê. Você vai lá, descobre e conta. Prazer é você cobrir olimpíada, cinco copas do mundo, você estar dentro do Palácio no contragolpe da Venezuela, você assistir à eleição dentro da sala do cara." Para ele, como jornalista, você tem a oportunidade de fazer coisas que poucas pessoas vão ter oportunidade de fazer e de viver. "Você está vivendo a história, você não é parte da história, mas você vai contar a história a sua maneira."

Fernanda Cirenza avalia que "prazer é vivenciar uma redação", onde você encontra vários tipos de pessoas, de diferentes gerações, e estabelecer trocas de informação, de ideias, de comportamento. "É essa coisa da redação, do jovenzinho na internet achando que ele também vai revolucionar o planeta. O cara que é meu 
contemporâneo brigando comigo porque eu mudei o texto. Ou eu pedindo ajuda... Isso é uma delícia." Também é prazeroso ir para a rua entrevistar as pessoas.

Conhecer diferentes pessoas, em diferentes lugares, é fonte de prazer para Antonio. Olhar as matérias, que produziu, depois de um tempo, e pensar: "olha cara, que legal, eu fiz isso". "E ao mesmo tempo é uma profissão apaixonante. É uma profissão que possibilita você conhecer o mundo, conhecer o outro, se explicar no outro, saber o que existe." Destaca ainda a possibilidade de conhecimento que o jornalismo traz ao profissional. "Você consegue entender um pouco mais o que é cada coisa. E a comunicação, o jornalismo está dentro da comunicação, é o motor que une os povos. Nesse sentido é uma profissão bonita, mas acho que se ganha pouco em qualquer lugar do mundo" (risos).

A conclusão de um trabalho é prazer para Ivan Marsiglia. "É terminar um texto que eu tenha orgulho de ter escrito, que eu goste de ter feito." Ele avalia que o processo todo do jornalismo é muito desgastante e cansativo. "Eu não diria que eu sinto muito prazer nem indo fazer as matérias nem mesmo no momento de escrever". Na verdade, considera "mais sofrido do que prazeroso". "Mas quando eu termino e acho que aquilo ficou bom, eu sinto uma grande satisfação que me empurra a procurar o trabalho de novo".

Maria considera que prazer no trabalho do jornalista é sugerir uma pauta e executá-la, com apoio e infraestrutura necessários e depois ter o reconhecimento desse trabalho. "Não é sempre que a gente consegue, mas há espaços a serem cavados. Fico muito satisfeita quando eu consigo pensar fora do quadrado e quando vejo que meu trabalho tem resultado." O efeito positivo da matéria, por exemplo, é ajudar uma rádio comunitária a ter uma programação jornalística. "Isso é uma coisa que me dá prazer e satisfação. Eu sei que tem impacto direto em vida de pessoas."

Para Bruno Torturra, o prazer vem de "participar do mundo": "É me tornar um elo conector entre a realidade e as pessoas que não têm acesso direto a ela. Ser um olho público. Eu gosto muito desse papel. Eu me sinto parte do corpo coletivo. Isso me dá felicidade."

Já Pedro fala da satisfação que o trabalho lhe dá, em outros momentos da entrevista, como fazer "com que as ideias que ele tem sejam respeitadas e valorizadas", ver essa ideia ganhar forma no papel e estar lá com o nome dele assinado. "Isso gera uma satisfação para o jornalista e é um pouco o que segura a profissão... Mexe com o 
ego, eu acho que o jornalista costuma ser vaidoso..." Outro exemplo é quando pensa uma pauta e ela vira um caderno especial.

$\mathrm{Na}$ questão específica sobre prazer, Pedro fala do reconhecimento do público. "Prazer é você ter um retorno muito direto do seu leitor. Várias vezes eu me sentia muito satisfeito de receber uma resposta positiva ali." Uma das cartas que recebeu de leitores chegou a guardar. "Eu senti uma satisfação muito grande de muitas vezes prestar um serviço que era útil pro leitor. Um dia eu até guardei a carta de um senhor que tinha uns 70 anos, escrita a mão, agradecendo um serviço que a gente tinha dado." Para ele, isso causa uma satisfação "inigualável em termos do seu trabalho" e "uma felicidade muito grande". Outras fontes de prazer são: “entrevistar pessoas que você admirava antes", adquirir muito conhecimento à medida que você vai trabalhando e mais uma vez cita ter a matéria assinada. "Ver seu nome ali, que ele está sendo espalhado pelo Brasil inteiro, que ele vai chegar à casa de seu pai, à casa do seu tio, as pessoas na sua cidade vão olhar... Também é um tipo de satisfação que é gostoso sentir."

Leonardo Sakamoto é outro jornalista a colocar como prazer ver a matéria que escreveu e sua repercussão, especialmente quando há uma mudança efetiva do problema relatado ou uma mudança sistemática nas consciências das pessoas sobre aquele determinado tema. "Se você consegue ajudar e contribuir nisso, você se sente muito realizado."

Miguel, por sua vez, sente prazer no trabalho quando tem autonomia, quando consegue fazer escolhas e colocar aquilo que, tendo as informações, você concorda e acredita, considera importante colocar em discussão à sociedade. "Realmente você informar, acho que isso está um pouco nas origens da minha escolha profissional.. Trazer elementos para que as pessoas possam conseguir alguns direitos, avançar, se apoderar." Ele conta que conseguiu em alguns momentos tratar de assuntos que gostava bastante. "Pena que não é sempre, às vezes você tem que tratar de outras coisas." Mas conclui que a maior parte do tempo tratou de assuntos relevantes.

Aline Scarso coloca como prazer "a possibilidade de conhecer coisas novas o tempo todo, de estar em lugares que você nem imaginou que pudesse estar", conhecer realidades diferentes das suas, "conversar com pessoas que você não iria normalmente conversar". Ela escolheu o jornalismo pela possibilidade de vivenciar essas realidades diferentes, mostrando às pessoas o que realmente existe e por que as coisas são como são. 
A falta de liberdade para atuar nos meios de comunicação é um aspecto negativo que Aline levanta. "Mas é muito bom ser jornalista também. Eu não acho que é uma profissão ruim. Há todas essas questões, mas tem tanta coisa boa. A principal dessas coisas é o conhecimento." Ela avalia que o jornalista deveria ser estimulado a aprofundar mais a realidade e fazer matérias maiores. "Tanto pro nosso crescimento pessoal e profissional quanto pra própria compreensão do telespectador, do leitor."

Para João, o prazer no trabalho de jornalista vem da possibilidade de criar alguma coisa que não existia e influenciar alguém por causa da sua criação. "Um jornalista quando publica uma matéria, quando faz uma reportagem, ele influencia a sociedade, acho que tem esse fator de criar algo que tem um impacto sobre a vida de outras pessoas."

A aprendizagem e o reconhecimento apareceram na resposta de Priscilla Nery. “O maior prazer meu é o conhecimento, e acredito que seja da maioria, porque você aprende muita coisa em pouco tempo, você fala com muitas pessoas que você nunca falaria." Como trabalha em um veículo especializado, ela diz conhecer coisas importantes e que vê os resultados de seu trabalho mais facilmente.

Do site Vila Mulher, Priscilla recorda uma matéria sobre depressão pós-parto, que foi marcante e prazerosa. As pessoas agradeceram muito pela reportagem. $\mathrm{O}$ agradecimento dos leitores e das fontes também ocorre nas áreas de emergência e de segurança e saúde. "Falam que conheceram tal coisa, que não sabiam... Pessoas da emergência dizendo que salvaram uma vida, porque tiveram conhecimento através dali. Isso é muito prazeroso." Para ela, esse reconhecimento gera "uma sensação de dever cumprido", de contribuir "para melhorar o mundo" e "a vida das pessoas". "Isso é muito legal, não tem nada que pague. Por isso eu escolhi a profissão e acho que estou no caminho certo."

\footnotetext{
Essa interface com o público acrescenta muito pra nós também. Lá na Arena Corinthians, quando teve o acidente com guindaste e matou dois trabalhadores, um socorrista de lá me ligou, porque eu tinha ido lá uma vez pra acompanhar uma atividade da Sipat deles... Oi, então vocês vão publicar alguma coisa? Nossa obrigado pelo trabalho, não sei o que. Já tive outras pessoas também ligando... Acho que o prazer por isso acaba superando o sofrimento nesse tipo de trabalho Priscilla Nery.
}

Vivian Fernandes acha prazerosa a convivência com os colegas de profissão e a conversa diária da redação. Quando o trabalho dá certo, ele também é fonte de prazer. "Nem precisa que ninguém te elogie, se você sentiu que isso aconteceu, você já fica 
feliz. Se alguém te elogia, se um leitor escreve uma carta falando disso, nossa, aí você sente que valeu a pena e aquela dor que você sentiu antes foi superada... Isso dá prazer."

Os depoimentos mais uma vez mostram que o trabalho dá sentido à vida do jornalista. Apesar das condições precárias, esse trabalhador acredita na importância do seu trabalho. A idealização da profisssão e o próprio papel do jornalismo na democracia contribuem para a construção desse sentido.

Na prática, os próprios ritos e conteúdos do trabalho e o reconhecimento que ele proporciona são fontes de prazer. Os jornalistas se veem contribuindo para a transformação da sociedade e se transformam pelo trabalho, como quando relatam o prazer de conhecer o novo e de aprender com as pessoas. O reconhecimento, que leva ao prazer, pode vir do outro, como quando o leitor agradece pela informação, mas também de si mesmo, quando se escreve sobre aquilo que acredita ou quando se gosta do resultado do trabalho. É o próprio sujeito aferindo um resultado positivo ao seu trabalho.

Ainda há o reconhecimento dos pares, que não foi citado na questão sobre o prazer, mas claramente contribui para um bom ambiente de trabalho, o que pode ser percebido ao longo das colocações dos entrevistados. Ambientes ruins são causas de sofrimento e adoecimento, além de possibilitarem a ocorrência de assédio moral, que não se trata de uma questão individual e sim organizacional.

\subsection{0 - Espaço de criatividade e autonomia}

Um trabalho, que se caracterize como espaço de criatividade e autonomia, contribui para a transformação do sofrimento em prazer. Abordamos esses dois temas nas entrevistas para que os jornalistas avaliassem até que ponto a criatividade e a autonomia estavam presentes em suas carreiras.

Segundo Seligmann-Silva (2011, p.81), é “indispensável que haja uma flexibilidade através da qual a prescrição e o controle das tarefas possam abrir o espaço da liberdade para atender às necessidades do conjunto psicossomático", pois só assim o trabalho não assumirá um papel “desorganizador”.

Dejours (2012b,p.118) afirma que "uma identidade consolidada de forma insuficiente não oferece a autonomia necessária". Por outro lado, explica que "o 
reconhecimento não dá qualquer garantia de encaminhar o sujeito rumo à autonomia". Isso porque há casos em que "o sujeito se torna cada vez mais preso ao reconhecimento de que beneficia, mesmo se este reconhecimento é inerente ao seu trabalho". O autor trabalha ainda o conceito de emancipação.

Para além da prescrição ou do constrangimento em produzir, onde se realiza antes a experiência da servidão (mas é necessário partir desta experiência primeira), o sujeito engaja-se de maneira deliberada em uma provação consigo mesmo, quando ele afirma sua vontade de emancipação vis-à-vis a servidão. Emancipação que procede do poder em substituir o constrangimento da dominação pela exigência de mensurar-se, de seu próprio grado, com os poderes de seu corpo e de sua inteligência confrontados à resistência do real.

A emancipação não se avalia aqui no direito de circular livremente, de praticar sua religião ou de expressar sua opinião, mas no poder de encontrar no seu trabalho a via que leva ao gozo de si, em outros termos, da ampliação da subjetividade e da revelação da vida em si. (DEJOURS, 2012b, p.158)

Um ponto que aparece entre nossos entrevistados é de que não existe uma autonomia total no trabalho do jornalista. Seligmann-Silva (2011, p.496) fala sobre a existência de uma autonomia limitada, que é concedida aos trabalhadores e até estimulada pela gerência, mas dentro de restrições, visando ao interesse e às metas da empresa. A autora defende ainda a superação do medo, que impera nas organizações e impedem uma autonomia verdadeira:

A desumanização do trabalho contemporâneo e a expansão do desamparo exigem um enfrentamento. Como foi visto esse enfrentamento exige uma primeira etapa cujo passo inicial consiste em ampliar uma desmistificação - a da ideologia que implantou a crença em uma globalização todo-poderosa que teria enredado todos os que vivem do próprio trabalho na inexorabilidade de um aprisionamento sem saída. Essa desmistificação conduzirá à superação do medo, em que o mundo do trabalho foi submergido. Constitui passo indispensável para que as energias bloqueadas sejam libertadas para superar a submissão...

(...) Assim, após vencer o medo, será também possível reencontrar o sentido da (re)construção solidária da saúde e do trabalho, assim como de um mundo no qual a dignidade humana seja restaurada e a vida seja valorizada. Vida na qual cada um possa assumir $o$ direito de ser dono de si mesmo. (SELIGMANN-SILVA, 2011, p. 560)

Durante as entrevistas desta pesquisa, questionou-se aos jornalistas: Você acredita que tem autonomia para realizar o seu trabalho? Se sim, de que forma? Se não, por quê? Também se perguntou se havia liberdade para a sugestão de pautas. De maneira geral, há um discurso de que o bom jornalista conquista o seu espaço, mas há limites que vão desde a linha editorial à falta de recursos. A maioria dos entrevistados 
acredita ter autonomia, e a falta de espaço aparece como exceção. Em alguns discursos, aparece que é preciso trabalhar muito para conseguir essa abertura e não há lugar para todos. Outros acreditam que as sugestões de pauta são estimuladas. Ainda há aqueles como Dines avaliam que falta liberdade.

Alberto Dines considera que conforme você evolui na carreira, quer mais autonomia, mas chega um ponto em que não é possível obtê-la. "No Jornal do Brasil, eu aceitava as regras do jogo durante a ditadura. $\mathrm{O}$ dono do jornal fazia com o jornal o que ele queria, mas eu tentei influenciar muito, até que chegou num momento que não deu mais, eu não aguentava mais a autocensura e o jogo todo." Então, ele foi "expelido". Quando chegou à Folha, parecia que teria liberdade total. "O Cláudio Abramo é demitido, sobe o Boris Casoy, que é o outro lado do espectro ideológico, e ele me demite porque eu escrevi um artigo e insisti em publicar este artigo, então, na medida em que você vai crescendo, você vai encontrando mais limitações.” Para Dines, são poucos os que têm liberdade no Brasil para desenvolver o raciocínio e ir para determinadas direções. Para ter isso, ele criou o Observatório de Imprensa, e Lúcio Flávio Pinto o Jornal Pessoal.

Já Audálio Dantas acredita que há autonomia. "Isso é uma das minhas alegrias. Eu tive muita autonomia pra fazer meu trabalho tanto na Folha, como na revista $\mathrm{O}$ Cruzeiro, e, muitas vezes, eu escrevi matérias que contrariavam a pauta inicial, porque ao fazer achei que a pauta devia ser outra." Para ele a liberdade de pautas é uma conquista do bom profissional.

Clóvis Rossi também acredita na autonomia, mas limitada pelo projeto editorial do jornal. No caso da Folha, ele destaca o jornalismo moderno, independente e crítico. "Isso eu não posso mexer. Não posso passar contrabando ideológico e se eu não estiver satisfeito com essas regras de trabalho, procuro outro jornal.” Em relação à liberdade, ele avalia que nem todo jornalista tem a liberdade para dizer o que quer, depende do jornal em que ele trabalha: "A liberdade é muito mais da empresa do que dos próprios jornalistas. Isso é evidente.” Mas para ele os jornais procuram separar bem opinião, que fica nos editoriais, de informação. Já a liberdade para sugerir pautas sempre foi total, a realização delas é que depende de vários fatores como "mãos de obras disponíveis, tipos de assuntos, momento político", verba para a cobertura.

Ricardo Kotscho fala que a liberdade de imprensa não pode ser uma liberdade de empresa. Ele defende o "direito da sociedade ter acesso às informações", mas para ele, “o jornalismo hoje é muito dirigido". Da época da ditadura, recorda que tinha liberdade 
para tratar de todos os assuntos, mesmo os proibidos pela censura. O raciocínio era: "nós fazemos o nosso trabalho, e o censor faz o trabalho dele". Com o fim da censura do Estado, as empresas passaram a exercer o controle como corporações e construíram um pensamento único.

Eu não noto no jornalista uma coisa fundamental hoje que é tesão pelo que faz.. Está tudo muito parecido... Então você tem a impressão que tem um editor único no Brasil inteiro, um pauteiro único, um veículo único, um pensamento único... Isso é o que ameaça muitos veículos, muito mais do que a internet, do que as novas tecnologias. Você tem que oferecer ao público, alguma coisa que não tem em outros lugares, alguma coisa a mais - Ricardo Kotscho.

Como repórter, Kotscho sempre buscou fazer suas pautas, mesmo se fosse preciso falar com o dono do jornal para isso. Diz nunca ter sofrido limitações impostas pelas empresas no seu trabalho. "Desde o começo eu sempre fui muito intrometido e curioso, e não me limitava a fazer só aquilo que o jornal me pedia, eu procurava descobrir informações, coisas novas que não estavam na mídia e tal, que estavam começando a acontecer..." Para ele, nenhum chefe recusa uma boa pauta.

Uma vez quando eu estava na Bandeirantes, um repórter veio reclamar comigo que só pegava pauta ruim.. Eu falei, vamos fazer o seguinte, a partir de hoje, não tem mais pauta pra você. Você só faz aquilo que você quer. Todo dia me traz uma boa pauta e eu autorizo você a fazer. $\mathrm{O}$ cara entrou em pânico, ele nunca tinha feito isso na vida, não sabia nem como descobrir um assunto e fazer. Então eu acho que essa é outra mudança bastante importante entre o jornalismo antigo de quando eu comecei e hoje... Os repórteres mais experientes não aceitam esse prato feito, discutem, mas o pessoal que está começando, que hoje é a grande maioria, que há uma alta rotatividade de mão de obra, acaba aceitando porque tem medo de perder o emprego... Ricardo Kotscho.

Lúcio Flávio Pinto, quando trabalhava na grande imprensa, não tinha toda a liberdade, mas a possuía em quantia suficiente para brigar por suas pautas. Ele conta um caso de uma pauta sobre a lei de demarcação de terras da União, Lei 6383 de dezembro de 1976. Lúcio chegou a ser chamado pelo Conselho de Segurança Nacional e conseguiu argumentar sobre as falhas da norma. Depois veio o convencimento do jornal para que publicasse a reportagem em 10 páginas ao longo da semana, que saiu em $\mathrm{O}$ Estado de S. Paulo, mas com uma ressalva: "No dia que saiu a primeira matéria, o editorial saiu mais ou menos assim - está saindo na página tal uma série de matérias sobre terras, isso é obra de comunistas que se infiltraram nessa redação e nós não pudemos fazer nada pra impedir" (risos). Atualmente os processos que sofre tentam 
intimidá-lo. Já foi condenado, por exemplo, por ter denunciado a grilagem de terras de uma pessoa que a própria Justiça Federal condenou por ser grileiro.

Aureliano Biancarelli acredita que, de forma geral, ele teve autonomia na carreira. No início, na Veja, havia censura prévia e teve um outro texto que não saiu. Uma limitação para a autonomia é a autocensura que se estabelece nos veículos de comunicação. Em relação às pautas, acredita que essa liberdade é estimulada. Já sobre o texto, conta ter vivenciado uma grande liberdade de escrita no caderno Aliás do Estadão. "Você podia começar do jeito que você pudesse imaginar, o mais inusitado possível."

Paula Puliti conta que em sua carreira nunca houve intromissão no seu trabalho. Por outro lado, cada veículo tem a sua linha, que é conhecida pelo jornalista. "Eu sempre tive autonomia, mas sempre sabendo quem era o meu público alvo... Eu não falava o que eu queria, eu falava o que o meu público queria ouvir. Mas isso não foi o dono do jornal ou o chefe que falou. Você vai aprendendo. É um certo jogo de cintura." Em relação às pautas, todos tinham liberdade para falar.

Ao longo de sua carreira, Marilu Cabañas avalia que a maior parte dos momentos teve autonomia e liberdade total de pauta, inclusive com o apoio das chefias em matérias de denúncia de problemas sociais, que incomodavam os responsáveis, como secretários de saúde e educação. As exceções foram os casos que vivenciou em uma das gestões da Rádio Cultura e em alguns momentos no SBT.

Bob Fernandes também teve autonomia no trabalho: "O meu epitáfio é fiz como quis. Briguei muito pra isso, fiz do meu jeito desde o primeiro minuto, primeiro instante, e tive a sorte de trabalhar com gente que era não só competente como não cerceava isso.” Ele conta que sempre buscou suas próprias pautas e teve liberdade para desenvolvê-las. As exceções foram casos de reportagens sobre política na Bahia, em especial uma que abordava um quebra-quebra de ônibus e outra sobre uma greve da Polícia Militar. O jornalista levantou as informações para a Veja, no início da carreira, enviadas para a revista como um relatório com o material apurado, que não foi aproveitado, pois prevaleceram as versões do então governador Antonio Carlos Magalhães. Embora a matéria não fosse assinada, depois disso, ele não quis mais cobrir política para a revista e passou a fazer reportagens para o miolo da publicação, que era voltado para comportamento.

Fernanda Cirenza é outra jornalista a avaliar que teve autonomia no trabalho e que as sugestões de pautas são fundamentais em uma redação. "É impossível um diretor 
de redação chefiar a cabeça de muita gente o tempo todo." Ela conta que quando se publica alguma coisa que a direção da publicação não gosta, a pessoa é chamada. Isso aconteceu com ela quando fez a manchete: “A música perde a alegria de Tim Maia”.

-Não, não, não. Tá louca? Tim Maia, x anos, morre de qualquer coisa. Fui chamada, ouvi, minha avaliação deve ter caído (risos). Em algum momento eu tive autonomia, depois aguentei as consequências. Mas eu não tenho nenhum episódio - ah, eu fui controlada politicamente, não - Fernanda Cirenza

Para Ivan Marsiglia, nessa fase da carreira em que se encontra, tem bastante autonomia. "Com esse tempo de trabalho, eu consegui ter certa liberdade na escolha dos temas e na maneira que vou abordar. Claro que cada veículo tem as peculiaridades, mas eu sinto que eu trabalho com grande liberdade." Ele diz existir o perfil do leitor e da empresa, mas nunca sentiu que isso ferisse sua liberdade. "Eventualmente uma matéria ou outra que você propõe não emplaca, você pode questionar os critérios, mas isso é evidente que o dono do jornal tem bons editores, têm autonomia pra decidir também.”

Já Antonio acha que a autonomia é relativa. "Um jornal necessariamente não manipula conscientemente, às vezes, ele também é manipulado por uma informação que chega com outra intenção e não é verificada." Se o perfil do jornalista é acomodado, ele fica refém da pauta direcionada. "Cabe um pouco ao profissional dizer, olha, eu encontrei essa outra fonte, ela diz uma outra coisa e é muito importante por isso." Por outro lado, afirma que dependendo das situações, você não consegue evoluir no que é pedido, entrega e pronto.

Maria relata que na Radioagência Nacional tem abertura para propor projetos. "A minha chefia confia no meu trabalho, no meu discernimento. Então não é aquela chefia que fica em cima de você achando que ela sabe e você não sabe. Eu posso tomar as decisões e depois comunicar." Em relação às pautas, elas ficam a cargo dos pauteiros. "Eu gosto de editar, mas fico pensando nas pautas, então, eu sugiro pra diversos setores." Mas não há um canal oficial para isso. A EBC deveria criar um Comitê Editorial, para receber as sugestões, o que é uma das reivindicações da Comissão de Empregados. Mesmo como editora, Maria sugere e faz, quando possível, coberturas especiais.

Bruno Torturra diz ter liberdade total de expressão atualmente. "Muito mais do que eu tinha na Trip. Não porque me tolhiam, é o que cabia ou não cabia na revista. Hoje em dia eu posso falar do que eu quiser. Mas eu não tenho autonomia nenhuma financeira pra realizar as matérias que eu gostaria." Ele conta que na revista sempre foi 
encorajado a sugerir pautas. A única limitação era do tema escolhido para o mês. Por exemplo, a revista trataria de alimentação. Então as sugestões giraravam em torno disso, mas podia arriscar e explorar ângulos diferentes.

Pedro conta que quando era frila, costumava sugerir as pautas para os locais que fazia matérias. Mesmo no jornal teve autonomia. Nunca sentiu qualquer interferência enquanto estava na Folha. "Eu conseguia fazer com que minhas ideias fossem desenvolvidas. Então eu não sentia que estava sendo podado... Eu nunca tive, ah, isso aqui você não vai publicar, isso aqui a gente vai dar uma mudada." As sugestões de pautas também ocorriam. "Era estimulada certa loucura nas pautas, a criatividade dos repórteres era respeitada, eu nunca tive nenhum problema em relação a isso."

Leonardo Sakamoto avalia ter mais autonomia do que os colegas que atuam na imprensa convencional. Por outro lado, eles podem ter mais recursos do que a Repórter Brasil para fazer produções. "Mas a gente nunca se tolheu por conta de falta de recurso pra produção, a gente sempre viajou, fez a reportagem que queria de uma forma até com mais liberdade do que outros colegas, liberdade de tempo." Ele também cita, como Lúcio Flávio Pinto, os processos judiciais que a ONG sofre como tentativa de intimidação. Já sobre a liberdade de criação de pautas, ela existe, mas está atrelada a linha editorial do veículo. "Se você trabalha numa revista de moda, você não vai querer fazer uma matéria sobre carros possantes, não faz sentido.” Ele diz que já teve matéria que caiu por causa de interesse de anunciante. "Mas de uma maneira geral, o impedimento da pauta, eu nunca tive não, nunca me senti tolhido."

Miguel considera que ao longo da carreira teve momentos de autonomia e outros de quase nenhuma. Mas nunca teve interferência no trabalho. Na avaliação dele, a independência total é inalcançável. "Onde a autonomia se perde? Quando você é escalado para fazer uma coisa que você acha que não é tão importante.” No entanto, pôde tratar os assuntos da forma que achou melhor. Mesmo em coberturas difíceis, quando estava na $\mathrm{CBN}$, como o mensalão, teve autonomia. "Ninguém falou é assim ou assado. Eu tratava da maneira que eu achasse melhor e procurava tratar com equilíbrio e cautela. E ninguém falou pra fazer diferente." Também é possível mudar o tratamento dado inicialmente a uma pauta e dar uma nova abordagem. "Por isso que eu acho que existe certa autonomia, você consegue estabelecer limites, estabelecer certa defesa do seu trabalho." A sugestão de pauta na rádio dependia da função. Como repórter, já se recebia os temas sem discussão, mas às vezes conseguia encaixar algum assunto. Quando ele produzia notas, escolhia praticamente todos os assuntos. Nos veículos em 
que trabalhou na internet havia espaço para sugestões. “Às vezes o que acontece, não só comigo, como com os colegas, você é tão absorvido por essa rotina, que a criatividade parece que some e você não consegue nem pensar em uma coisa interessante.” Para ele, é preciso enfrentar isso, mas não há espaço para todos.

Aline Scarso considera que de forma geral tem autonomia na TV Brasil. "Tenho liberdade de sugerir, tenho liberdade de fazer determinado ângulo, claro que sempre é uma discussão eterna entre produtor, repórter e editor." Quando ela é repórter, por exemplo, não pode entrevistar outra pessoa, pois a entrevista já foi pré-combinada. "A minha autonomia está em tirar o que há de melhor... Então, nesse sentido, ela é um pouco restrita... Eu tenho que continuar aquela proposta que foi pensada em início pelo produtor." Mas mesmo como repórter pode sugerir pautas. Como produtora, ela tem mais autonomia para fazer a pauta, mas não executa o trabalho. No dia a dia, ela sugere muitas pautas. Ela defende que o interesse público deve nortear a TV Pública, que ainda se confunde com uma TV governamental.

Recentemente uma pauta minha foi barrada e eu fiquei muito mal, porque foi uma pauta sobre um ano das manifestações de junho [de 2013] e o editor chefe do jornal, de Brasília, barrou... Era só pra marcar um ano, fazer uma matéria especial, uma leitura histórica do que tinha acontecido. Então ia ter personagem, especialista, o lado do governo, o lado da polícia, do MPL [Movimento Passe Livre], dos novos movimentos, da Juventude. Ia abarcar todo mundo, uma matéria especial, bem construída. A ideia era que o telespectador que assistisse a essa matéria pudesse compreender o fenômeno com mais profundidade. E eles não quiseram fazer porque isso de certa forma ia afrontar o governo. $\mathrm{O}$ ano certinho ia cair com a abertura da copa... Foi a única vez que eu tive uma censura mesmo das minhas pautas, de uma sugestão - Aline Scarso.

João, na revista de informação, já recebia a pauta com um viés. Na reunião de pauta, ele costumava sugerir, mas muitas sugestões não iam para frente. Uma mesma sugestão que não vingou em uma editoria, por exemplo, poderia dar certo em outra. As escolhas dependiam de avaliações subjetivas dos editores.

Priscilla Nery acredita ter autonomia no seu trabalho. "Acho que em nenhum lugar você tem autonomia em tudo. É utopia. Mas lá na Proteção eu tenho bastante liberdade, eu posso sugerir pautas, eu posso sugerir as fontes, (...) confiam no meu trabalho."

Vivian Fernandes também considera ter autonomia, tanto quando trabalhou na radioagência quanto no Brasil de Fato SP. “As equipes são muito jovens, então a gente não tem tantos vícios da redação. A gente quer fazer, vai lá e faz, quando é possível, e 
nunca ninguém tolheu a gente das iniciativas...” Tudo é muito dialogado. Em relação à sugestão de pauta, havia liberdade de propor nos dois casos. No jornal, ela recebe muitas sugestões dos movimentos sociais.

Também abordamos nas entrevistas a questão da criatividade. Os jornalistas responderam se o trabalho permite que eles a exerçam. De maneira geral, eles avaliam que exercem a criatividade. Alguns citam limitações organizacionais como a falta de tempo e mais uma vez a linha editorial. Outros destacam os próprios fazeres jornalísticos como criativo - escrever, entrevistar. Assim como a autonomia, pode-se dizer que há uma criatividade relativa. Ela não é total, mas é essencial para o jornalismo e os jornalistas.

Alberto Dines avalia que o trabalho jornalístico é todo baseado em criatividade. Para ele, as empresas jornalísticas vivem crises de identidade, política e financeira, e tudo isso dificulta o exercício da criatividade. No entanto, os jornalistas estão buscando novos caminhos, criando seus veículos, blogs e sites.

Audálio Dantas acredita que o trabalho permitiu que ele exercesse a criatividade. Ele fala sobre a matéria que abordou a caça do caranguejo para a revista Realidade em que buscou uma maneira original de contar a história. No entanto, falta espaço para reportagem nos veículos atualmente, e muitos jornalistas recorrem aos livros para contarem suas histórias.

Já para Clóvis Rossi há espaço para a criatividade, mas limitada pelos horários de fechamento. "O que limita é realmente o tempo que você tem para fazer as coisas. Às vezes você faz correndo tudo, e a criatividade fica necessariamente prejudicada. Ninguém é máquina para produzir um texto criativo, brilhante em cinco minutos.” Em relação ao trabalho si, nunca teve interferências sobre a forma que escrevia.

Aureliano Biancarelli também fala em exercício da criatividade com limitações. Isso porque, apesar de ter autonomia, matérias tiveram que ser reduzidas por causa da edição ou deixaram de entrar para dar lugar a uma notícia mais quente. "Eu trabalhava numa faixa de matéria menos perecível, resistia um pouco mais, mas que eram substituídas. Então se tem alguma matéria que pode esperar pra amanhã, vai esperar. E amanhã você vai ter outras matérias."

Uma experiência muito criativa que Biancarelli teve foi o trabalho no Jornal da Tarde, que permitia que ele soltasse o texto e fosse criativo, como nenhum outro possibilitava. "O importante pro jornal era como você ia começar uma matéria, não o clássico lide com o que, quem, quando, como, por quê. $\mathrm{O}$ importante era prender o 
leitor... Nós tínhamos que começar bem uma matéria e terminá-la bem." Lá não se cortava a matéria pelo pé, e o trabalho era mais livre.

Ricardo Koscho sempre lutou para exercer a sua criatividade. "No jornalismo nada é de graça, nem a pauta, você ficar esperando a grande pauta, pra fazer a grande reportagem, não existe isso, você tem que correr atrás.” Ele avalia que até 1984 se fazia um jornalismo de autor, no qual a criatividade e o estilo de cada um eram respeitados. "A partir do Projeto Folha, e isso se espalhou praticamente por toda a imprensa brasileira, ficou uma coisa mais pasteurizada, mais padronizada, mais controlada... Existe é um controle das chefias de cada redação sobre os trabalhos dos repórteres..."

Paula Puliti avalia que usou sua criatividade na escolha das perguntas aos entrevistados, na elaboração da pauta e na forma da escrita. Já Marilu Cabañas acha que o rádio é um meio que força o jornalista a ser criativo através da edição, sonorização e o jogo das palavras. E para Bob Fernandes a criatividade "é uma das principais armas que você tem para escapar da camisa de força que o jornalismo pode lhe impor".

Fernanda Cirenza, por sua vez, afirma que a criatividade é fundamental para o jornalismo. Ela vivencia isso na revista Brasileiros e vivenciou no jornal. "O que a gente foi criativa na Folha pra fazer aquele jornal sair, todas as pessoas, pra conseguir botar um jornal na gráfica às $8 \mathrm{~h}$ da noite, é toda uma operação que exige muito desse talento, da criatividade, do espírito coletivo, da briga."

Para Ivan Marsiglia, no geral, ele teve liberdade para exercer a criatividade em todos os locais que trabalhou, propondo ideias e tendo espaço para experimentar. $\mathrm{O}$ trabalho no caderno Aliás no Estadão dá para ele a possibilidade de um texto mais livre, mais solto, que aceita a autoria do repórter. "Qualquer reportagem embute um olhar, e o olhar do repórter não é um erro a ser purgado das matérias, porque é impossível fazer isso, mas é uma parte do que interessa ao leitor." As reportagens, em sua opinião, poderiam ter um olhar mais autoral, estilístico, pessoal. Ele cita a repercussão de alguns blogs, que têm essa característica. Nos jornais, com exceção dos repórteres especiais, falta liberdade estilística, o que é “um elemento de satisfação para o trabalhador”.

Antonio acredita que a criatividade no jornalismo vem de você se deparar com coisas muito diferentes, e tornar o trabalho mais criativo depende das condições de trabalho. Maria tem opinião parecida, percebe a criatividade em seu trabalho, mas há uma limitação de tempo dada pela produção industrial que é editar as matérias e publicar. 
Por outro lado, Maria tem a possibilidade de tomar decisões sobre o seu trabalho e fazer projetos fora da rotina, como um programa em espanhol para a América Latina. "É um trabalho que exige. Pra mim é mais gratificante porque eu sinto que eu estou fazendo mais jornalismo do que eu faço hoje."

Pedro concorda com as falas anteriores: "É uma profissão que permite muita criatividade, apesar de todos os problemas que são vinculados ao jornalismo”. Bruno Torturra não tem dúvida de que seu trabalho é criativo e de que essa é uma característica essencial, que o motivou a ser jornalista. "É minha vontade de descobrir coisas e de narrá-las da minha forma."

Leonardo Sakamoto vê muita criatividade em seu trabalho. A criação de seu blog, quando a Repórter Brasil tinha cinco anos, veio da necessidade de dar "vazão a um processo criativo que tinha sido tolhido" porque ele estava coordenando a ONG jornalística. "Então ele foi minha válvula de escape."

Miguel, por sua vez, acredita que o trabalho de jornalista permite a criatividade, mas episódica e dentro de certos contextos. "Dá pra criar, pra fazer o que você gosta, o que você propõe, mas dificilmente você vai conseguir fazer disso a sua rotina." A rotina jornalística passa por obrigações e por repetições, que estão longe de ser um trabalho mais criativo. "Você vai ter chance de fazer o que é mais prazeroso, com o que você mais se identifica, em momentos mais curtos."

Aline Scarso se sente mais criativa quando atua como repórter, porque ela viu as coisas, esteve no local para fazer a reportagem. Já na produção a criatividade está principalmente na escolha da pauta. Há algumas matérias que são mais burocráticas, como a visita de um ministro ou a cobertura de uma evento. O jornalista simplesmente faz. "Mas eu acho que o jornalismo é uma fonte de criatividade. Eu vejo experiências interessantes... Não é na grande mídia brasileira. Não é esse caminho, está muito desgastada."

João teve momentos de menos criatividade e outros de mais conforme a editoria que atuou. Uma delas era muito criativa, as pessoas muito engajadas, amigas e colaborativas, o que proporcionava uma capacidade de criar. Já Priscilla Nery avalia que exerce a criatividade até certo ponto, pois não pode sair da proposta do veículo. Os momentos mais criativos são as matérias em que ela vai ao local do fato, o que possibilita que ela escreva de forma mais livre e com mais detalhes.

Por fim, Vivian Fernandes avalia que tem espaço para exercer a criatividade, mas falta tempo para fazer isso. Tem várias pautas que ela gostaria de fazer, mas não 
consegue, porque tem outras funções como editora. Quando era repórter, da radioagência, ela conseguia um pouco mais. "Mas eu sempre tento escrever uma pauta. $\mathrm{Eu}$ não queria deixar totalmente o meu lado repórter. Então sendo repórter eu exerço mais a criatividade do que sendo editora." 


\section{Conclusão}

A centralidade do trabalho não deixou de existir como defendem muitos. No mundo do trabalho do jornalista, essa é uma questão primordial. Ainda que nem sempre o jornalista se veja como um trabalhador, apesar de reconhecer que atua em uma empresa, ele vivencia uma relação capitalista de produção, na qual vende a sua força de trabalho.

Tendo a clareza dessa centralidade, este estudo se baseou no depoimento de 21 jornalistas, que contaram suas histórias de vida em relação ao trabalho, colocando suas subjetividades e a forma como cada um lida com o sofrimento e o prazer no trabalho. A análise de conteúdo das falas teve como base teórica a psicodinâmica do trabalho para pensar essa relação. Sem a mediação dessa teoria, essa abordagem do conteúdo não poderia ser feita.

Um fator importante levantado pela pesquisa foi que os jornalistas com menos de 45 anos se reconhecem como trabalhadores e questionam a organização de forma mais enfática do que os com mais de 45 anos, provavelmente por vivenciarem ou terem vivenciado mais a precarização do trabalho. No entanto, os dois grupos mostram muito envolvimento com a profissão e se reconhecem como apaixonados pelo jornalismo, fazendo de seu trabalho sua própria vida na maioria das vezes. Essa identificação é importante para o sentido do trabalho, mas não se pode perder de vista uma visão crítica em relação à organização do trabalho.

Fica claro com os depoimentos que os jornalistas gostam muito de seu trabalho. Esse envolvimento de certa forma os impede de lutar por melhores condições de trabalho. Os direitos são deixados de lado, e cada um vai encontrando formas de lidar com o sofrimento, emergindo as subjetividades dos sujeitos. Mas mesmo com todo esse envolvimento, em quatro casos relatados, três jornalistas pediram demissão porque não aguentavam mais a situação de trabalho em que viviam, tanta eram a pressão e a intensidade do trabalho, mesmo gostando muito do que faziam. Todos continuam fazendo jornalismo, pois como disse um deles, não saberia fazer outra coisa.

A mística em torno da profissão alimenta um discurso de adesão e dedicação, que serve, na verdade, aos interesses do capital: extrair mais produtividade, maximizar a produção. A isso se acrescenta o discurso atual pós-fordista de flexibilização do 
trabalho e das relações trabalhistas. A subjetividade do trabalhador jornalista também é subtraída.

Ao lado do discurso toyotista, convivem as heranças fordistas e tayloristas. Como vimos, elas também ajudaram a organizar o trabalho no jornalismo com planos de metas, controle de produtividade e os manuais de redação. O ritmo de trabalho, que já havia aumentado, cresce mais ainda nos tempos de flexibilidade. O jornalista mais do que nunca precisa ser polivalente e realizar diferentes atividades para várias plataformas de comunicação, especialmente, com os impactos das novas tecnologias à profissão, que se por um lado facilitam o trabalho, por outro, promovem sua intensificação. A pressão do tempo e a tensão da profissão também aumentam.

A flexibilidade atinge os direitos do trabalhador jornalista. Se por um lado existem instrumentos para um ambiente de trabalho mais saudável, como normas, lei e itens da Convenção Coletiva, por outro, falta o cumprimento dos itens e uma organização do trabalho que realmente olhe para as necessidades do ser humano que executa a atividade.

Os jornalistas sofrem ao cumprir longas jornadas de trabalho, fazer plantões, não ter a compensação de horas ou o pagamento de horas extras devidos e há casos em que não são contratados conforme a CLT. Algumas peculiaridades do jornalismo mostram que às vezes é preciso ultrapassar as 7 horas (5horas +2 horas extras conforme a legislação). Isso deve ser considerado, mas a exceção não deve se tornar regra. Além disso, as instruções para o pagamento de extras e banco de horas estão na própria Convenção Coletiva da categoria, como a do Sindicato dos Jornalistas Profissionais no Estado de São Paulo, que é assinada pelos representantes patronais e utilizamos como referência nesta pesquisa.

Nas entrevistas, foram discutidas a situações da Pessoa Jurídica, que abrange tanto pessoas que realmente têm uma empresa e prestam serviços quanto jornalistas que cumprem jornada, não são celetistas e precisam dar nota, e do frila fixo, que geralmente cumpre jornada, não é celetista e não precisa dar nota. Características essas que mostram a precarização do trabalho no jornalismo, em um cenário em que a terceirização e até quarteirização ganham espaços.

Para o cumprimento da legislação, uma fisscalização trabalhista mais presente é necessária. Os auditores fiscais do trabalho podem exigir adequações, estipular prazos e multas, porém enfrentam dificuldades devido ao pequeno contingente de profissionais que o Ministério do Trabalho e Emprego possui. No caso do Ministério Público do 
Trabalho, uma das saídas utilizadas é o estabelecimento de TAC (Termo de Ajustamento de Conduta). Muitas vezes o acionamento se dá por meio de denúncias.

A mudança das condições de trabalho também depende da reivindicação dos profissionais e do fortalecimento da categoria. Um sindicato mais ativo e atento aos problemas, com maior participação dos jornalistas, pode ser um caminho. As notícias apresentadas na tese mostram avanços e que o sindicato da categoria em São Paulo tem se mobilizado junto ao Ministério Público do Trabalho e ao Ministério do Trabalho e Emprego, o que é bastante positivo. A busca do sindicato em ter os direitos trabalhistas convencionados também para os jornalistas que atuam na internet também é necessária.

A união dos profissionais na redação é outra possibilidade para a efetivação dos direitos. No entanto, nem sempre as ações coletivas são buscadas. O jornalista busca soluções individuais para ganhar mais espaço, trabalhando e se dedicando mais. Atitude motivada não só para o crecimento na carreira, mas para garantir sua manutenção no trabalho. A ameaça dos passaralhos é constante, e o medo de perder o emprego mina saídas coletivas.

Mas a ação coletiva é fundamental para a efetivação dos direitos e para gerar mudanças na sociedade, inclusive quando se pensa nas condições de trabalho. Dificilmente se conseguem resultados agindo-se de forma isolada, pois como mostra Milton Santos:

Sozinhos, ficamos livres, mas não podemos exercitar a nossa liberdade. Com o grupo, encontramos os meios de multiplicar as forças individuais, mediante a organização. É assim que nosso campo de luta se alarga e que um maior número de pessoas se avizinha da consciência possível, rompendo as amarras da alienação. É também pela organização que pessoas inconformadas se reúnem, ampliando, destarte, sua força e arrastando, pela convicção e o exemplo, gente já predisposta mas ainda não solidamente instalada nesses princípios redentores. (SANTOS, 2007, p.103-104)

O engajamento dos profissionais como categoria para gerar melhores condições de trabalho e maior autonomia na realização do trabalho é fundamental para construir um ambiente mais saudável para o jornalista. Os reflexos positivos para a saúde do jornalista são inegáveis e, ao mesmo tempo, podem contribuir para uma qualidade melhor dos textos.

É necessário buscar uma organização do trabalho em que se respeitem os limites físicos e mentais dos profissionais e assim o próprio direito à saúde no trabalho. Com condições organizacionais adequadas, possibilita-se um espaço mais propício ao 
diálogo, à observação do interesse público e ao direito à informação que todo cidadão tem.

Chegamos a discutir com nossos entrevistados o que seria necessário para melhorar as condições de trabalho e saúde do jornalista e foram levantados aspectos ligados à organização do trabalho. Alguns jornalistas mais jovens destacaram que esse é um momento de transição no jornalismo, em que estão se rompendo paradigmas, mas não se sabe ao certo qual será o futuro. Tanto mais jovens quanto os mais velhos defendem que mesmo com as transformações, o jornalismo é necessário à democracia.

De uma forma geral, os pontos levantados durante as entrevistas sobre as melhorias das condições foram: o cumprimento da jornada de 7 horas com a devida compensação ou pagamento de horas extras, quando essas forem necessárias, e folgas logo após os plantões; mais jornalistas contratados pelas redações em contraponto aos cortes que têm acontecido; melhor aproveitamento do modelo home office, pois se perde muito tempo no trânsito; apoio psicológico ao jornalista; investimento das empresas no aperfeiçoamento e capacitação dos jornalistas; mais recursos para as coberturas; autonomia; busca de novas alternativas na internet de uma lado e o reconhecimento por outro de que ainda não se aprendeu a ganhar dinheiro com notícias na rede (o negócio jornal impresso ainda é mais lucrativo do que ela); melhor remuneração, inclusive para os freelancers; rever o modelo de dar conta de tudo e produzir a todo custo, pensando mais na qualidade dos produtos oferecidos ao leitor/receptor/telespectador/ouvinte/internauta; acabar com o uso indevido da pessoa jurídica; registro como celetistas dos trabalhadores que atuam diretamente nas redações e estão precarizados; por outro lado houve quem defendesse que o jornalista se libertasse do modelo de funcionário e buscasse criar seus próprios meios e estruturas menores; direitos como alimentação, transporte e saúde; relações de trabalho horizontais e mais diálogo para a elaboração dos trabalhos, inclusive com outros setores, como o de tecnologia; formações de núcleos de trabalho com diferentes profissionais - edição, reportagem, fotografia, diagramação; união dos jornalistas para enfrentar as demissões e a não efetivação de direitos; criação de veículos de comunicação próprios; misturar jornalistas jovens e mais experientes; participar da discussão de novos modelos de negócios; diminuir a sobrecarga de trabalho; oferecer condições materiais para a realização do trabalho. Um entrevistado defendeu ainda a criação do Conselho Federal de Jornalistas, com a função de coibir abusos em relação ao trabalho. 
Muito desses pontos a ser coibidos têm a ver com a precarização do trabalho. Não é só o medo de perder o emprego que faz os jornalistas aceitarem essas condições ruins. O sentido que o trabalho tem para esses profissionais é outro fator preponderante, aproximando até jornalistas que atuam em meios diferentes. É o caso de jornalistas atuantes em mídia alternativa, em que a militância fez com que aceitassem a supressão de direitos (não ser registrado conforme a CLT, baixos salários) por ter a oportunidade de cobrir movimentos sociais, ainda que com o tempo isso passasse a ser questionado. $\mathrm{Ou}$ dos jornalistas que aceita ficar um tempo sem registro e, mesmo depois de registrado, fazer horas extras sem remuneração ou sem ter folgas, pelo reconhecimento de trabalhar na grande imprensa.

Ambos acreditam no trabalho que realizam. Ao falarem de suas atividades diárias, em vários momentos, era possível ver o brilho nos olhos e o sorriso dos entrevistados. As críticas também vinham carregadas de emoção e sofrimento. Não há dúvidas de que o trabalho faz sofrer, mas também é fonte de prazer para os jornalistas.

O sofrimento no trabalho está atrelado à organização do trabalho, ao próprio conteúdo do trabalho e ao ineditismo da atividade, sempre presente em qualquer trabalho. Os jornalistas entrevistados pela pesquisa consideram sofrimento as condições precárias de trabalho, a pressão do tempo, a baixa remuneração, o próprio ato de escrever, a falta de condições e recursos para realizar o trabalho, a falta de preparo, temas com os quais não há afinidade, falta de reflexão, a perseguição, a falta de liberdade para se expressar e não fazer o jornalismo que acredita.

Ao discutirmos a presença de dores e adoecimentos no trabalho no jornalismo percebemos que muitos sintomas ocorrem porque se passou do limite do corpo devido a um ritmo intenso de trabalho. Os jornalistas relataram problemas como cansaço, ansiedade, insônia, dor de cabeça, dor na coluna, dor de pescoço, faringite, ronquidão, dor de garganta, LER/DORT e pressão alta. Desgastes físico e mental também foram relatados, além de outros casos específicos de adoecimento.

$\mathrm{Na}$ pesquisa também ficou clara a presença de assédio moral em alguns ambientes jornalísticos: seis entrevistados vivenciaram e presenciaram casos de assédio moral, três apenas presenciaram, três relataram situações que podem ser assediadoras, e três ouviram histórias de assédio moral. Também foram feitos três relatos de assédio sexual. Os depoimentos mostram que o assédio moral é um problema organizacional, muitas vezes, ocorrendo em gestões assediadoras ou com o aval da gestão, não é uma 
questão individual. Além disso, fazem-se necessários estudos que olhem para a questão de gênero no trabalho jornalístico.

Também podemos afirmar que a profissão de jornalista é estressante, já que a maioria dos entrevistados a considerou dessa forma e todos apresentaram relatos de estresse no trabalho. Além disso, é uma atividade de ritmo intenso, com forte tensão e pressão do tempo para a conclusão das tarefas. Características que estimulam o estresse.

O trabalho do jornalista ainda pode ser fonte de risco e violência, que abrange desde a cobertura de manifestações, em que muitas vezes a agressão ao jornalista parte da própria polícia, até guerras. Também tivemos relatos de situações de riscos em que há presença de um senso de aventura, que busca mostrar o inusitado. O jornalista ainda se coloca em risco por pautas que têm cunho social, para mostrar injustiças e problemas enfrentados pela sociedade, por exemplo.

Outro sofrimento abordado na pesquisa foi o uso de álcool e drogas. Em geral alguns jornalistas com mais de 45 anos relataram casos de colegas com alcoolismo, mas não sabem se há alguma relação com o trabalho. Entre os mais jovens, a maioria também não vê uma relação direta, mas percebem o uso de álcool por jovens para relaxar e em alguns casos de drogas. Alguns chegam a falar da tensão do trabalho como um fator que pode estimular, outros acham que não há uma intensificação por causa do trabalho, que depende da pessoa e que a realidade não é diferente de outros trabalhadores. De qualquer forma, é uma questão a ser refletida, já que o trabalho do jornalista ocorre em um ambiente permeado pela tensão e ao mesmo tempo a ida ao bar faz parte da realidade de alguns e do imaginário da profissão. Por outro lado, há o problema da insônia, uso de remédios para dormir e analgésicos para as dores, pontos que apareceram na pesquisa, mas não foram aprofundados.

Os jornalistas suportam todos esses sofrimentos do trabalho e conseguem em muitos casos transformá-los em prazer pelo sentido que dão ao trabalho. Eles acreditam no jornalismo e no seu papel democrático, que pode contribuir para a disseminação de direitos e até para a transformação da realidade. O sentido do trabalho aliado ao reconhecimento do outro e de si mesmo sobre o seu trabalho fazem com seja possível encontrar a satisfação profissional.

O conteúdo do trabalho, a afinidade com os temas abordados, o trabalho bem realizado, a autonomia, a criatividade, o resultado do trabalho, o reconhecimento dos leitores, dos colegas e de si mesmo, a assinatura na matéria, o local de trabalho (quando se trabalha em um veículo no qual se acredita), a aprendizagem e o conhecimento, a 
transformação de situações, a possibilidade de contar histórias e ser lido são fontes de prazer.

O trabalho do jornalista ainda tem espaço para a autonomia e a criatividade, mas de forma limitada. O próprio fazer jornalístico necessita dessa abertura ao sujeito para ser realizado. Não se pode esquecer ainda que por mais que as normas sejam colocadas, o trabalho real não se restringe ao prescrito e no jornalismo isso não é diferente.

O conteúdo do trabalho também pode levar o jornalista ao prazer, quando há identificação com o material que se produz. Esse prazer pode funcionar como defesa que faz suportar todo o sofrimento anterior. A naturalização dos riscos e da tensão também pode ocorrer como uma defesa como condição para realizar alguns tipos de cobertura. Essas são possíveis estratégias defensivas que ajudam a trabalhar mais e lidar com o sofrimento. Essas questões podem ser indícios de uma ideologia ocupacional defensiva para os jornalistas, que necessita ser comprovada com a metodologia da psicodinâmica do trabalho.

O trabalho, muitas vezes, é caracterizado pelos jornalistas por palavras como paixão e gostar. Ele não só suplanta a vida social, como é defendido por muitos como a própria vida. Se o trabalho é capaz de dar sentido à vida do jornalista, que se vê como jornalista 24 horas do dia, com melhores condições de trabalho, seria possível não só atuar na construção da saúde do sujeito e contribuir à transformação do sofrimento em prazer, como também possibilitar o exercício de um jornalismo que realmente atue para a consolidação da democracia e para que o cidadão tenha o seu direito à informação efetivado.

No entanto, vive-se uma situação de precarização do trabalho, que tem consequências negativas para a qualidade do jornalismo praticado e para a saúde física e mental do jornalista. O sofrimento é intensificado, e o prazer oriundo dessa vocação ao jornalismo pode não ser no futuro uma defesa suficiente para suportar as condições ruins. Além disso, se o jornalista deixar de acreditar no seu trabalho, não haverá identidade com o que ele produz, nem reconhecimento possível. O trabalho será cada vez mais alienado, e o espaço para o prazer será suplantado pelo sofrimento. Não haverá possibilidades de transformação da sociedade e de si próprio.

No trabalho, nós nos produzimos como ser social e podemos ampliar nossa subjetividade ou mutilá-la, se nos depararmos com uma organização do trabalho muito rígida. É preciso que o papel do sujeito jornalista seja reconhecido, não para extrair mais 
produtividade e subtrair ou controlar a subjetividade, mas sim para construir melhores condições de trabalho.

A autonomia no trabalho é extremamente necessária no jornalismo, especialmente para se reconhecer a informação como um direito. Por outro lado, o jornalista deve se reconhecer como trabalhador, e a mistificação da profissão deve ser questionada, o que não significa destruir o sentido do trabalho, pois ele é extremamente necessário ao sujeito. Dessa forma, as relações de trabalho podem deixar de ser mascaradas, e o trabalho contribuir para uma vida com sentido. Trilhar um caminho para a ampliação da subjetividade por meio do trabalho é necessário para transformar o sofrimento em prazer. Para tanto, uma nova organização do trabalho deve ser proposta e só pode ser alcançada com a união dos trabalhadores jornalistas para a construção de uma saída coletiva. 


\section{Referências bibliográficas}

ABRAHÃO, Júlia, SZNELWAR, Laerte, SILVINO, Alexandre, SARMET, Maurício, PINHO, Diana. Introdução à ergonomia: da prática à teoria. São Paulo: Editora Blucher, 2011.

ABRAJI. Planilha com as violações durante manifestações registradas de maio/2013 a julho/2014. 14 julho 2014. Disponível em:

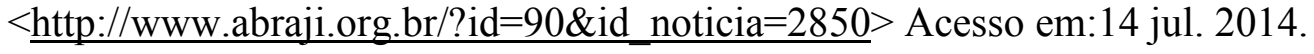

ABRAMO, Cláudio. A regra do jogo. São Paulo: Cia das Letras, 1988.

ABRAMO, Perseu. Um trabalhador da notícia. São Paulo: Fundação Perseu Abramo, 2007.

ABREU, Alzira Alves de. Jornalismo Cidadão. Estudos Históricos, Rio de Janeiro, n. 31, 25-40, 2003. Disponível em:

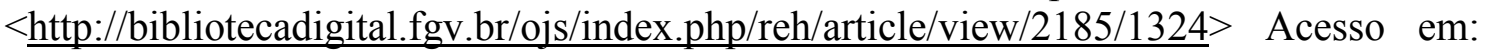
26 ago. 2011.

ALCÂNTARA, Alex Sander. Droga nas redações. Revista Imprensa, São Paulo, v.217, p. 28-29, out. 2006.

ALCÂNTARA, Alex Sander; GRILLO, Otávio. Quando o jornalismo provoca DORT. Revista Imprensa, São Paulo, v.217, p. 24-27, out. 2006.

ALVES, Giovanni. Trabalho e subjetividade: o espírito do toyotismo na era do capitalismo manipulatório. São Paulo: Boitempo, 2011.

ANTUNES, Ricardo. Adeus ao trabalho? Ensaio sobre as Metamorfoses e a Centralidade do Mundo do Trabalho. 12. ed. São Paulo: Cortez/Editora da Unicamp, 2007.

Os sentidos do trabalho. Ensaio sobre a afirmação e a negação do trabalho. 2.ed. São Paulo: Boitempo, 2009.

BAHIA, Juarez. Jornal, história e técnica: História da imprensa brasileira, volume 1. Rio de Janeiro: Mauad X, 2009. 
BARDIN, Laurence. Análise de conteúdo. Lisboa: Edições 70, 2009.

BIRMAN, Joel. O assédio em questão. In: Assédio Moral: desafios políticos, considerações sociais, incertezas jurídicas. Uberlândia: EDUFU, 2006.

BLOG Jornalismo Freelance. Falso Empreendedorismo ganha ação judicial. Disponível em: $<$ http://jornalismofreelance.wordpress.com/2012/04/16/falso-empreendedorismoganha-acao-judicial/> Acesso em: 16 abr. 2012.

BOBBIO, Norberto. A era dos direitos. Rio de janeiro: Campus, 1992.

Campus, 2004. . Os direitos do homem hoje. In: A era dos direitos. Rio de janeiro:

BRASIL. Constituição (1988). Constituição da República Federativa do Brasil. Brasília, DF: Senado, 1988.

BRASIL. Decreto-Lei n ${ }^{\circ}$ 5452, de 1 de maio de 1943. Aprova a Consolidação das Leis do Trabalho. Disponível em: $<$ http://www.planalto.gov.br/ccivil_03/decretolei/del5452.htm> Acesso em: 18/12/2014.

Brasil. Decreto $\mathrm{n}^{\circ}$ 7.602, de 7 de novembro DE 2011. Dispõe sobre a Política Nacional de Segurança e Saúde no Trabalho - PNSST. Disponível em: $<\underline{\text { http://www.planalto.gov.br/ccivil_03/_Ato2011-2014/2011/Decreto/D7602.htm> }}$

Acesso em: $23 \mathrm{dez} 2014$.

BRASIL. Norma Regulamentadora $17-$ Ergonomia. Disponível em: $<$ http://portal.mte.gov.br/data/files/FF8080812BE914E6012BEFBAD7064803/nr_17.pd f> Acesso em: $23 \mathrm{dez} 2014$.

BRASIL. Portaria Interministerial $\mathrm{n}^{0}$ 147, de 31 de maio de 1995. Dispõe sobre a criação do Comitê Gestor Internet do Brasil. Disponível em: $<$ http://cgi.br/portarias/numero/147> Acesso em: 08 jan 2015.

BRASIL. Ministério da Saúde. Secretaria de Atenção a Saúde. Departamento de Ações Programáticas Estratégicas. Área Técnica de Saúde do Trabalhador. Lesões por esforços repetitivos (LER) distúrbios osteomusculares relacionados ao trabalho (DORT). Brasília: Ministério da Saúde, 2005. Disponível em:

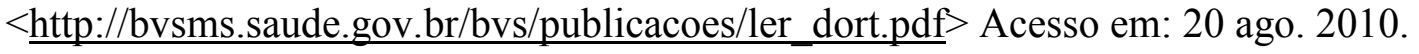


BRAVERMAN, H. Trabalho e capital monopolista. A degradação do trabalho no século XX. 3.ed.Rio de Janeiro: Zahar, 1981, p.49-60.

CANCLINI, Néstor García. Consumidores e Cidadãos. Rio de Janeiro: Editora UFRJ, 2010.

CARVALHO, José Murilo de. Cidadania: tipos e percursos. Estudos Históricos, Rio de Janeiro, n. 18, 1996. Disponível em: http://www.cpdoc.fgv.br/revista/arq/199.pdf

CARRION, Ana Paula. Cresce número de assédio moral contra jornalistas. Unidade: Jornal dos Jornalistas, São Paulo, v. 338, p. 6-7, maio 2011.

CASTELLS, Manuel. Comunicación y poder. Madrid: Alianza, 2009. Cap. I, II e III.

COLOMBINI, Luís Fernando. As drogas no jornalismo. Revista Imprensa, São Paulo, v.74, nov. 1993.

COUTINHO, Maria Chalfin. Sentidos do trabalho contemporâneo: as trajetórias identitárias como estratégia de investigação. Cadernos de Psicologia Social do Trabalho, vol. 12, n.2, pp. 189-201, 2009.

CPJ. Segundo tempo para a imprensa brasileira - a justiça prevalecerá sobre a censura e a violência? Nova York: Comitê para a Proteção dos Jornalistas (CPJ), 2014. Disponível em: <http://cpj.org/pt/brazil2014-portuguese.pdf $>$ Acesso em: 01 dez. 2014.

CT-SST (Comissão Tripartite de Saúde e Segurança no Trabalho). Plano Nacional de Segurança e Saúde no Trabalho. Brasília: Ministério do Trabalho e Emprego, 2012.

DAGNINO, Evelina. ¿Sociedade civil, participação e cidadania: de que estamos falando? In: MATO, Daniel (coord.). Políticas de ciudadanía y sociedad civil en tiempos de globalización. Caracas: FACES, Universidad Central de Venezuela, 2004. pp. 95-110. Disponível em: $<$ http://bibliotecavirtual.clacso.org.ar/ar/libros/venezuela/faces/mato/Dagnino.pdf $>$ Acesso em: 26 ago. 2011.

DANTAS, Audálio. As duas guerras de Vlado Herzog: Da perseguição nazista na Europa à morte sob tortura no Brasil. Rio de Janeiro: Civilização Brasileira, 2012a. 
Céu de Luiz. Fortaleza: Editora Tempo d’Imagem, 2013.

. (Org.) Repórteres. São Paulo: Senac, 2004.

- Tempo de reportagem: Histórias que marcaram época no jornalismo brasileiro. São Paulo: Leya, 2012b.

DE GAULEJAC, Vincent. Do assédio moral ao assédio social. In: Assédio Moral: desafios políticos, considerações sociais, incertezas jurídicas. Uberlândia: EDUFU, 2006.

DEJOURS, Christophe. A loucura do trabalho: estudo de psicopatologia do trabalho. São Paulo: Cortez-Oboré, 1992.

. Entrevista Christophe Dejours. Revista Proteção, Novo Hamburgo, $\mathrm{n}^{\circ} 122$, p.8-14, junho/2010.

Laboreal, vol. VII, n.1, 13-16, 2011 a.

. Psicopatologia do trabalho - Psicodinâmica do trabalho. . “Trabalhar” não é “derrogar”. Laboreal, vol. VII, n.1, 76-80, $2011 b$.

. Trabalho Vivo I: Sexualidade e trabalho. Brasília: Paralelo 15, $2012 \mathrm{a}$.

$15,2012 b$.

. Trabalho Vivo II: Trabalho e emancipação. Brasília: Paralelo

DIMENSTEIN, Gilberto. KOTSCHO, Ricardo. A aventura da reportagem. São Paulo: Summus Editorial, 1990.

DINES, Alberto. O papel do jornal: uma releitura. $4^{\text {a }}$ edição. São Paulo: Summus, 1986. 
DUARTE, Jorge. Entrevista em profundidade. In: DUARTE, Jorge; BARROS, Antonio (org.). Métodos e Técnicas de Pesquisa em Comunicação. São Paulo: Editora Atlas, 2005. p.62-83.

FALZON, Pierre. Natureza, objetivos e conhecimentos da ergonomia. In: FALZON, Pierre (org.). Ergonomia. São Paulo: Editora Blucher, 2007.

FERNANDES, Daniela. Brasil é $\mathbf{1}^{\mathbf{0}}$ em mortes de jornalistas nas Américas, diz ONG. BBC Brasil. 12 fevereiro 2014. Disponível em: http://www.bbc.co.uk/portuguese/noticias/2014/02/140212_jornalistas_brasil_df dg Acesso em: 01 dez. 2014.

FERRACIOLLI, Márcio César. A gente nem comenta porque isso, no dia a dia, acontece com todo mundo: trabalho e sofrimento - o caso dos jornalistas. Florianópolis: UFSC - Dissertação (Mestrado), 2000. Disponível em : < http://repositorio.ufsc.br/xmlui/bitstream/handle/123456789/78958/173227.pdf?sequenc $\mathrm{e}=1$ \&isAllowed $=\mathrm{y}>$ Acesso em: 11 nov. 2014 .

FIGARO,Roseli. (coord.) 2005/2008 - As mudanças no mundo do trabalho nas empresas de comunicação. Disponível em: $<$ http://www.eca.usp.br/comunicacaoetrabalho/wp/index.php/pesquisas/20052007/\#2005/2008\%20\%E2\%80\%93\%20Communication\%20and\%20work:\%20the\%20 changes $\% 20$ in $\% 20$ the $\% 20$ working $\% 20$ world $\% 20$ of $\% 20$ communication $\% 20$ companies $>$ Acesso em: 16 jan. 2013.

Comunicação e Trabalho: binômio teórico produtivo para as pesquisas de recepção. Mediaciones Sociales. Revista de Ciencias Sociales y de la Comunicación, $\mathrm{n}^{\mathrm{o}}$ 4, primer semestre de 2009, p. 23-49.

. Comunicação e trabalho. Estudo de recepção: o mundo do trabalho como mediação da comunicação. São Paulo: Anita Garibaldi/Fapesp, 2001.

Comunicação e trabalho para mudanças na perspectiva sócio-técnica. REVISTA USP, n. 86, 2010. . (coord.) 2009/2012 - O perfil do jornalista e os discursos sobre o jornalismo. Um estudo das mudanças no mundo do trabalho do jornalista profissional em São Paulo. Disponível em: $<$ http://www2.eca.usp.br/comunicacaoetrabalho/wp/index.php/pesquisas/2009-2012/> Acesso em: 16 jan. 2013. 
Perfis e Discursos de Jornalistas no Mundo do Trabalho. In: FIGARO, Roseli (org.), NONATO, Cláudia, GROHMANN, Rafael. As mudanças no mundo do trabalho do jornalista. São Paulo: Salta, 2013.

FIGARO, Roseli (org.), NONATO, Cláudia, GROHMANN, Rafael. As mudanças no mundo do trabalho do jornalista. São Paulo: Salta, 2013.

Folha de S. Paulo. Brasil bloqueia plano da ONU contra mortes de jornalistas. 01 abril 2012. Disponível em: < http://www1.folha.uol.com.br/fsp/poder/34669-brasilbloqueia-plano-da-onu-contra-mortes-de-jornalistas.shtml> Acesso em: 1 abr. 2012.

FREITAS, Maria Esther de, HELOANI, José Roberto, BARRETO, Margarida. Assédio Moral no Trabalho. São Paulo: Cengage Learning, 2008.

GENTILLI, Victor. Democracia de Massas: Jornalismo e Cidadania: estudo sobre as sociedades contemporâneas e o direito dos cidadãos. Porto Alegre: EDIPUCRS, 2005.

GIANNOTTI, Vito. História das lutas dos trabalhadores no Brasil. Rio de Janeiro: Mauad X, 2007.

GOHN, Maria da Glória. Teoria dos movimentos sociais: paradigmas clássicos e contemporâneos. São Paulo: Edições Loyola, 1997.

Grohmann, Rafael. O Jornalista como Receptor. In: FIGARO, Roseli (org.), NONATO, Cláudia, GROHMANN, Rafael. As mudanças no mundo do trabalho do jornalista. São Paulo: Salta, 2013.

GRISCI, Carmen Lígia Iochis, RODRIGUES, Paulo Henrique.Trabalho imaterial e sofrimento psíquico: o pós-fordismo no jornalismo industrial. Psicologia \& Sociedade, Porto Alegre, vol.19, n.2, pp. 48-56, maio/agosto 2007. Disponível em: $<$ http://www.scielo.br/scielo.php?script=sci_arttext\&pid $=$ S0102-71822007000200007> Acesso em: 15 ago. 2013.

HARVEY, David. A condição pós-moderna - uma pesquisa sobre as origens da mudança cultural. São Paulo: Edições Loyola, 1992.

HELLER, Agnes. O cotidiano e a história. $3^{\text {a }}$ edição. São Paulo: Editora Paz e Terra, 1989. 
HELOANI, José Roberto. Entrevista José Roberto Heloani. Unidade. Sindicato dos Jormalistas Profissionais no Estado de São Paulo, n.357, p.6-7 , abril/2013.

. Gestão e organização no capitalismo globalizado: história da manipulação psicológica no mundo do trabalho. São Paulo, Atlas, 2003a.

Mudanças no Mundo do Trabalho e Impacto na

Qualidade de Vida do Jornalista. São Paulo, Fundação Getúlio Vargas, NPP - Série Relatórios de Pesquisa - Relatório ${ }^{\circ}$ 12/2003b.

O trabalho do jornalista: estresse e qualidade de vida. Interações, vol. XII, n.65, julho/dez 2006, pp. 171-178. Disponível em: http://www.redalyc.org/articulo.oa?id=35402208 Acesso em: 6 abril 2011.

. Vivendo no limite: quem são nossos formadores de opinião? REVISTA USP, São Paulo, n.65, p. 148-168, março/maio 2005. Disponível em: < http://www.revistas.usp.br/revusp/article/view/13418/15236> Acesso em: 6 abril 2011.

HIME, Gisely Valentin Vaz Coelho. A hora e a vez do progresso: Cásper Líbero e o exercício do jornalismo nas páginas d' A Gazeta. São Paulo: ECA/USP -

Dissertação (Mestrado), 1997.

HIRSCHMAN, Albert. A retórica da intransigência: perversidade, futilidade, ameaça. São Paulo: Companhia das Letras, 1992.

KILESSE, Sérgio, MACHADO, Marília Novais da Mata. O trabalho do jornalista e o estresse profissional: ocorrências de risco de estresse nas fases de alerta, resistência e exaustão. In: ENCONTRO NACIONAL DA ABRAPSO, 15, 2009, Maceió. Anais... Maceió: Abrapso, 2009a. Disponível em: $<$ http://www.abrapso.org.br/siteprincipal/images/Anais XVENABRAPSO/563.\%20o\%

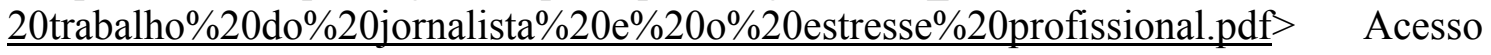
em: 6 abr. 2011

Relações entre o trabalho do jornalista e seu estado geral de saúde. In: ENCONTRO NACIONAL DA ABRAPSO, 15, 2009, Maceió. Anais... Maceió: Abrapso, 2009b. Disponível em: $<$ http://www.abrapso.org.br/siteprincipal/images/Anais XVENABRAPSO/11.\%20rela $\%$ C $7 \%$ D5es $\% 20$ entre $\% 20 \mathrm{o} \% 20$ trabalho $\% 20$ do $\% 20$ jornalista $\% 20 \mathrm{e} \% 20$ seu $\% 20$ estado $\%$ 20geral $\% 20 \mathrm{de} \% 20$ sa $\%$ DAde.pdf $>$ Acesso em: 6 abr. 2011 
KOSHIYAMA, Alice Mitika. O assassinato da jornalista Sandra Gomide: violência de gênero em uma rotina de assédio moral no trabalho. In: CONGRESSO BRASILEIRO DE CIÊNCIAS DA COMUNICAÇÃO, 28, 2005. Rio de Janeiro. Anais... São Paulo: Intercom, $2005 . \quad$ Disponível em: $<$ http://www.intercom.org.br/papers/nacionais/2005/resumos/R1597-2.pdf $>$ Acesso em: 15 nov. 2011

KOTSCHO, Ricardo. Do golpe ao planalto: uma vida de repórter. São Paulo: Companhia das Letras, 2006.

Brasiliense, 1984.

. Serra Pelada: uma ferida aberta na selva. São Paulo:

KOUBI, Geneviève. Variáveis da noção de assédio. In: BRESCIANI, Maria Stella; SEIXAS, Jacy (org.). Assédio Moral: desafios políticos, considerações sociais, incertezas jurídicas. Uberlândia: EDUFU, 2006.

KUCINSKI, Bernardo. A síndrome da antena parabólica: ética no jornalismo brasileiro. São Paulo: Editora Fundação Perseu Abramo, 1998.

Jornalismo na Era Virtual: ensaios sobre o colapso da razão ética. São Paulo: Editora Fundação Perseu Abramo; Editora UNESP, 2005.

LIPP, M. ; ROCHA, J.C. Stress,hipertensão arterial e qualidade de vida. Campinas: Papirus, 1996.

LORENZOTTI, Elizabeth. Jornalismo Século XXI: O modelo \#MídiaNINJA. São Paulo: Elizabeth Lorenzotti, e-galáxia, 2014. E-book.

MAGALHÃES, Marion Brepoh de. Ascensão social e figuras do assédio na política institucional In: Assédio Moral: desafios políticos, considerações sociais, incertezas jurídicas. Uberlândia: EDUFU, 2006.

MANZINI-COVRE, Maria de Lourdes. O que é cidadania? São Paulo: Brasiliense, 1993.

MARSHALL, T. H. Cidadania, classe social e status. Rio de Janeiro: Zahar Editores, 1967. 
MARCONDES FILHO, Ciro. Comunicação e Jornalismo: A Saga dos Cães Perdidos. São Paulo: Hacker Editores, 2000.

ilusões. São Paulo: Paulus, 2009.

Ser jornalista: o desafio das tecnologias e o fim das

MARTIN-BARBERO, Jesús. Dos meios às mediações: comunicação, cultura e hegemonia. Rio de Janeiro: Editora UFRJ, 2006.

Ofício de cartógrafo: Travessias latino-americanas da comunicação na cultura. São Paulo: Loyola, 2004.

MARTINS, Ana Luiza, LUCA, Tania Regina de. História da imprensa no Brasil. São Paulo: Contexto, 2012.

MARX, K, ENGELS,F. A ideologia alemã. São Paulo; Boitempo, 2007, p.29-66.

MARX, Karl. Existência social e consciência social. In: MARX, K, ENGELS,F. Cultura, arte e literatura. Textos escolhidos. São Paulo: Expressão Popular, 2010a, p. 97-101.

. O trabalho do artista na sociedade capitalista. In: MARX, K, ENGELS,F. Cultura, arte e literatura. Textos escolhidos. São Paulo: Expressão Popular, 2010b, p. 151-156.

O Capital: Crítica da economia política: Livro I. Rio de Janeiro: Civilização Brasileira, 2012, p.21-29.

O Capital. Crítica da economia política. Vol I, livro Primeiro, O processo de produção do Capital. Tomo I. São Paulo: Nova Cultural, 1985, p.45-53. (Coleção Os Economistas).

MICK, Jacques (Coord.), LIMA, Samuel. Perfil do Jornalista Brasileiro: Características demográficas, políticas e do trabalho jornalístico em 2012. Florianópolis: Insular, 2013.

MINAYO, Maria Cecília de Souza. O desafio do conhecimento: pesquisa qualitativa em saúde. 12a ed. São Paulo: Editora Hucitec, 2010. 
MORETZSOHN, Sylvia. Pensando contra os fatos: jornalismo e cotidiano: do senso comum ao senso crítico. Rio de Janeiro: Revan, 2007.

. O caso Tim Lopes: o mito da "mídia cidadã". Universidade Federal Fluminense. Covilhã: BOCC-Biblioteca Online de Ciências da Comunicação da Universidade da Beira Interior, 2003. Disponível em: $<$ htpp://www.bocc.ubi.pt/pág/moretzsohn-sylvia-tim-lopes.pdf $>$ Acesso em: 1 ago 2011.

NASSIF, Luís. O jornalismo nos anos 90. São Paulo: Futura, 2003.

NONATO, Cláudia. O perfil Diferenciado dos Jornalistas Associados ao Sindicato de São Paulo. In: FIGARO, Roseli (org.), NONATO, Cláudia, GROHMANN, Rafael. As mudanças no mundo do trabalho do jornalista. São Paulo: Salta, 2013.

OIT. Convenção 155: Segurança e Saúde dos Trabalhadores. $67^{\text {a }}$ Conferência Internacional do Trabalho, Genebra, 1981. Disponível em:

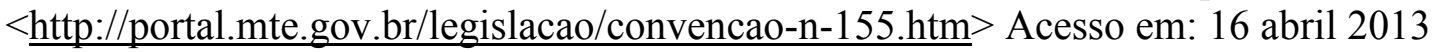

OIT. Convenção 187: Estrutura de Promoção da Segurança e Saúde no Trabalho. 95 Conferência Internacional do Trabalho, Genebra, 2006. Disponível em: $<$ http://www.abs.org.br/site/index.php/the-community/57-barack-obama-on-summertour-.html > Acesso em: 16 abril 2013

OLIVEIRA, Maurício. Manual do frila: o jornalista fora da redação. São Paulo: Contexto, 2010.

OLIVEIRA, Michelle Roxo de. O projeto de reestruturação do trabalho jotnalístico na Folha de S. Paulo: racionaliade e gerenciamento. Cadernos Ceru, vol.24, n.2, pp. 159$179,2007$.

ONU. Declaração Universal dos Direitos Humanos. Assembleia Geral das Nações Unidas, $1948 . \quad$ Disponível em: $<$ http://portal.mj.gov.br/sedh/ct/legis intern/ddh bib inter universal.htm $>$ Acesso em: 8 jul. 2011

ONU. Pacto Internacional dos Direitos Econômicos, Sociais e Culturais. 1966. Disponível em: $<$ http://portal.mj.gov.br/sedh/ct/legis_intern/pacto_dir_economicos.htm $>$ Acesso em: 8 jul. 2011 
PATROCINIO, Jacqueline. Brasil é o quinto em raking de assassinatos de jornalistas. Comunique-se. 05 julho 2012. Disponível em: $<$ http://portal.comuniquese.com.br/index.php?option $=$ com content\&view $=$ article\&id $=69119$ :brasil-e-o-quintoem-raking-de-assassinatos-de-jornalistas \&catid=3:imprensa-a-comunicacao\&Itemid=20> Acesso em: 6 jul. 2012.

PIERNES, Guillermo. Comunicação e desintegração na América Latina. Brasília: Editora Universidade de Brasília, 1990.

POLLAK, Michael. Memória, esquecimento, silêncio. Estudos históricos. Rio de Janeiro: CPDOC/FGV, v1, n.3, 1989. Disponível em: $<$ http://bibliotecadigital.fgv.br/ojs/index.php/reh/article/viewArticle/2278/1417> Acesso em: 6 out. 2014.

REIMBERG, Cristiane Oliveira. A organização do trabalho no rádio: reflexos para as práticas profissionais e para a saúde do jornalista. Revista Alterjor, Vol. 1, no 5, 2012a. Disponível em: < http://www.usp.br/alterjor/ojs/index.php/alterjor/article/view/aj5-a2>. Acesso em: 01 Jun. 2013.

Extraprensa, Ano VI, No $\mathrm{N}^{\circ}$, jun. 2012b. Disponível em: $<$ http://www.revistas.usp.br/extraprensa/article/view/77252/81117>. Acesso em: 01 Jun. 2013.

Marco histórico: Política Nacional de Segurança Saúde no Trabalho finalmente é publicada e promete ações integradas entre Trabalho, Saúde e Previdência. Revista Proteção, Ano XXV, Edição 240, Dezembro/2011, p. $39-52$.

RIBEIRO, Jorge Cláudio. Sempre Alerta - Condições e Contradições do Trabalho Jornalístico. São Paulo: Editora Brasiliense e Olho Dágua, 2001.

RIBEIRO, José Hamilton. Jornalistas: 1937 a 1997: história da imprensa de São Paulo vista pelos que trabalham laudas (terminais), câmeras e microfones. São Paulo: Imprensa Oficial do Estado, 1998.

RIBEIRO, Herval Pina. O público e o privado das políticas contemporâneas do Estado Moderno. A ascensão e queda dos direitos de cidadania e a emergência do individualismo e do neocorporativismo em saúde. In: LOURENÇO, Edvânia; NAVARRO, Vera; BERTANI, Iris; SILVA, José F. da; SANT’ANA, Raquel (Orgs.). O 
Avesso do Trabalho II - Trabalho, precarização e saúde do trabalhador. São Paulo: Expressão Popular, 2010, p.307-316.

ROSSI, Clóvis. Enviado Especial: 25 anos ao redor do mundo. São Paulo: Editora Senac, 1999.

. Vale a pena ser jornalista? São Paulo: Moderna, 1986.

SADER, Emir. Apresentação. In: MARX, K, ENGELS,F. A ideologia alemã. São Paulo; Boitempo, 2007, p.9-16.

SAES, Décio Azevedo Marques de. Cidadania e capitalismo: uma crítica à concepção liberal de cidadania. Série Especial da Coleção Documentos do Instituto de Estudos Avançados da Universidade de São Paulo, São Paulo, n. 8, abril de 2000. Disponível em:

$<$ http://www.unicamp.br/cemarx/criticamarxista/16saes.pdf $>$ Acesso em: 26 ago. 2011.

SANTOS, Milton. O Espaço do Cidadão. $7^{\text {a }}$ ed. São Paulo: Edusp, 2007.

Por uma outra globalização: do pensamento único à consciência universal. $17^{\mathrm{a}}$ edição. Rio de Janeiro: Record, 2008.

SCHAFF, Adam. O marxismo e o indivíduo. Rio de Janeiro: Civilização Brasileira, 1967, p.53-109.

SCHWARTZ, Y. Entrevista Yves Schwartz. Revista Trabalho, Educação, Saúde. Fiocruz, v. 4 n. 2, 2006.

Trabalho e uso de si. Pro-Posições, v.1, n.5 (32), p. 34-50, 2000.

SCOLARI, Carlos. Hipermediaciones. Elementos para una Teoria de la comunicación digital interactiva. Barcelona: Gedisa, 2008.

SEGNINI, Marina Petrilli, LANCMAN, Selma. Sofrimento psíquico do bailarino: um olhar da psicodinâmica do trabalho. Laboreal, vol. VII, n. 1, 42-55, 2011.

SELIGMANN-SILVA, Edith. Entrevista Edith Seligmann Silva. Revista Proteção, Novo Hamburgo, $\mathrm{n}^{\circ}$ 206, p.8-12, fev. 2009a. 
. Saúde mental no trabalho contemporâneo. In: $9^{\circ}$ Congresso de Stress da ISMA-BR e $11^{\circ}$ Fórum Internacional de Qualidade de Vida no Trabalho, 2009b. mesmo. São Paulo: Cortez, 2011.

Trabalho e desgaste mental: o direito de ser dono de si

SILVA, Carlos Eduardo Lins da. Mil Dias: os bastidores da revolução em um grande jornal. São Paulo: Trajetória Cultural, 1988.

SILVA, Sérgio. Entrevista Sérgio Silva. Unidade. Sindicato dos Jormalistas Profissionais no Estado de São Paulo, n.362, p.8, set./2013.

SINDICATO DOS JORNALISTAS PROFISSIONAIS DO ESTADO DE SÃO PAULO. Convenção Coletiva de Trabalho 2013/2014. Disponível em: < http://jornalistasp.org.br/images/stories/mural/CCT_JRCAPITAL_2013-2014.pdf> Acesso em: 11 dez. 2014.

SINDICATO DOS JORNALISTAS PROFISSIONAIS DO ESTADO DE SÃO PAULO. Produtores de conteúdo de internet serão regularizados como jornalistas. São Paulo, 11 dez. 2014. Disponível em: $<\underline{\text { http://jornalistasp.org.br/index.php?option }=\text { com_content\&view }=\text { article\&id }=5251 \& \text { cati }}$ d=5251\&Itemid=1> Acesso em: 22 dez. 2014.

SINDICATO DOS JORNALISTAS PROFISSIONAIS DO ESTADO DE SÃO PAULO. Sindicato apresenta denúncias ao Ministério Público do Trabalho. São Paulo, 09 dez. 2014. Disponível em: $<$ http://jornalistasp.org.br/index.php?option $=$ com_content\&view $=$ article\&id $=5245 \&$ cati $\underline{\mathrm{d}=5245}>$ Acesso em: $11 \mathrm{dez} .2014$.

SINDICATO DOS JORNALISTAS PROFISSIONAIS DO ESTADO DE SÃO PAULO. Sindicato protesta contra demissões na Editora Abril. São Paulo, 07 dez. 2012. Disponível em: $<$ http://www.sjsp.org.br/index.php?option=com content\&view $=$ article\&id=4039:sindic ato-protesta-contra-demissoes-na-abril $>$ Acesso em: 18 fev. 2013.

SODRÉ, Nelson Werneck. História da Imprensa no Brasil. São Paulo: INTERCOM; Porto Alegre: EDIPUCRS, 2011. 
SPINK, Peter. A organização como fenômeno psicossocial: notas para a redefinição da Psicologia do Trabalho. Psicologia \& Sociedade, v.8, n.1, p.174-192, 1996.

TRAQUINA, Nelson. Teorias do jornalismo. A tribo jornalística - uma comunidade interpretativa transnacional. Florianopolis: Insular, 2. Ed, 2008.

. Teorias do jornalismo, por que as notícias são como são. Florianopolis: Insular, 2. Ed, 2005.

TRAVANCAS, Isabel Siqueira. O mundo dos jornalistas . São Paulo: Summus, 1993.

UNESCO. Lanzamiento del proceso de consulta del Plan de acción de la UNESCO para mejorar la seguridad de los periodistas y combatir la impunidad. 17 julho 2012. Disponível em: <http://www.unesco.org/new/es/communication-andinformation/resources/news-and-in-focus-articles/all-

news/news/consultative process begins for unesco plan on the safety of journalists and combating impunity/> Acesso em: 18 jul. 2012.

Unidade. Basta: “A dor da gente não sai no jornal”. São Paulo, v.349, junho 2012, p. 67.

Unidade. São Paulo, v.346, março 2012, p.4-5.

. São Paulo, v.352, setembro 2012, p.12.

. São Paulo, v.353, outubro 2012, p.4.

. São Paulo, v.356, março 2013, p.3.

. São Paulo, v.357, abril 2013, p.6-7.

. São Paulo, v.360, julho 2013, p.4.

. São Paulo, v.361, agosto 2013, p.2, 9.

São Paulo, v.363, outubro 2013, p.4-5. 
. São Paulo, v.364, novembro/dezembro 2013, p.5.

. São Paulo, v.365, janeiro/fevereiro 2014, p.7.

. São Paulo, v.367, junho 2014, p.4, 5, 11.

. São Paulo, v.368, julho 2014, p.3, 5.

. São Paulo, v.370, setembro 2014, p.5.

. São Paulo, v.371, outubro 2014, p.1, 3, 5-7.

UCHIDA, Seiji, SNELWAR, Laerte Idal, LANCMAN, Selma. Aspectos Epistemológicos e Metodológicos da Psicodinâmica do Trabalho. Travailler, n. 25, 2011.

VASCONCELOS, Izabela. "Filho pobre". Grupo Folha é acusado de precarizar redação do jornal Agora SP. Comunique-se. Disponível em: <http://www.comuniquese.

com.br/index.asp?p=Conteudo/NewsShow.asp\&p2=idnot\%3D58230\%26Editoria\%3D8 \%26Op2\%3D1\%26Op3\%3D0\%26pid\%3D405136384\%26fnt\%3Dfntnl> Acesso em: 19 mar. 2011.

WEIL, Simone. A condição operária e outros estudos sobre a opressão. Rio de janeiro: Paz e Terra, 1979.

WILLIAMS, Raymond. Cultura e materialismo. [1980] São Paulo: Ed. Unesp. 2011. 



\section{Jornalistas entrevistados por ordem cronológica}

1. $10 / 12 / 2013$ - Antonio, 40 anos.

2. $15 / 12 / 2013$ - Miguel, 39 anos.

3. 19/12/2013 - Priscilla Nery Rocha, 25 anos.

4. 08/01/2014 - Aureliano Biancarelli, 63 anos.

5. 10/01/2014 - Leonardo Sakamoto, 36 anos.

6. $13 / 02 / 2014$ - Pedro, 32 anos.

7. 26 e 27/02/2014 - Ricardo Kotscho, 66 anos a completar em março.

8. 24/03/2014 - Vivian de Oliveira Neves Fernandes, 27 anos.

9. $01 / 04 / 2014$ - Fernanda Cirenza, 49 anos.

10. 08/04/2014 - Ivan Marsiglia, 43 anos.

11. 09/04/2014 - Clóvis Rossi, 71 anos.

12. $16 / 04 / 2014$ - Paula Puliti, 50 anos.

13. $29 / 04 / 2014$ - Alberto Dines, 82 anos.

14. $01 / 05 / 2014$ - Bruno Torturra, 35 anos.

15. 06/05/2014 - Marilu Calo Cabañas - 51 anos.

16. $08 / 05 / 2014$ - Audálio Dantas, 81 anos.

17. 09/05/2014 - Bob Fernandes, 58 anos.

18. 03/06/2014 - João, 27 anos.

19. 20/06/2014 - Aline Scarso, 27 anos.

20. 01/07/2014 - Maria, 33 anos.

21. 21/08/2014 - Lúcio Flávio Pinto, 65 anos a completar em setembro. 


\section{TERMO DE CONSENTIMENTO LIVRE E ESCLARECIDO}

\section{Pesquisa de doutorado - "O cotidiano jornalístico: organização do trabalho, práticas, prazer e sofrimento"}

Eu.......

RG. dei o meu Consentimento Livre e Esclarecido para participar como voluntário do projeto de pesquisa supracitado, sob a responsabilidade da pesquisadora Cristiane Oliveira Reimberg, doutoranda do Programa de Pós-Graduação em Ciências da Comunicação, da Escola de Comunicações e Artes, da Universidade de São Paulo, sob a orientação da Profa Dra Alice Mitika Koshiyama.

Assinando este Termo de Consentimento Livre e Esclarecido estou ciente de que:

1. O objetivo da pesquisa é investigar como se dá a organização do trabalho no jornalismo, avaliando, a partir das falas de jornalistas, quando o trabalho é fonte de sofrimento e quando é fonte de prazer, e quais são os impactos dessa organização à saúde e à vida do jornalista.

2. Para isso, traçamos o percurso da organização do trabalho no jornalismo, relacionando estudos da sociologia do trabalho com os aspectos organizacionais encontrados em obras sobre o jornalismo. Esse mapeamento é complementado por entrevistas com profissionais que atuam na área, de diferentes faixas etárias e com experiência em diferentes meios. Pretendemos trilhar um caminho de reconstrução das palavras e recuperação das vivências dos jornalistas no trabalho por meio dessa parte qualitativa da pesquisa com entrevistas semiabertas.

3. A participação neste estudo não acarreta riscos físicos ou psicológicos; uma vez que a natureza da pesquisa e o método adotado não oferecem riscos de quaisquer naturezas, portanto, não estão previstos nenhum tipo de ressarcimento, bem como estou isento (a) de qualquer ônus financeiro.

4. Os depoimentos poderão ser descritos e analisados para a pesquisa no sentido de alcançar os objetivos acima expostos, e os resultados poderão ser utilizados para fins pedagógicos e científicos, incluindose a tese de doutorado, apresentação em atividades acadêmicas, publicações e eventos científicos de áreas afins, respeitando os limites da ética e do proceder científico íntegro e idôneo.

5. A pesquisa permite que o entrevistado opte pelo sigilo de seu nome e pela proteção de sua identidade:

( ) Prefiro que meu nome não seja identificado durante a pesquisa.

( ) Não há problema em que meu nome seja citado na pesquisa.

6. Poderei a qualquer momento, para esclarecer dúvidas, entrar em contato com a responsável pelo estudo, Cristiane Oliveira Reimberg, pelos telefones (11) XXXX-XXXX, (11)XXXXX-XXXX ou e-mail: crisreim@yahoo.com.br

7. Este Termo de Consentimento Livre e Esclarecido foi assinado por mim e pela pesquisadora em duas cópias de igual teor, ficando uma em meu poder e outra para os arquivos da pesquisa.

de de 2014.

Assinatura do Participante

outoranda Programa de Pós-Graduação em Ciências da Comunicação da ECA/USP 